九州大学学術情報リポジトリ

Kyushu University Institutional Repository

Neogene Gastropods from Panay Island, the Philippines : Contributions to the Geology and Palaeontology of Southeast Asia, LXVIII

Shuto, Tsugio

Faculty of Science, Kyushu University

https://doi.org/10.5109/1543678

出版情報：九州大學理學部紀要：Series D, Geology. 19 (1)，pp.1-250，1969-01-25. Faculty of Science, Kyushu University バージョン：

権利関係 : 
Mem. Fac. Sci., Kyushu Univ., Ser. D, Geol., Vol. XIX, No. 1, pp. 1-250, figs. 1-43, tables 1-5, plates 1-24, Jan. 25, 1969

\title{
Neogene Gastropods from Panay Island, the Philippines

\author{
Contributions to the Geology and Palaeontology \\ of Southeast Asia, LXVIII
}

By

\section{Tsugio SHUTO}

\begin{abstract}
In this report are treated with the faunal analysis, age correlation, and systematic description of the gastropods from the younger Caenozoic formations in the Iloilo basin, Panay Island, the Philippines. It is one of the results of the activities of the Association for Palaeontological Research in Southeast Asia.

The molluscan samples were obtained along the eastern section of the basin at five localities representing respectively different stratigraphic horizons. The molluscan assemblages belong to the shallow to deep shelf faunas of the IndoWest Pacific zoogeographical province. The age of the five assemblages ranges from Mio-Pliocene to Plio-Pleistocene. The discrepancy of the results of the intra- and inter-regional correlations by means of the molluses and the planktonic foraminifers is discussed in some details. Systematical descriptions of total 136 gastropods include 10 new genera and subgenera, 31 new species and subspecies, and one new name. The taxonomical discrimination is based chiefly on the detailed features of the morphological development from the veliger to adult illustrated on the protoconch and teleoconch.
\end{abstract}

\section{Contents}

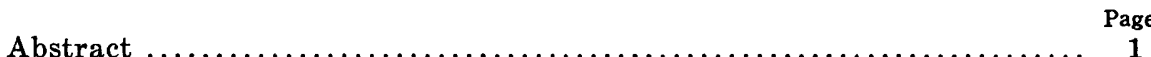

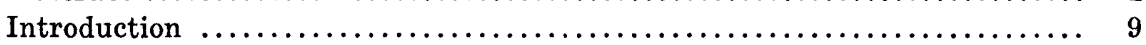

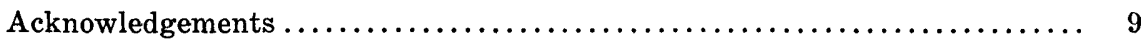

Geological outline of the Iloilo basin and the fossil localities .......... 10

General features of the gastropod assemblages and the environments.... 13

(A) Assemblage at loc. SKGS-71 $\ldots \ldots \ldots \ldots \ldots \ldots \ldots \ldots \ldots \ldots \ldots \ldots \ldots \ldots$

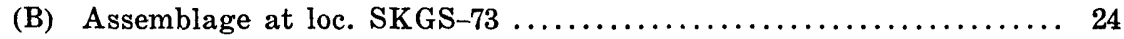

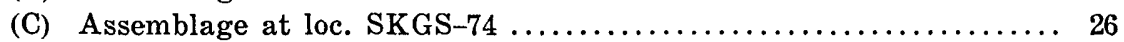

(D) Assemblage at loc. SKGS-72 and $75 \ldots \ldots \ldots \ldots \ldots \ldots \ldots \ldots \ldots \ldots \ldots$

Age of the fossil assemblages $\ldots \ldots \ldots \ldots \ldots \ldots \ldots \ldots \ldots \ldots \ldots \ldots \ldots \ldots \ldots$

(A) Age of the assemblage at loc. SKGS $-71 \ldots \ldots \ldots \ldots \ldots \ldots \ldots \ldots \ldots$

(B) Age of the assemblage at loc. SKGS-72 $\ldots \ldots \ldots \ldots \ldots \ldots \ldots \ldots \ldots$

(C) Age of the assemblage at loc. SKGS-73 $\ldots \ldots \ldots \ldots \ldots \ldots \ldots \ldots \ldots$

(D) Age of the assemblage at loc. SKGS $-74 \ldots \ldots \ldots \ldots \ldots \ldots \ldots \ldots \ldots \ldots$

(E) Age of the assemblage at loc. SKGS-75 $\ldots \ldots \ldots \ldots \ldots \ldots \ldots \ldots$

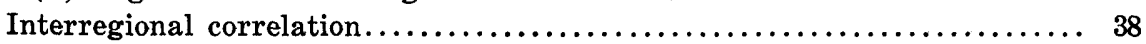


Systematic descriptions $\ldots \ldots \ldots \ldots \ldots \ldots \ldots \ldots \ldots \ldots \ldots \ldots \ldots \ldots \ldots \ldots \ldots \ldots$

(A) Morphology and measurements of the gastropod-shell.......... 45

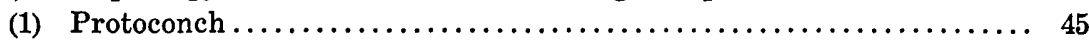

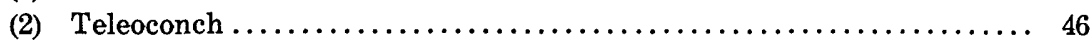

(B) Systematics of the Gastropoda....................... 49

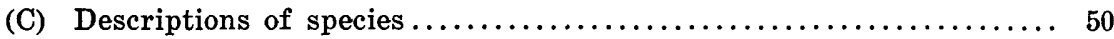

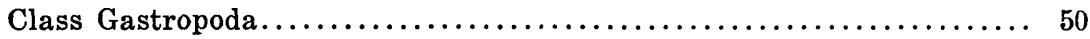

Subclass Prosobranchia ............................. 50

Order Archaeogastropoda .......................... 50

Superfamily Trochoidea......................... 50

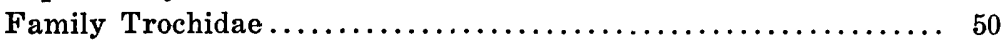

Subfamily Gibbulinae.......................... 50

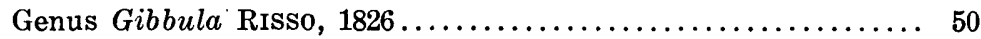

Subgenus Colliculus Monterosato, $1888 \ldots \ldots \ldots \ldots \ldots \ldots \ldots \ldots .50$

Gibbula (Colliculus) sp....................... 50

Subfamily Umboniinae........................... 52

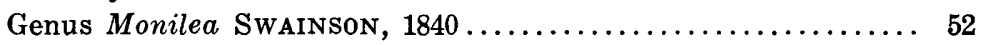

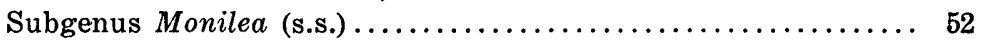

Monilea (Monilea) lentiginosa A. AdAMs ............... 52

Genus Umbonium LINK, $1807 \ldots \ldots \ldots \ldots \ldots \ldots \ldots \ldots \ldots \ldots \ldots$

Subgenus Umbonium (s.s.) ..................... 53

Umbonium (Umbonium) vestiarium (LINNÉ) .......... 53

Superfamily Rissoidea ......................... 54

Family Tornidae ................................. 54

Genus Pygmaeorota KURODA and HABE, $1952 \ldots \ldots \ldots \ldots \ldots \ldots 5$

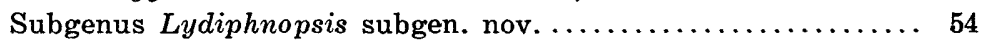

Pygmaeorota (Lydiphnopsis) philippinensis subgen et sp. nov.. 55

Superfamily Turritelloidea........................ 56

Family Turritellidae ........................... 56

Genus Turritella LAMARck, $1799 \ldots \ldots \ldots \ldots \ldots \ldots \ldots \ldots \ldots \ldots \ldots$

Subgenus Turritella (s.s.) ....................... 57

Turritella (Turritella) terebra bantamensis MARTIN ....... 57

Subgenus Kurosioia IDA, $1952 \ldots \ldots \ldots \ldots \ldots \ldots \ldots \ldots \ldots \ldots \ldots$

Turritella (Kurosioia) cingulifera filiola Yoкоуама........ 59

Superfamily Vermetoidea .......................... 59

Family Vermetidae ............................ 59

Genus Dendropoma Mörch, $1861 \ldots \ldots \ldots \ldots \ldots \ldots \ldots \ldots \ldots \ldots$

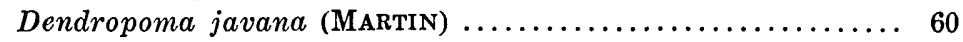

Superfamily Cerithioidea $\ldots \ldots \ldots \ldots \ldots \ldots \ldots \ldots \ldots \ldots \ldots \ldots \ldots .60$

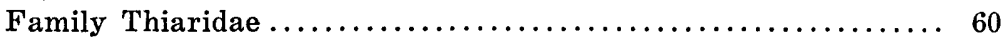

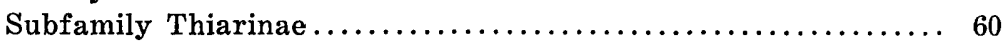

Genus Sermyla H. and A. AdAMs, $1854 \ldots \ldots \ldots \ldots \ldots \ldots \ldots \ldots 60$

Sermyla riqueti (GRATEROUP) $\ldots \ldots \ldots \ldots \ldots \ldots \ldots \ldots \ldots \ldots \ldots \ldots$

Genus Tarebia H. and A. ADAMs, $1854 \ldots \ldots \ldots \ldots \ldots \ldots \ldots \ldots 6 . \ldots \ldots \ldots \ldots$

Tarebia submadiunensis (YoKоYамA) ................ 61

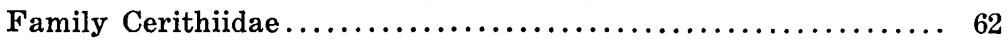

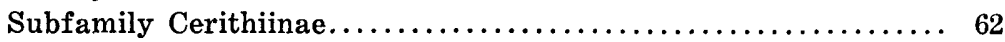

Genus Bittium LeACH (in Gray), $1847 \ldots \ldots \ldots \ldots \ldots \ldots \ldots \ldots . \ldots \ldots$

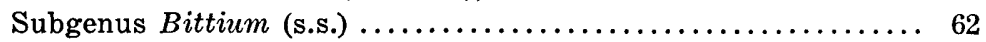

Bittium (Bittium) glareosum Gound................. 62

Genus Argyropeda Melvill and Standen, $1901 \ldots \ldots \ldots \ldots \ldots .63$

Argyropeda divina Melvill and Standen............ 64

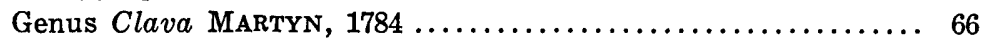

Subgenus Proclava Thiele, $1929 \ldots \ldots \ldots \ldots \ldots \ldots \ldots \ldots \ldots \ldots$ 
Clava (Proclava) kochi (PHILIPPI)................ 66

Genus Clypeomomes Jousseaume, $1888 \ldots \ldots \ldots \ldots \ldots \ldots \ldots \ldots 6$

Clypeomorus tuberculatus (LINNÉ)................ 67

Family Potamididae ............................. 69

Subfamily Potamidinae .......................... 69

Genus Cerithidea SwaInson, $1840 \ldots \ldots \ldots \ldots \ldots \ldots \ldots \ldots \ldots \ldots$

Subgenus Cerithideopsilla THIELE, $1929 \ldots \ldots \ldots \ldots \ldots \ldots \ldots \ldots .69$

Cerithidea (Cerithideopsilla) sp. cf. C. (C.) preangerensis

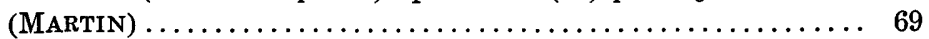

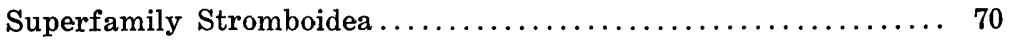

Family Strombidae ............................ 70

Genus Dientomochilus Cossmann, $1904 \ldots \ldots \ldots \ldots \ldots \ldots \ldots \ldots . \ldots$

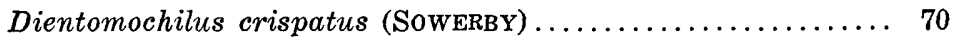

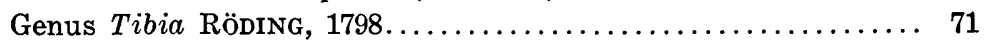

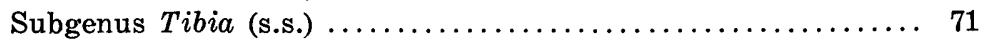

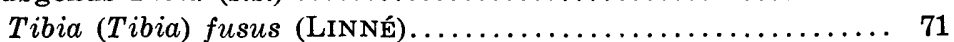

Subgenus Sulcogladius SACco, $1893 \ldots \ldots \ldots \ldots \ldots \ldots \ldots \ldots \ldots$

Tibia (Sulcogladius) powisii modesta (MARTIN) .......... 72

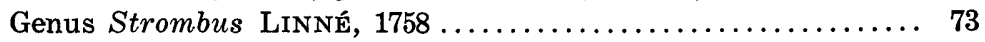

Subgenus Laevistrombus KIRA, $1955 \ldots \ldots \ldots \ldots \ldots \ldots \ldots \ldots \ldots . \ldots 7$

Strombus (Laevistrombus) canarium LINNÉ ............. 73

Subgenus Dolomena IREdALE, $1931 \ldots \ldots \ldots \ldots \ldots \ldots \ldots \ldots \ldots$

Strombus (Dolomena) sp. cf. S. (D.) togopiensis Cox....... 75

Superfamily Cypraeoidea .......................... 75

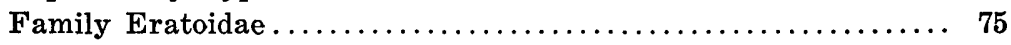

Subfamily Tribiinae ........................... 75

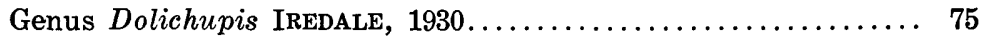

Subgenus Trivellona IREDALE, $1931 \ldots \ldots \ldots \ldots \ldots \ldots \ldots \ldots \ldots \ldots$

Dolichupis (Trivellona) shimajiriensis MACNEIL .......... 76

Genus Trivirostra Jousseaume, $1884 \ldots \ldots \ldots \ldots \ldots \ldots \ldots \ldots \ldots$

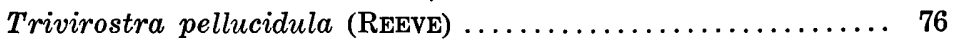

Superfamily Naticoidea......................... 77

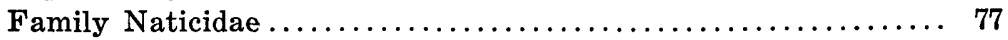

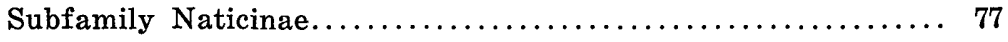

Genus Naticarius DUMÉRIL, $1806 \ldots \ldots \ldots \ldots \ldots \ldots \ldots \ldots \ldots 77$

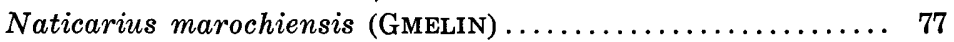

Genus Natica Scopoli, $1777 \ldots \ldots \ldots \ldots \ldots \ldots \ldots \ldots \ldots \ldots \ldots \ldots . \ldots \ldots$

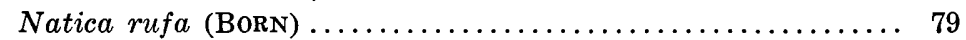

Natica zebra LAMARCK........................ 80

Subfamily Polinicinae .......................... 81

Genus Mamilla Schumacher, $1817 \ldots \ldots \ldots \ldots \ldots \ldots \ldots \ldots \ldots . \ldots \ldots$

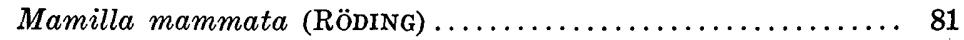

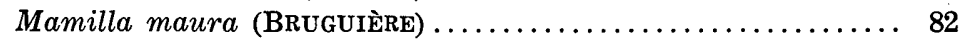

Genus Polinices Montfort, $1810 \ldots \ldots \ldots \ldots \ldots \ldots \ldots \ldots \ldots \ldots$

Subgenus Plinices (s.s.) ......................... 83

Polinices (Polinices) aurantius (RöDING) .............. 83

Polinices (Polinices) sp. cf. P. (P) jukesii(REeve)........ 84

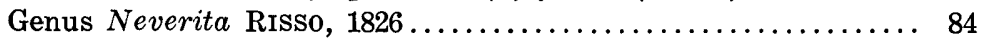

Subgenus Glossaulax PilsBRY, $1929 \ldots \ldots \ldots \ldots \ldots \ldots \ldots \ldots \ldots . \ldots$

Neverita (Glossaulax) petiveriana (RECLUZ)............. 85

Neverita (Glossaulax) petiveriana compressa subsp. nov. ... 85

Subgenus Neverita (s.s.) .......................... 87

Neverita (Neverita) albula bagacayensis subsp. nov ........ 87

Superfamily Tonnoidea ........................ 88 
Family Cymatiidae $\ldots \ldots \ldots \ldots \ldots \ldots \ldots \ldots \ldots \ldots \ldots \ldots \ldots, 88$

Genus Apollon Montfort, $1810 \ldots \ldots \ldots \ldots \ldots \ldots \ldots \ldots . \ldots . \ldots 8$

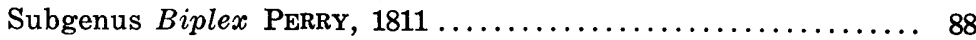

Apollon (Biplex) perca (PERRY) ...................... 88

Genus Distorsio RöDING, $1798 \ldots \ldots \ldots \ldots \ldots \ldots \ldots \ldots \ldots \ldots . \ldots . \ldots$

Subgenus Distorsio (s.s.).......................... 89

Distorsio (Distorsio) reticulatus decipiens (REEvE) .......... 89

Distorsio (Distorsio) reticulatus reticulatus RöDING ........ 90

Family Bursidae .................................... 91

Genus Gyrineum LINK, $1807 \ldots \ldots \ldots \ldots \ldots \ldots \ldots \ldots \ldots . \ldots . \ldots 1$

Subgenus Chasmotheca DALL, $1904 \ldots \ldots \ldots \ldots \ldots \ldots \ldots \ldots \ldots . . \ldots 1$

Gyrineum (Chasmotheca) sp. aff. G. (C.) cavitense (SowERBY).. 91

Gyrineum (Chasmotheca) nobile (REEvE) ................ 93

Family Tonnidae ................................. 94

Genus Tonna BRüNNICH, $1772 \ldots \ldots \ldots \ldots \ldots \ldots \ldots \ldots \ldots \ldots . . \ldots 4$

Tonna costata (MENKE) ............................ 94

Tonna variegata (LAMARCK) ........................... 95

Order Heterogastropoda ................................ 96

Superfamily Architectonicoidea $\ldots \ldots \ldots \ldots \ldots \ldots \ldots \ldots \ldots \ldots, 96$

Family Architectonicidae ............................ 96

Genus Architectonica RöDING, $1978 \ldots \ldots \ldots \ldots \ldots \ldots \ldots \ldots \ldots, 96$

Subgenus Architectonica (s.s.) ....................... 96

Architectonica (Architectonica) perspectiva (LINNÉ) ......... 96

Superfamily Epitonioidea.............................. 98

Family Janthinidae .................................. 98

Genus Janthina Röbrng, $1798 \ldots \ldots \ldots \ldots \ldots \ldots \ldots \ldots \ldots \ldots . \ldots 9$

Subgenus Janthina (s.s.).......................... 98

Janthina (Janthina) ianthina (LINNÉ) ................. 98

Order Neogastropoda ................................. 99

Superfamily Muricoidea $\ldots \ldots \ldots \ldots \ldots \ldots \ldots \ldots \ldots \ldots \ldots \ldots, 99$

Family Muricidae................................... 99

Subfamily Muricinae ................................. 99

Genus Typhis MontFoRT, $1810 \ldots \ldots \ldots \ldots \ldots \ldots \ldots \ldots . \ldots 9$

Subgenus Talityphis Jousseaume, $1880 \ldots \ldots \ldots \ldots \ldots \ldots \ldots .69$

Typhis (Talityphis) macropterus MARTIN............... 99

Genus Murex Linné, $1758 \ldots \ldots \ldots \ldots \ldots \ldots \ldots \ldots \ldots \ldots \ldots . \ldots \ldots$

Subgenus Haustellum BRUGUİ̀Re, 1792 ................. 100

Murex (Haustellum) bantamensis saplisi MacNeIL .......... 100

Murex (Haustellum) bonneti Cossmann ................... 101

Subgenus Murex (s.s.) ............................. 102

Murex (Murex) troscheli verbeeki MARTIN............... 102

Murex (Murex) sp. cf. M. (M.) rectirostris aduncospinosus

REEVE ........................................ 104

Genus Pterynotus SwaInson, $1833 \ldots \ldots \ldots \ldots \ldots \ldots \ldots \ldots \ldots . \ldots \ldots$

Subgenus Naquetia JousSeaume, $1880 \ldots \ldots \ldots \ldots \ldots \ldots \ldots \ldots . \ldots 105$

Pterynotus (Naquetia) sondeianus solidus subsp. nov. ....... 105

Genus Chicoreus Montront, $1810 \ldots \ldots \ldots \ldots \ldots \ldots \ldots \ldots \ldots . \ldots \ldots$

Subgenus Foveomurex IREDALE, 1936................... 107

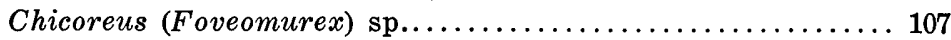

Genus Bedeva Iredale, $1924 \ldots \ldots \ldots \ldots \ldots \ldots \ldots \ldots \ldots \ldots \ldots \ldots \ldots$

Bedeva blosvillei curvirostra subsp. nov............... 108

Subfamily Drupinae................................ 109

Genus Acantinella gen. nov............................. 109

Acantinella javana (MARTIN) ....................... 111 
Family Coraliophilidae.......................... 111

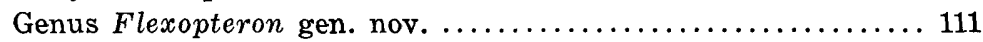

Flexopteron philippinesis gen. et sp. nov............. 112

Superfamily Buccinoidea ........................ 113

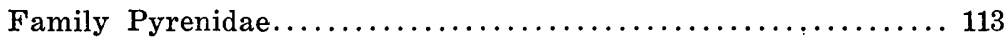

Genus Indomitrella OostingH, $1940 \ldots \ldots \ldots \ldots \ldots \ldots \ldots \ldots \ldots$

Indomitrella kobayashii sp. nov.................. 114

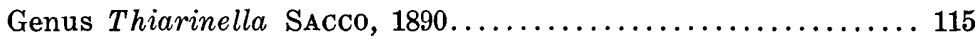

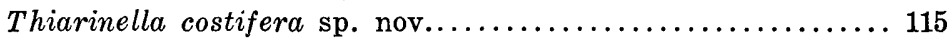

Family Buccinidae .................................. 117

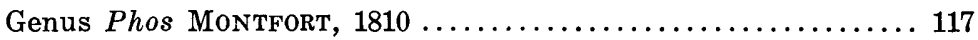

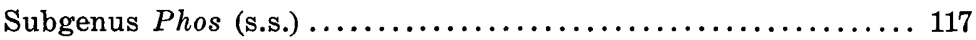

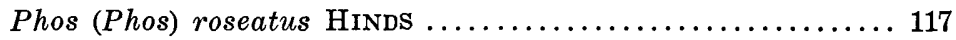

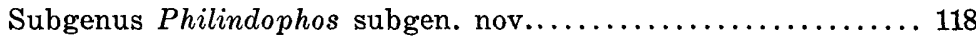

Phos (Philindophos) dijki Martin, subgen. nov. ......... 118

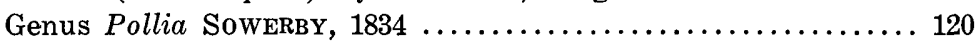

Pollia martini sp. nov........................... 120

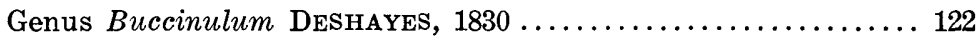

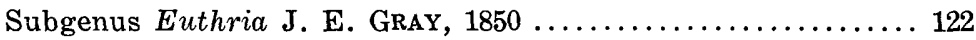

Buccinulum (Euthria) dinglensis sp. nov............. 122

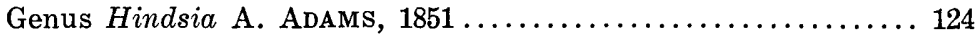

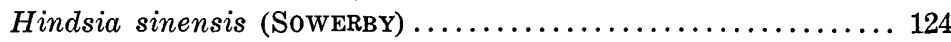

Hindsia varicifera A. ADAMs..................... 125

Hindsia sp. cf. H. palenbangensis HaANSTRA and SPIKER ... 126

Family Nassariidae ................................ 127

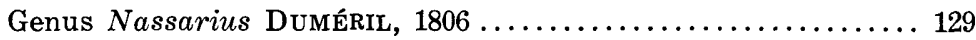

Subgenus Nassarius (s.s.)........................ 129

Nassarius (Nassarius) arcularius (LINNÉ) ............. 129

Nassarius (Nassarius) coronatus philippinensis subsp. nov... 130

Subgenus Zeuxis H. and A. AdAMs, 1853............... 132

Nassarius (Zeuxis) caelatus verveeki (MARTIN) ........... 133

Nassarius (Zeuxis) macrocephalus greyanus subsp. nov..... 134

Nassarius (Zeuxis) schepmani (KoPERBERG) ............. 136

Subgenus Tarazeuxis IREDALE, $1936 \ldots \ldots \ldots \ldots \ldots \ldots \ldots \ldots \ldots \ldots$

Nassarius (Tarazeuxis) dorsatus (RöDING)............. 137

Nassarius (Tarazeuxis) badius (A. AdAMs) ............. 138

Subgenus Plicarcularia THIELE, 1929 ................... 140

Nassarius (Plicarcularia) thersites (BRUGUIÈRE) .......... 140

Subgenus Chelenassa subgen. nov. .................. 142 Nassarius (Chelenassa) elegantissimus subgen. et sp. nov. ... 142

Subgenus Niotha H. and A. AdAMs, $1853 \ldots \ldots \ldots \ldots \ldots \ldots \ldots$

Nassarius (Niotha) gemmulatus (LAMARCK) ............. 144

Genus Glabrinassa gen. nov...................... 145

Glabrinassa amycliforma gen. et sp. nov. ........... 146

Genus Tritia RIsso, $1826 \ldots \ldots \ldots \ldots \ldots \ldots \ldots \ldots \ldots \ldots \ldots \ldots \ldots$

Subgenus Phrontis H. and A. Adams, 1853............ 147 Tritia (Phrontis) sp. cf. T. (P.) ovoidea (SchePMEN) . . . . 147

Subgenus Tritonella A. AdAMs, $1853 \ldots \ldots \ldots \ldots \ldots \ldots \ldots \ldots \ldots$

Tritia (Tritonella) crenulicostata sp. nov. .............. 148

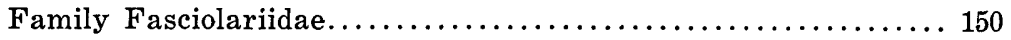

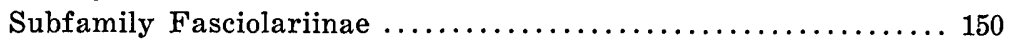

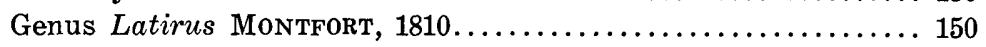

Subgenus Dolicholatirus BeLlard, $1884 \ldots \ldots \ldots \ldots \ldots \ldots \ldots \ldots$

Latirus (Dolicholatirus) esi (KOPERBERG) . . . . . . . . . . 150 
Latirus (Dolicholatirus) fusiformis TESCH ............... 150

Genus Ollaphon IREDALE, 1929.......................... 152

Ollaphon? sp. aff. O. ? gembacanus (MARTIN) ............ 152

Genus Clavilithes SwaInson, $1840 \ldots \ldots \ldots \ldots \ldots \ldots \ldots \ldots \ldots \ldots$

Subgenus Clavilithes (s.s.) ........................ 154

Clavilithes (Clavilithes) tjidamarensis (MARTIN) ............ 154

Superfamily Voltoidea .............................. 155

Family Olividae.................................... 155

Subfamily Olivinae ................................. 155

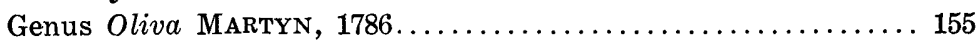

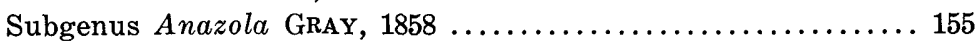

Oliva (Anazola) djocdjocartae MARTIN.................. 155

Oliva (Anazola) rufula junghuhni Martin .............. 157

Subgenus Galeola GraY, $1858 \ldots \ldots \ldots \ldots \ldots \ldots \ldots \ldots \ldots \ldots \ldots \ldots \ldots$

Oliva (Galeola) funebralis LAMARCK .................. 157

Genus Olivella SwaInson, $1831 \ldots \ldots \ldots \ldots \ldots \ldots \ldots \ldots \ldots \ldots . \ldots \ldots$

Subgenus Dactylidia H. anp A. AdAMs, $1853 \ldots \ldots \ldots \ldots \ldots \ldots . . \ldots 158$

Olivella (Dactylidia) gonzalesi sp. nov. ................ 158

Family Mitridae ................................ 159

Subfamily Mitrinae.............................. 160

Genus Tiara Swainson, $1831 \ldots \ldots \ldots \ldots \ldots \ldots \ldots \ldots \ldots \ldots \ldots$

Tiara acuminata sp. nov........................... 160

Tiara flammea (QUAY and GAIMARD) $\ldots \ldots \ldots \ldots \ldots \ldots \ldots \ldots \ldots$

Tiara gerthi philippinensis subsp. nov.................. 162

Subfamily Vexillinae ................................... 164

Genus Vexillum RöDING, $1798 \ldots \ldots \ldots \ldots \ldots \ldots \ldots \ldots \ldots \ldots . \ldots \ldots$

Subgenus Vexillum (s.s.)........................... 164

Vexillum (Vexillum) batavianum minahassae (ScHEPMAN) ... 164

Subgenus Pulchritima IREDALE, $1929 \ldots \ldots \ldots \ldots \ldots \ldots \ldots \ldots \ldots \ldots . \ldots \ldots$

Vexillum (Pulchritima) schepmani KOPERBERG ............ 166

Subgenus Costellaria SwaInson, $1840 \ldots \ldots \ldots \ldots \ldots \ldots \ldots \ldots . \ldots 167$

Vexillum (Costellaria) cruentatum greyi subsp. nov........ 167

Vexillum (Costellaria) obeliscus teschi (KOPERBERG).......... 169

Family Volutidae ..................................... 170

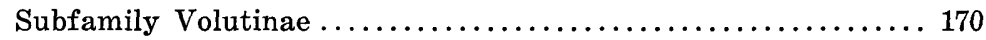

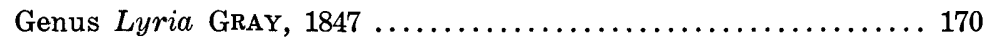

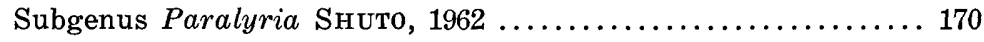

Lyria (Paralyria) sp. cf. L. (P.) hanzawai MACNEIL ....... 170

Family Cancellariidae................................ 171

Genus Merica H. and A. AdAMs, $1854 \ldots \ldots \ldots \ldots \ldots \ldots \ldots \ldots \ldots \ldots . \ldots \ldots 17$

Merica asperella (LAMARK) .......................... 171

Merica asperella varicosa subsp. nov.................. 172

Merica sp. cf. M. laticosta (LÖBECKE) .................. 173

Genus Scalptia Jousseaume, $1887 \ldots \ldots \ldots \ldots \ldots \ldots \ldots \ldots \ldots \ldots \ldots$

Scalptia crenifera (SoWERBY) ....................... 174

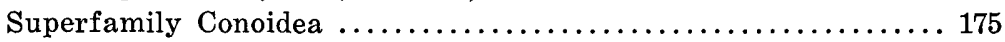

Family Turridae...................................... 175

Subfamily Turrinae................................. 175

Genus Gemmula Weinkauff, $1875 \ldots \ldots \ldots \ldots \ldots \ldots \ldots \ldots \ldots \ldots$

Subgenus Gemmula (s.s.) ............................ 175

Gemmula (Gemmula) speciosa (REEVE) .................. 175

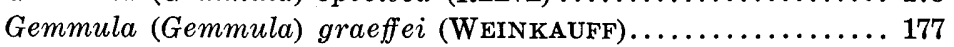

Gemmula (Gemmula) hombroni HedLeY.................. 179

Gemmula (Gemmula) kieneri woodwardi (MARTIN)........... 180 
Subgenus Unedogemmula MacNeIL, $1960 \ldots \ldots \ldots \ldots \ldots \ldots \ldots 18$

Gemmula (Unedogemmula) butonensis asanoi subsp. nov. ... 181

Gemmula (Unedogemmula) gendinganensis (MARTIN) . ...... 184

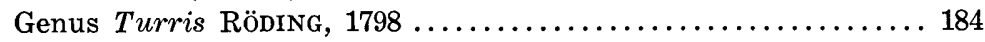

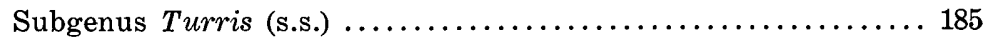

Turris (Turris) panayensis sp. nov. ............... 185

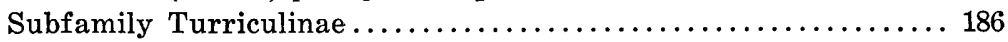

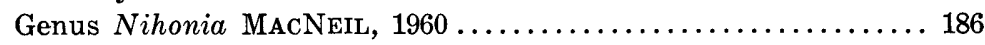

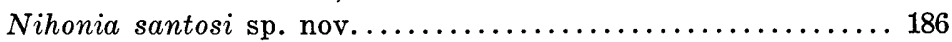

Genus Pleurofusia de Gregorio, $1890 \ldots \ldots \ldots \ldots \ldots \ldots \ldots \ldots \ldots . \ldots \ldots$

Subgenus Pseudofusia subgen. nov.................. 188

Pleurofusia (Pseudofusia) dinglensis subgen. et sp. nov..... 189

Genus Ancistrosyrinx DALL, $1881 \ldots \ldots \ldots \ldots \ldots \ldots \ldots \ldots \ldots \ldots$

Subgenus Pagodasyrinx subgen. nov.................. 190 Ancistrosyrinx (Pagodasyrinx) granulata Sмгтн, subgen.

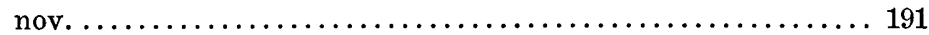

Genus Paradrillia MakiYama, $1940 \ldots \ldots \ldots \ldots \ldots \ldots \ldots \ldots \ldots \ldots$

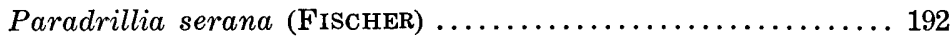

Paradrillia inconstans (SMITH) . . . . . . . . . . . . . 194

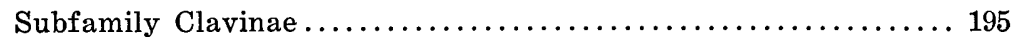

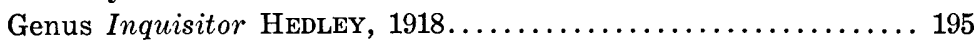

Subgenus Ptychobela THIELE, $1925 \ldots \ldots \ldots \ldots \ldots \ldots \ldots \ldots \ldots \ldots$

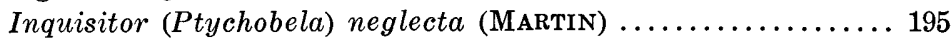

Subgenus Inquisitor (s.s.) .......................... 196

Inquisitor (Inquisitor) molengraafi dinglensis subsp. nov. ... 196

Inquisitor (Inquisitor) batavianus (MARTIN)........... 198

Genus Microdrillia Gasey, $1903 \ldots \ldots \ldots \ldots \ldots \ldots \ldots \ldots \ldots \ldots \ldots$

Subgenus Pulsarella LAsseron, $1954 \ldots \ldots \ldots \ldots \ldots \ldots \ldots \ldots \ldots . \ldots \ldots$

Microdrillia (Pulsarella) madiunensis (MARTIN) .......... 200

Microdrillia (Pulsarella) sp. cf. M. (P.) madiunensis (MAR-

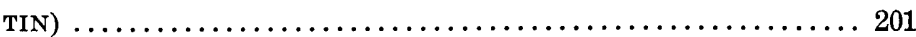

Subfamily Mangeliinae ............................. 202

Genus Euclathurella Woodring, $1928 \ldots \ldots \ldots \ldots \ldots \ldots \ldots \ldots \ldots 2$

Subgenus Miraclathurella Woodring, 1928............... 202

Euclathurella (Miraclathurella) bagacayensis sp. nov....... 202

Subgenus Thelecythara WoodRING, 1928 ................ 204

Euclathurella (Thelecythara) franciscoana sp. nov. ........ 204

Subgenus Euclathurella (s.s.) ..................... 206 Euclathurella (Euclathurella) sp................. 206

Subgenus Thelecytharella subgen. nov.................. 208 Euclathurella (Thelecytharella) oyamai (SHUTo) subgen. nov... 209

Genus Benthomangelia Thiele, 1925.................. 209 Benthomangelia vandervlerki (BEETs) . .............. 209

Subfamily Conorbiinae........................... 211

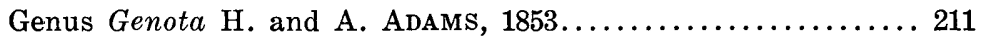

Subgenus Paragenota subgen. nov................... 211 Genota (Paragenota) gonzalesi subgen. et sp. nov......... 212

Family Conidae .................................. 214

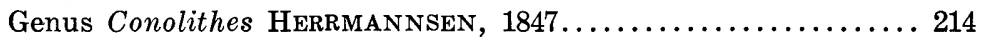

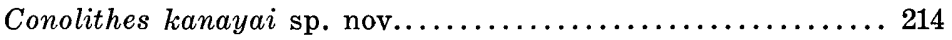

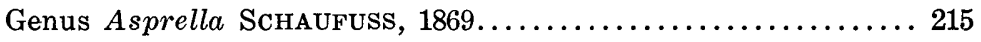

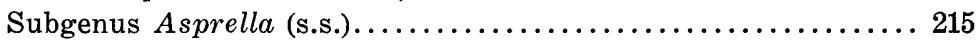

Asprella (Asprella) busuegoi sp. nov................. 215

Asprella (Asprella) insculpta (KIENER) ............... 217 
Asprella (Asprella) sinensis (SowERBY) ................. 219

Asprella (Asprella) mucronata (REEVE) ................. 220

Asprella (Asprella) ornatissima (MARTin) . ............. 221

Genus Phasmaconus Mörch, $1852 \ldots \ldots \ldots \ldots \ldots \ldots \ldots \ldots \ldots \ldots 22$

Phasmaconus martini nom. nov ..................... 222

Family Terebridae .............................. 224

Genus Triplostephanus DALL,.................... 224

Triplostephanus santosi sp. nov ................... 224

Triplostephanus sp. cf. T. pamotanensis timorensis (KOPER-

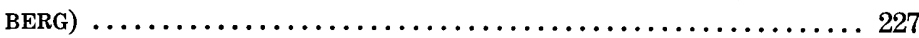

Triplostephanus sp. cf. T. jenkinsi (MARTIN)............ 227

Triplostephanus sp. cf. T. cumingii (DESHAYES).......... 228

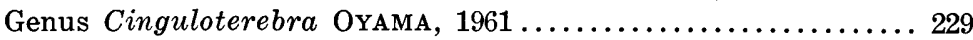

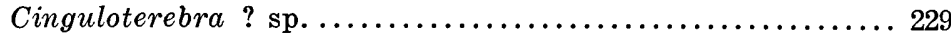

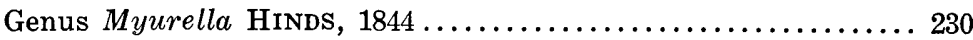

Subgenus Clathroterebra OYамA, $1961 \ldots \ldots \ldots \ldots \ldots \ldots \ldots \ldots \ldots 230$

Myurella (Clathroterebra) woodwardiana (MARTIN)........ 230

Genus Diplomeriza DALL, $1919 \ldots \ldots \ldots \ldots \ldots \ldots \ldots \ldots \ldots \ldots \ldots . \ldots \ldots$

Diplomeriza duplicata (LINNÉ)................... 231

Genus Punctoterebra BARTsch, $1923 \ldots \ldots \ldots \ldots \ldots \ldots \ldots \ldots \ldots 232$

Punctoterebra cabatuanensis sp. nov............... 232

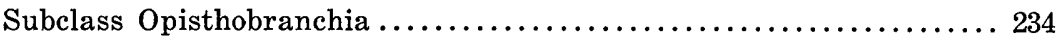

Order Cephalaspidea .............................. 234

Superfamily Bulloidea ............................ 234

Family Ringiculidae............................ 234

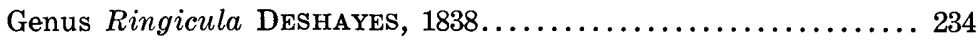

Subgenus Ringiculina Monterosato, $1884 \ldots \ldots \ldots \ldots \ldots \ldots \ldots . \ldots 234$

Ringicula (Ringiculina) arctata glabra MARTIN .......... 234

Family Acteonidae............................. 235

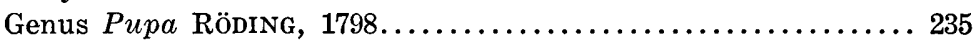

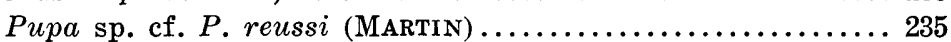

Family Scaphandridae ............................ 236

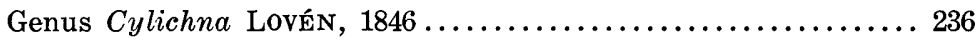

Subgenus Eocylichna Kuroda and Habe, $1952 \ldots \ldots \ldots \ldots \ldots . \ldots 236$

Cylichna (Eocylichna) sibogae SchEPMAN ............. 237

Genus Atys Montfort, $1810 \ldots \ldots \ldots \ldots \ldots \ldots \ldots \ldots \ldots \ldots \ldots \ldots \ldots \ldots \ldots \ldots \ldots \ldots \ldots . \ldots \ldots$

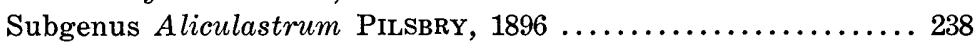

Atys (Aliculastrum) porcellanus Gould.............. 238

Family Bullidae................................ 238

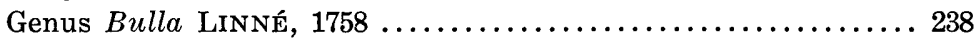

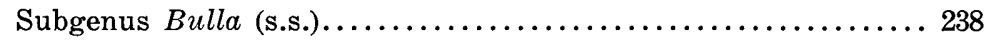

Bulla (Bulla) ampulla LINNÉ .................... 239

Order Entomotaeniata ............................ 239

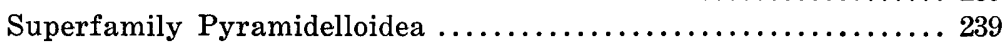

Family Pyramidellidae........................... 239

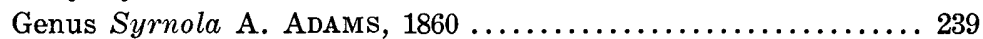

Subgenus Puposyrnola Cossmann, $1921 \ldots \ldots \ldots \ldots \ldots \ldots \ldots \ldots . \ldots . \ldots . \ldots 239$

Syrnola (Puposyrnola) brunnea (A. ADAMS) ............ 239

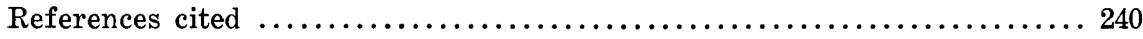




\section{Introduction}

In the southeast part of Panay Island, Central Philippines, the thick Neogene formations are extensively developed, which provide the important type sections for the Neogene biostratigraphy in the country. The biostratigraphic investigations have been carried out by several workers for establishing the standard in this area. Particularly the workers on foraminifers and petroleum geology such as CORBY et al. (1951), KLeINPEL (1957), BANDY (1963), and GONZALES (1963) gave the fine contributions along this line of the investigation. The researches were, however, concentrated to the lower sections of the Neogene strata in Panay and in consequence the biostratigraphy of the upper sections has not been made necessarily clear yet. This owes partly to the insufficient knowledge on the intercontinental correlation of the younger Neogene by means of the benthonic and especially planktonic foraminifers hitherto. It is also partly caused through neglect of the molluscan faunas, which are concentrated in the upper formations in the Iloilo basin, Panay Island.

The biostratigraphic re-examination of the classic type sections along the Tarao and Tanian rivers was undertaken as a part of the project, the palaeontological reconnaissance of the Southeast Asia supervised by Professor R. ToRIYAMA and Professor Emeritus T. Kobayashi. The field work was carried out by Drs. T. KANAYA of Tohoku University and T. SHuto of Kyushu University with the colaboration of Mess. S. A. Gonzales and P. J. SANTos of the Petroleum Division of the Bureau of Mines, Republic of the Philippines under the conduct of Professor K. AsANo of Tohoku University in November of 1964.

In that occasion the molluscan samples from higher horizons were also collected for the bifolded purpose of the preliminary study of the stratigraphic correlation of the upper formations and the biological investigation of the faunas. The sampling is, however, neither necessarily systematic nor plenty enough to be serviceable as the concrete basis for the correlation and palaeobiological study being interrupted by the typhoon under the limited program. This report is the result of the examination of the gastropods comprising the general consideration of the fossil assemblages and the systematic descriptions of 136 species and subspecies including 10 new genera and subgenera and 31 new species and subspecies. All the material studied and registered are stored at the Palaeontological Laboratory, Department of Geology, Kyushu University.

\section{Acknowledgements}

The success of the project, 'Palaentological Reconnaissance Work of the Philippines' owed to the governmental organizations and individuals on both sides of the Philippines and Japan.

The author should like to express his sincere thanks to Mr. Fernando S. BusuEgo, Jr., the Director of the Bureau of Mines of the Republic of the Philippines, who together with Mr. Elpidio C. VERA, the Vice Director, enabled the 
Japanese party to operate in the Republic with thorough support of the Bureau. The Petroleum Division conducted by Mr. Felipe U. Francisco gave the full cooperation and assistance to the Japanese party during their stay in the Republic from November 4 to December 11, 1964. Above all the author is deeply indebted to Mess. Benjamin Gonzales and Perfecto J. Santos for their kind arrangement of the field schedule and full cooperation during the field work in Panay from November 7 to November 21. Mr. Roberto R. GREY, Chief of the Paleontology Section, also gave to the party advice and help in several ways. The author wishes to express his cordial thanks to these personnels, without whose support the project could not have succeeded.

The author is also indebted the success of the expedition and laboratory works to Professor Ryuzo ToRIYama of Kyushu University, Professor Kiyoshi Asano of Tohoku University, and Professor Emeritus Teiichi KoBAYAshi of the University of Tokyo for their careful arrangement, advice, and help. Professor ToriYama also gave the thorough criticism on the type script. The author should like to thank to Drs. Katura OYAma of the Geological Survey of Japan, Tadashige HABE of the National Science Museum in Tokyo, and Masuoki HorIKoshI of the Ocean Research Institute of the University of Tokyo for their advice and criticism concerning the taxonomy of the gastropods. Sincere thanks are due to Drs. Taro KANAYA and Yokichi TAKAYANAGI of Tohoku University for the cooperation in the field survey and instructive criticism on the biostratigraphic problems.

Many personnels kindly assisted the author in having the opportunity to examine the Indonesian fossil and recent molluscan specimens stored in several institutions in Holland in occasion of comparison with the material from the Philippines during his stay in that country in the spring and summer of 1966. Professor H. J. MACGILlavRY of the University of Amsterdam, Dr. C. BeETS, the Director of the National Museum of Geology in Leiden, Dr. C. O. van Regteren Altena, Chief of the Invertebrata Section of the National Museum of Natural History in Leiden, and Dr. Henny E. Coomans, the Director of the Zoological Museum of the University of Amsterdam made him access to the material needed.

Mr. Norman TEBbLE, Chief of the Molluscan Section, Department of Zoology, British Museum (N. H.) gave to the author the permission to examine the East Asian specimens of turrid species.

The author also expresses his gratitude to the Minister of Education for the financial aid both to the expedition and the laboraory works.

\section{Geological outline of the Iloilo basin and the fossil localities}

The petroleum reconnaissance group conducted by G. W. CoRBY proposed the stratigraphic divisions of the younger Caenozoic strata of the Iloilo basin, Panay Island. According to them (1951) the strata overlying the basement complex are divided lithologically into the Singit Formation, the Tarao Formation (or Silt), the Iday Conglomerate, the Ulian Mudstone, the Balic Clay, the Maraget Sand, and the Santa Barbara Silt in ascending order. Furthermore the biostratigraphic type sections based on the benthonic foraminifers were selected 
along the Tarao, Ulian, and Suagus-Tigum rivers. They are the Singit and the lower part of the Tarao for the type of the Tertiary W, the main part of the Tarao Silt for the Tertiary X, the upper part of the Tarao and the Iday Conglo-

Table 1. Stratigraphy of the Iloilo basin, Panay island.

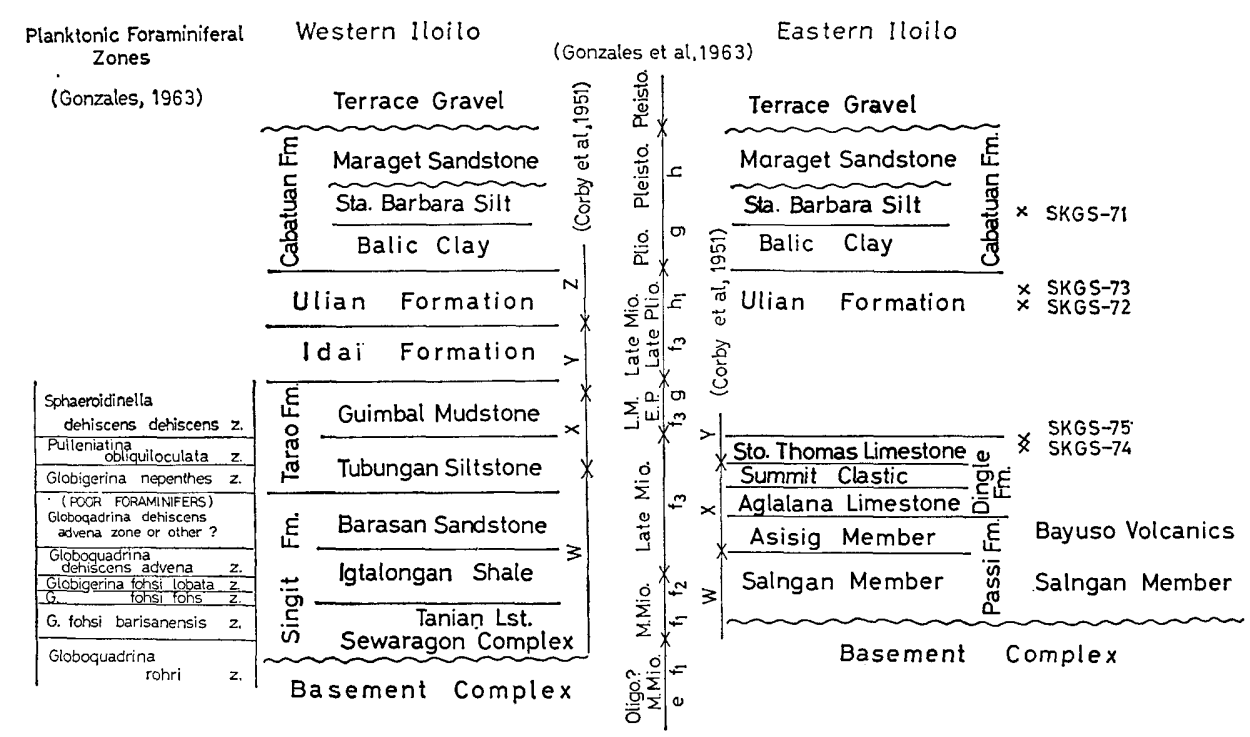

The stratigraphic divisions and correlation of the eastern and western sections are based on the report by GoNZALES et al (1963) and the planktonic foraminiferal zonation by GoNzALES (1963). All the age-assignments except for $X, Y$, and $Z$ follow GoNZALES et al (1963) and the latter after CoRBY et al (1951).

merate for the Tertiary $\mathrm{Y}$, and the Ulian Clay for the Tertiary $\mathrm{Z}$.

The geologists and palaeontologists of the Petroleum Division of the Bureau of Mines of the Republic of the Philippines gave the fine revision of the stratigraphy after the extensive field survey through the Iloilo basin and the laboratory work on the foraminifers. The rock- and time-stratigraphic divisions of the younger Caenozoic units in the surveyed area are summarised in the Table 1 after Gonzales et al. (1963). According to them all the formations from the Singit through the Ulian comprising mostly the bathyal or deep shelf sediments were considered to have been laid in the eugeosynclinal trough, in which the sinking during deposition was greater at the south than at the north part.

The Maraget Sandstone, the main part of the Cabatuan Formation, overlies several units of the older rocks, including even the Santa Barbara Silt and the Balic Clay of the same formation, with remarkable unconformity and is assigned to Pliocene to Pleistocene. The stratigraphic relation of the Santa Barbara Silt and the Balic Clay to the Ulian Formation seems to be uncertain because of the limited outcrops of the former two units at the very narrow strips along the small rivers.

The molluscan samples dealt in this paper were collected at the eastern sections of the basin from the Dingle, the Ulian, and the Cabatuan Formation. 


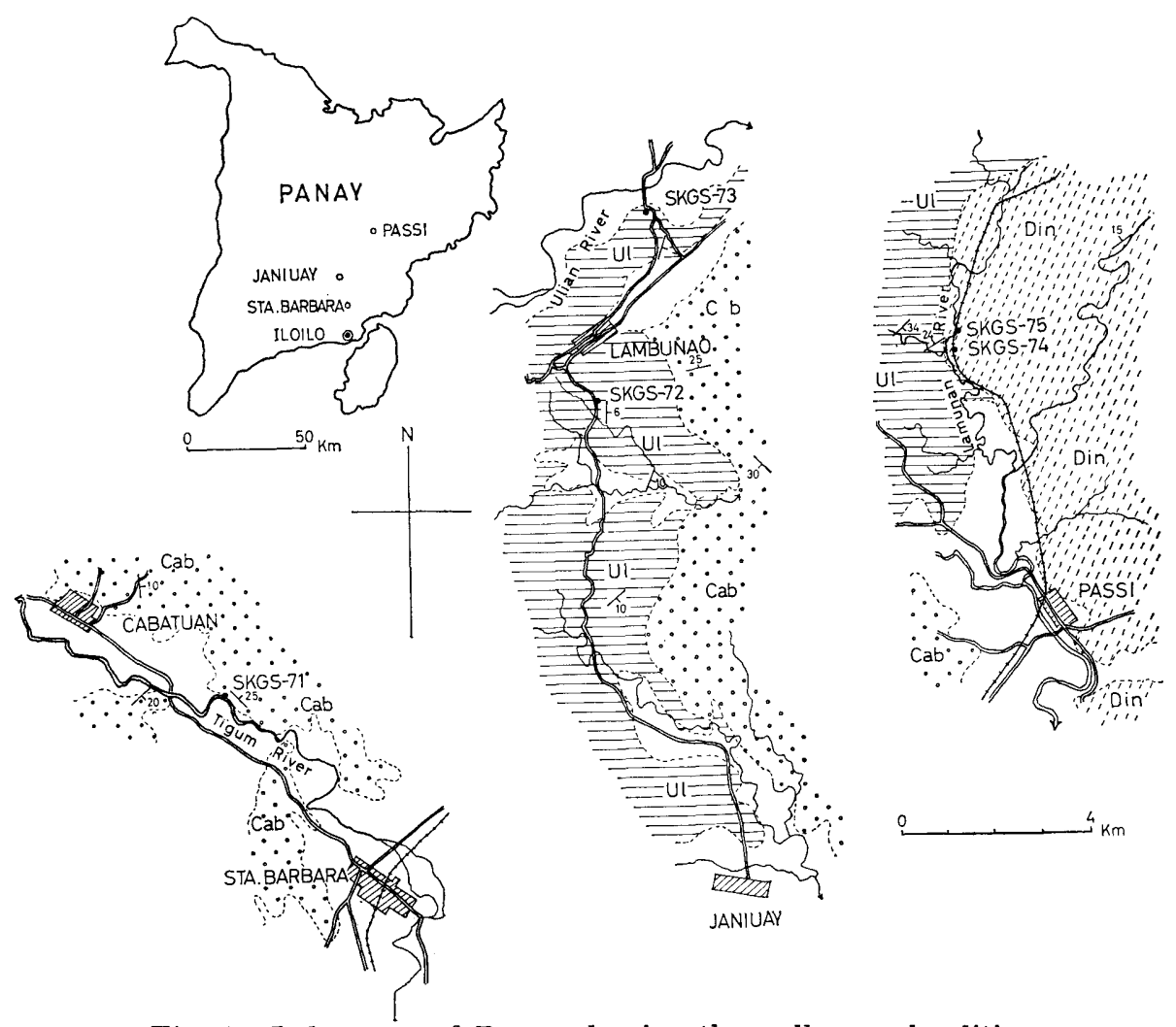

Fig. 1. Index map of Panay showing the molluscan localities.

Din: Dingle Formation, Ul: Ulian Formation, and

Cab: Cabatuan Formation.

The locality SKGS-74, Bario Bagacay along the Matiao River, $5 \mathrm{~km}$ northwest of Passi, is situated stratigraphically at the uppermost part of the Santo Thomas Limestone, the upper member of the Dingle Formation. The fossil bed consists of the gray calcareous, unconsolidated, and very fine sandstone with densely scattered fossils. The sample from the loc. SKGS-75, $500 \mathrm{~m}$ north of the preceding locality, was obtained from the gray sandy mudstone-muddy sandstone of the transitional part from the top of the Santo Thomas Limestone to the overlying Ulian Formation. Consequently this locality represents slightly higher horizon than the preceding one. The fossil occurrence is also sporadic. The detailed stratigraphic relation of the two localities is illustrated in the text-fig. 2 .

The loc. SKGS-72 and 73 are situated respectively $1500 \mathrm{~m}$ southeast of Lambunao along the Sibacongan Creek and $2500 \mathrm{~m}$ north of Lambunao along the main road leading to Calinog via Ulian River-bridge. At the locality SKGS-72 the lithology is the alternation of the gray muds and fine and medium sands and the fossils are yielded in the mud beds. At the loc. SKGS-73 the bed consists of well sorted fine sand with some calcareous patches. The sand is more or less whethered to yellowish or brownish at the outcrop and yields the fossils also sporadically. Both the loc. SKGS-72 and 73 represent stratigraphically the upper 


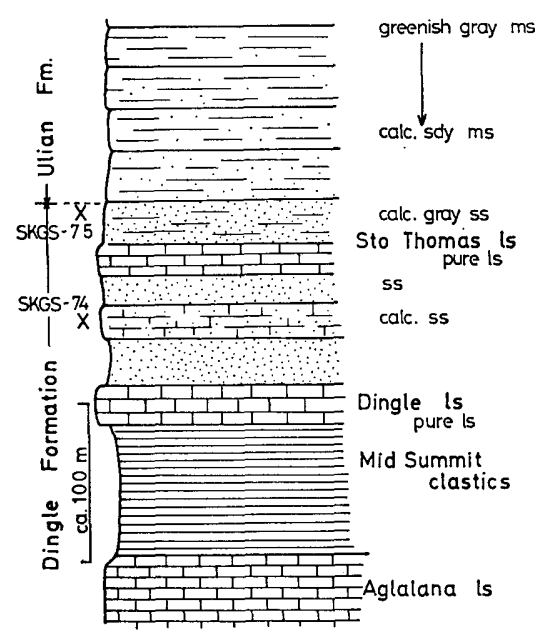

Fig. 2. Columnar section of the upper Dingle to lowest Ulian Formation at Bario Bagacay, north of Passi. part of the Ulian Formation.

The sample from the loc. SKGS-71 was collected at the cliff along the left bank of the Tigum River between Santa Barbara and Cabatuan. The fossil bed at that locality is the bluish gray sandy mud with sandy intercalations and comprises the part of the Santa Barbara Silt. The fossil occurrence is also sporadic and preservation is generally excellent.

The fairly large molluscan samples were obtained at the localities SKGS-71, 73 , and 74 , which serve for the detailed analyses. While the samples from the localities SKGS-72 and 75 are so small that any significant conclusion about the biostratigraphy and palaeoecology can not be expected from them.

All the gastropod taxa examined are listed in Table 2.

\section{General features of the gastropod assemblages and the environments}

Some ecological and environmental analyses of the molluscan assemblages obtained at three major localities shall be given in the following paragraphs. The consideration, however, is limited to a part of the community ecology and the megafeatures of the environments, because both the analytical data of the individual ecology and of the detailed environmental factors are too scanty for the fine consideration.

\section{(A) Assemblage at loc. SKGS-71}

The molluscan fossils were obtained from the bluish gray sandy silt-silty sand at the loc. SKGS-71. The individual fossils are neither piled up nor gathered together, but occur sporadically throughout the medium as mentioned in the preceding section.

Sampling was made at the vertical surface of the cliff by seven persons, one malacologist, two micropalaeontologists, one field geologist, and three assistants. As is suggested by the constitution of the sampling members random sampling can not be necessarily expected. The large specimens were possibly more atractive than the minute ones especially for the assistant collectors. To avoid the expected bias in the sampling procedure some blocks of silt and silty sand were collected for obtaining the minute specimens. The detouched and cleaned specimens, however, consist mainly of medium and moderately large species and contain only a few small and minute ones. Hence arised a question whether the sample in hand really represents the fossil population or not. A minute species, Ringicula 
Table 2. List of gastropods from the Iloilo basin, Panay island.

\begin{tabular}{|c|c|c|c|c|c|c|c|c|c|}
\hline \multirow{2}{*}{ Taxonomical Name } & \multicolumn{5}{|c|}{ Locality SKGS- } & \multirow{2}{*}{ Known Range } & \multicolumn{3}{|c|}{ Protoconch } \\
\hline & 71 & 72 & 73 & 74 & 75 & & $\mathrm{D}$ & $\mathrm{H}$ & vols \\
\hline \multicolumn{10}{|l|}{ Prosobranchia } \\
\hline \multicolumn{10}{|l|}{ Archaeogastropoda } \\
\hline \multicolumn{10}{|l|}{ Trochoidea } \\
\hline \multicolumn{10}{|l|}{ Trochidae } \\
\hline \multicolumn{10}{|l|}{ Gibbulinae } \\
\hline Gibbula (Colliculus)? sp. & & & & 1 & & & 0.34 & & 1.2 \\
\hline \multicolumn{10}{|l|}{ Umboniinae } \\
\hline Umbonium (Umbonium) vestiarium (LINNÉ) & 1 & 2 & 13 & & & Plio.-Rec. & 0.21 & & 1.2 \\
\hline Monilea (Monilea) lentiginosa A. ADAMS & & & 2 & & & Plio.-Rec. & 0.43 & & 1.8 \\
\hline \multicolumn{10}{|l|}{ Rissoidea } \\
\hline \multicolumn{10}{|l|}{ Tornidae } \\
\hline Pygmaeorota (Lydiphnopsis) philippinensis subgen. et sp. nov. & & 1 & & & & & 0.42 & & 2.8 \\
\hline \multicolumn{10}{|l|}{ Vermetoidea } \\
\hline \multicolumn{10}{|l|}{ Vermetidae } \\
\hline Dendropoma javana (MARTIN) & & & & 38 & & Low. Mio.-Plio. & & & \\
\hline \multicolumn{10}{|l|}{ Cerithioidea } \\
\hline \multicolumn{10}{|l|}{ Turritellidae } \\
\hline Turritella (Turritella) terebra bantamensis MARTIN & 15 & 1 & & & & Low. Mio. ? Plio. & & & \\
\hline T. (Kurosioia) eingulifera filiola YокоҮАмА & & & 2 & & & Up. Mio.-Plio. & & & \\
\hline \multicolumn{10}{|l|}{ Thiaridae } \\
\hline Sermyla requeti (GRATEROUP) & & & 1 & & & Pleisto.-Rec. & & & \\
\hline Tarebia submadiunensis (YoKоYAMA) & 2 & 1 & 6 & & & Up. Plio. & & & \\
\hline Cerithiidae & & & & & & & & & \\
\hline $\begin{array}{l}\text { Bittium (Bittium) glareosum Gould } \\
\text { Argyropeda divina MeLvill et STANDEN }\end{array}$ & & 10 & & 1 & & $\begin{array}{l}\text { Rec. } \\
\text { Plio.-Rec. }\end{array}$ & 0.28 & 0.32 & $2.5-3.2$ \\
\hline
\end{tabular}


Clava (Proclava) kochi (PHILIPPI)

Clypeomorus tuberculatus (LINNÉ)

Potamididae

Cerithidea (Cerithideopsilla) cf. preangerensis (MARTIN)

Stromboidea

\section{Strombidae}

Dientomochilus crispatus (SowERBY)

Tibia (Sulcogladius) powisii modesta (MARTIN)

T. (Tibia) fusus (LINNÉ)

Strombus (Laebistrombus) canarium LINNÉ

S.

(Dolomena) cf. togopiensis CoX

Cypraeoidea

Eratonidae

Dolichupis (Trivellona) shimajiriensis MACNEIL

Trivirostra pellucidula (GASKoIN)

Naticoidea

Naticidae

Naticarius marochiensis (GMELIN)

Natica (Natica) rufa (BORN)

N. (N.) zebra LAMARCK

Polinices (Polinices) aurantius (LAMARCK)

$P . \quad$ (P.) $\quad$ cf. jukesii (REEVE)

Neverita (Glossaulax) petiveriana (RECLUZ)

N. (G.) petiveriana compressa subsp. nov.

$N$. (Neverita) albula bagacayensis subsp. nov.

Mamilla mammata (RöDING)

M. maura (BRUGUIÈRE)

Tonnoidea

Cymatiidae

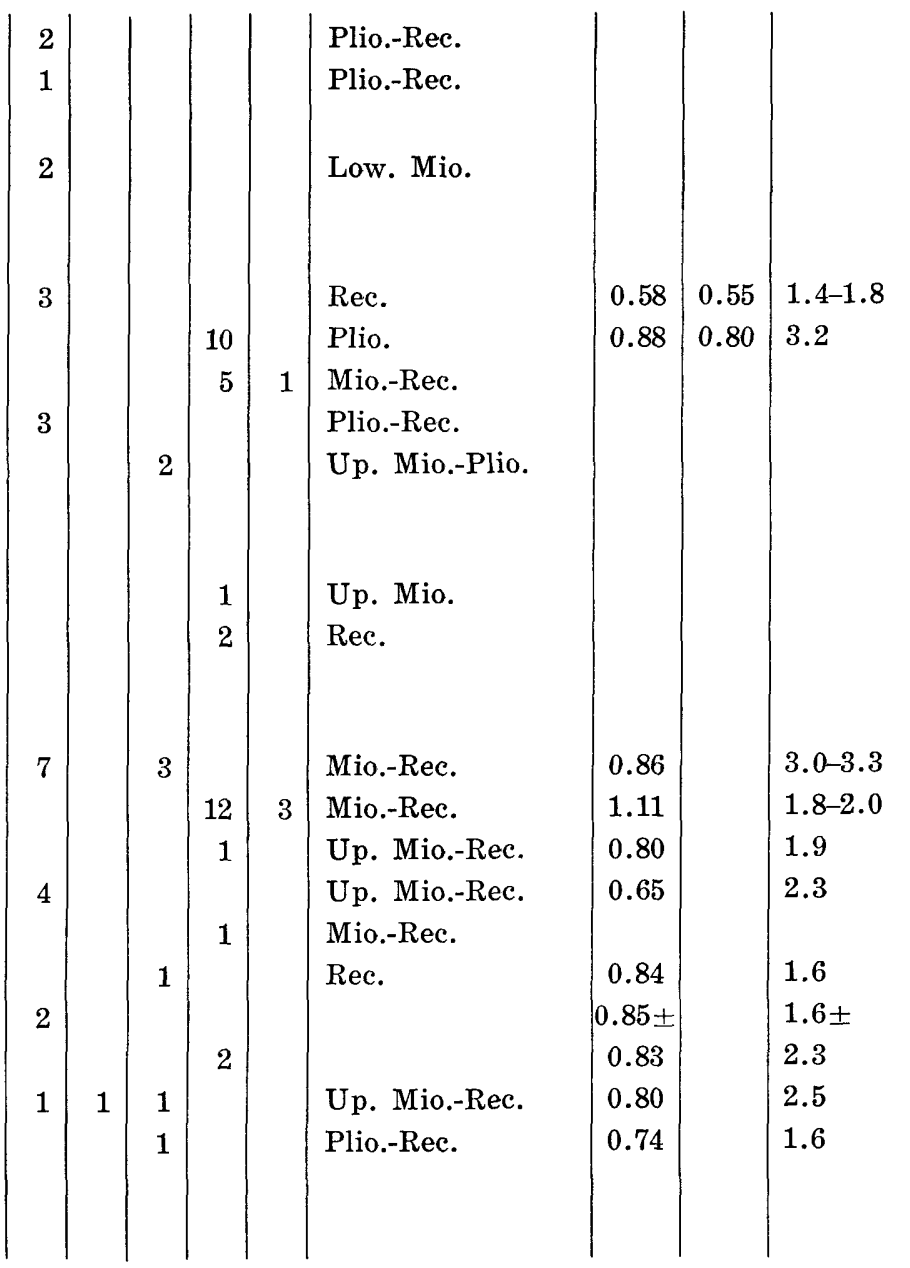




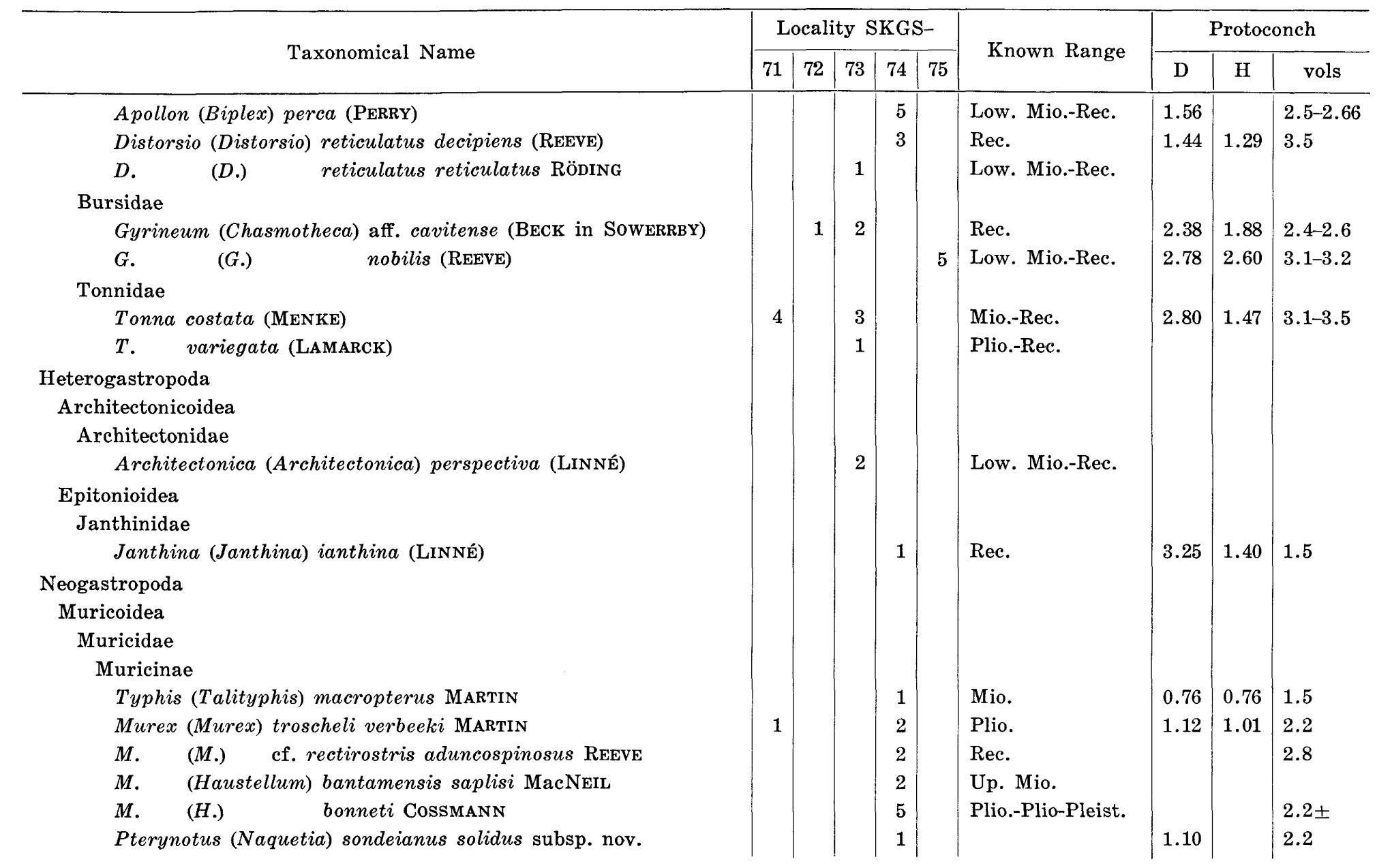


Chicoreus (Foveomurex) sp. (sp. nov. ?)

Bedeva blosvillei curvirostra subsp. nov.

Acanthinella javana (MARTIN), (gen. nov.)

Coralliophilidae

Flexopteron philippinensis gen. et sp. nov.

\section{Buccinoidea}

Pyrenidae

Indomitrella kobayashii sp. nov.

Thiarinella costifera sp. nov.

\section{Buccinidae}

Phos roseatus HiNds

P. (Philindophos) dijki NARTIN, gen. nov.

Pollia martini sp. nov.

Buccinulum (Euthria) dinglensis sp. nov.

Hindsia sinensis (SOWERBY)

$H$. cf. palembangensis HAANSTRA et SPIKER

H. varicifera A. ADAMS

\section{Nassariidae}

Nassarius (Nassarius) arcularius (LINNÉ)
N. $\quad(N$.
coronatus philippinensis subsp. nov.
$N$.
(Tarazeuxis) dorsatus (RöDING)
N. (T.) badius (A. ADAMS)
N. (Zeuxis) caelatus verbeeki (MARTIN)
$N$. (Z.) macrocephalus greyanus subsp. nov.
N. (Z.) schepmani (KOPERBERG)
N. (Plicarcularia) thersites (BRUGUIÈRE)
N. (Chelenassa) elegantissimus subgen. et sp. nov.
N. (Niotha) gemmulatus (LAMRCK)
Glabrinassa amycliforma gen. et sp. nov. 


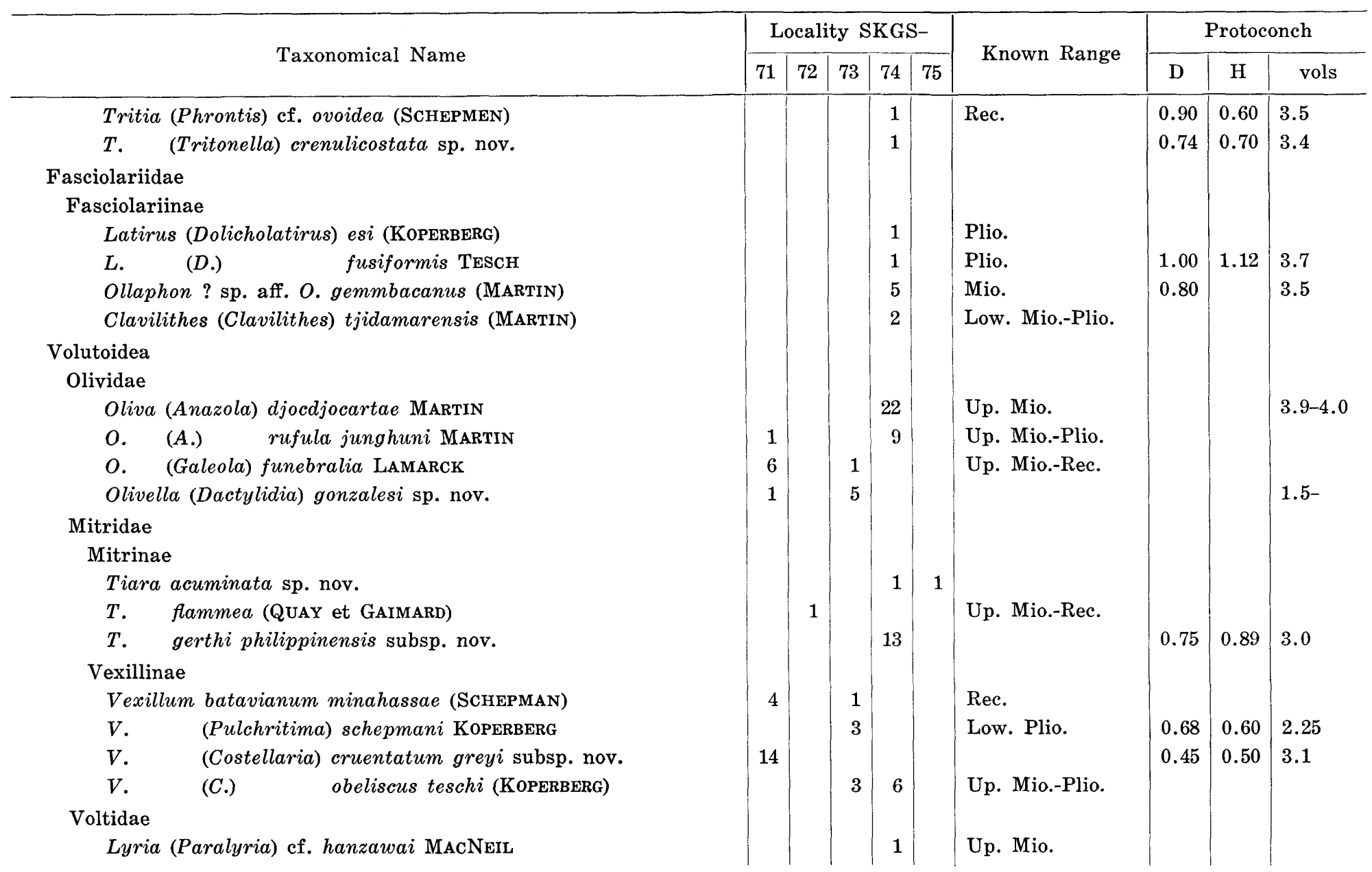




\section{Cancellariidae}

Merica asperella (LAMARCK)

$M$. asperella varicosa subsp. nov.

$M$. cf. laticosta (LÖBECKE)

Scalptia crenifera (SOWERBY)

\section{Conoidea}

Turridae

Turrinae

Gemmula (Gemmula) speciosa (REEvE)

$\begin{array}{lll}G . & (G .) & \text { graeffei (WEINKAUFF) } \\ \text { G. } & (G .) & \text { hombroni HEDLEY } \\ \text { G. } & (G .) & \text { kieneri woodwardi (MARTIN) }\end{array}$

G. (Unedogemmula) gendinganensis (MARTIN)

G. $(U$.$) \quad butonensis asanoi subsp. nov.$

Turris (Turris) panayensis sp. nov.

Turriculinae

Nihonia santosi sp. nov.

Pleurofusia (Pseudofusia) dinglensis subgen. et sp. nov.

Ancistrosyrinx (Pagodasyrinx) granulatus SMITH, (subgen. nov.)

Paradrillia serana (FISCHER)

$P$. inconstans (SMITH)

\section{Clavinae}

Inquisitor (Ptychobela) neglectus (MARTIN)

I. (Inqusitor) molengraafi dinglensis subsp. nov.

I. (I.) batavianus (MARTIN)

Microdrillia (Pulsarella) madiunensis (MARTIN)

$M . \quad(P$.$) \quad cf. madiunensis (MARTIN)$

Mangeliinae

Euclathurella (Miraclathurella) bagacayensis sp. nov.
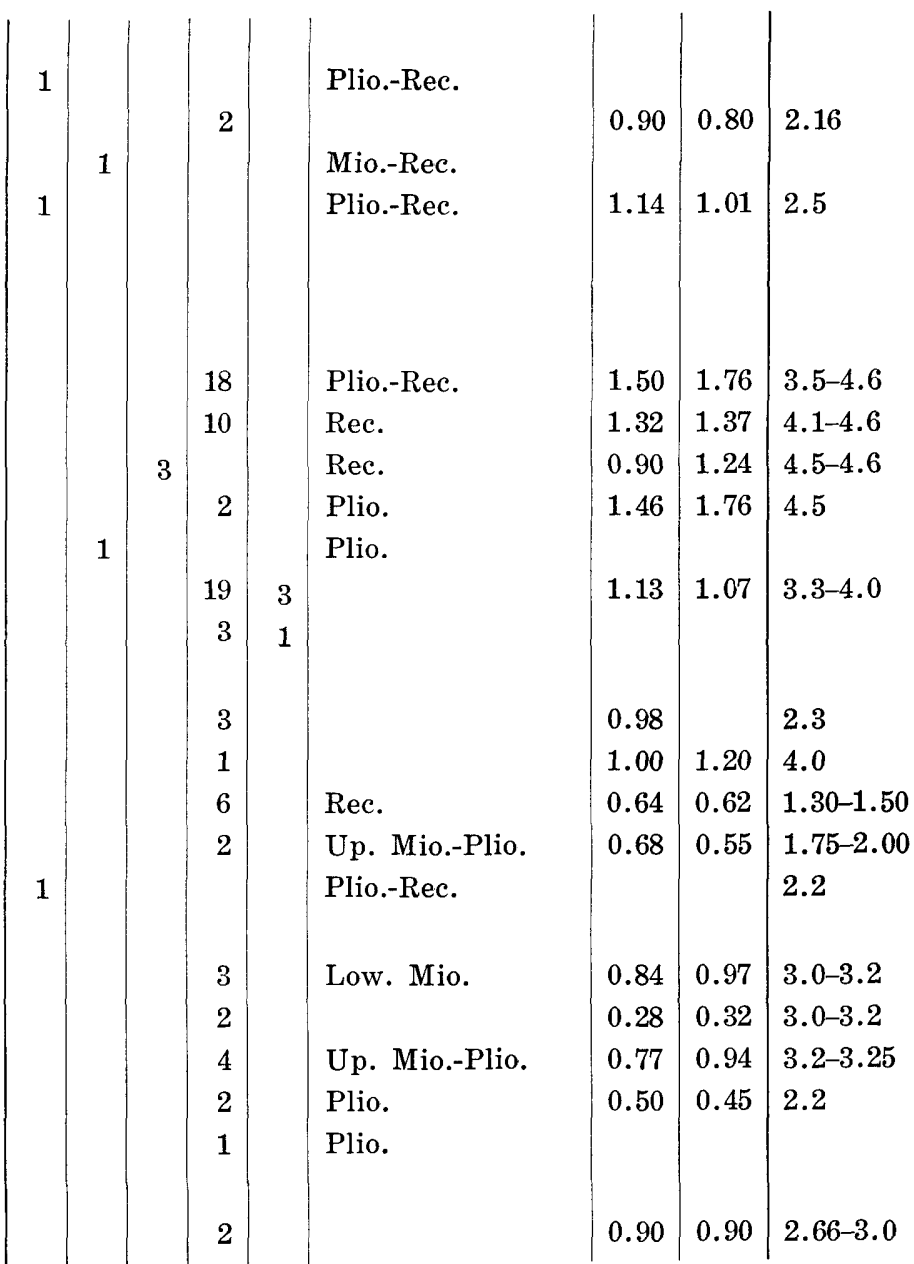


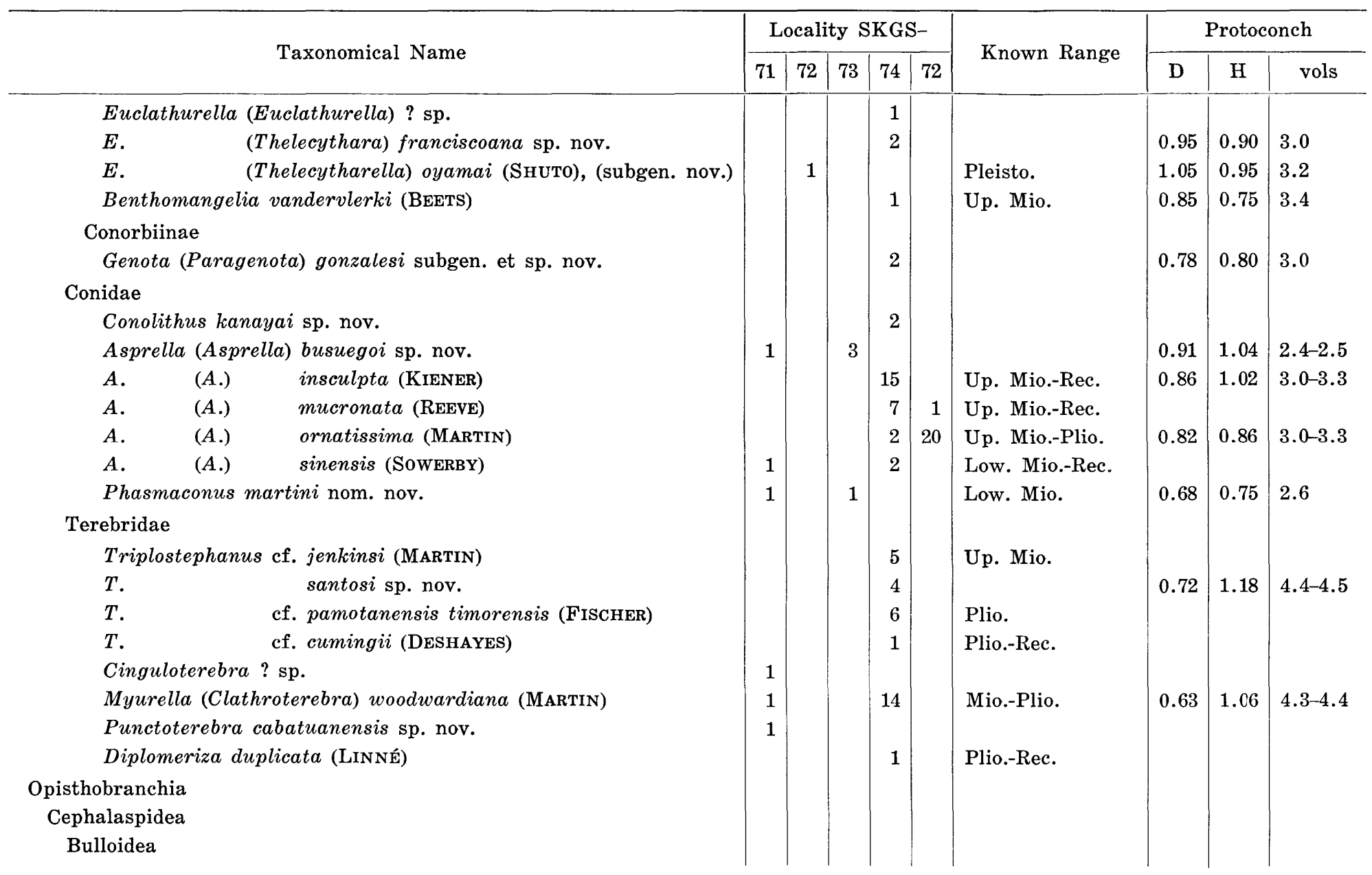


Ringiculidae

Ringicula (Ringiculina) arctata glabra MARTIN

Actaeonidae

Pupa cf. reussi (MARTIN)

Scaphandridae

Cylichna (Eocylichna) sibogae (SCHEPMAN)

Atycidae

Atys (Aliculastrum) porcellanus GoULD

Bullidae

Bulla (Bulla) ampulla LINNÉ

Entomotaeniata

Pyramidelloidea

Pyramidellidae

Syrnola (Puposyrnola) brunnea (A. ADAMS)

\begin{tabular}{|c|c|c|c|c|c|c|}
\hline & 8 & 2 & 4 & 1 & & $\begin{array}{l}\text { Plio. } \\
\text { Mio. } \\
\text { Pleist.-Rec. } \\
\text { Rec. } \\
\text { Plio.-Rec. } \\
\text { Rec. }\end{array}$ \\
\hline species & 38 & 16 & 33 & 74 & 9 & \\
\hline individuals & 135 & 30 & 86 & 385 & 36 & \\
\hline
\end{tabular}

Total number 
(Ringiculina) arctata glabra MARTIN, is included in the sample as a predominant species. This fact seems to deny the significant bias in sampling to have neglected the minute specimens. In consequence it is estimated that the sample in hand nearly represent the fossil polulation at the locality SKGS-71.

Relation of the fossil and living (original) populations is the next problem. The gastropod sample consists of 38 species (135 individuals), of which 13 species (47 individuals) are Archaeo- and Mesogastropoda. The percentage of the archaeo- and mesogastropod specimens to the whole sample is almost equal both at the species-level and at the individual-level. That is to say they are respectively 34.2 percent by species and 32.4 percent by individual. In other words number of the individuals per species is almost equal in Archaeo- and Mesogastropoda and in other gastropods. In this case 3.6 and 3.5 individuals per species respectively for the former and the latter group.

All the elements in the sample are purely marine, except two specimens of Tarebia submadiunensis (YoKOYAMA), which should have been brackish-water dweller as is suggested by the ecology of the living allies. The fossil specimens of Tarebia submadiunensis are markedly broken at the apical part and somewhat worn on whole surface. This fact suggests the transportation of the shells at remarkable distance before burrial or abrasion during the life time. The fossil sample also contains such imperfect specimens as Cerithidea (Cerithideopsilla) sp. cf. C. (C.) preangerensis (MARTIN) (extremely imperfect), Clava (Proclava) kochi (PHILIPPI) (remarkably imperfect) and Clypeomorus tuberculatus (LINNÉ) (somewhat worn). They were not broken or abraded during the procedure of sampling or cleaning, but are imperfectly preserved in the medium primarily. This fact also suggests that they were abraded at life time or moved at some distance after death before deposition. Absence of the rocky coast elements in the allochthonous species is the indication that there must have not been rocky coast near by.

The remaining specimens, the majority of the sample, are in general preserved so excellent that almost all the species, not to say all the specimens, contain at least a specimen with perfectly preserved protoconch. The ornamentation is also finely preserved to serve for the detailed examination of the morphological development on these specimens. The bivalve shells occurring in common with these gastropods also show superior preservation. That is to say these specimens were neither moved for significant distance after death, nor abraded by the passing-by particles of detritus during the life time and after death. Accordingly it is presumed that the assemblage except for a few species derived from outside pointed above is practically autochthonous or at least paraautochthonous, although there are few evidences that the elements are autochthonous in the strict sence of meaning. In other words the individuals except for those of Tarebia submadiunensis (YokoYama), Cerithidea (Cerithideopsilla) sp. cf. C. (C.) preangerensis (MARTIN), Clava (Proclava) kochi (PHILIPPI) etc. must have deposited at their nitches or at least in the close vicinity to their nitches. The preference to the substratum of the elements at life time is almost of the same kind as far as the knowledge on the living representatives are concerned. According to the known 
data, although they are still scanty, the living representatives of the elements of this assemblage prefer the substratum of sandy silt to medium sand. The lithology of the fossil bed at the loc. SKGS-71 is within the range of this particle size. This also supports the assumption that the majority of the gastropod assemblage at this locality is autochthonous or paraautochthonous.

Examining the predominance of the species, a very distinct unevenness is recognized with the marked predominance of Turritella bantamensis MARTIN $(11.1 \%)$, several species of nassariids $(31 \%)$, Vexillum cruentum greyi sp. nov. (10.3\%), and Ringicula arctata glabra MARTIN (5.9\%) occupying 58 percent of the total number of the individuals (text-fig. 3 ), if the predominance is expressed by the number of the individuals. Thus the assemblage excluding the exotic elements may be called Turritella-Nassarius assemblage so far as the gastropods are concerned. If the stress is put on the bio-mass as in the recent marine ecological investigation, the assemblage can be called Turritella-Nassarius-Tonna association on the basis of the rough calculation of the relative size of the biomass distribution of the sediments on the level bottom.

of each dominant species. Many of the dominant species seems to prefer more sandy bottom than the average of preference of the total species. This may suggest the clump-distribution of species at the life time according to the patchy

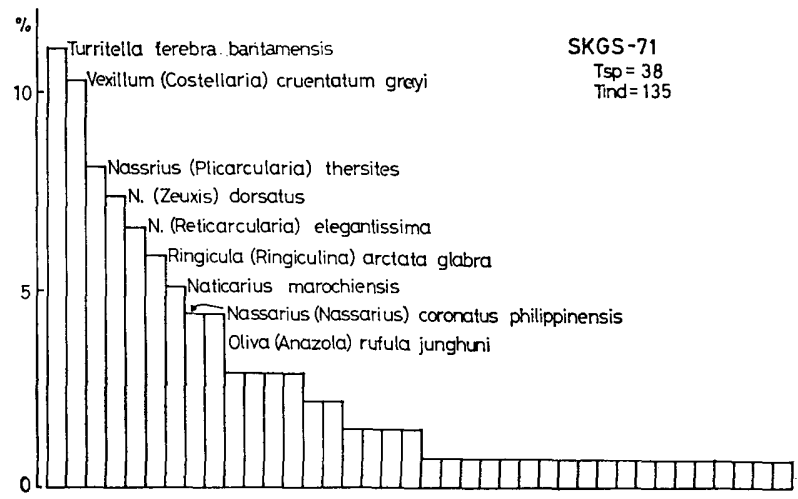

Fig. 3. Diagram showing the predominance of the species of the gastropod assemblage at SKGS-71.

The estimation of the depth of the habitat of this 'autochthonous' association have very imperfect foundation, because, on one hand, the knowledge of the depth-ranges of the living species is very poor and, on the other hand, the molluscan species tend to dwell at the different depth place by place. Accordingly only the crude result may be expected from the bathymetric analysis of any fossil assemblage. An attempt, however, was made on the material from Panay along this line of the purpose. The known ranges of the living elements of the present assemblage are diagrammatically illustrated in text-fig. 4, in which the number of species are counted at every 10 meters-intervals of depth-ranges. The species which are considered to be allochthonous are of course omitted in this calculation. As is indicated in the text-figure the number of the species is large between 0-40 m, especially between $10-30 \mathrm{~m}$, with the median at $20+\mathrm{m}$ and abruptly 
decreased below $40 \mathrm{~m}$. None of the extinct species demand the significant modification of the suggested depth of the habitat so far as the 'autochthonous' elements are concerned.

In conclusion the gastropod assemblage obtained at the loc. SKGS-71 consists mainly of the association of the silty sand-sandy silt bottom of the sublittoral zone $(10-30 \mathrm{~m}$ below sea level) with the exotic elements brought from the shallower and protected area. The movement of the water must have not prevent the deposition of silt and not allowed the free erosion of it in normal condition. That is to say the movement of the water must have been less than $1 \mathrm{~cm}$ per second at the dull phase and less than $40 \mathrm{~cm}$ per second at the full current. The occasional turbidity masses reaching this level bottom should be postulated for the agency of transportation of the exotic gastropods. The weakly patchy pattern of the sediment may be also attributed to the turbidity currens of small scale.

\section{(B) Assemblage at loc. SKGS-73}

At the locality SKGS-73 the sampling was carried out at the small area $(3 \mathrm{~m} \times$ $9 \mathrm{~m}$ ) on the steep cliff by the road and
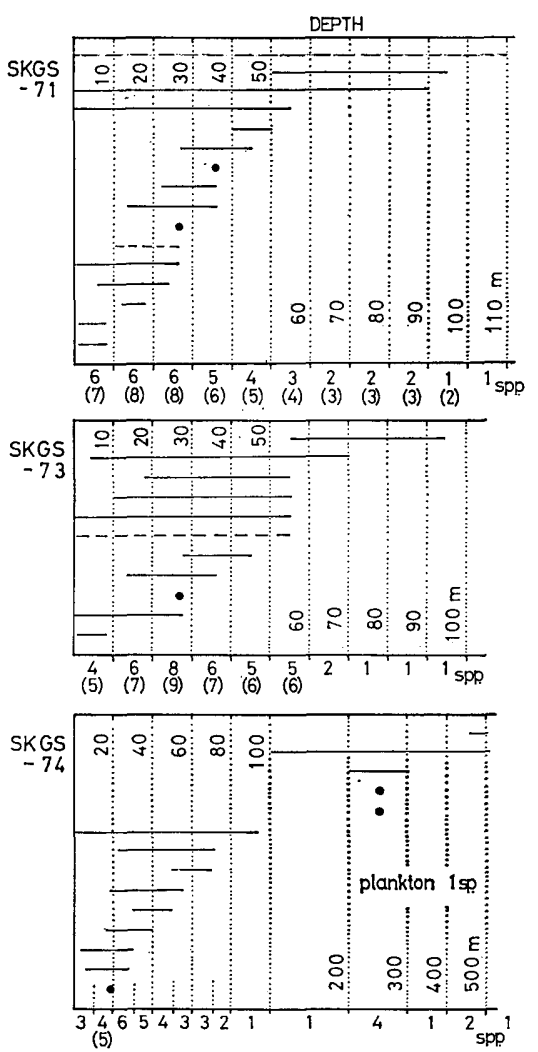

Fig. 4. Known depth-ranges in the tropic waters of the living components of the gastropod assemblages in Panay. Depth is represented in term of meters. Broken lines indicate the infered range. supplemented through the collection from the blocks immediately below the cliff by the same persons as at the loc. SKGS-71. The matrix of the shell is well-sorted and imperfectly consolidated fine sandstone. Detouching of the fossils is so easy that the sampling is expected not to be significantly biased.

The grastropod assemblage at the loc. SKGS-73 is similar to the preceding one including 14 common species out of 33 total species (42 percent). Among 86 total individual specimens 45 belong to these common species ( 52 percent) and the bivalves from the two localities also contain many common species. The figure of 42 percent of the common species is extremely high among the fossil records and comparable with the percentage of the common species between the Cheribonian Pliocene assemblages of Tji Djoeroi and Tji Djadjar (19/34=56 percent) and between $\mathrm{Tji}$ Djoeroi and Goenoeng Gombel $(28 / 42=66$ percent) in Java or the figure between the Dainitian molluses of the sixth horizon of the Miyazaki Group and the Tenno sand of the Kakegawa Group (34/78=44 percent) in Southwest Japan. 
The assemblage at the loc. SKGS-73 also contains the imperfectly preserved specimens of the brackish species of Tarebia submadiunensis (YoKoYAMA) and Sermyla requeti (GRATELOUPE). The other specimens are generally good in preservation like as at the preceding locality and do not show the feature of transportation for remarkable distance. They are reasonably considered to belong to an autochthonous or paraautochthonous community. In spite of the high percentage of the common species between the gastropod assemblages at the loc. SKGS-71 and 73 the similarity of the assemblages is lower than the value expected. The similarity index after Morisita (1959)* is only 0.208 between the two assemblages. Although this figure seems to be unreasonably small affected by the fact that many of the common species are represented by only one specimen, it can not be denied that two assemblages are remarkably different each other. They differ really in the ecological conditions. This is suggested, on one hand, by the lithological divergence between two localities and, on the other hand, by particular association of the species in both assemblages. The lithology of the fossil-bearing bed at loc. SKGS-73 is well-sorted fine sandstone as noted above instead of silty sand-sandy silt at loc. SKGS-71. The pure sand-dwellers and the elements of slightly deeper water such as Monilea (Monilea) lentiginosa A. AdAMs, Architectonica (Architectonica) perspectiva (LINNE்)**,Distorsio (Distorsio) reticulatus RöDING, Nassarius (Zeuxis) caelatus verbeeki MARTIN (pure sand-dwellers), Vexillum (Pulchritima) schepmani KOPERBERG, and Gemmula (Gemmula) hombroni HEDLEY (deeper water elements) characterize one feature of this assemblage. Furthermore the fact that the deeper water elements just

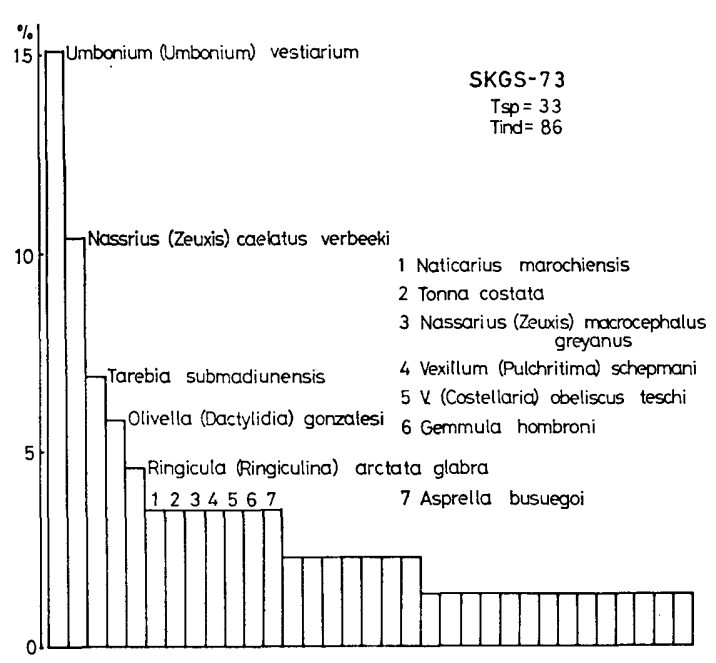

Fig. 5. Diagram showing the predoninance of the species of the gastropod assemblage at SKGS-73. mentioned are respectively one of the dominant species of this assemblage should be noted.

The composition of the assemblage is diagrammatically illustrated in the text-fig. 5. The assemblage is predominated by Umbonium (Umbonium) vestiarium (LINNÉ) (15.1 percent), Nassarius (Zeuxis) caelatus verbeeki MARTIN (10.4 percent), Tarebia submadiunensis (YokoYAMA) (6.9 percent), and Olivella (Dactylidia) gonzalesi sp. nov. (5.8 percent). Ringicula (Ringiculina) arctata glabra MARTIN, Naticarius marochiensis (GMELIN), Tonna costata $* C_{\lambda}=\frac{2 \Sigma n_{1 i} n_{2 i}}{\left(\lambda_{1}+\lambda_{2}\right) N_{1} N_{2}}, \quad \lambda_{1}=\frac{\sum n_{1 i}\left(n_{1 i}-1\right)}{N_{1}\left(N_{1}-1\right)}, \quad \lambda_{2}=\frac{\Sigma n_{2 i}\left(n_{2 i}-1\right)}{N_{2}\left(N_{2}-1\right)}$

where $N_{1}$ and $N_{2}$ are total number of the individuals in the sample I and II. Similarity index $C_{\lambda}$ may be between 1.0 and 0 . If it is about 1.0, two samples belong one and same community and it will be 0 , when no common species occur in both samples.

** Strictly speaking it is synbiotic with sand-dwelling sea anemones. 
(MENKE), Nassarius (Zeuxis) macrocephalus greyanus subsp. nov., Vevillum (Pulchritima) schepmani KoPERBERG, V. (Costellaria) obeliscus teschi (KoPERBERG), Gemmula (Gemmula) hombroni HEDLEY, and Asprella busuegoi sp. nov. are the next dominant species. Accordingly the 'autochthonous' association is tentatively called Umbonium (Umbonium) vestiarium-Nassarius (Zeuxis) caelatus verbeeki association.

In the depth-range chart the number of the species is largest at the interval of $10-20 \mathrm{~m}$ and gradually decreased at the deeper intervals. While the number of the species of the shallowest interval, $0-10 \mathrm{~m}$, is only a half of that of the next deeper one. From these data the depth of the habitat of the original community is roughly estimated around $20 \mathrm{~m}(10-40)$ below sea level. In conclusion the fossil assemblage at the loc. SKGS-73 mainly consists of almost autochthonous purely marine association of the fine sand bottom of slightly more than $20 \mathrm{~m}$ deep with the exceptional exotic elements from the brackish environment. The water-movement at this habitat is supposed to be less than a few tens $\mathrm{cm}$ per second at the stronger phase and between $2-3 \mathrm{~cm}$ and $0.5 \mathrm{~cm}$ per second at the dull phase letting the particles of only fine sand size deposits. At the bottom under such environmental condition as noted above the thick growth of the aqueous vegitation can not be expected. Low percentage of the phytophagous species to the total gastropods $(7 / 33=21$ percent) may be the reflexion of the sparse vegitation.

\section{(C) Assemblage at loc. SKGS-74}

At the loc. SKGS-74 quite similar way of sampling as at the loc. SKGS-73 was practiced both at the small cutting by the rail-road track and the weathered stuff below the cutting. In consequence there might be some chance for biased sampling affected by the specimens with conspicuous form or rigid shell, although the degree of bias is expected to be small as is indicated by the structure of predominance in the assemblage (text-fig. 6).

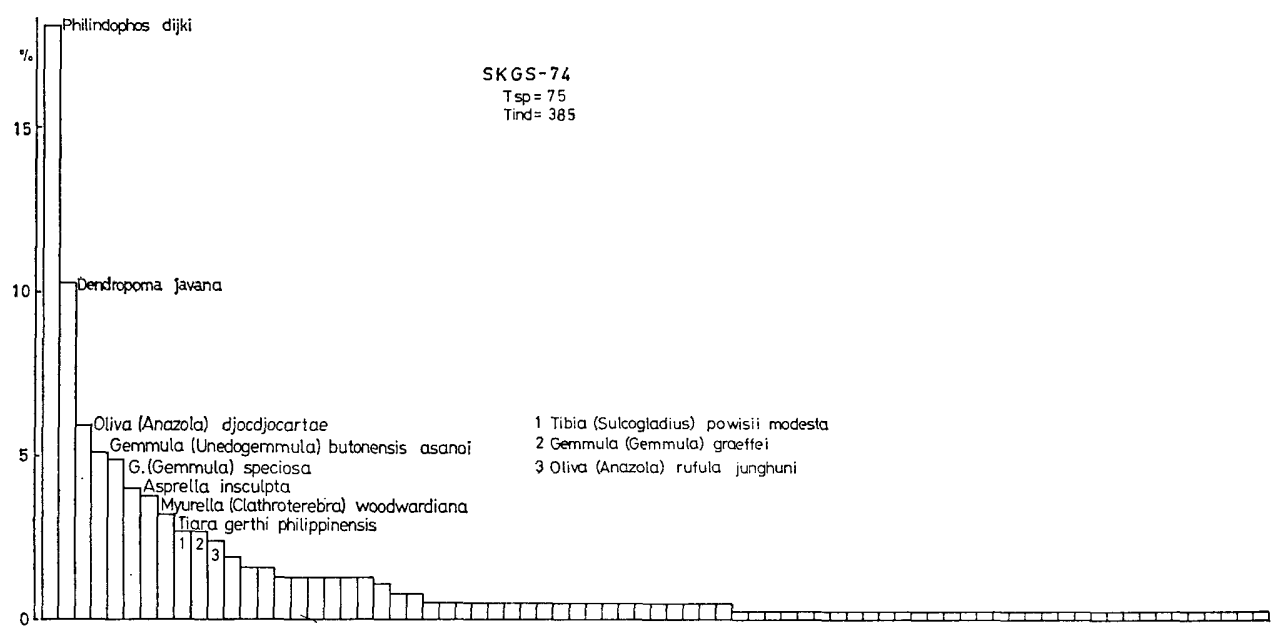

Fig. 6. Diagram showing the predominance of the species of the gastropod assemblage at SKGS-74. 
The gastropods at the loc. SKGS-74 are quite different from those of the loc. SKGS-71 and 73. The former contains only two and one common species respectively with the assemblage at SKGS-71 and 73. The assemblages of SKGS-71 and 73 respectively contain Archaeo- and Mesogastropoda by 34.2 percent (13 spp/38 spp) and 42.4 percent (14/33), while the present assemblage has species of these taxa only by 17.5 percent (13/74). Among the Neogastropoda many species of muricids, buccinids, fasciolariids, turrids, conids, and terebrids are conspicuous in the assemblage of SKGS-74, while those of SKGS-71 and 73 are predominated by nassariids.

Occurrence of the fossils is dens but sporadic and the preservation of the individual specimens ranges from quite perfect to very slightly worn at the apeces. Any considerable transportation of the shells after death before burial can not be concluded by the facts just mentioned. Furthermore none of the constituent species of the assemblage have been reported from the significantly different type of substratum from the silty sand of SKGS-74. The structure of assemblage illustrated in the frequency distribution diagram is perfectly normal. These lead to the assumption that this assemblage also represents an autochthonous or paraautochthonous association.

As is diagrammatically illustrated in text-fig. 6, the specific diversity of the assemblage is remarkably great. The high specific diversity associated with lack of clear predominance by a few species is said to be one of the major features of the tropic terrestrial flora and marine fauna. This assemblage, however, fairly illustrates the marked predominance by Philindophos dijki (MARTIN) (18.1 percent), Dendropoma javana (MARTIN) (10.3 percent), Oliva (Anazola) djocdjocartae MARTIN (5.9 percent), Gemmula (Unedogemmula) butonensis asanoi subsp. nov. (5.1 percent), G. (Gemmula) speciosa (REEVE) (4.9+ percent), and Asprella insculpta (KIENER) and is tentatively called Philindophos dijki-Dendropoma javana association.

The estimation of the depth of the habitat of this association is very difficult because it contains only a small number of the living species. In the chart of the depth-ranges of the elements of this association the number of the species in the given intervals show apparently two maxima. One maximum is situated at the interval between 20 and $30 \mathrm{~m}$ and the other at the interval between 200 and $300 \mathrm{~m}$. This does not mean that the assemblage is the mixture of two associations of different habitats, but simply reveals the imperfection of the data concerning the depth-range of the marine gastropods. In this chart a remarkable tendency may be recognized that the elements of the deeper shelf zone tend to range either up to the shallower or down to the deeper zones. In other words the shallower shelf elements and the bathyal ones of the gastropods overlap their habitats at the deeper zone of the shelf. Similar bathymetric feature of the molluscan association was noted by KOPERBERG (1931) on the data obtained at JONKERKoPerberg loc. 2 (Fundord 2) in Timor. DeLL (1959) also mentioned the tendency for overlapping of the upper bathyal elements and lower shelf ones at the lower margin of the continental shelves. The assemblage from loc. SKGS-74, moreover, contains a pelagic molluscan species, Janthina (Janthina) ianthina 
(LINNÉ) and the sediments removed from the shells during the cleaning procedure have the planktonic foraminifers at higher percentage than the benthonic ones. These facts suggest that the off-shore pelagic water was drifted over the habitat in question.

There is another line of the fact that the assemblage contains only 3 phytophagous and detritophagous species ( 4 percent), which should be controlled by the supply of the plant or detritus. The growth of the plant is, in turn, primarily regulated by the depth of penetration of the light into the water. Paucity of the autochthonous phytophagous elements suggests the deep nature of the habitat so far as the depth-range is above the edge of the shelf. Below the edge of the shelf the percentage of the non zoophagous elements may be increased by the presence of seemingly detritus eater.

In conclusion the gastropod assemblage at the loc. SKGS-74 is autochthonous or at least paraautochthonous and the habitat was silty sand bottom near shelf edge and drifted by the pelagic water which was occasionally oversaturated with calcium-carbonate.

\section{(D) Assemblages at loc. SKGS-72 and 75}

Ecological data are insufficient as to the assemblages of loc. SKGS-72 and 75. The latter is, however, closely allied to that of SKGS-74 having 6 common species out of total 8 ones ( 75 percent). Its environmental condition might have been similar to that of SKGS-74 except for more silty and remarkably shallower nature of the habitat without bathyal species. This assemblage is considered almost autochthonous by the same reasons as the preceding one.

The environmental conditions at the loc. SKGS-72 seems to be similar to those of SKGS-71 and 73, and probably closer to the latter controlled by the more sandy nature of the substratum than at SKGS-71.

\section{Age of the fossil assemblages}

In estimation of the age of the fossil assemblages the Lyellian method, index-fossil method, and range-chart method are adopted synthetically. As pointed out by many workers, age-estimation by the percentage of the number of the living species to the total (Lyellian percentage) implies the fault that the Lyellian percentage of any fossil assemblage have been steadily increasd in the course of time through the discoveries of the living representatives of the "extinct" species. Moreover the marked tendency for longer geological range of the tropical species than the temperate and cool water elements causes the serious difficulty in the procedure of the regional correlation over the climatic zones. The index-fossil method of correlation also can not exclude the weakness, because the index fossils can not demand the absolute value as a nature. Any species, which is recognized as the index fossil of a certain age in one province, can not be expected to have absolutely the same geological range as in the former in other province. It is concerned with the palaeobiogeography and particularly with the history of the evolution and migration of the species in question. 
The range-chart method, in which the age of the fauna can be estimated by the stratigraphic position of the maximum density of the number of the species on the compiled range-chart of the elements, can not be necessarily based on the reliable data. In consequence it is suggested that the plausible estimation of the age of the fossil assemblage can not be expected from the result through only a single method. It, however, does not deny the possibility of the appropriate ageestimation of the fossil assemblages, if the methods mentioned above are adopted synthetically together with the careful comparison with the results through other lines of the investigation.

\section{(A) Age of the assemblage at loc. SKGS-71}

At the loc. SKGS-71 the fossil specimens were collected from the Santa Barbara Silt in the area of $1.5 \mathrm{~m} \times 20 \mathrm{~m}$ on the vertical cliff by river. In the fossil sample of moderate size the total 58 species of mollusca $(\mathrm{T})$ are distinguished, of which 38 species are gastropods $(\mathrm{Tg})$ and 20 species are bivalves $(\mathrm{Tb})$. Total number of the species identified at the species- or subspecies-level (I) is 51 including new species, of which the gastropod ( $\mathrm{Ig}$ ) and bivalve ( $\mathrm{Ib}$ ) fractions are respectively 37 and 14 . The number of the living species (L) is 29 , of which the gastropod ( $\mathrm{Lg}$ ) and bivalve ( $\mathrm{Lb}$ ) fractions are respetcively 21 and 8 . Accordingly the Lyellian percentage is as follows:

$$
\begin{gathered}
\mathrm{L} / \mathrm{I}=29 / 51=56.8 \text { percent }(\mathrm{Lg} / \mathrm{Ig}=21 / 37=56.7 \text { percent, } \mathrm{Lb} / \mathrm{Ib}=8 / 14= \\
57.1 \text { percent })
\end{gathered}
$$

The difference of the Lyellian percentages for gastropods and bivalves is only 0.4 percent. This figure is rather small comparing with the difference in percentage of living species for gastropods and bivalves of other known assemblages, in which there is a significant tendency that the Lyellian percentage for the bivalves is remarkably larger than that for the gastropods reflecting the longer geological range of the Caenozoic bivalves than the gastropods.

The Lyellian percentage of the assemblage at the loc. SKGS-71 for whole mollusca, 57 percent, should be compared with those of the assemblages from Atjeh I in Sumatra (56 percent, MARTIN) and Tjidjadjar in Java (56 percent, MARTIN). It is also similar to, but is apparently distinguished from those of JoNKER's loc. 4 in Timor ( 52 percent, KoPERBERG), Sonde in Java ( 53 percent, MARTIN), and Menengten in Java (54 percent, MARTIN) with somewhat larger figure among the southeast Asian fossil molluscan assemblages. This comparison suggests the age of the assemblage at loc. SKGS-71 may be "early Late Pliocene" in the sence of the malacologists such as MARTin, Oostingh, BeEts, Altena, and KOPERBERG.* The confidence interval of this figure at 95 percent confidence coefficient is 47-66 percent. That means the age of the fossil molluses of SKGS-71 is Pliocene at significant level of 95 percent. According to BIRD (1967) about 400 molluscan species, at least, are needed to distinguish Upper Miocene, Lower Pliocene, and Upper Pliocene at significance level of 95 percent (one half interval:

* In this section the epoch names will be used in the sence of the malacologists noted above. 
about 5 percent). The difference of a few percent in Lyellian percentage can not be statistically significant at 95 percent level, unless a sample consisting of more than 4000 species is examined. In other words more than 4000 species belonging one and same horizon should be examined to distinguish statistically the Sondian, Cheribonian, and Bantamian.

The following index species are included in the assemblage.

Cerithidea (Cerithideopsila) cf. preangelensis MARTIN

Phasmaconus martini nom. nov. (for Conus jenkinsi MARTIN, partim, 1895)

Turritella (Turritella) terebra bantamensis MARTIN

Oliva (Anazola) rufula junghuhni MARTIN

Veremolpa bataviana (MA,RTIN)

Murex (Murex) troscheli verbeeki MARTIN

Nassarius (Zeuxis) schepmani (KOPERBERG)

Mabellarca tambacana (MARTIN)

Tarebia submadiunensis (YoKOYAMA)

Tellina prototenuilirata NomURA

Low. Mio., Indonesia

$\begin{array}{cc}\text { ditto, } & \text { ditto } \\ \text { (Low. Mio.?) Plio., } & \text { ditto } \\ \text { Up. Mio.-Plio., } & \text { ditto } \\ \text { ditto, } & \text { ditto } \\ \text { Plio., } & \text { ditto } \\ \text { ditto, } & \text { ditto } \\ \text { ditto, } & \text { ditto } \\ \text { Up. Plio., } & \text { Taiwan } \\ \text { ditto, } & \text { ditto }\end{array}$

All the indices except for Cerithidea (Cerithideopsilla) cf. preangerensis and Phasmaconus martini, the former of which may need some taxonomic revision, range through Pliocene. The most dominant species, Turritella (T.) terebra bantamensis, has been taken for the most reliable index of the Bantamian stage in Java, which is the lowest Pleistocene according to OostingH (1938), although MARTIN mentioned its occurrence in the lower Miocene bed.

The number of the species of whole molluscs (and gastropods) ranging through respective time-stratigraphic intervals are 9 (5) for Lower Miocene, 16 (10) for Upper Miocene, 30 (22) for Lower Pliocene, 32 (23) for Upper Pliocene, 24 (18) for Pleistocene, and 29 (21) for Recent as indicated in the range-chart of the species. The maximum [32 (23)] apparently lies in Upper Pliocene with almost equal submaximum [30 (22)] in Lower Pliocene. It is notable that the species ranging through Upper Miocene are abruptly decreased in number in comparison to those ranging through Pliocene contrasting to gradual down-fall to Pleistocene. In case that the numbers of the individuals of respective species in the range chart are counted as parameter, the frequencies of the individuals at respective time-stratigraphic intervals show a quite harmonious tendency to the frequency-pattern at species level.

The affinity among the known fossil assemblages can be simply estimated by the rate of the common species. In this sence the assemblage at loc. SKGS-71 does not show the close affinity to any known fossil assemblages in Southeast Asia, but illustrates moderate affinity to the Pliocene assemblages from Atjeh I (Rotalia bed, Main fossil bed, and Operculina bed) of MARTIN's locality with common species by 5-8 (13-21 percent) and also to the Pliocene assemblage from TESCH's loc. MI and MIV in Timor with common species by 4-6 (11-16 percent).

The data mentioned above indicates the age of the fossil assemblage at the 


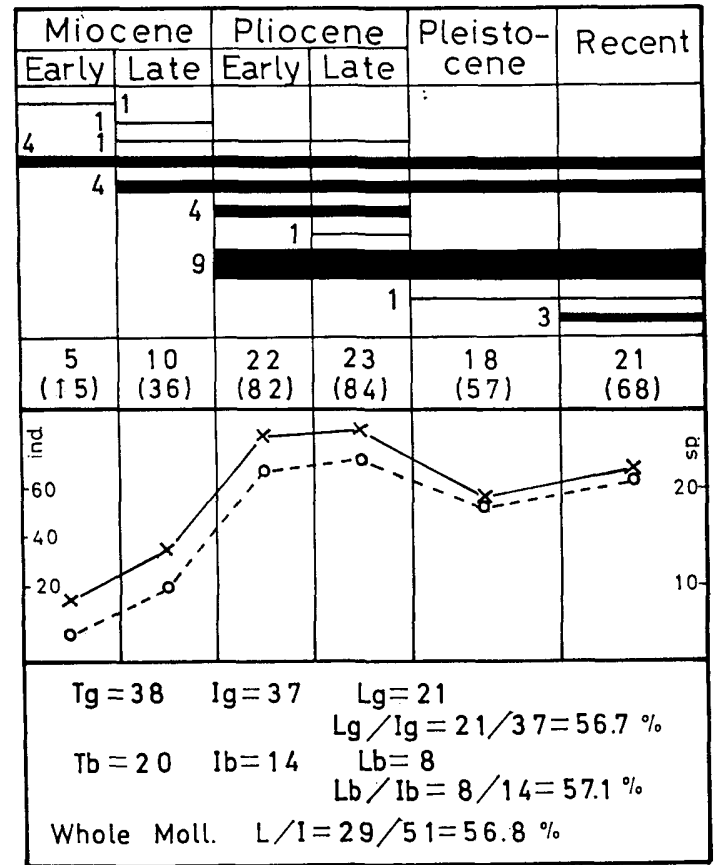

Fig. 7. Diagram showing geological range of the gastropod species and the Lyellian percentage of the assemblage at SKGS-71.

In the upper diagram length and width (number) of the bars indicate the geologic range and the number of species with respective range. Total number of species (individuals) occuring in a single geologic span is also indicated in numerical form. This is diagrammatically illustrated in the middle figure. At the lower part are presented the Lyellian percentages for gastropods, bivalves, and whole molluses. T: total number of species, I: number of identified species, L: number of living species, $\mathrm{g}$ : gastropods, b: bivalves, and $\mathrm{s}$ : scaphopods.

loc. SKGS-71 is most probably "Late Pliocene", Sondian [or Bantamian].

(B) Age of the assemblage at loc. SKGS-72

The molluscan assemblage at the loc. SKGS-72 is so small that the accurate estimation can not be expected. Here some consideration on the range of the possible age of the assemblage based on the data in hand is given.

$$
\mathrm{T}=23(\mathrm{Tg}=16, \mathrm{~Tb}=7), \mathrm{I}=22(\mathrm{Ig}=16, \mathrm{Ib}=6), \mathrm{L}=8(\mathrm{Lg}=8, \mathrm{Lb}=0)
$$

Accordingly $\mathrm{L} / \mathrm{I}=8 / 22=36.3$ percent* $(\mathrm{Lg} / \mathrm{Ig}=8 / 16=50, \mathrm{Lb} / \mathrm{Ib}=0 / 6=0)$

Index fossils of this assemblage are as follow:

Macoma rotunda MARTIN

Mio.,

ditto, ditto

Indonesia

Pupa cf. reussi MARTIN

* confidence interval at 95 percent confidence coefficient: 19-53 percent. 
Turritella (Turritella) terebra bantamensis MARTIN

Nassarius (Zeuxis) caelatus verbeeki (MARTIN)

Ostrea cf. disciformis MARTIN

Gemmula (Unedogemmula) gendinganensis (MARTIN)

Veremolpa teschi nom. nov. (for Venus trigonalis, TESCH, 1915, non MARTIN, 1883)

Mabellarca tambacana (MARTIN)

Striarca (Verilarca) bataviana (MARTIN)

Tarebia submadiunensis (YoKOYAMA)

Euclathurella (Thelecytharella) oyamai (SHUTo)

(Low. Mio.?) Plio., ditto

Up. Mio.-Plio., ditto ditto,

ditto

Plio., ditto

ditto, ditto

ditto, ditto

ditto, ditto

Up. Plio., Taiwan

Up. Pleisto., S. Japan

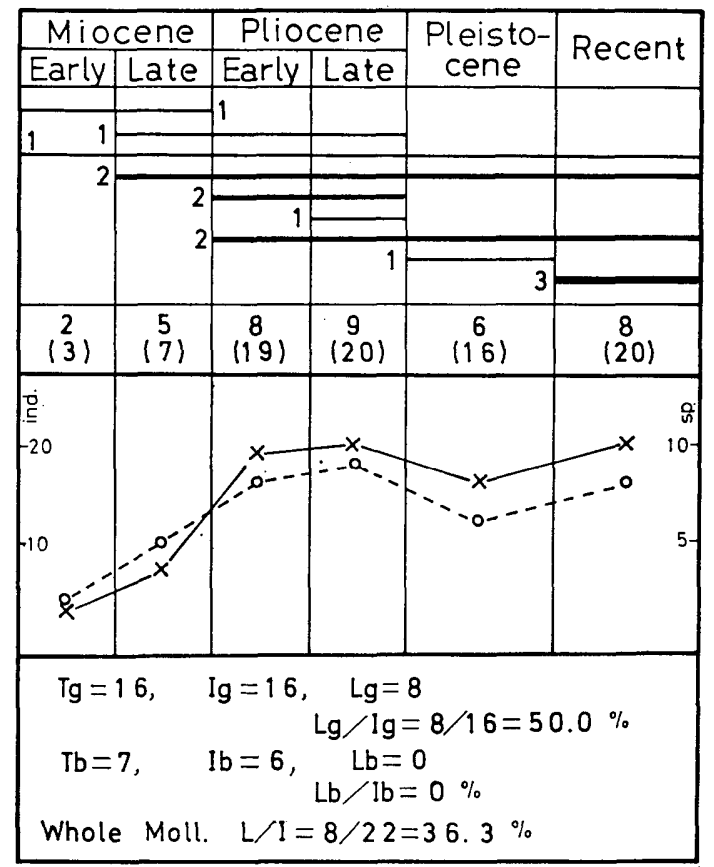

Fig. 8. Diagram showing geological range of the gastropod species and the Lyellian percentage of the assemblage at SKGS-72.

The number of the molluscan (gastropod) species ranging through respective time-stratigraphic intervals are 3 (2) for Lower Miocene, 6 (5) for Upper Miocene, 12 (8) for Lower Pliocene, 13 (9) for Upper Pliocene, 6 (6) for Pleistocene, and 8 (8) for Recent.

The faunal affinity is closest to the several beds of the Pliocene of Atjeh I of MARTIN with the percentage of the common species by about 13 percent. The small figure of the Lyellian percentage of the assemblage for whole molluscs ( 36.3 percent) is caused through the abnormal absence of the living bivalves, which might have been affected by small size of the sample and/or the biased sampling, if the taxonomical identification is correct. 
The Lyellian percentage for gastropods is 50 percent and suggests the "Pliocene" age of the assemblage. Among the index species the Pliocene indices definitely predominate over the others. Accordingly the probable age of the assemblage lies in Pliocene or Late Pliocene on the range chart of the species. Basing upon these data synthetically the estimation of the age of the assemblage at the loc. SKGS-72 may be practical. It is Pliocene.

(C) Age of the assemblage at loc. SKGS-73

The molluscan sample from the loc. SKGS-73 is almost as large as that from the loc. SKGS-71 and the plausible result about the age-estimation may be expected. The basic data are as follow.

$$
\begin{aligned}
& \mathrm{T}=49(\mathrm{Tg}=33, \mathrm{~Tb}=15, \mathrm{Ts}=1), \mathrm{I}=46(\mathrm{Ig}=33, \mathrm{Ib}=13, \mathrm{Is}=0), \mathrm{L}=29 \\
& (\mathrm{Lg}=19, \mathrm{Lb}=10, \mathrm{Ls}=0) \\
& \text { accordingly } \mathrm{L} / \mathrm{I}=29 / 46=63.0 \text { percent* } \\
& \quad(\mathrm{Lg} / \mathrm{Ig}=19 / 33=57.5 \text { percent }, \mathrm{Lb} / \mathrm{Ib}=10 / 13=76.9 \text { percent })
\end{aligned}
$$

The Lyellian percentage for the whole molluscs, 63.0 percent, is somewhat larger than that for gastropods, 57.5 percent, affected by the large number of the living species of the bivalves, 10 out of 13 . If these figures of Lyellian percentage are simply evaluated, the suggested age of the assemblage is Late Pliocene. The figure of 63.0 percent is comparable with those of TESCH's localities of MIV and MVI in Timor (respectively 64 percent), which were included in Pliocene by the original author.

Index fossils in the assemblage

Phasmaconus martini nom. nov. (for Conus jenkinsi MARTIN, partim, 1895)

Strombus (Dolomena) cf. togopiensis CoX

Nassarius (Zeuxis) caelatus verveeki (MARTIN)

Vexillum (Costellaria) obeliscus teschi (KOPERBERG)

Turritella (Kurosioia) cingulifera filiola YoKoYAMA)

Ringicula (Ringiculina) arcta glabra MARTIN

Catelysia (Eumarcia) cheribonensis OOSTINGH

Lioconcha (Sulchilioconcha) molenglaafi (TESCH)

Anadara (Scapharca) gendinganensis (MARTIN)

Tarebia submadiunensis (YoKoYAMA)

$\begin{array}{cc}\begin{array}{c}\text { Low. Mio., } \\ \text { Up. Mio.-Plio., } \\ \text { ditto, }\end{array} & \begin{array}{c}\text { ditto } \\ \text { Indonesia }\end{array} \\ \text { ditto, } & \text { ditto } \\ & \\ \text { ditto, } & \text { ditto } \\ \text { Plio., } & \text { ditto } \\ \text { ditto, } & \text { ditto } \\ \text { ditto, } & \text { ditto } \\ \text { ditto, } & \text { ditto }\end{array}$

Up. Plio., Taiwan

The Pliocene indices ( 6 species) dominate over the other ones and the species of the second importnce are those ranging from Upper Miocene through Pliocene (3 species). Furthermore such dominant species as Lioconcha (Sulchilioconcha) molengraafi and Ringicula (Ringiculina) arctata glabra are confined in Pliocene and Nassarius (Zeuxis) caelatus verbeeki has its hemera also in Pliocene. Accordingly it should be a natural conclusion that the age of the assemblage is Pliocene. If the characteristic occurrence of Catelysia (Eumarcia) cheribonensis is reasonably evaluated, the age may be assigned to Sondean or Cheribonian.

* confidence interval at 95 percent confidence coefficient: 52-72 percent. 
In the range-chart diagram the numbers of the species of whole molluses (gastropods) ranging through respective time-stratigraphic intervals are 8 (4) for Lower Miocene, 16 (11) for Upper Miocene, 30 (19) for Lower Pliocene, 30 (19) for Upper Pliocene, 21 (13) for Pleistocene, and 29 (19) for Recent. The maximum density of the species in the chart lies in Pliocene and Recent. While the number of the species ranging through Late Miocene is definitely smaller than that of Pliocene suggesting Pliocene age of the assemblage. In Pliocene the Upper and the Lower are quite equally probable respectively containing 30 (19) species so far as the counting is made in term of species. Essentially same result is obtained when the counting is practised in term of individuals, although the raw data, strictly speaking, show very slight inclination of the maximum to Upper Pliocene as illustrated in the text-fig. 9.

As a whole the assemblage shows the affinity to that of Pliocene of Atjeh I, especially of the Rotalia bed, Main fossil bed, and Operculina bed with the common species of the gastropods by 27.2-30.3 percent.

In conclusion the age of the assemblage at the loc. SKGS-73 is estimated to be early Late Pliocene, Sondian (or Cheribonian). In other words the fossil assemblage of SKGS-73 is slightly older than (or equivalent to) that of SKGS-71. This conclusion seems to be contradict to the Lyellian percentage, which claims older age of the assemblage of SKGS-71 than that of SKGS-73. The reason why

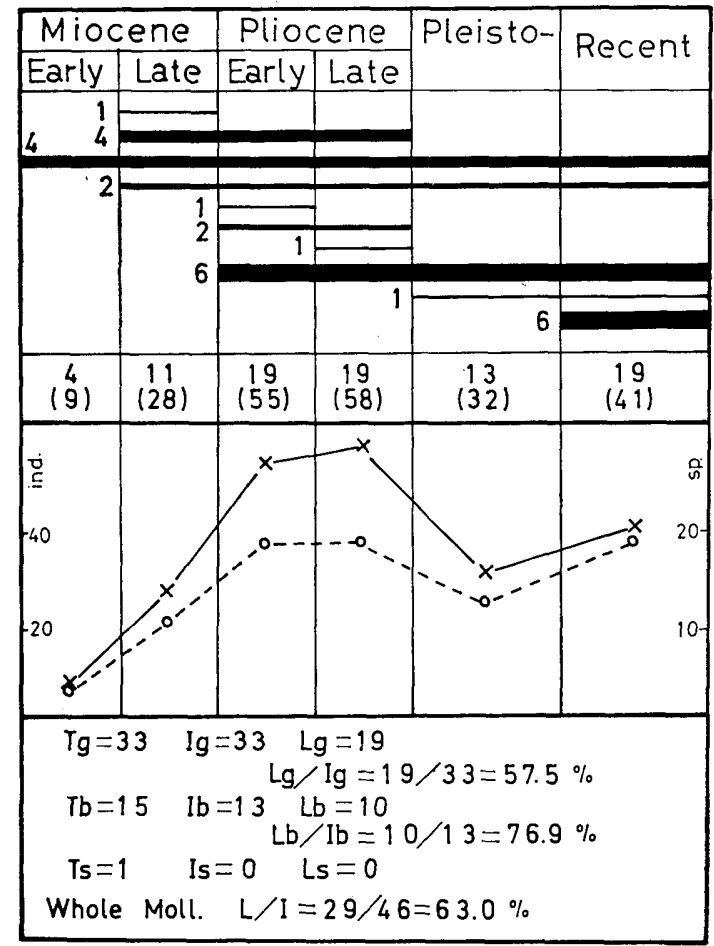

Fig. 9. Diagram showing geological range of the gastropod species and the Lyellian percentage of the assembalge at SKGS-73. 
this claim is rejected is that the Lyellian method is not so reliable as to evaluate the difference of a few to several percent and that special importance is put on the particular indices.

(D) Age of the assemblage at the loc. SKGS-74

This is the largest sample taken from the Iloilo basin consisting of 86 species.

The basic data for age-estimation are as follow.

$$
\begin{aligned}
& \mathrm{T}=86(\mathrm{Tg}=74, \mathrm{~Tb}=10, \mathrm{Ts}=2), \mathrm{I}=80(\mathrm{Ig}=70, \mathrm{Ib}=10, \mathrm{Is}=0), \mathrm{L}=27 \\
& (\mathrm{Lg}=22, \mathrm{Lb}=5, \mathrm{Ls}=0) \\
& \text { Accordingly } \mathrm{L} / \mathrm{I}=27 / 80=33.7 \text { percent* }(\mathrm{Lg} / \mathrm{Ig}=22 / 70=31.4 \text { percent, } \\
& \mathrm{Lb} / \mathrm{Ib}=5 / 10=50.0 \text { percent })
\end{aligned}
$$

Indices are given below.

Inquisitor (Ptychobela) neglectus (MARTIN)

Typhis (Talityphis) macropterus MARTIN

Phos (Philindophos) dijki (MARTIN)

Dendropoma javana (MARTIN)

Clavilithes (Clavilithes) tjidamarensis (MARTIN)

Myurella (Clathroterebra) woodwardiana (MARTIN)

Anisocorbula socialis (MARTIN)

Hindsia palembangensis HAANSTRA et SPIKER

Dolichupis (Trivellona) shimajiriensis MACNEIL

Murex (Haustellum) bantamensis saplisi MACNEIL

Acanthinella javana (MARTIN)

Oliva (Anazola) djocdjocartae MARTIN

Benthomangelia vandervlerki (BEETS)

Triplostephanus cf. jenkinsi (MARTIN)

Venericardia javana (MARTIN)

Oliva (Anazola) rufula junghuhni MARTIN

Vexillm (Costellaria) obeliscus teschi (KOPERBERG)

Paradrillia serana FISCHER

Inquisitor (Inquisitor) batavianus (MARTIN)

Asprella (Asprella) ornatissima (MARTIN)

Tibia (Sulcogladius) powisiana modesta (MARTIN)

Murex (Murex) troscheli verbeeki MARTIN

Latirus (Dolicholatirus) esi (KOPERBERG)

L. (D.) fusiformis TESCH

Gemmula (Gemmula) kieneri woodwardiana (MARTIN)

Microdrillia (Pulsarella) madiunensis (MARTIN)

Triplostephanus cf. pamotanensis timorensis (FISCHER)

Murex (Haustellum) bonneti CossmaNN

Low. Mio.,

Mio.,

Mio.-Plio.,

ditto,

ditto,

ditto,

ditto,

Mid. Mio.,

Up. Mio.

ditto,

ditto,

ditto,

ditto,

ditto,

ditto,

Up. Mio.-Plio.,

ditto,

ditto,

ditto,

ditto,

Plio.,

ditto,

ditto,

ditto,

Indonesia

ditto

ditto

ditto

ditto

ditto

ditto

ditto

Okinawa

ditto

Indonesia

ditto

ditto

ditto

ditto

ditto

$\begin{array}{cc}\text { ditto, } & \text { ditto } \\ \text { ditto, } & \text { ditto } \\ \text { ditto, } & \text { ditto } \\ \text { Plio.-Plio-Pleisto., } & \text { ditto }\end{array}$

ditto

ditto

ditto

ditto

ditto

ditto

ditto

ditto

Plio.-Plio-Pleisto., ditto

The number of the species of whole molluses (gastropods) ranging through

$\bar{*}$ confidence interval at 95 percent confidence coefficient: $27-41$ percent. 
respective time-stratigraphic intervals are 12 (11) for Lower Miocene, 29 (26) for Upper Miocene, 33 (29) for Lower and Upper Pliocene, 16-15 (13-12) for Pleistocene, and 27 (22) for Recent.

The Lyellian percentage for whole molluscs and gastropods are quite similar to those of Tjilanang assemblage which shows the figures, 34.9 percent for whole molluses and 31.7 percent for gastropods (BEETs, 1941). The figures are also similar to that of Benkoelen assemblage of Sumatra, in which the Lyellian percentage is 36.1 (HAANSTRA and SPIKER, 1931). This seems to be liable basis for the estimation of the age as Priangerian (Upper Miocene). Statistically speaking the confidence interval of the Lyellian percentage of the assemblage of SKGS-74 at confidnce coefficient of 95 percent is between 27 and 41 percent. That is to say the age of the assemblage is highly probably Upper Miocene (s. l.).

The index species of the loc. SKGS-74 contain 6 Upper Miocene indices, 2 Miocene ones, 5 Lower Miocene-Pliocene ones, 5 Upper Miocene-Pliocene ones, and 7 Pliocene ones. The species of the most abundant occurrence range from

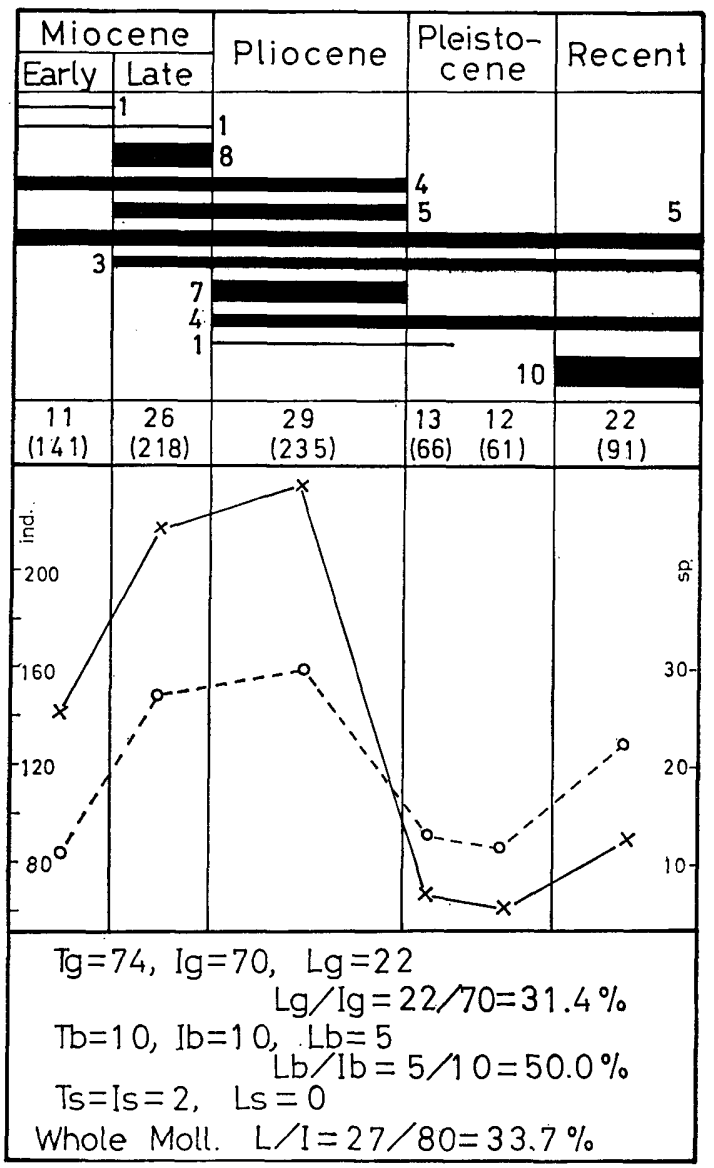

Fig. 10. Diagram showing geological range of the gastropod species and the Lyellian percentage of the assemblage at SKGS-74. 
Miocene through Pliocene [Phos (Philindophos) dijki and Dendropoma javana], while those species with younger ranges are found among the species of common occurrence. They are Myurella (Clathroterebra) woodwardiana and Anisocorbula socialis (from Upper Miocene through Pliocene), Tibia (Sulcogladius) powisiana modesta (Pliocene), and Murex (Haustellum) bonneti (Pliocene through PlioPleistocene). If the co-occurrence of the typical Miocene species of Acantinella javana, Clavilithes (Clavilithes) tjidamarensis (s.s.), and Typhis (Talityphis) macropterus is taken in consideration together with the data mentioned above, the age estimation of this assemblage leans rather to Miocene than to Pliocene.

On the contrary the maximum of the species-density in the range-chart of the species lies at Pliocene, although the number of the species ranging through Pliocene (33) does not surpass by far that through Upper Miocene (29). Speciesdensity of Pleistocene and Recent is extremely low. If the number of the individuals is counted on the same chart, quite harmonious, but more exaggerated result is obtained illustrating the distinct maximum and submaximum respectively at Pliocene and Upper Miocene and abrupt fall at Pleistocene. Accordingly Lowest Pliocene is the logical conclusion from the data of the range-chart.

As mentioned above very controversial results come from the different lines of estimation. That is to say, the analytical data along the Lyellian method claims the oldest age, Upper Miocene, the result of the range-chart analysis presumes the youngest one, Pliocene, and the intermediate estimation is followed by the index-fossil analysis. As noted in the introductory note it is the well known fact that these methods of age-estimation of the fossil assemblage have respective faults. However, the percentage method is particularly considered as the chief cause of apparent discrepancy of the results so far as the present case is concerned. The assemblage at loc. SKGS-74 represents the deep shelf faunule as noted in the preceding section.

It is evident that the information about the living marine benthos is much denser of shallower habitats than of the deeper ones. In consequence it is easily supposed that much more species are left unknown in deeper habitats than in shallower places. The simply logical conclusion of this recognition is that the fossil assemblage of deeper water should contain the "living species" by smaller percentage than the contemporaneous shallower water fossil assemblages. In spite of close similarity of the Lyellian percentage of the present assemblage to that of Tjilanang, they are quite different each other in the faunistic composition. The present assemblage is featured by the turrids, conids, buccinids, and mitrids of deep shelf, while the assemblage of Tjilanang is dominantly represented by potamidids, cerithiids, cypraeids, and even neritids showing the shallow nature of the original habitat. Consequently two assemblages contain only four common species, although either of the assemblages consist of large number of the species. Time-stratigraphically they can not be equivalent each other, but the present assemblage may be probably younger than the assemblage of Tjilanang. Uppermost Miocene, Odengian, may be the reasonable conclusion of the discussion on age of the assemblage of SKGS-74 weighing the results of the analyses of range-chart and indices. 
(E) Age of the assemblage at the loc. SKGS-75

The size of the molluscan sample from the loc. SKGS-75 is extremely small and can not be serviceable for reliable age-estimation.

The basic data are given below.

$$
\mathrm{L} / \mathrm{T}=\mathrm{Lg} / \mathrm{Tg}=\mathrm{Lg} / \mathrm{Ig}=4 / 9=44.4 \text { percent* }
$$

Asprella (Asprella) ornatissima (MARTIN) [Up. Mio.-Plio., Indonesia] is the sole index species.

The number of the species ranging through the respective time-stratigraphic intervals are 3, 5, 5, 4, and 4 for Lower Miocene, Upper Miocene, Pliocene, Pleistocene, and Recent.

\begin{tabular}{|c|c|c|c|c|}
\hline \multicolumn{2}{|c|}{ Miocene } & \multirow{2}{*}{ Pliocene } & \multirow{2}{*}{$\begin{array}{l}\text { Pleisto- } \\
\text { cene }\end{array}$} & \multirow{2}{*}{ Recent } \\
\hline Early & Late & & & \\
\hline \multicolumn{5}{|l|}{3} \\
\hline & & & & \\
\hline $\begin{array}{c}3 \\
(9)\end{array}$ & $\begin{array}{c}5 \\
(30)\end{array}$ & $\begin{array}{c}5 \\
(30)\end{array}$ & $\left(\begin{array}{c}4 \\
(10)\end{array}\right.$ & $\left(\begin{array}{c}4 \\
10\end{array}\right)$ \\
\hline 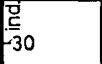 & & & & in \\
\hline & & & & ${ }_{--0}^{x} 5$ \\
\hline & $\begin{array}{l}=9 \\
L\end{array}$ & $\begin{array}{l}I=I g=9 \\
L g / I g=\end{array}$ & $\begin{array}{l}L=L g=4 \\
9=44.4^{\circ}\end{array}$ & \\
\hline
\end{tabular}

Fig. 11. Diagram showing geological range of the gastropod species and the Lyellian percentage of the assemblage at SKGS-75.

The Lyellian percentage together with other data suggests the age of the assemblage being probably Mio-Pliocene. This assumption is in harmony with its faunal similarity to the assemblage at the loc. SKGS-74, which represents a little lower horizon than SKGS-75 at the field.

\section{Interregional correlation}

In the preceding section is presented the result of the biostratigraphical correlation of five molluscan assemblages from Panay Island to the molluscan biostratigraphical standard in Indonesia after MARTIN, OOSTINGH etc.

Prior to the present study the attempt of correlation of the formations in question to Indonesian stages were carried out in some details by CoRBY et al. (1950) and Gonzales (1963).

CORBY et al. selected the standard area for their Tertiary stages $\mathrm{W}, \mathrm{X}, \mathrm{Y}$, and $\mathrm{Z}$ in the western sections of the Iloilo basin in Panay (Table 1). According

* confidence interval at 95 percent confidence coefficient: $22-69$ percent. 
Table 3. Time-stratigraphic divisions of the Tertiary in the Philippines and their correlation to the Indonesian and European units after Bureau of Mines of the Republic of the Philippines, 1962.

\begin{tabular}{|c|c|c|c|c|c|c|c|}
\hline \multirow{2}{*}{\begin{tabular}{|l} 
Europe \\
series \\
\end{tabular}} & \multicolumn{2}{|c|}{$\begin{array}{c}\text { Indonesia } \\
(\text { Van der Vlerk }, 1931) \\
\end{array}$} & \multicolumn{2}{|c|}{$\begin{array}{c}\text { Philippines } \\
\text { (corby et al, 1951) }\end{array}$} & \multicolumn{3}{|c|}{$\begin{array}{l}\text { Philippines } \\
\text { (Bureau of Mines. }\end{array}$} \\
\hline & stage & zone & stage & zone & stage & zone & series \\
\hline Pleist & & low & & & \multirow[b]{2}{*}{ h } & & Pleisto \\
\hline \multirow{2}{*}{ Plio } & \multirow{2}{*}{$\mathrm{h}$} & $\frac{10 w}{2}$ & \multirow{2}{*}{$z$} & Up & & $\frac{2}{1}$ & \multirow{2}{*}{ Plio } \\
\hline & & 1 & & low & $\mathrm{g}$ & & \\
\hline \multirow{3}{*}{$\begin{array}{l}\text { Mio } \\
\text { Plio }\end{array}$} & $\mathrm{g}$ & & $Y$ & & \multirow{4}{*}{$f$} & \multirow{2}{*}{3} & \multirow{6}{*}{ Mio } \\
\hline & \multirow{3}{*}{$f$} & 3 & \multirow{3}{*}{$x$} & up & & & \\
\hline & & 2 & & mid & & 2 & \\
\hline \multirow[t]{3}{*}{ Mio } & & 1 & & low & & 1 & \\
\hline & \multirow{5}{*}{ e } & 5 & \multirow{5}{*}{ W } & \multirow{2}{*}{ up } & \multirow{5}{*}{ e } & \multirow{2}{*}{$\begin{array}{l}5 \\
4 \\
-\end{array}$} & \\
\hline & & 4 & & & & & \\
\hline \multirow{5}{*}{ Pligo } & & 3 & & \multirow{3}{*}{ mid } & & \multirow{3}{*}{$\begin{array}{l}3 \\
2 \\
1\end{array}$} & \multirow{3}{*}{$\begin{array}{l}\text { Oligo } \\
\text { Mio }\end{array}$} \\
\hline & & 2 & & & & & \\
\hline & & 1 & & & & & \\
\hline & $d$ & & $?$ & & d & & \\
\hline & c & & V & & c & & Oligo \\
\hline & b & & & & b & & 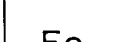 \\
\hline EO & 7 & 2 & $U$ & undit. & 2 & & \\
\hline & $a$ & 1 & & & a & & Paleo \\
\hline
\end{tabular}

to the original authors these stages in ascending order correspond respectively to Indonesian stages $\mathrm{Te}, \mathrm{Tf}, \mathrm{Tg}+$ lowest $\mathrm{Th}$, and main part of $\mathrm{Th}$. In that occasion they also tried the intrabasinal correlation of the formations of eastern and western sections. The upper half of the Dingle Formation, the Sto. Thomas Limestone, which include at its upper part the horizons of SKGS-74 and 75, was correlated to the Idai Formation and was assigned to their Tertiary Y. That is to say the Sto Thomas Limestone is correlative to the Indonesian $\mathrm{Tg}$ or lowest $\mathrm{Th}$.

Recently a letter classification of the Tertiary was proposed by the Bureau of Mines of the Republic of the Philippines (1962), in which the letters used are same as the Indonesian ones but the definition is not necessarily equal to them (Table 3). In occasion of the restudy of CoRBY's standard area GoNZALES et al. practised the correlation under the scheme of the last mentioned classification and considered that the Dingle Formation is equivalent to the lower half of the Tarao Formation, the Tubungan Siltstone, and assigned it to the upper half of Tertiary $f_{3}$ of the Bureau of Mines. It is, in consequence, correlative to Indonesian $\mathrm{Tg}$, because Tertiary $\mathrm{f}_{3}$ of Bureau of Mines spans from Indonesian $\mathrm{Tf}_{3}$ to $\mathrm{Tg}$. While the molluscan assemblage from loc. SKGS-74 is probably correlative to the Indonesian Odengian, which is reasonably included in $\mathrm{Tg}$. Independent results of correlation of the upper part of the Dingle Formation to the Indonesian standard stages seem almost harmonious as above mentioned. Accordingly it seems reasonable to correlate the upper part of the Dingle to "Upper Miocene" of European standard. Some discussion will be given below concerning the reliability of this presumption with the aid of the recent knowledge of Neogene biostratigraphy. 
Recent progress in the study of the planktonic foraminifers has given the firm basis to the interregional correlation of the Tertiary strata. Clean-cut result, however, can not be necessarily expected in applying this method to the younger Neogene and Quaternary. It is simply because the definition of the species and range of the zones have not settled yet. This must be considered as an inevitable consequence of the circumstances that the status quo of planktonic foraminiferal biostratigraphy is, so to speak, really mobile.

TAKAYANAGI (1968, written communication) regarded the difference in the concept of the species of planktonic foraminifers by authors, misidentification of species, and difference in local geological ranges of the species as the chief causes

Table 4. Comparison of the geological ranges of the late Caenozoic planktonic foraminifers in Panay (after Gonzales, 1963), Java (after Bolli, 1966), and the deep sea cores (after BANNER and Blow, 1965, 1967 and PARKer, 1967).

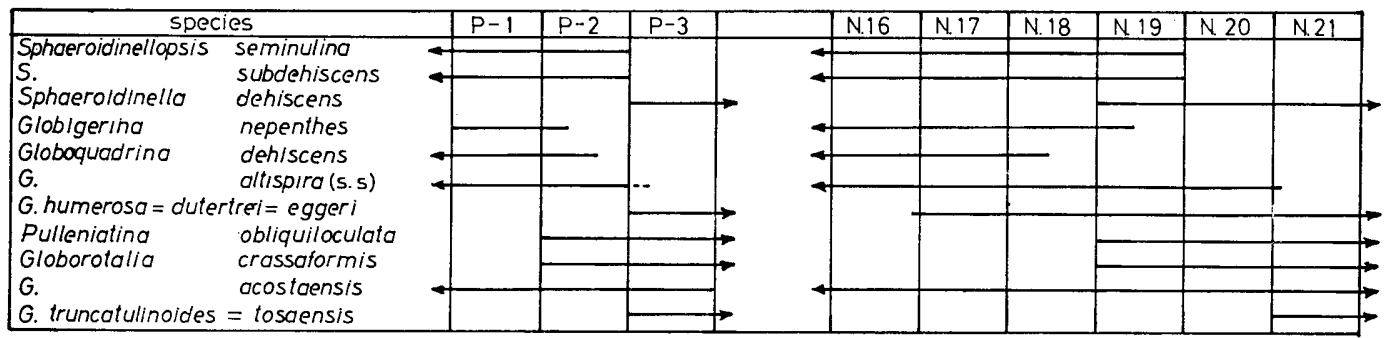

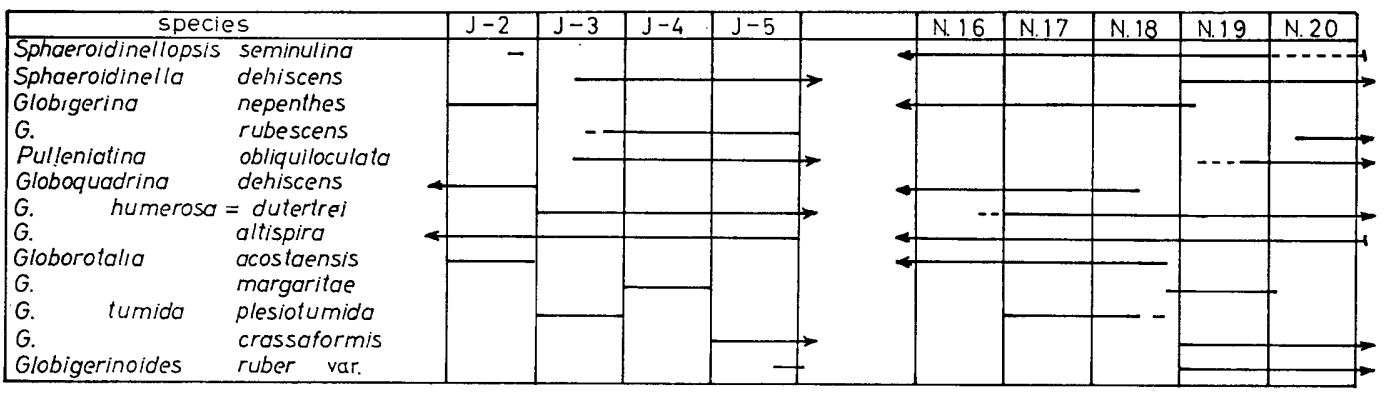

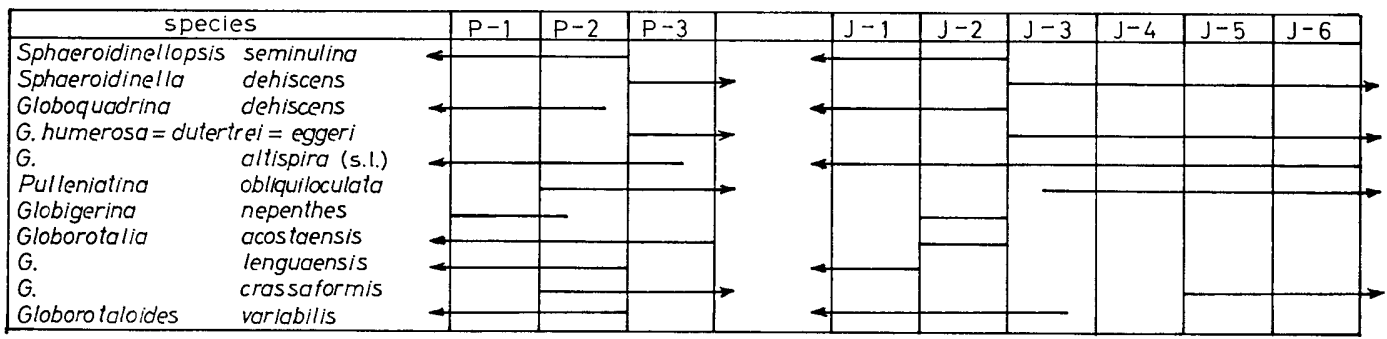

P-1: Globigerina nepenthes zone, P-2: Pulleniatina obliquiloculata zone, and P-3: Sphaeroidinella dehiscens zone in Panay.

J-1: Globorotalia menardi zone, J-2: Globorotalia acostaensis zone, J-3: Globorotalia dutertrei/Globigerinoides obliquus extremus zone, J-4: Globorotalia margaritae zone. J-5: Globoquadrina altispira altispira/Globorotalia crassaformis zone, and J-6: Globoquadrina altispira altispira/Globorotalia truncatulinoides zone in Java.

N. 16 to N. 21 represent respectively BANNER and BLow's Zone N. 16 to Zone N. 21. 
of vagueness of the planktonic foraminiferal zonation. He emphasized the importance of recognition of both the co-occurrence of many species for zonal correlation and off-spring horizons of the species belonging to the well established lineage for datum-plane to overcome the difficulties mentioned above.

In table 4 is summarized the comparison of the ranges of the planktonic foraminifers of the Tarao Formation of Panay (Gonzales, 1963) with those in the upper part of the "Well Bodjonegoro-1" core section in Java (BoLLI, 1966) and in the deep sea cores (BANNER and BLOW, 1965 and 1967 and PARKER, 1967). According to Gonzales et al. (1963) the Tarao Formation is divided into the Tubungan Siltstone (lower) and the Guimbal Mudstone (upper). The former represents GoNZALES' Globigerina nepenthes zones and Pulleniatina obliquiloculata zone in ascending order and the latter Sphaeroidinella dehiscens dehiscens zone. These zones are here abbreviated respectively as P-1, P-2, and P-3 zones for convenience.

According to BoLli's zonation the upper sequence of the Well Bodjonegoro-1 is represented in ascending order by Globorotalia menardi zone (abbreviation: $\mathrm{J}-1)$, G. acostaensis zone (J-2), Globorotalia dutertrei/Globigerinoides obliquus extremis zone (J-3), Globorotalia margaritae zone (J-4), and Globoquadrina altispira altispira/Globorotalia crassaformis zone (J-5). Zone N. 16 to Zone N. 21 of BANNER and BLOW are also adopted in the table.

If the importance is put on the co-occurrence of the species, P-2 zone is most probably correlated to Zone N. 19 with the greatest number of common species such as Sphaeroidinellopsis seminulina (ScHWAGER), S. subdehiscens (BLOW), Sphaeroidinella dehiscens (PARKER and JONES), Globigerina nepenthes TODD, Globorotalia crassaformis (GALLOWAY and WISSLER), Pulleniatina obliquiloculata (PARKER and JONES), Globoquadrina altispira altispira (CUSHMAN and JARVIS), and Globorotalia acostaensis BLow. This correlation is supported by the timestratigraphic planes expressed by the first appearance and extinction of the species. Sphaeroidinellopsis seminulina (ScHWAGER) and S. subdehiscens (BLow) extinct at the top of P-2 zone and Zone N. 19. Globigerina nepenthes TopD extinct within the zones in question. While Globorotalia crassaformis (GALLowaY and WISSLER) appears at the base of two zones. Pulleniatina obliquiloculata (PARKER and JONES) has its first appearance in P-2 zone and Zone No. 19, although it is somewhat lower in the former than in the latter.

The examination of the stratigraphic horizons of off-shooting in the lineage, however, does not necessarily show the harmonious results. In the lineage of Sphaeroidinellopsis subdehiscens (BLOW)-Sphaeroidinella dehiscens (PARKER and JONES) the latter species springs off at the base of P-2 zone and Zone N. 19 giving the concordant basis for correlation to the foregoing result. While the horizons of off-spring of Globorotalia humerosa TAKAYANAGI and SAITo from G. acostaensis BLOW seems to lie at the base of P-3 zone and at the middle of Zone N. 18 and Globorotalia truncatulinoides (d'ORBIGNY) has it supposed branching horizon from $G$. tosaensis TAKAYANAGI and SAITO at the base of both P-2 zone and Zone N.22. Considering that the lineage was not strictly checked by GoNZALES in his work, it seems rather difficult to apply the marker horizons 
of off-shooting of the descendant species in his range chart of the species. Consequently serious importance should not be attached to the discrepancy in the critical horizons of the seeming off-spring in the lineage. In conclusion the correlation of P-2 zone to Zone N. 19 is considered reasonable. P-3 zone may probably correlated to Zone N.21 supported by the evidences of co-occurrence of many species and first appearance of Globorotalia truncatulinoides (d'OBIGNY).

The comparison of BoLLI's zones to BANNER and BLow's is not so clear cut as the preceeding case. J-5 zone with Zone N. 20 and J-2 zone with Zone N. 16 is the tentative correlation on the basis of the co-occurrence of the species. J-5 zone and Zone N. 19 have eight species in common, while J-5 zone and Zone N. 20 include besides these eight species Globigerinoides ruber var. of BoLLI and Globigerina rubescens HOFKER in common. J-4 zone has the greatest number of common species with Zone N.19, while J-3 zone does so with the upper half of Zone N. 18 to lower half of Zone N.19. The correlation of J-3 zone to Zone N. 18/19 is supported by the marker horizon of the off-spring of Sphaeroidinella dehiscens dehiscens (PARKER and JONES) and Pulleniatina obliquiloculata (PARKER and JONES) in their lineages. Through the similar procedure J-2 zone should be correlated to Zone N.16. Six species occur in common and the offspring horizons of Globorotalia humerosa TAKaYANAGI and SAITO and G. tumida plesiotumida BANNER and BLOW are within these zones.

The result of the ocrrelation mentioned above is summarized in tabular form below.

$\begin{array}{ll} & \text { Zone N. } 21 \ldots . . . \text { P-3 zone } \\ \text { J-5 zone...... } & \text { Zone N. } 20 \\ \text { J-4 zone..... } & \text { Zone N. } 19 . \ldots . \text { P-2 zone } \\ \text { J-3 zone...... } & \text { Zone N. } 18 \\ & \text { Zone N. } 17 \\ \text { J-2 zone...... } & \text { Zone N. } 16\end{array}$

This correlation is checked by the counter comparison of Panay and Javan zones to get inharmonious result. So far as the available data are concerned, P-2 and P-3 zones seem to be equivalent respectively to J-2 and J-4-5 zones on the ground of the heaviest co-occurrence of the species. The first appearance and extinction of the species leads to the different correlation from any of the foregoing ones. It seems for the present author that the conflicting result of correlation should be attributed to the deficiency of data of planktonic foraminifers in Panay section and especially in Javan one. Under such circumstance the author prefers to continue the consideration on the assumption that the preliminary correlation of P-2 zone to Zone N. 19 is the most reasonable supported by several reliable data.

BANNER and BLOW (1967) mentioned that the boundary between the Indonesian $\mathrm{Tg}$ and $\mathrm{Th}$ is probably within Zone N.18 on the basis of their finding of the planktonic foraminiferal faunas in the beds probably referable to Cheribonian and Odengian of Java. According to them the boundary between $\mathrm{Tf}$ and $\mathrm{Tg}$ is within Zone N.15 and Bantamian corresponds to Zone N.21. They further 
proposed the correlation of their zones to European classical stages. The result is summarized in Table 5.

Table 5. Correlation of the Neogene molluscan fossil horizons and planktonic foraminiferal zones in East Asian Archipelagoes.

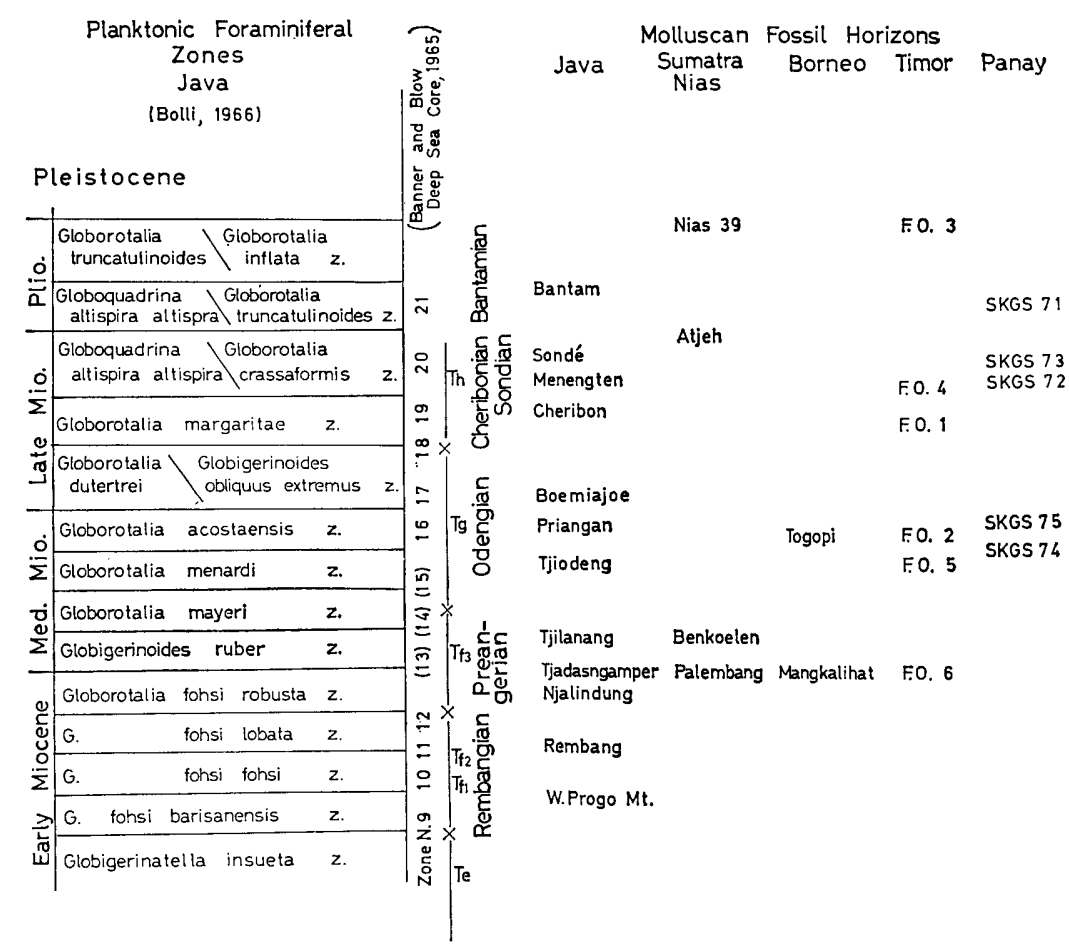

Comparison of this table with the result of the analysis of the molluscan assemblage readily reveals the remarkable difference existing between the correlation by means of molluscs and planktonic foraminifers.

As were discussed in some details before, the analyses of the ranges of the species, Lyellian percentage, and predominancy of indices of the molluscan assemblage of SKGS-74 afford the basis of its correlation respectively to "Pliocene", "Upper Miocene", and "Mio-Pliocene" in the sence of Martin, Oostingh, etc. The assemblage was synthetically judged to be equivalent to Odengian of Java regarding the less reliability of Lyellian percentage of deep shelf fauna.

While the Tubungan Siltstone, an equivalent strata to the upper Dingle Formation according to GoNZALES et al. (1963), is correlated by its planktonic foraminifers with BANNER and BLow's Zone N.18 and 19, which are in turn considered to be equivalent to Piacentian. To come to the harmonious conclusion the upper part of the Dingle Formation, Sto Thomas Limestone including the horizon of SKGS-74, must be equivalent to the lower part of the Tubungan Siltstone (P-1 zone: Glogiberina nepenthes zone of Gonzales, 1963). The former, however, correlated by the original authors to the upper part of the Tubungan Siltstone (P-2 zone: Pulleniatina obliquiloculata zone of Gonzales, 1963), which 
is equivalent to Zone N.19. In other words the Sto. Thomas Limestone is correlated, on one hand, to Zone N.19 and, on the other hand, to Zone N.18 and older through the different procedure of comparison.

What is the cause of this serious discrepancy? The probable cause of this discrepancy, in the author's opinion, is assumed, on one hand, to lie in the intrabasional correlation of eastern and western sections of the Iloilo basin of Panay and, one the other hand, in the intraregional correlation of the molluscan and planktonic foraminiferal faunas in Southeast Asia.

As to the former problem the author has nothing to say and is awaiting the future re-examination of the field evidences.

Concerning the second problem attention should be given to the procedure of age-estimation of the molluscan assemblage at loc. SKGS-74, which the author assigned to Odengian in spite of the conflicting results through the different ways of analyses even using only molluses. As a matter of natural consequence the probability of younger age of the molluscan fauna, say Cheribonian, is to be re-examined to get the concordant result with the planktonic foraminiferal correlation.

The last mentioned correlation, however, seems rather improbable so far as the field relation of the fossil horizon of SKGS-74 to that of SKGS-73 is concerned, the latter of which is assigned to Sondian (or Cheribonian), because the strata intercalated in two horizons, lower part of the Ulian Formation and uppermost part of the Sto. Thomas Limestone, are remarkably thick, although the thickness of the Strata is not necessarily proportionate to the time-span. The Lyellian percenage of 33.7 (confidence interval of 27-41 percent at 95 percent confidence coefficient) seems to be unnegligible even considering the paucity of the knowledge on present-day deep shelf fauna, although there is a chance that the paucity of the data on the living species may cause the unreasonably small figure of the Lyellian percentage.

BANNER and BLow's beds "probably referable to Tjiodeng stage" need more strict comparison with the type Odengian to provide the concrete basis for inter-regional correlation. Same is the case of the neotypes of the European stages to the classical ones, because the reference of the authors to the classical epoch has its logical basis on the material from these neostratotypes.

BANDY discussed the foraminiferal biostratigraphy of the younger Neogene of the Iloilo basin (1963). His proposed correlation is remarkably different from BANNER and BLOW's. Recently BANDY and WADE (1967) emphasized the biostratigraphic significance of "Sphaeroidinella dehiscens datum", at which, according to them, species and subspecies of Sphaeroidinellopsis, Globoquadrina altispira altispira (CUSHMAN and JARVIS), and Globorotalia tumida miocenica PALMAR terminate and "Sphaeroidinella dehiscens" and Pulleniatina obliquiloculata (PARKER and JONES) appear. They considered this datum as the MiocenePliocene boundary and recognized it at the uppermost part of the Tarao Formation in Panay. As the natural consequence of their intension, the Tubungan Siltstone, lower part of the Tarao, should be included in the apparent Miocene. The conflicting results of the inter-regional correlation by means of only plank- 
tonic foraminifers reveal the serious difficulty existing in this method of biostratigraphic correlation.

Under such circumstance mentioned above the author suspends the concrete conclusion, but is inclind to correlate the Sto. Thomas Limestone to upper Odengian, that is to say, to Messinian.

Some notes on the inter-regional correlation of the assemblages of SKGS-73 and 71 will be given below, although there is few to mention about that problem.

The Ulian Formation overlies the Idai Formation at the western section of the Iloilo basin, while it directly covers the Dingle Formation at the eastern section. Accordingly the Ulian at the eastern section represents remarkably longer time-stratigraphic span than at the western section. CoRBY et al. (1951) selected the Ulian Formation of the western section for the type of the Philippine Tertiary $Z$, almost equivalent to the Indonesian $T h$. Now the Indonesian $T h$ is considered to be equivalent to Tertiary $g-h$ of the Bureau of Mines of the Philippines (1962). BANDY and WADE (1967) noted that the Ulian Formation of the western section is Middle and Upper Pliocene on the basis of both the planktonic foraminifers of that formation and its field relation to the Panoran Mudstone which is assigned to Lower Pliocene of BANDY's sence. His correlation leads to the conclusion that the upper part of the Ulian is the Uppermost Pliocene. This part of the Ulian is, of course, apparently Pleistocene in the scheme of BANNER and BLOW (1965 and 1967) and PARKER (1967). If the ocrrelation of the assemblage at SKGS-73 to Sondian (or Cheribonian) by the present author is correct, it may be, in turn, equivalent to Upper Piacentian according to BANNER and BLow's scheme.

The molluscan assemblage of SKGS-71 is assigned to Bantamian (or Sondian) in spite of slightly smaller figure of its Lyellian percentage than that of the SKGS-73, evaluated the particular index species such as Turritella (Turritella) terebra bantamensis MARTIN. In consequence the Santa Barbara is tentably correlated to Astian (or Upper Pliacentian) in BANNER and BLow's sence. Any way there is no available data on the planktonic foraminifers from the Santa Barbara and it can not be compared directly with BANNER and BLOW's zones.

\section{Systematic Descriptions}

\section{(A) Morphology and measurements of the gastropod-shell}

(1) Protoconch.-The shell of the Gastropoda is generally divided into the protoconch and the teleoconch, which respectively represent the different stages of the morphological development. There are, however, some controversial opinions about the definition of the protoconch, larval conch, embryonic whorls, etc. Cox's definition* of the protoconch (1955) is adopted here, because his

\footnotetext{
* Cox (1955), pp. 195-198.-Protoconch: "those initial whorls which either differ in attitude, outline or ornament from the succeeding ones, are clearly demonstrated from them by a varix or other evidence of growth interruption, or (when limit is not so sharply defined) differ from them in the absence of ornament"- "The term carries with it no implication that the whorls to which it refers coincided with a definite phase in life history."
} 
descriptive term is the most applicable to the fossil material.

The morphology of the protoconch is more complicated than it may be expected from its small size making the generalization difficult. The following remarks are only some crumbs of information of its morphology. The details are given in the descriptive notes of respective species. The measured protoconchs of the Philippine gastropods vary in several aspects. Generally speaking the species of the Archaeogastropoda have small protoconchs with minute tip and few volutions suggesting the small eggs and short duration of the larval stage.

The generalization of the results of the observation of the protoconchs of the Mesogastropoda is much more difficult because of the remarkable diversity. The protoconchs of Cerithioidea are also small but polygyrate. Stromboidea and Naticoidea have moderately numerous volutions. Tonnoidea have extremely large and polygyrate protoconchs examplified by Tonna costata (MENKE) on which the diameter and number of the volutions of the protoconch are $2.6-3.0 \mathrm{~mm}$ and 3.1-3.5 respectively. Whole species of the Archaeogastropoda and Mesogastropoda from the Iloilo basin show entirely smooth and simple protochonchs.

Among the Neogastropoda the species of Muricoidea also possess the smooth, simple, and low conical protoconch of moderately large size attaining around $1.0 \mathrm{~mm}$ in diameter, but in general the apices are decidedly larger than those of the Mesogastropoda and Archaeogastropoda indicating the larger size of the eggs. Number of the volutions ranges from 1.5 to 2.8 .

Many species of Buccinoidea have the ornamented protoconchs, although the ornamentation is generally simple and appears only on the later volutions. The most common ornamentation is the spiral thread(s) or keel(s). Close axial riblets are also often observed. Some genera carry on them the decussate ornamentation consisting of a few spirals and axial riblets as is illustrated by Philindophos. The size of the protochonch is moderate ranging from 0.6 to $1.0 \mathrm{~mm}$ in diameter, while the volutions are counted more than three indicating the long veliger stage. The protoconchs of Volutoidea is simply conical and moderately large. Number of the volutions ranges 1.5 to 4.0.

Conoidea shows the widest diversity in the morphology of the protoconchs. Simple, low conical, smooth, and paucigyrate protochonch with moderately large nucleus of Turriculinae, high conical and polygyrate one with close brephic axials of Gemmula, very high conical and polygyrate one with basal keel of Myurella and Triplostephanus, etc.

The protoconchs are measured in the height $(\mathrm{H})$, maximum diameter (D), and number of the volutions with the note of the ornamental features.

(2) Teleoconch.-Among the morphological aspects of the development of the teleoconch the author should call the attention to the development of the ornamentation, which consists of the axials and the spirals. The change of the axial and spiral ornamentation realized through the growth stages may be classified into the change in strength and in the relative position of the ornamental elements. The change of the former category may be retrogressive development (from strong to weak or obsolete), progressive development (from weak to 
strong), or stational (practically constant).

Change in the relative position of the spiral ornamentation corresponds to the gradual removal of the relative position of respective shell-secreting parts along the margin of the mantle. The latter is the reflection of the definite pattern of the growth of the mantle itself. This character seems, so far as the observations of the present author are concerned, to be very stable among the intraspecific specimens and to afford a reasonable basis for recognization of any lineage of the gastropod species.

Concerning the relative position of the spiral ornaments the following terms are introduced:

stational-Constant from the first to the penultimate whorl;

abapical development-Successively new primary spirals appear at the upper suture and gradually migrate anteriorly, so that the primary spirals become closer on later whorls between the sutures;

adapical development-Successively the primary spirals appear at the lower
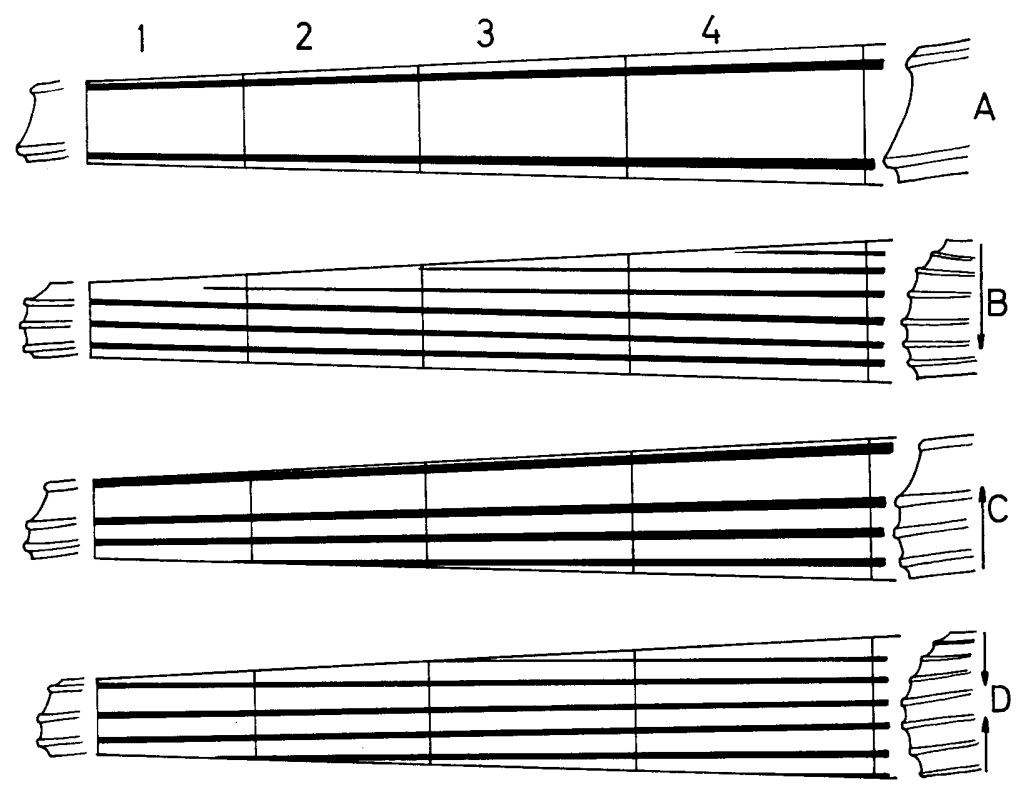

Fig. 12. Development of the spiral ornamentation on the teleoconch of gastropod.

A: stational, B: abapical, C: adapical, and D: concentrating development. $1,2,3$, and 4 indicate the whorl-number.

suture under the overlapping part of the next whorl and gradually migrate upward, so that the primary spirals become closer on the later whorls between the sutures;

concentrating development-Successively the primary spirals appear at the upper and lower sutures.

The following terms are also introduced concerning the change in the relative position of the axial ornaments : 
stational-Constant from the first to the penultimate whorl; retreating development

(a) accentuate-Axials are weakened or disappear near the sutures but strengthened at the periphery;

(b) decrescent-Axials disappear near the sutures and weakly present at the periphery;

off-fainting-Axials are weakened near the upper suture but exist below the periphery. (text-fig. 13)

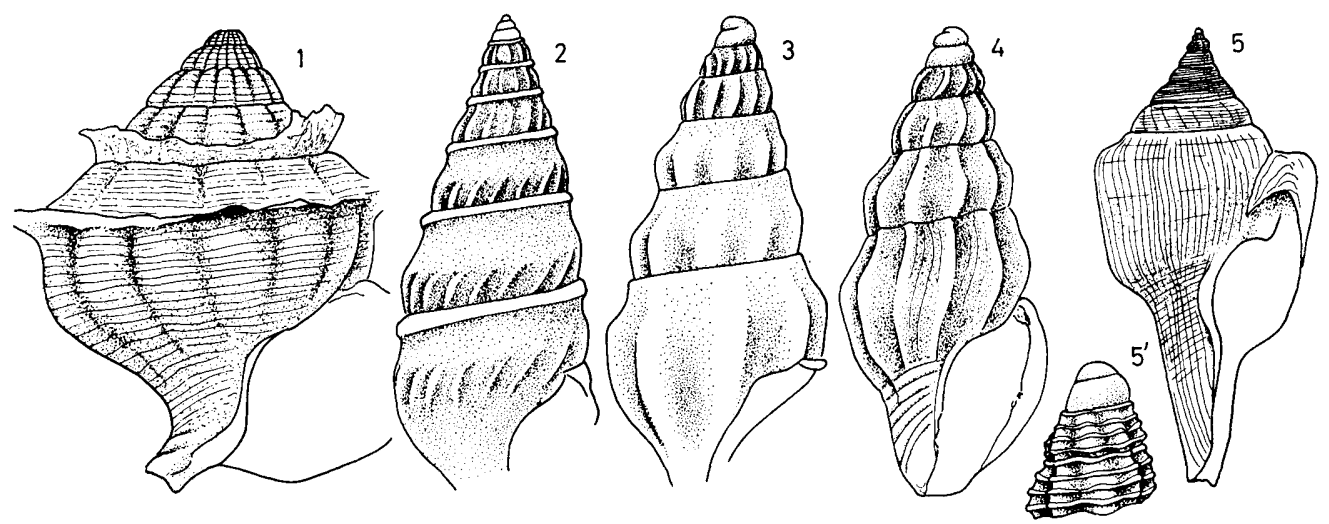

Fig. 13. Development of the axial ornamentation on the teleoconch of gastropod. 1: stational, 2: accentuate, 3: decrescent, 4: stational, and 5: retrogressive development.

The teleoconch is measured in height $(\mathrm{H})$, maximum diameter (D), height of the body whorl (Bd), length of the aperture $(\mathrm{Ap})$, apical angle $(\angle \mathrm{A})$, pleural angle $(\angle P)$, suture angle, whorl profile on the penultimate whorl $(D / H \%)$, number of the whorls*, and number of the axials and spirals (Text-fig. 14).

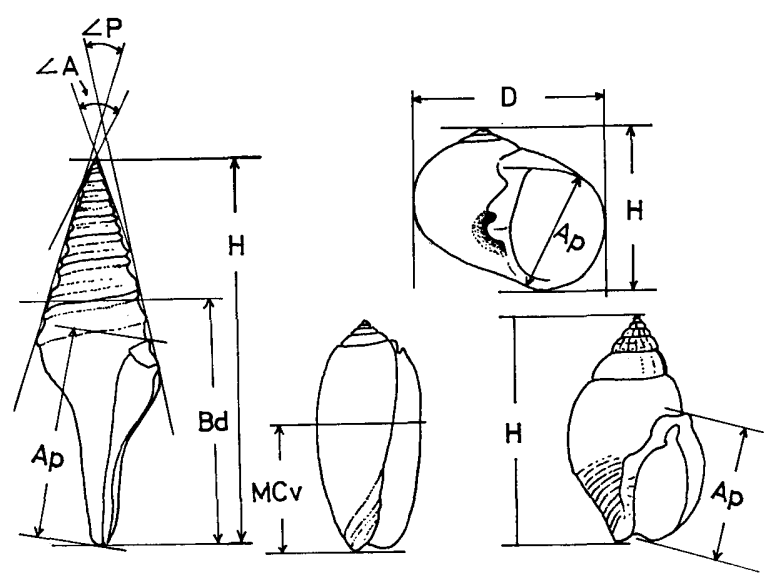

Fig. 14. Measurements of the shell of gastropod.

* The terms "volution" and "whorl" are separately used in this report for avoiding the confusion, although they have not different meaning literally. Volution is applied to the protoconch and whorl to the teleoconch. 
Specially designed comparator was used in this study to obtain the accurate measurements (Text-fig. 15). The comparator consists of the microscope and the sample-holder. The microscope is set up on the carriage quite similar to the ordinal comparator. The specimen of the gastropod can be rotated around the axis of coiling on the sample holder and the amount of the rotation is readily read on the subcircular protractor with vernier. On the same holder the specimen can be also rotated around the axis, which is perpendicular to the axis of coiling and parallel to the axis of the microscope. The rotation is measured on the circular protractor with vernier. This aparatus enables the minute and refined measurements above noted. The possible errors of the measurements are confined less than $1 / 20 \mathrm{~mm}$ and $1 / 20$ degree.

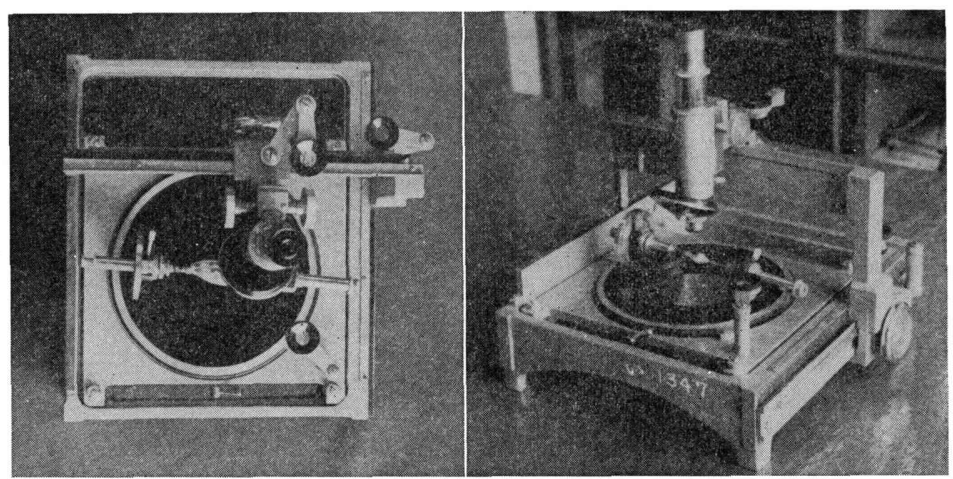

Fig. 15. Special comparator for the measurement of molluscan shells.

\section{(B) Systematics of the Gastropoda}

In classifying the tropical gastropods at species-level the author met the serious difficulty how to adopt the appropriate name among so many, closely related, and almost identical forms. Specific names have been given respectively to several local forms, which are taxonomically hardly separable from one another. Do the named species really represent the biologically valid taxa?

Rich in specific diversity in the tropical marine benthic communities is, according to THORSON (1957), the reflection of the variable controling factors governing the benthos, contrasting to the phenomena in the arctic and subarctic environments where the temperature acts as the sole controling factor. This suggests a possibility of the wide variability of individual species which tend to adapt to the diverse minor-environments and leads to the necessary revision of the close allies on the basis of the extensive survey as was excellently examplified by Аввотт (Strombus, 1960), Powell (turrids, 1964 and 67), KeEN (vermetids, 1961) etc.

Revision of this sort is indispensable, while it is also advisable that some of the geographical and geological "varieties" preserve their names as subspecies for the purpose of easy recognition of the phylogenic lineages and also for convenience of the biostratigraphical procedure. From this point of view the author tried to adopt the wide range in each species and to treat the particular varietal 
forms as subspecies. The result, however, does not necessarily come up to his expectation because of the insufficient comparison of the specimens, as the taxonomical revision needs extensive survey of the original type and subsequent specimens.

As to the classification of the Gastropoda at genus- and subgenus-level the author followed principally WENz's (1938-44) with some necessary emendation based on the recent works by several authors and partly with his own revision.

(C) Descriptions of species

$$
\begin{gathered}
\text { Class Gastropoda } \\
\text { Subclass Prosobranchia } \\
\text { Order Archaeogastropoda } \\
\text { Superfamily Trochoidea } \\
\text { Family Trochidae } \\
\text { Subfamily Gibbulinae } \\
\text { Genus Gibbula Risso, } 1826
\end{gathered}
$$

(type-species: Trochus magus LiNNÉ by original designation)

Subgenus Colliculus Monterosato, 1888*

(type-species: Trochus adansoni PEYRADEAU by original designation)

$$
\text { Gibbula (Colliculus) sp. }
$$

Pl. 1, Figs. 16, 17, and 18

Material.-GK-L 6904. Preservation is fairly well but the upper layer of the shell was removed at some portion of the apical part. Pattern of the coloration is well preserved on the later whorls.

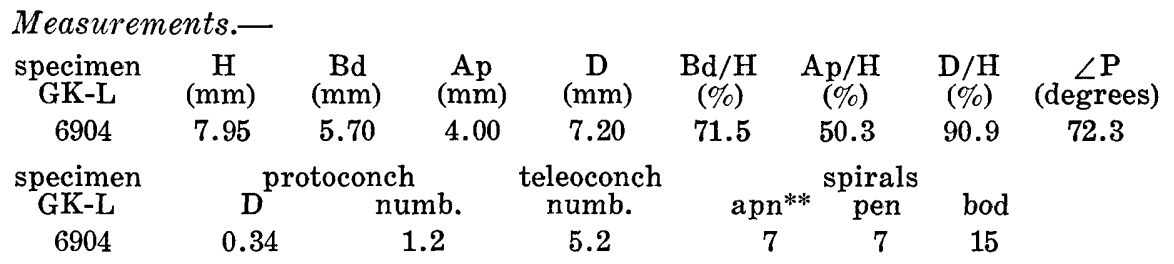

Description.-The shell is small, trochoid, slightly higher than wide, and moderately thick. The protoconch is depressed conical, smooth, polished and paucispiral with about 1.2 volutions. The tip is minute and very depressed and the remainder is rather swollen. The beginning of the teleoconch is indicated by the abrupt appearance of the spiral threads. The teleoconch consists of moderately convex 5.2 whorls, of which the first one is provided with three distinct spiral threads; one is at the middle and the others are situated respectively between the median thread and the upper and lower sutures. The succeeding development of the lirae is concentrating. That is to say on the second whorl the fourth thread comes out from the lower suture and the fifth one, somewhat weaker than the others, appears close to the upper suture. All the five spirals are rapidly increased in size to be treated as the lirae. On the next whorl sixth

* Synonym: Glomulus Monterosato, 1888

** apn: antipenultimate whorl; pen: penultimate one; and bod: body whorl. 
primary spiral appears close to the upper suture and the fine first secondary is intercalated between the lowest two lirae. All the interstices except for the uppermost one have respectively a secondary thread on the penultimate whorl.

The body whorl is rather sharply angulated at the periphery; the surface above and below the angulation is somewhat convex with broadly curved outline. Six primary lirae are counted at and above the peripheral angulation and another nine threads are on the basal surface. The peripheral lira is bifid by a superimposed narrow groove. The basal threads are remarkably weaker than the lirae on the upper surface.

The threads and lirae on the spire are separated by wider interspaces and exhibit step-like profile with more elevated posterior side than the anterior. The suture is simple except for the last part of the body whorl, where it is somewhat channelled. The growth lines are distinct, antecurrently oblique, and very slightly curved. The straight line passing the cross-points of the growthline with the upper and the lower suture forms an acute angle of about 45-50 degrees to the axis of coiling.

The umbilicus is very narrow and moderately deep. The aperture is composed of the semi-circular outer lip and reflexed inner lip. The labrum is thin and sharp at the very margin and distinctly nacreous inside. The columellar lip is vertical and provided with a weak fold near the anterior end. The columellar callus is moderately thick. Whole surface is painted with irregular radiation of white and dark coloration; the darker ones are broader on the early whorls and becomes narrower on the later ones.

Comparison.-The morphology of the present specimen almost perfectly conforms with the subgeneric diagnosis of Colliculus Monterosato, 1888, with the type-species, Trochus adansoni PeYradeau, but the suture is not canaliculate except for the last part of the body whorl and the umbilicus is not deep on the present specimen. It shows some resemblance to Iwakawatrochus KURODA and HABE, 1954, with the type species, Gibbula vittata PILSBRY. The former, however, is clearly distinguished from the latter in having weak but distinct columellar fold and more defined basal angulation. The author places tentatively the present specimen under the subgenus Colliculus.

Gibbula njalindungensis MARTIN (1922, p. 476, Taf. 60, fs. 84 \& 84a), belonging to the same subgenus as the present species, is a close ally, but the former has almost flat-sided whorls with closer spirals ( 6 on the first and 7 on the second whorl).

Gibbula (Colliculus) leupoldi BeETs (1942, p. 12, Taf.1, fs.11-13 \& 17) is another ally to the present specimen, but the former has the deeply impressed suture and deep umbilicus, and devoid of the secondary spirals. Furthermore the early development of the spirals quite differs from that of the latter.

The present specimen possibly represent a new species, but the author prefers to suspend the establishment of new species because of deficiency in comparison.

Horizon.-Upper part of the Dingle Formation.

Locality.-SKGS-74. 


\section{Subfamily Umboniinae \\ Genus Monilea SwaINson, 1840*}

(type-species: Trochus calliferus LAMARCK by original designation)

Subgenus Monilea (s.s.)

Monilea (Monilea) lentiginosa A. AdAMS

Pl. 1, Figs. 12, 13, and 14; Text-fig. 16

1854. Monilea lentiginosa, A. Adams, Proc. Zool. Soc. London, p. 41.

1854. Monilea corrugata, A. AdAMS non KocH, ibid. p. 41.

1889. Monilea lentiginosa, Pilsbry, Man. Conch. Ser. 1, Vol. 11, Trochidae, p. 248, pl. 41, fs. 8-10 and pl. 60, fs. 23-24.

1928. Gibbula (?) taiwanica Yoкоуама, Imp. Geol. Surv. Japan Rep. No.101, p. 66 , pl. 6 , f. 3 .

1935. Monilea lentiginosa, Nomura, Sci. Rep. Tohoku Imp. Univ. 2nd Ser. Vol.18, No. 2, p. 215, pl. 10, fs. 23a and b.

Material.-GK-L 6394 and 7465. The specimen GK-L 6394 is perfectly preserved and GK-L 7465 is broken at the later part of the body whorl.

\begin{tabular}{|c|c|c|c|c|c|c|c|c|c|}
\hline \multicolumn{3}{|c|}{ Measurements.- } & \multirow[b]{2}{*}{$\underset{(\mathrm{mm})}{\mathrm{D}}$} & \multirow[b]{2}{*}{$\begin{array}{c}\mathrm{Bd} / \mathrm{H} \\
(\%)\end{array}$} & \multirow[b]{2}{*}{$\underset{(\%)}{\mathrm{D} / \mathrm{H}}$} & \multirow[b]{2}{*}{$\underset{\text { (degrees) }}{\angle \mathrm{P}}$} & \multirow{2}{*}{\multicolumn{2}{|c|}{$\begin{array}{l}\text { protoconch } \\
\text { D numb. }\end{array}$}} & \multirow[b]{2}{*}{$\begin{array}{l}\text { teleoconch } \\
\text { numb. }\end{array}$} \\
\hline $\begin{array}{l}\text { Gecimen } \\
\text { GK-L }\end{array}$ & $\underset{(\mathrm{mm})}{\mathrm{H}}$ & $\underset{(\mathrm{mm})}{\mathrm{Bd}}$ & & & & & & & \\
\hline 6394 & 11.0 & 8.95 & 15.45 & 81.2 & 140.4 & 105.3 & 0.42 & - & 6.1 \\
\hline 7465 & ca 11.4 & 9.10 & 16.80 & 79.9 & 147.3 & 103.5 & ca 0.43 & 1.8 & 6.0 \\
\hline
\end{tabular}

Remarks.-The protoconch is very small, smooth, and naticoid with about 1.8 convex volutions. The end of the protoconch is marked by a obsolete radial ridge (text-fig. 16-[1]). The development of the spirals is abapical. The early

Fig. 16. Protoconch and some morphological features of the Neogene Archaeogastropoda and Heterogastropoda from Panay.

1-4: Monilea (Monilea) lentiginosa A. AdAMS, GK-L 7465. 1: Protoconch, 2: profile of the early whorls of the teleoconch, 3: umbilical area, and 4: datails of the spiral ornamentation at the peripheral part of the body whorl.

5: protocondh of Pygmaeorota (Lydiphnopsis) philippinensis subgen. et sp. nov., GK-L 7103.

6: profile of the body whorl of Architectonica (Architectonica) perspectiva (LINNÉ), GK-L 6396.

Unit bars indicate $0.2 \mathrm{~mm}$ for 1 and $5,0.5 \mathrm{~mm}$ for 2 and 3 , and $4 \mathrm{~mm}$ for 6 .

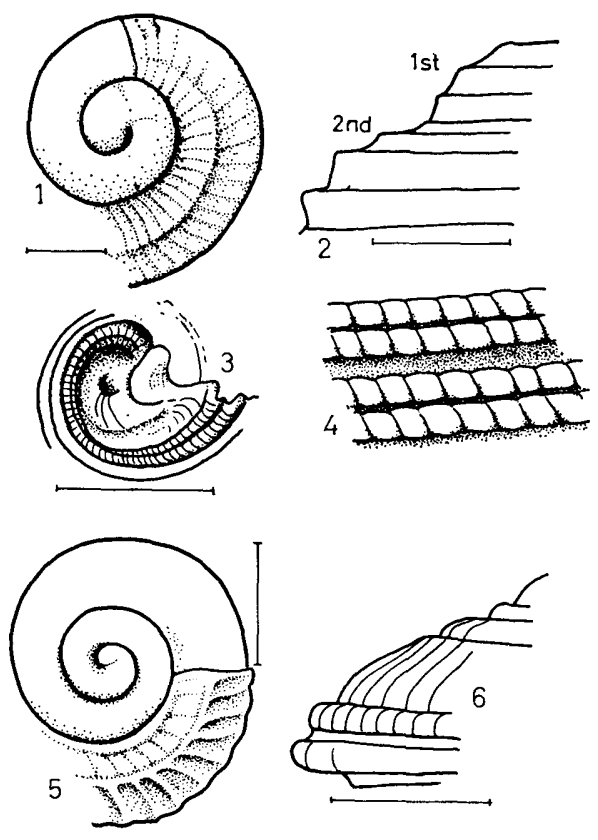

* Synonym: Talopia Gray, 1842. 
part of the first whorl of the teleoconch is almost smooth except for the median angulation with lira. Then appear the very weak peripheral thread and numerous minute axial lines. At the early part of the second whorl the third lira, which is very weak at the beginning and rapidly increased in size later, appears between the upper suture and the angle-forming lira (text-fig. 16-[2]). At the later part of the third whorl, on one hand, the fourth lira appears below the suture; on the other hand three older lirae become splitted into two by superimposing of a narrow and shallow longitudinal groove respectively on each lira. Then the superimposed grooves become distinct rapidly. The body whorl is provided with about 13 lirae between the upper suture and the rim of the umbilicus, of which the upper 10 are bifid. On the specimen GK-L 7465 the sixth lira counted from the uppermost one is tripartile. All the lirae are crossed by the growthlines and distinctly granular (text-fig. 16-[4]). The umbilicus is emarginated by a prominent bifid lira, which is ended at the small notch at the junction of the outer and columellar lips (text-fig. 16-[3]). There is a large spiral cord within the umbilicus and its termination is covered with a heavy umbilical callus.

Monilea callifera (LAMARCK), which was reported from the Pliocene and the Pleistocene of Java, is a close ally to the present specimens, but is readily distinguished from the latter in having taller shell and being devoid of the bifid lirae on the basal surface. YokоYамA described a species, Gibbula (?) taiwanica, from the upper Pliocene of Taiwan (1928, p. 66, pl.6, f. 3), but it can not be separable in every respects from Monilea lentiginosa.

Geological occurrence.-Upper Pliocene (Taiwan).

Recent distribution.-Malay, Indonesia, and northern Australia.

Horizon in Panay.-Upper part of the Ulian Formation.

Locality.-SKGS-73.

Genus Umbonium LINK, 1807*

(type-species: Trochus vestiarius LINNÉ by original designation)

Subgenus Umbonium (s.s.)

Umbonium (Umbonium) vestiarium (LINNÉ)

Pl. 1, Figs. 1-3 and 5-7

1758. Trochus vestiarius LinNÉ, Systema Naturae ed. 10, p. 758.

1822. Rotella lineolata LamarcK, Hist. Anim. s. Vert., Tom. 7, p. 7.

1843. Rotella lineolata, Deshayes, Hist. Anim. s. Vert., $2^{\mathrm{e}}$ ed., Tom. 9, p. 116.

1843. Rotella rosea, DeshaYes, ibid. p. 117.

1853. Umbonium vestiarium, A. AdAMs, Proc. Zool. Soc. London, p. 187.

1853. Umbonium depressa A. AdAMs, ibid. p. 188.

1878. Rotella vestiaria, Soweriby, Conch. Icon. Vol. 20, Rotella, pl. 3 , fs. 12a-12f.

1887. Rotella vestiaria, Sowerby, Thes. Conch. Vol. 5, p. 135, pl. 472, fs. 1-5 and 19-20.

1889. Umbonium vestiarium, PILSBRy, Man. Conch. Ser. 1, Vol. 11, p. 450, pl. 58, fs. $1-8$.

1935. Umbonium (Umbonium) vestiarium, Nomura, Sci. Rep. Tohoku Imp. Univ.

* Synonym: Pitonnellus MontFort, 1810; Pitonnilus Montfort, 1810; Globulus SchUMACHER, 1817; and Rotella LAMARCK, 1822. 
2nd Ser. Vol. 18, No. 2, p. 213, pl. 10, fs. 26a and b.

1935. Umbonium vestiarium, MaKIYAMA, Venus Vol. 1, p. 252 , f. 1.

1938. Umbonium (Umbonium) vestiarium, WeNZ, Gastropoda, p. 321, f. 730.

1966. Umbonium vestiarium, HABE and KoSUGE, Shells of the world in colour, Vol. 2, p. 7, pl. 3, fs. 5-7.

Material.-GK-L 6381-93 from loc. SKGS-73, GK-L 6468 from SKGS-71, and GK-L 7061-62 from SKGS-72. Preservation is moderately well.

$\begin{array}{ccrrcccc}\begin{array}{l}\text { Measurements.- } \\ \text { specimen }\end{array} & \begin{array}{c}\mathrm{H} \\ \text { GK-L }\end{array} & \begin{array}{c}\mathrm{D} \\ (\mathrm{mm})\end{array} & \begin{array}{c}\mathrm{Cal}^{*} \\ (\mathrm{~mm})\end{array} & \begin{array}{c}\mathrm{D} / \mathrm{H} \\ (\times 100)\end{array} & \begin{array}{c}\text { Cal/D } \\ (\%)\end{array} & \begin{array}{c}\angle \mathrm{P} \\ (\text { degrees })\end{array} & \begin{array}{c}\text { whorls } \\ \text { numb.** }\end{array} \\ 6381 & 8.2 & 12.9 & 10.4 & 157.4 & 80.5 & 110.3 & 7.1 \\ 6382 & 7.4 & 12.0 & 8.3 & 162.3 & 69.1 & 111.5 & 6.7 \\ 6385 & 5.6 & 8.9 & 6.1 & 158.9 & 68.5 & 116.5 & \text { ca } 5.5 \\ 6468 & 6.8 & 11.0 & 6.7 & 161.9 & 60.9 & 117.5 & 5+ \\ 7061 & 6.6 & 9.7 & 6.7 & 147.2 & 69.1 & 111.4 & 5+\end{array}$

Remarks.-The present specimens are quite identical to Umbonium vestiarium (LINNÉ) living in the Philippines. Its umbilical callus pad is extremely large and thick and its differentiation into lobes is very obscure. The Pleistocene specimens from Java (Univ. Amsterdam, Reg. No. 0-9854) have remarkably smaller callus pad (Cal/D 60\%) than the present material, otherwise they perfectly conform each other. The protoconch is similar that of the preceding species. It is very small, smooth, and naticoid with about 1.1-1.2 volutions. The largest diameter is only $0.21 \mathrm{~mm}$. The development of the sculpture is quite retrogressive. The first teleoconch whorl has three obsolete spiral threads and numerous axial lines. The spirals are the lateral extension of the original obsolete angulations, which soon become obscure and finally disappear on the later part of the second whorl rendering the flat profile to the whorl.

Geological occurrence.-Upper Pliocene (Taiwan) and Pliocene to Pleistocene (Indonesia).

Recent distribution.-Tropical part of the Indo-Pacific region from east coast of Africa to New Ireland.

Horizons.-Santa Barbara Silt and the upper part of the Ulian Formation.

Localities.-SKGS-71, 72, and 73 .

\section{Superfamily Rissoidea}

Family Tornidae

Genus Pygmaeorota KURODA and HABE, 1952***

(type-species: Cyclostrema duplicata LISCHKE by original designation)

Subgenus Lydiphnopsis subgen. nov.

(type-species: Pygmaeorota (Lydiphnopsis) philippinensis sp. nov., here designated)

\footnotetext{
* Cal: diameter of the callus pad.

** Number of the whorls including the protoconch and teleoconch.

*** Synonym: Circlotoma LASERON, 1958.
} 
Subgeneric diagnosis.-The shell is small and depressed-conical with very low spire. The protoconch is minute, smooth, and simply coiled. The teleoconch is ornamented with the prominent spiral keels. The aperture is ovoid, thickened by the callous deposit at the inner lip, and obscurely grooved at the posterior end to form an obsolete posterior canal. The callus is bi-lobed, of which the anterior one coincides with the termination of the spiral ridge inside the umbilicus. The umbilicus is wide and deep and has a spiral lira at the rim.

Comparison.-KURODA and HABE(1952, p. 80) established the genus Pygmaeorota under the family Tornidae on the basis of the type-species, Cyclostrema duplicata LISCHKE, which is closely similar in morphology to Liotia lodderae PetTERd, the type-species of Lodderia TATE, 1899. The comparison of the descriptions and figures of these two type-species leads to the conclusion that Pygmaeorota can not be easily distinguished from Lodderia on the morphological basis except for slight difference in the aperture. Lodderia lodderae has the remarkably thickened aperture, while Pygmaeorota duplicata is provided with simple one. The radula, however, is quite different between them. HABE (1958, pp. 47 and 57) clarified that Pygmaeorota has the Tornidae-type of radula (taenioglossate), while the radula of Lodderia, according to THIELE (1931, p. 61), is similar to that of Cirsonella ANGAs, 1877. That is to say Lodderia has the rhipidoglossate radula.

The present fossil subgenus is morphologically similar to both Pygmaeorota and Lodderia, but is apparently distinguished from them in having the characteristic aperture, which consists of the simple outer lip and modified inner lip with bi-lobed callus and obsolete posterior channel. The author has not any direct evidence to verify which genus this subgenus belongs to. However, the following fact is very suggestive for phylogenetic relation between Lydiphnopsis and Pygmaeorota. There is a weak tendency for thickening of the lower part of the inner lip on the species of Pygmaeorota. Postulating that Lydiphnopsis is an evolved group from Pygmaeorota, the author tentatively places this subgenus under Pygmaeorota.

Lydiphnopsis is easily distinguished from Lydiphnis MeLviLL, 1907, which is based on the type-species Cyclostrema euchilopteron MeLvill and STANDEN, in having the elevated spire and callous inner lip of the aperture.

Pygmaeorota (Lydiphnopsis) philippinensis subgen. et sp. nov. Pl. 1, Figs. 9, 10, and 11; Text-fig. 16

Material.-Holotype: GK-L 7103. A single perfect specimen.

Measurements.-

\begin{tabular}{|c|c|c|c|c|c|c|c|c|c|c|}
\hline $\begin{array}{l}\text { specimen } \\
\text { GK-L }\end{array}$ & $\underset{(\mathrm{mm})}{\mathrm{H}}$ & $\underset{(\mathrm{mm})}{\operatorname{Dmax}}$ & $\underset{(\mathrm{mm})}{\operatorname{Dmin}}$ & $\underset{(\times 100)}{\mathrm{Dmax} / \mathrm{H}}$ & $\underset{(\times 100)}{\mathrm{Dmin} / \mathrm{H}}$ & $\underset{\mathrm{D}}{\operatorname{prot}}$ & $\begin{array}{c}\text { oconch } \\
\text { numb. }\end{array}$ & $\begin{array}{l}\text { teleoconch } \\
\text { numb. }\end{array}$ & $\begin{array}{l}\text { spiral } \\
\text { pen }\end{array}$ & $\begin{array}{l}\text { keels } \\
\text { bod }\end{array}$ \\
\hline 7103 & 1.80 & 3.85 & 3.08 & 214 & 171 & 0.24 & 2.8 & 2.2 & 2 & \\
\hline
\end{tabular}

Diagnosis.-The shell is very small attaining less than four millimeters in maximum diameter, almost planispiral but apparently has the low and depressed spire above the body whorl. The protoconch consists of slightly less than three smooth volutions, of which the first tip is minute and globose, the succeeding one 
volution is roundly convex and slowly increasing its size, and the last one is also roundly convex but rapidly increasing (Text-fig. 16-[5]). The beginning of the teleoconch is indicated by the first appearance of the distinctly raised growth lines simultaneously with two spiral lirae, the latter of which later turn out to the raised keels. The suture of the protoconch is impressed but that of the teleoconch is only very slightly adpressed.

The cariate spiral lirae are stational in development. They, two on the penultimate whorl and ten on the body whorl, render the whorls polygonal profile. Of ten keels on the body whorl the peripheral two are much more prominent and a few ones close to the upper suture and umbilicus are much weaker than the others. The antecurrently obliquely radiating growthlines are regular and fine but distinct and form the very fine crenulations at the intersections with the spirals.

The umbilicus is wide and deep, emarginated by a spiral lira at the entrance, and provided with heavy growth lines outside and a median spiral ridge inside. The aperture is ovoid, somewhat thickened by the callous deposit at the inner lip forming the bi-lobed callus, and obscurely channelled posteriorly to form an obsolete posterior canal. The anterior semicircular lobe of the callus coincides with the termination of the median ridge of the umbilicus.

Comparison.-The present species closely resembles Pygmaeorota tornata (A. ADAMS) (1864, p. 251, pl. 255, fs. 19 and 20 as Cyclostrema), but the latter is about half as large as the former and its aperture is not provided with the callus.

WISSEMA reported Cyclostrema martini FISCHER as Vitrinella (Lydiphnis) martini from the island of Nias (1947, p. 31, pl. 1, fs. 22-24). While the typespecies of Lydiphnis MELVILL, 1907, Cyclostrema euchilopteron MELVILL and STANDEN from Persian Gulf (1903, p. 292, pl. 20, f. 7), has the almost perfectly planispiral shell with only two keels at the periphery furnishing a quadrate cross-section of the whorl. Furthermore the labrum of the aperture is not thickened by the callous deposit. These diagnoses do not conform with that of C. martini. This fact indicates that C. martini does not belong to Lydiphnis, but is included in Lydiphnopsis with the typical aperture. The present new species closely resembles $L$. martini, but the latter is much less compressed (Dmax $/ \mathrm{H}=$ 1.50-1.52) than the former $(\mathrm{D} \max / \mathrm{H}=2.14)$.

The present species is also allied to Pygmaeorota cingulifera (A. ADAMs) (1850, p. 43), but the former is readily distinguished from the latter in having the callous inner lip of the aperture and more depressed shell with less prominently carinate spiral lirae than the latter.

P. laevis (KIENER) (1864, p. 251, pl. 255, f. 3) is another ally to the present species, but the former is distinguished from the latter in the morphological difference in the columellar lip.

Horizon.-Upper part of the Ulian Formation.

Locality.-SKGS-72.

Superfamily Turritelloidea

Family Turritellidae 
Genus Turritella LAMARcK, 1799

(type-species: Turbo terebra LINNÉ by monotype)

Subgenus Turritella (s.s.)

Turritella (Turritella) terebra bantamensis MARTIN

Pl. 2, Figs. 13 and 18-23 and Pl. 4, Figs. 14 and 15; Text-fig. 17

1905. Turritella bantamensis MARTiN, Samml. Geol. Reichs-Mus. Leiden, N. F. Bd. 1, Abt. 1, p. 230, Taf. 35, fs. 539-545.

Material.-GK-L 6510-6518, 7461-7463, and 7476-7478 from loc. SKGS-71 and GK-L 7063 from loc. SKGS-72. All the specimens are more or less broken at the apex and the body whorl.

\begin{tabular}{|c|c|c|c|c|c|c|c|}
\hline \multicolumn{3}{|c|}{ Measurements.- } & \multirow[b]{2}{*}{$\underset{(\mathrm{mm})}{\mathbf{D}}$} & \multirow[b]{2}{*}{$\underset{\text { (degrees) }}{\angle \mathrm{P}}$} & \multirow[b]{2}{*}{$\begin{array}{l}\text { suture angle } \\
\text { (degrees) }\end{array}$} & \multirow[b]{2}{*}{$\begin{array}{l}\text { whorls } \\
\text { numb. }\end{array}$} & \multirow[b]{2}{*}{$\begin{array}{l}\text { whorl profile } \\
\mathrm{D} / \mathrm{H} \text { on pen }\end{array}$} \\
\hline $\begin{array}{l}\text { specimen } \\
\text { GK-L }\end{array}$ & $\underset{(\mathrm{mm})}{\mathrm{H}}$ & $\underset{(\mathrm{mm})}{\mathrm{Bd}}$ & & & & & \\
\hline 6510 & $44.35+$ & - & 12.10 & 12.4 & 12.6 & $10+$ & $9.8 / 5.65=1.70$ \\
\hline 6511 & $41.50+$ & - & 9.45 & 12.2 & 13.2 & $12.5+$ & $7.84 / 4.0=1.98$ \\
\hline 6517 & $14.70+$ & - & 4.25 & 16.4 & 13.2 & $11.5+$ & $2.0 / 1.22=1.63$ \\
\hline 7063 & $7.70+$ & $2.35+$ & 2.50 & 11.8 & 13.1 & $9.5+$ & $2.0 / 1.1=1.82$ \\
\hline 7461 & $84.90+$ & - & 21.00 & 13.8 & 13.2 & $15+$ & $19.2 / 11.1=1.73$ \\
\hline 7462 & $81.90+$ & 20.7 & 19.40 & 14.3 & 14.9 & $15+$ & $15.1 / 8.9=1.69$ \\
\hline 7463 & $68.70+$ & 19.5 & 18.10 & 15.1 & 15.5 & $16.6+$ & $13.9 / 7.8=1.78$ \\
\hline
\end{tabular}

Remarks.-The present turritellid specimens are featured by the large size, roundly convex adult whorls, and simply curved and protractly oblique growth lines and readily included in the group of Turritella (Turritella) terebra (LINNÉ).

The protoconch is unknown. The early three whorls are sharply carinated at lower two-fifths and provided with two spiral lirae, one at the carina (Per) and the other close to the lower suture $\left(\mathrm{P}_{1}\right)$. On the fourth whorl two secondary spirals $\left(S_{1}\right.$ and $S_{2}$ ) appear on the upper slope and on the next whorl another secondary $\left(\mathrm{S}_{3}\right)$ is intercalated between the carina and suprasutural lira. On the seventh to nineth whorl two secondaries $\left(S_{4}\right.$ and $\left.S_{5}\right)$ are intercalated respectively close to the upper suture and between $S_{1}$ and $S_{2}$. The profifile of the whorl is still sharply carinated at the lower two-fifths of the whorl-height with almost flat surface above and below until eighth to nineth whorls, but it becomes round and more round in keeping pace with the rapid increase in relative size of the secondary spirals (Text-fig. 17-[1] and [4]).

The adult whorls on the spire are ornamented with distinct seven spiral lirae and other fine threads and minute lines of tertiary and quaternary order. Of the distinct seven lirae Per, $\mathrm{P}_{2}, \mathrm{~S}_{2}$, and $\mathrm{S}_{3}$ are somewhat stronger than the others. $\mathrm{P}_{2}$ may be partly concealed by the succeeding whorl. On some specimens the tertiary thread between $S_{1}$ and $S_{5}$ is distinct and only slightly weaker than $S_{1}$. The basal surface below $P_{1}$ is provided with two or three distinct spiral threads, which may be intercalated by finer lines. The straight line connecting the crossings of the growth line with the upper and lower sutures makes the angle of about 32 degrees with the axis of coiling. 

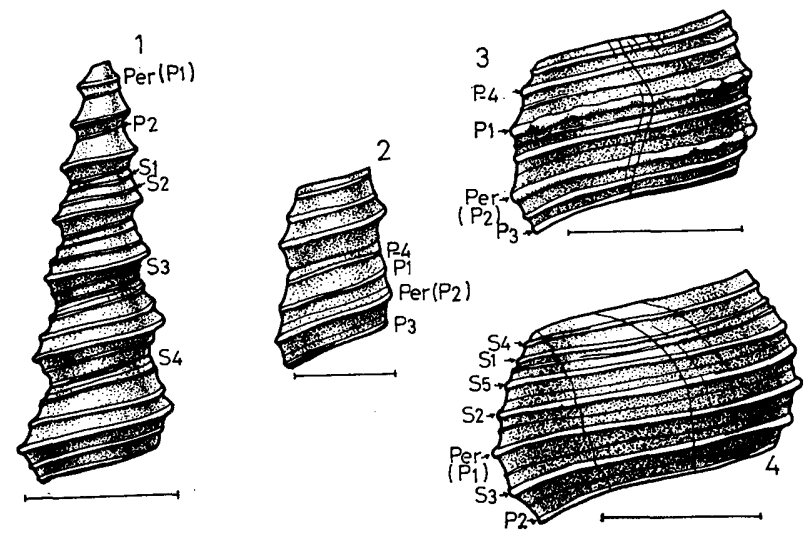

Fig. 17. Profile and ornamentation of the teleoconch of Turritella 1 and 4: Turritella (Turritella) terebra bantamensis MARTIN, GK-L 7063 and 7461 .

2 and 3: T. (Kurosioia) cingulifera filiola YoкоYAMA, GK-L 6377.

The pattern of the ornamentation on the adult and adolescent whorls consisting of four prominent and widely spaced spirals, of which the lowest, $\mathrm{P}_{2}$, may be concealed by the succeeding whorl, at the lower half and three weaker and narrowly spaced ones at the upper half is the most characteristic feature of Turritella bantamensis MARTIN according to the original author. This is well exhibited on some specimens from Panay, while others illustrate somewhat diversed pattern having more numerous and irregularly spaced upper spirals, although the early morphological development is quite same among all the specimens in hand. It seems natural to identify these specimens to $T$. bantamensis. The distinction of T. bantamensis MARTIN from T. terebra (LINNÉ), however, is not sharp, because two species perfectly conform each other as to the size and general outline of the shell, profile of the whorl, and configuration of the growthlines. Moreover the early development of the spirals is very similar between two species. The only difference is concerned with the general strength of the spirals on the adult whorls and the pattern of the spirals on the upper half of the whorls. T. terebra is said to have on an average somewhat stronger spirals and its upper spirals on the later whorls are more numerous and widely separated than on $T$. bantamensis. The author agrees with the idea that T. terebra and T. bantamensis respectively belong to particular populations, but can not recognize the specific values of the difference mentioned above. Hence the author treats them and their allies, T. bantamensis talahabensis MARTIN, T. bantamensis producta MARTIN, T. terebra kendengensis Altena, as the subspecies of T. terebra (s.l.).

Geological occurrence.-Lower Miocene? and Pliocene (Indonesis).

Horizons.- Santa Barbara Silt and the upper part of the Ulian Formation. Localities.-SKGS-71 and 72 .

Subgenus Kurosioia IDA, 1952

(type-species: Turritella kurosio IDA by original designation) 


\section{Turritella (Kurosioia) cingulifera filiola YoKочама Pl. 2, Figs. 14 and 15; Text-fig. 17}

1928. Turritella filiola Yokoyama, Imp. Geol. Surv. Japan Rep. No. 101, p. 57, pl. 4, f. 7 .

1938. Turritella filiola, OtukA, Japan. Jour. Malac. Vol. 8, No. 1, p. 39, text-fig. 13.

1952. Turritella (Kurosioia) filiola, IDA, Geol. Surv. Japan Rep. No. 150, p. 44, pl. 1 , fs. 5 and $6 ;$ pl. 7, f. 7 .

1959. Turritella (Kurosioia) filiola, Kotaka, Sci. Rep. Tohoku Univ. 2nd Ser. Vol. 31 , No. 2, p. 85, pl. 3, fs. 6,7 , and 8; pl. 11, fs. 1 and 3.

1960. Turritella filiola, MacNeIL, U.S. Geol. Surv. Prof. Pap. No. 339, p. 36, pl. 1, f. 20 ; pl. 11, fs. $22-26$.

Material.-GK-L 6377 and 6378.

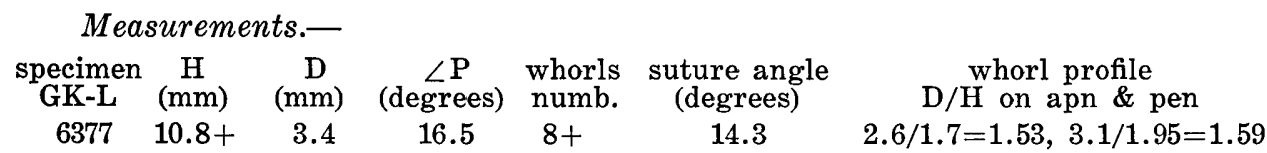

Remarks.-Turritella (Kurosioia) kurosio IDA, T. $(K$.$) filiola Yoкочамa,$ T. (K.) fascialis MENKE, and $T$. $(K$.) cingulifera SOWERBY are so closely allied that distinction of them is not easy task. According to KoTAKA (1959, pp. 85 and 86 ) the ornamentation of $T$. (K.) kurosio develops more rapidly and the profile of its whorls is more convex than that of $T$. (K.) filiola. $T$. (K.) fascialis is provided with finer ornamentation than $T$. (K.) filiola. C. BEETs $(1950$, p. 330) considered that $T$. (K.) filiola is a synonym of $T$. (K.) cingulifera, but the author prefers to separate them each other at subspecies-level. The reason is as follows. On $T$. cingulifera the secondaries are intercalated at earlier stage and soon become strong accompanid by the distinct tertiaries at both sides. The uppermost primary lira $\left(\mathrm{P}_{1}\right)$ is granulated on $T$. cingulifera instead of the smooth one of T. fliola. Consequently the spiral ornamentation of the former is much heavier than that of the latter. Moreover the opisthocyrt growthliness are somewhat deeper on the former than on the latter.

Detailed characteristics of the late whorl and ornamental design on the early whorls are illustrated in Text-fig. 17-[2] and [3].

Geological occurrence.-Pliocene (Taiwan, Okinawa, and Southwest Japan) and Pleistocene (Southwest Japan).

Horizon.-Upper part of the Ulian Formation.

Locality.-SKGS-73.

Superfamily Vermetoidea

Family Vermetidae

Genus Dendropoma MöRCH, 1861*

(type-species : Siphonium lituella MörCH by subsequent designation, KeEN, 1961)

* Synonym: Spiroglyphus auct, non DAUDIN, 1800; Stoa auct, non De SERRES, 1846; Bivonia Gray, 1847, non SACCo, 1832; Siphonium Mörch, 1858, non LINK, 1807; Magilina Vélain, 1877?; Vermitoma Kuroda, 1926; and Veristoa Iredale, 1937. 


\title{
Dendropoma javana (MARTIN) \\ Pl. 4, Figs. 10, 11, and 12
}

1879-80. Vermetus javanus MarTIN, Tertiärschicht. a. Java, p. 77, tab. 14, f. 13. 1905. Vermetus javanus, Martin, Samml. Geol. Reichs-Mus. Leiden, N. F. Bd. 1, Abt. 1, p. 223, Taf. 34, fs. 513-516.

1920. Vermetus javanus, Tesch, Paläont. v. Timor, Lief. 8, p. 59, Taf. 132, fs. $192 \mathrm{a}$ and $\mathrm{b}$.

1935. Lemintina javana, Nomura, Sci. Rep. Tohoku Imp. Univ. 2nd Ser. Vol. 18, No. 2, p. 192 , pl. 8 , f. 39 .

Material.-GK-L 7514 to 7523 and many other unregistered specimens from one and same locality. The specimens are more or less broken.

Measurements.-Large specimens are measured $6.0-6.5 \mathrm{~mm}$ in maximum diameter of the tube.

Remarks.-The specimens in hand are generally broken but are characteristic enough to be identified to Vermetus javanus MARTIN from Javan Miocene and Pliocene. The protoconch is visible only on a few specimens, on which the first whorl of the teleoconch turns at right angle to the coiling axis of the protoconch and embraces the latter.

The early part of the shell forms a somewhat irregular spiral coil (six whorls being counted on GK-L 7519). Thereafter the coiling abruptly becomes irregular and finally becomes linear. Many specimens representing adult or adolescent stage are almost straight or only slightly curved. The sculpture starts as the smooth, close, and regularly spaced growth lirae. On the next whorl a few granules are developed on the growth lirae, especially those at the lateral surface and gradually increased in number on each lira. At the same time the interspaces of the lirae become wider and wider. On the next whorl the granules are longitudinally connected by the weak spiral threads, which become abruptly strong. then the granules show a tendency for longitudinal elongation. On the adult tube the prominent primary spiral ridges are intercalated by a few, fine, and granular secondaries at each interspace.

Smooth inner surface of the tubes and the general facies of the morphologic features indicate the specimens belong either to Serpulorbis SASSI, 1827, or Dendropoma MöRch, 1861. As was pointed out by KEEN (1961, p. 184) distinction of the genera of Vermetidae by means of shell-morphology is very difficult. The present specimens are, however, classified to Dendropoma evaluated the apparent tendency for loose coiling of early part and right angle turning of medial part and being devoid of the scars of the broken tubes.

Geological occurrence.-Lower Miocene to Pliocene (Indonesia).

Horizon.-Upper part of the Dingle Formation.

Locality._SKGS-74.

\author{
Superfamily Cerithioidea \\ Family Thiaridae \\ Subfamily Thiarinae
}

Genus Sermyla H. and A. AdAMs, 1854

(type-species: Melania tornatella LEA by original designation) 


\section{Sermyla riqueti (GRATELOUP)}

Pl. 1, Figs. 24 and 25

1853. Tarebia riqueti, H. and A. AdAMs, Gen. Rec. Moll. p. 304.

1874. Melania riqueti, Küster, Conch. Cab. Bd. 1, Melaneidae, p. 333, Taf. 34, fs. 6 and 6 a.

1951. Melanoides riqueti, (HIRASE) TAKI, Illustr. Handb. Shells pl. 82, f. 8.

Material.-GK-L 6442. The later whorls of the specimen is excellently preserved but the apical part has lost the surface layer.

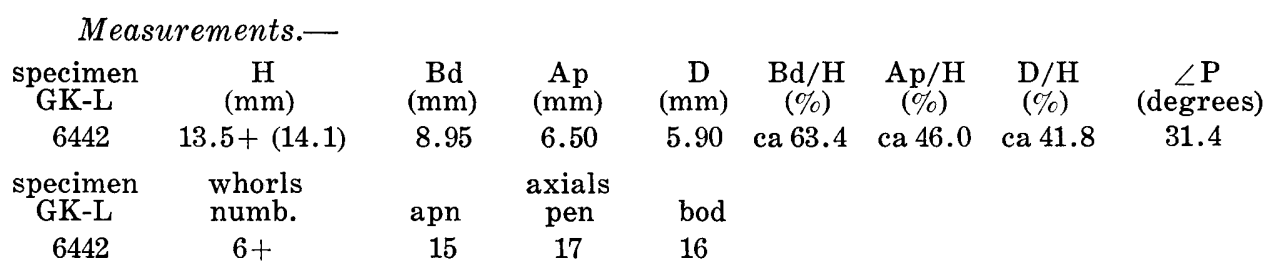

Remarks.-The details of the early whorls of the present specimen can not be examined because of imperfect preservation. The last whorl is provided with 16 strong axial ribs at the lateral side and 9 spiral lirae on the basal surface. The axial ribs are slightly retrocurrently oblique, simply curved with concave face forwardly (opisthocyrt), sharply elevated with steep sides, separated by somewhat wider interspaces, and terminated abruptly by a distinct spiral groove anteriorly. Of the basal spiral lirae the upper two are much stronger than the others and separated by narrower interspaces. The more anterior is the position, the weaker and narrower is the lira. The axial ribs sharply cut by the basal spirals are the typical feature of the genus Sermyla H. and A. ADAMs, 1854, with the type-species, Melania tornatella LEA.

The present species is allied to Sermyla tornatella (LEA) (1850, p. 185 and REEve, 1860, pl.24 fs. 173a and b), but is readily distinguished from the latter in having less numerous axial ribs, which are not sigmoid but simply curved. The present specimen is not included in the range of variation of S. tornatella, although the latter is variable in morphology as pointed out by MARTIN (1905, p. 245). The present specimen conforms with $S$. riqueti (Grateloup), which has been reported from southeast Asia from Indonesia to Okinawa.

Geological occurrence.-Pleistocene (Indonesia and Taiwan).

Recent distribution.-Philippines, Taiwan, and Okinawa.

Horizon.-Upper part of the Ulian Formation.

Locality.-SKGS-73.

Genus Tarebia H. and A. ADAMs, 1854

(type-species: Melania granifera LAMARCK by original designation)

Tarebia submadiunensis (Yokoyama)

Pl. 1, Figs. 19, 20, 21, 22, and 23

1928. Melania submadiunensis Yokоyama, Imp. Geol. Surv. Japan Rep. No. 101, p. 59 , pl. 5 , fs $2-5$. 
Material.-GK-L 6443 to 6448 from loc. SKGS-73, GK-L 6465 and 6566 from SKGS-71, and GK-1 7067 from SKGS-72. All the specimens are more or less abraded.

\begin{tabular}{|c|c|c|c|c|c|c|c|}
\hline $\begin{array}{l}\text { specimen } \\
\text { GK-L }\end{array}$ & $\underset{(\mathrm{mm})}{\mathrm{H}}$ & $\underset{(\mathrm{mm})}{\mathrm{Bd}}$ & $\underset{(\mathrm{mm})}{\mathrm{Ap}}$ & $\underset{(\mathrm{mm})}{\mathrm{D}}$ & $\underset{(\%)}{\mathrm{Bd} / \mathrm{H}}$ & $\underset{(\%)}{\mathrm{Ap} / \mathrm{H}}$ & $\underset{(\%)}{\mathrm{D} / \mathrm{H}}$ \\
\hline 6443 & 12.85 & 9.35 & 7.40 & 6.80 & 72.6 & 57.5 & 52.9 \\
\hline 6444 & 8.75 & 6.30 & 5.00 & 4.50 & 72.0 & 57.0 & 51.4 \\
\hline 6465 & $11.5+(12.0)$ & 8.90 & 6.95 & 6.15 & 74.1 & 57.9 & 51.3 \\
\hline $\begin{array}{l}\text { specimen } \\
\text { GK-L }\end{array}$ & $\underset{\text { (degrees) }}{\angle \mathrm{P}}$ & $\begin{array}{l}\text { who } \\
\text { proto }\end{array}$ & teleo & pen $^{\text {axi }}$ & bod & & \\
\hline 6443 & 44.4 & - & ca 6 & 15 & 16 & & \\
\hline 6444 & 37.5 & - & 5.6 & 14 & - & & \\
\hline 6465 & 47.1 & ca 2 & ca 3.8 & 16 & 16 & & \\
\hline
\end{tabular}

Remarks.-The present specimens illustrate rather the wide range of morphological variation concerning especially with the strength of the granulations. They, however, show the following stable features; the early spire-whorls are ornamented with four spiral lirae which are much wider than the interspaces and about 13-14 axial riblets which are slightly curved with the concave face forward. The intersections of the spirals and the axials are distinctly granular. On the penultimate and the body whorl of the adult shells the spirals predominate over the axials on the lateral surface except for the subsutural area where the axials are somewhat stronger than the spirals. In general the axial riblets do not stop abruptly but gradually disappear on the basal surface and in consequence a few lirae on the upper part of the basal surface are still granular. This character is more peculiarly pronounced at the early stage of growth and becomes indistinct later in accordance with predominance of the spirals over the axials. The suture is distinctly step-like.

In these respects the present specimens are reasonably included in Tarebia H. and A. ADAMS, 1854, and quite identical to Melania submadiunensis YokoYAMA from the Upper Pliocene of Taiwan. They also show some resemblance to M. madiunensis MARTIN (1905, p. 242, Taf. 36, fs. 578-580) from the Pliocene of Java, but the former is easily distinguished from the latter in having coarser axial riblets. Furthermore the spiral lirae on the spire whorls are regularly four in the present species instead of five on $M$. madiunensis.

Geological occurrence.-Upper Pliocene (Taiwan).

Horizons.-Santa Barbara Silt and the Upper part of the Ulian Formation. Localities.-SKGS-71, 72, and 73 .

\author{
Family Cerithiidae \\ Subfamily Cerithiinae
}

Genus Bittium LEACH (in GRAY), 1847

(type-species: Strombiformis reticulatus Da Costa by original designation)

Subgenus Bittium (s.s.)

Bittium (Bittium) glareosum GouLD

Pl. 2, Figs. 1 and 2; Text-fig. 18 
1861. Bittium glareosum Gould, Proc. Boston Soc. Nat. Hist. Vol. 7, p. 387.

1942. Bittium glareosum, YEN, Proc. Malac. Soc. London, Vol. 24, p. 207, pl. 15, f. 79 .

1964. Bittium glareosum, JoHnson, Smithsonian Inst. U. S. Nat. Mus. Bull. 239, p. 84, pl. 12 , f. 15 .

Material.-GK-L 6737. Preservation of the shell is not perfect, but is serviceable for identification.

\begin{tabular}{|c|c|c|c|c|c|c|c|}
\hline $\begin{array}{l}\text { specimen } \\
\text { GK-L }\end{array}$ & $\underset{(\mathrm{mm})}{\mathrm{H}}$ & $\underset{(\mathrm{mm})}{\mathrm{Bd}}$ & $\underset{(\mathrm{mm})}{\mathrm{Ap}}$ & $\underset{(\mathrm{mm})}{\mathrm{D}}$ & $\underset{(\%)}{\mathrm{Bd} / \mathrm{H}}$ & $\underset{(\%)}{\mathrm{Ap} / \mathrm{H}}$ & $\underset{(\%)}{\mathrm{D} / \mathrm{H}}$ \\
\hline 6737 & 10.45 & 3.70 & 2.15 & 3.10 & 35.4 & 20.6 & 29.7 \\
\hline $\begin{array}{l}\text { specimen } \\
\text { GK-L }\end{array}$ & $\underset{\text { (degrees) }}{\angle \mathrm{P}}$ & $\begin{array}{l}\text { whorls } \\
\text { numb. }\end{array}$ & \multicolumn{2}{|c|}{$\begin{array}{c}\text { suture angle } \\
\text { (degrees) }\end{array}$} & \multicolumn{2}{|c|}{$\begin{array}{l}\text { whorl profile } \\
\mathrm{D} / \mathrm{H} \text { on pen }\end{array}$} & \\
\hline 6737 & 4.2 & $10+$ & \multicolumn{2}{|c|}{14.1} & \multicolumn{2}{|c|}{$2.7 / 1.5=1.8$} & \\
\hline
\end{tabular}

Remarks.-The preserved first whorl of the present specimen is hexagonal in profile with sharply bi-angulated periphery. The angulations are situated respectively at upper fourth and lower third. The surface above the upper angulation and below the lower one are remarkably contracted, while the area between the angulations is almost vertical and concave. Distinct spiral lirae are situated respectively on the angulations and another weak primary thread is close to the lower suture. Besides the spirals there are 13 axials and their crossings with the spirals are distinctly nodular. On the third whorl the fourth primary appears at some distance below the upper suture and on the next whorl the fifth thread appears close to the upper suture. In consequence with the appearance of these new threads the relative position of the preceding spirals is moved downward. That is to say the development of the spirals is abapical. The ornamental pattern consisting of five primary spirals and 13-16 axials is, however, maintained throughout the later growth stages.

Small size, weak canal, and varices of the present specimen indicate that it belongs to Bittium (s.s.). The present specimen conforms very well with B. glareosum Gould living in the tropical east Asian waters. The only slight difference is visible as to the paired lirae separating the basal surface from the lateral one. They are more close-set and somewhat finer on the present specimen than on the type specimen figured by JoHNSON.

It is also allied to Bittium dijki (MARTIN) (1883-87, p. 156, tab. 8, f. 153). They show the quite similar morphological development at early growth-stage, but the upper two spiral lirae are not so developed later on $B$. dijki as on the present species. Consequently the upper part of th adult whorl of $B$. dijki is more contracted than the present species. Furthermore the pleural angle is remarkably larger in the former than in the latter (Fig. 18-[2]).

Recent distribution.-Okinawa, China Sea, and Bonin Island.

Horizon.-Upper part of the Dingle Formation

Locality._SKGS-74.

Genus Argyropeda Melvill and Standen, 1901

(type-species: Argyropeda divina MelviLl and STANDEN by original designation) 


\section{Argyropeda divina MELvill and StANDEN \\ Pl. 2, Figs. 7-11; Text-figs. 18 and 19}

1901. Argyropeda divina Melvill and Standen, Proc. Zool. Soc. London, p. 372, pl. 21 , f. 3 .

1909. Argyropeda divina, Schepman, Resultats Siboga Expeditie, Monogr. 49, pt. 1, p. 169 , pl. 15, f. 11.

1912. Argyropeda divina, Melvill, Proc. Malac. Soc. London, Vol. 10, pt. 3, p. 246, pl. 12 , f. 10.

1960. Argyropeda cf. A. divina, MacNeIL, U. S. Geol. Surv. Prof. Pap. No. 339, p. 40 , pl. 11, f. 19.

Material.-GK-L 7069 to 7078 from one and same locality. Preservation is generally good.

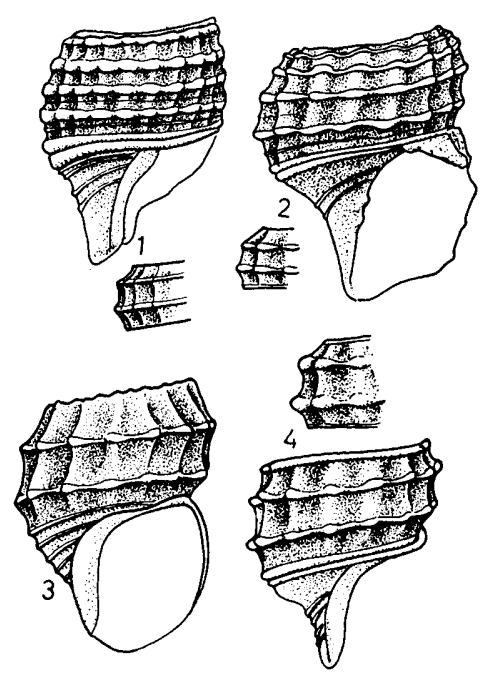

Fig. 18. Comparison of the teleoconch-whorls of certain species of Bittium and Argyropeda (not scale).

1: Bittium (Bittium) glareosum Gould, GKL 6737 .

2: B. (B.) dijki (MARTIN), Rijksmus. Geol. Min. Leiden, St. 10459, Martin's figured type specimen.

3: Argyropeda divina Melvill et Standen, GK-L 7071.

4: A. spinigera (Martin), Rijksumus. Geol. Min. Leiden, St. 10578, Martin's figured type specimen.

\begin{tabular}{|c|c|c|c|c|c|c|c|c|c|}
\hline \multicolumn{10}{|c|}{ Measurements.- } \\
\hline $\begin{array}{l}\text { specimen } \\
\text { GK-L }\end{array}$ & $\underset{(\mathrm{mm})}{\mathrm{H}}$ & $\underset{(\mathrm{mm})}{\mathrm{Bd}}$ & $\underset{(\mathrm{mm})}{\mathrm{Ap}}$ & $\underset{(\mathrm{mm})}{\mathrm{D}}$ & $\underset{(\%)}{\mathrm{Bd} / \mathrm{H}}$ & $\underset{(\%)}{\mathrm{Ap} / \mathrm{H}}$ & $\begin{array}{l}\mathrm{D} / \mathrm{H} \\
(\%)\end{array}$ & $\angle \underset{(d g}{A}$ & $\underset{\mathrm{es})}{\angle \mathrm{P}}$ \\
\hline 7069 & 9.30 & 3.4 & 2.05 & 3.05 & 36.5 & 22.1 & 32.8 & 53.2 & 11. \\
\hline 7070 & 8.95 & 3.4 & 1.95 & 3.00 & 37.9 & 21.8 & 33.4 & 47.5 & 12 \\
\hline 7071 & 9.00 & 3.7 & 2.30 & 3.05 & 41.1 & 25.6 & 33.8 & 52.8 & 14. \\
\hline 7075 & 8.35 & 3.3 & 1.90 & - & 39.5 & 22.7 & - & 48.5 & 13 \\
\hline
\end{tabular}

Remarks.-Argyropeda has a few spiral rows of the granules on the lateral surface of the whorls. Among the known species of Argyropeda A. izekiana KURODA and $A$. melvilli SCHEPMAN are readily distinguished from the others in having the upper row of the granules much closer to the upper suture than the other species. A. divina MELvill and StANDEN is separated from A. schepmaniana MELVILL on the basis of the smooth subsutural thread instead of the granulated one of the latter. Furthermore the former is provided with more convex whorl and less numerous axials than the latter.

The present specimens are characterized by the following features. Firstly they have the convex profile of the whorls with two distinct peripheral angulations, 
of which the upper one is remarkably apart from the upper suture; secondly their axials are as close as those of $A$. divina (14-16 on the penultimate and body whorl) (Text-fig. 18-[3]). These facts lead to the conclusion that the present specimens are the closest to A. divina among the species mentioned above. The adult whorls of the present material, however, have the weakly granulated subsutural thread, while the subsutural thread of $A$. divina, according to the original description, is smooth. That is to say, they seemingly represent the transitional form between $A$. divina and $A$. schepmaniana. The close examination, however, reveals that the subsutural thread is granulated only on the adolescent and adult whorls on the present specimens, while the granular feature of the subsutural thread begins even at the neanic stage on $A$. schepmaniana. Considering the above mentioned facts the present author is inclined to include the present specimen in A. divina. The adult specimens have a distinct varix outside the labrum.

Cerithium (s.s.) spinigerum MARTIN (1883-1887, p. 156, Tab.8, f. 152) is included in Argyropeda on the basis of the size, ornamentation of the teleoconch, and characteristics of the protoconch. It shows the similar profile of the whorls to that of the present specimens, but its basal ornamentation is quite different from that of the latter (Text-fig. 18-[4]). There is a bifurcate, smooth, and distinct spiral thread at the basal angulation on A. spinigera and the basal surface itself is almost smooth except for four weak threads on the snout. While the basal surface and the snout of the present specimens are provided with equally spaced weak spiral threads. The subsutural thread of the body whorl of the type specimen of $A$. spinigera (Rijksmus. Geol. Min., Leiden, St. 10,578) is quite smooth, while TESCH described the specimens with subsutural granulation from Timor. Otherwise the specimens from Timor quite conforms with MARTIN's species.

The protoconch of the present specimens consists of about three and one-fifth volutions of which the last half is bi-carinate, although the text-figure does not illustrate it clearly because of the partial abrasion on the figured specimen (Text-fig. 19).

Geological occurrence.-Pliocene (Okinawa).

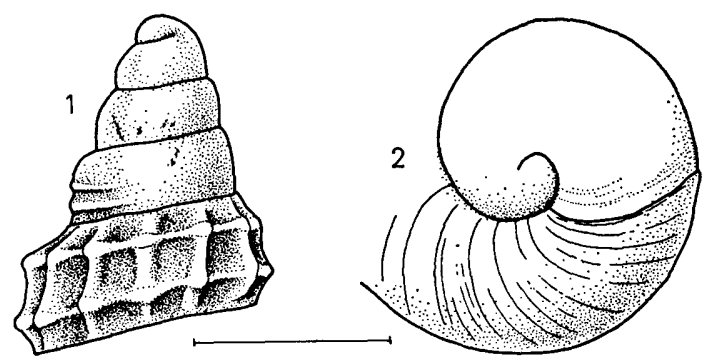

Fig. 19. Protoconch and early part of the teleoconch of Argyropeda and Janthina.

1: Argyropeda divina MeLvill et STANDEN, GK-L 7075. Unit bar indicates $0.5 \mathrm{~mm}$.

2: Janthina (Janthina) ianthina (LINNÉ), GK-L 6905. Unit bar indicates $2.5 \mathrm{~mm}$.

Recent distribution.-Indo-Pacific region from Persian Gulf to the Philippines.

Horizon.-Upper part of the Ulian Formation.

Locality.-SKGS-72. 
Genus Clava Martyn, 1784*

(type-species: Clava rugata MARTYN=Murex asperus LINNÉ by subsequent designation, PILsBry, 1901)

Subgenus Proclava THIELE, 1929

(type-species: Cerithium pfefferi DUNKER by monotype)

Clava (Proclava) kochi (PhILIPPI)

Pl. 2, Figs. 3, 4, and 16

1848. Cerithium kochi PHILIPPI, Testaceorm novorum centuria, Zeitschr. f. Malak. Bd. 4, p. 152.

1851. Cerithium kochi, PHILIPPI, Abbild. u. Beschr., Abt. 3, Cerithium, p. 2, Taf. 1, f. 3.

1855. Cerithium kochi, Sowerby, Thes. Conch. Vol. 2, p. 853, pl. 176, fs. 13-15.

1866. Vertagus kochi, ReEve, Conch. Icon. Vol.15, Vertagus, pl. 5, fs. 26a and b.

1887. Cerithium (Vertagus) kochi, TrYon, Man. Conch. Ist Ser. Vol.9, p. 147, pl. 28, fs. 48 and 49.

1906. Cerithium kochi, TokunaGa, Jour. Coll. Sci. Imp. Univ. Tokyo, Vol.21, Art. 2, p. 24, pl. 1, fs. 49a and b.

1922. Cerithium (Clava) kochi, Yokoyama, ibid. Vol. 44, Art. 1, p. 71, pl. 3, f. 13.

1935. Cerithium (Proclava) kochi, OTUKA, Bull. Earthq. Res. Inst. Vol. 13, p. 858, pl. $54, f .78$.

1942. Cerithium (Vertagus) kochi, ABrard, Arch. Mus. Nat. d'Hist. Paris, Tom. 6, No. 18 , pp. 61 and 94, pl. 6, f. 29.

1947. Clava (Proclava) kochi, WIssema, Young Tert. Quat. Gastrop. p. 52, pl.2, f. 40.

1951. Cerithium kochi, (HIRAse) Taki, Handb. Illustr. Shells, pl. 83, f. 5.

1954. Proclava kochi, KIRA, Colored Illustr. Shells Japan, Vol. 1, p. 24, pl. 12, f. 18.

1954. Cerithium (Proclava) kochi, TAKI and OYAMA, Palaeont. Soc. Japan Spec. Pap. No. 2, p. 10, pl. 23, f. 13.

1960. Cerithium kochi, Hayasaka and Hayasaka, Trans. Proc. Palaeont. Soc. Japan, N. S. No. 38, p. 270, pl. 31, f. 15.

1961. Cerithium kochi, HaYASAKA, Sci. Rep. Tohoku Univ. 2nd Ser. Vol. 33, No. 1, p. 71, pl. 9 , fs. $8 \mathrm{a}$ and $b$.

Material.-GK-L 6477 and 6478. Preservation is imperfect especially at the apical part.

\begin{tabular}{|c|c|c|c|c|c|c|c|}
\hline \multicolumn{2}{|c|}{ Measurements.- } & \multirow[b]{2}{*}{$\underset{(\mathrm{mm})}{\mathrm{Bd}}$} & \multirow[b]{2}{*}{$\underset{(\mathrm{mm})}{\mathbf{A p}}$} & \multirow[b]{2}{*}{$\underset{(\mathrm{mm})}{\mathrm{D}}$} & \multirow[b]{2}{*}{$\begin{array}{c}\mathrm{Bd} / \mathrm{H} \\
(\%)\end{array}$} & \multirow[b]{2}{*}{$\underset{(\%)}{\mathrm{Ap} / \mathrm{H}}$} & \multirow[b]{2}{*}{$\begin{array}{l}\mathrm{D} / \mathrm{H} \\
(\%)\end{array}$} \\
\hline $\begin{array}{l}\text { specimen } \\
\text { GK-L }\end{array}$ & $\underset{(\mathrm{mm})}{\mathrm{H}}$ & & & & & & \\
\hline 6477 & $19.6+(21.4)$ & 11.2 & 6.3 & 6.65 & 54.2 & 29.4 & 31.1 \\
\hline 6478 & 18.7 & 7.4 & 5.1 & 6.00 & 38.5 & 27.3 & 32.2 \\
\hline $\begin{array}{l}\text { specimen } \\
\text { GK-K }\end{array}$ & $\underset{\text { (degrees) }}{\angle \mathrm{P}}$ & $\begin{array}{l}\text { protoconch } \\
\text { numb. }\end{array}$ & & $\begin{array}{l}\text { conch } \\
\text { nb. }\end{array}$ & & & \\
\hline 6477 & 12.6 & - & & 9 & & & \\
\hline 6478 & 12.1 & ca 1.8 & & & & & \\
\hline
\end{tabular}

Remarks.-Cerithium kochi PHILIPPI is one of the common species in south Japan and Taiwan. It is readily distinguished from the related species by the characteristic feature of the alternating three pairs of strong and weak spirals * Synonym: Vertagus Schumacher, 1817, non Link, 1807 and Rhinoclava Swainson,
1840 . 
on the spire whorls. The primary spirals are quadrate in cross section with almost flat top. While the secondaries are rather strong and more than a half as wide as the primaries. The present specimens almost perfectly conform with the recent specimens from south Japan, but the anterior canal of the aperture of the former is somewhat longer and more distinctly bent than that of the latter. Furthermore the shell-size of the former is only about sixty percent of the latter, although they show the adult feature. WISSEMA reported the Pleistocene specimens of the same species from the island of Nias, Indonesia (1947, p. 52, pl. 2, f. 40). The figured specimen is almost same size as the present specimens from Panay. They may represent a new subspecies of $C$. (P.) kochi.

The generic identification of the present species to Proclava THIELE, 1929, is verified by the characteristic morphology of the moderately elongate and distinctly bent canal, weak but apparent columellar fold, and the regular ornamentation. These features at the same time indicate the closer relation of Proclava to Clava Martyn, 1784, than to Cerithium BRuguiÈRe, 1785.

Geological occurrence.-Pliocene (Taiwan and Okinawa) and Pleistocene (Indonesia, Taiwan, and Southwest Japan).

Recent distribution.-Indo-Pacific region.

Horizon.-Santa Barbara Silt.

Locality.-SKGS-71.

\section{Genus Clypeomorus Jousseaume, 1888 \\ (type-species: Clypeomorus clypeomorus JoUsSEAUME by original designation)}

\section{Clypeomorus tuberculatus (LINNÉ)}

Pl. 2, Figs. 6 and 12

1758. Strombus tuberculatus LiNNÉ, Systema Naturae, ed. 10, p. 1213.

1848. Cerithium carbonarum, PHILIPPI, Zeitschr. f. Malak. p. 142.

1855. Cerithium tuberculatum, Sowerby, Thes. Conch. Vol. 2, p. 870, pl.182, fs. 162 and 164.

1865. Cerithium tuberculatum, ReEve, Conch. Icon. Vol. 15, Cerithium, pl. 4, sp. 21, fs. 21a and b.

1899. Cerithium (s.s.) tuberculatum var. Martin, Samml. Geol. Reichs-Mus. Leiden, N. F. Bd. 1 Abt. 1, p. 202, Taf. 31, fs. 463 and 463a.

1920. Cerithium verbeeki, Tesch, Paläont. v. Timor, Lief. 8, p. 53, Taf. 130, f. 177.

Material.-GK-L 6479. A single almost perfect specimen.

\section{Measurements.-}

\begin{tabular}{|c|c|c|c|c|c|c|c|}
\hline $\begin{array}{l}\text { specimen } \\
\text { GK-L }\end{array}$ & $\underset{(\mathrm{mm})}{\mathrm{H}}$ & $\underset{(\mathrm{mm})}{\mathrm{Bd}}$ & $\underset{(\mathrm{mm})}{\mathrm{Ap}}$ & $\underset{(\mathrm{mm})}{\mathrm{D}}$ & $\begin{array}{c}\mathrm{Bd} / \mathrm{H} \\
(\%)\end{array}$ & $\underset{(\%)}{\mathrm{Ap} / \mathrm{H}}$ & $\begin{array}{l}\mathrm{D} / \mathrm{H} \\
(\%)\end{array}$ \\
\hline 6479 & $27.7+(28.3)$ & 9.0 & 6.6 & 8.0 & 31.7 & 23.3 & 28.2 \\
\hline $\begin{array}{c}\text { specimen } \\
\text { GK-L } \\
6479\end{array}$ & $\begin{array}{c}\angle \mathrm{P} \\
\text { (degree) } \\
16.2\end{array}$ & $\begin{array}{l}\text { whorls } \\
\text { numb. } \\
8+\end{array}$ & $\begin{array}{c}\text { II } \\
14(2)\end{array}$ & \begin{tabular}{l}
\multicolumn{2}{c}{$\begin{array}{l}\text { axials } \\
\text { V }\end{array}$} \\
VII \\
$18(1) \quad 16(2)$
\end{tabular} & $\begin{array}{l}\text { VIII } \\
\quad 16(2)\end{array}$ & & \\
\hline
\end{tabular}

Remarks.-The present specimen is moderately small and bulbous with rather short spire for the family. Spinous granules of the primary spirals and the widely ovoid aperture with short and straight anterior canal, moderate pos-

\footnotetext{
* The figures in the parentheses indicate the number of the varices.
} 
terior notch, and distinct labrum teeth characterize the present specimen. These features closely resemble those of Clypeomorus JousSEAUme, 1888. The spiral ornamentation of the type-species of Clypeomorus, Clypeomorus clypeomorus JoUSSEAUME, consists of the wide and strong primaries and very weak secondaries. Furthermore the granules are not spinous but blunt. The present specimen also resembles Thericium MoNTERosato, 1890 (type-species: Cerithium vulgatum BRUGUIERE), but the former is distinguishable from the latter, which has the moderately large to large shell with smooth labrum, although the ornamentation is similar with comparatively weaker spirals and spinous granules. Under such circumstances mentioned above the author is inclined to treat the present specimen as Clypeomorus evaluating the apertural feature.

The body whorl of the present specimen is provided with six primary spirals on the lateral surface and other two on the base and snout. They are elevated with defined sides, sharply granulated at the intersections by the close axials, and intercalated by the secondary and tertiary threads and lines. Of the six primaries on the lateral surface the median two are stronger and the uppermost one is remarkably weaker than the others and the uppermost interspace is much narrower than the others, while the remaining five primaries are equally and widely spaced. On the penultimate whorl only upper five primaries are visible because of the overlapping at the lower part by the body whorl. Of the five the peripheral two are prominent and the subsutural and suprasutural ones are remarkably weaker and provided closer and smaller granules than the peripheral ones. The second upper one is on one hand intermediate in strength, and on the other hand its granulation is as coarse as those of the peripheral ones. These ornamental features of the present specimen together with the general outline conform with the diagnosis of $C$. tuberculatus (LINNE) living in South China Sea and Philippines waters.

Clypeomorus verbeeki (WooDWARD) (WoODWARD, 1879, p. 540, pl.14, f.9; Martin, $1883-87$, p. 152, Tab. 8, f. 149) is a close ally to the present species. The former, however, is distinguished from the latter on the basis of the difference in the ornamentation and labrum. That is to say, the subsutural and second upper primary spirals of $C$. verbeeki are not so closely spaced as those of $C$. tuberculatus, although both species have five primary spirals on the spire whorls. The spirals on the basal surface are more numerous, larger, and much closer on C. verbeeki than C. tuberculatus. The anterior part of the labrum of the former is less expanded than that of the latter. Furthermore the labrum teeth are remarkably less in number on $C$. verbeeki than $C$. tuberculatus. As mentioned above they are apparently separable, but the difference is not so great.

Tesch (1920, p. 53, Taf. 130, f. 175) reported C. verbeeki from Timor. As far as the diagnosis mentioned above is concerned TESCH' specimen seems to be better included in C. tuberculatus.

Clypeomorus kobelti (DUNKeR) (1877, p. 67; 1882, p. 106, Tab. 4, fs. 8 and 9 ), living in south Japan and Okinawa, is another ally to the present species, but is distinguishable from the latter in having narrower outline, much more prominent peripheral two spirals, and much less numerous axials than the latter. 
Geological occurrence.-Pliocene to Pleistocene (Indonesia and East Africa). Recent distribution.--Sino-Malayan waters.

Horizon.-Santa Barbara Silt.

Locality.-SKGS-71.

\author{
Family Potamididae \\ Subfamily Potamidinae \\ Genus Cerithidea SwaInson, 1840
}

(type-species: Melania lineolata GRIFFITH and PIDGEON=Murex decollata LiNNÉ by subsequent designation, MAKIYAMA, 1936)

Subgenus Cerithideopsilla THIELE, 1929

(type-species: Cerithium fluviatilis POTIEZ and MICHARD=Murex cingulatus

GMELIN by original designation)

Cerithidea (Cerithideopsilla) sp. cf. C. (C.) preangerensis (MARTIN)

Pl. 2, Fig. 5 and Pl. 4, Fig. 6.

1899. Potamides (Cerithidea) preangerensis Martin, Samml. Geol. Reichs-Mus. Leiden, N. F. Bd. 1, Abt. 1, p. 217, Taf. 33, fs. 503-506.

Material.-GK-L 6480 and 7506 from one and same locality. Both specimens are more or less abraded at the apical part.

\begin{tabular}{|c|c|c|c|c|c|c|c|c|c|}
\hline \multicolumn{2}{|c|}{ Measurements.- } & \multirow[b]{2}{*}{$\underset{(\mathrm{mm})}{\mathrm{Bd}}$} & \multirow[b]{2}{*}{$\underset{(\mathrm{mm})}{\mathrm{Ap}}$} & \multirow[b]{2}{*}{$\underset{(\mathrm{mm})}{\mathrm{D}}$} & \multirow[b]{2}{*}{$\underset{\text { (degrees) }}{\angle \mathrm{P}}$} & \multirow[b]{2}{*}{$\begin{array}{l}\text { whorls } \\
\text { numb. }\end{array}$} & \multirow{2}{*}{\multicolumn{2}{|c|}{$\begin{array}{c}\text { axials } \\
\text { pen }\end{array}$}} & \\
\hline $\begin{array}{l}\text { pecimen } \\
\text { GK-L }\end{array}$ & $\underset{(\mathrm{mm})}{\mathrm{H}}$ & & & & & & & & \\
\hline 648 & $20.7+$ & 8.3 & 5.45 & 9.0 & 14.4 & $7.5+$ & 14 & 15 & \\
\hline 7506 & $22.1+$ & 8.6 & 6.70 & 9.2 & 18.8 & $8+$ & 16 & 14 & \\
\hline
\end{tabular}

Remarks.-The present specimens have the quadrate aperture with its labrum expanded outwardly, heavy callus at the inner lip, and very slightly channelled anterior canal and are reasonably included in Cerithideopsilla THIELE, 1929. Their spire-whorls are provided with three wide spiral cords, which are separated one another by much narrower and shallow interstices and crossed by about 15 axials. The axials are wave-shaped in cross-section and curved with the concave face forward. On the body whorl there are three wide spiral cords on the lateral surface, two moderately strong lirae at the basal angulation, and about five small threads on the basal surface. The interspaces especially at the lower part on the lateral surface are weakly or obsoletely excavated. The present specimens almost conform with the type-specimen of Cerithidea (Cerithideopsilla) preangerensis (MARTIN) (Rijksmus. Geol. Min. Leiden, St. 10,697) except that the spiral grooves of the former is much weaker than that of the latter. The effect of abrasion on the present specimens may be the cause of the apparent difference just mentioned. As to the preserved sculpture the present specimens show some resemblance to Cerithidea (Cerithideopsilla) cingulata (GMELIN) living in Southeast Asian waters, but they are quite different in the aperture.

Geological occurrence.-Lower Miocene (Indonesia).

Horizon.-Santa Barbara Silt.

Locality.-SKGS-71. 


\section{Superfamily Stromboidea \\ Family Strombidae \\ Genus Dientomochilus Cossmann, 1904}

(type-species: Strombus ornatus DEsHAYES by original designation)

Dientomochilus crispatus (SowERBY)

Pl. 3, Figs. 7-9, 11-12, and 16-17; Text-fig. 20

1842. Strombus crispatus SowERBY, Thes, Conch. Vol. 2 , pt. 1, p. 26, pl. 8 , fs. 62 and 63.

1843. Rostellaria crispata, KIENER, Coq. Viv. Tom. 4, Rosterlaria, p. 10, pl. 4, f. 2.

1845. Rostellaria crispata, KÜSTER in MARTINI-ChemnitZ, Conch. Cab. 2nd. ed. Strombus, p. 76, p. 25, fs. 4 and 5.

1851. Rostellaria crispata, ReEve, Conch. Icon. Vol. 6, Rostellaria, pl. 3, fs. 8 a and $\mathrm{b}$.

1885. Rostellaria crispata, TRYON, Man. Conch. Ist Ser. Vol. 7, p. 129, pl. 10, f. 19.
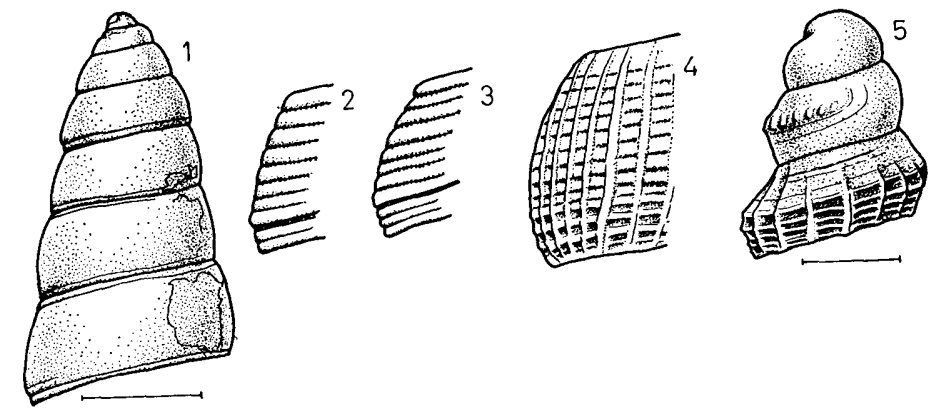

Fig. 20. Protoconch and ornamental features of teleoconchs of some strombiids.

1-3: Tibia (Sulcogladius) powisii modesta (MARTIN)

1: protoconch and early whorls of teleoconch, GK-L 7421. Unit bar indicates $1 \mathrm{~mm}$.

2: sixth whorl on the same specimen as the preceding one.

3: sixth whorl on GK-L 7418.

4: Tibia (Tibia) fusus (LINNÉ), GK-L 7424. Whorl of $5 \mathrm{~mm}$ in diameter.

5: Dientomochilus crispatus (SowERBY), GK-L 6432. Unit bar indicates $0.4 \mathrm{~mm}$.

Material.-GK-L 6432-6439 from loc. SKGS-73 and GK-L 6483, 7413, and 7485 from loc. SKGS-71. GK-L 7432,7413 , and 7485 are perfect in preservation and the others are more or less broken.

\begin{tabular}{cccccccc}
$\begin{array}{c}\text { Measurements. } \\
\text { specimen }\end{array}$ & $\begin{array}{c}\mathrm{H} \\
\text { GK-L }\end{array}$ & $\begin{array}{c}\mathrm{Bd} \\
(\mathrm{mm})\end{array}$ & $\begin{array}{c}\mathrm{Ap} \\
(\mathrm{mm})\end{array}$ & $\begin{array}{c}\mathrm{(mm}) \\
(\mathrm{mm})\end{array}$ & $\begin{array}{c}\mathrm{Bd} / \mathrm{H} \\
(\%)\end{array}$ & $\begin{array}{c}\mathrm{Ap} / \mathrm{H} \\
(\%)\end{array}$ & $\begin{array}{c}\mathrm{D} / \mathrm{H} \\
(\%)\end{array}$ \\
6432 & 20.00 & 13.20 & 12.75 & 10.45 & 66.0 & 63.7 & 52.3 \\
6483 & 22.45 & 15.40 & 14.40 & 10.45 & 68.7 & 64.3 & 46.7 \\
7413 & 11.20 & 7.45 & 7.10 & 5.55 & 66.5 & 63.4 & 49.4 \\
7485 & 22.50 & 14.80 & 14.30 & 10.60 & 65.7 & 64.7 & 47.1 \\
specimen & $\angle \mathrm{A}$ & $\angle \mathrm{P}$ & \multicolumn{2}{c}{ protoconch } & & teleoconch & \\
GK-L & $($ degrees) & $\mathrm{D}$ & $\mathrm{H}$ & numb. & numb. & \\
6432 & 42.4 & 50.0 & .60 & .60 & 1.8 & 8.1 & \\
6483 & - & 43.2 & .58 & .51 & $1.5 ?$ & ca 7.0 & \\
7413 & 33.7 & 49.6 & - & - & ca 1.2 & ca 6.8 & \\
7485 & 40.5 & 40.4 & - & - & 1.4 & 8.2 &
\end{tabular}


Remarks.-The present specimens are very peculiar with their posterior canal, which does not extend to the apical part like Rimella L. AGAssiz, 1840, or Ectinochilus CossmanN, 1889, but curves backward just above the aperture. This is the typical feature of Dientomochilus Cossmann, 1904. This character is very stable among the specimens without any exception. The specimens are readily identified to Dientomochilus crispatus (SOWERBY) and distinguished from the allied species by the bending position of the posterior canal, which curves immediately above the extremity of the aperture.

Recent distribution.-Philippines.

Horizons.-_Santa Barbara Silt and the upper part of the Ulian Formation. Localities.-SKGS-71 and 73.

Genus Tibia RöDING, 1798*

(type-species: Murex fusus LINNÉ by original designation)

Subgenus Tibia (s.s.)

Tibia (Tibia) fusus (LINNÉ)

Pl. 3, Figs. 14, 15, 18, and 19; Text-fig. 20

1758. Murex fusus LiNNÉ, Systema Naturae, ed. 10, p. 725.

1842. Rostellaria rectirostri (partim), G. B. SowerbY, Thes. Conch. Vol. 2, p. 22, pl. 5 , f. 8 .

1845. Rostellaria fusus, Küster, Conch. Cab. Bd. 4, pt.12, p. 94, Taf. 23, fs. 1-3.

1851. Rostellaria fusus (partim), REEve, Conch. Icon. Vol.6, Rostellaria, pl.2, fs. $5 \mathrm{a}, \mathrm{b}$, and 7 .

1885. Rostellaria fusus, Tryon, Man. Conch. Ist. Ser. Vol. 7, p. 128, pl.10, f. 17; pl. 11, f. 21.

1899. Rostellaria (s.s.) verveeki MarTin, Samml. Geol. Reichs-Mus. Leiden, N. F. Bd. 1, Abt 1, p. 189, Taf. 30, fs. 438-440.

1903. Rostellaria fusus, Cossmann, Jour. de Conch. Tom. 48, p. 165, pl. 6, fs. 24 and $25 ; \mathrm{pl} .7, \mathrm{f} .1$

1922. Rostellaria fusus, Dickerson, Rev. Philip. Palaeont. p. 202, pl. 5, fs. 1a and $b$.

1928. Rostellaria sp., Yokoyama, Imp. Geol. Surv. Japan Rep. No. 101, p. 51, pl. $4, \mathrm{f} .2$.

1929. Rostellaria fusus, Yokoyama, ibid. No.104, p. 13, pl. 7, f. 1.

1935. Tibia fusus, Nomura, Sci. Rep. Tohoku Imp. Univ. 2nd Ser. Vol. 18, No. 2, p. 180, pl. 8 , fs. 19 and 20.

1941. Tibia fusus, KUrodA, Mem. Fac. Sci. and Agr. Taihoku Imp. Univ. Vol. 22, No. 4 , p. 96, pl. 9, f. 18.

1942. Tibia fusus, YeN, Proc. Malac. Soc. Vol. 24, p. 210, pl. 16, f. 90.

1966. Tibia fusus, HABE and Kosuge, Shells of the world in colour, Vol. 2, p. 28, pl. 8, f. 6 .

Material.-GK-L 7122 from loc. SKGS-75 and GK-L 7424-7428 from SKGS-74.

Measurements.-

* Synonym: Rostellaria Lamarck, 1799; Rostellum MONTFORT, 1810; Gladius H. and A. AdAMS, 1854; and Platyoptera Conrad, 1855. 


$\begin{array}{cccccc}\begin{array}{c}\text { specimen } \\ \text { GK-L }\end{array} & \begin{array}{c}\mathrm{H} \\ (\mathrm{mm})\end{array} & \begin{array}{c}\mathrm{Bd} \\ (\mathrm{mm})\end{array} & \begin{array}{c}\mathrm{D} \\ (\mathrm{mm})\end{array} & \begin{array}{c}\angle \mathrm{P} \\ (\text { degrees })\end{array} & \begin{array}{c}\text { whorls } \\ \text { numb. }\end{array} \\ 7122 & 60.4+ & - & 20.7 & - & 7+ \\ 7424 & 49.4+ & 28.1 & 11.5 & 16.4 & 7+ \\ 7425 & 44.3+ & - & 12.7 & - & 15+\end{array}$

Remarks.-MARTIN distinguished Rostellaria (s.s.) verbeeki MARTIN from R. fUsus (LINNÉ) on the basis that the former has less convex whorls than the latter. There are apparently two end forms among the specimens in hand from one and same locality; one has convex whorls with curved axials and the other has less convex whorl with scarcely curved axials. The former conforms with $R$. fusus and the other to $R$. verbeeki typologically. They differ actually each other in the mentioned character, but any other difference is not examplified as far as the specimens in hand are concerned. Their apertural feature can not be compared because of imperfect preservation and the concrete conclusion can not be given. It seems, however, that the separation at specific level of the sympatric two end forms with the intermediate forms is unreasonable. In other words there is a strong possibility that $R$. verbeeki MARTIN may be a synonym of Murex fusus LINNÉ, which is the type-species of Tibia RöDING, 1798.

Geological occurrence.-Miocene (Indonesia and Philippines) and Pliocene (Taiwan and Southwest Japan).

Recent distribution.-Tropical Indo-Pacific region.

Horizons.-Upper and uppermost parts of the Dingle Formation.

Localities.-SKGS-74 and 75 .

Subgenus Sulcogladius SACCO, 1893

(type-species: Rostellaria collegnoi BELLARDI et MICHELOTTI by original designation)

Tibia (Sulcogladius) powisii modesta (MARTIN)

Pl. 3, Figs. 2-6 and 13; Text-fig. 20

1899. Rostellaria powisii var. modesta Martin, Samml. Geol. Reichs-Mus. Leiden, N. F. Bd. 1, Abt. 1, p. 191, Taf. 30, fs. 443 and 444.

1934. Tibia cf. powisii modesta, LADD, Bernice P. Bishop Mus. Bull. 119, p. 217, pl. 39, fs. 1 and 2.

Material.-GK-L 7414-7423 from one and same locality. All the specimens are more or less broken.

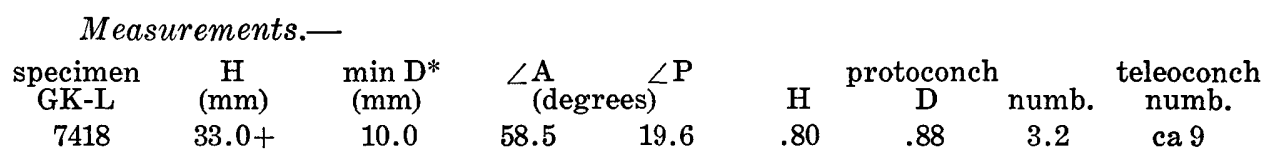

Remarks.-The practically smooth early whorls of the spire are abruptly contracted to form rather the sharp angulation just above the lower suture and there is a distinct spiral groove closely below the angulation just mentioned.

\footnotetext{
* Minimum diameter of the preserved last whorl.
} 
On some specimens one or two more grooves are visible below the angulation. Another weak spiral groove appears slightly below the upper suture on the third or fourth whorl and then it becomes distinct. Five to six spiral rows of small punctations appear on the seventh or eighth whorl and then they are rapidly developed to the distinct spiral grooves with punctations. They, however, do not exceed in strength the spiral grooves below the angulation until on the penulimate whorl, where the angulation becomes obsolete. Besides the spiral ornamentation distinct varices are discernible on the whorls, which are very slightly curved with the concave face forward and more sharply defined at the anterior side than the posterior one. On the basis of these characteristic features the present specimens are quite identical to Rostellaria powisii modesta MARTIN from Indonesia, which is distinguished from the species in having practically smooth early whorls.

The present subspecies is included in Sulcogladius SACC0, 1893, on the basis of the Tibia-like aperture and the distinct spiral ornamentation.

Geological occurrence.-Lower Miocene to Pliocene (Indonesia).

Horizon.-Upper part of the Dingle Formation.

Locality._SKGS-74.

Genus Strombus LINNÉ, 1758*

(type-species: Strombus pugilis LINNÉ by subsequent designation,

MONTFORT, 1810)

Subgenus Laevistrombus KIRA, 1955

(type-species: Strombus canarium LINNÉ by original designation)

Strombus (Laevistrombus) canarium LINNÉ

Pl. 3, Figs. 1 and 10 and Pl. 4, Figs. 2, 3, and 7

1758. Strombus canarium LiNNÉ, Systema Naturae, ed. 10, p. 745, No. 438.

1798. Lambis turturella RöDING, Museum Boltenianum, pt. 2, p. 65, No. 833.

1822. Strombus isabella LAMARCK, Hist. de Anim. Sans Vert. Tom. 7, p. 207.

1834. Strombus vanikorensis QUAY and GaIMARD, d'Urville's Voy. l'Astrolabe, Zool. Tom. 3, p. 73, pl. 51, fs. 7-9.

1851. Strombus canarium, Reve, Conch. Icon. Vol. 6, Strombus, pl. 18, fs. 46a and $b$.

1851. Strombus isabella, REEve, ibid. pl. 18, f. 51.

1885. Strombus canarium, TrYoN Man. Conch. Ist Ser. Vol. 7, p. 110, pl. 2, fs. 18$20 ;$ pl. 3, f. 21.

1895. Strombus canarium, R. BERGH, Zoologische Jahrb., Jena, Bd. 8, pp. 359-362, Taf. 23, fs. 50-53.

1899. Strombus isabella thersites Martin non Swainson, 1823, Samml. Geol. Reichs-Mus. Leiden, N. F. Bd. 1, Abt. 1, p. 184, Taf. 30, fs. 423-425.

1920. Strombus isabella, Tesch, Paläont. v. Timor, Lief. 8, p. 48, Taf. 129, fs. $165 \mathrm{a}$ and $\mathrm{b}$.

1922. Strombus canarium, Dickerson, Rev. Philippine Palaeont. p. 202, pl. 5, f. 3; and pl. 15, f. 14.

1935. Strombus (Labiostrombus) varinginensis martini OosTingH (nom. nov.), Wet. Meded. No. 26, p. 57.

* Synonym: Strombella F. ScHLÜTER, 1838. 
1941. Strombus canarium, HAtAI, Rec. Mar. Shell-bearing Moll. South Sea Islands. (pt. 1), p. 103, pl. 19, fs. 6-7.

1948. Strombus (Labiostrombus) martini, Cox, Schweiz. Paläont. Abhandl. Vol. 66, p. 24, pl. 2, fs. $9 \mathrm{a}$ and b.

1954. Laevistrombus canarium, KIRA, Colored Illustr. Shells Japan Vol. 1, p. 31, pl. 15 , f. 11 .

1954. Laevistrombus isabella, KIRA, ibid. p. 31, pl. 15, f. 12.

1960. Strombus (Laevistrombus) canarium, Аввотт, Indo-Pacific Moll. Vol. 1, No. 2, p. 48, pl. 17, fs. 15 and 16; and pls 12, 23, and 24.

1960. Strombus (Laevistrombus) varinginensis martini, Аввотт, ibid. p. 50, pl. $25, \mathrm{fs} .2$ and 6.

Material.-GK-L 7460 (mature and perfect), 7466 (mature, broken at the labrum), and GK-L 6476 (immature and imperfect) from one and same locality.

\begin{tabular}{ccccccccccc}
\multicolumn{4}{c}{ Measurements.- } & & & & & & \\
specimen & $\underset{\mathrm{GK}-\mathrm{L}}{\mathrm{H}}$ & $\underset{(\mathrm{mm})}{\mathrm{Bd}}$ & $\underset{(\mathrm{mm})}{\mathrm{Ap}}$ & $\underset{(\mathrm{mm})}{\mathrm{D}}$ & $\begin{array}{c}\mathrm{Bd} / \mathrm{Hm}) \\
(\%)\end{array}$ & $\begin{array}{c}\mathrm{Ap} / \mathrm{H} \\
(\%)\end{array}$ & $\underset{(\%)}{\mathrm{D} / \mathrm{H}}$ & $\underset{(\text { degrees })}{\angle \mathrm{A}}$ & $\begin{array}{c}\text { whorls } \\
\text { numb. }\end{array}$ \\
7460 & 48.7 & 40.8 & 39.1 & 34.2 & 83.8 & 80.3 & 70.2 & 78 & 88 & 7.8 \\
7466 & $42.6+$ & 35.4 & 35.0 & - & 83.1 & 82.1 & - & 73 & $93+$ & $6+$
\end{tabular}

Remarks.-Strombus canarium LINNÉ is so variable in morphology that sereval names were introduced for respective varieties. The specimens in hand, came from one and same locality, also illustrate the remarkable variation especially in the profile of the whorls, posterior expansion of the labrum, and elevation of the spire. GK-L 6476 shows distinctly convex profile of adolescent whorls with moderate angulation, while 7466 has very slightly convex profile on the whorls of same stage as the preceding. Concerning with this character GK-L 7460 shows the intermediate feature between the two end forms. The spires of GK-L 6476 and 7466 are moderately high and remarkably extraconical instead of the low and almost conical one of GK-L 7460. The posterior part of the labrum is not so expanded on GK-L 7460, while that of 7466 is remarkably expanded forming sharp wing. The surface ornamentation of the present species consists of weak axial riblets and distinct spiral lirae on the early whorls and its development is negative. The spirals are seven and separated by narrower grooves on the first whorl, and then the lower one or two lirae are concealed under the overlapping part of the succeeding whorl on the third whorl. They become abruptly weak on the adolescent whorl and finally disappear except for the subsutural groove. The axial riblets are numerous at first and disappear on the second whorl. Besides the riblets there are a few strong varices on the early whrols. The mentioned features of the ornamentation are rather stable on the specimens in hand.

MARTIN separated the Pliocene specimens from the species and named them Strombus isabella thersites (non SwaInson, 1823) (1899, p. 184, Taf. 30, fs. 423425), which was renamed S. varinginensis martini by OoSTINGH (1935, p. 57), on the basis of the difference in size. It seems, however, reasonable to include them in $S$. (L.) canarium, because the former is clearly in the range of variation of the latter concerning the size and other morphological characters.

Geological occurrence.-Pliocene to Pleistocene (Indonesia, Philippines, and 
Taiwan).

Recent distribution.-Indo-Pacic from South India at the west to New Caledonia at the east and to South Japan at the north.

Horizon.-Santa Barbara Silt.

Locality.-SKGS-71.

Subgenus Dolomena IREDALE, 1931

(type-species: Strombus plicatus pulchellus REEVE by original designation)

Strombus (Dolomena) sp. cf. S. (D.) togopiensis Cox

Pl. 4, Figs. 9 and 13

1948. Strombus (Laevistrombus) togopiensis Cox, Schweiz. Paläont. Abhandl. Vol. 66, p. 27, pl. 2, fs. 10a and b.

1960. Strombus (Dolomena) togopiensis, Аввотт, Indo-Pacific Moll. Vol. 1, No. 2, p. 102 , pl. 77.

Material.-GK-L 7429 and 7430. Both specimens are imperfect; the early whorls are broken and the large part of the surface layer of the shell was removed.

\title{
Measurements.-
}

GK-L $7429: \quad B d=35.6 \mathrm{~mm}$ and $\mathrm{D}=26.4 \mathrm{~mm}$.

Remarks.-The specimens in hand are imperfect in preservation but characteristic enough with the labrum, posterior canal, angulated spire-whorls, blunt nodes on the body whorl etc. to serve for identification. They have the distinct posterior sinus and are readily distinguished from Laevistrombus OostingH, 1925. Among the several species of Dolomena they are closely related to Strombus togopiensis Cox (1948, p. 27, pl. 2, fs. 10a and b) and S. fennemani MARTIN (1899, p. 181, pl. 29, fs. 418-420). It is considered that the present specimens show closer relation to $S$. togopiensis than to $S$. fennemani having "the narrow, forwardreaching" posterior canal which is the criterion to distinguish $S$. togopiensis from S. fennemani. The present author is, however, inclined to suspend the concrete identification of the present specimens because of the imperfect preservation which does not allow the further detailed examination.

Geological occurrence.-Pliocene (Indonesia).

Horizon.-Upper part of the Ulian Formation.

Locality.-SKGS-73.

\author{
Superfamily Cypraeoidea \\ Family Eratoidae \\ Subfamily Triviinae
}

Genus Dolichupis IREDALE, 1930

(type-species: Cypraea producta GASKoIN by original designation)

Subgenus Trivellona IREDALE, 1931

(type-species: Trivellona excelsa IREDALE by original designation) 


\section{Dolichupis (Trivellona) shimajiriensis MACNEIL \\ Pl. 6, Figs. 12 and 26}

1960. Dolichupis (Trivellona) shimajiriensis MacNeIL, U. S. Geol. Surv. Prof. Pap. No. 339, p. 49, pl. 2, fs. 10, 13, 14, and 15.

Material.-GK-L 6813. A single almost perfect specimen.

\begin{tabular}{|c|c|c|c|c|c|}
\hline spe & & & & teeth & al lirs \\
\hline GK-L & $(\mathrm{mm})$ & $(\mathrm{mm})$ & $(\%)$ & inner & right \\
\hline 6813 & 8.1 & 7.0 & 86.4 & 16 & 25 \\
\hline
\end{tabular}

Remarks.-The present specimen agrees well with the paratype specimen of Dolichupis (Trivellona) shimajiriensis MACNEIL from the Miocene Yonabaru Clay in Okinawa on the basis of the inflately ovoid outline, curved and narrow aperture with distinct posterior pustule, thickened outer lip, and the pattern of the ornamentation. Its anterior part is not elongated, back surface is devoid of the longitudinal furrow, and the columellar furrow is not sharp. These features serve for distinguishing it from the allied genera and subgenera such as Trivia Broderip, 1837, Pseudotrivia Schilder, 1936, or Niveroa Jousseaume, 1884.

The present specimen is also allied to Dolichupis (Trivellona) paucicostatus (Schepman) (1908, p. 139, pl.11, f. 2) from Sulu Sea. The former is distinguished from paucicostatus in having somewhat weaker lirae, more outwardly expanded right side, and less curved aperture than the latter. It is also separable from $D$. (T.) sibogae minor (SchepmaN) (1908, p. 140, pl.11, f.4) in having coarser lirae and different aperture which is not widened anteriorly.

Dolichupis (Trivellona) candidulus (GASkoIN) from the Atlantic from the west Africa to Portugal is another ally. The present specimen is typologically separated from $D$. candidulus in being provided with narrower aperture than the latter. However, the species noted above, at least some of them, may be conspecific, although the author tentatively described them here as separated species because of scanty of the detailed measurements.

Geological occurrence.-Upper Miocene (Okinawa).

Horizon.-Upper part of the Dingle Formation.

Locality.-_SKGS-74.

Genus Trivirostra JoUsSeAUme, 1884

(type-species: Cypraea oryza LAMARCK by original designation)

\section{Trivirostra pellucidula (REEve)}

Pl. 6, Figs. 13, 22, 23, and 24

1846. Cypraea pellucidula (GASkoIN) ReEve, Conch. Icon. Vol. 3, Trivia, pl.26, f. 153.

1846. Cypraea pellucidula Gaskoin, Proc. Zool. Soc. London, p. 23.

1880. Cypraea pellucidula, Sowerby, Thes. Conch. Vol. 4, p.50, pl.327, fs. 497499.

1881. Cypraea pellicula (sic) WeInKaufF, Conch. Cab. Bd. 5, pt. 3, p. 161, Taf. 43, 
fs. 1 and 4.

1885. Trivia pellucidula, Tryon, Man. Conch. Ist Ser. Vol. 7, p. 204, pl. 22, fs. 31 and 32.

1959. Trivirostra pellucidula, OYama, Molluscan Shells, Trivirostra, fs. 13-15.

1968. Trivirostra (Dolichupis) pellucidula, CERNOHORSKY, Veliger, Vol. 10, No. 4, p. 369 , pl. 52, fs. 21 and 21a.

Material.-GK-L 6814 and 6815 from one and same locality. Preservation is almost perfect.

\begin{tabular}{|c|c|c|c|c|c|c|}
\hline \multicolumn{7}{|c|}{ Measurements.- } \\
\hline $\begin{array}{l}\text { specimen } \\
\text { GK-L }\end{array}$ & $\underset{(\mathrm{mm})}{\mathrm{H}}$ & $\underset{(\mathrm{mm})}{\mathrm{D}}$ & $\begin{array}{l}\mathrm{D} / \mathrm{H} \\
(\%)\end{array}$ & inner & outer & lirae \\
\hline 6814 & 4.7 & 3.5 & 74.4 & 18 & 22 & \\
\hline 6815 & 4.9 & 3.6 & 73.4 & 19 & 23 & $\operatorname{lir}<$ int \\
\hline
\end{tabular}

Descriptive remarks. - The shell is small attaining less than $5 \mathrm{~mm}$ in height. It is rather thick, ovoid in outline, and somewhat produced at the anterior and posterior ends. The left side in the front view is more bulbous than the right. The aperture is almost vertical and straight at the middle and anterior parts and slightly curved at the posterior part. The inner lip is somewhat elevated at the posterior end and sharply reflexed along the outer margin of the columellar furrow, which is deep and wide. The anterior end of the aperture is somewhat wider than the main part and truncated at the terminal. The outer lip is not thickened except for the posterior part, which is together with the posterior part of the innerlip emarginated by the slight thickening. The teeth on both inner and outer lips are laterally elongated. The lateral lirae are rather sharp, regular, and somewhat granular at the margin of the longitudinal furrow on the back surface. The back furrow is shallow, rather wide, and moderately short.

Comparison.-The present specimens are peculiar with the shallow axial furrow on the back side surface and included in Trivirostra Jousseaume, 1884. They are quite identical with the living specimens of T. pellucidula (GASKoIN in REEVE) on the basis of the diagnostic feature above mentioned.

Recent distribution.-Southeast Asian waters.

Horizon.-Upper part of the Dingle Formation.

Locality.-SKGS-74.

Superfamily Naticoidea

Family Naticidae

Subfamily Naticinae

Genus Naticarius DUMERIL, 1806*

(type-species: Nerita canrenus LINNÉ by monotype)

Naticarius marochiensis (GMELIN)

Pl. 6, Figs. 1-4 and 6-9

1790. Nerita marochiensis Gmelin, Systema Naturae ed. 13, Vol. 1, p. 3673.

1838. Natica marochiensis, Lamarck, Hist. d. Anim. Sans Vert. ( $2^{e}$ ed. DeshaYes'), Vol. 8, f. 642.

* Synonym: Naticus MoNTForT, 1810 
1855. Natica marochiensis, ReEve, Conch. Icon. Vol. 9, Natica, pl. 13, f. 52 .

1886. Natica marochiensis, TrYoN, Man. Conch. Ist Ser. Vol. 8, p. 22, pl. 5, fs. 7496.

1883-87. Natica chinensiformis MARTIN, Samml. Geol. Reichs-Mus. Leiden Ser. 1, Bd. 3, p. 166, Tab. 8, f. 161.

1887. Natica marochiensis, Sowerby, Thes. Conch. Vol. 5, p. 82, pl. 461, fs. 108 and 109.

1905. Natica (s.s.) marochiensis, Martin, Samml. Geol. Reichs-Mus. Leiden, N. F. Bd. 1, Abt. 1, p. 258, Taf. 38, fs. 616 and 617.

1920. Natica marochiensis, Tesch, Paläont. v. Timor, Lief. 8, p. 68, Taf.132, fs. 205a and b.

1934. Natica (Natica) marochiensis, LAdD, Bernice P. Bishop Mus. Bull. 119, p. 209, pl. 36, fs. 2 and 3.

1942. Natica marochiensis, ABRARD, Arch. Mus. Nation. d'Hist. Nat. Tom. 6, No. 18 , pp. 57 and 94 , pl. 6 , f. 16.

1950. Natica morochiensis, NICKLÈs, Manuels ouest Africains Vol. 2, p. 81, f. 120.

1960. Naticarius marochiensis, MacNeIL, U. S. Geol. Surv. Prof. Pap. No. 339, p. 55, pl. 15, fs. 21-22.

Material.-GK-L 6372-6375 from loc. SKGS-73 and GK-L 6471-75 and 6481-82 from loc. SKGS-71. Preservation is generally perfect or almost perfect.

Measurements.-

\begin{tabular}{|c|c|c|c|c|c|c|c|c|c|}
\hline Gecimen & $\underset{(\mathrm{mm})}{\mathrm{H}}$ & $\underset{(\mathrm{mm})}{\mathrm{Ap}}$ & $\underset{(\mathrm{mm})}{\mathrm{D}}$ & $\underset{(\%)}{\mathrm{Ap} / \mathrm{H}}$ & $\underset{(\%)}{\mathrm{D} / \mathrm{H}}$ & $\underset{\text { (degrees) }}{\angle \mathrm{P}}$ & prot & $\begin{array}{l}\text { conch } \\
\text { numb. }\end{array}$ & $\begin{array}{l}\text { teleoconch } \\
\text { numb. }\end{array}$ \\
\hline 6372 & 10.50 & 8.80 & 9.8 & 87.6 & 97.5 & 106.4 & .80 & 3.2 & 2.8 \\
\hline 6374 & 7.05 & 5.60 & 6.4 & 79.4 & 90.7 & 103.6 & .92 & 3.2 & 2.2 \\
\hline 6471 & 6.40 & 5.25 & 5.8 & 82.0 & 90.5 & 111.4 & .80 & 3.3 & 2.0 \\
\hline 6472 & 4.50 & 3.85 & 4.5 & 85.5 & 100.0 & 124.8 & .86 & 3.0 & 1.6 \\
\hline 6481 & 10.20 & 8.40 & 9.5 & 82.3 & 93.0 & 108.2 & .85 & 3.1 & 2.1 \\
\hline 6482 & 9.90 & 8.15 & 9.3 & 82.4 & 93.9 & 111.5 & .84 & 3.0 & 2.0 \\
\hline
\end{tabular}

Remarks.-The specimens in hand are identical to the Indonesian fossil specimens of "Natica marochiensis GMELIN", which are featured by its small size, distinct axial rugae on the whorls, and semicircular funicle occupying the central part of the umbilicus. These characteristics indicate that the specimens belong to Naticarius DUMÉRIL, 1806.

It is rather a problem whether the Indonesian specimens are conspecific with GMELIN's marochiensis from North Africa, which is much larger than the former. TESCH mentioned the difficulty to distinguish Natica marochiensis GMELIN from $N$. zebra Lamarck, $N$. lineata Lamarck, $N$. orientalis Gmelin, and $N$. chinensis LAMARCK, which, according to TESCH, illustrate the continuous series of morphological variation. The original figured-specimen of marochiensis is, however, readily distinguished from all of the mentioned species by its unique coloration. Some of the specimens from Philippines preserve the coloration, which is very similar to that of type $N$. marochiensis. In consequence it is reasonable to include the present material in $N$. marochiensis on the basis of the morphological characteristics mentioned above and coloration.

Geological occurrence.-Miocene (Indonesia), Pliocene (Indonesia, Philippines, and India), and Pleistocene (East Africa, Indonesia, and Southwest Japan). 
Recent distribution.-Indo-Pacific region.

Horizons.-Santa Barbara Silt and the upper part fo the Ulian Formation. Localities.-SKGS-71 and 73.

\section{Genus Natica Scopoli, 1777 *}

(type-species: Nerita vitellus LiNnÉ by subsequent designation, G. F. HARRIS, 1897)

Natica rufa (BoRN)

Pl. 5, Figs. 13 and 15-18 and Pl. 6, Figs. 5 and 14

1778. Nerita rufa BoRN, Index Rerum Naturalium Musei Caesarei Vindobonensis, Testacea, p. 398, pl. 17, fs. 3 and 4.

1838. Natica rufa, Lamarck, Hist. d Anim. Sans Vert. (2 $2^{\mathrm{e}}$ ed. Deshayes'), Tom. 8, p. 639.

1855. Natica rufa, Reeve, Conch. Icon. Vol. 9, Natica, pl. 16, fs. 70a and b.

1886. Natica rufa, Tryon, Man. Conch. Ist Ser. Vol. 8, p. 29, pl. 9, fs. 62 and 63.

1887. Natica rufa, SowerBY, Thes. Conch. Vol. 5, p. 80, pl. 457, f. 42.

1905. Natica rufa, MarTin, Samml. Geol. Reichs-Mus. Leiden, N. F. Bd. 1, Abt.1, p. 260, Taf. 39, fs. 621-623.

1920. Natica rufa, Tesch, Paläont. v. Timor, Lief. 8, p. 69, Taf. 133, fs. 208a and $\mathrm{b}$.

1927. Natica rufa, Fischer, ibid. Lief. 15, p. 46, Taf. 212, f. 6.

1935. Natica (Natica) rufa, NomUrA, Sci. Rep. Tohoku Imp. Univ. 2nd Ser. Vol. 18, No. 2, p. 200, pl. 9, fs. 29a, b, and c.

1948. Natica rufa, Cox, Schweiz. Paläont. Abhandl. Vol.66, p. 18, pl. 1, fs. 3a, b, and $c$.

Material.-GK-L 7115-17 from loc. SKGS-75 and GK-L 7433-44 from loc. SKGS-74. Immature small specimens are preserved very well, while the larger ones are more or less broken at the labrum.

\begin{tabular}{|c|c|c|c|c|c|c|c|c|c|}
\hline \multicolumn{3}{|c|}{ Measurements.- } & \multirow[b]{2}{*}{$\underset{(\mathrm{mm})}{\mathrm{D}}$} & \multirow[b]{2}{*}{$\underset{(\%)}{\mathrm{Ap} / \mathrm{H}}$} & \multirow[b]{2}{*}{$\underset{(\%)}{\mathrm{D} / \mathrm{H}}$} & \multirow[b]{2}{*}{$\underset{\text { (degrees) }}{\angle \mathbf{P}}$} & \multirow{2}{*}{\multicolumn{2}{|c|}{ protoconch }} & \multirow[b]{2}{*}{$\begin{array}{l}\text { teleoconch } \\
\text { numb. }\end{array}$} \\
\hline $\begin{array}{l}\text { specimen } \\
\text { GK-L }\end{array}$ & $\underset{(\mathrm{mm})}{\mathbf{H}}$ & $\underset{(\mathrm{mm})}{\mathrm{Ap}}$ & & & & & & & \\
\hline 7115 & 31.7 & 26.5 & 33.3 & 83.5 & 105.0 & 136.4 & 1.08 & 2.0 & 3.6 \\
\hline 7116 & 27.0 & 24.4 & ca 29.5 & 90.5 & ca 109.5 & 120.2 & 1.10 & 2.0 & 3.2 \\
\hline 7433 & 17.6 & 14.5 & 17.9 & 82.4 & 101.9 & 121.5 & 1.12 & 2.2 & 3.15 \\
\hline 7434 & 14.9 & 11.9 & 14.8 & 79.9 & 99.2 & 117.6 & 1.15 & 2.0 & 3.1 \\
\hline 7435 & 11.2 & 9.2 & 11.8 & 82.0 & 105.2 & 118.1 & 1.10 & 2.0 & 2.7 \\
\hline 7437 & 10.3 & 8.6 & 11.3 & 83.4 & 109.6 & 124.2 & 1.10 & 1.8 & 2.4 \\
\hline
\end{tabular}

Remarks.-The specimens from loc. SKGS-75 show a remarkable range of variation in profile of the shell. GK-L 7115 has abnormally depressed outline with lower spire and less convex base than the others and suggests the similarity to $N$. orientalis GMELIN. The present specimens have distinct axial rugae near the suture on the spire-whorls, depressed suture, and moderately narrow but deep umbilicus. Its umbilical funicle is moderately small and ends with a heavy callus, which is quite continuous to the wide parietal callus.

\footnotetext{
* Synonym: Cochlis RöDING, 1798
} 
Although GK-L 7115 is similar to $N$. orientalis GMELIN in its outline and the produced eversion of the aperture, it is readily distinguished from the latter in the characteristic feature of the umbilicus and callus. The present specimens are reasonably included in $N$. rufa (BORN), a widely spread Indo-Pacific species.

The specimens from loc. SKGS-74 illustrate an almost perfect growth-series from the nepionic stage with the maximum diameter of $4.5 \mathrm{~mm}$ to the adolescent stage with the maximum diameter of $17.6 \mathrm{~mm}$. This growth series indicates that the character of the funicle and the callus is settled at the preserved earliest stage and the succeeding modification is only relative enlarging of the posterior lobe of the umbilical callus.

Geological occurrence.-Miocene (Indonesia and Philippines) and Pliocene (Indonesia and Taiwan).

Recent distribution.-Indo-Pacific from Southwest Japan to Madagascar.

Horizons.-Upper and uppermost parts of the Dingle Formation.

Localities.-SKGS-74 and 75.

\section{Natica zebra LAMARCK}

Pl. 6, Figs. 10 and 11.

1822. Natica zebra Lamarck, Hist. d. Anim. Sans Vert. Tom. 6, pt. 2, p. 203.

1838. Natica zebra, LAMARCK, ibid. (2 ed., DeshaYes') Tom. 8, p. 643.

1855. Natica zebra, REEve, Conch. Icon. Vol. 9, Natica, pl. 13, fs. 53a and b.

1886. Natica zebra, TrYon, Man. Conch. Ist Ser. Vol. 8, p. 16, pl. 2, f. 32.

1887. Natica zebra, SowerBy, Thes Conch. Vol. 5, p. 79, pl. 460, f. 92.

1905. Natica (Natica) zebra, Martin, Samml. Geol. Reichs-Mus. Leiden, N. F. Bd. 1, Abt. 1, p. 258, Taf. 38, fs. 615, 615a, and 615b.

1935. Natica (Natica) zebra, NomUra, Sci. Rep. Tohoku Imp. Univ. 2nd Ser. Vol. 18, No. 2, p. 199, pl. 9, fs. 25a and b.

1935. Natica zebra, OostingH, Wetensch. Meded. Mijnb. Nederlansch-Indië No. 26, p. 46, pl. 5 , fs. 54 and 55.

Material.-GK-L 7432. A single but almost perfect specimen.

Measurements.-

\begin{tabular}{|c|c|c|c|c|c|c|c|c|}
\hline $\begin{array}{l}\text { specimen } \\
\text { GK-L }\end{array}$ & $\underset{(\mathrm{mm})}{\mathrm{H}}$ & $\underset{(\mathrm{mm})}{\mathrm{Ap}}$ & $\underset{(\mathrm{mm})}{\mathrm{D}}$ & $\underset{(\%)}{\mathrm{Ap} / \mathrm{H}}$ & $\begin{array}{l}\mathrm{D} / \mathrm{H} \\
(\%)\end{array}$ & $\underset{\text { (degrees) }}{\angle \mathbf{P}}$ & $\begin{array}{l}\text { protoconch } \\
\text { D numb. }\end{array}$ & $\begin{array}{l}\text { teleoconch } \\
\text { numb. }\end{array}$ \\
\hline 7432 & 9.0 & 7.0 & 9.25 & 77.8 & 102.8 & 114.4 & .80 & 2.75 \\
\hline
\end{tabular}

Remarks.-The present specimen is slightly wider than high. There is a weak but distinct depression below the suture. Its umbilical funicle is regularly semicircular and situated slightly below the center of the umbilicus. The umbilical callus is separated from the parietal one by a deep notch as indicated in the text-figure. The specimen with these diagnostic features well agrees with Natica zebra LAMARCK.

It is readily distinguished from $N$. lineata LAMARCK in the profile of the shell, which is higher in the latter than in the former. It is also distinguished from $N$. concinna DUNKER in having heavier funicle and wider profile than the latter.

The protoconch of the present specimen is paucispiral with about 1.9 volutions, of which the nucleus is rather large and globose and the remainder one is 
a very slowly growing narrow tube.

Geological occurrence.-Miocene (Indonesia) and Pliocene (Indonesia and Taiwan).

Recent distribution.-Indo-Pacific region from Southwest Japan to Madagascar.

Horizon.-Upper part of the Dingle Formation.

Locality.-SKGS-74.

Subfamily Polinicinae

Genus Mamilla ScHUMACHER, 1817*

(type-species: Mammilla fasciata SCHUMACHER=Nerita melanostoma GMELIN by monotype)

\section{Mamilla mammata (RöDING)}

Pl. 5, Figs. 5, 6, and 9

1798. Albula mammilla Rödıng, Museum Boltenianum, p. 20, sp. 246.

1855. Natica filosa, Reeve (non PhILIPPI, 1845), Conch. Icon. Vol.9, Natica, pl. 17 , fs. $72 a$ and $b$.

1886. Natica (Mammilla) filosa, TrYon, Man. Conch. Ist Ser. Vol. 8, p. 51, pl. 22, f. 22.

1887. Natica filosa, Sowerby, Thes. Conch. Vol. 5, p. 98, pl. 459, f. 74.

1905. Natica melanostoma, MarTin, Samml. Geol. Reishs-Mus. Leiden, N. F. Bd. 1, Abt. 1, p. 266, Taf. 39 , fs. 642 and 642a.

1920. Natica melanostoma, Tesch, Paläont. v. Timor, Lief. 8, p. 72, Taf. 133, fs. $212 \mathrm{a}$ and $\mathrm{b}$.

1924. Uber mammatum, Hedley, Rec. Austral. Mus. Vol. 14, No. 3, p. 157, pl. 12, f. 1.

1925. Natica (Mammilla) melanostoma, Cossmann, Essais de Paleoconch. Comp. Tom. 13, p. 129, pl. 1, fs. 36 and 37; and pl. 2, fs. 3 and 4.

1935. Polinices (Polinices) filosus, NomUra, Sci. Rep. Tohoku Imp. Univ. 2nd Ser. Vol. 18, No. 2, p. 203, pl. 9, f. 34 .

1961. Mammilla mammata, Habe, Colored Illustr. Shells Japan, Vol. 2, p. 38, pl. 17, f. 10.

Material.-GK-L 6376 from loc. SKGS-73, GK-L 6487 from loc. SKGS-71, and GK-L 7110 from loc. SKGS-72.

Measurements.-

\begin{tabular}{|c|c|c|c|c|c|c|c|c|}
\hline $\begin{array}{l}\text { specimen } \\
\text { GK-L }\end{array}$ & $\underset{(\mathrm{mm})}{\mathrm{H}}$ & $\underset{(\mathrm{mm})}{\mathrm{Ap}}$ & $\underset{(\mathrm{mm})}{\mathrm{D}}$ & $\underset{(\%)}{A p / H}$ & $\underset{(\%)}{\mathrm{D} / \mathrm{H}}$ & $\underset{\text { (degrees) }}{\angle \mathrm{P}}$ & $\begin{array}{l}\text { protoconch } \\
\text { D numb. }\end{array}$ & $\begin{array}{l}\text { teleoconch } \\
\text { numb. }\end{array}$ \\
\hline 6376 & 12.3 & 11.3 & 11.0 & 91.8 & 89.5 & 107.4 & 2.5 & 2.8 \\
\hline
\end{tabular}

Remarks.-The specimens in hand are well conform with the living specimens of Mamilla mammata (RöDING) with pear-shaped and tall profile, rather narrow umbilical callus, and fine and close spiral ornamentation of the shell surface. They differ from $M$. melanostoma (GMELIN) in having fine but distinct spiral lines on the whole surface. Furthermore $M$. melanostoma attains generally much larger size than $M$. mammata. It is separable from $M$. subfilosus van Regteren

* Synonym: Naticaria Swainson, 1840; Mamma Mörch, 1852, non Bruguière, 1792; Ruma H. and A. ADAMs, 1853. 
Altena (1942, p. 66, f. 19a and b) in having broader outline and different type of umbilical callus as pointed out by the original author.

Mamilla kurodai TAKI (1943, p. 111, new name for Sigaretus (Eunaticina) oblongus, Yoкочама, 1922, pl.4, f. 11) from the lower Pleistocene of central Japan is another ally to the present species. The former, however, has posteriorly more expanded labrum, more convex parietal part, and narrower and pillar-like columellar callus.

Geological occurrence.-Pliocene (Indonesia, Taiwan, and Southwest Japan).

Recent distribution.-Western tropical Pacific region from South Japan to Australia through Indonesia.

Horizons.-Santa Barbara Silt and the upper part of the Ulian Formation.

Localities.-SKGS-71, 72, and 73 .

\section{Mamilla maura (BRUGUIÈRE)}

PI. 5, Fig. 10

1792. Natica maura BruguiÈRe, Encyclopedie methodique, pl. 453, fs. $4 \mathrm{a}$ and b.

1852. Natica maura, Philippi (in Martini-Chemnitz) Conch. Cab. Bd. 2, Natica, p. 58, Taf. 9 , f. 6 .

1856. Natica maura, ReEve, Conch. Icon. Vol. 9, Natica, pl. 7, f. 25.

1886. Natica (Mammilla) maura, TrYoN, Man. Conch. Ist Ser. Vol. 8, p. 51, pl. 22, f. 24.

1887. Natica maura, Sowerby, Thes. Conch. Vol. 5, p. 98, pl. 456, f. 36.

1951. Polinices maurus, (HIrase) TAKI, Handb. Illustr. Shells, pl. 91, f. 3.

1954. Polinices (Mammilla) maurus, KIRA, Colored Illustr. Shells Japan Vol. 1, p. $35, \mathrm{pl} .17, \mathrm{f} .12$.

1964. Mammila maura, Shuto, Proc. Trans. Palaeont. Soc. Japan N. S. No. 55, p. 287, pl. 42 , fs. 7 and 9.

1966. Mammilla maura, HABE and Kosuge, Shells of the world in colour, Vol. 2, p. 35 , pl. 12, f. 12 .

Material.-GK-L 6341. Almost perfect except for a part of the labrum.

Measurements.-

\begin{tabular}{|c|c|c|c|c|c|c|c|c|c|}
\hline $\begin{array}{l}\text { specimen } \\
\text { GK-L }\end{array}$ & $\underset{(\mathrm{mm})}{\mathrm{H}}$ & $\underset{(\mathrm{mm})}{\mathrm{Ap}}$ & $\underset{(\mathrm{mm})}{\mathrm{D}}$ & $\underset{(\%)}{\mathrm{Ap} / \mathrm{H}}$ & $\underset{(\%)}{\mathrm{D} / \mathrm{H}}$ & $\underset{\text { (degrees) }}{\angle \mathrm{P}}$ & $\underset{D}{\text { protoconen }}$ numb. & $\begin{array}{l}\text { teleoconch } \\
\text { numb. }\end{array}$ & $\begin{array}{l}\text { labrum } \\
\text { angle }\end{array}$ \\
\hline 6341 & 9.6 & 8.7 & 8.2 & 90.6 & 85.4 & 115 & .74 & 3.8 & 22.5 \\
\hline
\end{tabular}

Remarks.-The present specimen agrees with the living form in the diagnostic features except for smaller size. It is also quite identical to the Pliocene specimen from the Miyazaki Group in South Japan. Although the taxonomical meaning of small size is not clear, there is an evident fact that the majority of the Pliocene specimens of Mamilla-species is much smaller than the living representatives.

Mamilla maura can be distinguished from $M$. melanostoma by its less slender profile, more solid shell, and heavier umbilical callus than those of the latter. Furthermore the protoconch of $M$. maura is paucispiral with about one and two-thirds volutions instead two and a half volution of the protoconch of $M$. melanostoma, although the maximum diameter of the protoconchs of the two species is almost equal each other. 
The present specimen is entirely devoid of the spiral striation.

Geological occurrence.-Pliocene (Southwest Japan).

Recent distribution.-Indo-Pacific from central Japan to Indonesia.

Horizon.-Upper part of the Ulian Formation.

Locality.-SKGS-73.

Genus Polinices MONTFORT, 1810*

(type-species: Polinices albus MONTFORT $=$ Nerita mamilla LINNÉ

by original designation)

Subgenus Polinices (s.s.)

Polinices (Polinices) aurantius (RöDING)

PI. 5, Figs. 3 and 4

1798. Albula aurantia RöDING, Museum Boltenianum, p. 21, sp. 248.

1838. Natica aurantia, Lamarck, Hist. d. Anim. Sans Vert. (2 ${ }^{\circ}$ ed., DeshaYes'), Tom. 8, p. 632 .

1852. Natica aurantia, KüSter and Kobelt, Conch. Cab. Bd.2, pt. 1, p. 34, Taf. 4, fs. 13 and 14.

1856. Natica aurantia, REEve, Conch. Icon. Vol. 9, Natica, pl. 6, f. 20.

1887. Natica aurantia, Sowersy, Thes. Conch. Vol. 5, p. 85, pl. 455, fs. 15 and 16 .

1905. Natica aurantia, Martin, Samml. Geol. Reichs-Mus. Leiden, N. F. Bd.1, Abt. 1, p. 263, Taf. 39, fs. 631 and 632.

1920. Natica aurantia, Tesch, Paläont. v. Timor, Lief. 8, p. 72, Taf. 133, fs. 211a and $\mathrm{b}$.

1954. Polynices aurantius, (HIRASE) TAKI, Handb. Illustr. Shells pl.91, f. 6.

1961. Polinices aurantius, HABE, Colored Illustr. Shells Japan, Vol. 2, p. 38, pl. 17, f. 9.

1966. Polinices aurantiacus, HABE and Kosuge, Shells of the world in colour, Vol. 2, p. 35, pl. 12, f. 10 .

Material.-GK-L 6485, 6486, 6488, and 7502 from one and same locality.

Measurements.-

\begin{tabular}{|c|c|c|c|c|c|c|c|c|}
\hline $\begin{array}{l}\text { specimen } \\
\text { GK-L }\end{array}$ & $\underset{(\mathrm{mm})}{\mathrm{H}}$ & $\underset{(\mathrm{mm})}{\mathrm{Ap}}$ & $\underset{(\mathrm{mm})}{\mathrm{D}}$ & $\underset{(\%)}{\mathrm{Ap} / \mathrm{H}}$ & $\begin{array}{c}\mathrm{D} / \mathrm{H} \\
(\%)\end{array}$ & $\underset{\text { (degrees) }}{\angle \mathrm{P}}$ & $\begin{array}{l}\text { protoconch } \\
\text { D numb. }\end{array}$ & $\begin{array}{l}\text { teleoconch } \\
\text { numb. }\end{array}$ \\
\hline 6485 & 17.3 & 14.2 & 15.8 & 82.0 & 81.3 & 113.5 & 2.3 & 3.5 \\
\hline 7502 & 19.2 & 15.4 & 16.9 & 80.2 & 88.0 & 118.6 & - & $3.5-$ \\
\hline
\end{tabular}

Remarks.-The present specimens are characterized by their solid shell with porcelaineous ruster, extremely small spire, and fully developed umbilical callus, which entirely covers the umbilicus. The distinction of $P$. aurantius (RöDING) and $P$. mamilla (LINNÉ) is rather difficult among fossil specimens, because the living specimens of the mentioned species are quite similar except for coloration, which is in many cases hardly preserved on the fossil specimens. On the specimens in hand the dark brown coloration is still observed. Accordingly they are readily identified to $P$. aurantius.

Geological occurrence.-Upper Miocene (Indonesia), Pliocene (Indonesia), and Pleistocene (Southwest Japan).

* Synonym: Polinicis Blainville, 1826 and Polynices Herrmannsen, 1847. 
Recent distribution.-Southeast Asian waters from southernmost Japan to Indonesia.

Horizon.-Santa Barbara Silt.

Locality.-SKGS-71.

$$
\begin{gathered}
\text { Polinices (Polinices) sp. cf. P. (P.) jukesii (REEve) } \\
\text { Pl. 5, Fig. } 8
\end{gathered}
$$

1844. Natica candidissima, Recluz (non LeGuillou), Proc. Zool. Soc. London, p. 130.

1855. Natica jukesii Reeve, Conch. Icon. Vol. 9, Natica, pl. 19, fs. 84a and b.

1886. Natica jukesii, Tryon, Man. Conch. Ist Ser. Vol. 8, p. 46, pl. 19, f. 95.

1887. Natica jukesii, Sowersy, Thes. Conch. Vol. 5, p. 88, pl. 458, f. 55.

1905. Natica (Polinices) jukesii, Martin, Samml. Geol. Reichs-Mus. Leiden, N. F. Bd. 1, Abt. 1, p. 265, Taf. 39, f. 639

Material.-GK-L 7431. The shell surface is partly coroded but is characteristic enough for the taxonomical comparison.

\begin{tabular}{|c|c|c|c|c|c|c|c|}
\hline${ }_{\text {GK-L }}^{\text {specimen }}$ & $\underset{(\mathrm{mm})}{\mathrm{H}}$ & $\underset{(\mathrm{mm})}{\mathrm{Ap}}$ & $\underset{(\mathrm{mm})}{\mathbf{D}}$ & $\underset{(\%)}{\mathrm{Ap} / \mathrm{H}}$ & $\begin{array}{l}\mathrm{D} / \mathrm{H} \\
(\%)\end{array}$ & $\underset{\text { (degrees) }}{\angle \mathrm{P}}$ & $\begin{array}{l}\text { protoconch }+ \\
\text { teleoconch }\end{array}$ \\
\hline 7431 & 12.4 & 9.65 & 11.9 & 77.7 & 95.9 & 110.5 & ca 5 \\
\hline
\end{tabular}

Measurements.-

Remarks.-The present specimen conforms with the fossil specimens of Polinices (s.s.) jukesii (REEve) from Indonesia. MARTIN's specimens (Reg. No. St. 11360 and 11361, Rijksmus. Geol. Min. Leiden) show some variation in the umbilical feature. Some of the specimens are perfectly covered at the umbilicus by the callus, while the others have the narrow but clearly open umbilicus.

They are featured by the oblong outline with weak but apparent shoulderflexure, heavy parietal callus, and a distinct and moderately wide spiral groove along the umbilical funicle. In these respects the Philippine and Indonesian fossil specimens conform almost perfectly with the living species. The latter, however, is somewhat wider in profile than the fossils. This is the reason why the author suspends the concrete identification.

Geological occurrence.-Miocene to Pliocene (Indonesia).

Recent distribution.-Southeast Asian waters.

Horizon.-Upper part of the Dingle Formation.

Locality.-SKGS-74.

Genus Neverita RIsso, 1826

(type-species: Neverita josephina Risso by monotype)

Subgenus Glossaulax PILsBRY, 1929

(type-species: Natica reclusiana DEshaYES by original designation)

Opinions concerning with the taxonomical relation of Polinices, Glossaulax, and Neverita are not necessarily approval. Some ones include Glossaulax and Neverita respectively as a subgenus in Polinices, while the others place Glossaulax under Neverita, etc. As to the general outline of the shell, Glossaulax illustrates a wide range of variation including both typical form of Polinices and Neverita, 
although its type species is closer to Neverita-form (axially compressed) than to Polinices-form (obliquely compressed). The umbilical features of these three groups apparently differ one another with respective characteristics. Under such circumstance the author prefers to separate Neverita and Glossaulax from Polinices at generic level.

Neverita (Glossaulax) petiveriana (RECLUZ)

Pl. 5, Figs. 12 and 14; Text-fig. 21

1855. Natica petiveriana Recluz in ReEve, Conch. Icon. Vol. 9, Natica, pl. 5, f. 17, 1886. Neverita petiveriana, TrYoN, Man. Conch. Ist Ser. Vol. 8, p. 33, pl. 11, f. 11.

Material.-GK-L 6371. A single perfect adult specimen.

\begin{tabular}{|c|c|c|c|c|c|c|c|c|}
\hline \multicolumn{3}{|c|}{ Measurements.- } & \multirow[b]{2}{*}{$\underset{(\mathrm{mm})}{\mathrm{D}}$} & \multirow[b]{2}{*}{$\underset{(\%)}{\mathrm{Ap} / \mathrm{H}}$} & \multirow[b]{2}{*}{$\underset{(\%)}{\mathrm{D} / \mathrm{H}}$} & \multirow[b]{2}{*}{$\underset{\text { (degrees) }}{\angle \mathrm{P}}$} & \multirow[b]{2}{*}{$\begin{array}{l}\text { protoconch } \\
\text { D numb. }\end{array}$} & \multirow[b]{2}{*}{$\begin{array}{l}\text { teleoconch } \\
\text { numb. }\end{array}$} \\
\hline $\begin{array}{l}\text { specimen } \\
\text { GK-L }\end{array}$ & $\underset{(\mathrm{mm})}{\mathrm{H}}$ & $\underset{(\mathrm{mm})}{\mathrm{Ap}}$ & & & & & & \\
\hline 6371 & 25.2 & 25.1 & 27.85 & 99.5 & 110.5 & 131.6 & .84 & 3.8 \\
\hline
\end{tabular}

Remarks.-The present specimen show the typical form of Glossaulax with depressedly orbicular profile, widely open umbilicus, slightly depressed subsutural part, and medially grooved umbilical calls. It is distinguishable from the allied species by its umbilical feature. The moderately weak funicle is ended with a dark colored heavy callus, which is continuous to the parietal callus. The continuation of the two parts, however, is not smooth but interrupted by a moderately deep notch between as indicated in the Text-figure (Text-fig. 21-[1]). Immediately above this notch the lowest part of the parietal callus is pointed forward along the border of the umbilicus. Further continuation of this point clearly separates the white coloration of the umbilical region from the dark one of the lateral side. On the basis of these diagnostic features the present specimen is identified to $N$. (G.) petiveriana (RECLUz), living in Philippines waters. $N$. (G.) vesicalis (PHILIPPI) resembles the present specimen, but the two differ each other in the character of the umbilical callus and labrum. There is no notch between the lower end of the parietal and the umbilical callus on $N$. (G.) vesicalis and its anterior part of the labrum is narrowly rounded showing a rather angular flexure. The protoconch of the present specimen is dark brown and clearly separated from the teleoconch (Text-fig. 21-[2]).

Neverita (Glossaulax) hayashii Azuma (1961, p. 193, fs. 3 and 4) from Central Japan is considered to be conspecific to $N$. (G.) petiveriana.

Recent distribution.-Philippines waters.

Horizon.-Upper part of the Ulian Formation.

Locality.-SKGS-73.

Neverita (Glossaulax) petiveriana compressa subsp. nov. Pl. 4, Figs. 1, 4, and 5; Text-fig. 21

Material.-Holotype: GK-L 7474 and paratype: GK-L 7475. Preservation is perfect. 

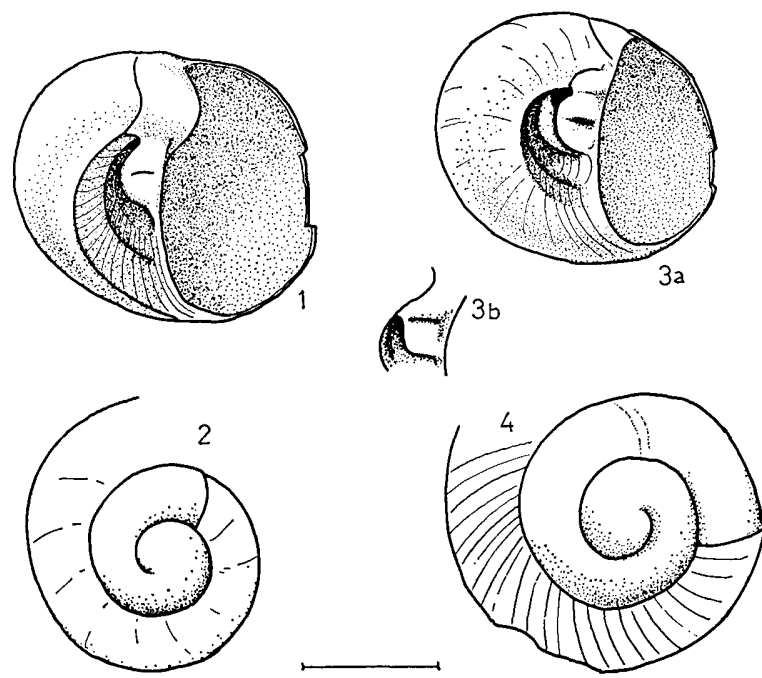

Fig. 21. Protoconchs and umbilical features of some naticids.

1 and 2: Neverita (Glossaulax) petiveriana (RECLUZ), GK-L 6371.

3a and b: $N$. (G.) petiveriana compressa subsp. nov., GK-L $7474(3 \mathrm{a})$ and $7475(3 \mathrm{~b})$.

4: $\quad$ N. (Neverita) albula bagacayensis subsp. nov., GK-L 7447.

Unit bar indicates $0.5 \mathrm{~mm}$ for protoconchs.

\begin{tabular}{|c|c|c|c|c|c|c|c|c|}
\hline \multicolumn{3}{|c|}{ Measurements.- } & \multirow[b]{2}{*}{$\underset{(\mathrm{mm})}{\mathrm{D}}$} & \multirow[b]{2}{*}{$\underset{(\%)}{\mathrm{Ap} / \mathrm{H}}$} & \multirow[b]{2}{*}{$\begin{array}{l}\mathrm{D} / \mathrm{H} \\
(\%)\end{array}$} & \multirow[b]{2}{*}{$\underset{\text { (degrees) }}{\angle \mathrm{P}}$} & \multirow[b]{2}{*}{$\begin{array}{l}\text { protoconch } \\
\text { numb. }\end{array}$} & \multirow[b]{2}{*}{$\begin{array}{l}\text { teleoconch } \\
\text { numb. }\end{array}$} \\
\hline $\begin{array}{l}\text { specimen } \\
\text { GK-L }\end{array}$ & $\underset{(\mathrm{mm})}{\mathrm{H}}$ & $\underset{(\mathrm{mm})}{\mathrm{Ap}}$ & & & & & & \\
\hline 7474 & 17.5 & 17.6 & 23.8 & 100.6 & 136.0 & 140.3 & - & 5.6 \\
\hline 7475 & 10.6 & 10.7 & 14.6 & 100.9 & 137.3 & 142.8 & - & 5.1 \\
\hline
\end{tabular}

Diagnosis.-The shell is moderately small attaining about $24 \mathrm{~mm}$ in maximum diameter, orbicular in outline, and extremely compressed with hardly elevated spire and almost flat base. The protoconch is paucispiral and similar to that of $N$. (G.) petiveriana. The spire whorls are almost flat and separated one another by the slightly depressed suture. The aperture is semicircular. The labrum profile is almost straight, retrocurrently oblique, forming an angle of about 40 degrees to the axis of coiling. The umbilicus is widely open and is not separated by any sharp angulation from the basal surface but there is a longitudinally and slightly step-like concavity just inside the umbilicus. This concavity is more distinct at the early stage of growth than at the later. One more step-like concavity, which is more distinct, is discernible along the medial part between the umbilical border and the funicle. The umbilical region, especially at the inner concave belt is finely reticulate with the distinct growth lines and the spiral lines. The funicle is prominent and situated closer to the posterior end. The umbilical callus is heavy and transversely grooved at the middle, and its continuation to the parietal callus is interrupted by a notch between. The parietal callus is heavy at the posterior part.

Comparison.-The present specimens are apparently allied to $N$. (G.) peti- 
veriana (RECLUZ) (in REEVE, 1855), but is somewhat smaller and much more compressed than the latter. Although the umbilical callus of the present subspecies is variable as shown in the Text-fig. 21 -[3a and $3 \mathrm{~b}$ ], it is generally more prominent than that of petiveriana. Furthermore the lower part of the parietal callus is not pointed forwardly along the border of the basal and umbilical regions. The difference just mentioned is, however, so small that the former should be separated from the latter at the subspecific level.

The callus of the paratype specimen resembles that of $N$. (G.) hyugaensis SHuto (1964, p.282, text-fig. 1), but the shell of the latter species is less compressed than the former. Furthermore the latter is devoid of the distinct spiral groove in the umbilicus.

Horizon.-Santa Barbara Silt.

Locality.-SKGS-71.

\author{
Subgenus Neverita RIsso (s.s.) \\ Neverita (Neverita) albula bagacayensis subsp. nov. \\ Pl. 5, Figs. 1, 2, 7, and 11; Text-fig. 21
}

Material.-Holotype: GK-L 7445 and paratypes: GK-L 7446 to 7449 from one and same locality.

\begin{tabular}{|c|c|c|c|c|c|c|c|c|c|}
\hline \multicolumn{3}{|c|}{ Measurements.- } & \multirow[b]{2}{*}{$\underset{(\mathrm{mm})}{\mathrm{D}}$} & \multirow[b]{2}{*}{$\underset{(\%)}{\mathrm{Ap} / \mathrm{H}}$} & \multirow[b]{2}{*}{$\begin{array}{l}\mathrm{D} / \mathrm{H} \\
(\%)\end{array}$} & \multirow[b]{2}{*}{$\underset{\text { (degrees) }}{\angle \mathrm{P}}$} & \multirow{2}{*}{\multicolumn{2}{|c|}{$\begin{array}{l}\text { protoconch } \\
\text { D numb. }\end{array}$}} & \multirow[b]{2}{*}{$\begin{array}{l}\text { teleoconch } \\
\text { numb. }\end{array}$} \\
\hline $\begin{array}{l}\text { specimen } \\
\text { GK-L }\end{array}$ & $\underset{(\mathrm{mm})}{\mathrm{H}}$ & $\underset{(\mathrm{mm})}{\mathrm{Ap}}$ & & & & & & & \\
\hline 7445 & 12.2 & 11.3 & $13.8+$ & 92.5 & - & 119.8 & - & - са 4 & - \\
\hline 7447 & 9.5 & 9.3 & 10.90 & 97.7 & 114.9 & 129.9 & .86 & 2.3 & 2.5 \\
\hline 7449 & 10.8 & 9.4 & 11.65 & 86.7 & 108.6 & 127.3 & .80 & 2.3 & 2.2 \\
\hline
\end{tabular}

Diagnosis.-The shell is small, depressedly ovoid, flattened at the apertural face, moderately thick, and porcelaineous with luster. The protoconch is rather polygyrate for the genus. It consists of about 2.1 to 2.3 smooth volutions, of which the tip is globose and somewhat elevated and the remainder ones are moderately convex and very slowly growing. The end of the protoconch is marked by a sharp oblique furrow (text-fig. 21-[4]). The teleoconch consists of about two and a half whorls, which grow slowly at the early half whorl and is then rapidly increased. The convexity of the spire whorls is much less than that of the protoconch-volutions. The suture is impressed. There is no remarkable concavity below the suture except on the latest part of the gerontic specimen. The surface is ornamented with the antecurrently oblique growth lines, which are very fine at first and become coarser later. Besides the growth lines several microscopic spiral striae are discernible below the suture. The aperture is semicircular and normal for the genus. The umbilicus is deep and open. The inner surface is provided with coarse and regular growth lines. The umbilical funicle is moderately strong with the prominent furrow on both sides and ended with a very wide and heavy umbilical callus, which is elongate extending from the funicle to the posterior extremity of the umbilicus and separated from both columellar lip and the parietal callus respectively by a distinct groove. The 
parietal callus is thick and solid, but not so wide.

Comparison.-The wide and elongate umbilical callus which is separated from both the columellar lip and parietal callus respectively by a distinct groovelike depression is peculiar and stable character of the present specimens. This feature is clearly illustrated in figure 2 of the plate 5. They are closely allied to Natica albula Recluz (1854, Jour. de Conch. Tom. 2, p. 194) in the general character especially in the feature of the callus, but the former is distinguished from the latter in having much smaller shell and more depressed and less angular profile than the latter.

There is no other species comparable with the present specimens.

Horizon.-Upper part of the Dingle Formation.

Locality.-SKGS-74.

\author{
Superfamily Tonnoidea \\ Family Cymatiidae \\ Genus Apollon MONTFORT, 1810*
}

(type-species: Murex gyrinus LINNÉ by original designation)

Subgenus Biplex PERRY, 1811

(type-species: Biplex perca PERRY by original designation)

Apollon (Biplex) perca (PERRY)

Pl. 7, Figs. 6, 13, and 16: Text-fig. 22

1811. Biplex perca Perry, Conchology, pl. 4, f. 5.

1836. Ranella pulchra GrAY in G. B. SOWERBY, Conch. Illustr. Ranella, p. 8, pl.93, f. 19.

1840. Ranella bufo, J. de C. Sowerby, Trans. Geol. Soc. Ser. 2, Vol. 5, p. 329, pl. 26 , f. 16.

1844. Ranella pulchra, REEve, Conch. Icon. Vol. 2, Ranella, pl. 8, f. 47.

1884. Ranella (Eupleura) pulchra var, MarTiN, Samml. Geol. Reichs-Mus. Leiden, Ser. I, Bd. 3, p. 135, Tab. 7, f. 136.

1920. Ranella (Biplex) pulchra, TEScH, Paläont. v. Timor, Lief. 8, p. 43, pl. 129, f. 156.

1948. Gyrineum (Biplex) perca, Cox, Schweiz. Paläont. Abhandl. Vol.66, p. 41, fs. $3 a$ and b.

1954. Apollon (Biplex) perca, KIRA, Colored Illustr. Shells Japan, Vol. 1, p. 43, pl. 21, f. 11.

1958. Apollon (Biplex) perca, Oyama, Moll. Shells. Apollon, pl. 1, fs. 7-11.

Material.-GK-L 6945 to 6949 from one and same locality.

Measurements.-

\begin{tabular}{|c|c|c|c|c|c|c|c|c|c|}
\hline $\begin{array}{c}\text { specimen } \\
\text { GK-L }\end{array}$ & \multicolumn{2}{|c|}{$\underset{(\mathrm{mm})}{\mathrm{H}}$} & \multicolumn{2}{|l|}{$\underset{(\mathrm{mm})}{\mathrm{Bd}}$} & \multicolumn{2}{|l|}{$\underset{(\mathrm{mm})}{\mathbf{A p}}$} & $\underset{(\mathrm{mm})}{\operatorname{Dmax}}$ & \multicolumn{2}{|c|}{$\underset{(\mathrm{mm})}{\operatorname{Dmin}}$} \\
\hline 6946 & \multicolumn{2}{|c|}{$27.8+(28.8)$} & \multicolumn{2}{|c|}{$18.6+(19.6)$} & \multicolumn{2}{|l|}{$15.0+(16.0)$} & 21.4 & 10. & \\
\hline 6947 & 26.5 & & 18.45 & & 13.75 & & 19.5 & 9. & .7 \\
\hline $\begin{array}{l}\text { specimen } \\
\text { GK-L }\end{array}$ & $\underset{(\%)}{\mathrm{Bd} / \mathrm{H}}$ & $\underset{(\%)}{\mathrm{Ap} / \mathrm{H}}$ & $\mathrm{D} \max _{(\%)} / \mathrm{H}$ & $\underset{(\%)}{\mathrm{Dmin}} / \mathrm{H}$ & $\underset{\min }{\angle \mathrm{P}}(\mathrm{deg}$ & $\begin{array}{c}\text { grees) } \\
\max \end{array}$ & & & $\begin{array}{l}\text { whorls } \\
\text { teleo }\end{array}$ \\
\hline 6946 & ca 68 & ca 56 & ca 74 & ca 35 & 35.7 & 59.8 & & & 6.0 \\
\hline 6947 & 69.6 & 51.8 & 73.5 & 35.7 & 38.9 & 64.9 & & & 5.5 \\
\hline
\end{tabular}

* Synonym: Apollo P. FISCHER, 1884 
Remarks.-The specimens in hand are quite identical to the living specimens in Southeast Asian waters.

The protoconch is dome-shaped, smooth, swollen, and consists of rapidly growing two and a half volutions. The first volution is small but globose and the remainder ones are also roundly convexed at the sides. The axis of the protoconch is slightly oblique to that of the teloconch. There is no end-mark of the protoconch, but the teleoconch is clearly indicated by the abrupt appearance of the axial and spiral ornamentations, which are equally strong and granular at the intersections (text-fig.22-[3]). The primary spirals are four and equally spaced. Subsequent development is stational. The lowest one of the primaries may be concealed under the overlapping part of the succeeding whorl. The secondary lines appear even on the first whorl. The bi-serial leaf-like varices are almost on a simple plane or very slightly twisted one.

Geological occurrence.-Lower Miocene (India), Middle Miocene to Pliocene (Indonesia), and Pleistocene (Indonesia and Japan).

Recent distribution.-Indo-Pacific from India to Southwest Japan.

Horizon.-Upper part of the Dingle Formation.

Locality.-SKGS-74.

Genus Distorsio RöDING, 1798*

(type-species: Murex anus LINNÉ by subsequent designation, PILsBRY, 1922)

Subgenus Distorsio (s.s.)

\section{Distorsio (Distorsio) reticulatus decipiens (REEVE)}

Pl. 7, Figs. 9 and 10

1844. Triton decipiens ReEve, Conch. Icon. Vol. 2, Triton, pl. 20, f. 102.

1881. Distorsio cancellinus, TrYoN (partim), Man. Conch. Ist Ser. Vol. 3, p. 35, pl. 17, f. 178.

1958. Distorsio decipiens, Oyama, Moll. Shells, Distorsio, pl. 1, fs. 5 and 6.

1961. Distorsio (Rhysema) decipiens, HABE, Colored Illustr. Shells Japan Vol. 2, p. 46 , pl. 23, f. 2.

Material.-GK-L 6951 to 6953 from one and same locality.

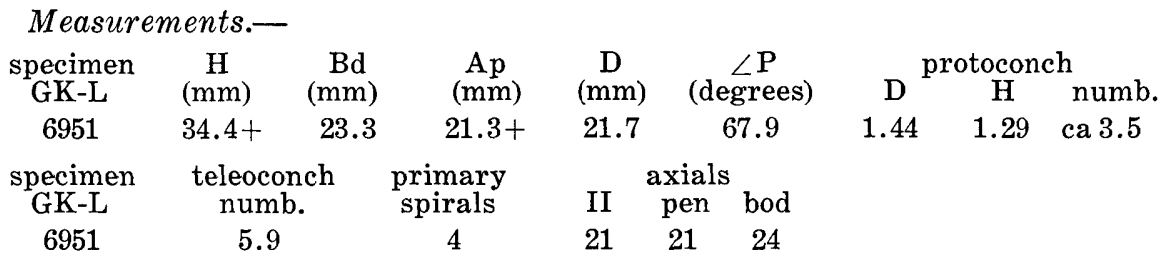

Remarks.-Distorsio (Distorsio) decipiens (REEve) living in Southeast Asian waters are closely allied to $D$. (D.) reticulatus $\mathrm{RöDING}=D$. (D.) cancellinus (De RoISSY), also living in Southeast Asian seas. The difference is only recognizable concerning the size and ornamentation on the later whorls. D. decipiens is

* Synonym: Distortrix Link, 1807; Persona Montfort, 1810; and Distorta Perry, 1811. 
remarkably smaller in size than $D$. reticulatus. Although the ornamentation on the early whorls is very similar between the two, it is apparently deviated from each other on the later whorls. On the early whorls the primary spirals are four and almost equally spaced between the upper and lower sutures except for the second upper one $\left(\mathrm{P}_{2}\right)$, which is separated from the subsutural one $\left(\mathrm{P}_{1}\right)$ by somewhat wider interspace. The third lira $\left(\mathrm{P}_{3}=\mathrm{Per}\right)$ coincides with the peripheral angulation. In the course of the growth the subsutural lira $\left(\mathrm{P}_{1}\right)$ slightly retreats from the suture forming a narrow, horizontal and concave shoulder below the suture on both species. On D. decipiens the second lira $\left(\mathrm{P}_{2}\right)$ at the same time goes down remarkably. Consequently the second $\left(\mathrm{P}_{2}\right)$ and third $\left(\mathrm{P}_{3}\right)$ lirae lie side by side and form the peripheral double-angulations. The surface between the uppermost lira $\left(\mathrm{P}_{1}\right)$ and the second $\left(\mathrm{P}_{2}\right)$ is wide, steeply sloped, somewhat concave, and provided with two moderately weak secondary threads on the fourth and later whorls. While on $D$. reticulatus the second lira $\left(\mathrm{P}_{2}\right)$ does not go down so much as on the preceding species. In consequence the peripheral double angulations are moderately widely separated each other and the surface between the first $\left(\mathrm{P}_{1}\right)$ and the second $\left(\mathrm{P}_{2}\right)$ primary lirae is moderately sloped, somewhat concave, moderately wide, and provided with only one but distinct secondary thread between on the later whorls. These facts indicate that the two named species are the off-springs of a common ancestor. Considering the degree of difference the author prefers to treat $D$. decipiens as a subspecies of $D$. reticulatus.

The present specimens quite conform with REEvE's figured type, which has the laterally expanded and angularly pointed posterior part of the labrum. Comparing with these fossil specimens from Panay, the figured specimens by the Japanese authors cited above are somewhat different having less expanded and gradually contracted posterior part of the labrum, although the pattern of the sculpture is practically similar between them.

Recent distribution.-Southeast Asian waters.

Horizon.-Upper part of the Dingle Formation.

Locality.-SKGS-74.

\section{Distorsio (Distorsio) reticulatus reticulatus RöDING}

$$
\text { Pl. 4, Fig. } 8
$$

1798. Distorsio reticulata RöDING, Museum Boltenianum, p. 133, sp. No. 1674.

1805. Murex cancellinus De Rorssy in Buffon, Hist. Gén. et Part. Moll. 6, p. 56, No. 12.

1844. Triton reticulatus, ReEve, Conch. Icon. Vol. 2, Triton, pl. 12, f. 45.

1881. Distorsio cancellinus, Tryon (partim), Man. Conch. Ist Ser. Vol. 3, p. 35, pl. 17, f. 175 .

1884. Nassa (?) lamonganana Martin, Samml. Geol. Reichs-Mus. Leiden, Ser.1, Bd. 3, p. 125, Tab. 7, f. 128.

1899. Persona reticulata, MarTin, ibid. N. F. Bd.1, Abt.1, p. 145, Taf. 23, f. 146.

1906. Distorsio cancellina, DaLTon, Quart. Jour. Geol. Soc. London, Vol. 64, p. 629, pl. 55, f. 4.

1915. Persona (Distortrix) reticulata, Tesch, Paläont. v. Timor, Lief. 5, p. 69, Taf. 82, fs. 151a and b.

1922. Distorsio clathrata, Dickerson, Philippine Jour. Sci. Vol. 20, pp. 202 and 
216, pl. 2, f. 20 .

1928. Distorsio cancellinus, Yokoyama, Imp. Geol. Surv. Japan Rep. No. 101, p. 44 , pl. 3 , f. 8 .

1941. Distorsio reticulata, HataI, Rec. Mar. Shell-bearing Moll. South Sea Islands. (Pt. 1), p. 123, pl. 11, fs. 8 and 9.

1951. Distorsio reticulata, (HIRASE) TAKI, Handb. Illustr. Shells pl. 96, f. 5.

1954. Distorsio reticulata, KIRA, Colored Illustr. Shells Japan, Vol. 1, p. 43, pl. 21, f. 10 .

1958. Distorsio reticulatus, OYama, Moll. Shells, Distorsio, pl. 1, fs. 1 and 2.

Material.-GK-L 6413. Imperfect specimen broken at the apex and the labrum.

Measurements.-

Preserved height of the shell: $42.8 \mathrm{~mm}$ (lacking the apex and part of the canal); max diameter: $26.1 \mathrm{~mm}$ (lacking the labrum); pleural angle: 69 degrees; and the number of the preserved whorls: 5.5.

Remarks.-Descriptive remarks were given in the preceding paragraphs. Distorsio (Rhysema) horrida KURODA and HABE (1961, p. 46 and app. p. 17, pl. 23, f. 3) living off Southwest Japan may be synonym of the present species with typical features.

Geological occurrence.-Miocene (India, Burma, Indonesia, and Philippines), Pliocene (Indonesia and Taiwan), and Pleistocene (Indonesia and Okinawa).

Recent distribution.-Indo-Pacific from South Japan to Madagascar.

Horizon.-Upper part of the Ulian Formation.

Locality.-SKGS-73.

Family Bursidae

Genus Gyrineum LiNk, 1807*

(types-species: Ranella spinosa LAMARCK by subsequent designation, ROBERET0, 1889)

Subgenus Chasmotheca DaLL, 1904

(type-species: Ranella foliata BRODERIP by original designation)

Gyrineum (Chasmotheca) sp. aff. G. (C.) cavitense (G. B. SOWERBY)

Pl. 7, Figs. 1 and 8; Text-fig. 22

1841. Ranella cavitensis BECK in Sowerby, Proc. Zool. Sec. Vol. 9, p. 185.

1844. Ranella crumena, REEve (partim), Conch. Icon. Vol. 2, Ranella, pl. 4, f.17a.

1960. Gyrineum (Chasmotheca) cavitense, Oyama, Moll. Shells, Gyrineum, fs. 3-6.

Material.-GK-L 6412a and b from loc. SKGS-73 and GK-L 7105 from SKGS-72.

Measurements.-

$\begin{array}{lccrrrrrr}\underset{\text { specimen }}{\mathrm{GK}-\mathrm{L}} & \begin{array}{c}\mathrm{H} \\ (\mathrm{mm})\end{array} & \begin{array}{c}\mathrm{Bd} \\ (\mathrm{mm})\end{array} & \begin{array}{c}\mathrm{Ap} \\ (\mathrm{mm})\end{array} & \begin{array}{c}\mathrm{D} \\ (\mathrm{mm})\end{array} & \begin{array}{c}\mathrm{Bd} / \mathrm{H} \\ (\%)\end{array} & \begin{array}{c}\mathrm{Ap} / \mathrm{H} \\ (\%)\end{array} & \begin{array}{c}\mathrm{D} / \mathrm{H} \\ (\%)\end{array} & \begin{array}{c}\angle \mathrm{P} \\ \text { (degrees) }\end{array} \\ 6412 \mathrm{a} & 37.5 & 27.2 & - & - & 72.5 & - & - & \text { ca 79 } \\ 7105 & 14.2 & 11.3 & - & - & 79.5 & - & - & 81.6 \\ & 22.3+ & 17.9 & 15.7 & 16.9 & 80.3 & 70.4 & 75.6 & 77.8\end{array}$

* Synonym: Bufonaria SCHUMACHER, 1817 


\begin{tabular}{|c|c|c|c|c|}
\hline specimen & \multicolumn{3}{|c|}{ protoconch } & teleoconch \\
\hline GK-L & $\mathrm{H}$ & D & numb. & numb. \\
\hline $6412 a$ & 1.90 & 2.35 & 2.4 & 4.6 \\
\hline $6412 b$ & 2.85 & 2.40 & 2.6 & 2.5 \\
\hline 7105 & - & - & - & $4+$ \\
\hline
\end{tabular}
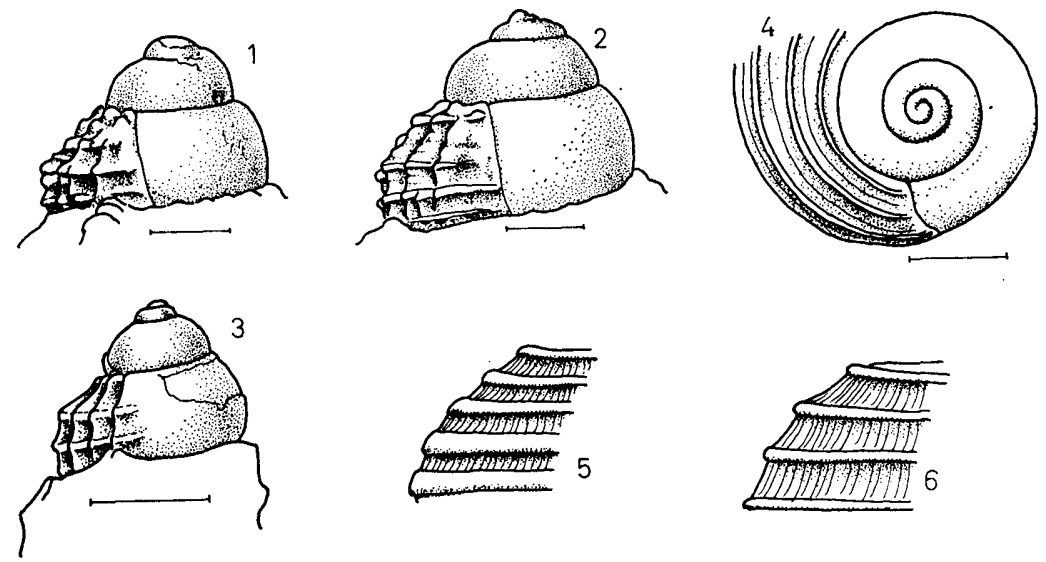

Fig. 22. Protoconchs and teleoconchs of some Mesogastropoda.

1: Gyrineum (Chasmotheca) sp. aff. G. (C.) cavitense (BECK in G. B. SowerBY), GK-L 6412 b.

2: G. (C.) nobile (REEvE), GK-L 7112.

3: Apollon (Biplex) perca (PERRY), GK-L 6948.

4 and 6: Tonna costata (MENKE), GK-L 7499.

5: T. variegata (LAMARCK), GK-L 6407.

Unit bars indicate $1 \mathrm{~mm}$ respectively.

Remarks.-The present specimens are characterized by the large pleural angle, remarkably micro-granular spirals and very coarse, sharp, and widely spaced tubercles at the periphery. The first whorl of the teleoconch is provided with six primary spiral threads, of which the uppermost and the lowest one are situated respectively close to the upper and the lower suture. The others are spaced equally between the sub- and suprasutural lirae. They are remarkably granular altogether and the fourth upper lira coincides with the tuberculate peripheral angulation. The secondary lines appear even on the first whorl and rapidly become larger and granular. The tertiaries are intercalated first on the later part of the third whorl.

On the basis of the features mentioned above the present specimens are reasonably included in Chasmotheca DALL, 1904. They are quite identical with the specimens of "Gyrineum (Chasmotheca) cavitense (BECK)" from Philippines and South Japan figured by OYAMA (1960, fs. 3-6). The latter, however, is not perfectly identical with REEVE's specimen (1844, pl. 4, f. 17b), which has more numerous peripheral spinous granules and much less contracted base than the former. Furthermore G. cavitense is provided with three series of the granulated angulations on the body whorl, while OYAMA's specimens show only two. These differences can not be negligible and OYAMA's specimens together with the present specimens should be separated from G. cavitense. They may represent 
a new species.

The protoconch of the present specimens are large attaining about $2.4 \mathrm{~mm}$ in diameter, smooth, dome-shaped, and paucispiral with about two and a half volutions. The end of the protoconch is marked by a faint and slightly retrocurrently oblique line (text-fig. 22-[1]). The teleoconch is coarsely decorated even at the very beginning.

Recent distribution.--Philippines to South Japan.

Horizon.-Upper part of the Ulian Formation.

Localities.-SKGS-72 and 73.

\section{Gyrineum (Chasmotheca) nobile (REEVE)}

Pl. 7, Figs. 2, 7, and 11; Text-fig. 22

1844. Ranella nobilis ReEve, Proc. Zool. Soc. p. 137.

1844. Ranella nobilis, ReEve, Conch. Icon. Vol. 2, Ranella, pl. 4, f. 16.

1879. Ranella elegans, MARTin, Tertiärschicht. a. Java, p. 55, Tab. 10, f. 3.

1899. Ranella (Ranella) nobilis, Martin, Samml. Geol. Reichs-Mus. Leiden, N. F. Bd. 1, Abt. 1, p. 146, Taf. 23, fs. 340-342.

1960. "Gyrineum" nobile, Oyama, Moll. Shells, Gyrineum, fs. 1 and 2.

Material.-GK-L 7112, 7113, 7114a, b, and c from one and same locality.

Measurements.-

\begin{tabular}{|c|c|c|c|c|c|c|c|}
\hline specimen & $\mathrm{H}$ & I & 21 & \multirow{2}{*}{\multicolumn{3}{|c|}{ protoconch }} & leoconch \\
\hline & $(\mathrm{mm})$ & & egrees) & $\mathrm{H}$ & & numb. & numb. \\
\hline 7112 & 32.9 & 22.6 & 65.7 & 2.50 & 2.70 & 3.1 & 4.6 \\
\hline 7113 & 30.4 & 21.9 & 58.2 & 2.55 & 2.85 & 3.2 & 4.5 \\
\hline
\end{tabular}

Remarks.-The protoconch is very large attaining about 2.7 to $2.85 \mathrm{~mm}$ in diameter and dome-shaped with convex and smooth 3.2 volutions. The beginning of the teleoconch is sharply marked by abrupt and simultaneous appearance of the distinct spiral and axial ornamentation all over the surface from suture to suture (text-fig. 22-[2]). The primary spiral threads are seven, of which the uppermost one is close to the upper suture and granular, the second one is at the upper one-eighth, spinously granular, and forms the upper sharp angulation, the fifth is at about the middle and makes the median angulation, and the lowest one is close to the lower suture. The third and fourth are remarkably smaller and much less granular than the others. One distinct secondary thread, which is as large as the third and fourth primary threads and starts at the very beginning of the first whorl, is discernible slightly below the peripheral (median) angulation.

The upper angulation abruptly becomes indistinct on the second whorl and that part is even slightly concave on the late whorls. Keeping pace with this phenomenon its granulation becomes finer comparable to those of the third thread. While the fourth thread becomes comparatively weak to be similar to the third one. The axials are generally weak. Each axial is not extending from suture to suture but limited near the upper suture, lower suture, or at the periphery.

The present specimens, although preservation is not perfect, are identical to Gyrineum nobile (REEVE). 
Geological occurrence.-Miocene (Indonesia), Mio-Pliocene (Philippines), Pliocene (Indonesia), and Pleistocene (Indonesia).

Recent distribution.-Sino-Malayan waters.

Horizon.-Uppermost part of the Dingle Formation.

Locality._-SKGS-75.

Family Tonnidae

Genus Tonna BRÜNNICH, 1772*

(type-species: Buccinum galea LINNÉ by original designation)

Tonna costata (MENKE)

Pl. 6, Figs. 19-21; Text-fig. 22

1777. Dolium latescens latesulcatum MarTiNI (nomem illegitimum), Syst. Conch. Cab. Bd. 3, p. 390.

1777. Dolium late sulcatum MARTINI (nom. illegit.), ibid. Bd.3, p. 396, Taf.116, f. 1072 and Taf. 118 , f. 1082.

21817. Buccinum allium, Dillwyn, Descr. Catal. Rec. Shells, Vol. 2, p. 585 (fide IREDALE, 1931).

1830. Dolium costatum Menke, Synops. Meth. Moll. p. 63.

1835. Dolium fasciatum var. KIENER, Icon. Coq. Viv. Tom. 11, Dolium, pl. 4, f. 6.

1879-80. Dolium costatum, Martin, Tertiärschicht. a. Java, p. 40, Tab. 7 , fs. 9 and 10.

1885. Dolium costatum, TrYoN (partim), Man. Conch. Ist Ser. Vol. 7, p. 263, p. 4, f. 19.

1899. Dolium costatum, Martin, Samml. Geol. Reichs-Mus. Leiden, N. F. Bd. 1, Abt. 1, p. 245, Taf. 37, fs. 591-593.

1920. Dolium costatum, Tesch, Paläont. v. Timor Lief. 8, p. 45, Taf. 129, f. 159

1931. Tonna allium, Iredale, Rec. Austral. Mus. Vol. 18, p. 215, pl. 23, f. 23.

1943. Tonna allium, K-Osima, Conchologia Asiatica, Vol. 1, p. 125, pl. 5, f. 3.

1947. Tonna niasensis WIssema, Young Tert. and Quat. Gastrop. Nias, p. 163, pl. 6, fs. 145-147.

1954. Tonna allium, KIRA, Colored Illustr. Shells Japan, Vol. 1, p. 44, pl. 22, f. 3.

1962. Tonna costata, KILIAS, Das Tierreich, Lief. 77, p. 28, f. 23.

1966. Tonna allium, HABE and Kosuge, Shells of the world in colour, Vol. 2, p. 48, pl. 16, f. 10 .

Material.-GK-L 6408-11 from loc. SKGS-73 and GK-L 6490-91 and 7499 from loc. SKGS-71.

\begin{tabular}{|c|c|c|c|c|c|c|c|c|}
\hline \multicolumn{9}{|c|}{ Measurements.- } \\
\hline $\begin{array}{l}\text { specimem } \\
\text { GK-L }\end{array}$ & $\underset{(\mathrm{mm})}{\mathrm{H}}$ & $\underset{(\mathrm{mm})}{\mathrm{Bd}}$ & $\underset{(\mathrm{mm})}{\mathrm{Ap}}$ & & $\begin{array}{l}\text { D } \\
\text { im) }\end{array}$ & $\underset{(\%)}{\mathrm{Bd} / \mathrm{H}}$ & $\underset{(\%)}{\mathrm{Ap} / \mathrm{H}}$ & $\underset{(\%)}{\mathrm{D} / \mathrm{H}}$ \\
\hline 6409 & 25.3 & 23.05 & 20.20 & & 9.95 & 91.1 & 79.8 & 78.8 \\
\hline 6410 & 18.1 & 16.65 & 14.95 & & 5.40 & 91.8 & 82.4 & 84.9 \\
\hline 6490 & 41.8 & 39.50 & 36.00 & & 0.35 & 94.4 & 86.2 & 72.6 \\
\hline $\begin{array}{l}\text { specimen } \\
\text { GK-L }\end{array}$ & \multicolumn{2}{|c|}{$\angle \mathrm{A} \quad \angle \mathrm{P}$} & \multicolumn{3}{|c|}{$\begin{array}{l}\text { protoconch } \\
\mathrm{H} \stackrel{\text { D numb. }}{ } \text {. }\end{array}$} & \multicolumn{3}{|c|}{$\begin{array}{l}\text { teleoconch } \\
\text { numb. }\end{array}$} \\
\hline 6409 & 99.7 & 101.5 & 1.48 & & 3.5 & & & \\
\hline 6410 & 99.9 & 116.8 & 1.44 & 2.8 & 3.5 & 2.0 & & \\
\hline 6490 & 104.7 & 121.2 & 1.50 & 3.0 & 3.4 & 3.0 & & \\
\hline
\end{tabular}

* Synonym: Cadus Röbing, 1798; Dolium Lamarck, 1801; Cadium Link, 1807; and Perdix MONTFORT, 1810. 
Remarks.-The present specimens are featured by the widely separated, well defined, and smooth spiral ribs and quite agree with the living Tonna costata (MENKE) except for smaller size than the latter. The detailed examination clarifies that the first whorl of the teleoconch has the secondary and even tertiary spirals, which are gradually weakened and disappear in the course of the growth. Consequently the interspaces of the spiral ribs on the body whorl are quite smooth except for the distinct growth lines.

Tonna allium, reported from the Japanese waters by many authors, is rather variable in outline but almost constant in ornamental design, which is quite identical to T. costata (MENKE). The former, however, has somewhat thicker and more solid shell than the latter. This seems to depend upon the local ecological condition.

The present species spends very long pelagic larval stage in the life history and shows very wide geographic distribution. There may be some relation between wide geographic distribution and rich local variation in morphology.

Geological occurrence.-Miocene (Indonesia and Philippines), Pliocene (Indonesia, Taiwan, and Southwest Japan), Pleistocene (Indonesia).

Recent distribution.-Indo-Pacific warm waters.

Horizons.-Santa Barbara Silt and the upper part of the Ulian Formation. Localities.-SKGS-71 and 73.

\section{Tonna variegata (LAMARCK) \\ Pl. 6, Fig. 25; Text-fig. 22}

1822. Dolium variegatum Lamarck, Hist. de Anim. Sans Vert. Tom. 7, p. 261.

1835. Dolium variegatum, KIENER, Icon. Coq. Viv., Tom. 11, Dolium, p.9, No.5, pl. 2 , f. 3.

1847. Dolium kieneri PhilipPI, Abbild. Beschr. Conch. Bd. 3, pt. 2, Dolium, p. 36, Nr. 6.

1849. Dolium variegatum, ReEve (partim), Conch. Icon. Vol. 5, Dolium, pl.5, f. $7 \mathrm{~b}$.

1860. Dolium variegatum var. tankervillei HANLEY, Proc. Zool. Soc. London for 1859, p. 490 (syn. fide KirIAS, 1962).

1860. Dolium variegatum var. angusta HANLEY, ibid. p. 491 (syn. fide KirIAS, 1962).

1899. Dolium variegatum, Martin, Samml. Geol. Reichs-Mus. Leiden, N. F. Bd.1, Abt. 1, p. 162, Taf. 25, fs. 376 and 376a.

1919. Tonna variegata, HeDLey, Rec. Austral. Mus. Vol. 12, p. 332, pl. 44, f. 6.

1962. Tonna variegata, KIRIAS, Das Tierreich, Lief. 77, p. 53, f. 46.

Material.-GK-L 6407.

\begin{tabular}{|c|c|c|c|c|c|c|c|c|c|}
\hline \multicolumn{10}{|c|}{ Measurements.- } \\
\hline $\begin{array}{l}\text { specimen } \\
\text { GK-L }\end{array}$ & $\underset{(\mathrm{mm})}{\mathrm{H}}$ & $\underset{(\mathrm{mm})}{\mathrm{Bd}}$ & $\underset{(\mathrm{mm})}{\mathrm{Ap}}$ & $\underset{(\mathrm{mm})}{\mathbf{D}}$ & $\underset{(\%)}{\mathrm{Bd} / \mathrm{H}}$ & $\underset{(\%)}{\mathrm{Ap} / \mathrm{H}}$ & $\underset{(\%)}{\mathrm{D} / \mathrm{H}}$ & $\underset{\text { deg }}{\angle A}$ & $\underset{\mathrm{es})}{\angle \mathrm{P}}$ \\
\hline 6407 & 44.2 & 40.4 & 35.0 & 31.05 & 91.3 & 79.0 & 70.3 & 104.3 & 96.1 \\
\hline $\begin{array}{l}\text { specimen } \\
\text { GK-L }\end{array}$ & $\mathrm{H}$ & $\begin{array}{c}\text { rotocon } \\
\text { D }\end{array}$ & numb & $\begin{array}{c}\text { teleocc } \\
\text { num }\end{array}$ & & & & & \\
\hline 6407 & - & 2.6 & 2.5 & 3. & & & & & \\
\hline
\end{tabular}

Remarks.-Moderately elevated spire, deep suture, and broad spiral lirae 
separated by narrower interspaces are characteristic features of the present specimen. The primary spiral lirae are five on all the spire-whorls and 17 on the body whorl. That is to say their development is stational. At first they are separated by much wider interspaces and gradually increased in their relative size. The lirae, however, still narrower than the interspaces on the penultimate whorl. On the body whorl they are wider than the interspaces except for the subsutural one, which is narrow and elevated to form the rim of the deep suture like a collar. The secondary spiral lines are discernible at a few grooves of infrasutural area. The growth lines are distinct especially at the early stage of the growth. The protoconch, tinted with reddish brown color, is very large consisting of about 2.5 smooth volutions.

The specimen is reasonably identified to Tonna variegata (LAMARCK) on the basis of the morphological characteristics mentioned above.

The present specimen quite conforms with the Pliocene specimens from Menengten in Cheribon, Java, (Martin, 1899). They show somewhat smaller relative size of the spiral lirae on the last whorl comparing with the recent specimens. This, however, does not imply the taxonomical distinction between these fossil and recent groups, because this feature depends upon the growth stage as is illustrated by the ontogenetic change on the present specimen. The fossil specimens from Java and Philippines are much smaller than the living adult specimens showing their immaturity.

Geological occurrence.-Pliocene (Indonesia).

Recent distribution.-Indo-Pacific from Japan to South Africa and Australia. Horizon.-Upper part of the Ulian Formation.

Locality._SKGS-73.

\section{Order Heterogastropoda}

HABE and Kosuge (1966, p. 101) proposed to separate the families Architectonidae, Mathildidae, Epitoniidae, Janthinidae, and Triphoridae from Mesogastropoda and grouped them under the new order Heterogastropoda putting the stress on the difference in the radulae and other organs. According to them gastropods of this group has the ptenoglossate radulae instead of taenioglossate ones of Mesogastropoda. Mode of life of the majority of the Heterogastropoda is parasitic in the coral, sea anemone, etc. or planktonic.

Superfamily Architectonicoidea

Family Architectonicidae

Genus Architectonica RöDING, 1798*

(type-species: Trochus perspectivus LINNÉ by subsequent designation, GRAY, 1847)

Subgenus Architectonica (s.s.)

Architectonica (Architectonica) perspectiva (LINNÉ)

Pl. 1, Figs. 4, 8, and 15; Text-fig. 16

* Synonym: Soralium Lamarck, 1789 
1758. Trochus perspectivus LiNNÉ, Systema Naturae 10th ed. p. 757.

1843. Solarium perspectivum, LAMARck, Hist. Anim. s. Vert. $2^{\mathrm{e}}$ ed. Tom. 9, p. 97.

1863. Solarium (Architectonica) perspectivum, HANLEY, Thes. Conch. Vol. 3, p. 228, fs. 36-38.

1866. Solarium perspectivum, ReEve, Conch. Icon. Vol. 15, Solarium, pl. 2, f. 11.

1887. Solarium perspectivum, TrYon, Man. Conch. Ist Ser. Vol. 9, p. 8, pl. 2, fs. $18-19$.

1879. Solarium perspectivum, Martin, Tertiärsch. a. Java, p. 74, tab. 13, fs.1-2.

1905. Solarium (Solarium) perspectivum, Martin, Samml. Geol. Reichs-Mus. Leiden, N. F. Bd. 1, Abt. 1, p. 246, Taf. 37, fs. 594-597.

1920. Solarium perspecivum, TESCH, Paläont v. Timor, Lief. 8, p. 65, Taf. 132, fs. $200 \mathrm{a}$ and $\mathrm{b}$.

1928. Solarium perspectivum, Yokoyama, Imp. Geol. Surv. Japan Rep. No. 101, p. 62, pl. 5, f. 7 .

1934. Architectonica (Architectonica) perspsectiva, LADD, Bull. B. P. Bishop Mus. No. 119, pp. 91 and 214, pl. 38, fs. 2-4.

1935. Architectonica perspectiva, Nomura, Sci. Rep. Tohoku Imp. Univ. 2nd Ser. Vol. 18, No. 2, p. 194, pl.9, f. 41.

1939. Architectonica (Architectonica) perspectiva, WeNz, Gastropoda p. 670, f. 1912.

1941. Architectonica perspectiva, Oostingh, De Ingen. Ned.-Indië, No. 8, pp. 22 and $25, \mathrm{pl} .1$, fs. $10 \mathrm{a}$ and b.

1942. Solarium perspectivum, Agrard, Arch. Mus. Nat. d'Hist. Nat. Paris, pp. 56 and 93 , pl. 6, f. 14 .

1951. Architectonica perspectiva, (HIRASE) TAKI, Handb. Illustr. Shells, pl. 128, f. 7 .

1960. Architectonica perspectiva, MacNeil, U.S. Geol. Surv. Prof. Pap. No. 339, p. 38 , pl. 1, fs. 18, 22, and 26 ; pl. 12, fs. 1, 7, and 11.

1961. Architectonica perspectiva, HABE, Colored Illustr. Shells Japan, Vol. 2, p. $30, \mathrm{pl} .13$, f. 19.

1966. Architectonica perspectiva, HABE and KoSUGE, Shells of the world in colour, p. 101, pl. 40, f. 5 .

Material.-GK-L 6395 and 6396.

Measurements.-

\begin{tabular}{|c|c|c|c|c|c|c|c|}
\hline peci & $\mathrm{H}$ & 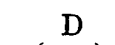 & $\mathrm{D} / \mathrm{H}$ & & rhorl & & is \\
\hline GK & $(\mathrm{mm})$ & $(\mathrm{mm})$ & $(\%)$ & proto & & teleo & pen \\
\hline 6395 & ca 9.0 & 22.2 & 246 & - & 6.8 & - & 43 \\
\hline 6396 & 10.25 & ca 22.3 & 217 & $2.0+$ & & 5.2 & 38 \\
\hline
\end{tabular}

Remarks.-Architectonica perspectiva (LINNÉ) is the wide-spread and well known species of the genus. It is featured by the profile of the shell and the ornamentation. The spire-whorls are ornamented with three spiral bands and radiating close grooves (Text-fig. 16-[6]). The median band is 2.5-3.0 times broader than the subsutural one and the suprasutural one is somewhat narrower than the subsutural one but raised prominently. Three bands are separated one another by the sharp and narrow grooves. The radiating grooves are somewhat oblique antecurrently and curved slightly with the convex face forward. They are not continuous from suture to suture, but are limited on respective spiral band. The basal angulation is superimposed by another prominent spiral band, which is quite smooth. The basal surface is provided with four spiral grooves of which two lean to the periphery and the others close to the deep umbilicus. 
The umbilicus is surrounded at the entrance by about 16 crenulations. These features are very constant among the specimens both recent and fossil.

Geological occurrence.-Lower Miocene to Pleistocene (Indonesia, Taiwan, and southern Japan).

Recent distribution.-Tropic and subtropic areas of Indo-Pacific.

Horizon.-Upper part of the Ulian Formation.

Locality._SKGS-73.

\author{
Superfamily Epitonioidea \\ Family Janthinidae \\ Genus Janthina RöDING, 1798 \\ (type-species: Helix janthina GMELIN=Helix ianthina LINNÉ by \\ original designation) \\ Subgenus Janthina (s.s.) \\ Janthina (Janthina) ianthina (LINNÉ) \\ Pl. 6, Figs. 15-18; Text-fig. 19
}

1758. Helix ianthina LinNÉ, Systema Naturae ed. 10, p. 772.

1797. Helix janthina Gmelin, ibid (GMelin's ed.), p. 914.

1798. Janthina janthina, RöDING, Museum Boltenianum, p. 75.

1858. Ianthina communis, ReEve non LAMARCK, Conch. Icon, Vol.11, Ianthina, pl. 1, sp. 5 , fs. $5 a$ and b.

1940. Janthina (Janthina) ianthina, Wenz, Gastropoda p. 816, Abb. 2386.

1953. Janthina janthina, LAURSEN, Dana-Report No. 38, p. 15, pl. 1, f. 1.

1954. Janthina janthina, KIRA, Colored Illustr. Shells Japan Vol. 1, p. 27, pl. 13, f. 22.

1962. Ianthina janthina, MACPHerSoN and GABRIEL, Marine Moll. Victoria, p. 118, text-f. 145 .

Material.-GK-L 6905. Preservation is perfect.

Measurements.-

\begin{tabular}{|c|c|c|c|c|c|c|c|}
\hline $\begin{array}{l}\text { specimen } \\
\text { GK-L }\end{array}$ & $\underset{(\mathrm{mm})}{\mathrm{H}}$ & $\underset{(\mathrm{mm})}{\mathrm{Bd}}$ & $\underset{(\mathrm{mm})}{\mathrm{Ap}}$ & $\underset{(\mathrm{mm})}{\mathrm{D}}$ & $\underset{(\%)}{\mathrm{Bd} / \mathrm{H}}$ & $\underset{(\%)}{\mathrm{Ap} / \mathrm{H}}$ & $\underset{(\times 100)}{\mathrm{D} / \mathrm{H}}$ \\
\hline 6905 & 8.0 & 6.9 & 5.4 & 8.2 & 86.2 & 67.5 & 102.5 \\
\hline $\begin{array}{l}\text { specimen } \\
\text { GK-L }\end{array}$ & $\underset{\text { (degrees) }}{\angle \mathrm{P}}$ & & $\begin{array}{c}\text { otoconc } \\
\mathrm{D} \text { nv }\end{array}$ & & & & \\
\hline 6905 & 87.5 & 1.4 & .25 & & & & \\
\hline
\end{tabular}

Remarks.-The present specimen is quite identical to Janthina (Janthina) ianthina (LINNÉ). It has very large protoconch, which is smooth, rapidly growing, and separated from the teleoconch by a sharp step. D. LAURSEN described the morphological development of several species of Janthina. According to him Janthina $(J$.) ianthina is readily distinguished from the others in being devoid neither of the peripheral keel nor of the peripheral furrow throughout the growth stages.

Recent distribution.-World wide; chiefly tropical seas.

Horizon.-Upper part of the Dingle Formation.

Locality.-SKGS-74. 


\author{
Order Neogastropoda \\ Superfamily Muricoidea \\ Family Muricidae \\ Subfamily Muricinae \\ Genus Typhis MONTFORT, 1810
}

(type-species: Murex tubifer BRUGUIÈRE by original designation)

Subgenus Talityphis Jousseaume, 1880*

(type-species: Typhis expansus SowERBY by original designation)

Typhis (Talityphis) macropterus MARTIN

Pl. 8, Figs. 3 and 7; Text-fig. 24

1883-87. Typhis macropterus MARTIN, Samml. Geol. Reichs-Mus. Leiden, Ser. 1, Bd. 3, p. 98 , Tab. 6, f. 100 .

Material.-GK-L 6944. Preservation is almost perfect except for the anterior end of the canal and the outer part of the labrum-varix.

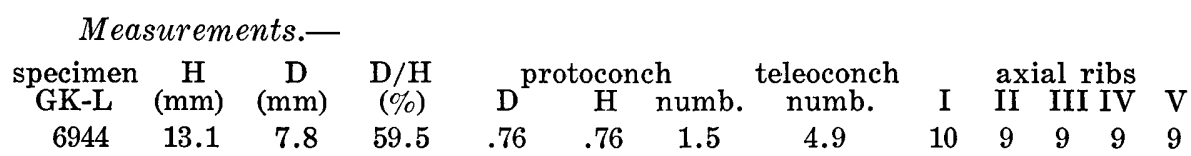

Remarks.-The present specimen is very characteristic by its peculiar morphology. The protoconch is globose and paucigyrate consisting of smooth one and a half volutions. The ornamentation is composed of the wing-like varices, of which the last one, the labrum-varix, is especially thin and expanded outward, a short tube between the varices at the shoulder, and very weak and widely spaced spiral threads. The aperture is ovoid with the closed, somewhat oblique, and moderately long canal. On the basis of these characteristics it is reasonably included in Talityphis JoussEaUme, 1880. Concerning with the features mentioned above the present specimen is identical to Typhis macropterus MARTIN, which is also included in the subgenus Talityphis. The type specimen of T. (Talityphis) macropterus MARTIN (Reg. No. St. 9628, Rijksmus. Geol. Min. Leiden) seemingly shows some difference from the present specimen, because firstly the aperture of the former is broken at the anterior part and does not show entire outline and secondly the labrum-varix of the present specimen is broken at the outer margin to give an impression of smaller size.

Geological occurrence.-Miocene (Indonesia).

Horizon.-Upper part of the Dingle Formation.

Locality.-SKGS-74.

Genus Murex LINNÉ, 1758**

(type-species: Murex pecten MONTFORT=Murex tribulus LINNÉ by subsequent designation, MONTFORT, 1810)

\footnotetext{
* Synonym: Pterotyphis Jousseaume, 1880, Trigonotyphis Jousseaume, 1880, and Typhisala Jousseaume, 1880.

** Synonym: Aranea PERry, 1810.
} 


\section{Subgenus Haustellum BRUGUiÈre, 1792* \\ (type-species: Murex haustellum LINNÉ by tautonomy) \\ Murex (Haustellum) bantamensis saplisi MACNEIL}

Pl. 8, Fig. 6

1960. Mulex saplisi MACNeIL, U.S. Geol. Surev. Prof. Pap. No. 339, p. 63, pl. 8. fs. 14 , and 15 .

Material.-GK-L 6939 and 6942 from one and same locality. Preservation is imperfect, but the specimens are characteristic enough for identification.

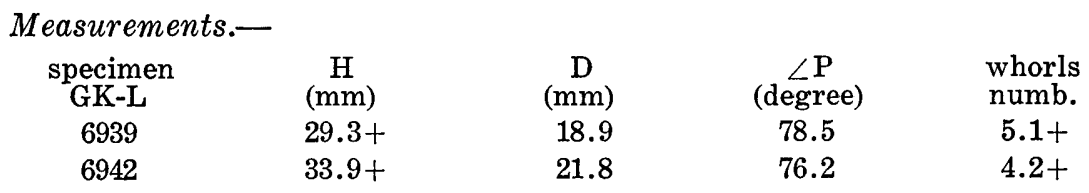

Remarks.-The present specimens are identical to Murex saplisi MACNEIL. Seemingly slight difference exists between the two. That is to say, the latter has a rudimentary spines on each varix of even body whorl, while the former is perfectly devoid of the spine on the body whorl of the full grown specimen. This difference, however, depends on the growth stage, because a general tendency is observed on the specimens that the spines are distinct at early, weak or obsolete later, and finally faded out. The larger one of the present specimens is one and a half times larger than MACNEIL's specimen. The author is inclined to consider them conspecific.

The specimens in hand are closely similar to the type specimens of Murex bantamensis MARTiN (Reg. No. St. 9656, Rijksmus. Geol. Min. Leiden) from the Pliocene bed of Java. Three sets of rectilinear varices are remarkably elevated but rather thin and the axial ribs are also thin but sharp. The spiral ornamentation on the early whorls of the present specimens, although the earliest part is not examined, is quite similar to that of $M$. bantamensis to have the sets of five primary threads. Of five threads the lowest $\left(P_{5}\right)$ is close to the lower suture and partly concealed by the succeeding whorl, the second lowest one $\left(\mathrm{P}_{4}=\mathrm{Per}\right)$ is the strongest and coincides with the peripheral angulation at the lower fifth, and the others $\left(\mathrm{P}_{1}, \mathrm{P}_{2}\right.$, and $\left.\mathrm{P}_{3}\right)$ are situated on the lateral slope. The interspace between the second $\left(\mathrm{P}_{2}\right)$ and the third upper thread $\left(\mathrm{P}_{3}\right)$ is remarkably wider than the others. This pattern of the spirals is quite similar to that of Javan specimen. While the axial ribs on the specimens in hand are more angulated at the periphery than those on $M$. bantamensis. That is to say the peripheral angulation becomes obsolete at the adolescent stage on the Javan species, while it persists until on the adult whorl on the Philippine specimens. Furthermore the secondary spiral lines on the later whorls of the former are as distinct as the primaries and much stronger than those of the latter species. The taxonomic value of the mentioned difference in morphology is not clear. The author is, however, inclined to

\footnotetext{
* Synonym: Brontes MontFort, 1810, non FABricius, 1801, and Haaustellaria SwaiNSON, 1840.
} 
separate them tentatively at the subspecies-level.

Cox did not recognize the importance of the difference in the feature of the protoconch and treated M. embryoliratus Fischer (1927, p. 78, Taf. 213, fs. 50a, $\mathrm{b}, 51 \mathrm{a}$, and $\mathrm{b}$ ) as a synonym of $M$. bantamensis MARTIN. The protoconch of $M$. bantamensis is smooth and rounded throughout and marked by a curved axial at the end, while the protoconch of $M$. embryoliratus is sharply carinate at the later part. This difference is considered to be more than specific level.

M. (H.) hirasei HIRASE (1915, f. 322) is also allied to the present specimens, but the latter is clearly distinguished from the former in having more regular set of the primary and secondary spirals, wider callus, and more curved columellar lip than the former.

Geological occurrence.-Upper Miocene (Okinawa).

Horizon.-Upper part of the Dingle Formation.

Locality.-SKGS-74.

\section{Murex (Haustellum) bonneti CossmanN}

Pl. 7, Figs. 3, 12, 14, and 15 and Pl. 8, Figs. 8, 13, and 14.

1903. Murex bonneti Cossmann, Jour. de Conch. Tom. 51, p. 150, pl. 5, fs. 26 and 27.

1947. Murex (Haustellum) bonneti, WIssema, Younger Tert. Quat. Gastrop. Nias, p. 173, pl. 6, f. 149.

Material.-GK-L 6938, 6940,6941, 6963a and 6963b from one and same locality.

\begin{tabular}{|c|c|c|c|c|c|c|c|}
\hline \multicolumn{2}{|c|}{ Measurements.- } & \multirow[b]{2}{*}{$\underset{(\mathrm{mm})}{\mathrm{Bd}}$} & \multirow[b]{2}{*}{$\underset{(\mathrm{mm})}{\mathrm{Ap}}$} & \multirow[b]{2}{*}{$\underset{(\mathrm{mm})}{\mathrm{D}}$} & \multirow[b]{2}{*}{$\underset{\text { (degrees) }}{\angle \mathrm{P}}$} & \multirow[b]{2}{*}{$\begin{array}{l}\text { protoconch } \\
\text { numb. }\end{array}$} & \multirow[b]{2}{*}{$\begin{array}{l}\text { teleoconch } \\
\text { numb. }\end{array}$} \\
\hline $\begin{array}{l}\text { specimen } \\
\text { GK-L }\end{array}$ & $\underset{(\mathrm{mm})}{\mathrm{H}}$ & & & & & & \\
\hline & 27. & $22.1+$ & $10.0+$ & 15.4 & 67.3 & ca 2.2 & 5.6 \\
\hline 6940 & $36.8+$ & $28.5+$ & $10.8+$ & 21.2 & 64.2 & - & $3+$ \\
\hline
\end{tabular}

Remarks.-The present specimens are featured by the thick and solid test, moderately high spire, three sets of massive varices alined in slightly retrocurrently curved lines, angularly convexed whorls, and the prominent spirals. It is suggested that the protoconch, although it is not perfectly preserved, is smooth and paucispiral with a little more than two volutions, of which the first is small and elevated and the remainder ones are roundly convex at sides. The primary spiral lirae are five, of which the lowest one $\left(P_{5}\right)$ is situated at the lower suture and the uppermost one $\left(\mathrm{P}_{1}\right)$ is close to the upper suture. The second lowest $\left(\mathrm{P}_{4}=\right.$ Per $)$, which conincides with the peripheral angulation, is at the lower fourth and the others $\left(\mathrm{P}_{2}\right.$ and $\left.\mathrm{P}_{3}\right)$ are spaced between the peripheral (Per) and subsutural $\left(P_{1}\right)$ ones with equal interspaces. The varices appear on the third whorl firstly. At the peripheral angulation each varix has its short spine, which, however, becomes weak later and finally only rudimental on the body whorl of the adult specimens.

The present material is identical to $M$. bonneti from Karikal with the diagnostic features mentioned above, although the former differs slightly from the 
latter in having less orbicular aperture and more produced peripheral angulation than the latter.

$M$. (H.) bonneti is readily distinguished from $M$. (H.) bantamensis MARTIN by its more massive axial ribs and varices and stronger spiral lirae. OostingH figured an another topotype juvenile specimen of $M$. (H.) bantamensis from south Bantam (1940, p. 60, pl. 19, f. 33a). It is provided with more massive varices than MARTIN's specimens, but is also distinguished from the present specimens of even almost same size in having more rounded whorl-profile, more regularly spaced and less numerous spirals.

Geological occurrence.-Pliocene (India) and Plio-Pleistocene (Indonesia). Horizon.-Upper part of the Dingle Formation.

Locality.-SKGS-74.

Subgenus Murex (s.s.)

Murex (Murex) troscheli verbeeki MARTIN

Pl. 7, Figs. 4 and 5 and Pl. 8, Fig。 12; Text-figs. 23 and 24

1895. Murex verbeeki Martin, Samml. Geol. Reichs-Mus. Leiden, N. F. Bd. 1, Abt. 1, p. 125, Taf.19, fs. 278, 280, and 281.

1940. Murex verbeeki verbeeki, OosTiNGH, Ingenieur Ned.-Indië, 1940, p. 58, Taf. 19, f. 339 .

1950. Murex troscheli verbeeki, van Regteren Altena, Leidse Geol. Meded. Del. 15, p. 209.

Material.-GK-L 6961 and 6964 from loc. SKGS-74 and GK-L 7486 from SKGS-71.

Measurements.-

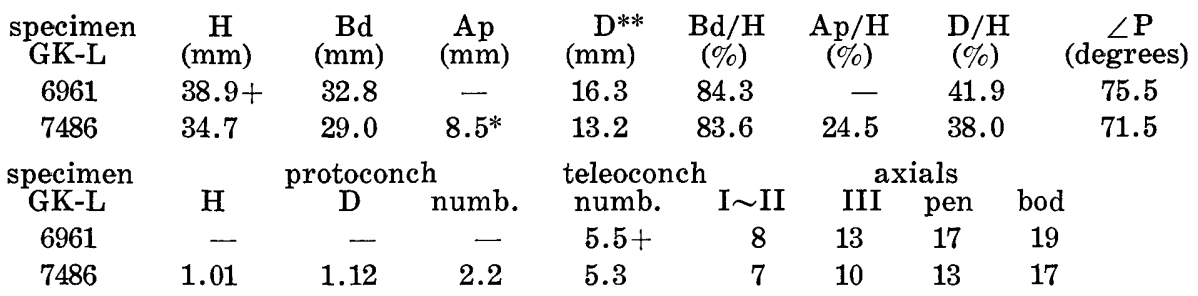

* Excluding the canal

** Excluding the spines

Remarks.-The characteristic features of the full grown specimens of Murex (M.) verbeeki MARTIN are roundly convex profile of the whorls, thin, weak, and crowded axial ribs, three sets of varices aligned respectively on a retrocurrently curved line, and moderately short spines on the varices and the canal. The axial ribs, counted six to seven between the varices, are sharply granular and even the growthlines are crenated at the intersections with the spirals.

The primary spiral threads are two, which coincide with the peripheral angulations respectively. The development of the secondaries varies by specimen, but it should be noted that the secondaries on the shoulder appear as a fine pair 


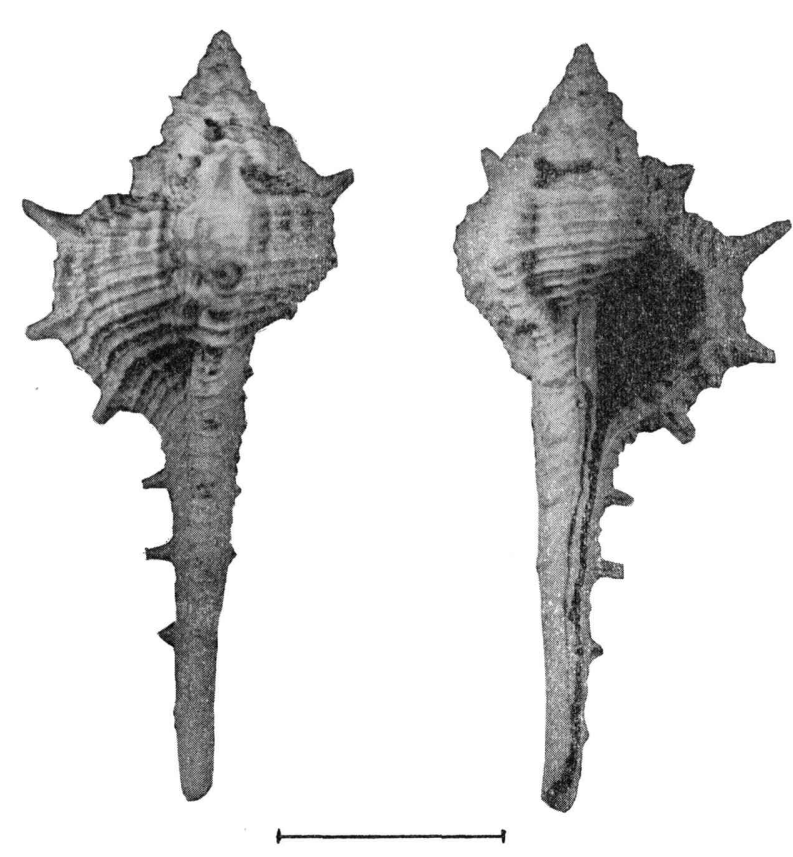

Fig. 23. Murex (Murex) troscheli verbeeki MARTIN, GK-L 7486, loc. SKGS-71. Unit bar indicates $10 \mathrm{~mm}$. of lines, which are close together, The protoconch is moderately conical consisting of two and a half volutions, which are somewhat swollen and smooth.

The specimen GK-L 6961 from loc. SKGS-74 is quite identical to the figured type specimen (Reg. No. St. 9633, Rijksmus. Geol. Min. Leiden) (MARTIN, 1895, pl. 19, f. 278). While GK-L 6964 from the same locality as the preceding one is provided with somewhat stronger spirals, although other features are identical. The another specimen, GK-L 7486 from loc. SKGS 71, is almost perfectly conformable with the types except for the protoconch, which is seemingly more bulbous

than that of the types. This, however, may be due to the abrasion of the shell material of GK-L 7486.

Tesch (1915, p. 63, Taf. 131, fs. 139a and b) identified a Pliocene specimen from Timor to $M$. verbeeki and placed the species under $M$. ternispina LAMARCK as a subspecies. His figured specimen, however, can not be identical to MARTIN's species in being provided with the extremely prominent primary spirals and stronger spines, both of which are never examplified on MARTIN's specimens.

Nomura (1935, p. 159) pointed out the possibility that $M$. verbeeki is a synonym of $M$. tribulus LiNNÉ, but the former is readily distinguished from the latter, which has much longer spines and much less numerous axials than the latter.

Van Regteren Altena (1950, p. 209) treated M. verbeeki as a subspecies of $M$. troscheli LischKe. They are really closely allied each other and only slight difference is recognized concerning the length of the spines and size of the shell on an average. $M$. troscheli generally attains larger size and its spines are somewhat longer than those of $M$. verbeeki. Under such circumstance the author is inclined to treat verbeeki as a subspecies of troscheli following van REGTEREN Altena.

Geological occurrence.-Miocene (Indonesia) and Pliocene (Indonesia and Taiwan).

Horizons.-Santa Barbara Silt and the upper part of the Dingle Formation.

Localities.-SKGS-71 and 74 . 
Murex (Murex) sp. cf. $M$. (M.) rectirostris aduncospinosus REEVE

Pl. 8, Figs. 4, 15, and 16

1834. Murex ternispina var. BECK in Sowerby, Conch. Illustr. Cat. Murices. No. 2 , f. 68 .

1845. Murex adunco-spinosus ReEve, Conch. Icon. Vol. 3, Murex, pl. 23, f. 93.

1880. Murex adunco-spinosus, TrYoN, Man. Conch. Ist Ser. Vol. 2, p.78, pl.10, f. 114.

Material.-GK-L 6936 to 6938 and 6962 from one and same locality.

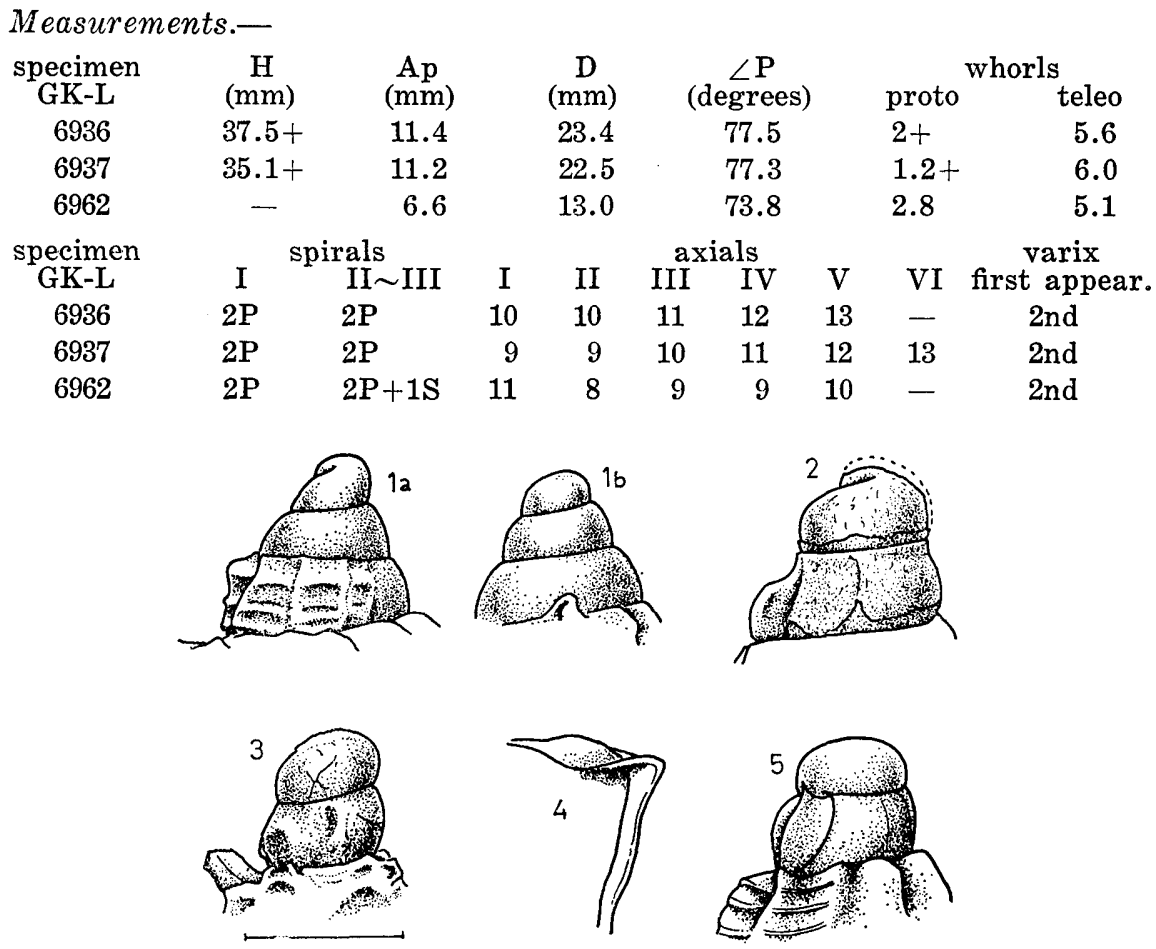

Fig. 24. Protoconchs and some ornamental features of muricids.

1 and 2: Murex (Murex) troscheli verbeeki Martin. la and b:

GK-L 6964 and 2: GK-L 7486.

3: Typhis (Talityphis) macropterus MarTin, GK-L 6944.

4 and 5: Flexopteron philippinensis gen. et sp. nov., GK-L 6943. 4: flexure of the axial lamella below the suture.

Unit bar indicates $1 \mathrm{~mm}$ for protoconchs.

Remarks.-The present specimens are featured by their crude sculpture consisting of sharply ridged axials, very coarse and raised spiral threads which are granular on the axial ribs, and the prominent varices with possibly short spines. The spire is moderatley low for the genus. The protoconch is conical with slightly less than three smooth volutions and its termination is defined by a curved fine but distinct axial line. The first whorl of the teleoconch is apparently provided with two angulations at the lower fifth and upper third which are superimposed by a primary spiral thread respectively. The angulations 
become distinct and rather spinous on the second whorl. The bi-angulated profile is kept until on the penultimate whorl, although the interspace between the angulations becomes gradually convex as a result of the development of the intervening thread which appears on the second or third whorl and gradually becomes distinct. Each varix is almost vertical but the varices on the spire-whorls are continuous one another along three retrocurrently oblique lines.

The present specimens are closely allied to Murex aduncospinosus REEVE living in the Philippines but the difference is also recognized. The aperture of the present specimens is much more narrowed by the apertural ridge inside the labrum, which is provided with spirally elongate teeth. The uppermost tooth is stronger than the others.

They also resemble and are hardly distinguished from $M$. rectirostris SowERBY (1841, p. 138) living in South China Sea. The difference is that the present specimens have somewhat stronger axials and more angulated periphery of the whorls than $M$. rectirostris. $M$. aduncospinosus and $M$. rectirostris should be treated respectively as a subspecies of a single species.

Recent distribution.-The Philippines.

Horizon.-Upper part of the Dingle Formation.

Locality.-SKGS-74.

Genus Pterynotus SwaInson, 1833*

(type-species: Murex pinnatus WoOD by original designation)

Subgenus Naquetia Jousseaume, 1880

(type-species: Murex triqueter BoRN by original designation)

Pterynotus (Naquietia) sondeianus solidus subsp. nov.

Pl. 8, Figs. 5 and 9

Material.-Holotype: GK-L 4950. Preservation is almost perfect.

\begin{tabular}{|c|c|c|c|c|c|c|c|c|}
\hline \multicolumn{9}{|c|}{ Measurements.- } \\
\hline specimen $_{\text {GK-L }}$ & $\underset{(\mathrm{mm})}{\mathrm{H}}$ & $\underset{(\mathrm{mm})}{\mathrm{Bd}}$ & $\underset{(\mathrm{mm})}{\mathbf{A p}}$ & $\underset{(\mathrm{mm})}{\mathrm{D}}$ & $\underset{(\%)}{\mathrm{Bd} / \mathrm{H}}$ & $\underset{(\%)}{\mathrm{Ap} / \mathrm{H}}$ & $\frac{\mathrm{D} / \mathrm{H}}{(\%)}$ & $\underset{\text { (degrees) }}{\angle \mathrm{P}}$ \\
\hline 4950 & 39.60 & 29.55 & 25.30 & 22.70 & 74.5 & 63.7 & 57.3 & 64.9 \\
\hline $\begin{array}{c}\text { specimen } \\
\text { GK-L }\end{array}$ & proto & vhorls & & II $\sim$ III & $\begin{array}{l}+v a \\
\text { IV }\end{array}$ & & & \\
\hline 4950 & ca 2. & & & $6+3 \mathrm{v}$ & $7+3 \mathrm{v}$ & & & \\
\hline
\end{tabular}

Diagnosis.-The shell is moderate in size, thick, solid, and fusiform with moderately high spire and moderately long canal. The protoconch is small, measured less than $1.1 \mathrm{~mm}$ in maximum diameter, conical, and consists of slightly more than two volutions. The volutions are possibly smooth. The first volution is depressed and small tip and the remainder ones are somewhat convex at the side. The detailed characteristics are not observed because of abrasion. The teleoconch consists of about 5.4 whorls, which are narrowly rounded at the periphery. The ornamentation is the combination of the prominent and sharp

* Synonym: Pteronotus SwaInson, 1840, and Pterymurex Revereto, 1899. 
axial ribs, three sets of massive varices, sharp and elevated primary spiral threads and dense and fine secondary and tertiary spirals. The whorls are bluntly angulated at the lower one-fifth to one-sixth on the spire and rather narrowly rounded on the body whorl. The basal contraction is distinct. The snout is short, straight, and ornamented by the spiral complex. The fasciole is moderately weak.

The primary spirals on the first whorl are not clearly observed. Those on the second whorl are six, almost equal in size, and almost equally spaced except for the uppermost one with wider interspace below. The secondary lines are also visible at the interspaces on the lateral surface of the same whorl. On the third whorl the tertiary lines are intercalated. The spirals, especially the primaries, are narrow but sharply elevated at the axial valleys and more prominent on the axial ribs and especially on the varices, which is angularly crenulated at the very crest. The axial ribs are strong at the periphery and weakened above but apparently reach the upper suture. On the body whorl they are also weakened below the periphery and disappear at the lower end of the basal surface. The axial ribs are almost straight, very slightly retrocurrently oblique, somewhat wider than the interspaces at the periphery, and counted by two or three between the varices. The rib immediately antecedent each varix is much smaller than the others. The varices are discernible even on the first whorl as round-topped ridges; they are solid, elevated like a kind of wing, sharp at the margin (crest), and aligned in somewhat antecurrently curve lines.

The aperture is moderately narrowed by the thickening of the labrum, ovoid, weakly notched posteriorly, and provided with a long, curved, and almost closed anterior canal. The outer lip is prominently variced outside and remarkably thickened and ridged inside. The labrum teeth are moderately weak and counted eight, of which the uppermost and the lowest one are stronger than the others and define respectively the entrance of the posterior notch and the anterior canal. The inner lip is narrowly curved at the upper one-third and covered with the moderately thick and wide callus, which is detouched and sharply reflexed at the anterior end to define the entrance of the canal. The parietal tooth is distinct and the columellar wrinkles are weak and irregular.

Comparison.-The present specimen is similar in general feature to Murex sondeianus MARTIN from the Pliocene of Java (1895, p. 128, Taf. 19, f. 292), but the former is remarkably broader and lower in outline than the latter. In short the former is decidedly more stout in structure than the latter. Furthermore the detailed examination clarifies that the development of the primary spiral ornamenation is different between the two. Three primaries on the lateral surface are much stronger than three infrasutural ones on the upper slope, which are thin, crowded, and of secondary order on the early whorls of $M$. sondeianus. Considering these facts the author prefers to treat the present material as a subspecies under $M$. sondeianus.

M. triqueter BoRN (1780, p. 291, pl.11, fs. 1 and 2), the type species of Naquetia Jousseaume, 1880 , is an ally to the present subspecies, but the latter is readily distinguished from the former in having more elevated varices, denser spirals, and more distinctly contracted base than the former. 
M. rubricentatus REEve, (1846, pl. 36, fs. 186a and b) shows more elongate profile with higher spire and less contracted base and its spirals are less in number, weaker, and less sharp than those of the present material.

Horizon.--Upper part of the Dingle Formation.

Locality.-SKGS-74.

Genus Chicoreus MontForT, 1810*

(type-species: Murex ramosus LINNÉ by original designation)

Subgenus Foveomurex IREDALE, 1936

(type-species: Murex denudatus PERRY by original designation)

Chicoreus (Foveomurex) sp.

Pl. 8, Figs. 10 and 11

Material.-GK-L 6965. A single immature specimen.

\begin{tabular}{|c|c|c|c|c|c|c|c|c|c|c|}
\hline \multicolumn{11}{|c|}{ Measurements.- } \\
\hline $\begin{array}{l}\text { specimen } \\
\text { GK-L }\end{array}$ & $\underset{(\mathrm{mm})}{\mathrm{H}}$ & $\underset{(\mathrm{mm})}{\mathrm{Bd}}$ & $\underset{(\mathrm{mm})}{\mathrm{Ap}}$ & & $\underset{\mathrm{mm})}{\mathrm{D}}$ & $\begin{array}{l}\mathrm{Bd} / \mathrm{I} \\
(\%)\end{array}$ & & $\underset{(\%)}{\mathrm{Ap} / \mathrm{H}}$ & $\underset{(\%)}{\mathrm{D} / \mathrm{H}}$ & $\underset{\text { (degrees }}{\angle \mathrm{P}}$ \\
\hline 6965 & 26.1 & 18.9 & 14.7 & & 2.15 & 72.4 & & 56.3 & 46.3 & 54.2 \\
\hline specimen & & horls & & & & ixials & & & spirals & rim.) \\
\hline GK-L & prot & teleo & & I & II & III & V & VI & $I \sim$ & \\
\hline 6965 & $1+$ & 5.95 & & 17 & 13 & 12 & 13 & 15 & 5 & \\
\hline
\end{tabular}

Descriptive remarks. - The shell is moderately small and fusiform with moderately high spire and long and slightly oblique canal. The protoconch is imperfect and the details are not known. The teleoconch consists of about six convex whorls, which are almost round at first and bluntly angled later. Regularly spaced spiral threads, sharply ridged axial ribs, and simple varices comprise the ornamentation. The first whorl has five primary threads, which are respectively situated close to the lower suture $\left(P_{5}\right)$, at the lower one- $\left(P_{4}\right)$, two- $\left(P_{3}\right)$, three-fourths $\left(P_{2}\right)$, and slightly below the upper suture $\left(\mathrm{P}_{1}\right)$. Three threads including $\mathrm{P}_{2}, \mathrm{P}_{3}$, and $\mathrm{P}_{4}$ are somewhat stronger than the others. On the later whorls a subsequent primary thread $\left(\mathrm{P}_{6}\right)$ appears below the upper suture and the secondaries and the tertiaries are intercalated between the primaries. That is to say the development of the spirals is abapical.

The axial ribs are raised with sharp crest, separated by wider interspaces, and somewhat sigmoidal with vertical upper and lower parts and retrocurrently oblique middle part. They are extended from suture to suture on the spire-whorls and faded out on the snout of the body whorl. The first varix appears on the second whorl. The varices are about three for one whorl and do not form the continuous series from whorl to whorl. They are simple on the early and middle whorls, while become scaly on the later whorls but are devoid of the spines.

The aperture is ovoid and narrowed at the labrum by the thickening, inside of which the laterally elongate fine teeth are discernible. The inner lip is simply curved and covered with the thin and narrow callus. The canal is semi-tubular

* Synonym: Triplex PeRry, 1810 and Frondosaria SchlÜter, 1838 
and curved with slightly oblique upper half and vertical lower one.

Comparison.-The present specimen shows some similarity to the Miocene specimen labelled as Murex grooti JENkINs from Njalindoeng bed of Java (Reg. No. St. 9704, Rijksmus. Geol. Min. Leiden) in the shell-form and ornamentation, but the latter has the more defined shoulder than the former. The Javan specimen mentioned above does not conform perfectly with JENKINs' species, which has much more angulated periphery with gently sloped shoulder and shorter outline of the shell. MARTIN's specimen is intermediate between the present specimen and JENKINS'. There is no other known species comparable.

Horizon.-Upper part of the Dingle Formation.

Locality.-SKGS-74.

Genus Bedeva IREDALE, 1924*

(type-species: Trophon hanlayi ANGAs by original designation)

Bedeva blosvillei curvirostra subsp. nov.

Pl. 17, Figs. 1, 2, and 3

1915. Semifusus Blosvillei, Tesch (non Deshayes, 1838), Paläont. v. Timor, Lief. 5, p. 52, Taf. 80, fs. 133a and b.

Material.-Holotype: GK-L 7489. The specimen lost the apex.

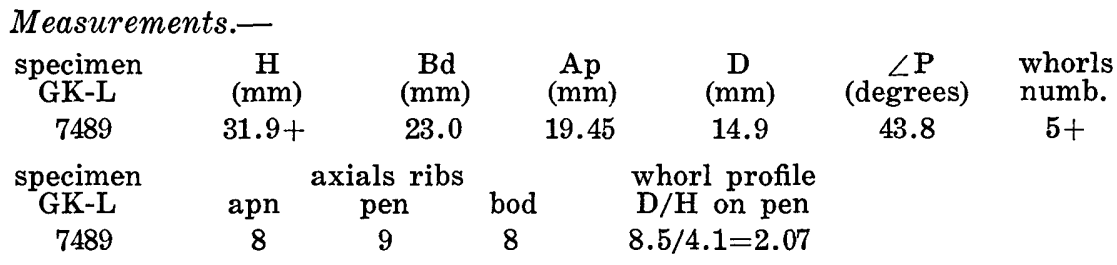

Diagnosis.-The shell is moderately small, solid, and fusiform with the high spire and the long canal. The early whorls are sharply bi-angulated at the periphery. The shoulder above the upper angulation is slightly concave and gently sloped. The lateral surface below the upper angulation, which is much sharper than the lower one, is slightly receded. In consequence of weakening of the lower angulation on the later whorls the whorl-profile becomes almost uni-angulated with the flat and gently receded lateral surface. The body whorl is large, gently sloped below the suture, sharply angulated at the periphery, gently narrowed anteriorly, and moderately contracted at the lower part of the basal slope. The snout is long and remarkably bent sidewards and provided with the massive fasciole with the association of the shallow false umbilicus. The aperture is pyriform with the distinct posterior notch and the slightly oblique and narrow anterior canal. The outer lip is thickened inside and has nine strong teeth on the thickening. Of nine teeth the lowest one marks the boundary between the labrum and the canal. The inner lip is quite smooth and bent with short, curved, and oblique parietal part and the long and vertical columellar one. The callus is

* Synonym: Ergalatax IREDALE, 1931. 
moderately narrow and moderately thin except for the anterior part, which is rather thick and free-edged.

The ornamental design is the combination of the coarse axial folds and the close spiral threads. The primary spiral lirae are six on the lateral and basal surface and four on the snout of the body whorl. They are generally prominent, but not so elevated and simple at the top. On the preceding three whorls three prominent spirals are observed respectively in same pattern. The secondaries appear on the antipenultimate whorl but the tertiaries are never developed throughout the growth stages. The equidimensional lirae on the snout are larger than those on the lateral surface. The interspaces are almost equal to or slightly wider than the primary lirae and intercalated by the distinct secondary threads and minute tertiary lines at the lateral surface. Those on the snout are narrower than the primary lirae and provided with only secondaries. The spiral threads are also developed on the shoulder; they are six, regularly spaced, almost equidimensional, micro-granular at the intersections with the growth lines, and one-fourth to one-third as wide as the primary lirae of the lateral surface. They can be traced back on the third last whorl but can not be observed on the preceding whorls because of partial abrasion. The axial folds are prominent at the periphery forming sharp nodules and weakened abruptly upward and downward. The growthlines show the distinct tendency for minor lamellation on the whole surface. The suture is wavy and slightly impressed.

Comparison.-The ovoid aperture is characterized by the weak but distinct posterior notch, moderately long and oblique anterior canal, strong labrum teeth, and the smooth inner lip. The growth lines show the tendency for lamellation. These characteristics indicate that this fusiform specimen belongs to Bedeva IREDALE, 1924.

The present specimen is quite comparable with Semifusus blosvillei of TESCH (1915, p. 52, Taf. 80, fs. 113a and b, non DeshaYES) from the Pliocene of Timor. The former is seemingly blunter at the peripheral angulation than TESCH's specimen, but this apparent difference is only due to the abrasion. They are quite similar in the pattern of the development of the ornamentation and also in the detailed feature of the aperture each other. They show some remarkable difference from DESHAYES' species, living in Philippines, in having slender outline and remarkably bent snout. The author is inclined to treat the fossil specimens from Panay and Timor as a subspecies of blosvillei.

The protoconch of the present specimen is not known.

Geological occurrence.-Pliocene (Indonesia).

Horizon.-Santa Barbara Silt.

Locality.-SKGS-71.

Subfamily Drupinae

Genus Acanthinella gen. nov.

(type-species: Acantina javana MARTIN, here designated)

Text-fig. 25 
Generic diagnosis.-The shell is moderately small and ovoidally fusiform. The protoconch is low conical, wider than high, blunt, smooth, and paucigyrate with about two volutions. The beginning of the teleoconch is indicated by the abrupt appearance of the spiral and axial ornamentation. The first whorl of the teleoconch is octangular in profile with two peripheral angulations respectively at about upper and lower one-third of the whorl-height. Four spiral lirae are smooth, surpass the close and vertical axial lirae, and situated respectively at the peripheral angulations $\left(\mathrm{P}_{2}\right.$ and $\left.\mathrm{P}_{3}\right)$ and close to the upper and lower sutures $\left(\mathrm{P}_{1}\right.$ and $\left.\mathrm{P}_{4}\right)$. Of the four, the subsutural one $\left(\mathrm{P}_{1}\right)$ is somewhat weaker than the others. The primary spirals, especially the subsutural one $\left(P_{1}\right)$, become granular at the intersections by the axials on the second whorl, on which the secondary spiral threads are intercalated in each interspace of the primaries. The uppermost secondary thread between $P_{1}$ and $P_{2}$ is somewhat stronger than the others and distinctly granulated like the subsutural primary $\left(P_{1}\right)$. Thereafter, on one hand, the secondary threads are rapidly increased in size to be comparable to the primaries on the third and fourth whorls and the whorl-side loses the peripheral angulations to furnish broadly rounded profile. Simultaneously with the increase
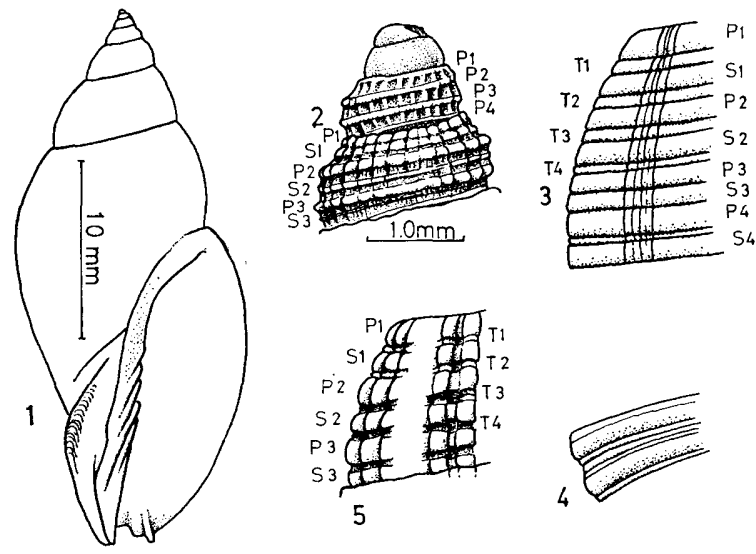

Fig. 25. Morphological features of Acantinella javana (MARTIN), gen. nov., MARTIN's figured type specimen, Rijksmus. Geol. Min. Leiden, St. 9755 .

1: general profile and aperture, ornamentation being omitted.

2: protoconch and early teleoconch.

3: 5th whorl (body whorl), upper part.

4: 5th whorl, spirals at the basal part.

5: 3rd whorl.

of size of the secondaries, the tertiaries and quaternaries are developed on the late whorls. In contrast to the progressive development of the spirals the axials become weaker and more irregular in the course of the growth. The basal fasciole is prominent. The aperture is elongately ovate, deeply notched anteriorly, and provided with distinct columellar plaits.

Comparison.-The present genus resembles Acanthina Fischer von WALDHeIM, 1807, with the type-species, Buccinum monoceros CHEMNITZ=B. calcar 
MARTYN, in the sculpture and the character of the outer lip, but is readily distinguished from the latter in that the former has smaller shell of slenderer outline than the latter and being provided with the clear columellar plaits.

It is also separated from Nucella RöDING, 1798, with the type-species, Buccinum filosum GMELIN=B. lapillus LINNÉ in being provided with the columellar plaits and tail-like projection at the anterior part of the labrum, which defines the entrance of the canal.

The general characteristics of the aperture of the present genus suggest some possibility that it belongs to Volutacea. The author, however, tentatively places this genus under Muricidae evaluating its tail-like projection at the anterior part of the labrum, because similar feature is often observed on the muricid species.

\section{Acantinella javana (MARTIN)}

Pl. 11, Fig. 3

1899. Acanthina javana Martin, Samml. Geol. Reichs-Mus. Leiden, N. F. Bd. 1, Abt. 1, p. 137, Taf. 21, f. 315 .

Material.-GK-L 6982. The specimen is almost perfectly preserved but the early whorls lost the upper layer of the shell material during the preparation.

\begin{tabular}{|c|c|c|c|c|c|c|c|c|c|}
\hline \multicolumn{10}{|c|}{ Measurements.- } \\
\hline $\begin{array}{c}\text { specimen } \\
\text { GK-L }\end{array}$ & $\underset{(\mathrm{mm})}{\mathrm{H}}$ & $\underset{(\mathrm{mm})}{\mathrm{Bd}}$ & $\underset{(\mathrm{mm})}{\mathrm{Ap}}$ & $\underset{(\mathrm{mm})}{\mathrm{D}}$ & $\underset{(\%)}{\mathrm{Bd} / \mathrm{H}}$ & $\underset{(\%)}{\mathrm{Ap} / \mathrm{H}}$ & $\underset{(\%)}{\mathrm{D} / \mathrm{H}}$ & $\underset{\text { (degrees) }}{\angle \mathrm{P}}$ & $\begin{array}{l}\text { whorls } \\
\text { numb. }\end{array}$ \\
\hline 6982 & $20.7+$ & 16.30 & 12.05 & 9.85 & 78.5 & 50.4 & 47.5 & 46.5 & 5 \\
\hline
\end{tabular}

Remarks.-The present specimen, although the preservation is not perfect at the early whorls, quite conforms with MARTIN's specimen in the development of the ornamentation on the third and later whorls together with the diagnostic features of the aperture. The original octangular outline of the second whorl is indicated by the bluntly angulated profile of the inner layer of the shell material on that whorl, although it is devoid of the upper layer.

Geological occurrence.-Upper Miocene (Indonesia).

Horizon.-Upper part of the Dingle Formation.

Locality.-SKGS-74.

\section{Family Coraliophilidae \\ Genus Flexopteron gen. nov.}

(type-species: Flexopteron philippinensis sp. nov., here designated)

Generic diagnosis.- The shell is moderately small and ovately biconical. The protoconch is paucispiral with less than two smooth volutions, of which the first is flattened at the tip and the remainder ones are swollen. The axis of coiling of the protoconch is slightly oblique to that of the teleoconch. The teleoconch consists of the angulated whorls with defined shoulder and ornamented with weak spirals of primary and secondary order and leaf-like lamellate axials (varices). The lamellate axials are elected vertically, crumpling at the margin, and rectan- 
gularly reflexed at the peripheral angulation so as to form the shallow and open posterior digitation. The reflexed upper part of the lamellae shows the horizontal attitude furnishing the part of the shoulder (text-fig. 24-[4]). The spirals are distinct on the lamellae and obsolete at the interstices. The fasciole of the snout is strong forming an elevated boundary of the wide umbilicus. The aperture is rhomboid with narrow, slightly oblique, and moderately short anterior canal and a weak and shallow posterior one. The labrum is remarkably widened and flattened in front. Its inner side is provided with a few fine but distinct teeth, of which the uppermost and the lowest one are respectively on the mound-like elevation. These callous mounds narrow the entrance of the anterior canal and the posterior notch.

Comparison.-The present genus seemingly shows the morphological resemblance to some genera of Muricidae and Coralliophilidae. Among the Muricidae Crassilabrum Jousseaume, 1880, with the type-species Murex crassilabrum GraY (Drupinae) and Emozamia IREDALE, 1929, with the type-species Murex licinus HedLeY and PETTERD (Muricinae) should be compared with the present genus. Crassilabrum is readily distinguished from the latter in having the thickened and solid labrum of the aperture and much more prominent spirals than the latter and being devoid of the umbilicus. Emozamia is also easily distinguished from Flexopteron in having pointed and polygyrate protoconch, oblique and unfolded axial lamellae, and being devoid of the umbilicus and the labrum teeth.

Among the Coralliophilidae Coralliobia H. and A. AdAMs, 1853, with the type-species Concholepas fimbriata A. ADAMs, is the closest genus to the present one with similar axial lamellae and aperture. The former, which has very low spire and laterally expanded body whorl, is, however, clearly separable from the latter.

Although it is difficult to set the concrete taxonomical position of this fossil genus, the author is inclined to place it under Coralliophilidae evaluating the meaning of the umbilical and apertural features.

Flexopteron philippinensis sp. nov.

Pl. 8, Figs. 1 and 2; Text-fig. 24

Material.-Holotype: GK-L 6943. A single perfect specimen.

\begin{tabular}{|c|c|c|c|c|c|c|c|c|}
\hline \multicolumn{9}{|c|}{ Measurements.- } \\
\hline $\begin{array}{c}\text { specimen } \\
\text { GK-L }\end{array}$ & $\underset{(\mathrm{mm})}{\mathrm{H}}$ & $\underset{(\mathrm{mm})}{\mathrm{Bd}}$ & $\underset{(\mathrm{mm})}{\mathrm{Ap}}$ & $\underset{(\mathrm{mm})}{\mathrm{D}}$ & $\underset{(\%)}{\mathrm{Bd} / \mathrm{H}}$ & $\underset{(\%)}{\mathrm{Ap} / \mathrm{H}}$ & $\begin{array}{l}\mathrm{D} / \mathrm{H} \\
(\%)\end{array}$ & $\underset{\text { (degrees) }}{\angle \mathrm{P}}$ \\
\hline 6943 & 17.15 & 13.40 & 10.80 & 12.00 & 78.1 & 62.9 & 69.9 & 76.9 \\
\hline $\begin{array}{l}\text { specimen } \\
\text { GK-L }\end{array}$ & $\mathrm{H}$ & $\begin{array}{l}\text { toconch } \\
\text { D }\end{array}$ & numb. & $\begin{array}{l}\text { teleoco } \\
\text { num }\end{array}$ & I & $\begin{array}{c}\text { axials } \\
\text { pen }\end{array}$ & bod & $\begin{array}{l}\text { brum } \\
\text { teeth }\end{array}$ \\
\hline 6943 & .72 & .92 & 1.75 & 5.0 & g & 10 & 8 & 5 \\
\hline
\end{tabular}

Diagnosis. - The shell is moderately small and ovately biconical with moderately low conical spire and the gradually contracted base. The protoconch is smooth, rather flat at the tip, swollen at sides, and paucispiral with one and three-fourths volutions. The axis of coiling of the protoconch is slightly oblique 
to that of the teleoconch. The teleoconch, which consists of five whorls, begins with thin, protractly oblique, and somewhat lammellate axial riblet. The axials are nine, ten, and eight respectively on the first to second, third to fourth, and fifth whorls. They are at first somewhat protractly oblique, very slightly sigmoidally curved, and extended upward beyond the upper suture, where they are reflexed protractly. At the later part of the first whorl the whorl-profile become slightly bi-angulated at the lower and upper one-third respectively. The angulations are superimposed with the weak primary spirals. Then the lamellae are abruptly bent just above the upper angulation so as to fold respectively in an open canal at the corner. These canals become more clear on the later whorls in keeping pace with the development of the lamellae to something like wings, which are elected more and more vertically. Their margin is crenulated and rather spinose at the termination of the primary lirae, which are never distinct at the axial valleys. The secondary and tertiary spiral lines are minute and crowded on the spire whorls and the former becomes distinct on the lamellae of the body whorl. The body whorl is large occupying more than three-fourths of the total height, ovate in outline, and gradually contracted at the base to the short and vertical snout. The basal fasciole, where the lamellae terminate, is prominent but rather simple and borders the very wide umbilicus. The aperture is rhomboid with narrowly rounded posterior notch and a moderately long, curved, and open canal anteriorly. The posterior notch is separated from the main part of the aperture by a projection with a distinct tooth inside the labrum. The outer lip is almost vertical, thickened by several lamellae, spinose outside, and denticulate inside. The labrum denticles are five in number and equally spaced. The uppermost and the lowest one, which marks the entrance of the canal, are stronger than the others. The inner lip is broadly curved, smooth, and simple. The callous deposit is wide and moderately thick.

Comparison.-The present species looks like Murex crassilabrum GRAY, the type-species of the genus Crassilabrum Jousseaume, 1880, but the two are clearly distinguished each other. The spiral lirae are sharply angulated at the periphery on $C$. crassilabrum. The false umbilicus is stronger on the present species than C. crassilabrum.

C. lugubrum (BRODERIP) (1832, p. 175, and REEVE, 1845, pl.30, f. 143) is another ally to the present specimen. The latter, however, is readily distinguished from the former, which has the anti-oralward curved pteno-axials, much more distinct spirals, and larger aperture without defined posterior notch than the former.

Horizon.-Upper part of the Dingle Formation.

Locality.-SKGS-74.

Superfamily Buccinoidea

Family Pyrenidae

Genus Indomitrella OosTingh, 1940

(type-species: Columbella puella SowERBY by original designation) 
Indomitrella kobayashii sp. nov.

Pl. 9, Figs. 1 and 2; Text-fig. 26

Material.-Holotype: GK-L 6984. A single specimen which lacks the apical part.

\begin{tabular}{|c|c|c|c|c|c|c|c|c|}
\hline \multicolumn{2}{|c|}{ Measurements.- } & \multirow[b]{2}{*}{$\underset{(\mathrm{mm})}{\mathrm{Bd}}$} & \multirow[b]{2}{*}{$\underset{(\mathrm{mm})}{\mathrm{Ap}}$} & \multirow[b]{2}{*}{$\underset{(\mathrm{mm})}{\mathrm{D}}$} & \multirow{2}{*}{\multicolumn{2}{|c|}{$\underset{(\%)}{\mathrm{Bd} / \mathrm{H}}$}} & \multirow[b]{2}{*}{$\underset{(\%)}{\mathrm{Ap} / \mathrm{H}}$} & \multirow[b]{2}{*}{$\begin{array}{c}\mathrm{D} / \mathrm{H} \\
(\%)\end{array}$} \\
\hline $\begin{array}{l}\text { specimen } \\
\text { GK-L }\end{array}$ & $\underset{(\mathrm{mm})}{\mathrm{H}}$ & & & & & & & \\
\hline 6984 & $23.3+(24.7)$ & 13.85 & 10.90 & 8.70 & & 56.0 & 44.2 & 35.2 \\
\hline $\begin{array}{l}\text { specimen } \\
\text { GK-L }\end{array}$ & $\underset{\text { (degrees) }}{\angle \mathrm{P}}$ & $\begin{array}{l}\text { whorls } \\
\text { numb. }\end{array}$ & $\begin{array}{l}\text { teet } \\
\text { col. }\end{array}$ & & I & $\underset{\text { II }}{\operatorname{axials}}$ & III & \\
\hline 6984 & 26.8 & $7+$ & 6 & & 11 & 12 & 4 & \\
\hline
\end{tabular}

Diagnosis.-The shell is moderately small and fusiform with turreted spire and moderately long base. The whorls are very flat at the side early and slightly rounded later. The tangential line to the spire is almost straight. The body whorl is large occupying more than half of the shell-height, broadly rounded at sides, and moderately contracted at the base. The snout is long, slightly bent, and provided with eight spiral lirae, which are more distinct at the anterior and faded away at the posterior. The preserved first whorl is ornamented with very regular, strong, and vertical axial riblets, which are somewhat crenulate immediately below the upper suture and slightly above the lower one. There is a distinct spiral groove just below the lower row of the crenulations rendering a channelled feature to the suture. The interspaces of the axials are narrower than the riblets and illustrate the depression-like ark. On the second whorl the axials are slightly curved with the convex face oralward. The other features are almost same as on the first whorl. On the next whorl the axial riblets and spiral lirae abruptly become weak and further obsolete, while the supra-sutural groove is still distinct and a fine spiral line is intercalated in this groove. The fourth whorl is practically smooth except for the supra-sutural groove, which persists to the body whorl. The fifth (penultimate) whorl shows slightly rounded profile. The aperture is elongate pyriform with open and oblique canal, which is truncated at the end. The labrum is thickened outside like broad varix, sharp at the very margin, and denticulate inside. The denticles are fifteen in number. The inner lip is abruptly bent at upper third and covered with the callus, which is thin and smooth at the parietal part, thick and nodulously denticulate at the columellar part, and detouched at the margin. The posterior extremity of the aperture is regularly rounded.

Comparison.-The present pyrenid specimen has fusiform general profile and axial sculpture on the early whorls. This indicates the intimate relation of the present specimen to Indomitrella OosTINGH, 1940. Columbella puella SowerBy, the type-species of this genus, however, has simple axial riblets, which slightly differ from those with two rows of weak crenulations of the present specimen. The difference is, however, very slight and the author prefers to include the present species in Indomitrella.

The present specimen resembles Columbella (Strombina) gracillima MARTIN 
(1895, p. 121, Taf. 18, fs. 274 and 275), which does not really belong to Strombina, because it is devoid of the peripheral nodules like Strombus. MARTIN's species illustrates the quite similar sculpture to that of the present specimen mentioned above, but the ornaments are apparently discernible even on the penultimate whorl and only body whorl is free from the axials. The posterior part of the aperture is somewhat narrowed on MARTIN's specimen. It may belong to the same group in Indomitrella as the present specimen. There is no other known allied species to the present species.

Horizon.-Upper part of the Dingle Formation.

Locality.-SKGS-74.

\author{
Genus Thiarinella SACCo, 1890 \\ (type-species: Fusus comptus BRoNN by monotype) \\ Thiarinella costifera sp. nov. \\ Pl. 9, Figs. $3-5$ and 10 ; Text-fig. 26
}

Material.-Holotype: GK-L 6641 and paratype: GK-L 6640 from one and same locality. The holotype specimen is mature and almost perfect in preservation, while the paratype is slightly broken at the apex and the end of the canal. The latter is larger than the former, but it shows the immature feature.

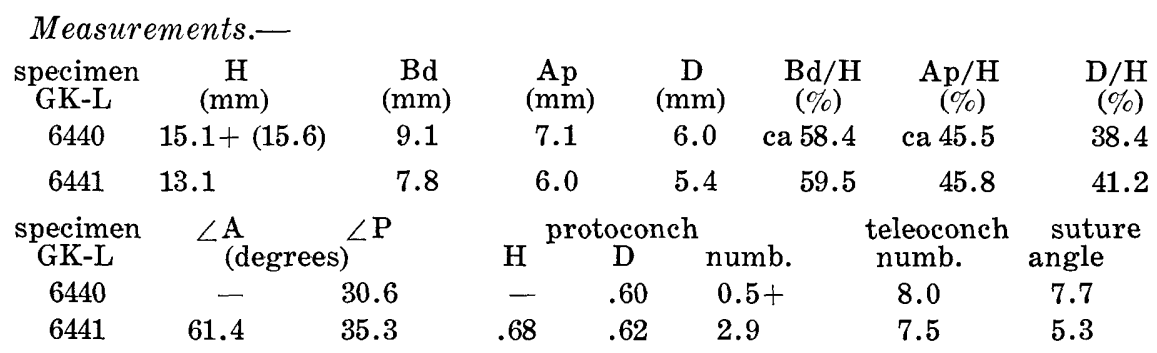

Diagnosis.-The shell is moderately small and fusiform with high conical spire and moderately long base. The protoconch is conical, smooth, and polygyrate with about three volutions, of which the first is depressedly rounded and the second and the third are somewhat convex and regularly rounded. The end of the protoconch is clearly marked by a sinusigera line. The teleoconch consists of about eight whorls, which are axially plicated throughout. The whorls are faintly contracted at some distance below the suture, then convexed, and finally slightly contracted near the lower suture on the spire, while the body whorl is bluntly angulated at the boundary between the lateral and the basal surface, which is provided with a few weak spiral grooves at the lowest part. The junction of the basal surface and the snout illustrates a sharp angle. The snout is rather long, vertical, and tapering toward the end. Ten regular and distinct spiral lirae are discernible on the snout.

The axials run from suture to suture on the spire whorls and are faded out below the basal angulation of the body whorl. They are roof-shaped, vertical or slightly retrocurrently oblique, and very slightly curved with the concave face 

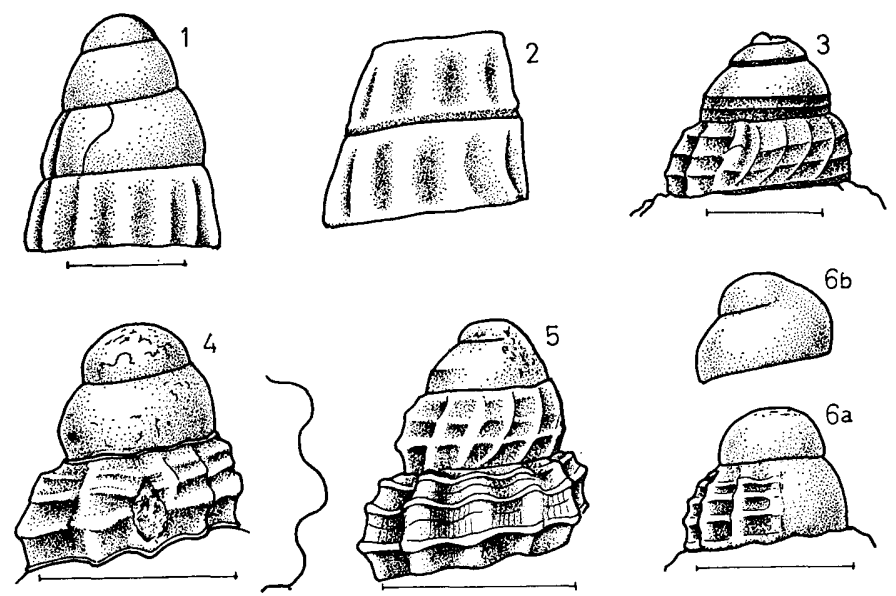

Fig. 26. Morpological features of the protoconchs and some whorls of teleoconchs of buccinaceans.

1: Thiarinella costifera sp. nov., GK-L 6641,

2: Indomitrella kobayashii sp. nov., GK-L 6984.

3: Phos (Philindophos) dijki (MARTIN), subgen. nov., GK-L 6988.

4: Hindsia varicifera A. ADAMs, GK-L 6957.

5: $H$. sp. cf. H. palembangensis HAANSTRA et SPIKER, GK-L 6958.

6: Pollia martini sp. nov., GK-L 6984.

Unit bars indicate $0.5 \mathrm{~mm}$ for fig. 1 and $1 \mathrm{~mm}$ for the others.

oralward. The axials are once weakened on the back side of the body whorl and again become distinct near the labrum on the holotype specimen, while they are equally distinct throughout on the later whorls of the paratype.

The aperture is elongate-pyriform with almost parallel margin at the middle and an oblique and open canal anteriorly. The labrum is thickened outside like a varix, simple at the very margin, and coarsely denticulate inside. The denticles are six, of which the uppermost and the lowest one are much stronger than the others and respectively narrow the entrance of the weak posterior notch and the anterior canal. The inner lip is sharply reflexed with the oblique parietal and the vertical columellar one. The callus is distinct at the columellar lip with free edge and six teeth, of which upper ones are stronger than the lower ones.

Comparison.-The present specimens are closely allied to Indomitrella smithi (YoKoYAMA) (1922, p.60, pl.22, f. 24) [=I. tokyoensis (KURODA and HABE) $=$ I. yabei (NomURA)], which was originally reported from the Peistocene of Central Japan and is also living in the Japanese waters. The former is distinguished from the latter in having the axial costae even on the body whorl and being devoid of the distinct subsutural lira.

The present specimens deviate from Indomitrella in the feature of the axial ornamentation persisting to the body whorl and are reasonably included in Thiarinella SACCo, 1890.

Horizon.-Upper part of the Ulian Formation.

Locality.-SKGS-73. 
Family Buccinidae

Genus Phos MoNTForT, 1810*

(type-species: Murex senticosus LINNÉ by original designation)

Subgenus Phos (s.s.)

Phos roseatus HiNDs

Pl. 10, Figs. 11 and 12

1844. Phos roseatus Hinds, Moll. Zool. Voy. Sulphur, Vol. 2, p. 38, pl.10, fs. 9 and 10.

1859. Phos roseatus, Sowerby, Thes. Conch. Vol. 3, p. 90, pl. 221, fs. 1-3.

1881. Phos roseatus, TrYon, Man. Conch. Ist Ser. Vol. 3, p. 217, pl. 88, fs. 507 and 509.

1895. Phos roseatus, Martin, Samml. Geol. Reichs-Mus. Leiden, N. F. Bd. 1, Abt. 1, p. 98, Taf. 16, fs. 220, 220a, and 220b.

1961. Phos roseatus, Kuroda, Prof. MakiYama Memorial Vol. p. 181, pl. 2, f. 12.

1966. Phos roseatus, HABE and Kosuge, Shells of the world in colour, Vol. 2, p. 59, pl. 21, f. 23.

Material.-GK-L 6966 and 7487 from one and same locality.

\begin{tabular}{|c|c|c|c|c|c|c|c|}
\hline $\begin{array}{l}\text { specimen } \\
\text { GK-L }\end{array}$ & $\underset{(\mathrm{mm})}{\mathrm{H}}$ & $\underset{(\mathrm{mm})}{\mathrm{Bd}}$ & $\underset{(\mathrm{mm})}{\mathrm{Ap}}$ & $\underset{(\mathrm{mm})}{\mathbf{D}}$ & $\underset{(\%)}{\mathrm{Bd} / \mathrm{H}}$ & $\underset{(\%)}{\mathrm{Ap} / \mathrm{H}}$ & $\underset{(\%)}{\mathrm{D} / \mathrm{H}}$ \\
\hline 6966 & $22.6+(22.9)$ & 13.60 & 10.25 & 10.30 & 59.4 & 44.8 & 45.1 \\
\hline 7487 & $22.8+$ & 13.90 & 10.60 & 11.50 & 60.9 & 46.5 & 50.4 \\
\hline $\begin{array}{l}\text { specimen } \\
\text { GK-K }\end{array}$ & $\underset{\text { (degrees) }}{\angle \mathrm{P}}$ & $\begin{array}{l}\text { whorls } \\
\text { numb. }\end{array}$ & $\begin{array}{l}\text { suture } \\
\text { angle }\end{array}$ & \multicolumn{3}{|c|}{$\begin{array}{l}\text { whorl profile } \\
\text { DH/ on pen }\end{array}$} & \\
\hline 6966 & 35.2 & $8.5+$ & 12.1 & \multicolumn{3}{|c|}{$6.7 / 3.4=1.97$} & \\
\hline 7487 & 45.1 & $6+$ & 10.5 & \multicolumn{3}{|c|}{$7.0 / 3.6=1.94$} & \\
\hline
\end{tabular}

Remarks.-The material in hand shows remarkable variation in morphology. GK-L 7487 is somewhat bulbous with roundly convex whorls and its sculpture is very sharply raised. It conforms with Phos roseatus HINDs very well. While GK-L 6966 is provided with more rounded whorls, coarser but less sharp axials, and more prominent basal fasciole than GK-L 7487, although the pattern of the ontogenetic development of the sculpture and the detailed feature of the aperture are identical each other. Considering the common occurrence of the two specimens from one and same locality the author is inclined to include them into a single species in spite of the mentioned difference in morphology.

The present specimens are readily distinguished from $P$. senticosus (LINNÉ), which has more angular profile of the whorls showing the very gently sloped shoulder and extremely elected ornamentation.

Geological occurrence.-Pliocene to Pleistocene (Indonesia).

Recent distribution.--Indo-Pacific from South Japan to Malayan region.

Horizon.-Upper part of the Dingle Formation.

Locality.-SKGS-74.

* Synonym: Rhinodomus SwaInson, 1840 
Subgenus Philindophos subgen. nov. (type-species: Phos dijki MARTIN, here designated) Text-fig. 26.

Subgeneric diagnosis.-The shell is small, thick, solid, and ovoid fusiform to ovoid-biconical. The protoconch is regularly conical with about four volutions. The tip is very small, somewhat depressed, and followed by the sharply angulated volution with a spiral thread at the angulation. Succeedingly another threads are added and consequently the last one-quater to one-third volution is ornamented with a few spiral threads and protractly curved axial threads (Text-fig. 26-[3]). The teleoconch consists of the moderately convex whorls, which are sculptured with the cancellation of the spirals and axials. The axial riblets are thin but elected and remarkably granulose at the intersections by the spirals, especially by the primaries. Some of the axials are prominent like as the varices. The spirals consists of the primary, secondary, and even tertiary ones. The basal contraction of the body whorl is not sharp so as to form the gradually tapered basal surface to the short snout. The fasciole is moderately strong.

The aperture is pyriform with narrowly rounded posterior end and open and oblique anterior canal, which is deeply notched at the end. The labrum is simple at the margin, thickened inside at some distance from the very margin, and provided with the close and distinct teeth, which are laterally elongated. The inner lip consists of the oblique parietal and vertical columellar ones and covered with the moderately thick callus. Three strong columellar teeth and a weak parietal one are generally discernible. Besides these dentitions there may be a few irregular wrinkles at the upper part of the columllar lip. The suture is distinctly channelled throughout.

Comparison.-The character of the protoconch of Philindophos is similar to that of Phos (s.s.), while the teleoconchs of the two are remarkably different each other. The basal contraction and the basal fasciole is much weaker on Philindophos than on Phos. The labrum- and columellar-teeth are much more prominent and regular on the present subgenus. On the basis of the mentioned differences Philindophos should be separated from Phos (s.s.) at the subgeneric level.

The unique feature of the protoconch, distinctly denticulate columellar lip, and sharp cancellation of the sculpture of the present subgenus remind us the resembling features of Antillophos Woodring, 1928. The latter is, however, more definitely contracted at the base and provided with less nodular sculpture. Furthermore the spiral thread on the protoconch volutions is only one throughout.

\section{Phos (Philindophos) dijki MartiN}

Pl. 9, Figs. 6-9, 12-15, 17, 18, 20, and 21; Text-figs. 26 and 29

1883-87. Phos dijki Martin, Samml. Geol. Reichs-Mus. Leiden, Ser. 1, Bd. 3, p. 128, Tab. 7, f. 130 .

1915. Phos dijki, Tesch, Paläont. v. Timor, Lief. 5, p. 56, Taf. 81, fs. 121a and b. 1931. Phos teschi Koperberg, ${ }^{\mathrm{e}}$ Nederl. Timor-Expeditie, 1916, Lief. 7, p. 100. 
Material.-GK-L 6988 to 7034 and many other unregistered specimens from one and same locality. Preservation is generally good.

\begin{tabular}{|c|c|c|c|c|c|c|c|c|}
\hline \multicolumn{9}{|c|}{ Measurements.- } \\
\hline $\begin{array}{l}\text { specimen } \\
\text { GK-L }\end{array}$ & $\underset{(\mathrm{mm})}{\mathrm{H}}$ & $\underset{(\mathrm{mm})}{\mathrm{Bd}}$ & $\underset{(\mathrm{mm})}{\mathrm{Ap}}$ & $\underset{(\mathrm{mm})}{\mathrm{D}}$ & \multicolumn{2}{|c|}{$\underset{(\%)}{\mathrm{Bd} / \mathrm{H}}$} & $\underset{(\%)}{\operatorname{Ap} / H}$ & $\underset{(\%)}{\mathrm{D} / \mathrm{H}}$ \\
\hline 6988 & 15.40 & 10.55 & 8.10 & 8.00 & \multicolumn{2}{|c|}{68.5} & 52.6 & 52.0 \\
\hline 6989 & 14.80 & 10.45 & 8.20 & 7.60 & \multicolumn{2}{|c|}{70.6} & 56.4 & 51.4 \\
\hline 6990 & 15.50 & 10.90 & 8.50 & 8.40 & \multicolumn{2}{|c|}{70.3} & 54.8 & 54.3 \\
\hline 6991 & 13.80 & 9.90 & 7.30 & 7.40 & \multicolumn{2}{|c|}{71.6} & 52.8 & 53.6 \\
\hline 6992 & 13.35 & 9.40 & 7.25 & 7.60 & \multicolumn{2}{|c|}{70.4} & 54.4 & 56.8 \\
\hline 6993 & 16.50 & 11.05 & 8.25 & 7.80 & \multicolumn{2}{|c|}{67.0} & 50.0 & 47.2 \\
\hline 6995 & 14.30 & 9.80 & 7.20 & 7.20 & \multicolumn{2}{|c|}{68.4} & 50.4 & 50.4 \\
\hline 6996 & 16.00 & 11.00 & 8.35 & 8.40 & & 3.7 & 52.2 & 52.5 \\
\hline 6999 & 10.05 & 10.80 & 7.95 & 8.00 & & 1.7 & 52.8 & 53.2 \\
\hline 7004 & 13.30 & 9.90 & 7.20 & 7.75 & & 4.4 & 54.2 & 58.2 \\
\hline 7005 & ca 15.35 & 10.45 & 7.20 & 7.70 & cat & 3.2 & ca 46.9 & ca 50.2 \\
\hline $\begin{array}{l}\text { specimen } \\
\text { GK-L }\end{array}$ & $\angle \mathrm{A}$ & egrees) $\angle \mathrm{P}$ & $\mathrm{H}$ & prc & $\stackrel{\text { tocon }}{\mathrm{D}}$ & & numb. & $\begin{array}{l}\text { teleoconch } \\
\text { numb. }\end{array}$ \\
\hline 6988 & 69.2 & 44.6 & ca 1.50 & & 1.56 & & 4.0 & 4.7 \\
\hline 6989 & 75.5 & 49.4 & ca 1.42 & & 1.52 & & 3.75 & 4.6 \\
\hline 6990 & 78.4 & 55.2 & ca 1.46 & & 1.56 & & ca 4.0 & 4.4 \\
\hline 6991 & 77.6 & 51.1 & ca 1.36 & & 1.44 & & ca 4.0 & 4.25 \\
\hline 6992 & 78.4 & 52.8 & 1.42 & & 1.55 & & 3.8 & 4.5 \\
\hline 6993 & 76.2 & 48.9 & 1.52 & & 1.52 & & ca 3.8 & 5.15 \\
\hline 6995 & 73.4 & 43.3 & - & & - & & 3.7 & 4.5 \\
\hline 6996 & 73.3 & 43.5 & 1.32 & & 1.48 & & 3.6 & 5.0 \\
\hline 6999 & 76.5 & 43.3 & 1.40 & & 1.56 & & 3.6 & 4.5 \\
\hline 7004 & 79.0 & 55.3 & - & & 1.46 & & ca 3.5 & 4.2 \\
\hline 7005 & 82.4 & 43.2 & - & & 1.40 & & $2+$ & 4.8 \\
\hline $\begin{array}{l}\text { specimen } \\
\text { GK-L }\end{array}$ & par & $\begin{array}{l}\text { teeth } \\
\text { col lab }\end{array}$ & I & II $^{\text {axia }}$ & III & IV & pr & $\begin{array}{l}\text { imary spirals } \\
\text { on I }\end{array}$ \\
\hline 6988 & 1 & 11 & 10 & 11 & 14 & 17 & & 4 \\
\hline 6989 & 1 & 10 & 10 & 11 & 14 & 16 & & 4 \\
\hline 6990 & 1 & 9 & 9 & 11 & 14 & 17 & & 4 \\
\hline 6991 & 1 & 9 & 12 & 12 & 15 & 21 & & 4 \\
\hline 6992 & 2 & 11 & 12 & 12 & 16 & 21 & & 4 \\
\hline 6993 & 1 & 10 & 10 & 11 & 13 & 15 & 24 & 4 \\
\hline 6995 & 1 & 10 & 9 & 11 & 14 & 15 & & 4 \\
\hline 6996 & 1 & 11 & 11 & 11 & 13 & 17 & 24 & 3 \\
\hline 6999 & 1 & 3 & 11 & 12 & 15 & 21 & & 4 \\
\hline 7004 & 1 & 9 & 10 & 11 & 13 & 14 & & 4 \\
\hline 7005 & 1 & 13 & 11 & 10 & 12 & 13 & & 4 \\
\hline
\end{tabular}

Remarks.-The material in hand consisting of abundant specimens shows a wide range of variation of the profile of the shell as indicated by the figures and measurements, although the other features are rather stable. The elongate form including the specimens GK-L 6988 to 6998 is similar to Phos dijki MarTIN (1883-87, p. 128, Tab. 7, f. 130) and the bulbous form including GK-L 6999 to 7034 is closer to Phos teschi KoPERBERG (1931, p. 100). KOPERBERG put the stress on the difference in the protoconch and number of the axial riblets between 
P. dijki and P. teschi, but the examination of the plenty material verifies that typical form of $P$. dijki and teschi are included in the range of normal variation of the morphology within a single fossil population. Accordingly the author is inclined to include these two named taxa in a single species.

Geological occurrence.-Lower Miocene to Lower Pliocene (Indonesia).

Horizon.-Upper part of the Dingle Formation.

Locality.-SKGS-74.

Genus Pollia Sowerby, 1834*

(type-species: Buccinum undosum LINNÉ by original designation)

Pollia martini sp. nov.

P1. 9, Figs. 11 and 16; Text-figs. 26 and 29

1895. Tritonidea proteus, MarTin (non ReEve, 1846), Samml. Geol. Reichs-Mus. N. F. Bd. 1, Abt. 1, p. 100, Taf. 16, f. 223.

Material.-Holotype: GK-L 6985. The specimens in Rijksmuseum van Geologie en Mineralogie (Leiden) were also examined.

\begin{tabular}{|c|c|c|c|c|c|c|c|c|c|c|}
\hline $\begin{array}{l}\text { specimen } \\
\text { GK-L }\end{array}$ & $\underset{(\mathrm{mm})}{\mathrm{H}}$ & $\underset{(\mathrm{mm})}{\mathrm{Bd}}$ & $\underset{(\mathrm{mm})}{\mathrm{Ap}}$ & $\underset{(\mathrm{mm})}{\mathbf{D}}$ & \multicolumn{2}{|c|}{$\underset{(\%)}{\mathrm{Bd} / \mathrm{H}}$} & $\underset{(\%)}{\mathrm{Ap} / \mathrm{H}}$ & $\underset{(\%)}{\mathrm{D} / \mathrm{H}}$ & \multicolumn{2}{|c|}{$\underset{\text { (degrees) }}{\angle \mathrm{A}} \quad \angle \mathrm{P}$} \\
\hline 6985 & 18.0 & 13.0 & 9.45 & 10.25 & 72 & & & 57.0 & 59.6 & 59.4 \\
\hline \multicolumn{11}{|l|}{ St(Leiden) } \\
\hline 9199 & $15.6+$ & 11.3 & 8.9 & 8.8 & & & $.0-$ & $56.4-$ & \multicolumn{2}{|l|}{ non } \\
\hline 9199 & 16.0 & 12.1 & 8.5 & 9.4 & 75 & & .1 & 58.7 & \multicolumn{2}{|c|}{ measurements } \\
\hline 9199 & 14.6 & 10.5 & 7.6 & 8.2 & 71 & & .0 & 56.1 & & \\
\hline $\begin{array}{l}\text { specimen } \\
\text { GK-L }\end{array}$ & \multicolumn{3}{|c|}{ protoconch } & \multicolumn{2}{|c|}{$\begin{array}{l}\text { teleoconch } \\
\text { numb. }\end{array}$} & \multicolumn{2}{|c|}{ plaits } & $\begin{array}{l}\text { teeth } \\
\text { lab }\end{array}$ & \multicolumn{2}{|c|}{ axials } \\
\hline 6985 & .72 & .96 & 1.7 & 5. & & 1 & 3 & 7 & 10 & 8 \\
\hline \multicolumn{11}{|l|}{ St(Leiden) } \\
\hline 9199 & \multirow{3}{*}{\multicolumn{3}{|c|}{ non measurements }} & & & 1 & 3 & & \multirow{2}{*}{\multicolumn{2}{|c|}{ non }} \\
\hline 9199 & & & & & & 1 & 3 & & & \\
\hline 9199 & & & & & & 1 & 3 & & & \\
\hline
\end{tabular}

Diagnosis.-The shell is moderately small, thick, solid, and ovatorhomboid. The protoconch is bountly conical and paucigyrate with about 1.7 swollen and smooth volutions. The beginning of the teleoconch is marked with a very sharp axial ridge, which is superimposed by four primary spiral lirae. The teleoconch consists of about five and a half whorls. The first whorl is rounded at side at first and abruptly becomes angulate later at the lower fifth. The succeeding whorls are angulated at some distance from the upper suture, moderately steeply sloped below this infrasutural angulation to the peripheral one, and then somewhat contracted to the lower suture. The weak basal contraction of the body whorl, rather sharp peripheral angulation, and the regularly conical spire result in the rhomboidal outline of the shell.

* Synonym: Tritonidea Swainson, 1840; Polliana J. E. Gray in M. E. GraY, 1842; and Algrus GREGoRIo, 1885. 
The axial ribs are prominent, elevated, rounded at the crest, reach the upper and lower sutures, and elongately granulated at the crossings by the spirals. They are as wide as or slightly wider than the interspaces. On the body whorl they apparently reach the lower extremity of the basal slope and further extend over the snout showing some granular appearance. They are counted $10,9,8,8$, and 8 respectively on the first to fifth whorl. The primary spiral threads are four at the very beginning and another weak one appears below the upper suture and is rapidly increased in size (abapical development). The ornamental design consisting of five primary threads, of which the lowest one $\left(\mathrm{P}_{4}\right)$ may be concealed under the suture of the succeeding whorl, persists to the penultimate whorl. The secondary lines appear on the later part of the third or fourth whorl, while the tertiary lines are discernible at some interspaces only on the body whorl. The spirals of the primary order are eleven on the body whorl. The suture is simply depressed at the early whorls but it is seemingly channelled by the subsutural swelling on the body whorl.

The aperture is pyriform with the rounded posterior end and the oblique and widely open anterior canal. The outer lip is thin and crenulated at the very margin and coarsely lirate inside. The lowest lira-like tooth defining the entrance of the canal is short and strong. The labrum profile is slightly retrocurrently oblique. The inner lip is curved, rather short, and covered with the moderately wide callus, which is thin at the parietal and thick at the columellar lip with free margin. The parietal ridge is strong and narrows the entrance of the posterior notch together with the uppermost bifid labrum tooth. The columellar denticles are three, of which the lowest one emarginate the canal. Besides these teeth a few irregular wrinkles are discernible on the callus especially at the upper part.

Comparison.-The present species is similar in morphology to Buccinum proteum REEVE (1846, pl. 7, f. 51), especially to the specimen illustrated in the figure $51 \mathrm{~b}$, but the former is readily distinguished from the latter in having the columellar denticles as MARTIN already mentioned (1895, p. 101) and also in being provided with less massive spiral lirae than the latter.

It is also allied to Tritonidea everwijni MARTIN (1906, p. 309, Taf. 17, f. 320). The ornament on the first and second whorls of the present species almost conforms with that of T. everwijni. On the latter, however, the pattern of four primary spirals continues to the penultimate whorl, while the axials become crowded abruptly. The present species should be separated from $T$. everwijni at the species level.

Van Regteren Altena described the Pliocene specimens of Cantharus (Cantharus) fumosus (DILlwYN) (1950, p.232, f.20), which is closely similar to the present species in the ornamental design of the coarse axial plicae and the primary spirals. The present species is, however, easily distinguished from Cantharus fumosus in having the prominent columellar plaits.

The present species is featured by the rhomboid shell of solid build, crude sculpture consisting of the prominent axials and the strong spirals, and elongately pyriform aperture with the moderately short anterior canal, strong 
labrum teeth, and irregular columellar denticles and similar both to Engina Gray, 1839, and Pollia Sowerby, 1834. The former, however, shows some difference from both of the genera. The aperture of the present species is not provided with so sharp and deep posterior notch as on Engina, but that part is only marked by the strong parietal and the uppermost labrum-tooth. Besides the anterior canal of the former is neither remarkably narrowed at the side nor distinctly notched at the end, but is moderately wide and obliquely subtruncated. In these respects the present species is much closer to Pollia than to Engina, but the former has more distinct axials than Pollia. In conclusion the author prefers to include the present species in Pollia evaluating the apertural features.

Geological occurrence.-Lower Miocene (Indonesia).

Horizon.-Upper part of the Dingle Formation.

Locality.-SKGS-74.

Genus Buccinulum DESHAYES, 1830

(type-species: Buccinum lineatum CHEMNITZ=Buccinum linea MARTYN

by subsequent designation, IREDALE, 1921)

Subgenus Euthria J. E. GRAY (in M. E. GRAY), 1850*

(type-species: Murex corneus LINNÉ by original designation)

Buccinulum (Euthria) dinglense sp. nov.

Pl. 9, Figs. 19 and 22-24

Material.-Holotype: GK-L 6935 and paratype: GK-L 6956 from one and same locality, loc. SKGS-74. Another paratype specimen GK-L 7123 came from loc. SKGS-75. GK-L 6935 and 6956 are almost perfect except for the protoconch and the anterior extremity of the canal. 7123 is broken both at the body whorl and the early whorls.

\begin{tabular}{|c|c|c|c|c|c|c|c|c|}
\hline \multicolumn{2}{|c|}{ Measurements.- } & \multirow[b]{2}{*}{$\begin{array}{l}\mathrm{Bd} \\
(\mathrm{mm})\end{array}$} & \multirow[b]{2}{*}{$\underset{(\mathrm{mm})}{\mathrm{Ap}}$} & \multirow[b]{2}{*}{$\underset{(\mathrm{mm})}{\mathrm{D}}$} & \multirow[b]{2}{*}{$\begin{array}{c}\mathrm{Bd} / \mathrm{H} \\
(\%)\end{array}$} & \multirow[b]{2}{*}{$\underset{(\%)}{\mathrm{Ap} / \mathrm{H}}$} & \multirow[b]{2}{*}{$\underset{(\%)}{\mathrm{D} / \mathrm{H}}$} & \multirow[b]{2}{*}{$\stackrel{\angle \mathbf{P}}{\text { (degrees) }}$} \\
\hline $\begin{array}{c}\text { specimen } \\
\text { GK-L }\end{array}$ & $\underset{(\mathrm{mm})}{\mathrm{H}}$ & & & & & & & \\
\hline 6935 & $64.8+$ & $44.4+$ & $35.8+$ & 25.05 & $68.5+$ & $55.2+$ & $38.6-$ & 32.4 \\
\hline 6956 & $57.9+$ & $40.4+$ & $32.3+$ & $23.60+$ & $69.6+$ & $55.7+$ & $40.7-$ & 38.4 \\
\hline $\begin{array}{l}\text { specimen } \\
\text { GK-L }\end{array}$ & \multicolumn{3}{|c|}{ whor } & \multicolumn{2}{|c|}{$\begin{array}{l}\text { suture } \\
\text { angle }\end{array}$} & \multicolumn{3}{|c|}{$\begin{array}{l}\text { whorl profile } \\
D / H \text { on pen }\end{array}$} \\
\hline 6935 & & & ca 7.5 & \multicolumn{2}{|c|}{11.3} & \multicolumn{3}{|c|}{$15.3 / 7.7=1.98$} \\
\hline 6956 & $\mathrm{ca} 2$ & & 8.1 & \multicolumn{2}{|c|}{13.4} & \multicolumn{3}{|c|}{$14.2 / 6.25=2.27$} \\
\hline
\end{tabular}

Diagnosis.-The shell is moderately large attaining about $65 \mathrm{~mm}$ in height, solid, and fusiform with moderately high conical spire and the long base. The protoconch is blunt and paucigyrate with about two and one third to one quater volutions, of which the first is very small and depressed tip and the second is roundly swollen at the sides. The detailed feature, however, can not be observed because of imperfect preservation. The teleoconch consists of about eight whorls, of which the last one is very large occupying about 70 percent of the

* Synonym: Siphonofusus KURoDA and HABE, 1952 
total height. The suture is adpressed. The whorls are slightly produced at the subsutural part, moderately concave and steeply sloped between the subsutural band and blunt angulation, and then remarkably convex at the periphery. The basal part of the body whorl is moderately contracted to the somewhat bent snout. The whorls are ornamented by the massive axial folds and the distinct spiral threads. The axials are about seven at first and progressively increased in number through the growth stages to ten or eleven on the body whorl, on which they are faded out at the basal contraction. The axials are remarkably elevated at the periphery and slightly weakened to the upper suture on the early whorls and the reducing tendency of the folds on the shoulder is emphasized on the later whorls. The interspaces are much narrower then the folds.

The spiral ornamentation begins as subequal five threads; one is subsutural $\left(\mathrm{P}_{1}\right)$, the second at the middle of the shoulder $\left(\mathrm{P}_{2}\right)$, the third at the peripheral angulation $\left(\mathrm{P}_{3}\right)$, and the others on the lateral surface $\left(\mathrm{P}_{4}\right.$ and $\left.\mathrm{P}_{5}\right)$. They are almost as wide as the interspaces and regularly spaced. The secondary lines are intercalated successively at every interstices on the second whorl and gradually increased in their relative size. Immediately after the first appearance of the secondaries the second primary thread $\left(\mathrm{P}_{2}\right)$ abruptly becomes weak. Thereafter the visible modification of the ornamental pattern does not take place on the lateral surface but one to two lines are added on the shoulder below the subsutural thread.

The body whorl has about 20 to 22 spiral threads on the shoulder, lateral surface, and the basal slope and five to seven ones on the snout. Those on the lateral and basal surfaces are distinct and subequal in strength, while those on the shoulder and snout are somewhat weaker than the others. The basal fasciole is moderately strong. The aperture is pyriform with the weak posterior gutter and the long, oblique, and bent anterior canal. The outer lip is vertical and sharp at the very margin but varicosely swollen outside and provided with the raised spiral lirae inside. Of the labrum lirae the uppermost and the lowest one, which respectively define the entrance of the posterior and anterior canal, are somewhat stronger than the others. The inner lip is broadly curved, covered with the moderately thin parietal and thick columellar callus, and provided with about nine irregular and weak teeth. Besides these teeth there is a distinct parietal teeth-like ridge posteriorly and a nodule-like columellar tooth anteriorly, which marks the entrance of the anterior canal. The canal is oblique, long, very narrow, especially at the upper end, and deposited with the thick callus, which is free at the edge.

Comparison.-BEETS (1942) gave the revision and description of the Indonesian species of Buccinulum and van REGTEREN ALTENA (1950) supplemented the descripition. While MACNEIL (1960) placed the same group of the species under the genus Afer CoNRAD, 1858. The species described under the generic name of Buccinulum by BEETs and van REGTEREN ALTENA do not necessarily conform with the type species of that genus, Buccinum lineatum CHEMNITZ, as MACNEIL pointed out. They are, however, also separated from Murex afer GMELIN, the type-species of Afer CoNRAD, 1858, which has remarkably shorter 
spire, swollen whorls, and two columellar plaits.

KURODA and HABE (1952) established a genus, Siphonofusus, on the basis of Siphonalia lubrica DALL, which is similar to Buccinulum (s.s.) in the general characteristics except for being provided with a distinct parietal teeth-like ridge, longer anterior canal, and more distinctly defined axial sculpture than the latter. Siphonofusus is readily distinguished from Afer being provided with fusiform shell and devoid of the columellar plaits.

The carefull comparison of the descripitions and figures of Siphonofusus Kuroda and HABE and Euthria Gray (KURODA and HABE, 1954, pp. 89 and 95, text-figs. 17 and 20; CossmanN, 1899, pp. 118-119, pl. 6, f. 24 and text-fig. 33; and THIELE, 1931, p.312) leads to the conclusion that Siphonofusus is a synonym of Euthria, because they do not illustrate any essential difference in morphology of the shell, operculum, and radula. Indonesian "Buccinulum" slightly differs from the type-species of Euthria in having distinct axials still on the body whorl. Cossmans, however, recognized that this feature is apparently within the range of normal variation. Accordingly the Indonesian species of "Buccinulum" should be also included in Euthria.

The present species closely resembles Buccinulum orangense BEETs from the Upper Miocene of East Borneo (1942, p. 225, pl. 24, fs. 10-13), but the former species is more than twice as large as orangense with almost same number of the teleoconch-whorls and the canal is longer and more distinctly narrowed at the entrance on the present species than on orangense.

Horizons.-Upper and uppermost parts of the Dingle Formation.

Localities.-SKGS-74 and 75.

Genus Hindsia A. ADAMs, 1851*

(type-species: Buccinum nivea GMELIN by subsequent designation, CossmanN, 1901)

\section{Hindsia sinensis (SOWERBY) \\ Pl. 10, Figs. 1 and 2}

1859. Nassaria sinensie Sowerby, Thes. Conch. Vol. 3, p. 86, pl. 220, fs. 8 and 9 .

1878. Hindsia sinensis, Küster, Conch. Cab. Bd. 3, pt. 2, p. 323, Taf. 77, f. 8.

1942. Hindsia sinensis, YeN, Proc. Malac. Soc. London, Vol. 24, p. 229, pl. 22, f. 154.

1961. Nassaria sinensis, HaBE, Colored Illustr. Shells Japan, Vol. 2, p. 62, pl. 31, f. 17 .

Material.-GK-L 7068. The protoconch and the end of the canal are broken off.

Measurements.-

$\begin{array}{ccc}\text { specimen } & \mathrm{H} & \mathrm{Bd} \\ \text { GK-L } & (\mathrm{mm}) & (\mathrm{mm}) \\ 7068 & 27.3+(29) & 16.50 \\ \text { specimen } & \angle \mathrm{P} & \text { teleo- } \\ \text { GK-L } & \text { (degrees) } & \text { conch } \\ 7068 & 45.6 & 7+\end{array}$

Ap
$(\mathrm{mm})$
12.40
suture
angle
13.2

\begin{tabular}{cc}
$\underset{\mathrm{m}}{\mathrm{m}})$ & $\mathrm{Bd} / \mathrm{H}$ \\
15.75 & $(\%)$ \\
whorl profile \\
D/H on pen \\
\multicolumn{2}{c}{ 9.8/3.65=2.68 }
\end{tabular}

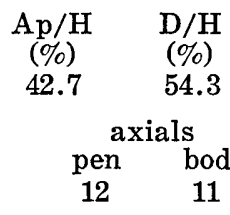

* Synonym: Benthindsia Iredale, 1936. 
Remarks.-In using the name Nassaria or Hindsia there has been serious confusion as to the type. Recently MACNEIL (1960, p. 71) and KURodA (1961, p. 175) gave the fine revision of the generic nomenclature for the species group of "Buccinum niveum GMELIN". MACNEIL recognized the validity of MöRCH's citation (1852, p. 107) that "Hindsia GRAY (=Nassaria LINK)" and the synonymy Nassa alba MARTINI = Buccinum niveum GMELIN = Neptunea pusilla RöDING=Nassaria lyrata LINK. Basing upon this recognition he designated Nassa alba MARTINI as the type of "Hindsia (GRAY) MörCH, 1852". While KURODA considered the validity of the first citation and figure of Hindsia by A. ADAMs (1851, p. 206, pl. 10, fs. 4 and 6) and accepted the type designation of Buccinum niverum GMELIN by CossmanN (1901, p. 143), although CossmanN erroneously cited $\mathrm{H}$. and A. ADAMss as the author of Hindsia. Putting the importance on the priority the author is inclined to adopt Hindsia A. ADAMs, 1851, with the type-species, Buccinum niveum GMELIN after KURODA.

Hindsia sinensis (SOWERBY) is one of the very variable species. Variation is chiefly concerned to the relative strength of the primary, secondary, and tertiary spirals, thickness of the axial plicae, and the strength of the basal fasciole. Some of the recent specimens show the close similarity to $H$. suturalis A. AdAMs (1855, p. 187), which is generally provided with coarser axials and spirals than the former. The present specimen conforms to the form-group with coarse spirals, although the $H / D$ ratio of the spire-whorls is somewhat larger in the former than the latter.

Hindsia wanneri Tesch from the Pliocene of Timor (1915, p. 69, Taf. 82, fs. $150 \mathrm{a}$ and $\mathrm{b}$ ) is closely allied to $H$. sinensis. The former is, however, distinguished from the latter by closer and less elected axial ribs and more distinctly developed varices than the latter. Furthermore the primary spiral threads on the lateral surface are more widely spaced in $H$. wanneri than in $H$. sinensis.

Recent distribution.-Sino-Malayan waters.

Horizon.-Upper part of the Ulian Formation.

Locality.-SKGS-72.

Hindsia varicifera A. ADAms

Pl. 10, Figs. 3 and 4; Text-fig. 26

1855. Hindsia varicifera A. Adams, Proc. Zool. Soc. London for 1853, p. 183.

1859. Nassaria varicifera, Sowerby, Thes. Conch. Vol. 3, p. 86, pl. 220 , f. 3.

1878. Hindsia varicifera, KüsteR, Conch. Cab. Bd. 3, pt. 2, p. 320, Taf. 77, f. 5.

1942. Hindsia varicifera, YEN, Malac. Soc. London, Vol. 24, p. 229, pl. 22, f. 158.

Material.-GK-L 6957 and 6959 from one and same locality. Preservation is not perfect.

Measurements.-

\begin{tabular}{|c|c|c|c|c|c|c|c|c|}
\hline $\begin{array}{l}\text { specimen } \\
\text { GK-L }\end{array}$ & $\underset{(\mathrm{mm})}{\mathrm{H}}$ & $\underset{(\mathrm{mm})}{\mathrm{Bd}}$ & $\underset{(\mathrm{mm})}{\mathrm{Ap}}$ & $\underset{(\mathrm{mm})}{\mathrm{D}}$ & $\underset{(\%)}{\mathrm{Bd} / \mathrm{H}}$ & $\underset{(\%)}{\mathrm{Ap} / \mathrm{H}}$ & $\begin{array}{c}\mathrm{D} / \mathrm{H} \\
(\%)\end{array}$ & $\underset{\text { (degrees) }}{\angle \mathrm{A}}$ \\
\hline 6957 & 24.4 & 15.6 & 10.5 & 12.6 & 63.9 & 43.1 & 51.7 & 59.6 \\
\hline
\end{tabular}




$\begin{array}{ccccccc}\text { specimen } & & \text { protoconch } & & \text { teleo- } & \text { suture } & \text { whorl profile } \\ \text { GK-L } & \text { H } & \text { D } & \text { numb. } & \text { conch } & \text { angle } & \text { D/H on pen } \\ 6957 & .64 & .76 & 1.6 & 8.0 & 9.3 & 8.6 / 3.6=2.38\end{array}$

Remarks.-The protoconch of the present specimen is globose, smooth, and paucispiral with one and three-fifths convex volutions. The first whorl of the teleoconch is sharply bi-angulated respectively below the narrow and horizontal shoulder and at lower two-fifths of the whorl-height. The surface between the angulations is almost flat and sloped and the lower surface below the lower angulation is concave and receded. At the beginning the primary spirals are five, which are situated respectively at the upper $\left(P_{1}\right)$ and lower suture $\left(P_{5}\right)$, at the angulations $\left(\mathrm{P}_{2}\right.$ and $\left.\mathrm{P}_{4}\right)$, and between the angulations $\left(\mathrm{P}_{3}\right)$. The subsutural one abruptly becomes fine at the later part of the first whorl. The lira between the angulations becomes strong and elevated later and sixth $\left(\mathrm{P}_{-6}\right)$ and seventh primary lirae $\left(\mathrm{P}_{-7}\right)$ appear below the suture one by one on the fourth to fifth whorl. That is to say the development of the spirals is abapical. The progressive increase of the primary lira makes the upper angulation indistinct. The secondary and the tertiary spirals are very fine. The axial ribs are vertical, suture to suture, prominently elevated, separated by narrower interspaces, and about 10 to 11 per one whorl including varices, which appear on the third whorl for the first time.

Hindsia tjemorensis MARTIN (1906, p. 316, Taf.22, f. 333; Taf. 23, fs. 334335 ) is closely allied to $H$. varicifera A. ADAMs (1855, p. 183), which are characterized by relatively sharp peripheral angulation even on the body whorl. The former is distinguished from the latter in having more bulbous outline with lower spire, more expanded labrum, and shorter anterior canal than the latter.

The present specimens conform fairly well to $H$. varicifera especially in the profile of the shell and the apertural feature, but have shorter canal than the latter. The present specimens illustrate very similar pattern of the ornamental development to $H$. tjemorensis, but the spire of the former is remarkably higher than the latter. Under such circumstance as mentioned above the author prefers to identify the present specimens to $H$. varicifera and to place $H$. tjemorensis as a subspecies of varicifera.

Recent distribution.-South China Sea.

Horizon.-Upper part of the Dingle Formation.

Locality.-SKGS-74.

Hindsia sp. cf. $H$. palembangensis HAANSTRA and SPIKER

Pl. 10, Figs. 8 and 9; Text-fig. 26

1932. Hindsia palembangensis HaAnstra and SpIKer, Proc. Roy. Acad. Amsterdam, Vol. 35, p. 1320, Taf.1, fs. 13-15.

Material.-GK-L 6958. A single juvenile specimen, broken at the labrum.

Measurements.-

$\begin{array}{ccccccccc}\underset{\text { specimen }}{\text { GK-L }} & \underset{(\mathrm{mm})}{\mathrm{H}} & \underset{(\mathrm{mm})}{\mathrm{Bd}} & \underset{(\mathrm{mm})}{\mathrm{Ap}} & \underset{(\mathrm{mm})}{\mathrm{D}} & \underset{(\%)}{\mathrm{Bd} / \mathrm{H}} & \underset{(\%)}{\mathrm{Ap} / \mathrm{H}} & \underset{(\%)}{\mathrm{D} / \mathrm{H}} & \underset{(\text { degrees })}{\angle \mathrm{P}} \\ 6958 & 18.7 & 12.4 & 10.4 & 9.9+ & 66.3 & 55.6 & 52.9+ & 57.4\end{array}$




\begin{tabular}{cccccccc} 
specimen & \multicolumn{3}{c}{ protoconch } & \multicolumn{3}{c}{ teleo- } & \multicolumn{2}{c}{ axials } \\
GK-L & $\mathrm{D}$ & $\mathrm{H}$ & numb. & $\begin{array}{c}\text { conch } \\
\text { pen }\end{array}$ & bod \\
6958 & .83 & .81 & 2.5 & 6.6 & 12 & 13 & 12
\end{tabular}

Remarks.-The present specimen is characterized by its sharp peripheral angulation of the whorls and the coarse and regular axial ribs. The protoconch is low conical with two and a half volutions, of which the first is small and rather globose tip, the following half volution is bluntly angulated at lower two-fifths, and the last one volution is sharply carinated at the extention of the former blunt angulation. At the last quater of the protoconch there are five curved, fine, and retrocurrently oblique axials. There is no definite end-mark of the protoconch but the beginning of the teleoconch is indicated by the appearance of coarse and slightly antercurrently oblique axial ribs and four spiral threads. The axials are prominent, sharply elevated, and somewhat narrower than the interspaces. Of four primary spirals the second lower one $\left(\mathrm{P}_{3}\right)$ is situated at the sharp angulation. The lowest $\left(\mathrm{P}_{4}\right)$ is close to the lower suture and the upper two $\left(\mathrm{P}_{1}\right.$ and $\left.\mathrm{P}_{2}\right)$ are spaced equally. The surface above the peripheral angulation is regularly rounded at first and becomes flatter and steeply sloped except for narrow and almost horizontal subsutural part on the later whorls. The concave surface below the peripheral angulation is remarkably receded. Consequently the peripheral angulation gradually becomes sharper on the later whorls. This is one of the diagnostic feature of H. tjemorensis MARTIN and $H$. palembangensis HAANSTRA and SPIKER. The secondary spirals appear on the second whorl, while the tertiaries are intercalated on the fourth one. The body whorl is provided with multiple sets of the primary to quaternary spirals.

It almost perfectly conforms with Hindsia palembangensis from the Upper Miocene of Sumatra. The author suspends, however, the concrete identification, because the present specimen is juvenile and imperfectely preserved.

The present specimen is also allied to $H$. tjemorensis MARTIN, but the former is less sharp at the peripheral angulation and provided with more regular spirals than the latter.

Geological occurrence.-Upper Miocene (Indonesia).

Horizon.-Upper part of the Dingle Formation.

Locality.-SKGS-74.

\section{Family Nassariidae}

Distinction of several genera and subgenera of the group Nassarius DUMÉRIL, 1806, is not necessarily clear cut but obvious with overlapping morphological features among the allied taxa. Facing with the puzzling difficulty the author felt the need of some revision on the taxonomy of that group.

Concerning the taxonomy of Nassarius OYAMa put the importance on the radular feature with or without lateral teeth, number (one or two) of the tail-like posterior projection(s) of the foot, and the morphology of the eggcapsules (personal communication, 1967). His idea seems to be hopeful. The 
knowledge of the radulae, especially morphology of the foot, and the egg-capsules based on hither-to-for reported descriptions is, however, not plenty enough to furnish the proper ground for grouping the taxa in question. Hence the author tentatively divided the group into two, one with the lateral teeth and the other without the laterals, and examined two subgroups in relation to such anatomical and morphological characters as the operculum, protoconch, foot, and eggcaspule. The subgroup with the lateral teeth includes Nassarius DUMÉRIL, 1806, Alectrion MontFonT, 1810, Zeuxis H. \& A. AdAMs, 1853, Niotha H. \& A. AdAMs, 1853, Arcularia LINK, 1807, Plicarcularia ThIELE, 1929, Amyculina Iredale, 1918, Naytiopsis IREdAle, 1918, Tarazeuxis Iredale, 1936, etc. and the other one without the laterals contains Tritia RIsso, 1826, Phrontis H. \& A. Adams, 1853, Uzita H. \& A. AdAMs, 1853, Tritonella A. AdAMS (in H. \& A. Adams), 1853, Caesia H. \& A. Adams, 1853, Reticunassa Iredale, 1936, Naytia H. \& A. AdAms, 1853, Sphaeronassa LoCARD, 1886, Desmoulea GrAY, 1847, Hebra H. \& A. Adam, 1853, Profundinassa Thiele, 1929, Illyanassa Stimpson, 1865 etc. All the taxa of the former subgroup are respectively provided with the operculum with crenated margin and their protoconchs are bluntly carinated or angulated at the periphery at least on the last volution except on Amyculina. While member of the latter subgroup have the smooth protoconch without peripheral angulation except for Profundinassa, the protoconch of which is sharply carinated. The operculum is crenated at the margin in the majority of the taxa, but Profundinassa and Ilyanassa have the operculum of smooth margin. The author has few to say about the tail of the foot and egg-capsule, but it must be mentioned that Amyculina has a single tail and differs from Nassarius. The egg-capsule of Ilyanassa is polygonal and quite different from the majority of other known ones, which are more or less simply lenticular with marginal rim.

From this point of view the group of Nassarius may be tentatively grouped into following taxa:

(I) Radula with lateral teeth and operculum with crenated margin.

(Ia) Protoconch carinated or angulated on the later part, foot with two tail (?), egg-capsule simply lenticular form (?)

Genus Nassarius DumerIL, 1806

Subgenus Nassarius (s.s.), type-sp.: Buccinum arcularium LINNÉ

Alectrion MONTFORT, 1810, type-sp.: Buccinum papillosum LiNNÉ

Zeuxis H. \& A. AdAMs, 1853, type-sp.: Buccinum taenium GMELIN

Tarazeuxis IREDALE, 1936, type-sp.: Nassa mucronata A. ADAMS

Niotha H. \& A. ADAms, 1853, type-sp.: Nassa cumingii A. ADAMS

Arcularia LINK, 1807, type-sp.: Buccinum gibbosulum LINNÉ

Plicarcularia THIELE, 1929, type-sp.: Nassa thersites BRUGUIÈRE

Naytiopsis THIELE, 1929, type-sp.: Nassa grana LAMARCK

(Ib) Protoconch dome-shaped, consisting of round and smooth volutions, foot with a single tail, and egg-capsule (?)

Genus Amyculina Iredale, 1918, type-sp.: Nassa cornicula Olivi

(II) Radula without lateral teeth

(IIa) Operculum with crenated margin, protoconch entirely smooth and 
round, foot (?) with two tails at least on $N$. mutabilis, and egg-capsule ovoido-lenticular but more or less modified.

Genus Tritia RIsso, 1826

Subgenus Tritia (s.s.) type-sp.: Buccinum reticulatum LINNÉ

Tritonella A. ADAMs, 1853, type-sp.: Nassa incrassata MÜLleR

Phrontis H. \& A. ADAMs, 1853, type-sp.: Nassa tiarula KIENER

Uzita H. \& A. ADAMS, 1853, type-sp.: Nassa miga BruguiÈre

Sphaeronassa LOCARD, 1886, type-sp.: Buccinum mutabilis LINNÉ

Caesia H. \& A. ADAMs, 1853, type-sp.: Nassa peripingia HiNDS

Reticunassa IREDALE, 1936, type-sp.: Nassa paupera GouLd

Naytia H. \& A. ADAMs, 1853, type-sp.: Nassa obliqua KIENER

Hebra H. \& A. ADAMS, 1853, type-sp.: Nassa muricata QUAY \& GAIMARD

(IIb) Operculum ovato-trigonal with smooth margin, protoconch high conical and carinated, foot (?), and egg-capsule (?)

Genus Profundinassa THIELE, 1929, type-sp.: Nassa babylonia Watson

(IIc) Operculum with smooth margin, protoconch smooth and rounded, foot

(?), and egg-capsule polygonal.

Genus Ilyanassa STIMPSON, 1865, type-sp.: Nassa obsoleta SAY

(IId) Operculum trigonal with smooth margin; protoconch, foot, and eggcaspule unknown.

? Genus Desmoulea GraY, 1847, type-sp.: Nassa pinguis A. ADAMS.

One can easily find out several morphologically corresponding couples within the large genera, Nassarius and Tritia. Nassarius (s.s.) and Phrontis, ZeuxisTarazeuxis and Sphaeronassa, Niotha and Tritia (s.s.)-Tritonella, Naytiopsis and Naytia etc. represent the homeomorphic couples, which might have been resulted from the parallel evolution of two genera.

Genus Nassarius DUMÉRIL, 1806*

(type-species: Buccinum arcularium LINNÉ by subsequent designation, FroRIEP, 1806)

Subgenus Nassarius (s.s.)

Nassarius (Nassarius) arcularius (LINNÉ)

Pl. 12, Fig. 13 and Pl. 14, Figs. 12, 13, and 14

1767. Buccinum arcularium LinNé, Systema Naturae 12th ed. p. 1200.

1844. Nassa arcularia, LamarcK, Hist. d. Anim. s. Vert. Tom. 10, p. 178.

1853. Nassa arcularia, REEve, Conch. Icon. Vol. 8, Nassa, pl. 4, fs. 25 a and b.

1882. Nassa (Arcularia) arcularia, TRYoN, Man. Conch. Ist Ser. Vol. 4, p. 24, pl. 7, fs. 9 and 10.

1931. Nasa (Nassa) arcularia, Thiele, Handb. System. Weichtierkunde, Bd.1, p. 325, f. 370 .

1941. Nassarius arcularius, HATAI, Rec. Mar. Shell-bearing Moll. South Sea Islands, (pt. 1), p. 135, pl. 34, fs. 3 and 4.

1943. Nassarius (Nassarius) arcularius, Wenz, Hanb. Paläozool. Bd. 6, Gastrop. p. 1234, f. 3517 .

* Synonym: Nassa LaMaRCK, 1799, non Röding, 1798 
Material.-GK-L 6423 from loc. SKGS-73 and GK-L 7458, 7471 to 7473 from loc. SKGS-71.

\begin{tabular}{|c|c|c|c|c|c|c|c|c|c|}
\hline \multicolumn{3}{|c|}{ Measurements.- } & \multirow[b]{2}{*}{$\underset{(\mathrm{mm})}{\mathrm{Ap}}$} & \multirow[b]{2}{*}{$\underset{(\mathrm{mm})}{\mathrm{D}}$} & \multirow[b]{2}{*}{$\begin{array}{c}\mathrm{Bd} / \mathrm{H} \\
(\%)\end{array}$} & \multirow[b]{2}{*}{$\underset{(\%)}{\mathrm{Ap} / \mathrm{H}}$} & \multirow[b]{2}{*}{$\begin{array}{l}\mathrm{D} / \mathrm{H} \\
(\%)\end{array}$} & \multirow[b]{2}{*}{$\underset{\text { (degrees) }}{\angle \mathrm{P}}$} & \multirow[b]{2}{*}{$\begin{array}{l}\text { whorls } \\
\text { proto teleo }\end{array}$} \\
\hline $\begin{array}{l}\text { specimen } \\
\text { GK-L }\end{array}$ & $\underset{(\mathrm{mm})}{\mathrm{H}}$ & $\underset{(\mathrm{mm})}{\mathrm{Bd}}$ & & & & & & & \\
\hline 7458 & 25.9 & 19.8 & 16.8 & 17.1 & 76.4 & 64.3 & 66.0 & 79.5 & $-7-$ \\
\hline 7471 & 26.4 & 20.1 & 17.3 & 16.2 & 76.1 & 65.5 & 61.3 & 70.7 & - \\
\hline 7473 & 30.1 & 22.6 & 19.1 & 18.5 & 75.0 & 63.4 & 61.4 & 68.3 & $2+\operatorname{ca} 7$ \\
\hline
\end{tabular}

Remarks.-The ornamental design on the early whorls of the present specimens is the combination of the distinct axial ribs and the spiral grooves. The axial ribs are almost vertical, prominently raised, and much wider than the interstices. The axials are counted by 20 to 22 on the second whorl and increased in number to the penultimate whorl. They also change the attitude; they are slightly recurrently oblique and slightly curved on the adolescent whorls, while they are abruptly faded on the lateral surface of the body whorl leaving the coarse nodes close to the suture. The spiral grooves, infrasutural and suprasutural, are deeply incised and cut through the axials on the nepionic to adolescent whorls, but are weakened abruptly on the penultimate whorl. Consequently the extension of the suprasutural groove is not discernible at all on the body whorl, although the infrasutural groove is still traceable. A few fine secondary grooves may exist on the lateral surface of the adolescent whorls on some specimens.

The present specimens are quite identical to Nassarius arcularius (LINNÉ), the type-species of Nassarius, on the basis of the diagnostic features mentioned above.

Nassarius nodifera (Powys) (1835, p. 95, and REEve, 1853, pl. 4, f. 23) is an ally to the present species, but the latter has closer axials and more step-like suture on the spire whorls, and stronger and coarser nodes on the last whorl than the former.

N. bronni (PHILIPPI) (1848, p. 137) and N. coronatus (LAMARCK) (1799, p. 180) are somewhat similar to the present specimens, but they lose the axial ribs at much earlier stage of growth than the present specimens and their nodes are not so elected.

Recent distribution.-Southeast Asian waters from Okinawa to Indonesia. Horizons.-Santa Barbara Silt and the upper part of the Ulian Formation.

Localities.-SKGS-71 and 73.

Nassarius (Nassarius) coronatus philippinensis subsp. nov. Pl. 12, Figs. 5, 6, and 7; Text-fig. 28

Material.-Holotype: GK-L 7409 and paratypes: GK-L 6540, 6541, 7508, 7509 , and 7510 from one and same locality.

Measurements.-

\begin{tabular}{|c|c|c|c|c|c|c|c|c|}
\hline $\begin{array}{l}\text { specimen } \\
\text { GK-L }\end{array}$ & $\underset{(\mathrm{mm})}{\mathrm{H}}$ & $\underset{(\mathrm{mm})}{\mathrm{Bd}}$ & $\underset{(\mathrm{mm})}{\mathrm{Ap}}$ & $\underset{(\mathrm{mm})}{\mathbf{D}}$ & $\underset{(\%)}{\mathrm{Bd} / \mathrm{H}}$ & $\underset{(\%)}{\mathrm{Ap} / \mathrm{H}}$ & ${ }_{(\%)}^{\mathrm{D} / \mathrm{H}}$ & $\angle \underset{\text { (degrees) }}{\mathrm{A}} \angle \mathrm{P}$ \\
\hline 6540 & 17.7 & 12.75 & 10.3 & 10.25 & 71.5 & 58.2 & 57.8 & 73.3 \\
\hline
\end{tabular}




\begin{tabular}{|c|c|c|c|c|c|c|c|c|c|}
\hline 7409 & 17.3 & 12.40 & 9.9 & 10.25 & 71.5 & 56.6 & 59.3 & ca 78 & 61.2 \\
\hline 7509 & 20.3 & 14.20 & 11.8 & 12.00 & 69.9 & 58.6 & 59.1 & ca 64.5 & 57.8 \\
\hline 7510 & 20.1 & 14.10 & 11.5 & 11.20 & 70.1 & 57.2 & 55.7 & ca 64 & 59.6 \\
\hline $\begin{array}{l}\text { specimen } \\
\text { GK-L }\end{array}$ & \multicolumn{4}{|c|}{ whorls } & $\begin{array}{l}\text { suture } \\
\text { angle }\end{array}$ & \multicolumn{4}{|c|}{$\begin{array}{l}\text { whorl profile } \\
\mathrm{D} / \mathrm{H} \text { on pen }\end{array}$} \\
\hline 6540 & \multicolumn{4}{|c|}{ ca 6.0} & 9.8 & \multicolumn{4}{|c|}{$5.25 / 2.1=2.50$} \\
\hline 7409 & \multicolumn{2}{|c|}{ ca 3} & \multicolumn{2}{|c|}{5.5} & 10.6 & \multicolumn{4}{|c|}{$5.25 / 2.3=2.28$} \\
\hline 7509 & & $1.5+$ & \multirow{2}{*}{\multicolumn{2}{|c|}{ ca 6}} & 11.1 & \multicolumn{4}{|c|}{$6.45 / 2.8=2.30$} \\
\hline 7510 & & $2+$ & & & 9.6 & & $6.15 / 2$. & $=2.46$ & \\
\hline
\end{tabular}

Diagnosis. - The shell is moderately thick, solid, small attaining about $20 \mathrm{~mm}$ in height, and ovately conical with moderately high spire and short base. The pleural angle ranges between 58 to 61 degrees. The protoconch is conical consisting of about three volutions. The details are unknown because of removing the upper layer of the protoconch, but the profile of the inner layer suggests the median angulation on the second and third volutions.

The whorls of the teleoconch are more than six. The first whorl is provided with coarse axial ribs and a infrasutural spiral groove. The axials are about 12 to 14 , rounded at the crest, separated by wider interstices, slightly recurrently oblique, and more or less granular below the flush suture. These sculptures are abruptly weakened on the later half of the second whorl to early part of the third. Consequently the third and fourth whorls have the broad axial folds which are subnodose at the subsutural part and abruptly faded out below the weak or obsolete infrasutural spiral groove. Above the subsutural nodes is the somewhat depressed flush suture, which is never canaliculated throughout. The tendency for nodosity of the subsutural band apparently persists to the body whorl. The body whorl is large occupying more than 70 percent of the total height, somewhat excavated at the flush suture, obsoletely or weakly nodulous below the suture, broadly rounded at the sides, and moderately contracted at the base, the lower part of which is encircled with a few step-like spirals. The snout is moderately short, slightly oblique, and separated from the basal surface by a remarkably large groove. The spiral lirae on the snout are five to six, of which the uppermost one is prominent and sharply elected.

The aperture is ovate with a distinct and narrow posterior canal. The labrum is slightly retrocurrently oblique, sharp at the very margin with a few weak serrations at the anterior one-fourth, remarkably varicose outside, and closely lirated inside at some distance from the margin. The inner lip is arcuate and provided with a distinct parietal ridge and several teeth-like ridges at the columellar lip and the lower part of the parietal one. The callus is thick and solid at the entrance of the posterior canal forming a mound, moderately thin at the lower half of the parietal lip, and again thick at the columellar lip with the sharply ridged free edge. The callus is not expanded to the upper part of the body whorl. The anterior notch is very deep and its boundary between the labrum is defined by the teeth-like lira.

Comparison.-The present specimens conforms almost perfectly with Nassa coronata LAMARCK (1844, DeshaYes' ed. Vol. 10, p. 180, and ReEVE, 1855, pl. 3 , fs. 20a and b) from Madagascar except for size and callus. The weak nodulous 
character of the subsutural band below flush suture is the most conspicuous feature of the two. The former is, however, about two-thirds as large as the latter and provided with much narrower callus than the latter, on which the callus is expanded to the upper part of the body whorl. The measured specimens apparently indicate that they are at maturity and the mentioned difference may be geographical, geological, or combination of both.

Nassa balteata LrschKe (1869, p. 61, Taf. 5, fs. 10 and 11) also resembles the present specimens, but the flush suture and nodulous subsutural band of the latter readily serve for separation of it from $N$. balteata.

Nassarius (Tarazeuxis) dorsatus (RöDING) is another ally to the present specimens, which occur together at one and same locality. The mixed specimens of two species are, however, clearly separated into two groups through measurements of several characters. $N$. (T.) dorsatus does not show any indication of the nodosity of the subsutral band.

The present specimens are also similar to Nassarius (Zeuxis) subbalteatus MACNEIL (1960, p. 82 , p. 8, f. 22) from the Mio-Pliocene of Okinawa, but the former is distinguished from the latter in having broader outline with outwardly expanded labrum, more numerous and stronger spiral grooves on the basal surface, and thicker and narrower callus with relief than the latter.

Horizon.-Santa Barbara Silt.

Locality.-SKGS-71.

Subgenus Zeuxis H. and A. AdAMs, 1853

(type-species: Buccinum taenium GMELIN by original designation)
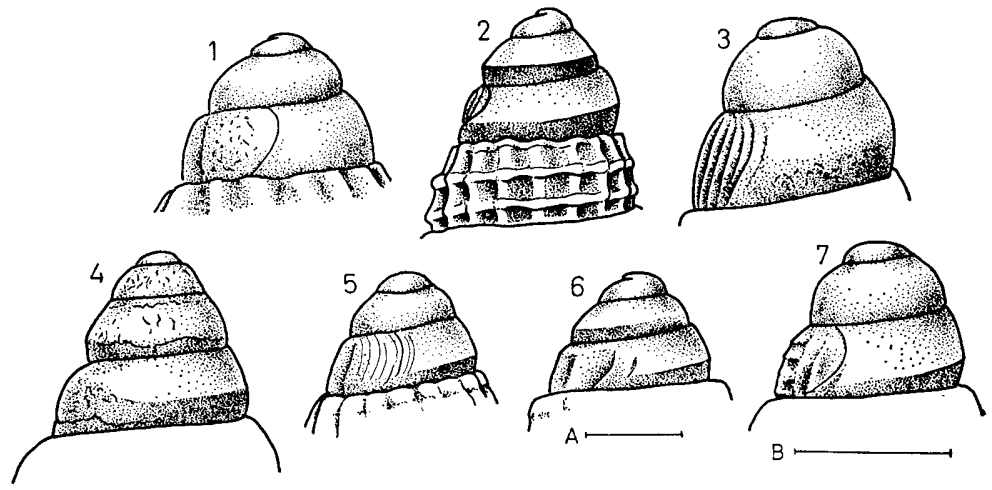

Fig. 27. Protoconchs of some nassariids.

1 and 5: Nassarius (Zeuxis) macrocephalus greyanus subsp. nov., GK-L 7405 (fig. 1) and GK-L 7406 (fig. 5).

2: N. (Z.) caelatus verbeeki (MARTIN), GK-L 6419.

3 and 7: N. (Chelenassa) elegantissimus subgen. et sp. nov., GK-L 6565 (fig. 3) and GK-L 6523 (fig. 7).

4: Glabrinassa amycliformis gen. et sp. nov., GK-L 7511.

6: Nassarius (Tarazeuxis) badius (A, ADAMS), GK-L 7101.

Unit bars A and B respectively indicate $0.5 \mathrm{~mm}$ for flgs. 1-6 and fig. 7 . 


\section{Nassarius (Zeuxis) caelatus verbeeki (MARTIN)}

Pl. 11, Figs. 9, 10, 14, 18, 19, and 20, Pl. 12, Fig. 16 and Pl. 24, Fig. 10; Text-figs. 27 and 28

1895. Nassa (Hinia) verveeki Martin, Samml. Geol. Reichs-Mus. Leiden, N. F. Bd. 1, Abt. 1, p. 110, Taf. 17, fs. 247-255.

Material.*-GK-L 6416 to 6422 and 6424 to 6425 from loc. SKGS-73 and GK-L 7080 to 7088 from SKGS-72. Preservation is generally good.

\begin{tabular}{|c|c|c|c|c|c|c|c|c|c|}
\hline \multicolumn{3}{|c|}{ Measurements.- } & \multirow[b]{2}{*}{$\underset{(\mathrm{mm})}{\mathrm{Bd}}$} & \multirow[b]{2}{*}{$\underset{(\mathrm{mm})}{\mathrm{Ap}}$} & \multirow[b]{2}{*}{$\underset{(\mathrm{mm})}{\mathrm{D}}$} & \multirow[b]{2}{*}{$\underset{(\%)}{\mathrm{Bd} / \mathrm{H}}$} & \multirow{2}{*}{\multicolumn{2}{|c|}{$\underset{(\%)}{\mathrm{Ap} / \mathrm{H}}$}} & \multirow[b]{2}{*}{$\begin{array}{l}\mathrm{D} / \mathrm{H} \\
(\%)\end{array}$} \\
\hline $\begin{array}{l}\text { specimen } \\
\text { GK-L }\end{array}$ & \multicolumn{2}{|c|}{$\underset{(\mathrm{mm})}{\mathrm{H}}$} & & & & & & & \\
\hline 6416 & \multicolumn{2}{|l|}{20.3} & 15.15 & 11.20 & 11.40 & 74.6 & & 5.2 & 56.2 \\
\hline 6417 & \multicolumn{2}{|l|}{19.4} & 14.70 & 11.00 & 10.60 & 75.6 & & 3.6 & 54.6 \\
\hline 6419 & \multicolumn{2}{|l|}{11.4} & 8.35 & 6.40 & 6.40 & 73.3 & & 3.2 & 56.2 \\
\hline 6421 & \multicolumn{2}{|l|}{18.9} & 13.45 & 9.80 & 9.45 & 71.3 & & 1.8 & 50.0 \\
\hline 7080 & \multicolumn{2}{|c|}{$25.0+(25.8)$} & 17.60 & 13.20 & 13.10 & 68.3 & & 1.2 & 50.8 \\
\hline 7082 & \multirow{2}{*}{\multicolumn{2}{|c|}{$\begin{array}{l}18.4+(28.7) \\
20.05+(20.4)\end{array}$}} & 13.70 & 9.55 & 9.75 & 73.3 & & 1.1 & 52.2 \\
\hline 7084 & & & 14.35 & 10.30 & 10.40 & 70.4 & & 0.5 & 50.9 \\
\hline 7085 & \multicolumn{2}{|l|}{18.8} & 14.10 & 9.70 & 9.75 & 74.2 & & 1.0 & 51.3 \\
\hline $\begin{array}{l}\text { specimen } \\
\text { GK-L }\end{array}$ & \multicolumn{2}{|c|}{$\angle \mathrm{A} \quad \angle \mathrm{P}$} & \multicolumn{3}{|c|}{$\begin{array}{l}\text { protoconch } \\
\text { D numb. }\end{array}$} & $\begin{array}{ll}\text { teleo- } & \mathrm{s} \\
\text { conch } & \mathrm{a}\end{array}$ & \multirow{2}{*}{$\begin{array}{c}\text { suture } \\
\text { angle } \\
9.9\end{array}$} & \multicolumn{2}{|c|}{$\begin{array}{l}\text { e whorl profile } \\
\mathrm{D} / \mathrm{H} \text { on pen }\end{array}$} \\
\hline 6416 & 75.5 & 52.9 & .68 & .76 & 3.3 & 5.8 & & \multicolumn{2}{|c|}{$5.7 / 2.5=2.28$} \\
\hline 6417 & 75.4 & 50.2 & ca .75 & ca .82 & 3.1 & 5.7 & 11.8 & \multicolumn{2}{|c|}{$5.95 / 2.35=2.53$} \\
\hline 6419 & 78.7 & 52.5 & .68 & .80 & 3.0 & 4.9 & 5.4 & \multicolumn{2}{|c|}{$3.35 / 1.15=2.95$} \\
\hline 6421 & - & 41.3 & ca .80 & ca .82 & ca 3.0 & ca 5.5 & 13.4 & \multicolumn{2}{|c|}{$5.95 / 2.5=2.38$} \\
\hline 7080 & - & 49.4 & - & - & $1.5+$ & ca 6.1 & 11.2 & \multicolumn{2}{|c|}{$7.4 / 3.15=2.36$} \\
\hline 7082 & - & 43.6 & - & - & $1.0+$ & 5.5 & 11.2 & \multicolumn{2}{|c|}{$5.6 / 2.25=2.48$} \\
\hline 7084 & - & 41.1 & - & - & $1.0+$ & 6.0 & & \multicolumn{2}{|c|}{$6.3 / 2.9=2.17$} \\
\hline 7085 & 71.5 & 49.3 & .76 & ca .80 & ca 3.3 & 5.6 & & \multicolumn{2}{|c|}{$5.2 / 2.5=2.08$} \\
\hline
\end{tabular}

Remarks.-The adult feature of Nassa (Hinia) verbeeki MARTIN is so closely similar to that of Nassa caelata A. ADAMs (1852, p. 108), living southeast Asian waters, that the distinction of the two is not necessarily easy. The distinction can be practical only through the statistical comparison of the large materials because of the wide range of the variability in morphological characters of the two nominated groups. The criteria for distinction are (1) the axials on the early whorls are one and a half times more numerous on $N$. verbeeki than on caelatus and (2) the axials, especially on the late whorls, are more oblique and thinner on the former than on the latter.

The protoconch of the two are quite similar; they are moderately low conical consisting of about three to three and one third volutions. They are regularly increased in size and smooth except for the peripheral carina on the last half to one and one third volutions. The end of the protoconch is marked by a defined curved axials. The early development of the spiral ornament is also quite similar between the two. The primary spiral lirae are four (five); subsutural $\left(\mathrm{P}_{1}\right)$,

* The immature specimen GK-L 6520, from loc. SKGS-71 is remarkably broader in outline than the normal specimens (pl.13, fs. 28 and 29). It is not quite clear whether it belongs to the nominated taxon or not. 
upper peripheral $\left(\mathrm{P}_{2}\right)$, lower peripheral $\left(\mathrm{P}_{4}\right)$, and suprasutural $\left(\mathrm{P}_{5}\right)$ at the beginning of the first whorl. The interspaces are almost equal except for the lowest one between the lirae $\mathrm{P}_{4}$ and $\mathrm{P}_{5}$, which is somewhat narrower than the others. Another primary, the median lira $\left(\mathrm{P}_{3}\right)$, appears slightly after the others at the interspace between $\mathrm{P}_{2}$ and $\mathrm{P}_{4}$. On some specimens the median lira $\left(\mathrm{P}_{3}\right)$ starts contemporaneously with others at the very beginning of the first whorl. The first secondary thread is intercalated on the interspace above the upper peripheral lira $\left(\mathrm{P}_{2}\right)$ on the second or third whorl. These facts indicate that the two species are very closely related each other. The author can not necessarily deny the possibility that the mentioned difference between the two may be in the range of normal variation, but he is inclined to separate $N$. verbeeki from $N$. caelatus as a subspecies evaluating the meaning of deviation of the axial ribs through growth stages.

YokоYama described the Pliocene fossils from Taiwan as Nassa (Hima) verbeeki (1928, p. 40, pl.11, fs. 9 and 13). Close examination of the specimens from the same locality as Yokoyama's indicates that they belong to $N$. (Zeuxis) caelatus caelatus being provided with less curved and less numerous axials.

Geological occurrence.-Upper Miocene to Pliocene (Indonesia).

Horizon.-Upper part of the Ulian Formation.

Localities.-SKGS-72 and 73.

Nassarius (Zeuxis) macrocephalus greyanus subsp. nov.

Pl. 14, Figs. 1-5; Text-figs. 27 and 28.

Material.-Holotype: GK-L 7405 and paratypes: GK-L 7406 and 7408 from one and same locality.

\begin{tabular}{|c|c|c|c|c|c|c|c|c|c|}
\hline \multicolumn{10}{|c|}{ Measurements.- } \\
\hline $\begin{array}{l}\text { specimen } \\
\text { GK-L }\end{array}$ & $\underset{(\mathrm{mm})}{\mathrm{H}}$ & $\underset{(\mathrm{mm})}{\mathrm{Bd}}$ & $\underset{(\mathrm{mm})}{\mathrm{Ap}}$ & $\underset{(\mathrm{mm})}{\mathrm{D}}$ & $\begin{array}{c}\mathrm{Bd} / \mathrm{H} \\
(\%)\end{array}$ & $\underset{(\%)}{A p / H}$ & $\begin{array}{l}\mathrm{D} / \mathrm{H} \\
(\%)\end{array}$ & \multicolumn{2}{|c|}{$\underset{\text { (degrees) }}{\angle \mathrm{A}} \quad \angle \mathrm{P}$} \\
\hline 7405 & 10.45 & 7.25 & 5.90 & 6.35 & 69.4 & 56.4 & 60.7 & 99.5 & 52. \\
\hline 7406 & 9.20 & 6.60 & 4.95 & 5.55 & 71.6 & 53.7 & 60.3 & 89.7 & 48. \\
\hline $\begin{array}{l}\text { pecir } \\
\text { GK- }\end{array}$ & \multicolumn{3}{|c|}{$\mathrm{H} \underset{\mathrm{D}}{\text { protoconch }}$} & $\begin{array}{l}\text { teleo- } \\
\text { conch }\end{array}$ & $\begin{array}{l}\text { suture } \\
\text { angle }\end{array}$ & \multicolumn{2}{|c|}{$\begin{array}{l}\text { whorl profile } \\
D / H \text { on pen }\end{array}$} & \multicolumn{2}{|c|}{$\begin{array}{c}\text { spiral } \\
\text { glooves (bod) }\end{array}$} \\
\hline 740 & .70 & 96 & & 5.0 & 1.0 & $3.8 / 1$. & $=3.17$ & & \\
\hline 7406 & .72 & 88 & & 4.5 & 4.1 & $3.4 / 1$. & $=3.09$ & & \\
\hline
\end{tabular}

Diagnosis.-The shell is small attaining 9 to $10 \mathrm{~mm}$ in height and ovoidconical with slightly conoidal spire and short snout. The protoconch is conoidal consisting of 3.0 to 3.3 volutions. The first volution is small, depressed, and horizontal tip, the second and early two-thirds of the third volution are somewhat convexed and obscurely angulated at the periphery, and the last half volution is sharply or bluntly carinated. The end mark of the protoconch is a fine curved line. The teleoconch consists of about five whorls, which are not canaliculate but only impressed at the suture and remarkably contracted at the infrasutural part at the upper fourth on the spire whorls. The body whorl is large occupying about 70 percent of the total height, broadly rounded at the sides below the infrasutural sulcus, and moderately contracted to the snout, which is separated from the basal 
slope by a distinct spiral furrow with sharply elected rim anteriorly.

The first teleoconch-whorl is ornamented by the raised axial ribs, which are weakly crossed by the infrasutural spiral groove. This spiral groove becomes distinct to separate the somewhat granular subsutural band above and the lateral surface below. The axial ribs are moderately raised illustrating the wavy form in the cross-section and separated one another by broader interspaces. At first the axials are very slightly retrocurrently oblique and the obliquity becomes greater through the growth stages. On the body whorl they are slightly sigmoidal consisting of the retrocurrently oblique upper part, almost vertical middle part, and again slightly retrocurrently oblique lower part.

The initial strength of the infrasutural spiral groove is variable; distinct on GK-L 6408, very weak on GK-L 7405, and moderate on the other. The early whorls from the first to second or to third are devoid of the fine spiral grooves on the peripheral surface, and those grooves appear on the later whorls. About 11 to 12 spiral grooves are discernible on the body whorl, of which the upper six to seven are very fine and the lower four to five are wide, impressed, and step-like. The short and straight snout is encircled by about five spiral lines. The aperture is narrowly rhomboid with the narrowly pointed posterior canal and deeply notched anterior end. The labrum is somewhat retrocurrently oblique, sharp and simple at the very margin, solidly variocse outside, and coarsely denticulated inside. The denticles are five to six, of which the lowest one is strong to emerginate the canal. The inner lip is bluntly flexed and covered with the callus, which is thick with free edge on the columellar lip and rather thin with obscure margin on the parietal part. The parietal ridge is prominent. The columellar denticles are variable in strength and number; obsolete to prominent and three to five; the lowest one is generally strong and marks the termination of the columella.

Comparison.-The present specimens are provided with the carinate protoconch and included in Nassarius (s.1.), because they are readily distinguished from the other genus with carinate protoconch, Profundinassa which has the smooth outer and inner lips and definitely stepped sutures. The present specimens, however, do not conform perfectly with any of the subgenera of Nassarius and fairly comparable to Zeuxis with the similar features of the profile of the whorls, infrasutural spiral groove associated with remarkable subsutural nodes, weakened axials on the body whorl, and the apertural feature.

The specimens in question are almost identical to Nassa macrocephala ScHEPMAN (1911, p. 317, pl. 20, f. 2) in the general features except for the slight difference in the protoconch and axial ribs. The protoconch of the present specimens consists of somewhat smaller number of volutions and the axials are more oblique and curved than those of macrocephala.

They are also closely allied to Nassa ovum MARTIN (1879-90, p. 35, Tab. 7, fs. 1 and $1^{*}$ ) from the Pliocene of Indonesia. They resemble each other in the outline of the shell, the general feature of the protoconch, and the pattern of the development of the ornament. The present specimens are, however, clearly distinguished from $N$. ovum in having the parietal ridge, more numerous axial ribs, and less numerous and weaker spiral grooves than the latter. Furthermore 
the present specimens have wider subsutural band especially on the body whorl and wider and heavier callus than $N$. ovum.

Nassarius (Tritia) celebensis mantjeuriensis OoSTINGH (1939, p. 172, pl.15, fs. 269a and b), which differs from typical Tritia being provided with a parietal ridge, is another ally to the present specimens, but the former has polygyrate protoconch consisting of four volutions, less numerous and more vertical axials, and narrower and thinner callus than the latter.

Horizon.-Upper part of the Ulian Formation.

Locality.-SKGS-73.

Nassarius (Zeuxis) schepmani (KOPERBERG)

Pl. 13, Figs. 15 and 16

1915. Nassa ovum, Tesch (non MARTin), Paläont. v. Timor, Lief. 5, p. 61, Taf. 131 , fs. $135 \mathrm{a}$ and $\mathrm{b}$.

1931. Nassa (Alectrion) schepmani KoPERBERG, $2^{\mathrm{e}}$ Nederlandsche Timor-Expeditie, Lief. 7, p. 103, Taf. 3, f. 40.

Material.-GK-L 6539 and 7407. Original preservation is almost perfect but the surface layer of the shell was partly lost during the preparation.

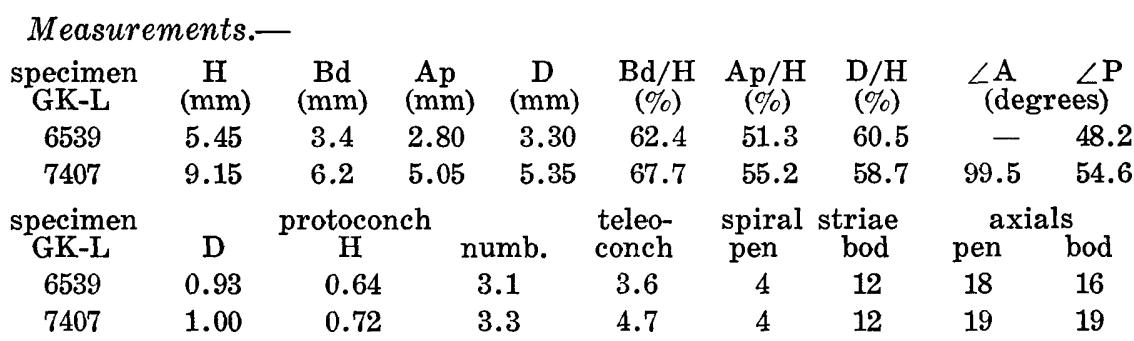

Remarks.-The present specimens are featured by the dome-shaped and weakly carinate protoconch and small and ovoid teleoconch. The ornament consists of the slightly oblique, strong, and roof-shaped axials overriden by the weaker spirals. The infrasutural groove is distinct associated with the sutural granules. They perfectly conform with the figured specimen of "Nassa ovum MARTIN" of TESCH (1915), which was named Nassa (Alectrion) schepmani by KOPERBERG (1931). Comparing with KoPERBERG's figured type, TESCH's specimen is slightly different in having less numerous axials and more prominent and wider callus at the inner lip. The features just mentioned are clearly illustrated on the specimens in hand.

Nassa (Niotha) dijki MARTIN (1895, p. 109, Taf. 17, fs. 244, 244a, and b) is also allied to the present specimens, but the latter is distinguished from the former in having more oblique axial riblets and more distinct spiral grooves even on the lateral surface of the body whorl than the former.

Nassarius (Alectrion) bantamensis OosTiNGH (1933, p. 194, text-fig. 2) is an another ally to the present species, but the former is provided with less numerous spirals on the whorls. Furthermore $N$. bantamensis is much blunter and more convex in outline than the present species. 
Geological occurrence.-Pliocene (Timor).

Horizon.-Santa Barbara Silt.

Locality.-SKGS-71.

\section{Subgenus Tarazeuxis IREDALE, 1936}

(type-species: Nassa mucronata A. ADAMs by original designation)

Nassarius (Tarazeuxis) dorsatus (RöDING)

Pl. 12, Figs. 1-4 and 8 and PI. 24, Fig. 11.

1798. Buccinum dorsatum RöDING, Museum Boltenianum p. 111, sp. 1431.

1799. Buccinum vulgatum Gmelin, Systema Naturae, Gmelin's ed. sp. 120, p. 3496.

1808. Buccinum vulgatum, Chemnitz, Neues Syst. Conch. Cab. Bd. 4, Taf. 124, fs. $1162-1164$.

1915. Nassa (Zeuxis) canaliculata, TeSch (partim), Paläont. v. Timor, Lief. 5, p. 59, Taf. 81, fs. 130 and 131.

1931. Nassa (Zeuxis) canaliculata teschi Koperberg, $2^{\text {e }}$ Nederl. Timor-Expenditie, 1916, Lief. 7, p. 108.

1954. Nassarius (Zeuxis) dorsatus, KIRA, Colored Illustr. Shells Japan Vol.1, pl. 56, pl. 28 , f. 25.

1966. Zeuxis dorsatus, HABE and KoSUGE, Shells of the world in colour, Vol. 2, p. 63, pl. 22, f. 40 .

Material.-GK-L 6542 to $6554,7459,7467$ to 7470 , and 7507 from one and same locality.

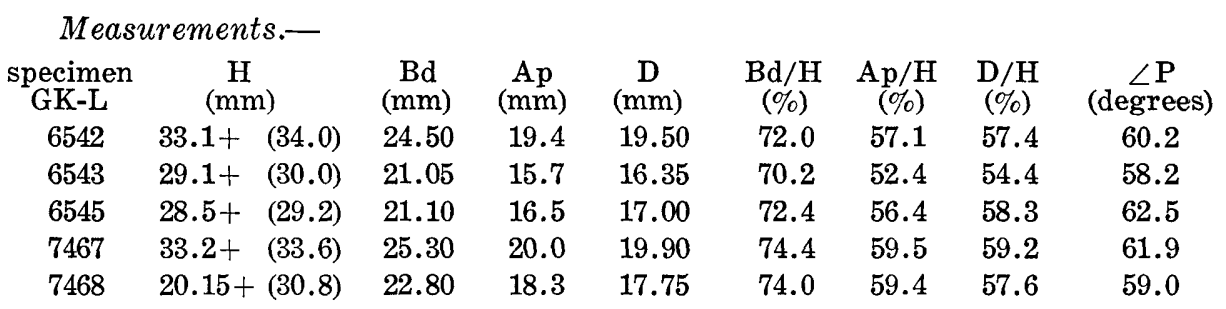

Remarks.-It is clear that the present specimens comprise a member of "Nassa canaliculata" group having relatively smooth late whorls and the distinctly canaliculate suture. It is, however, not quite easy to distinguish the species among that group because of the remarkable variability of the morphological features of the species.

The present specimens are distinguishable on an average from $N$. canaliculata LAMARCK $(1799$, p. 161) in having more roundly convex whorls, comparatively larger body whorl in proportion with the total height, smooth subsutural part on the later whorls instead of the plicate one of $N$. canaliculata, and more narrowly pyriform aperture with narrower posterior canal. It is, however, very doubtful that they really represent respectively different species.

They also closely resemble $N$. marmoreus A. ADAMs (1852, p. 106), living in south Philippines waters, in the general outline, but the former is provided with more distinct axial ribs, stronger growth lines, and infrasutural groove even on the body whorl. 
The distinction of the present specimens from N. picta DUNKeR (1846, p. 172), living also in Philippines waters, is not necessarily clear, but it may be acceptable that the former has less expanded anterior part of the labrum and narrower but more sharply ridged columellar callus. Moreover the coloration is quite different between the two. The figured specimen of Nassarius (Zeuxis) sp. cf. $N$. (Z.) picta of MACNEIL (1960, p. 81, pl. 17, fs. 12 and 13) may be included in $N$. dorsatus on the basis of the characteristic feature of the columellar callus as mentioned above.

Many species of Zeuxis show an apparent tendency for weakening the sculpture on the adult whorls, but the sculpture is clearly noticeable even on the last part of the body whorl. While the later whorls of Tarazeuxis are almost smooth except for the weak spiral grooves. The author is inclined to evaluate this difference to separate them at subgeneric level in spite of very close alliness.

Geological occurrence.-Upper Miocene to Pliocene (Indonesia).

Recent distribution.-Southeast Asian seas from southernmost Japan to the Philippines.

Horizon.-Santa Barbata Silt.

Locality.-SKGS-71.

\section{Nasssarius (Tarazeuxis) badius (A. ADAMs)}

Pl. 12, Figs. 9-12; Text-figs. 27 and 28

1852. Nassa badia A. AdAms, Proc. Zool. Soc. f. 1851, p. 107.

1853. Nassa badia, ReEve, Conch. Icon. Vol. 8, Nassa, pl. 10, f. 124.

1882. Nassa (Zeuxis) badia, Tryon, Man. Conch. Ist Ser. Vol. 4, p. 30, pl.9, fs. $76-82$.

Material.-GK-L 7089 to 7101 from one and same locality. Preservation is generally excellent.

\begin{tabular}{|c|c|c|c|c|c|c|c|c|c|}
\hline \multicolumn{10}{|c|}{ Measurements.- } \\
\hline $\begin{array}{l}\text { specimen } \\
\text { GK-L }\end{array}$ & $\underset{(\mathrm{mm})}{\mathrm{H}}$ & $\underset{(\mathrm{mm})}{\mathrm{Bd}}$ & $\underset{(\mathrm{mm})}{\mathrm{Ap}}$ & $\underset{(\mathrm{mm})}{\mathrm{D}}$ & $\underset{(\%)}{\mathrm{Bd} / \mathrm{H}}$ & $\underset{(\%)}{A p / H}$ & $\underset{(\%)}{D / H}$ & $\angle \underset{\text { de }}{\mathrm{A}}$ & $\underset{\text { ees) }}{\angle \mathrm{P}}$ \\
\hline 7089 & 13.45 & 9.40 & 7.15 & 7.00 & 69.8 & 53.2 & 52.1 & 73.1 & 42.3 \\
\hline 7090 & 12.30 & 8.80 & 6.25 & 6.80 & 71.5 & 50.8 & 55.3 & 81.9 & 49.4 \\
\hline 7091 & 12.10 & 8.60 & 6.25 & 6.10 & 71.0 & 51.6 & 50.5 & 76.3 & 39.4 \\
\hline 7095 & 13.40 & 9.60 & 7.00 & 7.20 & 71.5 & 52.3 & 53.6 & 76.1 & 50.4 \\
\hline $\begin{array}{l}\text { specimen } \\
\text { GK-L }\end{array}$ & $\mathrm{H}$ & $\begin{array}{c}\text { protoco } \\
\text { D }\end{array}$ & nur & & $\begin{array}{l}\text { teleo- } \\
\text { conch }\end{array}$ & $\begin{array}{r}\text { labru } \\
\text { teetr }\end{array}$ & & & \\
\hline 7089 & .76 & 1.0 & 2. & & 5.05 & 14 & & +3 & \\
\hline 7090 & .80 & 1.0 & 3. & & 4.55 & 16 & & +3 & \\
\hline 7091 & .80 & 1.0 & 3. & & 4.60 & 0 & & +3 & \\
\hline 7095 & .80 & 1.0 & 2. & & 5.00 & 18 & & +2 & \\
\hline
\end{tabular}

Descriptive remarks.-The present specimens, ovately fusiform small shells, are featured by their ornamentation and the aperture. The axial ribs are very slightly retrocurrently oblique, prickled at the upper suture, weakened to the lower suture, rather coarse counted by 12 to 13 , separated by the shallow interspaces, and crossed by a distinct infrasutural spiral groove on the first teleoconch whorl. Although this ornamentation is slightly weakened in the course of the 


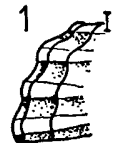

19 21

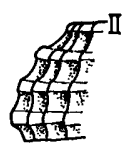

19 25

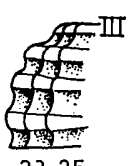

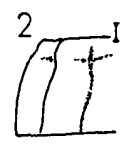

$12 \sim 13$

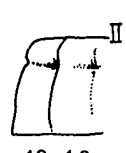

$12 \sim 16$
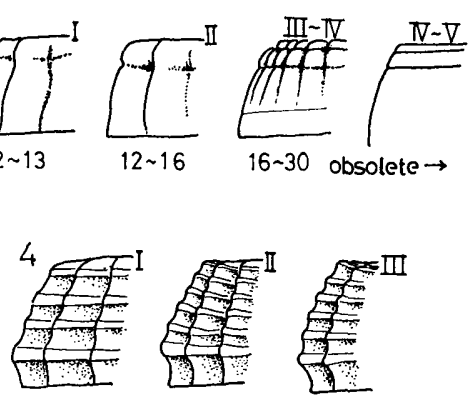

14

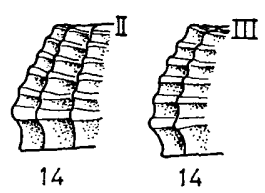

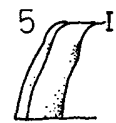

$12 \sim 14$

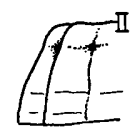

$14 \sim 15$
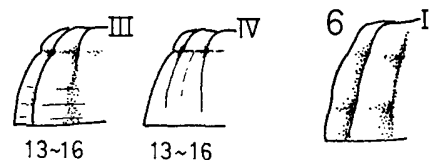

$15 \sim 16$
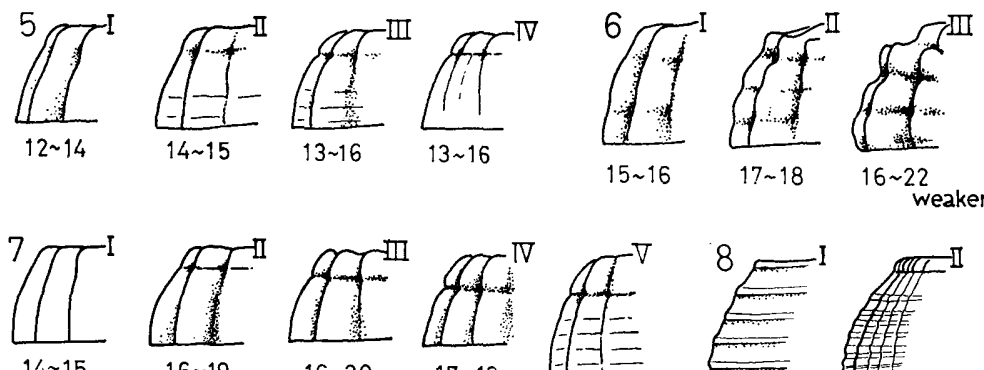

16 19

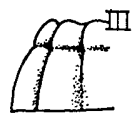

$16 \sim 20$
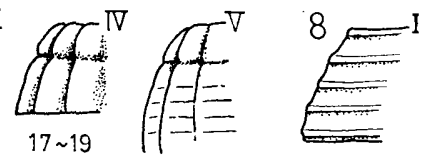

weaken $\rightarrow$

Fig. 28. Development of the ornamentation on the teleoconchs of some nassariids.

1: Nassarius (Niotha) gemmulatus (LAMARCK).

2: N. (Tarazeuxis) badius (A. ADAMS).

3: N. (Zeuxis) caelatus verbeeki (MARTIN).

4: Tritia (Tritonella) crenulicostata sp. nov.

5: Nassarius (N.) coronatus philippinensis subsp. nov.

6: N. (Plicarcularia) thersites (BRUGUIÉRE).

7: N. (Zeuxis) macrocephalus greyanus subsp. nov.

8: $N$. (Chelenassa) elegantissimus subgen. et sp. nov.

Numerical figures under respective profile of the whorl indicate the number of axials.

growth, it shows practically the same pattern still on the third as on the first whorl. On the fourth, however, the axials are abruptly reduced in elevation, increased in number, and only separated by narrow furrows from one another, while the spirals become distinct. It does not mean mere strengthening of the infrasutural groove but also the appearance of numerous striae on the lateral surface, which are especially distinct and pit-like at the axial furrows. Keeping pace with the mentioned change of the ornamentation, the suture is also modified remarkably. At first the suture is depressed but not channelled and the subsutural part has a faint stria close to the suture. In the course of the growth the suture becomes wide and channelled and the mentioned stria is rapidly increased in size to distinct groove and retreats from the suture downward. At the same time the second subsutural groove appears above the first one. In consequence the body whorl has a distinctly channelled suture, two infrasutural grooves, faint spiral striae on the lateral surface, and 6 to 7 distinct spiral grooves at the base, 
of which the lower one is stronger. The axials on the body whorl are only suggested by the obsolete granulations at the subsutural part and the irregularly spaced faint axial grooves. The growth lines are distinct. The roundly rhomboid aperture is moderately wide; the labrum is vertical, simple (not serrated), varicose outside, and denticulate inside. The inner lip is arcuate and provided with a distinct ridge respectively at some distance from the posterior end (parietal ridge) and at the end of the columellar lip. The callus is narrow for the family and moderately thick and provided with a few obsolete or weak plaitlike ridges. The coloration is not perfectly preserved but is considered to be simple and dark. The protoconch of the present specimens is moderately low conical with about three volutions, of which the last one and one-half to one and one-third volutions are sharply or moderately carinated at the lower third.

Comparison.-These features quite conform with those of Nassa badia A. AdAms from the Philippine waters. The present specimens are similar in shape to Amyclina IREDALE, 1918, with the type-species, Buccinum corniculum OLIVI, but the former is definitely distinguished from the latter in having the carinate protoconch and being devoid of the bulged basal fasciole.

TRYON considered that the present species is a synonym of Buccinum taenium GMELIN, the type species of Zeuxis, but the two are readily distinguished from each other. The latter is provided with the distinct axial plicae even on the body whorl, while on the former the axials are faded out on the penultimate whorl without any exception. It differs also from $N$. picta DuNKER in the early development of the ornamentation, although the morphological features on the later whorls are similar between the two species.

Recent distribution.-Southeast Asian waters.

Horizon.-Upper part of the Ulian Formation.

Locality.-SKGS-72.

Subgenus Plicarcularia THIELE, 1929

(type-species: Buccinum thersites BRUGUIÈRE by monotype)

Nassarius (Plicarcularia) thersites (BRUGUIÈRE)

Pl. 13, Figs. 17, 18, and 23-27; Text-fig. 28

1789. Buccinum thersites BRUGUIÈRE, Encyclopedie Methodique Tom. 1, p. 278, pl. 394, f. 8.

1844. Nassa thersites, Lamarck, Hist. d. Anim. s. Vert. Tom. 10, p. 180.

1853. Nassa thersites, REEvE, Conch. Icon. Vol. 8, Nassa, pl. 10, f. 65.

1882. Nassa thersites, TryoN, Man. Conch. Ist Ser. Vol. 4, p. 25, pl. 7, fs. 20 to 23.

1895. Nassa (Eione) leptospira, MarTin (non A. AdAMs), Samml. Geol. ReichsMus. Leiden, N. F. Bd. 1, Abt. 1, p. 105.

1895. Nassa (Eione) thersites, MarTin, ibid. p. 111, Taf. 18, fs. 256 and 256a.

1915. Nassa (Arcularia) thersites, Tesch, Paläont. v. Timor, Lief. 5, p. 58, Taf. 81, f. 126.

1961. Plicarcularia thersites, HABE, Colored Illustr. Shells Japan Vol. 2, p. 63, pl. 32 , f. 7 .

Material.-GK-L 6560 to 6564,6566 to 6569 , and 7503 to 7504 from one and same locality. Preservation is generally good. 


\begin{tabular}{|c|c|c|c|c|c|c|c|c|}
\hline \multicolumn{9}{|c|}{ Measurements.- } \\
\hline $\begin{array}{l}\text { specimen } \\
\text { GK-L }\end{array}$ & $\underset{(\mathrm{mm})}{\mathrm{H}}$ & $\underset{(\mathrm{mm})}{\mathrm{Bd}}$ & $\underset{(\mathrm{mm})}{\mathrm{Ap}}$ & $\underset{(\mathrm{mm})}{\mathrm{D}}$ & $\begin{array}{r}\mathrm{Bd} / \mathrm{H} \\
(\%)\end{array}$ & $\underset{(\%)}{\mathrm{Ap} / \mathrm{H}}$ & $\begin{array}{l}\mathrm{D} / \mathrm{H} \\
(\%)\end{array}$ & $\underset{\text { (degrees) }}{\angle \mathbf{P}}$ \\
\hline 6560 & 12.50 & 10.10 & 7.30 & 8.70 & 80.0 & 58.3 & 69.6 & 70.3 \\
\hline 6561 & 10.00 & 8.05 & 6.60 & 6.85 & 80.5 & 66.0 & 68.5 & 65.9 \\
\hline 6567 & 9.95 & 8.05 & 5.75 & 6.95 & 80.7 & 57.7 & 69.7 & 71.6 \\
\hline $\begin{array}{l}\text { specimen } \\
\text { GK-L }\end{array}$ & \multicolumn{3}{|c|}{$\begin{array}{l}\text { protoconch } \\
\text { numb. }\end{array}$} & \multicolumn{2}{|c|}{$\begin{array}{l}\text { teleo- } \\
\text { conch }\end{array}$} & $\begin{array}{l}\text { call } \\
\mathrm{H}(\mathrm{m}\end{array}$ & \multicolumn{2}{|r|}{$\underset{\text { labrum }}{\text { teeth }}$} \\
\hline 6560 & & & 3.0 & \multicolumn{2}{|c|}{ ca 5.0} & 10. & \multicolumn{2}{|r|}{9} \\
\hline 6561 & & & $1+$ & \multicolumn{2}{|c|}{4.5} & 8. & \multicolumn{2}{|r|}{10} \\
\hline 6567 & & & 2.3 & \multicolumn{2}{|c|}{4.0} & 8. & \multicolumn{2}{|r|}{7} \\
\hline
\end{tabular}

Remarks.-The present specimens are characterized by the solid and gibbous shell with axially ribbed conical spire and very wide and massive callus and readily identified to Plicarcularia THIELE, 1929.

The ornamentation of the first teleoconch consists of the widely spaced, rather thin 15-16 axial ribs and two weak primary spiral furrows, infrasutural and suprasutural. The suture has the horizontal shoulder. On the second whorl the median spiral furrow appears between the foregoing two, which become distinct giving the granular appearance. At the same time the shoulder becomes inclined. On the third whorl granulation becomes more distinct and a subsutural lira appears close to the suture. Thereafter the axials gradually become weak. The feature of the sculpture conforms with that of Plicarcularia thersites (BRUGUIERE). The ornamentation on the back of the body whorl is generally still distinct consisting of somewhat weak, close, and oblique axial riblets crossed by numerous spiral grooves even on the gibbous specimens of the present material, while it is obscure or very weak on the typical specimens of thersites according to REEVE. On this account the present specimens remind the author P. globosa (QUAY and GAIMARD) (1833, p. 448, pl. 32, fs. 25-27), but the latter has much closer riblets on the spire whorls and much more globose body whorl than the former. The majority of the present specimens, although gibbous at the back of the body whorl, are smaller than living $P$. thersites and never gibbous on the penultimate whorl. This suggests that the present specimens may be a primitive ancestral form or a pigmy variety of the species.

An Indonesian Quaternary specimen, reported as Nassa leptospira A. ADAMS by MARTIN, is almost perfectly identical to the present specimens in general features except for being devoid of the labrum dentition. All the specimens from Panay really have the labrum dentition, but that of GK-L 6560, the largest specimen, is very weak as illustrated on the photo-plate. This indicates the variability of the strength of the labrum teeth and MARTIN's Nassa leptospira should be included in $N$. (P.) thersites.

Geoolgical occurrence.-Pliocene (Indonesia).

Recent distribution.-Tropical Southeast Asian waters.

Horizon.-Santa Barbara Silt.

Locality.-SKGS-71. 
Subgenus Chelenassa subgen. nov. (type-species: Nassarius (Chelenassa) elegantissimus sp. nov.,
here designated)

Subgeneric diagnosis.-The shell is small attaining about $10 \mathrm{~mm}$ in height. The profile is ovoidofusiform with moderately high spire and gradually contracted base. The protoconch is low conical and paucispiral for the family with about 2.4 volutions, of which the last half to two-thirds volution is carinated. The end-mark of the protoconch is sharp. The teleoconch-whorls are round at sides and ornamented by fine reticulation of the close and regular axial riblets and spiral grooves throughout.

The body whorl is large, round at sides, and weakly gibbous at the back on the full grown specimens. The aperture is pyriform and narrowed by the thickening of the labrum and callus of the inner lip. The parietal ridge, columellar teeth, and labrum teeth are distinct. The callus is orbicular and large covering the entire front surface of the body whorl. The anterior notch of the aperture is remarkably deep.

Comparison.-The present subgenus resembles Plicarcularia in being provided with the gibbous body whorl and very large callus of cheleform. The former is, however, readily distinguished from the latter, because (1) the style of its morphological development is quite different from that of Plicarcularia and (2) its callus does not expanded beyond the suprasutural part of the penultimate whorl. This difference is as distinct as the difference between Nassarius (s.s.) and Zeuxis.

Nassarius (Chelenassa) elegantissimus sp. nov.

Pl. 13, Figs. 1-10, 13, 14, and 19-21; Text-figs. 27 and 28

Material.-Holotype: GK-L 6565 and paratypes: GK-L 6521 to 6538 from one and same locality.

\begin{tabular}{|c|c|c|c|c|c|c|c|c|c|}
\hline \multicolumn{10}{|c|}{ Measurements.- } \\
\hline $\begin{array}{l}\text { specimen } \\
\text { GK-L }\end{array}$ & $\underset{(\mathrm{mm})}{\mathrm{H}}$ & $\underset{(\mathrm{mm})}{\mathrm{Bd}}$ & $\underset{(\mathrm{mm})}{\mathrm{Ap}}$ & $\underset{(\mathrm{mm})}{\mathrm{D}}$ & $\underset{(\%)}{\mathrm{Bd} / \mathrm{H}}$ & $\underset{(\%)}{\mathrm{Ap} / \mathrm{H}}$ & $\begin{array}{l}\mathrm{D} / \mathrm{H} \\
(\%)\end{array}$ & \multicolumn{2}{|c|}{$\underset{\text { (degrees) }}{\angle \mathrm{A}}$} \\
\hline 6525 & 9.60 & 7.30 & 5.60 & 5.80 & 76.0 & 58.4 & 60.4 & 72.4 & 61.5 \\
\hline 6526 & 8.50 & 5.25 & 4.80 & 5.25 & 73.5 & 56.5 & 61.8 & 73.5 & 56.9 \\
\hline 6527 & 6.90 & 5.00 & 3.70 & 4.15 & 72.4 & 53.6 & 60.1 & 76.1 & 58.4 \\
\hline 6532 & 9.00 & 7.55 & 4.80 & 5.00 & 83.8 & 53.3 & 56.5 & 74.7 & 51.4 \\
\hline 6535 & 8.40 & 6.25 & 4.55 & 4.90 & 74.4 & 54.2 & 58.3 & - & 58.6 \\
\hline 6536 & 5.80 & 4.00 & 2.80 & 3.40 & 68.8 & 48.3 & 58.4 & 97.8 & 44.3 \\
\hline 6537 & 10.30 & 7.70 & 6.20 & 5.70 & 74.5 & 60.1 & 55.3 & - & 59.2 \\
\hline 6538 & 9.40 & 6.35 & 4.85 & 4.80 & 75.6 & 57.7 & 57.2 & - & 48.7 \\
\hline 6565 & 10.15 & 7.45 & 5.70 & 6.30 & 73.5 & 56.7 & 62.1 & - & 59.3 \\
\hline $\begin{array}{l}\text { specimer } \\
\text { GK-L }\end{array}$ & \multicolumn{3}{|c|}{$\begin{array}{c}\text { protoconch } \\
\text { D }\end{array}$} & numb. & $\begin{array}{l}\text { teleo } \\
\text { concl }\end{array}$ & \multicolumn{2}{|c|}{$\begin{array}{c}\text { callus } \\
\mathrm{H}(\mathrm{mm})\end{array}$} & \multicolumn{2}{|c|}{$\begin{array}{l}\text { denticles } \\
\text { col lab }\end{array}$} \\
\hline 6525 & .72 & \multicolumn{2}{|c|}{.76} & 2.0 & 4.7 & \multicolumn{2}{|c|}{7.40} & 4 & 8 \\
\hline 6526 & .50 & \multicolumn{2}{|c|}{.60} & 2.4 & 4.5 & \multicolumn{2}{|c|}{6.30} & 4 & 7 \\
\hline 6527 & - & \multirow{2}{*}{\multicolumn{2}{|c|}{$\overline{6 n}$}} & $\leftarrow$ & $\longrightarrow$ & \multicolumn{2}{|c|}{4.55} & 3 & 7 \\
\hline 6532 & .50 & & & 2.4 & 4.7 & \multicolumn{2}{|c|}{7.65} & 4 & 7 \\
\hline
\end{tabular}




$\begin{array}{lcclllll}6535 & - & - & 2.3 & 4.6 & \text { thin } & 4 & 8 \\ 6536 & .65 & .90 & 2.5 & 3.7 & \text { thin } & 5 & 8 \\ 6537 & - & - & 2.3 & 4.9 & \text { thin } & 3 & 0 \\ 6539 & - & - & 2.4 & 4.5 & \text { thin } & 2 & 0 \\ 6565 & .50 & .60 & 2.4 & 5.05 & 7.85 & 5 & 7\end{array}$

Diagnosis.-The shell is small attaining about $10 \mathrm{~mm}$ in height and ovately fusiform with bulbous body whorl and ratehr high and acute spire. The protoconch is roundly conical and paucispiral with about 2.4 volutions. The first volution is small, depressed, smooth, and horizontal tip; the second is very round and swollen at sides and smooth; and the last one half to one third volution is carinated. The carina is variable in strength ranging from blunt to sharp and also in position from the middle to lower one-third. The teleoconch-whorls are broadly and regularly rounded at the sides and ornamented with the regular reticulation consisting of the fine and close axial riblets and spiral grooves. The spiral grooves are weak on the axials. The axials are about 55 to 65 on the third whorl, slightly less on the earlier whorls, and also gradually decreased in number on the later whorls. They are counted less than 50 on the fourth whorl and much less on the body whorl, where the accurate counting is impossible because of the wide callus-cover on almost whole frontal area. On the holotype specimen the axials are 16 on the back of the body whorl. The spiral grooves become shallower and wider and hardly cross over the axials on the later whorls. They are still rather sharp on the body whorl of some specimens and step-like on the others including holotype. The suture is slightly impressed and provided with a subsutural lira, which is crenated and bordered by a wide groove below. The body whorl is large occupying about three-fourths of the total height, gibbous at the back, roundly convex at the sides, and moderately contracted at the base to the short snout, which is bordered by a raised spiral ridge.

The aperture is pyriform and narrowed by the thickening of the labrum and the callus on the inner lip. The labrum is thickened both inside and outside and coarsely denticulate inside. The inner lip is bent; the oblique parietal one is provided with a distinct ridge and the vertical columellar lip has a few denticulated ridges. The anterior notch is very deep. The callus is orbicular, wide, and thick covering 80 percent of the frontal part of the body whorl, but never reach the lower one-third of the penultimate whorl.

Comparison.-The high and acute spire, fine and regular reticulation of the ornamentation, and the orbicular and thick callus characterize the present species. It resembles Nassa leptospira A. ADAMS (1851, p. 103) in many characters including the outline of the shell, callus, and ornamentation, but the former is readily distinguished from the latter in having finer and closer axials than the latter. Nassa belluta A. ADAms is also an ally to this, but the latter is distinguished from the former on the basis of its much thinner and closer axials and less massive callus than the former. There is no other comparable species with such elegant sculpture as the present species.

Horizon.-Santa Barbara Silt.

Locality.-SKGS-71. 
Subgenus Niotha H. and A. ADAMs, 1853

(type-species: Niotha cumingii A. ADAMs by original designation)

Nassarius (Niotha) gemmulatus (LAMARCK)

P1. 12, Figs. 14, 15, and 17; Text-fig. 28

1844. Buccinum gemmulatum Lamarck, Hist. d. Anim. s. Vert. (Deshayes' ed.) Tom. 10, p. 169

1853. Nassa gemmulata, ReEve, Conch. Icon. Vol. 8, Nassa, pl. 5, f. 29.

1895. Nassa (Niotha) gemmulata var. MarTin, Samml. Geol. Reichs-Mus. Leiden, N. F. Bd.1, Abt. 1, p. 106, Taf. 17, f. 237.

1928. Nassa (Niotha) gemmulata, Yoкоyama, Imp. Geol. Surv. Japan, Rep. No. 101, p. 40 , pl. 2 , f. 8 .

1939. Nassarius (Niotha) gemmulatus, OostingH, de Ingenieur in Ned.-Indië 1939, No. 12, p. 185, pl. 16, fs. 290 and 291.

1951. Nassarius clathratus, (HIRASE) TAKI, Handb. Illustr. Shells pl.106, f.9.

1954. Nassarius (Niotha) clathratus, KIRA, Colored Illustr. Shells Japan, Vol. 1, p. 56, pl. 28, f. 19.

1960. Nassarius (Niotha) gemmulatus, MacNeIL, U. S. Geol. Surv. Prof. Pap. No. 339 , p. 79 , pl. 13, f. 29.

Material.-GK-L 6414 to 6415 from loc. SKGS-73 and GK-L 7490 from loc. SKGS-71. Preservation is almost perfect on all the specimens.

\begin{tabular}{|c|c|c|c|c|c|c|c|c|c|}
\hline \multicolumn{10}{|c|}{ Measurements.- } \\
\hline $\begin{array}{l}\text { specimen } \\
\text { GK-L }\end{array}$ & $\underset{(\mathrm{mm})}{\mathrm{H}}$ & $\underset{(\mathrm{mm})}{\mathrm{Bd}}$ & $\underset{(\mathrm{mm})}{\mathrm{Ap}}$ & $\underset{(\mathrm{mm})}{\mathrm{D}}$ & $\underset{(\%)}{\mathrm{Bd} / \mathrm{H}}$ & $\underset{(\%)}{\mathrm{Ap} / \mathrm{H}}$ & $\underset{(\%)}{\mathrm{D} / \mathrm{H}}$ & \multicolumn{2}{|c|}{$\angle \underset{\text { (degrees) }}{\mathrm{A}} \angle \mathrm{P}$} \\
\hline 6414 & 18.45 & 14.35 & 11.80 & 13.45 & 79.7 & 63.9 & 72.9 & 87.9 & 77.5 \\
\hline 6415 & 17.20 & 14.30 & 10.10 & 12.00 & 83.0 & 58.6 & 69.6 & 86.2 & 68.7 \\
\hline 7490 & 19.90 & 15.80 & 12.50 & 14.70 & 97.4 & 62.8 & 73.8 & 87.4 & 79.6 \\
\hline $7248^{*}$ & 27.00 & 19.45 & 14.60 & 18.45 & 71.0 & 54.0 & 68.4 & 72.2 & 64.6 \\
\hline $7250^{*}$ & 21.00 & 15.10 & 11.70 & 14.10 & 71.8 & 55.7 & 67.2 & 78.2 & 68.1 \\
\hline $7251^{*}$ & 21.05 & 15.25 & 11.05 & 13.55 & 72.4 & 52.4 & 64.4 & 78.3 & 61.7 \\
\hline $\begin{array}{l}\text { specime } \\
\text { GK-L }\end{array}$ & \multicolumn{3}{|c|}{$\begin{array}{c}\text { protoconch } \\
\mathrm{H}\end{array}$} & numb. & $\begin{array}{l}\text { teleo- } \\
\text { conch }\end{array}$ & \multicolumn{2}{|c|}{$\begin{array}{l}\text { suture } \\
\text { angle }\end{array}$} & \multicolumn{2}{|c|}{$\begin{array}{l}\text { whorl prifile } \\
D / H \text { on pen }\end{array}$} \\
\hline 6414 & .66 & \multicolumn{2}{|c|}{.80} & 3.1 & 5.30 & \multicolumn{2}{|c|}{2.7} & \multicolumn{2}{|c|}{$6.2 / 1.8=3.44$} \\
\hline 6415 & .60 & \multicolumn{2}{|c|}{.78} & 3.0 & 5.25 & \multicolumn{2}{|c|}{3.0} & \multicolumn{2}{|c|}{$5.4 / 1.85=2.92$} \\
\hline 7490 & .66 & \multicolumn{2}{|c|}{.90} & 2.9 & 5.40 & \multicolumn{2}{|c|}{5.8} & \multicolumn{2}{|c|}{$5.7 / 1.9=3.00$} \\
\hline $7248^{*}$ & .88 & \multicolumn{2}{|c|}{.92} & 2.7 & 6.95 & \multicolumn{2}{|c|}{3.6} & \multicolumn{2}{|c|}{$9.6 / 3.1=3.09$} \\
\hline $7250^{*}$ & .82 & \multirow{2}{*}{\multicolumn{2}{|c|}{.84}} & 3.3 & 6.20 & \multicolumn{2}{|c|}{8.9} & \multicolumn{2}{|c|}{$7.15 / 2.3=3.11$} \\
\hline $7251^{*}$ & .75 & & & 2.9 & 6.80 & 8 & & $6.75 / 2$ & $5=2.7$ \\
\hline
\end{tabular}

Remarks.-The protoconchs of the present specimens are low conical consisting of about three volutions, of which the first is small, depressed, and almost horizontal tip; the major part of the second volution is low, moderately convex, and round; the remainder one and a quarter to one and a third volutions are sharply carinated. The end of the protoconch is defined by a distinct curved and raised riblet. The ornamental design on the first whorl is the distinct cancellation of about 20 sharp axial riblets and four spiral lirae. The spirals consist of a subsutural $\left(\mathrm{P}_{1}\right)$, two peripheral $\left(\mathrm{P}_{2}\right.$ and $\left.\mathrm{P}_{3}\right)$, and a suprasutural lira $\left(\mathrm{P}_{4}\right)$, of

* Upper Pliocene specimens from Miaori, Taiwan. 
which the subsutural one is remarkably weaker than the others at the very beginning and the suprasutural one is separated below by a deep and wide groove from the suture. Subsequent development is stational. The axials are almost vertical, narrower than the interspaces, and moderately gemmulated and their development is also stational. The axials on the body whorl are almost equal in number between the specimen groups from Philippines and Taiwan.

The present specimens are quite identical to the living specimens of Niotha gemmulata (LAMARCK) from the Philippines waters in the general profile and the sculpture. The specimens from Panay are, however, remarkably smaller than the living ones, although the former shows the mature feature at the outer surface of the labrum.

The specimens from the Upper Pliocene of Miaori, Taiwan, together with MACNEIL's figured specimen from Okinawa illustrate the similar profile to $N$. cumingii A. ADAMS and N. reticosa A. ADAMs, living respectively in China Sea and the Philippines waters, but the ornament of these fossils is readily distinguished from that of the latter and perfectly conforms with that of $N$. gemmulata. This fact indicates that Niotha gemmulata is rather variable in morphology.

N. clathrata LAMARCK $(1799$, p. 79$)$ is another ally to the present species, but the former has much more crude sculpture than the latter.

N. gemmulifera A. AdAMs (1851, p. 99, REEVE, 1853, pl. 20, fs. 132a and b) may be conspecific with gemmulata, although the former is somewhat smaller and very slightly slenderer than the latter.

Geological occurrence.-Pliocene (Indonesia, Taiwan, Okinawa, and India) and Pleistocene (Okinawa and Southwest Japan).

Recent distribution.-Indo-Pacific form Red Sea to Southwest Japan through Indonesia.

Horizons.-Santa Barbara Silt and upper part of the Ulian Formation.

Localities.-SKGS-71 and 73.

Genus Glabrinassa gen. nov.

(type-species: Glabrinassa amycliforma sp. nov., here designated)

Generic diagnosis.-The shell is moderately small and ovoid fusiform with rather slender outline for the family. The protoconch is polygyrate and moderately high conical with a blunt peripheral keel on the later volutions. The teleoconch is quite smooth and polished except on the snout and the lower part of the basal surface, where the spirals are discernible like as on Amyclina. The whorls are regularly and broadly rounded at side and separated one another by the fine channelled suture. The aperture is rhomboid with shallow but distinct posterior canal and the deep and wide anterior notch. The labrum is almost vertical in profile, very slightly sigmoidally curved, varicosely thickened outside, and provided with numerous weak dentitions inside. The very margin of the labrum is thin and sharp and provided with a few serrations at the anterior part. The inner lip is arcuate and defined at the anterior end by a spiral ridge. The callus is moderately thick, narrow and provided with a parietal ridge. The relief of the callus is the mere reflexion of the spiral ornamentation under the callus. 
Comparison.-As to the general outline the present genus is similar to Amyclina IREDALE, 1918, but the former differs from the latter in having the entirely smooth spire whorls from the very beginning of the first whorl to the penultimate one and also being provided with the high conical and bluntly carinate protoconch.

It is easily distinguished from Bullia GRAY (in GRIFFITH), 1833, in the features of the suture and snout inspite of the apparent similarity in the shellform. The suture of Bullia is filled with the callous material and its snout is not defined being devoid of the basal contraction. There is no other similar genus in Nassariidae with fusiform outline, round and perfectly smooth whorls, and carinate protoconch.

The phylogenetic relation of Glabrinassa to the known taxa is not certain, but the following facts seem very suggestive. Zeuxis, Tarazeuxis, and Glabrinassa are, on one hand, similar one another in the characters of the protoconch and profile of the whole shell. On the other hand they illustrate an apparent morphoseries. Zeuxis shows a distinct tendency for degeneration of the sculpture on the last whorl, while the sculpture disappears on the penultimate whorl of Tarazeuxis and Glabrinassa is devoid of it even at the beginning of the teleoconch. Hence the author postulates the possible evolutional trend from Zeuxis to Glabrinassa via Tarazeuxis.

Glabrinassa amycliforma sp. nov.

Pl. 13, Fig. 22 and Pl. 14, Figs. 6, 8, and 10; Text-fig. 27

Material.-Holotype: GK-L 7511 from loc. SKGS-72 and paratype: GK-L 7410 from loc. SKGS-73.

\begin{tabular}{|c|c|c|c|c|c|c|c|c|c|}
\hline \multicolumn{10}{|c|}{ Measurements.- } \\
\hline$\underset{\text { GK-L }}{\text { specimen }}$ & $\underset{(\mathrm{mm})}{\mathrm{H}}$ & $\underset{(\mathrm{mm})}{\mathrm{Bd}}$ & $\underset{(\mathrm{mm})}{\mathrm{Ap}}$ & $\underset{(\mathrm{mm})}{\mathrm{D}}$ & $\underset{(\%)}{\mathrm{Bd} / \mathrm{H}}$ & $\underset{(\%)}{\mathrm{Ap} / \mathrm{H}}$ & $\underset{(\%)}{\mathrm{D} / \mathrm{H}}$ & \multicolumn{2}{|c|}{$\underset{\text { (degrees) }}{\mathrm{A}} \quad \angle \mathrm{P}$} \\
\hline 7410 & 12.65 & 8.80 & 6.35 & 6.45 & 69.5 & 50.2 & 50.9 & - & 41.5 \\
\hline 7411 & 11.90 & 8.40 & 6.40 & 6.45 & 70.6 & 53.8 & 54.1 & 70.5 & 47.5 \\
\hline $\begin{array}{l}\text { specimen } \\
\text { GK-L }\end{array}$ & \multicolumn{2}{|c|}{$\begin{array}{c}\text { whorls } \\
\text { proto+teleo }\end{array}$} & \multicolumn{5}{|c|}{$\begin{array}{l}\text { whorl profile } \\
\mathrm{D} / \mathrm{H} \text { on pen }\end{array}$} & & \\
\hline 7410 & \multicolumn{2}{|c|}{6.0} & \multicolumn{2}{|c|}{7.2} & \multicolumn{3}{|c|}{$4.65 / 1.6=2.80$} & & \\
\hline 7411 & \multicolumn{2}{|c|}{8.9} & \multicolumn{2}{|c|}{7.8} & \multicolumn{3}{|c|}{$3.38 / 1.45=2.33$} & & \\
\hline
\end{tabular}

Diagnosis.-The shell is moderately small and ovoid-fusiform with slender outline. The protoconch is moderately low conical with very small tip like Zeuxis and consists of about three and two-thirds volutions. The details of the early volutions are not clear because of removal of the surface shell-layer. The second last volution, at least, seems to have peripheral angulation or keel, which is indicated by the configuration of the inner shell-layer. The last half volution is lirated at slightly below the middle as the extension of the earlier peripheral angulation (or keel). The end mark of the protoconch does not exist. The teleoconch-whorls are convex, regularly rounded, smooth, and polished except for the base of the body whorl. The suture is narrowly canaliculate. The body whorl is large occupying about 70 percent of the total height, moderately contracted at 
the base to the short and straight snout. The lower part of the basal slope is encircled with three spiral grooves, of which the lower one is wider than the upper ones. The snout is also provided with six spiral threads, of which the second and third upper ones are very weak and the uppermost one is prominent and continues to the margin of the anterior notch. The aperture is ovatorhomboidal with narrow and shallow posterior canal and the very deep and wide anterior notch. The labrum is almost vertical, very slightly sigmoidally curved, moderately varicose outside, and weakly denticulate inside. The inner lip is arcuate and covered by the narrow and moderately thick callus. The parietal ridge bordering the posterior canal is weak and the plait marking the end of the columella is prominent.

Comparison.-The present specimens are somewhat similar to Nassa pallidula A. ADAMs living in Malacca. The former is, however, readily distinguished from the latter in being provided with the peculiar protoconch and quite smooth spire-whorls.

There is no other known species comparable to the present specimens.

Horizon.-Upper part of the Ulian Formation.

Localities.-SKGS-72 and 73.

Genus Tritia RIsso, 1826*

(type-species: Buccinum reticulatum LINNÉ by subsequent designation, GRAY, 1847)

Subgenus Phrontis H. and A. AdAms, 1853

(type-species: Nassa tiarula KIENER by subsequent designation, CoSSMANN, 1901)

\section{Tritia (Phrontis) sp. cf. T. (P.) ovoidea (SCHEPMAN) \\ Pl. 13, Figs. 11 and 12}

1911. Nassa (Alectrion, Aciculina ?) ovoidea SchePMAN, Siboga Exped. Prosobranchia, p. 316, Taf. 20, fs. $1 \mathrm{a}$ and b.

Material.-GK-L 6986. A single almost perfect specimen.

\begin{tabular}{|c|c|c|c|c|c|c|c|c|}
\hline \multicolumn{2}{|c|}{ Measurements.- } & \multirow[b]{2}{*}{$\underset{(\mathrm{mm})}{\mathrm{Bd}}$} & \multirow[b]{2}{*}{$\underset{(\mathrm{mm})}{\mathrm{Ap}}$} & \multirow[b]{2}{*}{$\underset{(\mathrm{mm})}{\mathrm{D}}$} & \multirow[b]{2}{*}{$\begin{array}{r}\mathrm{Bd} / \mathrm{H} \\
(\%)\end{array}$} & \multirow[b]{2}{*}{$\underset{(\%)}{A p / H}$} & \multirow[b]{2}{*}{$\underset{(\%)}{\mathrm{D} / \mathrm{H}}$} & \multirow[b]{2}{*}{$\underset{\text { (degrees) }}{\angle \mathrm{P}}$} \\
\hline $\begin{array}{l}\text { specimen } \\
\text { GK-L }\end{array}$ & $\underset{(\mathrm{mm})}{\mathrm{H}}$ & & & & & & & \\
\hline 6986 & 6.95 & 4.70 & 3.30 & 3.95 & 67.6 & 47.5 & 56.8 & 46 \\
\hline specimen $_{\text {GK-L }}$ & $\mathrm{H}$ & & & & I & $\underset{\text { II }}{\text { axials }}$ III & IV & \\
\hline 6986 & .60 & .90 & .5 & .1 & 12 & 18 & 22 & \\
\hline
\end{tabular}

Remarks.-The present specimen, although it is slightly abraded at the protoconch, is characteristic enough to serve for the taxonomical comparison. It is featured by its small and ovoid shell, very short snout, regularly spaced and elected axial riblets, close and distinct spiral grooves, massive labrum varix, prominent labrum teeth, and narrow but thick callus with a strong parietal plait

* Synonym: Hinia (LEACH) in Gray, 1847. 
and several pustules. With these characteristics it almost perfectly conforms with Nassa ovoidea Schepman living in Indonesian waters. The only visible difference is that the present specimen is provided with wider axial riblets than $N$. ovoidea, on which the axial riblets are narrower than the interspaces.

Nassarius ovum MARTIN is very variable species; some of the specimens are provided with the distinct parietal plait and the others are devoid of it. Comparing with the specimen-group of $N$. ovum with parietal plait the present specimen shows more oval outline, wider axial riblets, stronger spiral grooves, and shorter snout. They are considered to be separated each other at the specific level.

The characteristic features of the present species almost conform with the diagnosis of Phrontis $\mathrm{H}$. and A. ADAMs, but the former has so stronger spiral ornamentation than the latter that the definite identification can not be given. The author, however, prefers to include it in Phrontis on the basis of the general identity in the apertural features.

Recent distribution.-Indonesian waters.

Horizon.-Upper part of the Dingle Formation.

Locality.-SKGS-74.

Subgenus Tritonella A. ADAMs (in H. and A. ADAMs), 1853

(type-species: Tritonium incrassatum O. F. MÜLLER by original designation)

Tritia (Tritonella) crenulicostata sp. nov.

Pl. 17, Figs. 7, 8, and 9; Text-fig. 28

Material.-Holotype: GK-L 6987. A single almost perfect specimen with slightly eroded protoconch.

\begin{tabular}{|c|c|c|c|c|c|c|c|c|}
\hline \multicolumn{9}{|c|}{ Measurements.- } \\
\hline $\begin{array}{l}\text { specimen } \\
\text { GK-L }\end{array}$ & $\underset{(\mathrm{mm})}{\mathrm{H}}$ & $\underset{(\mathrm{mm})}{\mathrm{Bd}}$ & $\underset{(\mathrm{mm})}{\mathrm{Ap}}$ & $\underset{(\mathrm{mm})}{\mathrm{D}}$ & $\begin{array}{l}\mathrm{Bd} / \mathrm{H} \\
(\%)\end{array}$ & $\underset{(\%)}{\mathrm{Ap} / \mathrm{H}}$ & $\begin{array}{l}\mathrm{D} / \mathrm{H} \\
(\%)\end{array}$ & $\underset{\text { (degrees) }}{\angle \mathrm{A}} \angle \mathrm{P}$ \\
\hline 6987 & 5.7 & 3.3 & 2.2 & 3.1 & 57.9 & 38.6 & 54.4 & са 67 \\
\hline specimen & \multicolumn{8}{|c|}{ protoco } \\
\hline 6987 & .74 & .7 & 3.4 & & & 14 & 14 & 17 \\
\hline
\end{tabular}

Diagnosis.-The shell is very small less than $6 \mathrm{~mm}$ in height and bucciniform with moderately high spire and short base. The protoconch is high conical consisting of 3.4 smooth volutions. The end of the protoconch is marked by a curved fine line. The teleoconch consists of 4.3 whorls, which are ornamented by the prominent axial ribs and spiral threads. The spiral threads are fine but remarkably raised and separated one another by wider interspaces. The first whorl is sharply carinated at the lower two-sevenths of the whorl-height. The surface above the carina is steeply sloped and slightly convex and the surface below the carina is concave and remarkably receded. There are four spiral threads at the very beginning of the first whorl at and above the carina, of which the upper one is successively weaker than the lower one. At the middle of the first whorl the very weak fifth thread $\left(\mathrm{P}_{-5}\right)$ appears below the suture and then the sixth $\left(\mathrm{P}_{-6}\right)$ appears on the second whorl and so on. At the same time the relative position of each 
thread gradually moves toward the lower suture. That is to say the development of the spirals is abapical. On the penultimate whorl there are seven lirae at and above the peripheral carina and another one comes out under the overlapping part of the succeeding whorl. The secondary thread does not appear on the spire whorls and only two secondaries are visible at the lowest two interspaces on the basal slope of the body whorl.

The axials are prominent, wider than the interspaces, almost vertical, and counted by 14, 14, 14, and 17 respectively on the first to fourth whorl. Distinct crenulations are developed at the crossings of the axials with the spirals. The surface above the peripheral carina becomes more and more roundly convex in the course of growth and consequently the body whorl is so regularly rounded at sides that the peripheral carina can be hardly recognized. The basal contraction is distinct; the boundary between the basal surface and the snout is marked by a wide and deep spiral sulcus. The snout is short and encircled by about six threads, of which the uppermost one is by far the strongest and borders the spiral sulcus mentioned above.

The aperture is ovoid with bluntly pointed posterior end and a short but well defined anterior canal. The outer lip is provided with a massive varix outside and six denticles inside, of which the lowest one is prominent and defines the entrance of the canal and the third upper one is second largest. The inner lip is covered by a moderately narrow but thick callus, which is provided with a prominent parietal ridge and several irregular wrinkles. The anterior canal is very short, apparently separated from the labrum and columella and deeply notched at the end.

Comparison.-This small nassariid specimen is characterized by the prominent axial ribs and the strong spiral threads which render to the shell a crenulated cancellation. The aperture is provided with massive labrum varix, distinct labrum teeth, and parietal plait. On this morphological basis it is reasonably included in Tritonella A. ADAMs, 1853.

It shows some similarity to Nassa (Uzita) varicosecostata Fischer (1927, p. 77, Taf. 213, f. 49) from the Pliocene of Seram, which is also included in Tritonella with characteristic features. The present specimen is, however, readily distinguished from FISCHER's species in having the less convex spire-whorls, distinctly contracted part above the suture and more numerous axial ribs than the latter. Furthermore the protoconch of the present species consists of more numrous volutions. Some living species resembling the present one are also separated from the latter being devoid of the peculiar contraction above the suture.

Horizon.-Upper part of the Dingle Formation.

Locality.-SKGS-74. 
Family Fasciolariidae

Subfamily Fasciolariinae

Genus Latirus MoNTfort, 1810*

(type-species: Latirus aurantiacus MONTFORT=Murex gibbulus GMELIN

by original designation)

Subgenus Dolicholatirus BELLARDI, 1884**

(type-species: Turbinella bronni MrCHeLOTTI by original designation)

Latirus (Dolicholatirus) esi (KOPERBERG)

Pl. 10, Figs. 5 and 6

1931. Pseudolathyrus esi KoPERBERG, $2^{\text {e }}$ Nederlandsche Timor-Expeditie, Lief. 7 , p. 95 , pl. 3 , f. 34 .

Material.-GK-L 6955. The protoconch and the earliest whorl are broken off.

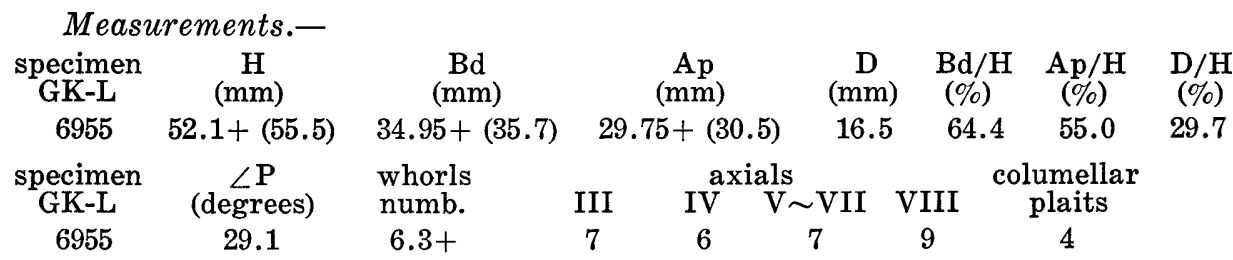

Remarks.-The specimen in hand conforms almost perfectly with Pseudolathyrus esi KOPERBERG from the Upper Pliocene of Timor except for somewhat narrower axials than the latter. This species is devoid of the concave smooth ramp below the suture, which is one of the most characteristic features of Pseudolathyrus BeLlard, 1884. The former, furthermore, has the aperture being distinctly narrowed at the entrance of the canal. Evaluating these facts it is better to be included in Dolicholatirus, although it has stronger axials than the type species of the genus and four columellar plaints instead of two of the latter.

The present species shows some similarity to Latirus gerthi WANNER and HAHN (1935, p. 248, Taf. 18, fs. 8-10) from the Miocene of Java, but the former is remarkably slenderer with longer and more straight canal than the latter. The axials of the present species are thinner and more numerous and the columellar plaits are twice as many as those of the latter.

Geological occurrence.-Upper Pliocene (Timor).

Horizon.-Upper part of the Dingle Formation.

Locality.-SKGS-74.

\section{Latirus (Dolicholatirus) fusiformis TESCH \\ Pl 11, Figs. 1 and 2; Text-fig. 30}

* Synonym: Lathyrus LATreille, 1825; Lathira ANDRzeJouski, 1830; and Lathirus J. E. Gray (in M. E. Gray), 1842.

** Synonym: Dolicholathyrus CossmanN, 1901. 
1915. Latirus fusiformis Tesch, Paläont. v. Timor, Lief. 5, p. 55, Taf. 81, fs. 119a and $\mathrm{b}$.

Material.-GK-L 6901. A single immature specimen. Preservation is almost perfect.

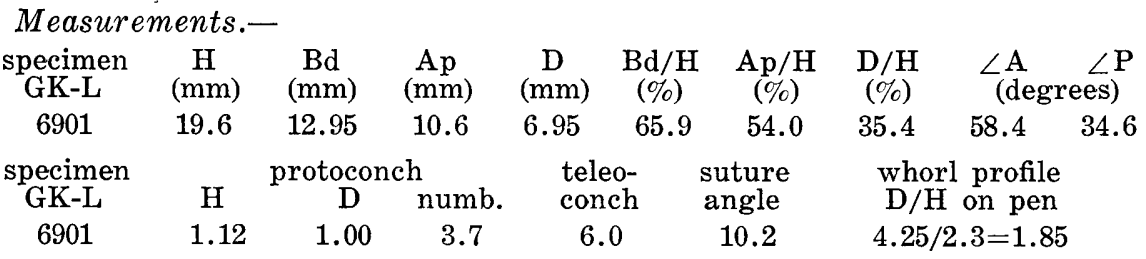

Remarks.-The present specimen is almost perfectly preserved except for the labrum. The protoconch is typically conical with about 3.7 volutions, of which the first one is very small, smooth, and horizontal tip; the second and the third volutions are also smooth and slightly rounded at the sides; and the last one is similar in profile to the preceding one but is provided with the curved axial riblets on its last one-third volution. The suture is very shallowly impressed. The end of the protoconch is marked with a coarse and curved axial rib, the oral side of which is provided with apparent primary spiral threads. The primary spiral ornamentation on the first teleoconch-whorl consists of five threads, of which the uppermost one $\left(P_{1}\right)$ is close to the suture and moderately weak, the fourth $\left(\mathrm{P}_{4}=\mathrm{Per}\right)$ is at the peripheral angulation and the strongest, the third $\left(\mathrm{P}_{3}\right)$ is situated slightly closer to the fourth than the subsutural one and the second largest, the fifth thread $\left(\mathrm{P}_{5}\right)$ is partly covered at the lower suture by the succeeding whorl, and the second thread $\left(\mathrm{P}_{2}\right)$ is at the middle of the interspace between the subsutural $\left(\mathrm{P}_{1}\right)$ and the third $\left(\mathrm{P}_{3}\right)$ one and the weakest. The arrangement of the primary spirals is stational through the growth stages, but the ornamentation becomes elaborate through the intercalation of the secondary and the tertiary lines. The secondary and the tertiary lines are intercalated on the third and fifth whorl respectively.

The axial folds are prominently elected, slightly granulated at the crossings with the spirals, narrower than the interspaces, and seven on both the early and last whorls, while the juvenile whorls have the folds of less number. The columellar plaits are two and situated at the entrance of the canal. The inside of the labrum is ornamented by the spiral teeth-like threads.

The present specimen is clearly included in Dolicholatirus on the basis of the morphological features mentioned above. It almost perfectly conforms with Latirus fusiformis TESCH from Pliocene and Quaternary of Timor except for the size of the shell and the details of the protoconch. The difference in size of the present specimen from TESCH's seems to depend simply on the growth stage, because TESCH's type-specimen has seven teleoconch-whorls instead of six of the present one. The protoconch-volution with brephic axials is one-third on the present specimen, while on TESCH's specimen one full volution has brephic axials. Although it is not decissive whether the mentioned kind of difference is valid to separate the species or not, the author is inclined to deal them conspecific. 
The present specimen is also allied to "Pseudolathyrus burcki KoPERBERG" (1931, p. 95, Taf. 3, f. 33), but the former is distinguished from the latter in being less contracted at the base and provided with two columellar plaits at the entrance of the canal instead of only one on burcki.

Geological occurrence.-Pliocene and Pleisstocene (Indonesia).

Horizon.-Upper part of the Dingle Formation.

Locality.-SKGS-74.

Genus Ollaphon IREDALE, 1929

(type-species: Trophon molorthus HEDLEY and MAY by original designation)

Ollaphon ? sp. aff. O. ? gembacanus (MARTIN)

Pl. 11, Figs. 11-13; Text-figs. 29 and 30
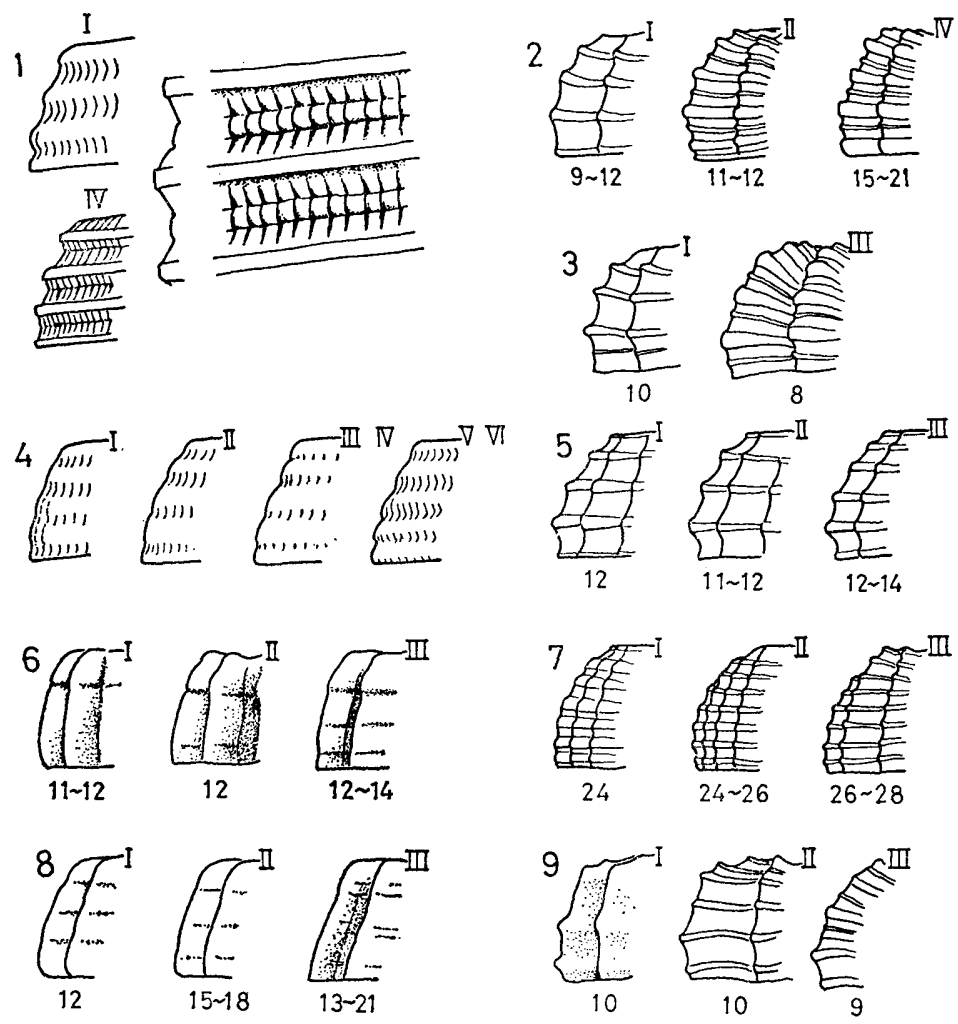

Fig. 29. Development of the ornamentation on the teleoconchs of some Neogastropoda.
1: Tiara flammea (QUAY et GAIMARD).
2: Phos (Philindophos) dijki Martin, subgen. nov.
3: Pollia martini sp. nov.
4: Tiara gerthi philippinensis subsp. nov.
5: Ollaphon? sp. aff. O.? gembacanus (MARTIN).
6: Vexillum (Costellaria) cruentatum greyi subsp. nov.
7: Merica asperella varicosa subsp. nov.
8: Vexillum (Pulchritima) schepmani KOPERBERG.
9: Scalptia crenifera (SowERBY). 

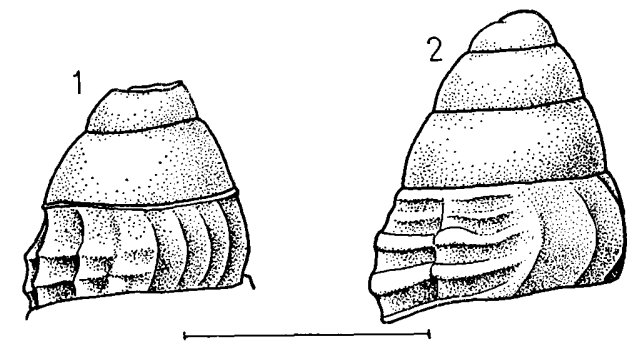

Fig. 30. Protoconchs of some

Neogastropoda.

1: Ollaphon? sp. aff. O.? gembacanus (MARTIN), GK-L 6898.

2: Latitus (Dolicholatirus) fusiformis TeSCH, GK-L 6901.

Unit bar indicates $1 \mathrm{~mm}$.

1883-87. Fusus gembacanus Martin, Samml. Geol. Reichs-Mus. Leiden, Ser. 1, Bd. 3, p. 105, Tab. 6, f. 103.

Material.-GK-L 6896 to 6900 from one and same locality.

\begin{tabular}{|c|c|c|c|c|c|c|c|c|c|}
\hline \multicolumn{10}{|c|}{ Measurements.- } \\
\hline $\begin{array}{c}\text { specimen } \\
\text { GK-L }\end{array}$ & $\underset{(\mathrm{mm})}{\mathrm{H}}$ & $\underset{(\mathrm{mm})}{\mathrm{Bd}}$ & $\underset{(\mathrm{mm})}{\mathrm{Ap}}$ & $\underset{(\mathrm{mm})}{\mathrm{D}}$ & $\underset{(\%)}{\mathrm{Bd} / \mathrm{H}}$ & $\underset{(\%)}{\mathrm{Ap} / \mathrm{H}}$ & $\begin{array}{l}\mathrm{D} / \mathrm{H} \\
(\%)\end{array}$ & \multicolumn{2}{|c|}{$\angle \underset{\text { (degrees) }}{\mathrm{A}} \angle \mathrm{P}$} \\
\hline 6897 & 8.35 & 5.15 & 3.70 & 3.60 & 61.6 & 44.2 & 43.1 & 59.9 & 25.5 \\
\hline 6898 & 9.60 & 5.70 & 4.15 & 3.80 & 59.4 & 43.2 & 39.7 & 51.2 & 24.9 \\
\hline $\begin{array}{l}\text { pecimen } \\
\text { GK-L }\end{array}$ & \multicolumn{2}{|c|}{$\begin{array}{l}\text { protoconch } \\
\text { D numb. }\end{array}$} & $\begin{array}{l}\text { teleo } \\
\text { conch }\end{array}$ & $\begin{array}{l}\text { suture } \\
\text { angle }\end{array}$ & \multicolumn{2}{|c|}{$\begin{array}{l}\text { whorl profile } \\
\mathrm{D} / \mathrm{H} \text { on pen }\end{array}$} & & & \\
\hline 6897 & .80 & ca 3.5 & 4.9 & 11.5 & \multirow{2}{*}{\multicolumn{2}{|c|}{$2.45 / 1.1=2.22$}} & & & \\
\hline 6898 & .80 & $2+$ & 5.5 & 8.0 & & & & & \\
\hline
\end{tabular}

Remarks.-The present specimens are featured by their small fusiform shell, regular ornamentation consisting of the vertical, thin, but strong axial ribs and thin but sharply raised spiral threads, and moderately long, rather wide, and simple anterior canal. The conical protoconch consists of about three and a half convex volutions, of which the last one-third is provided with thin and close brephic axials. The primary spiral threads are four on the spire-whorls. The uppermost one $\left(\mathrm{P}_{1}\right)$ is subsutural and the lowest one $\left(\mathrm{P}_{4}\right)$ conincides with the peripheral angulation at lower one-fifth of the whorl. The third one $\left(\mathrm{P}_{3}\right)$ is at about the middle and also forms a weak angulation. The second $\left(\mathrm{P}_{2}\right)$ may start at the very beginning of the teleoconch together with the others or may appear later by one-fifth whorl than the others. The primary spirals are thin but raised especially on the axial ribs. The axial ribs are about tewlve on the first whorl and gradually increased in number through the growth stages to 17 to 18 on the last whorl. They are prominent at the periphery and somewhat weakened both anteriorly and posteriorly and disappear on the basal surface of the body whorl, but reach clearly the upper suture. The axial ribs are sharply defined by the steep sides and separated from one another by the flat and wider interspaces.

The aperture is pyriform with the bluntly pointed posterior end and somewhat oblique and rather widely open anterior canal. The inner lip is curved, covered with a callus, and devoid of neither columellar plaits nor wrinkles. The callus is thin at the columellar lip and thick at the parietal one. The outer lip is almost vertical in profile, simple at the edge, and lirated inside.

The present specimens are closely similar to Fusus gembacanus MARTIN from 
the Miocene of Java in the features mentioned above. The former is, however, clearly distinguished from the latter in being remarkably smaller in size, broader in the general outline, and provided with definitely shorter snout than the latter. The obliquity of the anterior canal is less on the latter. It is not certain whether the differences just noted should be treated as the criteria for specific, subspecific, or intraspecific separation. Hence the author suspends the concrete identification.

Fusus gembacanus very closely resembles Trophon molorthus HEDLEY and MAY, the type-species of Ollaphon IREDALE, 1929, in the general diagnosis. WENZ placed the genus Ollaphon in the subfamily Fasciolariinae, but it may be reasonable to include it in Fusinae because Ollaphon is devoid of the columellar plait or teeth.

The present species is readily distinguished from Microcolus CoTTON and GoDFREY, 1932, with the type-species, Fusus dunkeri JoNAs, in being provided with the teeth-like threads inside the labrum.

Geological occurrence.-Miocene (Indonesia).

Horizon.-Upper part of the Dingle Formation.

Locality._SKGS-74.

Genus Clavilithes SwaInson, 1840*

(type-species: Fusus longaevus DESHAYES=Fusus parisiensis MAYER-EYMER by subsequent designation, GraBAU, 1904)

Subgenus Clavilithes (s.s.)

Clavilithes (Clavilithes) tjidamarensis (MARTIN)

Pl. 10, Figs. 7, 10, 13, and 14

1879-80. Strombus ? fusus, MARTin (non LiNNÉ), Tertiärschicht. v. Java, p.50, Tab. 9, f. 9.

1879-80. Fusus tjidamarensis MarTin, ibid. p. 58, Tab. 10, f. 7.

1881-83. Cyrtulus fusus, MarTin, Samml. Geol. Reichs-Mus. Leiden, Ser. 1, Bd.1, p. 100.

1881-83. Fusus tjidamarensis, Martin, ibid. p. 214, Tab. 9, f. 14.

1883-87. Fusus (Cyrtulus) tjidamarensis, MARTiN, ibid. Bd. 3, p. 100.

1895. Fusus (Clavella) tjidamarensis, Martin, ibid. N. F. Bd.1, Abt.1, p.86, Taf. 13, fs. 199 and 200.

1935. Clavilithes verveeki var acutangula WANNER and HAHN, Zeitschr. Deutsch. Geol. Gesel. Bd. 87, p. 248, Taf. 18, fs. 5-7

1939. Clavilithes verbeeki, Oostingh (non MARTIN), Ingen. Ned.-Indië, 1939, No. 8, p. 105, Taf. 12, fs. 217 and 218.

Material.-GK-L 6933 and 6969 from one and same locality.

$\begin{array}{cccccc}\begin{array}{c}\text { Measurements.- } \\ \text { specimen } \\ \text { GK-L }\end{array} & \begin{array}{c}\mathrm{H} \\ (\mathrm{mm})\end{array} & \begin{array}{c}\mathrm{Bd} \\ (\mathrm{mm})\end{array} & \begin{array}{c}\mathrm{D} \\ (\mathrm{mm})\end{array} & \begin{array}{c}\angle \mathbf{P} \\ (\text { degrees })\end{array} & \begin{array}{c}\text { teleoconch } \\ \text { numb. }\end{array} \\ 6933 & 124.4+ & 89.6+ & 46.10 & 57.5 & 7+ \\ 6969 & 43.3+ & 34.0 & 16.05 & 56.5 & 6+\end{array}$

Remarks.-The adult shell of Clavilithes tjidamarensis (MARTIN) so closely

* Synonym: Clavalithes SwaInson, 1840 and Clavellithes Gray, 1847. 
resembles C. verbeeki (MARTIN) (1895, p. 85, Taf. 12, fs. 188-192 and Taf. 13, fs. 193-198) that the distinction is seemingly difficult. The close examination, however, clarifies that the ornamental development is remarkably different between the two. Firstly the prominent subsutural band of $C$. tjidamarensis consists of the twin lirae on the early whorls and readily distinguished from the simple and moderately fine subsutural band of $C$. verbeeki. Secondly on the specimens of C. tjidamarensis the secondary and tertiary spirals appear remarkably earlier stage than on C. verbeeki. Thirdly the prominent axial folds and distinct spirals keep their strength untill the adolescent, or in some case even on the penultimate whorl on $C$. tjidamarensis, while they generally become weak on earlier whorls on C. verbeeki.

MARTIN mentioned that the long and straight snout of $C$. tjidamarensis contrasts to the slightly curved one of $C$. verbeeki, but the author can not agree with his opinion, because this apparent difference simply depends upon the difference of the growth stage.

Under such circumstance as mentioned above the author believes that Clavilithes tjidamarensis should be separated at the species level from $C$. verbeeki.

The present specimens are quite identical with $C$. tjidamarensis with the basic characteristics noted above.

Clavilithes verbeeki var. acutangula WANNER and HAHN (1935, p. 248, Taf. 18, fs. 5-7) has the prominent subsutural band and its axial folds persist throughout the spire-whorls. Its pleural angle is within the range of that of the present species. The author should point out the strong possibility that C. v. acutangula may be included in $C$. tjidamarensis, although the author has not examined the type of $C . v$. acutangula.

Fusus iizukai Yokoyama (1928, p. 37, pl. 2, f. 3) is closely allied to the present species in the general features except for somewhat weaker subsutural band and less acute spire-angle than the latter.

Geological occurrence.-Upper Miocene (Indonesia.)

Horizon.-Upper part of the Dingle Formation.

Locality.-SKGS-74.

\author{
Superfamily Volutoidea \\ Family Olividae \\ Subfamily Olivinae \\ Genus Oliva Martyn, 1786
}

(type-species: Oliva corticata MARTYN by subsequent designation,

DALL, 1905)

Subgenus Anazola GraY, 1858

(type-species: Oliva acuminata LAMARCK by original designation)

Oliva (Anazola) djocdjocartae MARTIN

P1. 15, Figs. 1-6, 9, and 10

1883-87. Oliva djocdjocartae MARTin, Samml. Geol. Reichs-Mus. Leiden, Ser.1, Bd. 3, p. 77 , Tab. 5 , f. 80 . 
1895. Oliva (Strephona) rufula djocdjocartae, MarTin, ibid. N. F. Bd.1, Abt.1, p. 58.

Material.-GK-L 6790 to 6812 from loc. SKGS-74. Preservation is generally very good.

\begin{tabular}{|c|c|c|c|c|c|c|c|c|c|c|}
\hline \multicolumn{3}{|c|}{ Measurements.- } & \multirow[b]{2}{*}{$\underset{(\mathrm{mm})}{\mathrm{D}}$} & \multirow[b]{2}{*}{$\underset{(\%)}{\mathrm{Bd} / \mathrm{H}}$} & \multirow[b]{2}{*}{$\begin{array}{l}\mathrm{D} / \mathrm{H} \\
(\%)\end{array}$} & \multirow[b]{2}{*}{$\begin{array}{l}\mathrm{MCv} * \\
(\%)\end{array}$} & \multirow[b]{2}{*}{$\underset{\text { (degrees) }}{\angle \mathrm{P}}$} & \multirow{2}{*}{\multicolumn{2}{|c|}{ whorls }} & \multirow[b]{2}{*}{$\begin{array}{c}\text { colum } \\
\text { teeth }\end{array}$} \\
\hline $\begin{array}{l}\text { pecimen } \\
\text { GK-L }\end{array}$ & $\underset{(\mathrm{mm})}{\mathrm{H}}$ & $\underset{(\mathrm{mm})}{\mathrm{Bd}}$ & & & & & & & & \\
\hline 6790 & 18.65 & 16.05 & 7.55 & 86.0 & 40.4 & 60 & 64.3 & 4.0 & 4.5 & 8 \\
\hline 6791 & 18.60 & $14 . ?$ & 6.6 & & 39 & 5 & 64. & 4. & & 10 \\
\hline 6792 & 18.3 & 15.85 & 7.4 & 86 & 40 & 58 & 61. & 4.8 & 4. & 9 \\
\hline 6793 & 16 & 1. & 6.7 & & 40 & 6 & 74. & 4. & 3. & 10 \\
\hline 94 & 17 & 1 & 7.2 & & 41 & $5 ?$ & 62 & 4. & 3. & 9 \\
\hline 6795 & 17.60 & 15. & 7.35 & 87 & 41.7 & 58 & 75.1 & 3.9 & 3.9 & 9 \\
\hline 6797 & 16. & 14.9 & 7.50 & 88 & 44.5 & 56 & 79.6 & $\longleftarrow 7$ & $1 \longrightarrow$ & 9 \\
\hline 6798 & 15.85 & 14.10 & 6.30 & 88.9 & 39.9 & 68 & 69.7 & $\longleftarrow 6$ & $4+\rightarrow$ & 10 \\
\hline
\end{tabular}

* Relative length between the position of the maximum diameter and the anterior end.

Remarks.-The present specimens are ovoid-cylindrical in profile with the acuminate spire and slightly tapered body whorl. The suture is channelled and the columellar lip is provided with the horizontal short teeth at the upper and middle part and oblique and elongate plaits at the lower part. On the basis of these features they are included in Anazola GRAY, 1858.

The material in hand shows the remarkably wide range of variation concerning the $\mathrm{D} / \mathrm{H}$ ratio of the shell (39.8 to 44.5 percent). The majority of the specimens is, however, quite similar to the type specimen from the Upper Miocene of Java in the mentioned aspect. Moreover they are quite identical each other in the characteristic feature of the basal fasciole and the columellar plaits as indicated in the figures.

Although MARTIN included Oliva djocdjocartae in O. rufula DucLos as a subspecies, the two can be critically distinguished each other in four points: (1) remakably lower spire of $O$. rufula consisting of concavo-convex whorls instead of the flat-sided whorls of $O$. djocdjocartae; (2) the outline of $O$. rufula being more cylindrical with the maximum diameter at higher postition than $O$. djocdjocartae; (3) the relative length of the aperture being much longer in O. rufula having the posterior extremity close to the suture than $O$. djocdjocartae; and (4) the difference in the detailed feature of the columellar plaits. Considering the remarkable difference mentioned above the author can not agree with MARTIN's opinion to include the two within a single species. They should be treated as independent species.

Oliva australis Duclos is another ally to the present species. They resemble each other in the features of the profile of the whole shell and the spire-whorls, relative length of the aperutre, and the basal fasciole. The present species is, however, readily distinguished from $O$. australis by the difference in the columellar plaits.

Geological occurrence.-Upper Miocene (Indonesia).

Horizon.-Upper part of the Dingle Formation.

Locality.-SKGS-74. 


\section{Oliva (Anazola) rufula junghuhni MARTIN}

Pl. 15, Figs. 13, 14, 19, and 20

1879-80. Oliva junghuhni MARTIN, Tertiärschicht. v. Java, p. 16, Tab. 3, fs. 3, and $3^{*}$.

1895. Oliva (Strephona) rufula junghuhni, Martin, Samml. Geol. Reichs-Mus. Leiden, N. F. Bd. 1, Abt. 1, p. 58.

Material.-GK-L 6781 to 6789 from loc. SKGS-74 and GK-L 7492 from SKGS-71.

\begin{tabular}{|c|c|c|c|c|c|c|c|}
\hline \multicolumn{2}{|c|}{ Measurements.- } & \multirow[b]{2}{*}{$\underset{(\mathrm{mm})}{\mathrm{Ap}}$} & \multirow[b]{2}{*}{$\underset{(\mathrm{mm})}{\mathrm{D}}$} & \multirow[b]{2}{*}{$\underset{(\%)}{\mathrm{Ap} / \mathrm{H}}$} & \multirow[b]{2}{*}{$\begin{array}{l}\mathrm{D} / \mathrm{H} \\
(\%)\end{array}$} & \multirow[b]{2}{*}{$\begin{array}{c}\mathrm{MCv} \\
(\%)\end{array}$} & \multirow[b]{2}{*}{$\begin{array}{l}\text { whorls } \\
\text { to teleo }\end{array}$} \\
\hline $\begin{array}{l}\text { specimen } \\
\text { GK-L }\end{array}$ & $\underset{(\mathrm{mm})}{\mathrm{H}}$ & & & & & & \\
\hline 6781 & 24.85 & 21.15 & 11.20 & 87.1 & 46.9 & 61 & ca 3.0 \\
\hline 6782 & 21.50 & 19.10 & 9.95 & 88.8 & 46.3 & 61 & $6.5 \longrightarrow$ \\
\hline 6783 & 14.90 & 12.60 & 6.70 & 84.6 & 45.0 & 57 & 3.0 \\
\hline 6784 & 25.15 & 22.80 & 11.95 & 90.6 & 47.5 & 60 & 3.1 \\
\hline 6787 & 25.70 & 23.50 & 12.40 & 91.4 & 48.2 & 70 & $-6+$ \\
\hline
\end{tabular}

Remarks.-The specimens in hand are considered to be identical to Oliva junghuhni MARTIN from the Upper Miocene and Pliocene of Java. The original author distinguished his species from $O$. rufula in having flat-sided spire-whorls, compressedly flattened posterior end of the columellar callus, and somewhat compressed columellar lip at its anterior part. The close examination of the present specimens reveals that a few full-grown specimens have the concave spire-whorls and furthermore the majority of the specimens is not distinctly compressed at the anterior part of the columella. Some are provided with the elected parietal callus at the posterior end. This fact indicates the extreme variability of the species. Thus the slender specimens with concavo-convex whorls and umcompressed columellar end take the appearance of $O$. (A.) rufula DucLos.

Geological occurrence.-Upper Miocene and Pliocene (Indonesia).

Horizons.-Santa Barbara Silt and the upper part of the Dingle Formation. Localities.-SKGS-71 and 74 .

Subgenus Galeola GraY, 1858*

(type-species: Voluta carneola GMeLIN by original designation)

Oliva (Galeola) funebralis LAMARCK

Pl. 15, Figs. 15, 17, 18, and 21-23

1922. Oliva funebralis Lamarck, Hist. d. Anim. s. Vert. Tom. 7, p. 437.

1844. Oliva funebralis, LAMARCK, ibid. $2^{\mathrm{e}}$ ed. Tom. 10, p. 617.

1850. Oliva funebralis, REEvE, Conch. Icon. Vol. 6, Oliva, pl. 7, f. 10.

1883. Oliva funebralis, TrYon, Man. Conch. Ist Ser. Vol. 5, p. 77, pl. 21, f. 97.

1879-80. Oliva funebralis, Martin, Tertiärschicht. v. Java, p. 16, Tab. 2, f. 14.

1895. Oliva funebralis, MarTin, Samml. Geol. Reichs-Mus. Leiden, N. F. Bd. 1, Abt. 1, p. 52, Taf. 8, fs. 118 and 119.

1915. Oliva funebralis, TESCH, Paläont. v. Timor, Lief. 5, p. 40, Taf. 79, f. 85.

* Synonym: Galeolopsis Rovereto, 1899 and Galeolella Cossmann, 1899. 
1938. Oliva (Oliva) funebralis, OostingH, Ingen. Ned.-Indië, 1938, p. 111, pl. 7, fs. 124-246.

Material.-GK.L 6397 from loc. SKGS-73 and GK-L 6492, 6493, 6494, 6519, 7491, and 7493 from loc. SKGS-71.

$\begin{array}{cccrcccc}\begin{array}{c}\text { Measurements.- } \\ \text { specimen }\end{array} & \begin{array}{c}\mathrm{H} \\ \text { GK-L }\end{array} & \begin{array}{c}\mathrm{Ap} \\ (\mathrm{mm})\end{array} & \begin{array}{c}\mathrm{D} \\ (\mathrm{mm})\end{array} & \begin{array}{c}\mathrm{Ap} / \mathrm{H}) \\ (\%)\end{array} & \begin{array}{c}\mathrm{D} / \mathrm{H} \\ (\%)\end{array} & \begin{array}{c}\mathrm{MCv} \\ (\%)\end{array} & \begin{array}{c}\text { whorls } \\ \text { numb. }\end{array} \\ 6397 & 29.55 & 27.20 & 14.40 & 92.0 & 48.7 & 61 & 7.1 \\ 6492 & 20.85 & 19.10 & 9.70 & 91.6 & 46.5 & 69 & 5.7 \\ 6794 & 11.40 & 10.30 & 6.10 & 90.3 & 53.5 & 58 & 5.4 \\ 6519 & 15.60 & 14.80 & 7.80 & 94.9 & 50.0 & 64 & 4.5+ \\ 7491 & 24.45 & 22.60 & 11.85 & 92.0 & 48.4 & 58 & 6.8 \\ 7493 & 16.35 & 14.90 & 8.30 & 91.1 & 50.7 & 57 & 6.1\end{array}$

Remarks.-The present specimens are characterized by the ovoid-cylindrical shell with very low mammilate spire, which is covered by the thick callus except for the protoconch and last one circle of the suture. The strong columellar plaits also characterizes the speciemens. The columellar plaits are counted three or four. On the basis of these features they are included in Galeola GRAY, 1858. They are perfectly identical to Oliva funebralis LAMARCK in the general features.

Oliva sondeiana MARTIN (1895, p. 54, Taf. 8, fs. 122 and 123) is an ally to the present species, but is distinguished from the latter, on which the suture of the body whorl is not covered by the callus but is clearly channelled and the columellar plaits are more numerous and finer than those of $O$. sondeiana.

O. carneola GMeliN (1791; REEve, 1850, pl.12, f. 60) is an another ally to this, but the latter is readily distinguished from the former in being provided with the channelled suture.

Geological occurrence.-Upper Miocene and Pliocene (Indonesia).

Recent distribution.-Indo-Pacific region.

Horizons.- Santa Barbara Silt and the upper part of the Ulian Formation.

Localities.-SKGS-71 and 73.

\section{Genus Olivella SwaInson, 1831}

(type-species: Oliva purpurata SwAINsoN by subsequent designation, DALL, 1909)

Subgenus Dactylidia H. and A. Adams, 1853

(type-species: Oliva mutica SAY by subsequent designation, CoSSMANN, 1899)

Olivella (Dactylidia) gonzalesi sp. nov.

Pl. 15, Figs. 7, 8, and 16

Material.-Holotype.-GK-L 6398 and paratypes: GK-L 6399 to 6402 from loc. SKGS-73 and GK-L 6495 from SKGS-71.

Measurements.-

$\begin{array}{cccccccccc}\underset{\text { specimen }}{\mathrm{GK}-\mathrm{L}} & \underset{(\mathrm{mm})}{\mathrm{H}} & \underset{(\mathrm{md})}{\mathrm{Bd}} & \underset{(\mathrm{mm})}{\mathrm{Ap}} & \underset{(\mathrm{mm})}{\mathrm{D}} & \underset{(\%)}{\mathrm{Bd} / \mathrm{H}} & \underset{(\%)}{\mathrm{Ap} / \mathrm{H}} & \underset{(\%)}{\mathrm{D} / \mathrm{H}} & \begin{array}{c}\angle \mathrm{P} \\ (\text { degrees })\end{array} & \begin{array}{c}\text { whorls* } \\ \text { numb. }\end{array} \\ 6398 & 7.90 & 6.05 & 4.50 & 3.10 & 71.6 & 56.9 & 39.2 & 43.5 & 5.6\end{array}$




$\begin{array}{llllllllll}6399 & 7.60 & 5.70 & 3.95 & 2.90 & 70.9 & 51.8 & 38.2 & 41.4 & 5.4 \\ 6495 & 5.20 & 4.25 & 3.00 & 2.10 & 81.7 & 57.6 & 40.4 & 42.3 & 4.9\end{array}$

* Including the protoconch and the teleoconch.

Diagnosis.-The shell is small, rather thick, solid, ovoid-cylindrical with moderately conical spire and scarcely narrowed base. The protoconch is smooth, shinning, and paucispiral with less than one and a half volutions. The first volution is very large and globose and the remainder volution is broadly rounded. The suture of the protoconch is impressed at the beginning and becomes channelled later. There is no end mark of the protoconch and the beginning of the teleoconch is indicated by the appearance of the distinct spiral furrow close to the lower suture. This channel-like furrow is formed by the wedge-like thickening of the callus which does not extend upward to the suprasutural part.

The teleoconch consists of about three and a half whorls. The spire-whorls are flat-sided, shinning, and separated by the channelled suture one another. The body whorl is very large occupying more than 70 percent of the total height of the shell, broadly rounded at the sides, and somewhat tapered anteriorly. There are two callous bands at the basal surface; one is thin, covers about lower 30 percent of the frontal part of the body whorl, and spirals down and the other is the anteriorward continuation of the parietal callus, moderately thick, overlaps the preceding one, and occupies the basal part. There is a distinct valley-like spiral furrow starting from the junction of the parietal and columellar lips. The aperture is wedge-shaped with narrowly pointed posterior end and widely open and truncated anterior end. The outer lip is moderately thick and simple. The inner lip consists of the long and olblique parietal lip and very short columellar one. The columella is very obliquely truncated at the end and provided with five spiral folds, of which the lowest one is weaker than the others. The parietal lip has seven to nine plaits. The callus of the spire-whorls is continuous to the parietal callus and further to the basal callus in the front. The parietal callus is moderately thick but narrow.

Comparison.-The present specimens are similar in some aspects to Olivella javana MARTIN) (1879-80, p. 19, Tab. 3, f. 8), but the former is readily distinguished from the latter in having several parietal plaits instead of one buldge on O. javana. The band of the thinner callus of two callous bands is narrower on the present specimens than on $O$. javana. The distinct parietal plaits of the present specimens clearly indicate that they belong to Dactylidia H. and A. ADAms, 1853. There is no other known Dactylidia species comparable to the present specimens, which are featured by slender outline like Olivella (s.s.).

Horizons.-Santa Barbara Silt and the upper part of the Ulian Formation. Localities.-SKGS-71 and 73 . 
Family Mitridae

Subfamily Mitrinae

Genus Tiara SwaINson, 1831*

(type-species: Mitra (Tiara) isabella Swainsosn by subsequent designation, HERRMANNSEN, 1849)

Tiara acuminata sp. nov.

Pl. 16, Figs. 18, 19, and 23

Material.-Holotype: GK-L 7122 from loc. SKGS-75 and paratype: GK-L 6968 from SKGS-74. The holotype is broken at the protoconch and the end of the canal and labrum. The paratype lost its apex and the lower half of the body whorl.

\begin{tabular}{|c|c|c|c|c|c|c|c|}
\hline $\begin{array}{l}\text { specimen } \\
\text { GK-L }\end{array}$ & $\underset{(\mathrm{mm})}{\mathrm{H}}$ & $\underset{(\mathrm{mm})}{\mathrm{Bd}}$ & $\underset{(\mathrm{mm})}{\mathbf{A p}}$ & $\underset{(\mathrm{mm})}{\mathrm{D}}$ & $\underset{(\%)}{\mathrm{Bd} / \mathrm{H}}$ & $\underset{(\%)}{\mathrm{Ap} / \mathrm{H}}$ & $\begin{array}{l}\mathrm{D} / \mathrm{H} \\
(\%)\end{array}$ \\
\hline 7122 & $96.5+(100.5)$ & $53.2+(56.7)$ & $39.3+(42.8)$ & 22.6 & 56 & 42 & 22 \\
\hline $\begin{array}{l}\text { specimen } \\
\text { GK-L }\end{array}$ & $\underset{\text { (degrees) }}{\angle \mathrm{P}}$ & $\begin{array}{l}\text { whorls } \\
\text { numb. }\end{array}$ & $\begin{array}{l}\text { sutu } \\
\text { angl }\end{array}$ & & & $\begin{array}{l}\text { rofile } \\
\text { h pen }\end{array}$ & \\
\hline 7122 & 17.4 & $10+$ & 15.4 & & $14.3 /$ & $2.7=1.21$ & \\
\hline
\end{tabular}

Diagnosis.-The shell is large attaining more than $100 \mathrm{~mm}$ in height, solid, and slender fusiform with the narrowly acuminate spire. The spire-whorls are slightly convex and broadly rounded and the body whorl is large occupying about 56 percent of the total height and gradually attenuated at the base to the canal. The tangential line of the spire-whorls is straight; that is to say the relative growth is regular. The pleural angle is narrow-about 17 degrees. The whorls are ornamented by the combination of the spiral lirae and the raised and close growth lines. The spiral lirae are flat-topped and sharply defined at sides by the steep lateral walls. The number and the width of the spiral lirae are remarkably variable on the late whorl, while the lirae are constantly six and much wider than the interstitial grooves on the early whorls. They are eight and one-third as wide as the grooves on the penultimate whorl of GK-L 6968 and nine and almost equal to or slightly wider than the grooves on the comparable whorl of GK-L 7122. On the body whorl they are counted by 23. The growth lines are very slightly antecurrently oblique and markedly raised in the spiral grooves and weaker on the top of the lirae. The grooves are moderately deep and triangular in cross-section with the sharp angle at the bottom.

The aperture is narrow, pointed at the posterior end and attenuated anteriorly to the open canal. The labrum is simple and very slightly antercurrently oblique. The inner lip is covered with the moderately thick callus and provided with six columelar plaits, of which the upper three are prominent, the lowest one is obsolete, and the others are of intermediate strength. The basal fasciole is strong.

Comparison.-At one glance the present specimens are so different each other

\footnotetext{
* Synonym: Cancilla Swainson, 1840
} 
in the ornamentation of the late whorls that one may hesitate the identification of them as a single species. The extreme variability in the mentioned character of Tiara is, however, verified by the examination of the Quaternary material of $T$. isabella SwaInson from South Japan and other species. According to the examination of the author of more than thirty specimens belonging to the mentioned species from one and same locality revealed that some specimens show the very wide spiral lirae separated one another by only narrow grooves, while other extreme form exhibits the thin and sharp lirae. The specimens show the quite continuous morpho-series between these end forms with the intermediate ones, which represent the majority of the material. This fact seems to support the idea to include the present two specimens in a single species.

The present specimens are readily distinguished from $T$. isabella in having relatively higher and slenderer spire than that of the latttr. Moreover the profile of the spire of the former is straight instead of conoidally curved one of the latter.

T. yokoyamai (Nomura) from the Pliocene of Taiwan (1935, p. 138, pl.7, fs. 25a and b) is closely allied to $T$. isabella and only separable in having closer spiral lirae than the latter. The present specimens are readily distinguished from $T$. yokoyamai in the slenderer outline and less numerous spirals than the latter.

Horizons.-Upper and uppermost parts of the Dingle Formation.

Localities.-SKGS-74 and 75.

\section{Tiara flammea (QUAY and GAIMARD)}

Pl. 15, Figs. 11 and 12; Text-fig. 29

1833. Mitra flammea QUAY and GaIMARD, Voy. de l'Astrolabe, II, p. 659, pl. 45, fs. 23 to 25 .

1844. Mitra flammea, REEve, Conch. Icon. Vol. 2, Mitra, pl. 16, f. 120.

1880. Mitra flammea, Sowerby, Thes. Conch. Vol. 4, p. 9, pl. 362, f. 173.

1882. Mitra flammea, Tryon, Man. Conch. Ist Ser. Vol. 4, p. 140, pl. 41, f. 190.

1895. Mitra flammea, MarTin, Samml. Geol. Reichs-Mus. Leiden, N. F. Bd 1, Abt. 1, p. 76, Taf. 11, f. 170.

1903. Mitra (Cancilla) flammea, Cossmann, Jour. de Conch. Tom. 51, p. 123, pl. 4, fs. 11 and 12.

1915. Mitra flammea, Tesch, Paläont. v. Timor, Lief. 5, p. 45, Taf. 79, fs. 96 a and $b$.

1935. Mitra (Cancilla) flammea, Nomura, Sci. Rep. Tohoku Imp. Univ. 2nd Ser. Vol. 18, No. 2, p. 139, pl. 7, f. 20.

1939. Mitra (Tiara) flammea, Oostingh, Ingen. Ned.-Indië, 1939, No.1, p.13, pl. 10, fs. 187-189.

Material.-GK-L 7064 from loc. SKGS-72.

\begin{tabular}{|c|c|c|c|c|}
\hline \multicolumn{5}{|c|}{ Measurements.- } \\
\hline $\begin{array}{l}\text { specimen } \\
\text { GK-L }\end{array}$ & $\underset{(\mathrm{mm})}{\mathrm{H}}$ & $\underset{(\mathrm{mm})}{\mathrm{Ap}}$ & $\underset{(\%)}{\mathrm{Ap} / \mathrm{H}}$ & $\underset{\text { (degrees) }}{\angle \mathrm{P}}$ \\
\hline 7064 & $15.9+$ & 6.35 & 39.9 & 39.4 \\
\hline $\begin{array}{l}\text { specimen } \\
\text { GK-L }\end{array}$ & $\begin{array}{l}\text { teleo- } \\
\text { conch }\end{array}$ & $\begin{array}{l}\text { suture } \\
\text { angle }\end{array}$ & $\begin{array}{l}\text { whorl profile } \\
\text { D/H on pen. }\end{array}$ & $\begin{array}{l}\text { plaits } \\
\text { numb. }\end{array}$ \\
\hline 7064 & $4.5+$ & 8.1 & $3.65 / 1.65=2.22$ & $\mathbf{5}$ \\
\hline
\end{tabular}


Remarks.-The present specimens, although they are not necessarily perfect in preservation, are characteristic enough to be identified to the living specimens of Tiara flammea QUAY and GAIMARD. They also quite conform with the Pliocene material from Java and Taiwan.

They are featured by the modereately small size, fusiform outline, and the peculiar ornamentation. The spire whorls are seemingly three-ridged but the fourth lira is close to the lower suture being halfly concealed by the succeeding whorl. The lirae are sharply elected, smooth at the narrow crest, separated by the wider and sharp interspaces, which are w-shaped and crossed by the coarse growth lines. There is a spiral thread at the base of each spiral groove and this spiral thread accompanies two shallow grooves at both sides as indicated in the text-figure.

Geological occurrence.-Pliocene (Indonesia, India, Taiwan, and South Japan) and Pleistocene (South Japan).

Recent distribution.-Tropic Indo-Pacific from Madagascar to Okinawa.

Horizons.-Upper part of the Ulian and the upper part of the Dingle Formation.

Localities.-SKGS-72 and 74.

Tiara gerthi philippinensis subsp. nov.

Pl. 16, Figs. 1-4 and 17; Text-figs. 29 and 31

Material.-Holotype: GK-L 6969 and paratype: GK-L 6970 to 6981 from one and same locality.

\begin{tabular}{|c|c|c|c|c|c|c|c|c|c|}
\hline \multicolumn{2}{|c|}{ Measurements.- } & \multirow[b]{2}{*}{$\underset{(\mathrm{mm})}{\mathrm{Bd}}$} & \multirow[b]{2}{*}{$\underset{(\mathrm{mm})}{\mathrm{Ap}}$} & \multirow[b]{2}{*}{$\underset{(\mathrm{mm})}{\mathrm{D}}$} & \multirow[b]{2}{*}{$\begin{array}{c}\mathrm{Bd} / \mathrm{H} \\
(\%)\end{array}$} & \multirow[b]{2}{*}{$\underset{(\%)}{\mathrm{Ap} / \mathrm{H}}$} & \multirow[b]{2}{*}{$\begin{array}{l}\mathrm{D} / \mathrm{H} \\
(\%)\end{array}$} & \multirow{2}{*}{\multicolumn{2}{|c|}{$\underset{\text { (degrees) }}{\angle \mathrm{A}} \stackrel{\angle \mathrm{P}}{ }$}} \\
\hline $\begin{array}{l}\text { pecimen } \\
\text { GK-L }\end{array}$ & $\underset{(\mathrm{mm})}{\mathrm{H}}$ & & & & & & & & \\
\hline 6969 & 29.7 & 19.0 & 15.50 & 8.7 & 64.0 & 52.3 & 29.3 & 47.1 & 25.5 \\
\hline 6970 & $25.9+$ & 17.0 & 14.00 & 8.2 & 65.6 & 54.2 & 31.7 & - & 30.8 \\
\hline 6971 & $25.8+(26.3)$ & 17.3 & 13.70 & 8.0 & 65.7 & 52.2 & 30.4 & - & 28.4 \\
\hline 6973 & $10.15+(11.1)$ & 7.1 & 6.55 & 4.1 & 63.9 & 58.9 & 36.8 & - & 41.1 \\
\hline $\begin{array}{l}\text { specimen } \\
\text { GK-L }\end{array}$ & pro & & $\mathrm{mb}$. & & $\begin{array}{c}\text { suture } \\
\text { angle }\end{array}$ & & $\begin{array}{l}\text { cofile } \\
\text { pen }\end{array}$ & & $\begin{array}{l}\text { aits } \\
\text { mb. }\end{array}$ \\
\hline 6969 & .89 & & & 3.2 & 9.8 & 6.1 & $3.6=1.69$ & & 5 \\
\hline 6970 & - & & $.5+$ & 3.1 & 9.6 & 5.6 & $3.05=1.83$ & & 4 \\
\hline 6971 & - & & & 3.1 & 10.5 & 5.5 & $2.95=1.86$ & & 5 \\
\hline 6973 & - & & - & $5.5+$ & 5.2 & 2.7 & $1.2=2.25$ & & 4 \\
\hline
\end{tabular}

Diagnosis.-The shell is moderately small and fusiform with the acuminately high conical spire and gradually attenuated base. The test is moderately thick. The protoconch is high conical and polygyrate consisting of three smooth and moderately convex volutions. The first volution is small, depressed, and horizontal tip and the succeeding volutions are moderately convex except for the last one which is less convex at the sides and narrower than the preceding volutions. The boundary between the protoconch and the teleoconch is marked by a slightly curved, moderately shallow, and distinct axial furrow. The teleoconch-whorls are ornamented with the regular spiral lirae and the axial lines. The spiral lirae are rounded at the top and relatively wide and separated by much narrower 
Fig. 31. Protonchs of some mitrids.

1: Tiara gerthi philippinensis subsp. nov., GK-L 6969.

2: Vexillum (Pulchritima) schepmani KOPERBERG, GK-L 6405.

3: V. (Costellaria) eruentatum greyi subsp. nov., GK-L 6502.

4: Merica asperella varicosa subsp. nov., GK-L 6983.

Unit bar indicates $0.5 \mathrm{~mm}$.
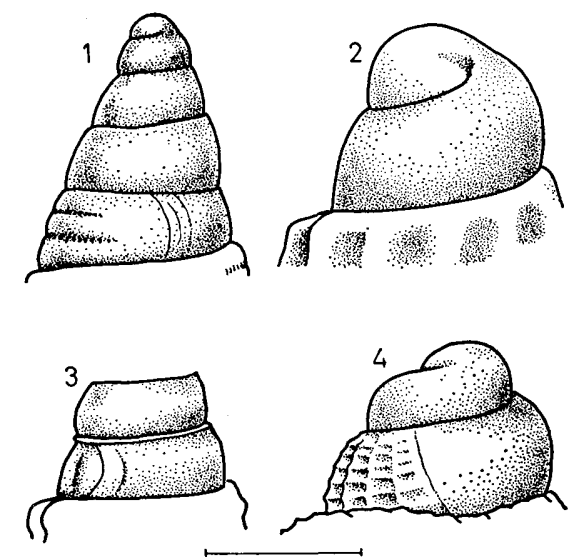

grooves. They are generally three at the very beginning of the first whorl and thereafter rather rapidly increased in number by appearance of fourth and fifth lirae from the lower suture on the first and second whorls. In other words the development of the spirals is adapical. In consequence of adapical development the third whorl has five lirae and thereafter this pattern is maitained untill on the penultimate whorl. In the course of the growth the lirae become flat and are decreased in their relative size comparative to the intervening V-shaped grooves, which are provided with a secondary groove at its sharply angulated bottom. The axial lines are close and very weakly cross over the spiral lirae on the early whorls, although they are much stronger at the grooves. On the later whorls the axials do not cross over the spiral lirae and distinct only at the grooves, especially at the bottom area of the grooves. The body whorl has about 13 (11 to 15) spiral lirae on the lateral and basal slope and about 5 weaker ones at the snout.

The aperture is long, narrow, pointed at the posterior end, and attenuated anteriorly to the widely open canal. The labrum is almost vertical and simple. The inner lip is slightly curved and covered with the very weak callus. The columellar plaits are five, of which the lower one is weaker than the higher ones.

Comparison.-Mitra gerthi PANNEKoEK (1936, p. 36, pl.1, f. 16) was described on the basis of the specimen from the lower Miocene of Rembang, Java, and readily identified to Tiara by its diagnostic ornamentation. The present specimens are closely allied to $T$. gerthi in the general feature, but clearly separated from the latter in having 1.3 times larger shell, about 1.4 times closer axial lines, and less contracted base than the latter, although the pattern of the ornamental development conforms between the two. The author is inclined to take this difference as geological variation and give to the present material the subspecific rank. The original author compared her specimen with Mitra (Cancilla) angsanana MARTIN (1921, p.453, Taf. 1, f. 23), but they are quite different each other in the pattern of the ornamental development and the detailed character of the lirae on the adult whorls.

Mitra sokkohensis MARTIN (1917, p. 237, Taf. 1, fs. 29 and 30) is also included 
in Taira and shows similar feature to the present specimens on the early whorls, but the detailed character of the spiral grooves on the adult whorls is quite different. Furthermore the former is only about three-fifths of the latter in size.

Tiara vandervlerki (BEETs) (1941, p. 116, pl. 6, fs. 241-244) is another ally to the present specimens. They are similar each other in the teleoconch with characteristic development of the ornament, but the present specimens are two and a half times larger than the latter and have high conical and polygyrate protoconch insead of low conical paucigyrate one of T. vandervlerki.

The present specimens are also similar to Mitra (Tiara) nasongoensis LADD (1934, p. 227, pl. 40, f. 8) in the size of the shell, general outline, and the aperture, but the former is readily distinguished from the latter in the different type of sculpture. The latter has four spirals on the spire-whorls and the upper two of four spirals are clearly bifid.

Horizon.-Upper part of the Dingle Formation.

Locality.-SKGS-74.

\section{Subfamily Vexillinae}

Genus Vexillum RöDING, 1798

(type-species: Voluta plicata RöDING=Voluta plicaria LINNÉ by subsequent designation, WOODRING, 1928)

Subgenus Vexillum (s.s.)*

Vexillum (Vexillum) batavianum minahassae (ScHEPMAN)

Pl. 16, Figs. 13, 14, and 22

1904. Turricula minahassae Schepman, Samml. Geol. Reichs-Mus. Leiden, Ist Ser., Bd. 8, p. 167, Taf. 10, fs. 6 and $6 a$.

1911. Turricula minahassae, SchePMAN, Siboga Exp. Lief. 49, p. 280, pl. 22, f. 7.

1915. Turricula (Vulpecula) javana, TESCH (non MARTIN), Paläont. v. Timor, Lief. 5, p. 48, Taf. 80, fs. 104a and b.

Material.-GK-L 6556, 6557, 7483, and 7484 from loc. SKGS-71 and GK-L 6427 from loc. SKGS-73. The former four specimens are fairly good in preservation and the last one is imperfect.

\begin{tabular}{|c|c|c|c|c|c|c|c|c|}
\hline \multicolumn{2}{|c|}{ Measurements.- } & \multirow[b]{2}{*}{$\underset{(\mathrm{mm})}{\mathrm{Bd}}$} & \multirow[b]{2}{*}{$\underset{(\mathrm{mm})}{\mathrm{Ap}}$} & \multirow[b]{2}{*}{$\underset{(\mathrm{mm})}{\mathrm{D}}$} & \multirow[b]{2}{*}{$\underset{(\%)}{\mathrm{Bd} / \mathrm{H}}$} & \multirow[b]{2}{*}{$\underset{(\%)}{\mathrm{Ap} / \mathrm{H}}$} & \multirow[b]{2}{*}{$\begin{array}{l}\mathrm{D} / \mathrm{H} \\
(\%)\end{array}$} & \multirow[b]{2}{*}{$\stackrel{\angle \mathbf{P}}{\text { (degrees) }}$} \\
\hline $\begin{array}{l}\text { specimen } \\
\text { GK-L }\end{array}$ & $\underset{(\mathrm{mm})}{\mathrm{H}}$ & & & & & & & \\
\hline 6556 & $28.3+(28.8)$ & 19.4 & 14.50 & 10.50 & 67.3 & 50.2 & 34.8 & 33.7 \\
\hline 6557 & $22.7+(23.5)$ & 16.0 & 13.05 & 8.35 & 68.0 & 55.4 & 35.4 & 33.2 \\
\hline 7483 & $30.7+(33.0)$ & 20.0 & 16.30 & 10.70 & 60.6 & 49.4 & 32.4 & 24.5 \\
\hline 7484 & $29.4+(30.6)$ & 19.9 & 16.10 & 10.05 & 65.0 & 52.6 & 33.1 & 29.3 \\
\hline $\begin{array}{l}\text { specimen } \\
\text { GK-L }\end{array}$ & $\begin{array}{l}\text { teleo- } \\
\text { conch }\end{array}$ & & $\begin{array}{l}\text { suture } \\
\text { angle }\end{array}$ & & $\begin{array}{l}\text { whorl pr } \\
D / H \text { on }\end{array}$ & $\begin{array}{l}\text { file } \\
\text { pen }\end{array}$ & coll & $\begin{array}{l}\text { ellar } \\
\text { its }\end{array}$ \\
\hline 6556 & $8+$ & & 12.3 & & $7.2 / 3.45=$ & $=2.08$ & & 1 \\
\hline 6557 & 6.5 & & 7.9 & & $5.55 / 2.6=$ & $=2.13$ & & 3 \\
\hline 7483 & $7+$ & & 11.2 & & $3.2 / 3.65=$ & $=2.25$ & & 1 \\
\hline 7484 & $7.9+$ & & 10.6 & & $3.65 / 3.2=$ & $=2.08$ & & 1 \\
\hline
\end{tabular}

* Synonym: Turris MONTFort, 1810, non RöDING, 1798, and Vulpecula BlainviLLe, 1824. 
Remarks.-The present specimens are swollen fusiform with the stepped sutures and the tapered base. The axials are strong, as wide as the interspaces, and about sixteen to seventeen on the early whorls. They are increased in number to about twenty-one and separated by wider interspaces on the antipenultimate whorl of the full-grown specimens. Finally they are very weak or obsolete on the penultimate and body whorls. The spiral grooves are distinct untill on the penultimate whorl. The number of the spiral grooves are variable ranging eight to thirteen on the penultimate whorl. It depends on the degree of the development of the secondary grooves. Two grooves at about upper one-fourth of the whorl are the strongest and those above these grooves are very weak. The basal contraction is weak and the lower part of the basal surface and the snout are encircled with the distinctly raised and weakly granular spiral lirae. The aperture is narrow and elongate with the subparallel lips. Its posterior end is pointed and narrowed by the distinctly thick parietal callus to form the weak posterior canal. The anterior canal is sharply bent and moderately notched at the end. The columellar plaits are oblique, strong, and four on the full-grown specimens. The uppermost plait is the strongest, less oblique, and shallowly grooved at the crest. The labrum is sharp and thin at the margin and spirally lirated inside.

The present specimens conform with the type specimen of Turricula minahassae SchePMAN from Quaternary of Celebes and also with the living one described by original author except for slightly smaller numer of the axials (21 to 22 on the penultimate whorl instead of 25 on the type specimen).

Vexillum batavianum (MARTIN) (1883-87, p. 89, Tab. 5, f. 89), a Pliocene species of Java is a close ally to $V$. minahassae, especially to the less slender examples, in the profile, sculpture, and the apertural feature. The distinction is not necessarily easy. The latter, however, can be distinguished from the former in being provided with somewhat smaller shell, more numerous axials, and less numerous spiral than the former. Considering the degree of difference between the two, the author prefers to treat $V$. minahassae as a subspecies of $V$. batavianum.

The present specimens also resemble Vexillum javanum (MARTIN) (1879-80, p. 27, Tab. 6 , fs. 2 and $3^{*}$ ), but the latter is much more distinctly stepped at the sutures and consequently the position of the maximum diameter of the whorls is much higher than the present specimens. The spiral lirae at the shoulder angulation are much stronger on $V$. javanum than on the present specimens, although the spiral grooves on the lateral surface are remarkably weaker on the former than on the latter. TESCH described the Pliocene specimen from Timor as Turricula javana, but it should be included in Vexillum minahassae on the basis of the diagnosis of the profile and the ornamentation.

Geological occurrence.-Pliocene and Pleistocene (Indonesia).

Recent distribution.-Indonesia.

Horizons.-Santa Barbara Silt and upper part of the Ulian Formation.

Localities.-SKGS-71 and 73. 
Subgenus Pulchritima IREDALE, 1929*

(type-species: Mitra stigmataria LAMARCK by original designation)

Vexillum (Pulchritima) schepmani KOPERBERG

Pl. 16, Figs. 5, 6, 20, and 21; Text-figs. 29 and 31

1931. Turricula (Callithea) schepmani KOPERBERG, $2^{\mathrm{e}}$ Nederland. Timor-Expeditie, Lief. 7, p. 81, pl. 2, f. 28.

Material.-GK-L 6403, 6404, and 6405 from one and same locality.

\begin{tabular}{|c|c|c|c|c|c|c|c|c|c|}
\hline \multicolumn{2}{|c|}{ Measurements.- } & \multirow[b]{2}{*}{$\underset{(\mathrm{mm})}{\mathrm{Bd}}$} & \multirow[b]{2}{*}{$\underset{(\mathrm{mm})}{\mathrm{Ap}}$} & \multirow[b]{2}{*}{$\underset{(\mathrm{mm})}{\mathrm{D}}$} & \multirow[b]{2}{*}{$\underset{(\%)}{\mathrm{Bd} / \mathrm{H}}$} & \multirow[b]{2}{*}{$\underset{(\%)}{\mathrm{Ap} / \mathrm{H}}$} & \multirow[b]{2}{*}{$\underset{(\%)}{\mathrm{D} / \mathrm{H}}$} & \multirow{2}{*}{\multicolumn{2}{|c|}{$\angle \underset{\text { ddegrees) }}{\mathrm{A}} \quad \angle \mathrm{P}$}} \\
\hline $\begin{array}{l}\text { specimen } \\
\text { GK-L }\end{array}$ & $\underset{(\mathrm{mm})}{\mathrm{H}}$ & & & & & & & & \\
\hline 6403 & $23.7+(24.3)$ & 15.0 & 11.6 & 7.65 & 61.7 & 47.7 & 31.5 & - & 22.7 \\
\hline 6404 & $19.6+(20.4)$ & 13.8 & 9.2 & 6.55 & 62.6 & 45.0 & 32.1 & - & 18.2 \\
\hline 6405 & 15.65 & 10.0 & 7.7 & 5.75 & 64.0 & 49.3 & 36.8 & 52.4 & 30.2 \\
\hline $\begin{array}{l}\text { specimen } \\
\text { GK-L }\end{array}$ & \multicolumn{2}{|c|}{ protoconch } & \multicolumn{2}{|c|}{$\begin{array}{l}\text { teleo- } \\
\text { conch }\end{array}$} & $\begin{array}{l}\text { suture } \\
\text { angle }\end{array}$ & \multicolumn{2}{|c|}{$\begin{array}{l}\text { whorl profile } \\
\mathrm{D} / \mathrm{H} \text { on pen }\end{array}$} & \multicolumn{2}{|c|}{$\begin{array}{l}\text { columellar } \\
\text { plaits }\end{array}$} \\
\hline 6403 & - & & - & $7+$ & 13.8 & $5.3 / 3$ & $3=1.60$ & & \\
\hline 6404 & - & & - & $7+$ & 9.2 & $4.0 / 2$ & $9=1.62$ & & $t$ \\
\hline 6405 & .60 & & 25 & 6.6 & 12.4 & $4.0 / 2$ & $05=1.83$ & & 4 \\
\hline
\end{tabular}

Remarks.-The present material includes two forms; the profile of the specimen GK-L 6405 is wider than the others illustrating larger pleural angle and larger $\mathrm{D} / \mathrm{H}$ ratio. The close examination, however, clarifies that this difference is due to their different stages of growth. GK-L 6405 is an adolescent specimen and its morphological features are quite conformable to those of the adolescent part of other specimens. Besides they exhibit the identical development of the ornamentation.

The protoconch is paucigyrate, smooth, and papyrate. The volutions are about two and a quater, of which the first one is depressed, very oblique, and small tip and the remainder ones are subcylindrical with almost straight sides. Although the termination of the protoconch is not indicated by any sharp mark, the teleoconch is readily recognized by its distinct axial ribs and the subsutural lira, which is bordered anteriorly by a deep spiral groove. The infrasutural spiral groove abruptly becomes weak and contemporaneously about five fine primary grooves appear on the lateral surface below the infrasutural one. The spiral grooves including the infrasutural one are about six on the penultimate whorl and 13 to 14 on the lateral and basal surface of the body whorl, of which the anterior seven grooves are wider and deeper and separated from one another by the raised and subgranular spiral lirae. The lirae just close to the basal fasciole is especially prominent. The axial ribs are almost vertical and slightly curved with the concave face forwardly. The body whorl is large occupying more than 60 per cent of the total height of the shell. The suture is impressed and slightly step-like.

The aperture is narrowed by the parietal callus at the posterior end. The columellar plaits are four, of which the upper two are prominent, thick, less

\footnotetext{
* Synonym: Callithea Swainson, 1840 non Borsduval, 1835.
} 
oblique, and provided with a shallow groove at the crest. The labrum is spirally lirated inside. The canal is somewhat bent outward.

The present specimens, especially GK-L 6403 and 6404, closely resemble Turricula (Callithea) schepmani KOPERBERG (1931, p. 81, pl. 2, f. 28) in their slender outline, ornamental design, and apertural feature except for the slight difference of the axial ribs. That is to say, the axial ribs on the body whorl of the full-grown specimen of the present material are closer than those of the latter. The difference is, however, so slight that they are better to be treated as conspecific.

$V$. stigmatarium (LAMARCK) $(1822$, p. 311) is also similar to the present specimens, but the latter have somewhat more convex whorls, relatively narrower and less curved axial ribs, and much more defined basal fasciole than the former.

They all are included in.Pulchritima IREDALE, 1929, on the basis of the slender outline, close and slightly sigmoid axial ribs, and fine and close spiral grooves.

Geological occurrence.-Lowest Pliocene (Indonesia).

Horizon.-Upper part of the Ulian Formation.

Locality.-SKGS-73.

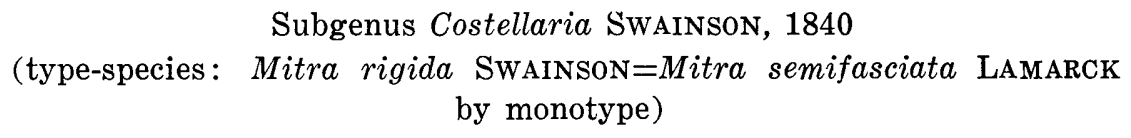

Vexillum (Costellaria) cruentatum greyi subsp. nov. Pl. 16, Figs. 7-11; Text-figs. 29 and 31

Material.-Holotype: GK-L 6502 and paratypes: GK-L 6496 to 6501 and 6503 to 6509 from one and same locality. All the specimens except for the holotype are more or less broken at the apical part.

\begin{tabular}{|c|c|c|c|c|c|c|c|c|c|}
\hline \multicolumn{10}{|c|}{ Measurements.- } \\
\hline $\begin{array}{l}\text { specimen } \\
\text { GK-L }\end{array}$ & $\underset{(\mathrm{mm})}{\mathrm{H}}$ & $\underset{(\mathrm{mm})}{\mathrm{Bd}}$ & $\underset{(\mathrm{mm})}{\mathrm{Ap}}$ & $\underset{(\mathrm{mm})}{\mathrm{D}}$ & $\underset{(\%)}{\mathrm{Bd} / \mathrm{H}}$ & $\underset{(\%)}{\mathrm{Ap} / \mathrm{H}}$ & $\begin{array}{r}\mathrm{D} / \mathrm{H} \\
(\%)\end{array}$ & \multicolumn{2}{|c|}{$\angle \underset{\text { (degrees) }}{\mathrm{A}} \angle \mathrm{P}$} \\
\hline 6496 & 16.75 & 8.00 & 5.95 & 5.45 & 47.8 & 35.6 & 32.6 & 54.2 & 28.0 \\
\hline 6497 & 11.90 & 7.95 & 5.70 & 5.00 & 66.7 & 47.8 & 42.6 & 52.9 & 33.4 \\
\hline 6501 & 7.15 & 4.80 & 3.40 & 3.50 & 64.0 & 45.2 & 46.7 & 57.8 & 31.5 \\
\hline 6502 & 10.90 & 6.70 & 4.85 & 4.55 & 61.5 & 44.5 & 41.8 & 48.7 & 30.1 \\
\hline 6503 & 9.15 & 5.75 & 4.05 & 4.30 & 62.9 & 44.3 & 47.0 & 64.4 & 32.3 \\
\hline $\begin{array}{l}\text { spec-men } \\
\text { GK-L }\end{array}$ & $\mathrm{H}$ & \multicolumn{2}{|c|}{$\underset{\text { protoconch }}{\text { pro }}$} & & $\begin{array}{l}\text { teleo- } \\
\text { conch }\end{array}$ & $\begin{array}{l}\text { suture } \\
\text { angle }\end{array}$ & \multicolumn{2}{|c|}{$\begin{array}{l}\text { whorl profile } \\
\mathrm{D} / \mathrm{H} \text { on pen }\end{array}$} & $\underset{\text { plaits }}{\text { columellar }}$ \\
\hline 6496 & - & _- & 0.8 & & 7.5 & 6.7 & $4.1 / 1.7$ & $=2.34$ & 4 \\
\hline 6497 & - & - & 1. & & 7.0 & 6.8 & $3.4 / 1.3$ & $=2.32$ & 3 \\
\hline 6501 & - & - & 1. & & 5.3 & 9.0 & $2.4 / 0.9$ & $=2.52$ & 4 \\
\hline 6502 & 0.50 & 0.45 & 3. & & 7.0 & 8.7 & $3.2 / 1.3$ & $=2.37$ & 4 \\
\hline 6503 & - & - & $1+$ & & 6.6 & 6.6 & $2.95 / 1$. & $=2.46$ & 4 \\
\hline
\end{tabular}

Diagnosis.-The shell is small and ovately fusiform. The protoconch is bluntly conical with smooth three volutions, of which the first one is somewhat depressed and oblique and the others are slightly convex. The suture is shallow. The boundary between the protoconch and the teleoconch is defined by 
a distinct, retrocurrently oblique and curved axial ridge. The teleoconch consists of more than seven whorls on the adult specimens. The spire-whorls are quadrate in outline, moderately stepped at the suture, and ornamented by the close and strong axial ribs and distinct spiral grooves. The axial ribs are about twelve to thirteen (full-range: 11-14) on the first whorl and gradually increased in number through the adolescent and adult stages to fifteen on the penultimate whorl. They are crowded on the last whorl of the full-grown specimen being counted 20 to 21 . They are vertical, slightly curved with concave face oral-ward, subgranular at the subsutural part above the infrasutural distinct spiral groove, and slightly weaker below that groove. The interspaces are widely open, V-shaped with a fine secondary transverse groove at each sharp bottom. The primary spiral grooves are two: the one is at the infrasutural part, very strong, and crosses over the axial ribs to illustrage the defined constriction, and the other is close to the lower suture and distinct, but does not cross over the ribs. The weak or obsolete secondary spiral grooves appear at the space between the primary grooves on the fifth or sixth whorl and gradually become distinct. The body whorl has eight to ten spiral grooves, of which the lower ones are stronger than the upper ones and separated by the raised and prominent spiral lirae. The axials are slightly sigmoidal and weakened at the basal slope. The basal fasciole is very prominent and encircles the pseudoumbilicus.

The aperture is elongately rhomboid with a very weak canal at the posterior end and the widely open, short, and deeply notched anterior canal. The labrum is sharp at the margin, not thickened outside, and spirally lirated inside. The inner lip is sharply bent consisting of the short and oblique parietal lip and the long, vertical, and straight columellar one. The callus is thick with the free edge anteriorly. The columellar plaits are four, of which the uppermost one is thick, prominent, almost horizontal, and provided with very faint groove at the crest and the lower ones are successively weaker and more oblique and almost in line with the columella. The parietal callus has a prominent ridge narrowing the posterior canal.

Comparison.-The present specimens show the close affinity to the living species, Mitra cruentata KÜSTER (1841, p. 95 Taf. 16, fs. 9 and 10) from the Philippines in coloring and morphology of the adult whorls. The former is, however, readily distinguished from the latter in its peculiar pattern of the sprial grooves. That is to say, it maintains the bi-grooved pattern untill at the adolescent stage instead the multistriated pattern of $M$. cruentata. Furthermore the basal fasciole of the present specimens is remarkably stronger than that of $M$. cruentata. On the basis of these differences the author prefers to separate the present specimens from $M$. cruentata as a subspecies. They are reasonably included in Costellaria SwaInson, 1840, with the diagnostic aperture and ornamentation mentioned above.

The present specimens are also similar to Vexillum (Costellaria) ickei (MARTIN) in the general feature especially in the diagnosis of the body whorl. The development of their sculpture, however, does not conform each other. $V$. (C.) ickei is provided with several spiral grooves even at the early stage of 
growth. The outline of the present specimens is, furthermore, more contracted at the base than $V .(C$.$) ickei. This kind of difference is also observed between$ the present specimens and $V$. (C.) multicostatum (SwaINson).

Horizon.-Santa Barbara Silt.

Locality.-SKGS-71.

\section{Vexillum (Costellaria) obeliscus teschi (KOPERBERG)}

Pl. 16, Figs. 12, 15, and 16

1915. Turricula (Vulpecula) gembacana, Tesch (non MarTin), Paläont. v. Timor, Lief. 5, p. 49, Taf. 80, f. 105a and b.

1931. Turricula (Costellaria) obeliscus teschi Koperberg, $2^{\circ}$ Nederland. TimorExpeditie, Lief. 7, p. 82.

1939. Vexillum (Costellaria) obeliscus teschi, Oostingh, Ingen. Ned.-indië 1939, p. 50, Taf. 12, f. 214.

Material.-GK-L 6406, 6450a and 6450b from loc. SKGS-73 and GK-L 6890 to 6895 from loc. SKGS-74.

\begin{tabular}{|c|c|c|c|c|c|c|c|c|c|}
\hline \multicolumn{3}{|c|}{ Measurements.- } & \multirow[b]{2}{*}{$\underset{(\mathrm{mm})}{\mathrm{Ap}}$} & \multirow[b]{2}{*}{$\underset{(\mathrm{mm})}{\mathbf{D}}$} & \multirow[b]{2}{*}{$\underset{(\%)}{\mathrm{Bd} / \mathrm{H}}$} & \multirow[b]{2}{*}{$\underset{(\%)}{\mathrm{Ap} / \mathrm{H}}$} & \multirow[b]{2}{*}{$\underset{(\%)}{\mathrm{D} / \mathrm{H}}$} & \multirow[b]{2}{*}{$\underset{\text { (degrees) }}{\angle \mathrm{P}}$} & \multirow[b]{2}{*}{$\begin{array}{l}\text { whorls } \\
\text { proto teleo }\end{array}$} \\
\hline $\begin{array}{l}\text { specimen } \\
\text { GK-L }\end{array}$ & $\underset{(\mathrm{mm})}{\mathrm{H}}$ & $\underset{(\mathrm{mm})}{\mathrm{Bd}}$ & & & & & & & \\
\hline 6406 & $12.40+$ & 7.7 & 5.95 & 4.85 & 62.1 & 47.9 & 39.1 & 18.1 & $5.5+$ \\
\hline 6890 & $13.45+$ & 7.9 & 5.70 & 4.70 & 58.7 & 42.3 & 34.9 & 20.1 & $1.0+$ \\
\hline 6893 & $14.00+$ & 8.6 & 6.20 & 4.90 & 61.4 & 45.3 & 35.0 & 21.0 & $0.5+$ ca 7.0 \\
\hline 6894 & $12.50+$ & 8.1 & 5.60 & 4.60 & 64.6 & 44.7 & 36.0 & 20.4 & $1.0+$ \\
\hline $\begin{array}{l}\text { specimen } \\
\text { GK-L }\end{array}$ & \multicolumn{2}{|c|}{$\begin{array}{l}\text { suture } \\
\text { angle }\end{array}$} & \multicolumn{2}{|r|}{$\begin{array}{l}\text { axials } \\
\text { numb. }\end{array}$} & \multicolumn{3}{|c|}{$\begin{array}{l}\text { whorl profile } \\
\mathrm{D} / \mathrm{H} \text { on pen }\end{array}$} & \multicolumn{2}{|c|}{$\begin{array}{l}\text { columellar } \\
\text { plaits }\end{array}$} \\
\hline 6406 & \multicolumn{2}{|r|}{10.3} & \multicolumn{2}{|r|}{$14-15$} & & \multicolumn{2}{|c|}{$3.75 / 1.9=1.97$} & \multicolumn{2}{|r|}{4} \\
\hline 6890 & \multicolumn{2}{|r|}{7.6} & \multicolumn{2}{|r|}{$10-15$} & & \multicolumn{2}{|c|}{$3.75 / 1.85=2.02$} & & 4 \\
\hline 6893 & \multicolumn{2}{|r|}{9.4} & \multicolumn{2}{|r|}{$10-19$} & & \multicolumn{2}{|c|}{$3.85 / 1.7=2.27$} & & 4 \\
\hline 6894 & \multicolumn{2}{|r|}{11.2} & \multicolumn{2}{|r|}{$10-14$} & & \multicolumn{2}{|c|}{$3.45 / 1.8=1.92$} & & 4 \\
\hline
\end{tabular}

Remarks.-The present specimens are featured by (1) fusiform outline with moderately high spire, remarkably contracted base, and moderately long canal; (2) sharply ridged and regularly spaced axial ribs; (3) deeply incised spiral grooves which are as wide as the spiral threads and hardly cross over the crest of the axial ribs on the lateral surface, while apparently cross the axials on the basal surface of the body whorl rendering the granular appearance, (4) the heavy parietal callus with a strong ridge to form the narrow posterior canal at the posterior termination of the aperture; (5) four columellar plaits, which are successively increased in size posteriorly and in consequence the uppermost one being the strongest and provided with fine groove at the crest; and (6) the spiral threads inside the labrum. In the mentioned features they are quite conformable with Turricula (Vulpecula) gembacana of TESCH, 1915, which was renamed T. (Costellaria) obeliscus teschi by KOPERBERG, 1931.

The present subspecies differs from the species in having smaller and less turreted shell and less numerous axial ribs than the latter.

V. (Costellaria) gembacanum (MARTIN) (1879-70, p. 27, Tab.6, f. 2) is similar to $V$. (C.) obeliscus teschi, but the former is distinguished from the latter 
in having finer and less numerous axials and weaker spiral grooves than the latter. The specimens from loc. SKGS-73, especially GK-L 6406 looks like $V$. (C.) gembacanum. The grooves on the former are, however, almost equal in strength throughout on the lateral surface, while those of gembacanum are successively weakened anteriorward.

Geological occurrence.-Pliocene (Indonesia).

Horizons.-Upper parts of the Ulian and Dingle Formations.

Localities.-SKGS-73 and 74.

\author{
Family Volutidae \\ Subfamily Volutinae \\ Genus Lyria GraY, 1847
}

(type-species: Voluta nucleus LAMARCK by original designation)

Subgenus Paralyria Shuto, 1962

(type-species: Lyria mizuhonica MAKIYAMA by original designation)

Lyria (Paralyria) sp. cf. L. (P.) hanzawai MACNeIL

Pl. 11, Fig. 17

1960. Lyria hanzawai MacNerL, U. S. Geol. Surv. Prof. Pap. No. 339, p. 98, pl. 9, f. 7 .

Material.-GK-L 6954. A single specimen which is broken at the body whorl. Measurements.-

$\mathrm{H}=33.6 \mathrm{~mm}, \mathrm{D}=18.2 \mathrm{~mm}$, numb. of whorls $=7.5$ (including the protoconch and teleoconch).

Remarks.-The present specimen, although broken at the lower half of the body whorl, is characteristic enough for identification with the high spire, coarse, prominent, and simple axial ribs, no spiral ornamentation, and the incised and slightly stepped suture. These characteristic features clearly indicate that the present specimen belongs to the subgenus Paralyria Sнuтo, 1962.

The present specimen closely resembles Lyria (Paralyria) hanzawai MACNEIL from the Pliocene and Miocene of Okinawa with the features mentioned above. The former, however, slightly differs from the latter in being provided with somewhat more distinct suture. The present specimen is ornamented with several teeth-like threads at the parietal lip, while the parietal part of $L$. (P.) hanzawai can not be observed on account of the coagulation of the sediments there.

$L$. (P.) mizuhonica MAKIYAMA has lower spire, less prominent axial ribs than the present specimen and is devoid of the teeth-like parietal threads. The fossil specimens of $L$. (P.) edwardsi (d'ARCHAQUE) from Indonesian Miocene beds described by MARTIN (1917, p. 233, Taf. 1, fs. 19 and 19a) show the closely similar outline of the shell, ornamentation, and parietal features to those of the present specimen, but the former is somewhat more bulbous and provided with somewhat closer axial ribs than the latter. Furthermore the axial ribs of $L$. (P.) edwardsi are sharply ridged illustrating roof-like shape throughout the growth stages untill even at the beginning of the body whorl, while those of 
the present specimen are rounded at the crest even on the early whorls.

Geological occurrence.-Upper Miocene to Pliocene (Okinawa).

Horizon.-Upper part of the Dingle Formation.

Locality.-SKGS-74.

Family Cancellariidae

Genus Merica H. and A. ADAMs, 1854*

(type-species: Cancellaria melanostoma SOWERBY by subsequent designation, CoSSMANN, 1899)

Merica asperella (LAMARCK)

Pl. 17, Figs. 11, 12, and 13

1822. Cancellaria asperella Lamarck, Hist. Nat. d. Anim. s. Vert. Tom. 9, p. 402,

1841. Cancellaria asperella, Kiener, Coq. Viv. Tom. 6, Cancellaria, p. 4, pl. 3, f.1.

1843. Cancellaria asperella, Deshayes, Hist. Nat. d. Anim. s. Vert. Deshayes' ed. Tom. 9, p. 402.

1849. Cancellaria elegans, Sowerby, (non Deshayes), Thesaurus Conch. p. 446, pl. 93 , f. 36 and pl. 96, f. 104.

1849. Cancellaria asperella, Sowerby, ibid. p. 447 , pl. 93 , f. 38 and pl. 95 , f. 74 .

1856. Cancellaria elegans, ReEve, Conch Icon. Vol. 10, Cancellaria, pl. 3, fs. 12a and $b$.

1856. Cancellaria asperella, ReEve, ibid. pl. 4, fs. 17a and b.

1881. Cancellaria asperella, LöBBECKe, Conch. Cab. Bd. 4, Cancellaria, p. 13, Taf. 3 , fs. $1-4$.

1885. Cancellaria (Merica) asperella, Tryon, Man. Conch. Ist Ser. Vol. 7, p. 74, pl. 3, fs. 53, and pl. 4, f. 50-54.

1895. Cancellaria asperella, Martin, Samml. Geol. Reichs-Mus. Leiden, N. F. Bd. 1, Abt. 1, p. 48, Taf. 7, fs. 113, 113a, 113b, 114a, and 114b.

1915. Cancellaria asperella, TeSch, Paläont. v. Timor, Lief. 5, p. 39, Taf. 79, fs. $82 \mathrm{a}$ and $\mathrm{b}$.

1935. Cancellaria (Cancellaria) reeveana, Nomura, Sci. Rep. Tohoku Imp. Univ. 2nd Ser. Vol. 18, No. 2, p. 131, pl. 6, f. 63.

1938. Cancellaria asperella, OostingH, Ingen. Ned.-Indië, 1938, No. 7, p. 105, Taf. 6, fs. 108-110.

1948. Cancellaria asperella, Cox, Schweiz. Paläont. Abhandl. Vol.66, p. 61, pl.5, fs. $9 \mathrm{a}, \mathrm{b}$, and $\mathrm{c}$.

1951. Cancellaria reeveana, (HIRASE) TAKI, Handb. Illustr. Shells pl.112, f. 2.

1954. Cancellaria (Merica) reeveana, KIRA, Colored Illustr. Shells Japan, Vol. 1, p. 63 , pl. 31, f. 21.

1961. Merica asprella, HaBe, Venus, Vol. 21, No. 4, p. 434, pl. 24, f. 26.

Material.-GK-L 7488. A single full-grown specimen.

\section{Measurements.-}

\begin{tabular}{|c|c|c|c|c|c|c|c|c|c|}
\hline$\underset{\text { GK-L }}{\text { specimen }}$ & $\underset{(\mathrm{mm})}{\mathbf{H}}$ & $\underset{(\mathrm{mm})}{\mathrm{Bd}}$ & $\underset{(\mathrm{mm})}{\mathrm{Ap}}$ & $\underset{(\mathrm{mm})}{\mathrm{D}}$ & $\begin{array}{c}\mathrm{Bd} / \mathrm{H} \\
(\%)\end{array}$ & $\underset{(\%)}{\mathrm{Ap} / \mathrm{H}}$ & $\underset{(\%)}{\mathrm{D} / \mathrm{H}}$ & $\underset{\text { (degrees) }}{\angle \mathrm{P}}$ & $\begin{array}{l}\text { Exhorls } \\
\text { numb. }\end{array}$ \\
\hline 7488 & 25.8 & 21.4 & 18.45 & 16.3 & 79.0 & 71.5 & 65.1 & 73.1 & $6+$ \\
\hline $\begin{array}{l}\text { specimen } \\
\text { GK-L }\end{array}$ & & $\begin{array}{l}\text { iture } \\
\text { ngle }\end{array}$ & & $\begin{array}{l}\text { whorl } \\
\mathrm{D} / \mathrm{H}\end{array}$ & & & & & \\
\hline 7488 & & 13.6 & & $.4 / 2.85$ & 2.59 & & & & \\
\hline
\end{tabular}

* Synonym: Nevia Jousseaume, 1887 and Contortia Sacco, 1894. 
Remarks.-Cancellaria asperella LAMARCK has the channelled suture and its anterior canal is very short, widely open, and truncated at the end. On this basis it is better to be included in Merica H. and A. ADAMs, 1854, rather than in Cancellaria (s.s.), on which the suture is not channelled and the canal is deeply sinuous at the anterior end.

The present species is extremely variable in morphology as pointed out by OosTINGH (1938), who discussed the variability and synonymy of C. asperella in some details. The present specimen represents a peculiar form having the sharply crested axial ribs and well developed tertiary spiral lines and quite identical to MARTIN's specimen (Rijksmus. Geol. Min. Leiden, Reg.No. St. 7956; Martin, 1895, Taf.7, f. 114). On both specimens one axial rib is large and varix-like on the body whorl, but real prominent varices are never developed on the spire-whorls.

Geological occurrence.-Pliocene (Indonesia, Burma?, and Taiwan). and Pleistocene (Southwest Japan).

Recent distribution.-Indo-Pacific from Oman to South Japan.

Horizon.-Santa Barbara Silt.

Locality.-SKGS-71.

Merica asperella varicosa subsp. nov.

Pl. 11, Figs. 4, 5, 15, and 16; Text-figs. 29 and 31.

Material.-Holotype: GK-L 6960 and paratype: GK-L 6983 from one and same locality. GK-L 6960 is full-grown and 6983 is adolescent specimen.

\begin{tabular}{|c|c|c|c|c|c|c|c|c|c|}
\hline \multicolumn{2}{|c|}{ Measurements.- } & \multirow[b]{2}{*}{$\underset{(\mathrm{mm})}{\mathrm{Bd}}$} & \multirow[b]{2}{*}{$\underset{(\mathrm{mm})}{\mathrm{Ap}}$} & \multirow[b]{2}{*}{$\underset{(\mathrm{mm})}{\mathrm{D}}$} & \multirow[b]{2}{*}{$\underset{(\%)}{\mathrm{Bd} / \mathrm{H}}$} & \multirow[b]{2}{*}{$\underset{(\%)}{\mathrm{Ap} / \mathrm{H}}$} & \multirow[b]{2}{*}{$\begin{array}{l}\mathrm{D} / \mathrm{H} \\
(\%)\end{array}$} & \multirow{2}{*}{\multicolumn{2}{|c|}{$\underset{\text { (degrees) }}{\angle \mathrm{A}} \stackrel{\angle \mathrm{P}}{ }$}} \\
\hline $\begin{array}{l}\text { specimen } \\
\text { GK-L }\end{array}$ & $\underset{(\mathrm{mm})}{\mathrm{H}}$ & & & & & & & & \\
\hline 6960 & 27.80 & 20.65 & 16.70 & 16.60 & 74.4 & 60.0 & 59.0 & - & 57.3 \\
\hline 6983 & 22.75 & 16.50 & 11.90 & 12.05 & 72.4 & 52.4 & 53.2 & 86.9 & 54.4 \\
\hline $\begin{array}{l}\text { specimer } \\
\text { GK-L }\end{array}$ & \multicolumn{3}{|c|}{ toconch } & $\begin{array}{l}\text { teleo- } \\
\text { conch }\end{array}$ & \multicolumn{2}{|c|}{$\begin{array}{l}\text { suture } \\
\text { angle }\end{array}$} & \multicolumn{3}{|c|}{$\begin{array}{l}\text { whorl profile } \\
\mathrm{D} / \mathrm{H} \text { on pen }\end{array}$} \\
\hline 6960 & - & - & $1+$ & 5.4 & \multicolumn{2}{|c|}{11.1} & \multicolumn{3}{|c|}{$8.3 / 3.25=2.55$} \\
\hline 6983 & .80 & .90 & 2.16 & 5.1 & \multicolumn{2}{|c|}{13.2} & \multicolumn{3}{|c|}{$6.75 / 2.55=2.64$} \\
\hline
\end{tabular}

Diagnosis.-The shell is moderate in size, solid, and bucciniform. The teleoconch-whorls are convex and regularly rounded at sides and separated one another by the distinctly channelled suture. The body whorl is large occupying more than seventy percent of the total height, broadly rounded at sides, and weakly contracted at the base to the short snout. The basal fasciole is moderately weak and emarginate the small pseudoumbilicus.

The protoconch is low conical consisting of 2.15 smooth volutions, of which the first one is very small and remarkably oblique and the remainder ones are swollen and low. The boundary between the protoconch and the teleoconch is not sharply defined but only indicated by the appearance of the obsolete primary spirals, which are seven, wider than the interspace, and weakly granular at first. On the second whorl the primary spirals are elected, as wide as the interspaces, difinitely granular at the intersections by the axials, and increased in number 
to eight through addition of a subsutural thread. On the third and fourth (penultimate) whorls the primary spirals keep the original pattern except for the relative size. The interspaces become rapidly much wider than the primary lirae. The secondary threads are intercalated on the third whorl and a few minute tertiary threads appear on the body whorl. The primary spirals are elected but almost flat at the crest. The axial ribs are about 24 per whorl at first and increased to 30-31 (excluding 3 varices) on the last two whorls. They are not roof-shaped but rounded at the top, rather irregularly spaced, and somewhat antecurrently oblique. The varices are extremely massive, crossed by the spirals, superimposed by the growth lines, and about three per one whorl. The first varix appears on the second whorl.

The aperture is rhomboid with the weak posterior gutter and the very short and open anterior canal, which is not sinused at the end but simply truncated furnishing a rostrum. The outer lip is almost straight, very slightly antecurrently oblique, sharp at the margin, and lirated inside. The inner lip is sharply bent. The columellar plaits are three and strong. The laterally eleogated teeth on the inner surface of the labrum are 16-17 and moderately strong. The callus is moderately thin at the parietal part and thick at the columellar lip with the free edge and a few irregular pustules.

Comparison.-The present specimens show notable variability in morphology as is indicated in the figures. The variation is chiefly concerned with the relative height of the whorls (or spire) and relative strength of the primary spirals.

The present specimens resemble Merica asperella (LAMARCK), but is readily distinguished from the latter in having flat-topped spirals, rounded and less oblique axials, and extremely massive varices. Furthermore the primary spirals on the early whorls are definitely more numerous on the present specimens than on asperella.

The immature specimen, GK-L 6983, looks like Merica verbeeki (MARTIN) (1895, p. 49, Taf.7, f. 115) in its profile, primary spirals, axials, and apertural feature. The latter is, however, devoid of the varix and tertiary spiral lines. Oostingh (1939, pp. 108 and 109) doubted the validity of the name verbeeki and treated it as a synynym of $M$. asperella. The axial and spiral ornamentation of $M$. verbeeki is not identical to that of $M$. asperella, but closer to that of the present subspecies. The author is inclined to separate verbeei from asperella (s.s.) at least at the subspecific level.

The present specimens are also allied to Merica bifasciata (DESHAYES), but the former has coarser axials and spirals than the latter. Moreover the former is provided with the varices.

Horizon.-Upper part of the Dingle Formation.

Locality.-SKGS-74.

Merica sp. cf. M. laticosta (LöBECKE)

PI. 11, Fig. 8

1881. Cancellaria laticosta LöBECKE, Conch. Cab. Bd. 4, Cancellaria, p.12, Taf. 2, fs. 7-9. 
1885. Cancellaria laticosta, Tryon, Man. Conch. Ist Ser. Vol. 7, p. 74, pl. 4, f. 52.

1936. Cancellaria laticosta, SuzUKI and ICHIMURA, Trans. Palaeont. Soc. Japan, No. 20, p. 725, pl. 40, fs. 13 and 13 a.

1940. Cancellaria reeveana laticosta, HataI and Nisiyama, Saito-Hoon Kai Mus. Res. Bull. No. 19, p. 127, pl. 5, f. 5.

1954. Cancellaria (Merica) laticosta, KIRA, Colored Illustr. Shells Japan, Vol. 1, p. 63, pl. 31 , f. 22.

1961. Merica laticosta, HaBe, Venus, Vol. 21, No. 4, p. 434, pl. 24, f. 25.

Material.-GK-L 7102. Imperfect specimen broken at the body whorl.

Measurements.-

Max. dia. $=13.1 \mathrm{~mm}$, preserved whorls $=4.75$, number of the axials $=21$ (pen) and 19 (bod), and pleural angle $=57$ degrees.

Remarks.-The present specimen conforms with Merica laticosta (LöBECKE) in having slender profile with the pleural angle of 57 degrees and moderately coarse and sharp axial ribs numbering about 20 per whorl, although it is not perfect in preservation. It is not necessarily clear whether $M$. laticosta should be included in $M$. asperella as TRYoN proposed or not. The author is, however, inclined to separate them at the specific level putting the importance on remarkably coarser axials and higher profile of laticosta than those of asperella.

Geological occurrence.-Pliocene and Pleistocene (Japan).

Recent distribution.-Japan.

Horizon.-Upper part of the Ulian Formation.

Locality.-SKGS-72.

Genus Scalptia Jousseaume, 1887

(type-species: Cancellaria obliquata LAMARCK by original designation)

Scalptia crenifera (SOWERBY)

Pl. 11, Figs. 6 and 7; Text-fig. 29

1832. Cancellaria crenifera Sowerby, Conch. Illustr. p't. 4, f. 29.

1849. Cancellaria crenifera, SowerBy, Thesaurus Conch. Vol. 2, p. 453, pl.96, fs. $84-86$.

1856. Cancellaria crenifera, ReEve, Conch. Icon. Vol. 10, Cancellaria, p1. 6, fs. 24a and $\mathrm{b}$.

1881. Cancellaria crenifera, LöBBECKE, Conch. Cab. Bd. 4, Cancellaria, p. 9, Taf. 1, fs. 13-16.

1903. Trigonostoma crispatum, Cossmann (non Sowerby), Jour. de Conch. Tom. p. 108, pl. 3, fs. 5 and 6.

1938. Trigonostoma (Scalptia) creniferum, OostINGH, Ingen. Ned.-Indië, 1938, No. 7, p. 107, Taf. 4, fs. 111-115.

1961. Scalptia crenifera, HABE, Colored Illustr. Shells Japan, Vol. 2, p. 73, pl. 36, f. 5 .

1961. Scapltia crenifera, HABE, Venus, Vol. 21, No. 4, p. 436, pl. 23, f. 7 and pl. 24, f. 4.

Material.-GK-L 6484. A single almost perfect specimen. 


\begin{tabular}{|c|c|c|c|c|c|c|c|c|}
\hline \multicolumn{2}{|c|}{ Measurements.- } & \multirow[b]{2}{*}{$\underset{(\mathrm{mm})}{\mathrm{Bd}}$} & \multirow[b]{2}{*}{$\underset{(\mathrm{mm})}{\mathrm{Ap}}$} & \multirow[b]{2}{*}{$\underset{(\mathrm{mm})}{\mathrm{D}}$} & \multirow[b]{2}{*}{$\underset{(\%)}{\mathrm{Bd} / \mathrm{H}}$} & \multirow[b]{2}{*}{$\underset{(\%)}{\mathrm{Ap} / \mathrm{H}}$} & \multirow[b]{2}{*}{$\begin{array}{l}\mathrm{D} / \mathrm{H} \\
(\%)\end{array}$} & \multirow[b]{2}{*}{$\underset{\text { (degree) }}{\angle \mathrm{P}}$} \\
\hline $\begin{array}{l}\text { specimen } \\
\text { GK-L }\end{array}$ & $\underset{(\mathrm{mm})}{\mathrm{H}}$ & & & & & & & \\
\hline 6484 & 10.50 & 7.95 & 6.10 & 7.55 & 75.7 & 58.1 & 71.8 & 73.9 \\
\hline $\begin{array}{l}\text { specimen } \\
\text { GK-L }\end{array}$ & \multicolumn{4}{|c|}{ protoconch } & $\begin{array}{l}\text { teleo- } \\
\text { conch }\end{array}$ & \multicolumn{3}{|c|}{ base } \\
\hline 6484 & 1.01 & & & & 3.6 & & bilicate & \\
\hline
\end{tabular}

Remarks.-The present specimen illustrates a slight deviation from SowERBY's figured type in having less numerous and less oblique axial ribs and weaker spines at the shoulder-angle than the latter. In these features it shows some affinity to Trigonaphera bicolor (HINDs) (1844, p. 43, pl. 12, fs. 13 and 14) from the Philippines, but is readily distinguished from the latter in being provided with weak but real spine at the shoulder-angle.

OostingH mentioned (1938, p. 107-108, Taf. 4, fs. 111-115) the morphological variability of Scalptia crenifera on the basis of the Pliocene material from Java. The present specimen quite conforms with the figured specimen from Tjidjoerej in Cheribon.

Geological occurrence.-Pliocene (Indonesia and India).

Recent distribution.-Tropical Indo-Pacific from Oman to the Philippines. Horizon.-Santa Barbara Silt.

Locality._SKGS-71.

\section{Superfamily Conoidea \\ Family Turridae \\ Subfamily Turrinae}

Genus Gemmula WeINKAUfF, 1875

(type-species: Pleurotoma gemmata REEVE by subsequent designation, Cossmann, 1896)

Subgenus Gemmula (s.s.)

Gemmula (Gemmula) speciosa (REEVE)

Pl. 18, Fig. 10 and Pl. 19, Figs. 1-5 and 11; Text-fig. 32.

1834. Pleurotoma carinata Gray in Griffith and Pidgeon, Mollusca and Radiata, arranged by Baron Cuvier, p. 599, pl.23, f.2. (non Pleurotoma carinata LINK, 1808 , nec $P$. carinata GRAY in REEve, 1843)

1843. Pleurotoma speciosa ReEve, Conch. Icon. Vol. 1, Pleurotoma, pl. 2, f. 9.

1884. Pleurotoma (Gemmula) speciosa, Tryon, Man. Conch. Ist Ser. Vol. 6, p. 173, pl. 4 , f. 48.

1915. Pleurotoma (s.s.) carinata, Tesch, Paläont. v. Timor, Lief. 5, p. 25, Taf. 77, f. $47 \mathrm{a}$.

1917. Turris (Gemmula) guadurensis Melvill, Proc. Malac. Soc. London, Vol. 12, p. 145.

1964. Gemmula (Gemmula) speciosa, PowelL, Indo-Pacific Moll. Vol.1, No.5, p. 245, pl. 186, f. 1.

1966. Gemmula (Gemmula) speciosa, Poweld, Bull. Auckland Inst. Mus. No.5, p. 47 , pl. 6, f. 2.

Material.-GK-L 6817 to 6822,6824 to $6827,6863,6865$ to 6867 , and 7302 from one and same locality. 


\section{Measurements.-}

\begin{tabular}{|c|c|c|c|c|c|c|c|c|c|}
\hline $\begin{array}{l}\text { specimen } \\
\text { GK-L }\end{array}$ & \multicolumn{2}{|c|}{$\underset{(\mathrm{mm})}{\mathrm{H}}$} & \multicolumn{2}{|r|}{$\underset{(\mathrm{mm})}{\mathrm{Bd}}$} & & $\underset{(\mathrm{mm})}{\mathrm{Ap}}$ & $\underset{(\mathrm{mm})}{\mathrm{D}}$ & $\underset{(\%)}{\mathrm{Bd} / \mathrm{H}}$ & $\underset{(\%)}{\mathrm{H}} \underset{(\%)}{\mathrm{Ap} / \mathrm{H}}$ \\
\hline 6618 & \multicolumn{2}{|c|}{$36.7+(38.0)$} & \multirow{2}{*}{\multicolumn{3}{|c|}{$22.6+(23.5)$}} & $7.8+(18.7)$ & 13.85 & 61.7 & 49.3 \\
\hline 6819 & $19.4+$ & $(20.3)$ & & & & $9.6+(10.5)$ & 7.80 & 66.1 & 51.6 \\
\hline 6820 & \multicolumn{2}{|l|}{$18.1+$} & \multicolumn{2}{|c|}{$11.35+$} & & $8.4+$ & 7.70 & 62.7 & 46.4 \\
\hline 6863 & \multirow{2}{*}{\multicolumn{2}{|c|}{$\begin{array}{r}12.55 \\
8.65\end{array}$}} & \multicolumn{2}{|c|}{8.00} & & 5.85 & 5.60 & 63.6 & 46.6 \\
\hline 6865 & & & \multicolumn{2}{|c|}{5.80} & & 4.15 & 3.65 & 66.8 & 47.8 \\
\hline 6866 & \multicolumn{2}{|l|}{$\begin{array}{l}8.00 \\
9.85\end{array}$} & \multirow{2}{*}{\multicolumn{2}{|c|}{$\begin{array}{l}6.05 \\
5.40\end{array}$}} & & 4.40 & 4.20 & 61.4 & 44.6 \\
\hline 6867 & \multicolumn{2}{|l|}{9.10} & & & & 3.85 & 3.70 & 59.3 & 42.2 \\
\hline 6869 & \multicolumn{2}{|l|}{$\begin{array}{l}9.10 \\
8.95\end{array}$} & \multicolumn{2}{|c|}{$\begin{array}{l}5.40 \\
5.50\end{array}$} & & 3.90 & 3.65 & 61.4 & 43.5 \\
\hline $\begin{array}{l}\text { specimen } \\
\text { GK-L }\end{array}$ & $\underset{(\%)}{\mathrm{D} / \mathrm{H}}$ & \multicolumn{2}{|c|}{$\underset{\text { (degrees) }}{\angle \mathrm{A}} \quad \angle \mathrm{P}$} & \multicolumn{3}{|c|}{$\mathrm{H} \stackrel{\text { protoconch }}{\mathrm{D}}$ numb.* } & \multicolumn{3}{|c|}{$\begin{array}{ll}\text { teleo- suture } & \text { whorl profile } \\
\text { conch angle } & \mathrm{D} / \mathrm{H} \text { on pen }\end{array}$} \\
\hline 6818 & 36.3 & 66.6 & 28.1 & 1.72 & 1.44 & $3.5 \quad(2.0)$ & 7.8 & $9.4 \quad 1$ & $10.1 / 4.8=2.10$ \\
\hline 6819 & 38.5 & 66.4 & 35.4 & 1.76 & 1.48 & $4.05(2.5)$ & 5.8 & 8.1 & $6.3 / 2.35=2.68$ \\
\hline 6820 & 42.5 & 60.8 & 37.9 & 1.54 & 1.40 & $3.9(2.5)$ & 6.0 & 7.0 & $5.1 / 1.85=2.76$ \\
\hline 6863 & 44.7 & 52.6 & 39.9 & 1.92 & 1.60 & $4.2 \quad(2.0)$ & 4.25 & 6.4 & $3.5 / 1.35=2.59$ \\
\hline 6865 & 42.1 & 62.1 & 29.3 & 1.92 & 1.52 & $4.5 \quad(1.0)$ & 3.3 & 10.5 & $3.0 / 1.25=2.40$ \\
\hline 6866 & 42.5 & 55.1 & 35.4 & 1.64 & 1.44 & $4.6 \quad(2.3)$ & 4.0 & 5.2 & $2.75 / 1.25=2.28$ \\
\hline 6867 & 40.6 & 49.2 & 25.9 & 2.08 & 1.60 & $4.6 \quad(1.6)$ & 3.1 & 8.2 & $2.75 / 1.2=2.29$ \\
\hline 6869 & 40.7 & 58.0 & 25.6 & - & - & $3+(1.2)$ & 3.8 & 5.8 & \\
\hline
\end{tabular}

Remarks.-The present specimens are featured by their (1) moderately broad fusiform outline of the shell, (2) prominent, elevated, and bi-lirated peripheral keel, (3) laterally compressed close gemmules on the peripheral keel, (4) extremely concave shoulder, (5) moderately strong subsutural fold which is superimposed by a sharply ridged lira, (6) remarkably raised but fine primary spirals, (7) moderately long and slightly curved canal, and (8) abruptly contracted basal slope. These features are quite identical to the diagnostic characters of Gemmula (Gemmula) speciosa (REEVE) (1843, pl. 2, f.9). The largest specimen of the present material is, however, only two-thirds of the normal adult shell of the living G. (G.) speciosa, although the former is considered to be adult on the basis of the fact that the peripheral gemmules are closer and rather irregular on the last half of the last whorl than on the earlier part in spite of its small size of $15 \mathrm{~mm}$ in maximum diameter.

TeSch described the same species from the Pliocene of Timor as Pleurotoma (s.s.) carinata GrAY (part) (1915, p. 25-26, pl. 77, fs. 47a only). His specimen is also small in size attaining about $12.5 \mathrm{~mm}$ in diameter. This difference in size between the living and fossil specimens may reflect an evolutional trend of this species.

The protoconch of the present specimens are moderately low conical and consists of three and a half to four and two-thirds volutions, of which the first one is very small and depressed, the following one to two volutions are slightly convex and also smooth, and the last one to two and a half volutions are moderately convex and provided with thin, close, and retractly curved axial riblets and the distinct subsutural lira. The teleoconch begins with the abrupt appearance of the peripheral keel in association with the deep anal sinus. The first whorl has the similar profile to the later ones and generally ornamented with the 
sharp peripheral keel emarginated by two side-lines, distinct subsutural lira, about 17 gemmules (15-21, averages: 17.0), and distinct growth lines. On some specimens, however, a few additional spiral lines are discernible on the shoulder and the lateral surface. The gemmules rapidly become closer and counted more than thirty-five on the seventh whorl. The spirals are also progressively increased in number on later whorls by the intercalation of the secondary, tertiary, and quaternary lines. In consequence the last whorl of the adult specimens is ornamented with the complicated spirals; two weak secondaries on the upper slope of the subsutural lira; five to six moderately distinct primary and secondary threads on the shoulder; five to six distinct primary lirae on the lateral and basal slope, on which each interstice is spaced with a seconday, two tertiary, and one to two quaternary lines; and 16 to 18 alternating pairs on the snout. The primary lirae on the lateral surface never develop as prominent as those of $G$. (G.) kieneri (Doumet).

Geological occurrence.-Pliocene (Indonesia).

Recent distribution.-Tropical Indo-Pacific from Oman to the Philippines. Horizon.-Upper part of the Dingle Formation.

Locality.-SKGS-74.

\section{Gemmula (Gemmula) graeffei (WEINKAUFF)}

P1. 18, Figs. 12, 13, and 16-18; Text-fig. 32

1875. Pleurotoma (Gemmula) graeffei Weinkauff, Conch. Cab. Bd. 4, p. 3, Pleurotoma, p. 71, Taf. 3 , fs. 9 and 10.

1875. Pleurotoma (Gemmula) graeffei, Weinkauff, Jahrb. deutsch. Malak. Gesel. Bd. 2, p. 290, Taf. 9, fs. 9 and 10.

1884. Pleurotoma (Gemmula) graeffei, TrYoN, Man. Conch. Ist Ser. Vol. 6, p. 173, pl. 4 , f. 50.

1964. Gemmula (Gemmula) graeffei, Powell, Indo-Pacific Moll. Vol.1, No.5, p. 263, p1. 200, f. 3.

Material.-GK-L 6852,6855 to 6862 and 6870 from one and same locality.

\begin{tabular}{|c|c|c|c|c|c|c|c|c|c|}
\hline \multicolumn{2}{|c|}{ Measurements.- } & \multirow[b]{2}{*}{$\underset{(\mathrm{mm})}{\mathrm{Bd}}$} & \multirow[b]{2}{*}{$\underset{(\mathrm{mm})}{\mathrm{Ap}}$} & \multirow{3}{*}{$\underset{(\mathrm{mm})}{\mathrm{D}}$} & \multirow{3}{*}{$\begin{array}{c}\mathrm{Bd} / \mathrm{H} \\
(\%) \\
66.2\end{array}$} & \multirow{3}{*}{$\begin{array}{c}\mathrm{Ap} / \mathrm{H} \\
(\%) \\
49.4\end{array}$} & \multirow[b]{2}{*}{$\mathrm{D} / \mathrm{H}$} & \multirow{2}{*}{\multicolumn{2}{|c|}{$\underset{\text { (degrees) }}{\angle \mathrm{A}} \stackrel{\mathrm{P}}{\mathrm{A}}$}} \\
\hline $\begin{array}{l}\text { specimen } \\
\text { GK-L }\end{array}$ & $\underset{(\mathrm{mm})}{\mathrm{H}}$ & & & & & & & & \\
\hline 6952 & 14.35 & 9.50 & 7.10 & & & & 43.6 & 60.2 & 19.3 \\
\hline 6855 & 12.20 & 7.2 & 5.10 & 4.80 & 58.8 & 41.7 & 39.3 & & 27. \\
\hline 6856 & 9.05 & 5.75 & 4.10 & 3.95 & 63.5 & 45.2 & 43.5 & 60.1 & 20.3 \\
\hline 685 & 8.60 & & 4. & 3. & 64 & 47.7 & 41.2 & & 21. \\
\hline 68 & 8.8 & 5.9 & 4.2 & 3.6 & 66.9 & 49.9 & 41.4 & 60 & 19 \\
\hline 68 & 8.2 & 5.4 & $4 .(1+2)-1$ & 3.7 & 66. & 48. & 45 & 66 & 20 . \\
\hline 6870 & 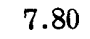 & 5.20 & 3.60 & 3.35 & 66 & 46 & 42.8 & 63.3 & 29.3 \\
\hline specir & & ot & & & tele & st & & & \\
\hline GK & $\mathrm{H}$ & & & numb.* & & & & & \\
\hline 68 & 1.04 & 1.0 & & $.1(1.7)$ & 5. & 5 & & 1.5 & .63 \\
\hline 68 & - & 1. & & $+(1.5)$ & 6. & & & 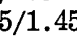 & 2.58 \\
\hline 68 & 1.48 & 1.5 & & $3(1.0)$ & 3. & 7. & & 1 & \\
\hline & 1.36 & 1.2 & & $3(2.0)$ & & 9 & & & \\
\hline & 1.40 & 1.48 & & $.5(1.7)$ & 3.75 & 6. & & $5 / 1$ & .65 \\
\hline & 1.30 & 1.44 & & $4(1.0)$ & 3.25 & 7. & & $/ 1$ & .47 \\
\hline 6870 & 1.70 & 1.6 & & $.6(1.3)$ & 2.7 & 8.3 & & $5 / 1.0=$ & .35 \\
\hline
\end{tabular}

* The figures in parentheses are number of volutions with brephic axials. 

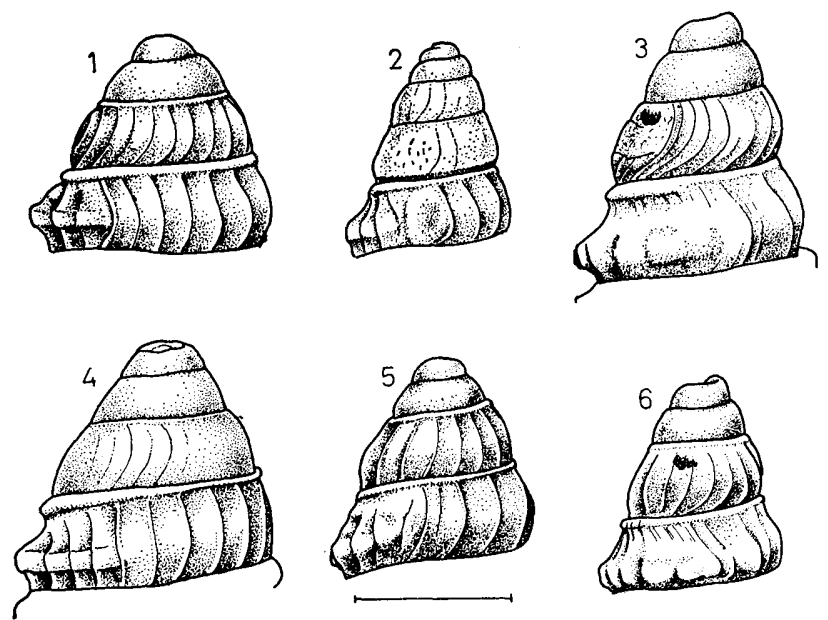

Fig. 32. Protoconchs of some turrids.

1: Gemmula (Gemmula) speciosa (REEvE), GK-L 6818.

2: G. (G.) hombroni HEDLEY, GK-L 6426.

3 and 6: G. (Unedogemmula) butonensis asanoi subsp. nov., GK-L 6828 (fig. 3) and GK-L 6830 (fig. 6).

4 and 5: G. (G.) graeffei (WeINKAUFF), GK-L 6870 (fig. 4) and GKL 6852 (fig. 5).

Unit bar indicates $1 \mathrm{~mm}$ for figs, $1,2,4,5$, and 6 and $0.8 \mathrm{~mm}$ for fig. 3 .

Remarks.-The majority of the present specimens is featured by the slightly conoidal high spire; long, slender, and slightly bent canal; gradually contracted basal slope; and massive and tripartile subsutural band, on which the central lira is subcarinated. They are quite identical to $G$. (G.) graeffei (WeINKAUFF) except for smaller size. Even the largest one of the present specimens is only about two-thirds as large as the average adult size of the living specimens and its teleoconch-whorls are apparently less in number than the latter. Furthermore it does not show any adult or gerontic feature on the last part of the body whorl. These facts indicate that non of the present specimens are at their maturity. The protoconch of the present specimens is slightly conoidal, moderately high, and consists of 4.1 to 4.6 volutions, of which the last 1.0 to 2.0 volutions are provided with the close brephic axials and a distinct subsutural thread. The size of the protoconch is evidently variable as indicated in the measurements, although the number of the volutions is rather stable.

The specimens GK-L 6856 and 6870 differ from the others in the characteristics of the subsutural band, which on these specimens is neither prominent nor tripartile, although they are quite similar to others as far as the other morphological features are concerned. Their subsutural band is rather thin and provided with the central sharp lira and several fine side-threads above and below. It is not clear whether these difference illustrate the intra-specific asexual variation, sexual dimorphism, or specific deviation. They are, however, tentatively included in G. (G.) graeffei evaluated the identity in the general 
diagnostic features and the biological meaning of co-occurrence.

Recent distribution.--Tropical West Pacific from the Philippines to Fiji. Horizon.-Upper part of the Dingle Formation.

Locality.-SKGS-74.

\section{Gemmula (Gemmula) hombroni HeDLEY}

Pl. 19, Figs. 8 and 15-17; Text-fig. 32

1853. Pleurotoma fusca Hombron and JaCQuinot (non C. B. Adams, 1845), Voy. Dole Sud. Zool. Tom. 4, p. 111, pl. 25, fs. 19 and 20.

1883. Pleurotoma gemmata, Tryon (partim), Man. Conch. Ist Ser. Vol. 6, p. 173.

1913. Pleurotoma (Gemmula) fusca, Schepman, Siboga Expeditie, Lief. 49, p. 402.

1922. Gemmula hombroni HedLeY, Rec. Austral. Mus. Vol. 13, No. 3, p. 218, nom. nov. for $P$. fusca HoMBroN and JACQUINOT, 1853.

1925. Pleurotoma (Gemmula) padangensis THIELE, Wissenschft. Ergebn. Deutsch. Tiefsee-Exped. Bd. 17, Gastrop. 2, p. 335, Taf. 23, f. 5.

1964. Gemmula (Gemmula) hombroni, Poweld, Indo-Pacific Moll. Vol. 1, No. 5, p. 262, pl. 200, f. 4 and pl. 201, f. 8 .

1967. Gemmula hombroni, PoweLl, ibid. Vol. 1, No. 7, p. 439, pl. 314.

Material.-GK-L 6424, 6425, and 6426 from loc. SKGS-73. Preservation is almost perfect.

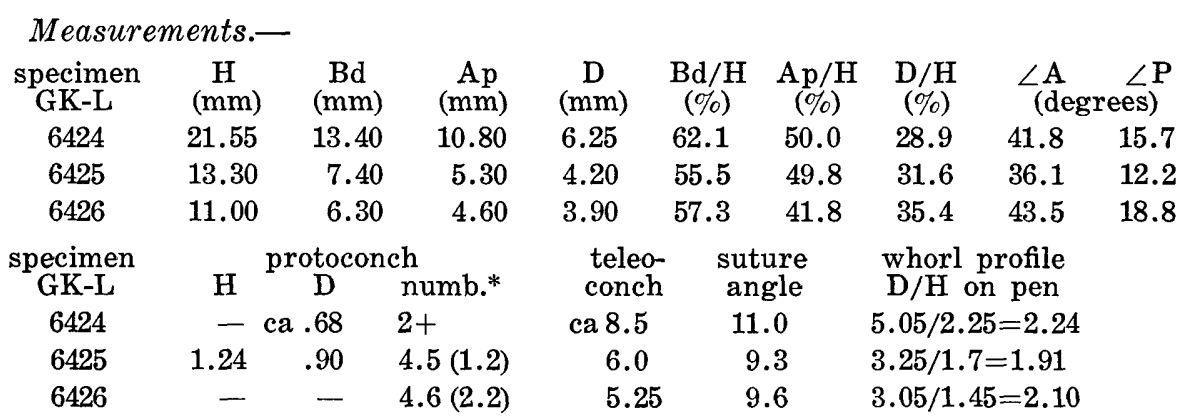

* The figures in parentheses are number of volutions with brephic axials.

Remarks.-The present specimens are quite identical with Gemmula (Gemmula) hombroni HEDLEY with following diagnostic features. Moderately small and slenderly fusiform outline, peculiar spire with the narrowly conical protoconch, slightly conoidal juvenile part of the teleoconch, and subcylindrical adult part characterize the species. The teleoconch-whorls are provided with the prominent and narrowly crested subsutural cord, coarsely gemmated wide peripheral carina at slightly below the middle of the whorl, and a distinct spiral lira just above the lower suture. The number of the spiral ornamentation on the basal slope of the body whorl is somewhat variable. Four to six simple spiral lirae are discernible there, of which the upper ones are successively carser and more widely spaced than the lower ones. The alternating pairs of distinct and weak threads on the snout are finer and closer at the lower than at the upper part. The peripheral gemmules are 14 to 17 per one whorl at the early stage of growth and very gradually increased in number to 18 to 20 at the adult stage. The space between the subsutural cord and the peripheral carina is deeply 
concave and has two or three weak spiral threads. The protoconch is very high conical and composed of about four and a half volutions, of which the last 1.2 to 2.5, at least, have the moderately close brephic axials. The subsutural cord appears on the first teleoconch-whorl.

Recent distribution.-Tropical Indo-Pacific from Andaman to Torres Strait eastward and Southwest Japan northeastward.

Horizon.-Upper part of the Ulian Formation.

Locality.-SKGS-73.

\section{Gemmula (Gemmula) kieneri woodwardi (MARTIN)}

Pl. 19, Figs. 6, 7, 9, and 10.

1879. Pleurotoma concinna, Woodward (non DUnker), Geol. Mag. Decade 2, Vol. 6, p. 537, pl. 14, fs. 3a and b.

1884. Pleurotoma woodwardi Martin, Samml. Geol. Reichs-Mus. Leiden, Ser.1, Bd. 3, p. 56, Tab. 4, f. 57 .

1895. Pleurotoma (Pleurotoma) carinata woodwardi, Martin, ibid. N. F. Bd.1, Abt. 1, p. 37, Taf. 6, fs. 91-96.

1938. Turris (Gemmula) granosa woodwardi, Oostingh, Ingen. Ned.-Indië, 1938, No. 7, p. 27.

1964. Gemmula (Gemmula) kieneri woodwardi, PoweLl, Indo-Pacific Moll. Vol. 1, No. 5, p. 247, pl. 188, f. 2.

Material.-GK-L 6816, 6823, 6864, and 6868 from one and same locality.

Measurements.-

\begin{tabular}{|c|c|c|c|c|c|c|c|c|c|}
\hline$\underset{\text { GK-L }}{\text { specimen }}$ & $\underset{(\mathrm{mm}}{\mathrm{H}}$ & & $\underset{(\mathrm{mm}}{\mathrm{Bd}}$ & & $\underset{(\mathrm{mm})}{\mathrm{Ap}}$ & $\underset{(\mathrm{mm})}{\mathrm{D}}$ & $\begin{array}{c}\mathrm{Bd} / \mathrm{H} \\
(\%)\end{array}$ & $\underset{(\%)}{\mathrm{Ap} / \mathrm{H}}$ & $\mathrm{D} / \mathrm{H}$ \\
\hline 6816 & 24.35 & & 14.20 & & 11.40 & 8.15 & 58.3 & 46.8 & \\
\hline 6823 & $20.25+$ & (20.8) & $12.05+$ & $(12.6)$ & $8.4+(\varepsilon$ & 7.45 & 60.5 & 43.0 & \\
\hline 6868 & 8.30 & & 10 & & 3.70 & 3.20 & 1.4 & 44.6 & 5 \\
\hline specin & $\underset{(\mathrm{de}}{\angle \mathrm{A}}$ & $\angle \mathrm{P}$ & \multicolumn{3}{|c|}{$\begin{array}{c}\text { protoconch } \\
\text { D }\end{array}$} & $\begin{array}{l}\text { teleo- } \\
\text { conch }\end{array}$ & $\begin{array}{l}\text { suture } \\
\text { angle }\end{array}$ & \multicolumn{2}{|c|}{$\begin{array}{l}\text { whorl profile } \\
\text { D/H on pen }\end{array}$} \\
\hline 6816 & 47.5 & 21.2 & ca 1.14 & ca 1.28 & $3.3(1.0)$ & 7.4 & 8.4 & \multicolumn{2}{|c|}{$5.8 / 2.95=1.96$} \\
\hline 6823 & 51.4 & 25.1 & 1.72 & 1.40 & $4.5(2.5)$ & 6.0 & 9.9 & \multirow{2}{*}{\multicolumn{2}{|c|}{$5.25 / 2.3=2.28$}} \\
\hline 6868 & 60.6 & 23.1 & 1.80 & 1.52 & $4.5(1.2)$ & 3.4 & 4.8 & & \\
\hline
\end{tabular}

* The figures in parentheses are number of volutions with brephic axials.

Remarks.-MARTIN's type-specimen (St. $\mathrm{N}^{\circ} 7840$ ) is moderately small, attaining $43 \mathrm{~mm}$ and $14.5 \mathrm{~mm}$ respectively in the height of the shell and maximum diameter. The protoconch is conical with more than four volutions, of which the last two and a half are provided with the brephic axials. The subsutural cord is remarkable on the last two volutions. The teleoconch-whorls are ornamented with the sharp and simple subsutural cord, gemmate peripheral carina, numerous spiral threads, and the raised growth lines. The peripheral carina is clearly defined at the both sides by the raised threads which appear on the later part of the last volution of the protoconch. The gemmules are laterally compressed and about 30 in number. The spiral threads on the concave shoulder are about seven to eight of which the central three are more distinct than the others. The spirals on the lateral surface between the peripheral carina and the lower suture consist of two primaries and five secondaries. The upper one of the primary lirae is stronger than the lower 
one, which is situated close to the lower suture. The base is gradually contracted and does not illustrate the basal angulation. It is ornamented with about nine sets of the primaries, secondaries, and tertiaries, of which a few primaries at the middle part are somewhat crenulated. About eleven pairs of the primaries and secondaries comprise the ornamentation of the long snout.

The ornamentation and especially the profile of the basal slope are the characteristic features of the present species. It seems, however, to be somewhat variable concerning the mentioned feature. That is to say some of the MARTIN's specimens from the Pliocene of Sondé, especially the specimen illustrated in Fig. 95 of the Plate 6, 1895, show the angled base.

The present species is distinguished typologically from G. (G.) kiener (DUMONT) in having smaller shell, less massive subsutural fold, more prominently elevated peripheral carina with less numerous gemmules, and gradually contracted base. Majority of the specimens of $G$. kieneri woodwardi from the Pliocene of Sondé is clearly provided with the same diagnostic features as the type specimens, but a few specimens are hardly distinguished from G. (G.) kieneri (s.s.).

The specimens in hand from Panay show slight difference from the typical form in having comparatively wider peripheral carina and less numerous gemmules. They, however, verify closer affinity to G. kieneri woodwardi than to the any other species.

Geological occurrence.-Pliocene (Indonesia).

Horizon.-Upper part of the Dingle Formation.

Locality.-SKGS-74.

Subgenus Unedogemmula MacNEIL, 1960

(type-species: Turris unedo KIENER by original designation)

Gemmula (Unedogemmula) butonensis asanoi subsp. nov.

Pl. 18, Figs. 1-8, 11, 14, 15, and 19; Text-figs. 32 and 33

Material.-Holotype: GK-L 6828 and paratypes: GK-L 6829 to 6837 from loc. SKGS-74. GK-L 6838 to 6843 and 7299 to 7301 from loc. SKGS-74 and GK-L 7118 to 7120 from loc. SKGS-75 are also examined. All the specimens are more or less abraded or broken at the apex and labrum.

\begin{tabular}{|c|c|c|c|c|c|c|c|c|c|}
\hline \multicolumn{2}{|c|}{ Measurements.- } & \multirow[b]{2}{*}{$\underset{(\mathrm{mm})}{\mathrm{Bd}}$} & \multirow{3}{*}{$\underset{(\mathrm{mm})}{\mathrm{Ap}}$} & \multirow[b]{2}{*}{$\underset{(\mathrm{mm})}{\mathrm{D}}$} & \multirow[b]{2}{*}{$\mathrm{Bd} / \mathrm{H}$} & \multirow[b]{2}{*}{$\underset{(\% /)}{\mathrm{Ap} / \mathrm{H}}$} & \multirow[b]{2}{*}{$\mathrm{D} / \mathrm{H}$} & \multirow{2}{*}{\multicolumn{2}{|c|}{$\angle \mathrm{A} \quad \angle \mathrm{P}$}} \\
\hline $\begin{array}{l}\text { specimen } \\
\text { GK-K }\end{array}$ & $\underset{(\mathrm{mm})}{\mathrm{H}}$ & & & & & & & & \\
\hline 6828 & 54.6 & & & 16.95 & 64.0 & 52.5 & 31.0 & 55.1 & 28.3 \\
\hline 6829 & 54.0 & 34.75 & 28.35 & 16.50 & 64.3 & 52.4 & 30.6 & 51.1 & 29 \\
\hline 6830 & 42.3 & 26.90 & 22.70 & 12.75 & 63.5 & 53.6 & 30.1 & 59.6 & 29.5 \\
\hline 6833 & 14.2 & 8.75 & 6.75 & 5.55 & 61 . & 47.4 & 39.0 & 58.5 & 38.2 \\
\hline 6834 & 50.1 & 32.10 & 26.05 & 16.30 & 63.9 & 52.0 & 32.5 & 56.3 & 28.4 \\
\hline 6835 & $48.9+(51.0)$ & 32.10 & 25.80 & 16.05 & 62.9 & 50.6 & 31.5 & - & 28.2 \\
\hline 6836 & $52.3+(53.5)$ & 34.80 & 29.00 & 16.15 & 64.9 & 54.1 & 30.1 & - & 24.4 \\
\hline 6837 & $46.6+(48.5)$ & 32.00 & 25.60 & 15.10 & 65.8 & 52.7 & 31.2 & - & 28.9 \\
\hline 7299 & 14.75 & 7.90 & 6.75 & 5.30 & 53.4 & 45.7 & 35.9 & 57.6 & 29.7 \\
\hline 7300 & 11.00 & 6.9 & 5.20 & 4.90 & 63.1 & 47.2 & 44.5 & 58.8 & \\
\hline 7301 & 8.85 & 5.75 & 4.35 & 4.80 & 64.9 & 49.1 & 54.2 & 50.4 & 38.7 \\
\hline
\end{tabular}


Fig. 33. Morphological features of some turrids.

1-4: Turris (Turris) panayensis sp. nov.

1: first whorl, 2: fourth whorl, 3: fifth whorl, ane

4: adult whorl showing the lamellate growthlines.

5: Gemmula (Unedogemmula) butonensis asanoi subsp. nov. showing the spiral lirae and growthlines.
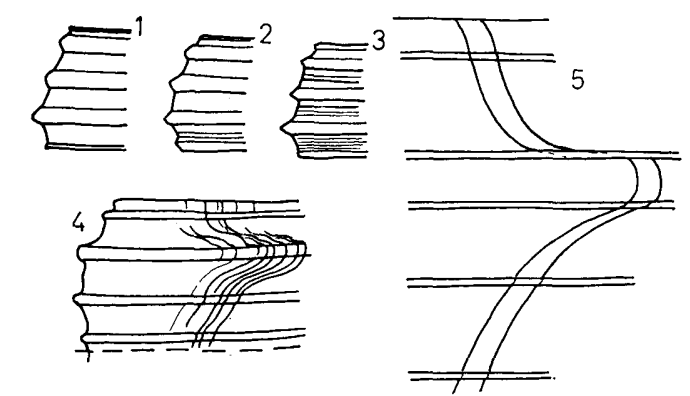

$\begin{array}{ccc}\begin{array}{c}\text { specimen } \\ \text { GK-L }\end{array} & \text { H } & \begin{array}{c}\text { protoconch } \\ \text { D }\end{array} \\ 6828 & \text { ca } 1.2 & 1.0 \\ 6829 & 1.0+ & 0.95 \\ 6830 & 1.24 & 1.24 \\ 6833 & 0.90 & 1.22 \\ 6834 & - & - \\ 6835 & - & - \\ 6836 & - & - \\ 6837 & - & - \\ 7299 & 1.24 & 0.96 \\ 7300 & 1.16 & 0.96 \\ 7301 & \text { ca } 1.2 & 1.00\end{array}$

\begin{tabular}{|c|c|c|}
\hline numb.* & $\begin{array}{l}\text { teleo- } \\
\text { conch }\end{array}$ & $\begin{array}{l}\text { suture } \\
\text { angle }\end{array}$ \\
\hline $3.5+(1.5)$ & 10.7 & 8.8 \\
\hline $3.3+(1.5)$ & 11.3 & 10.3 \\
\hline $4.0 \quad(1.5)$ & 10.0 & 7.4 \\
\hline $3.4 \quad(1.3)$ & 6.8 & 6.9 \\
\hline $1.5+(1.0 ?)$ & 12.2 & 8.2 \\
\hline - & $9+$ & 7.7 \\
\hline - & $7.5+$ & 6.5 \\
\hline - & - & 7.4 \\
\hline$(1.25)$ & 6.75 & 9.8 \\
\hline $4.1 \quad(2.0)$ & 5.75 & 6.9 \\
\hline $3.7 \quad(2.2)$ & 3.75 & 8.1 \\
\hline
\end{tabular}

whorl profile $\mathrm{D} / \mathrm{H}$ on pen

$12.3 / 5.15=2.38$

$12.15 / 4.9=2.47$

$9.3 / 3.8=2.44$

$3.75 / 1.4=2.68$

$11.7 / 4.55=2.67$

$11.5 / 5.15=2.23$

$11.9 / 5.1=2.33$

$11.0 / 4.5=2.24$

$3.8 / 1.6=2.37$

$3.25 / 1.1=2.95$

$3.55 / 1.05=3.38$

* The figures in parentheses are number of volutions with brephic axials.

Diagnosis.-The shell is medium attaining about $55 \mathrm{~mm}$ in height, fusiform with the regularly turreted spire and the somewhat broad and long canal. The protoconch is high conical with about four volutions which are respectively somewhat convex at the lower fourth. The last one and a quarter to two volutions are provided with the distinct brephic axials. The teleoconch of the adult specimens consists of about eleven to twelve whorls, which are ornamented with the sharply ridged subsutural cord, prominent peripheral carina at the lower third of each whorl, several spirals of various orders, and the raised growth lines. Generally the first whorl has the massive subsutural cord and the bi-lirated peripheral carina with the coarse gemmules. On that whorl the shoulder between the subsutural cord and the peripheral carina is remarkably concave and smooth except for the obsolete growth lines. The lateral surface below the carina is receded, also concave, and smooth. This profile persists on to the penultimate whorl and the growth rate of the whorl is almost constant through growth stages. In consequence the tangential line of the whorls is quite straight. The gemmules on the carina are somewhat broad and about sixteen (fifteen to seventeen) on the first whorl and increased to eighteen to twenty on the second, nineteen to twenty on the third, and gradually diminished on the fourth whorl. Consequently the carina on the later whorls is quite smooth except for two side-lirae. The spiral ornamentation appears on the shoulder of the second whorl as a primary thread, then increased in number to about five threads of almost equal dimension on the fourth whorl, and thereafter any remarkable modification of the pattern by the additional threads does not take place, although there are some exception in 
which the shoulder is decorated with seven to ten threads of diverse dimensions. The primary spiral on the lateral surface appears on the second, third, or fourth whorl and then secondaries and tertiaries are intercalated later progressively. The lateral and basal part of the last whorl is regularly rounded to the contracted junction between the snout and the basal slope. About eight to nine suits of the primary lirae and the secondary and tertiary threads comprise the spiral system on the lateral and basal surface. The spirals on the snout are fourteen to eighteen (mostly about eighteen) pairs of the primaries and secondaries. The primary spiral lirae are strong, elevated, and flat-topped on the lateral surface and somewhat irregularly wavy on the basal slope. The anal sinus detected by the growth lines on the body whorl is moderately deep with the apex on the carina. The upper and lower arms are asymmetrical. The former runs along the upper margin of the carina and then abruptly curved upward to marge to the upper suture with more than sixty degrees; the latter leaves the lower margin of the carina immediately and then broadly curved downward. The growth lines are so raised and broad that they are something like minor folds on the shoulder and apparently cross over the secondary and tertiary spirals.

The subsutural lira is round at the crest and close to the suture on the first whorl, while it becomes flat-topped and very slightly shifted anteriorly later. On the third whorl it is high-trapezoid in cross section with flat and moderately narrow top and steep and straight sides. There is a fine but distinct line respectively at the foot of these sloping sides. This pattern is maintained throughout the later growth stages with one or two additional fine lines at both sides.

The aperture is rather small and pyriform with acutely pointed posterior end and long, vertical, and straight anterior canal. The labrum is not preserved on all the specimens. Four to five fine spiral threads are discernible inside the outer lip and they are stopped at some distance from the very margin. The inner lip is covered with the very thin callus.

Comparison.-The present specimens are clearly included in Unedogemmula MACNEIL, 1960, on the basis of the anal sinus with its apex on the peripheral carina and the gemmules restricted to the early three teleoconch-whorls.

They are closely allied to Pleurotoma butonensis MarTiN from the OligoMiocene of Buton (1933, p. 19, Taf. 2, fs. 12 and 13), which is included in Unedogemmula by the reason just same as mentioned above. The present specimens are separable from MARTIN's species by only minor differences: the former has stronger and more elevated subsutural band, more deeply concave and more gently sloped shoulder, and more distinct spiral threads and growthlines on the shoulder than the latter. That is to say, the present specimens are characterized by the shell of more crude build. Considering the order of difference the author prefers to place the present specimens under $G$. (U.) butonensis as a subspecies.

The specimens in hand are also closely allied to Turris (Gemmula) koolhoveni Oostingh from the Pliocene of south Bantam, Java (1938, p. 28, Taf. 1, f. 22) which is also reasonably included in the mentioned subgenus. Comparing with $G$. $(U$.$) koolhoveni the present specimens have longer and broader canal. Con-$ sequently the upper half above the peripheral carina of the body whorl is shorter 
than the lower half below that carina on the latter. The shoulder of the present specimens is much more concave than that of koolhoveni and consequently the peripheral carina of the former is more prominently projected outward than on the latter. The gemmulate whorls are limited to the early three whorls in the present specimens instead of six in koolhoveni. It may indicate that they stand at the different stages on the course of phylogenetic trend.

The present specimens are readily distinguished from $G$. (U.) unedo (KIENER) in having smaller shell, less numerous whorls with gemmules, more concave shoulder, and weaker spirals than the latter.

Horizons.--Upper and uppermost parts of the Dingle Formation.

Localities.-SKGS-74 and 75.

\section{Gemmula (Unedogemmula) gendinganensis (MARTIN)}

Pl. 17, Figs. 5 and 6.

1895. Pleurotoma gendinganensis Martin, Samml. Geol. Reichs-Mus. Leiden, N. F. Bd. 1, Abt. 1, p. 32, Taf. 5, fs. 81-84.

1895. Pleurotoma (s. str.) odengensis MarTin, ibid. N. F. Bd. 1, Abt. 1, p. 33, Taf. 5, fs. 85-86, and Taf. 6, f. 87.

1915. Pleurotoma gendinganensis, TESCH, Paläont. v. Timor, Lief. 5, p. 23, Taf. 75 , fs. $30-33$.

1964. Lophiotoma (Lophioturris) indica, Powell (partim), Indo-Pacific Moll. Vol. 1, No. 5, p. 311.

Material.-GK-L 7104. A single imperfect specimen, which is broken at the apex and labrum and more or less abraded at the shell-surface.

Measurements.-

$\mathrm{H}=45.6+\mathrm{mm}, \mathrm{Bd}=30.5 \mathrm{~mm}, \mathrm{Ap}=22.6 \mathrm{~mm}, \mathrm{D}=15.9 \mathrm{~mm}, \angle \mathrm{P}=28.2$ degrees, numb. of preserved whorls $=6.1$

Remarks.-The present specimen is imperfect in preservation, but characteristic enough to furnish the basis for taxonomical comparison. It is quite similar to Pleurotoma gendinganensis MARTIN from the Pliocene of Sondé, Java in the profile both of the whole shell and individual whorls, pattern of the primary, secondary, and tertiary spirals, and the configuration of the anal sinus. The examination of the type specimens verified that $P$. gendinganensis does not belong to Lophioturris but to Unedogemmula on the basis of the gemmate first whorl. That is to say Martin's type specimens (Rijksmus. Geol. Min. Leiden, Reg. No. St. 7810) are provided with a few coarse granule-like gemmules at the very beginning of the first whorl.

MARTIN described Pleurotoma odengensis (1895, p. 33) on the basis of the material from the Odengian of Odeng, Java and distinguished it from $G$. (U.) gendinganensis. The present author, however, can not recognize the distinction of the two, because $P$. odengensis has quite similar anal sinus and spiral ornamentation to gendinganensis. Apparent divergence between the two seems to depend essentially on the difference of preservation. The author is inclined to treat Pleurotoma odengensis as a synonym of $G$. (U.) gendinganensis.

$G$. $(U$.$) gendinganensis is readily distinguished from G$. (U.) butonensis in 
having simple and much narrower peripheral carina, less concave shoulder, and shallower and more asymmetrical anal sinus.

Horizon.-Upper part of the Ulian Formation.

Locality.-SKGS-72.

Genus Turris RöDING, 1798*

(type-species: Murex babylonius LINNÉ by subsequent designation, MEEK, 1876)

Subgenus Turris (s.s.)

Turris (Turris) panayensis sp. nov.

Pl. 19, Figs. 12-14; Text-fig. 33

Material.-Holotype: GK-L 6844 and paratypes: GK-L 6845, 6846, and 7121. GK-L 6844 to 6846 came from loc. SKGS-74 and 7121 from SKGS-75. All the specimens are broken at the apex and labrum.

\begin{tabular}{|c|c|c|c|c|c|c|c|}
\hline \multicolumn{8}{|c|}{ Measurements.- } \\
\hline $\begin{array}{l}\text { specimen } \\
\text { GK-L }\end{array}$ & $\underset{(\mathrm{mm})}{\mathrm{H}}$ & $\underset{(\mathrm{mm})}{\mathrm{Bd}}$ & \multicolumn{2}{|c|}{$\underset{(\mathrm{mm})}{\mathrm{Ap}}$} & $\underset{(\mathrm{mm})}{\mathrm{D}}$ & $\underset{(\%)}{\mathrm{Bd} / \mathrm{H}}$ & $\underset{(\%)}{\mathrm{Ap} / \mathrm{H}}$ \\
\hline 6844 & $59.9+(63.5)$ & $37.7+(38.1)$ & \multicolumn{2}{|c|}{$29.6+(30.0)$} & 13.8 & 60 & 47 \\
\hline 6845 & $44.5+$ & $25.9+$ & \multicolumn{2}{|c|}{$20.1+$} & $11.2+$ & - & - \\
\hline $\begin{array}{l}\text { specimen } \\
\text { GK-L }\end{array}$ & $\begin{array}{l}\mathrm{D} / \mathrm{H} \\
(\%)\end{array}$ & $\stackrel{\angle \mathrm{P}}{\angle \mathrm{P}}$ & $\begin{array}{l}\text { whorls } \\
\text { numb. }\end{array}$ & $\begin{array}{c}\text { suture } \\
\text { angle }\end{array}$ & & $\begin{array}{l}\text { whorl } \\
\mathrm{D} / \mathrm{H}\end{array}$ & \\
\hline 6844 & 22 & 20.1 & ca 9 & 13.3 & & $10.7 / 6.1=$ & 1.76 \\
\hline 6845 & - & 20.4 & $6+$ & 12.8 & & $9.1 / 4.5=$ & 2.02 \\
\hline
\end{tabular}

Diagnosis.-The shell is medium attaining about $65 \mathrm{~mm}$ in height of the shell and slender fusiform with the acute pleural angle of about twenty degrees and long and straight canal. The protoconch is not preserved on all the specimens. The teleoconch consists of about nine whorls, the profile of which are almost flat at side at the early stage and slightly convex at the later. The ornamentation of the spire-whorls consists of four carinate primary spiral cords accompanying the minor threads at each interspace and the distinctly lammelate growth lines. All the primaries are sharply ridged and narrowly flattened at the crest. The uppermost one $\left(P_{1}\right)$ on the first whorl is close to the upper suture with a marginal thread just along the suture and the second $\left(\mathrm{P}_{2}\right)$ is the largest. The first to third cords are equally spaced with deep interspaces between and their crests are on a single straight line in the profile, while the fourth one is receded, separated by somewhat narrower interspace, slightly lower in elevation, and less prominent than the others. In consequence the third primary cord $\left(\mathrm{P}_{3}\right)$ furnishes the peripheral carina. Two secondary threads appear at the interspace between the third $\left(\mathrm{P}_{3}\right)$ and the fourth $\left(\mathrm{P}_{4}\right)$ cord on the third whorl and the additional threads are intercalated on the later whorls. The primary spirals on the body whorl from the lateral to the basal surface are seven, of which the anterior four, especially the most anterior and the second anterior one are remarkably weaker than the others. The interspaces except for the posterior two are provided with three to five fine threads respectively. The most posterior interspace has two threads on

* Synonym: Pleurotoma Lamarck, 1799 and Pleurotome Link, 1807. 
the posterior slope of the valley, while the second posterior interspace has its two threads on the anterior slope. The snout is ornamented with about twenty suits of the primaries of moderate size, fine secondaries, and minute tertiaries. They are weaker on the anterior part than on the posterior.

The growth lines are crisp and lammelate at the interspaces of the primary spirals on the whole surface except for the snout, where they are moderately raised but not lammelate. The aperture is not perfectly preserved, the labrum being more or less broken on all the specimen. It is pear-shaped, rather small, abruptly narrowed and pointed at the posterior end, and very gradually contracted to the canal anteriorly. The inner surface of the outer lip is encircled by the narrow spiral ridges corresponding to the bottom of the spiral valley of the outer surface. The anal sinus is deep and U-shaped with slightly asymmetrical upper and lower arms and its apex at the second primary spiral cord. The subparallel part of the both arms of the sinus does not coincide with the edges of the flat-topped cord, but runs far outside the edges.

Comparison.-The present specimens are reasonably included in Turris (s.s.) RöpING on the basis of the smooth cords and deeply U-shaped anal sinus which has its apex on the second upper cord $\left(\mathrm{P}_{2}\right)$, immediately posterior to the peripheral cord $\left(\mathrm{P}_{3}\right)$.

Slender fusiform outline with tapered base, lamellate growthlines, fourcorded design of the primaries on the spire-whorls are the basic feature of the present specimens and they are apparently allied to Turris (Turris) crispa (LAMARCK) (1816, pl. 439, f. 4, liste p. 8). Comparing with the known subspecies of $T$. (T.) crispa, the present specimens are quite distinctive with the diagnostic features described above. For instance they are much smaller and provided with more elevated, narrower, and flat-topped primaries and far weaker secondaries than crispa (s.s.).

They are more easily distinguished from T. (T.) crispa yeddoensis (JousSEAUME) (1883, p. 196, pl. 10, f. 7) in having much longer canal and more prominent and simpler spiral ornamentation than the latter.

Horizons.-Upper and uppermost parts of the Dingle Formation.

Localities.-SKGS-74 and 75.

Subfamily Turriculinae

Genus Nihonia MacNeIL, 1960

(type-species: Nihonia shimajiriensis MACNEIL by original designation)

Nihonia santosi sp. nov.

Pl. 19, Figs. 18, 19, and 21; Text-fig. 34

Material.-Holotype: GK-L 6847 and paratypes: GK-L 6848 and 7512 . The type specimens, came from one and same locality, are more or less broken at the apex and the labrum.

\begin{tabular}{|c|c|c|c|c|c|c|c|c|}
\hline \multicolumn{9}{|c|}{ Measurements.- } \\
\hline $\begin{array}{l}\text { pecimen } \\
\text { GK-L }\end{array}$ & $\underset{(\mathrm{mm})}{\mathrm{H}}$ & $\underset{(\mathrm{mm})}{\mathrm{Bd}}$ & $\underset{(\mathrm{mm})}{\mathrm{Ap}}$ & $\underset{(\mathrm{mm})}{\mathrm{D}}$ & $\underset{\text { (degrees) }}{\angle \mathrm{P}}$ & $\begin{array}{l}\text { teleo- } \\
\text { conch }\end{array}$ & $\begin{array}{l}\text { suture } \\
\text { angle }\end{array}$ & $\begin{array}{l}\text { whorl profile } \\
\text { D/H on pen }\end{array}$ \\
\hline 6847 & $78.0+$ & $49.4+$ & $40.1+$ & $20.1+$ & 20.3 & $7+$ & 8.3 & $14.1 / 8.6=1.64$ \\
\hline 684 & 69.7 & $45.4+$ & $36.0+$ & $17.7+$ & 26.1 & $8.5+$ & 8.1 & $12.7 / 7.95=1$. \\
\hline
\end{tabular}



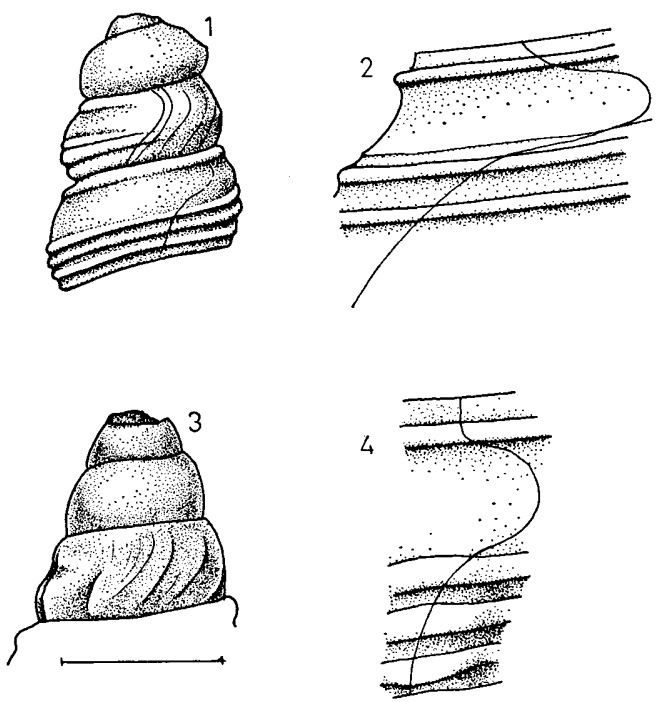

Fig. 34. Protoconchs and growthlines of some species of Turriculinae.

1 and 2: Nihonia santosi sp. nov., GK-L 7513.

3 and 4: Pleurofusia (Pseudofusia) dinglensis subgen. et $\mathrm{sp}$. nov., GK-L 6902.

Unit bar indicates $1 \mathrm{~mm}$ for 1 and 2 and $0.8 \mathrm{~mm}$ foa 3 and 4 .

Diagnosis.-The shell is rather thick, solid, and slenderly fusiform with the acute spire and the straight and tapered snout. The protoconch is smooth, bluntly conical and pausispiral with about two and a third volutions. The nucleus is very small and depressed, the second is abruptly increased in size, convex, and polished, and the remainder part is bluntly angled at the middle and provided with very fine sinusigera raised lines. The teleoconch-whorls are more than eight, moderately convex at the sides, and provided with distinct spiral lirae. The first whorl is ornamented with four spiral lirae; subsutural $\left(\mathrm{P}_{1}\right)$, peripheral $\left(\mathrm{P}_{2}\right)$, infraperipheral $\left(\mathrm{P}_{3}\right)$, and suprasutural one $\left(\mathrm{P}_{4}\right)$, of which the lower two are somewhat broader and stronger than the others. The area between the subsutural $\left(\mathrm{P}_{1}\right)$ and the peripheral lira $\left(\mathrm{P}_{2}\right)$ is wide and practically smooth. On the second whorl another primary lira $\left(P_{5}\right)$ appears from the lower suture. On the later whorls about five secondaries appear on the subsutural area and the subsutural lira is duplicated by a newly introduced subsutural thread and becomes granular. On the fifth whorl the spirals consist of bi-lirated subsutural cord $\left(P_{1}\right)$ and four prominent primary lirae on the lower surface between the medial part and the lower suture. Two secondary threads are paired at the middle of the shoulder and another one thread is immediately above the peripheral lira. A minute tertiary thread may be intercalated at the upper and lower interspaces of the paired secondaries of the shoulder on the fourth to fifth whorl. At the same time a fine tertiary thread may appear at each interspace of the primary lirae on the lateral surface. On the later whorls a minute quaternary may be intercalated at each interspace on the lateral surface. Consequently bi-lirated subsutural cord, six to seven fine threads on the concave shoulder, ten to eleven prominent lirae with minor ones between on the lateral and basal surface, and about fifteen suits on the snout comprise the spiral ornamentation of the body whorl.

The anal sinus, indicated by the growth lines, is deeply V-shaped with its 
apex at the middle of the sinus band, on which its upper and lower arms are almost symmetrical. The upper arm crosses the lower edge of the subsutural cord with very acute angle and then curved upward abruptly to merge to the suture at $\mathbf{5 0}$ degrees. The lower arm also merges to the first lateral cord with very acute angle and then broadly curved downward. The aperture is narrowly pyriform with the pointed posterior end and the gradually contracted anterior part. The labrum is broken. The inner lip is almost straight except for the broadly curved upper part and provided with very thin callus. The canal is long and straight.

Comparison.-The genus Nihonia MACNEIL, 1960, is one of the small group of the oriental turrids. The present species is included in the mentioned genus on the basis of the slender fusiform outline, rather simple pattern of the spiral ornamentation, and deep V-shaped anal sinus on the anal band.

The present specimens are allied to Nihonia soyomaruae (OTUKA) (1959, p. 247, f. 3) living in South Japan and to N. soyomaruae takanabensis (OTUKA) (1959, p. 248, fs. 4 and 5) from the Pliocene of Southwest Japan. They resemble especially in the pattern of the development of the ornamentation one another. The present species is, however, distinguished from the two Japanese species and subspecies in having much stronger subsutural cord, more deeply excavated shoulder, more produced periphery, and wider primary spirals than the latter.

$N$. australis (RoISSY) is another ally to the present species, but the latter has more prominent subsutural cord, more concave and narrower shoulder, more convex periphery, and closer primary spirals than the former.

Horizon.-Upper part of the Dingle Formation.

Locality._SKGS-74.

Genus Pleurofusia de GREgorio, 1890*

(Type-species: Pleurotoma (Pleurofusia) longirostropsis de GREGORIO

by original designation)

Subgenus Pseudofusia subgen. nov.

(type-species: Pleurofusia (Pseudofusia) dinglensis sp. nov., here designated)

Subgeneric diagnosis. - The shell is small and fusiform with the high spire, abruptly contracted base, and long snout. The protoconch is high conical with about four slightly convex volutions, of which the last quater is provided with a few brephic axials. The teleoconch-whorls are distinctly concave below the massive subsutural band and convex at the periphery. The spiral ornamentation consists of the subsutural lira, strong primary lirae on the lateral surface, moderately distinct secondary threads on the anal band, and very weak ones between the primaries on the lateral surface. The axials ribs are prominent at the periphery and abruptly weakened above and below it. There are a few massive varicose ribs among the normal ones. The suture is impressed and wavy. The aperture is rhomboid with bluntly pointed end posteriorly and long and narrow canal anteriorly. The anal sinus is moderately deep and V-shaped occupying the anal band. Its arms are asymmetrical with the upper one extending forward then

* Synonym: Tropisurcula CASEY, 1904, and Tropidosurcula Cossmann, 1906. 
being reflected upward and the lower one being broadly curved antero-oral-ward.

Comparison.-The present subgenus resembles the type species of Pleurofusia de GREgorio, 1890, in the general characteristics, but in details the former does not necessarily conform with the latter. That is to say, the former has remarkably deep anal sinus, polygyrate protoconch, and a few varicose-ribs instead of the shallow anal sinus, paucigyrate protoconch, and normal axials of the latter. Furthermore the present taxon is characterized by the strong subsutural lira, secondary spirals on the anal band, and distinct basal contraction. Evaluating these differences the author is inclined to place the present specimens as the representatives of a new subgenus under the genus, Pleurofusia.

Pseudofusia shows a superficial similarity of the profile of the shell and ornamentation to Fusinus RAFINESQUE, 1815, but is readily distinguished from the latter in the features of the protoconch and the anal sinus.

\section{Pleurofusia (Pseudofusia) dinglensis sp. nov.}

Pl. 14, Figs. 7, 9, and 11 and Pl. 21, Figs. 11 and 18; Text-figs. 34 and 37

Material.-Holotype: GK-L 6902. A single almost perfect specimen.

\begin{tabular}{|c|c|c|c|c|c|c|c|c|}
\hline \multicolumn{9}{|c|}{ Measurements.- } \\
\hline $\begin{array}{l}\text { specimen } \\
\text { GK-L }\end{array}$ & $\underset{(\mathrm{mm})}{\mathrm{H}}$ & $\underset{(\mathrm{mm})}{\mathrm{Bd}}$ & $\underset{(\mathrm{mm})}{\mathrm{Ap}}$ & $\underset{(\mathrm{mm})}{\mathrm{D}}$ & $\underset{(\%)}{\mathrm{Bd} / \mathrm{H}}$ & $\underset{(\%)}{\mathrm{Ap} / \mathrm{H}}$ & $\begin{array}{l}\mathrm{D} / \mathrm{H} \\
(\%)\end{array}$ & $\angle \underset{\text { (degrees) }}{\mathrm{A}} \angle \mathrm{P}$ \\
\hline 6902 & 12.40 & 7.75 & 5.70 & 5.05 & 62.4 & 45.9 & 40.7 & 49.2 \\
\hline $\begin{array}{l}\text { specimen } \\
\text { GK-L }\end{array}$ & $\mathrm{H}$ & $\begin{array}{c}\text { protoc } \\
\text { D }\end{array}$ & numk & & $\begin{array}{l}\text { teleo- } \\
\text { conch }\end{array}$ & $\begin{array}{l}\text { suture } \\
\text { angle }\end{array}$ & & $\begin{array}{l}\text { horl profile } \\
\text { H on pen }\end{array}$ \\
\hline 6902 & ca 1.2 & 1.0 & 4.0 & & 5.9 & 8.6 & & $5 / 1.3=2.49$ \\
\hline
\end{tabular}

Diagnosis.-The shell is small, fusiform, and moderately solid. The protoconch is high conical and polygyrate with about four volutions, of which the last quater is provided with a few retractly oblique and irregularly spaced brephic axials. The teleoconch-whorls are about six, of which the spire-whorls are concavo-convex in profile with remarkably concave anal band below the prominent subsutural band and the convex lateral part. The boundary between the anal band and the lateral part is a blunt angulation. The body whorl is large occupying more than sixty percent of the total height, extremely contracted at the base to the long, straight, and vertical snout. The ornamentation consists of the prominent axial ribs and the spirals. The axials are almost vertical, roundtopped, and separated one another by wider and deep interspaces. They are strong at the periphery, abruptly weakened above and below, and finally faded out on the anal band. On the body whorl they also abruptly disappear at the basal slope. Some of the axials (about three per one whorl) are varicose and more than twice as wide as the normal ones on the later three whorls, but do not reach the subsutural band.

The spirals consist of the subsutural band and three peripheral lirae; the peripheral ones are separated one another only by very narrow grooves which are deep between the axial ribs and very shallow on the axials. A few secondary lines appear on the anal band of the second whorl. On the course of the growth the 
primary spiral lirae on the lateral surface become more and more prominent and even subgranular on the axial ribs. The subsutural band is at first simple but differentiated into the prominent central lira and axially and finely granulated marginal rim. The suture is somewhat wavy. The growth lines are distinct and rather lamellose.

The aperture is pyriform with bluntly pointed posterior end and slightly oblique and long anterior canal. The labrum is broken but the growth lines indicate the moderately deep V-shaped anal sinus with asymmetrical upper and lower arms. The short and very oblique parietal lip and almost straight and vertical columellar lip comprise the inner lip. The junction of two lips is narrowly angled. The callus is very thin and smooth. The anterior canal is narrowed at the upper entrance and somewhat widened anteriorly.

Comparison.-The present specimen shows some affinity to the Javan Neogene specimens reported as Pleurotoma nodifera LAMARCK var. by MARTIN (1895, p. 27, Taf. 4, fs. 67 and 68) and also similar to $P$. nodifera LAMARCK of TESCH from Timor (1915, p. 28, Taf. 78, fs. 57 and 58). The former is, however, readily distinguished from the latter two, because the latter has the axials restricted to the periphery, steeply sloped and wide anal band, and weaker subsutural band and spirals.

There is no known species, both living and fossil, comparable to the present specimen.

Horizon.-Upper part of the Dingle Formation.

Locality.-SKGS-74.

Genus Ancistrosyrinx DALL, 1881

(type-species: Ancistrosyrix elegans DALL by original designation)

Subgenus Pagodasyrinx subgen. nov.

(type-species: Pleurotoma (Ancistrosyrinx) travancoria granulata SMITH, here designated)

Subgeneric diagnosis. - The shell is moderately small and fusiform with the turreted spire and the very long base. The protoconch is paucispiral consisting of less than one and a half smooth volutions. The tip is small and oblique and the remainder volution is swollen and rapidly increased in size. There is no end mark of the protoconch and the beginning of the teleoconch is indicated by the gradual appearance of the peripheral gemmules, which become abruptly gemmulate carina. The early two whorls are hexagonal with a prominent and gemmulate carina medially. The surface above and below the median carina are slightly concave, moderately steeply sloped, and practically smooth except for weak subsutural and suprasutural threads. The subsutural thread becomes micro-granular on the third whorl and at the same time a distinct spiral lira appears at the anterior foot of the median carina. In the course of the growth the surface below the carina and the anterior side of the carina itself are successively covered by the distinct spirals, which soon become granular. Keeping pace with the granulization of the lateral surface the inclination of the shoulder becomes gentler and 
gentler and the carina shows a tendency for upward turning. Another weak thread appears at the posterior foot of the carina on the third to fourth whorl and soon becomes larger and spinously serrated. The spines on respective spiral rows are connected one another by the transverse ridges radiating to the peripheral spines. The carinal spines of the innermost row point upward. The shoulder is almost smooth except for the growth lines.

The aperture is pyriform, pointed posteriorly, and gradually attenuated anteriorly to the very long, open, and slightly curved canal. Both the outer and inner lips are simple. The anal sinus is moderately shallow and fully occupies the smooth shoulder. Its upper arm merges to the upper suture with high angle, while the lower arm is extended forward.

Comparison.-Pagodasyrinx is applied to a group, which is closely allied to Ancistrosyrinx DALL, 1881, but is distinguished from the latter in having a inner row of the serration at the posterior foot of the peripheral carina instead of the simply elected lamella of Ancistrosyrinx. The present subgenus resembles Coronasyrix PowELL, 1944, at the early stage of growth with only serrated median carina, smooth shoulder, and lirated lateral surface, but the former deviates from the latter at the late stage of growth. The anal sinus of the present subgenus is also quite similar to that of Coronasyrinx. These facts indicate that Pagodasyrinx and Ancistrosyrinx have evolved from the common ancestor like Corona$\operatorname{syrinx}$.

\section{Ancistrosyrinx (Pagodasyrinx) granulata (SмITH)}

Pl. 20, Figs. 7, 16, 22, and 23; Text-fig. 35

1904. Pleurotoma (Ancistrosyrinx) travancoria granulata Sмiтh, Ann. Mag. Nat. Hist. Ser. 7, Vol. 13, p. 459.

Material.-GK-L 6878 to 6883 from one and same locality. GK-L 6878 and 6879 are adult and the others are immature.

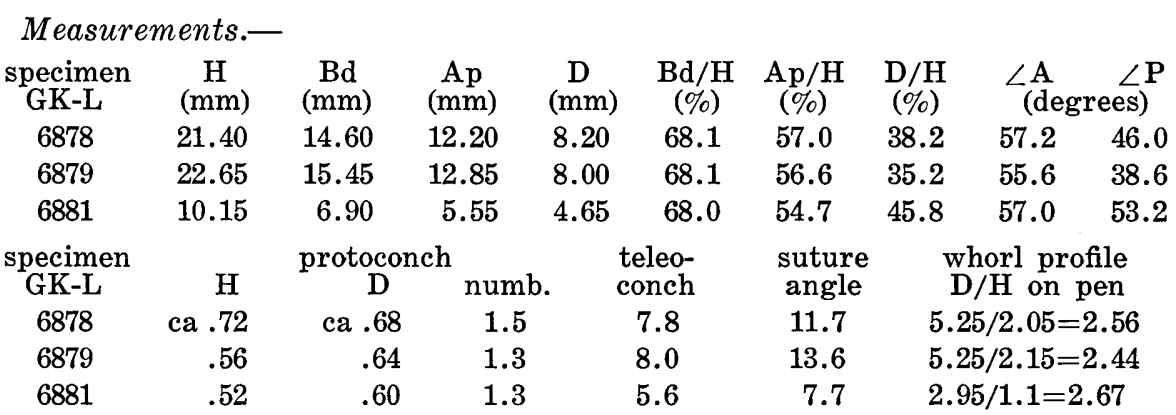

Remarks.-Although the present species was described as a variety of Pleurotoma (Ancistrosyrinx) travancoria SMITH by the original author, the original descriptions indicate that the two are different at subgeneric level. $P$. (A.) travancoria (1896, p. 368 and Zool. "Investigator" Moll. pl. 7, fs. 1 and 1a) really belongs to Coronasyrinx on the basis of the simply serrated peripheral 


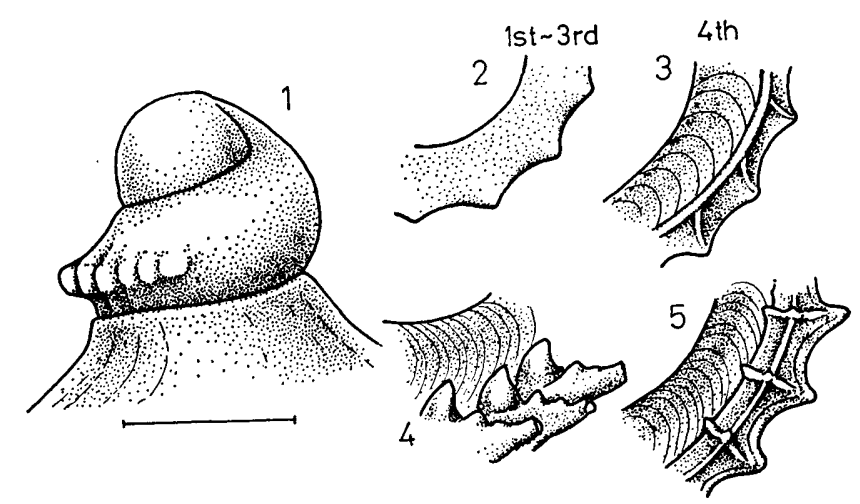

Fig. 35. Morphological features of Ancistrosyrinx (Pagodasyrinx) granulatus (SMITH), subgen. nov.

1: protoconch, GK-L 6879 , unit bar indicating $0.5 \mathrm{~mm}$.

2-5: development of the peripheral carina.

2: first to third whorls of the teleoconch.

3: fourth whorl. Note the spiral lira with narrow grooves at both sides.

4: adult whorl; carina being remarkably upturned, GK-L 6879 .

5: adult whorl; carina being almost horizontal, GK-L 6878 .

keel, while $P$. (A.) travancoria granulata is provided with two series of serration respectively at and above the peripheral carina and included in Pagodasyrinx.

In general the peripheral carina is horizontal at first and turns upward later on the present specimens. There is a wide range of variation concerning the degree of upward turning. On some specimen, for example GK-L 6883, the upward turning of the peripheral carina begins even on the third whorl and consequently the carina on the fifth whorl is elected almost vertically. While on GK-L 6878 the carina is slightly obliquely upturned even on the seventh whorl. The other morphological features are remarkably stable among the specimens.

Recent distribution.-Indian ocean.

Horizon.-Upper part of the Dingle Formation.

Locality.-SKGS-74.

Genus Paradrillia MakiYama, 1940

(type-species: Drillia dainichiensis YoкоYамA by original designation)

Paradrillia serana (FISCHER)

Pl. 20, Figs. 18-21; Text-fig. 36

1915. Pleurotoma (Clavatula) aff. djocdjocartae Tesch, Paläont. v. Timor, Lief. 5, p. 34, Taf. 78, fs. 71a and b.

1927. Clavatula djocdjocartae serana FISCHER, ibid. Lief. 15, p. 98, Taf. 214, f. 77.

Material.-GK-L 6849 and 6850 from one and same locality. 


\begin{tabular}{|c|c|c|c|c|c|c|c|c|c|}
\hline \multicolumn{2}{|c|}{ Measurements.- } & \multirow[b]{2}{*}{$\underset{(\mathrm{mm})}{\mathrm{Bd}}$} & \multirow[b]{2}{*}{$\underset{(\mathrm{mm})}{\mathrm{Ap}}$} & \multirow[b]{2}{*}{$\underset{(\mathrm{mm})}{\mathrm{D}}$} & \multirow[b]{2}{*}{$\begin{array}{c}\mathrm{Bd} / \mathrm{H} \\
(\%)\end{array}$} & \multirow[b]{2}{*}{$\underset{(\%)}{\mathrm{Ap} / \mathrm{H}}$} & \multirow[b]{2}{*}{$\underset{(\%)}{\mathrm{D} / \mathrm{H}}$} & \multirow{2}{*}{\multicolumn{2}{|c|}{$\underset{\text { (degrees) }}{\angle \mathrm{A}} \quad \angle \mathrm{P}$}} \\
\hline $\begin{array}{l}\text { specimen } \\
\text { GK-L }\end{array}$ & $\underset{(\mathrm{mm})}{\mathrm{H}}$ & & & & & & & & \\
\hline 6849 & 17.65 & 10.15 & 7.10 & 6.25 & 59.4 & 40.2 & 35.3 & 42.0 & 22.3 \\
\hline 6850 & 17.10 & 10.00 & 7.10 & 6.55 & 58.4 & 41.5 & 38.3 & 42.4 & 26.8 \\
\hline $7727^{*}$ & 15.10 & 8.05 & 5.70 & 5.35 & 53.6 & 37.9 & 35.7 & 42.5 & 21.9 \\
\hline $\begin{array}{l}\text { specimen } \\
\text { GK-L }\end{array}$ & \multicolumn{3}{|c|}{$\stackrel{\text { protoconch }}{ }$ numb } & \multicolumn{2}{|c|}{$\begin{array}{l}\text { teleo- } \\
\text { conch }\end{array}$} & $\begin{array}{l}\text { suture } \\
\text { angle }\end{array}$ & \multicolumn{3}{|c|}{$\begin{array}{l}\text { whorl profile } \\
D / H \text { on pen }\end{array}$} \\
\hline 6849 & .54 & .68 & \multicolumn{2}{|c|}{$\begin{array}{c}\text { numb. } \\
1.75\end{array}$} & 8.5 & 8.7 & \multicolumn{3}{|c|}{$4.7 / 2.2=2.13$} \\
\hline 6850 & .56 & .68 & \multicolumn{2}{|l|}{2.00} & 8.1 & 7.0 & \multicolumn{3}{|c|}{$4.8 / 2.0=2.40$} \\
\hline $7727^{*}$ & .84 & .76 & \multicolumn{2}{|l|}{3.20} & 8.3 & 8.2 & \multicolumn{3}{|c|}{$4.2 / 1.85=2.27$} \\
\hline
\end{tabular}

Remarks.-The present specimens are readily identified to Clavatula djocdjocartae serana FISCHER by their general characteristics of the protoconch and the teleoconch. The present species seems to be very stable in the pattern of the ornamentation as is indicated by the measurements.

Although the original author placed it under "Clavatula djocdjocartae (MARTIN)" as a subspecies, it is better to separate them as different species. The reasons are as follow. Firstly the both groups have different protoconch. FISCHER's species including the present specimens has the paucispiral protoconch consisting of less than two volutions. Its first volution is very small, oblique, and smooth and the succeeding volution is sharply carinated at lower fourth. Besides the carina the brephic axials are discernible on the last two-thirds volution. While the protoconch of MARTIN's species is polygyrate consisting of more than three volutions, of which the early two are smooth, the third one is sharply carinated at the lower fourth, and the remainder volution is provided with the brephic axials together with the carina. Secondly the teleoconch of the present species is broader in profile than that of djocdjocartae. Moreover the subsutural band of the present species consists of single prominent cord with a minor thread respectively close to its anterior and posterior margins throughout the growth stages, while that of djocdjocartae is similar to the former at the early stage but on the later whorl it consists of the double lirae. On the basis of the mentioned difference, especially of the protoconch the author prefers to separate the two at the specific level.

Nomura described Clavatula serana from the Upper Pliocene of Taiwan (1935, p. 66, pl. 6, fs. 58 and 59), but the figured specimen together with my own one from the same locality as NomURA's should be identified to MARTIN's species.

The present species reasonably belongs to Paradrillia MakiYama, 1940, on the basis of its characteristic morphology of both protoconch and teleoconch. The author separates Paradrillia from the genus Clavatula LAMARCK, 1801, and place it under the subfamily Turriculinae accepting OYAMA's citation (1953, p. 158) and PoweLL's (1967, p. 26).

Geological occurrence.-Pliocene (Indonesia).

Horizon.--Upper part of the Dingle Formation.

Locality.-SKGS-74. 


\section{Paradrillia inconstans (SMITH)}

Pl. 20, Figs. 9, 10, and 14; Text-fig. 36

1875. Pleurotoma (?) inconstans Sмгтн, Ann. Mag. Nat. Hist. Ser. 4, Vol. 15, p. 417.

1961. Paradrillia inconstans, HABE, Colored Illustr. Shells Japan, Vol. 2, p. 76, pl. 38, f. 4.

Material.-GK-L 6555. A single perfect specimen.

\begin{tabular}{|c|c|c|c|c|c|c|c|c|c|}
\hline \multicolumn{10}{|c|}{ Measurements.- } \\
\hline $\begin{array}{l}\text { specimen } \\
\text { GK-L }\end{array}$ & $\underset{(\mathrm{mm})}{\mathrm{H}}$ & $\underset{(\mathrm{mm})}{\mathrm{Bd}}$ & $\underset{(\mathrm{mm})}{\mathrm{Ap}}$ & $\underset{(\mathrm{mm})}{\mathrm{D}}$ & $\underset{(\%)}{\mathrm{Bd} / \mathrm{H}}$ & $\underset{(\%)}{\mathrm{Ap} / \mathrm{H}}$ & $\underset{(\%)}{\mathrm{D} / \mathrm{H}}$ & \multicolumn{2}{|c|}{$\underset{\text { (degrees) }}{\angle \mathrm{A}} \quad \angle \mathrm{P}$} \\
\hline 6555 & 10.30 & 5.50 & 3.85 & 3.80 & 53.4 & 37.3 & 36.8 & 39.2 & 20.1 \\
\hline $\begin{array}{l}\text { specimen } \\
\text { GK-L }\end{array}$ & \multicolumn{4}{|c|}{ whorls teleo } & \multicolumn{2}{|c|}{$\begin{array}{l}\text { suture } \\
\text { angle }\end{array}$} & \multicolumn{3}{|c|}{$\begin{array}{l}\text { whorl profile } \\
D / H \text { on pen }\end{array}$} \\
\hline 6555 & & & 7.8 & & 9.0 & & $2.8 / 1$ & $5=1.8$ & \\
\hline
\end{tabular}

Remarks.-The present specimen is quite identical to the type specimens of Pleurotoma (?) inconstans SMITH (1875, p. 417) from Japanese waters in its size, general outline, and ornamentation. The protoconch of the present specimen is, however, devoid of the original surface layer and represented by the inner layer of the original shell. Consequently its outline is somewhat slenderer and its peripheral carina on the last volution is blunter than those of the type specimens stored at the British Museum (N. H.). The examination of the type specimens reveals that the protoconch of $P$. inconstans consists of about two and two-thirds volutions, of which the early one and a half volutions are smooth and the succeeding one volution is carinated at lower two-fifths of the height of the volution and furthermore a few brephic axials are added on the latest part. This characteristic of the protoconch together with the general feature of the teleoconch indicates that the species belongs to the genus Paradrillia.

Recent distribution.-South Japanese waters.

Horizon.-Santa Barbara Silt.

Locality.-SKGS-71.

Fig. 36. Morphology of the protoconchs and adult whorls of the teleoconchs of some turrids.

1 and 2: Paradrillia serana (FISCHER), GK-L 6850 .

3 and 4: $P$. inconstans (SмIтH), GK-L 6555.

5: Inquisitor (Inquisitor) molengraafi dinglensis subsp. nov., GK-L 6873.

6: I. (I.) batavianus (MARTIN), GK-L 6871.

Unit bar indicates $0.5 \mathrm{~mm}$ for all the protoconchs.
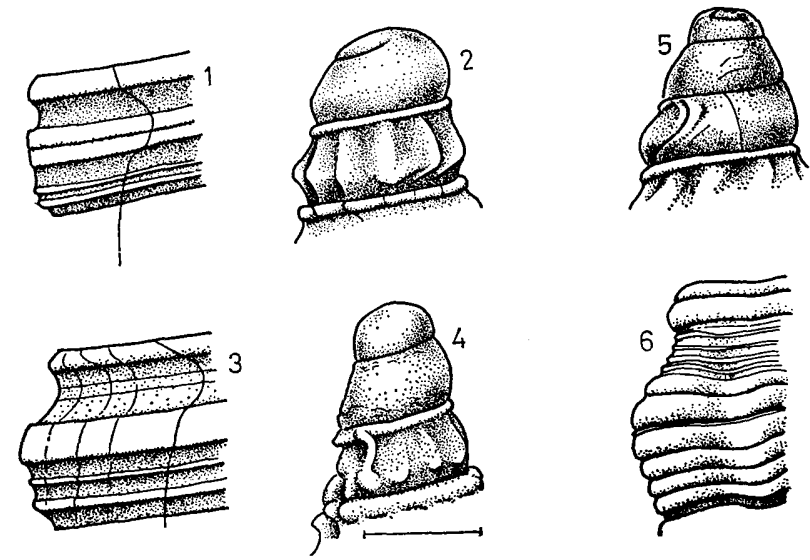
Subfamily Clavinae

Genus Inquisitor HEDLEY, 1918*

(type-species: Pleurotoma sterrha WATson by original designation)

Subgenus Ptychobela THIELE, 1925

(type-species: Pleurotoma crenularis LAMARCK by original designation)

Inquisitor (Ptychobela) neglectus (MARTIN)

Pl. 21, Figs. 1, 2, 14, and 15; Text-fig. 38 .

1883-87. Pleurotoma (Drillia) interrupta LAMARCK var. MARTiN (partim), Samml. Geol. Reichs-Mus. Leiden, Ser. 1, Bd. 3, p. 65, Tab. 4, f. 67.

1895. Pleurotoma (Drillia) neglecta Martin, ibid. N. F. Bd.1, Abt. 1, p. 42, Taf. 7, fs. 106 and 107.

Material.-GK-L 6852, 6853, and 6854 from one and same locality.

Measurements.-

\begin{tabular}{|c|c|c|c|c|c|c|c|c|c|}
\hline eci & $\underset{(\mathrm{mm})}{\mathrm{H}}$ & $\underset{(\mathrm{mm})}{\mathrm{Bd}}$ & $\underset{(\mathrm{mm})}{\mathrm{Ap}}$ & $\underset{(\mathrm{mm})}{\mathrm{D}}$ & $\underset{(\%)}{\mathrm{Bd} / \mathrm{H}}$ & $\underset{(\%)}{\mathrm{Ap} / \mathrm{H}}$ & $\underset{(\%)}{\mathrm{D} / \mathrm{H}}$ & & $\angle \mathrm{P}$ \\
\hline & $27.6+$ & 16.0 & 12.10 & 9.1 & $57.8-$ & $43.7-$ & $33.1-$ & - & 20 \\
\hline & .5 & 12. & 9. & .8 & 1. & 47 & 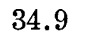 & 4. & 22.4 \\
\hline 6854 & 20.6 & 12.2 & 9.50 & 7.05 & 59.3 & 46.2 & 34.2 & 37.7 & 23. \\
\hline
\end{tabular}

\begin{tabular}{|c|c|c|c|c|c|c|c|c|c|c|}
\hline n & & prot & & teleo- & sut & & \multicolumn{4}{|c|}{ axials } \\
\hline & $\mathrm{H}$ & D & mb. & conch & ang & & 2 & & IV & VI \\
\hline 6852 & - & - & - & $9+$ & 9.6 & $=1.81$ & 9 & 7 & 8 & 9 \\
\hline 68 & .06 & .90 & .2 & 7.0 & 10. & & 0 & 7 & 8 & \\
\hline 6854 & 0.9 & 0.78 & 3.0 & 7.7 & 9.9 & $5.05 / 2.55=1.98$ & 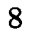 & 7 & 8 & \\
\hline
\end{tabular}

Remarks.-The present specimens are allied to Pleurotoma (Drillia) neglecta Martin (1895, p. 42, Taf. 7, fs. 106, and 107) and $P$. (D.) losariensis MARTiN (1895, p. 40, Taf. 6, fs. 99-101) from the Neogene of Java.

The protoconch is high conical consisting of about 3.0 to 3.2 volutions and smooth except for a few brephic axials at the latest part. The teleoconch is sculptured by rather sharp and retrocurrently oblique axial folds, moderately weak subsutural band, and fine and close spirals of primary, secondary, and tertiary orders. The axials are extended from suture to suture on the early whorls and progressively retreated from the anal band on the later whorls to be limited to the convex lateral surface. They are narrower than the interspaces. On the body whorl they hardly reach the boundary between the basal surface and the snout. The subsutural band is relatively strong at early and becomes relatively weak later. The anal sinus is deep V-shaped with the rounded apex slightly above the middle of the concave shoulder. The callus of the inner lip is very thick furnishing a prominent parietal tubercle posteriorly and the free edge anteriorly. A shallow pseudoumbilical depression is discernible close to the free edge of the columellar callus. There is a very obsolete fold-like elevation at the middle of the columellar lip. The outer lip is provided outside with the very wide and massive varicose thickening at some distance from the very margin. The inner surface is smooth.

\footnotetext{
* Synonym: Pseudoinquisitor Powell, 1942.
} 
They are apparently similar especially in the adult morphology to Drillia flavidula LAMARCK living in southeast Asian waters, but quite differ from the latter in the morphological development of the spiral ornamentation. On D. flavidula the distinct primary spiral lirae are clearly discernible on whole surface of the first teleoconch-whorl. Those on the anal band, however, gradually disappear at the half turn of the second whorl except for the subsutural lira, which is finally faded out on the adult whorls. While $D$. neglecta is provided with a distinct subsutural lira and other two primary lirae on the convex lateral surface with almost smooth anal band between. Besides, the subsutural lira holds its strength still on the last whorl on $D$. neglecta.

Drillia losariensis MARTIN from the Pliocene of Java is a close ally to $D$. neglecta, but the former is devoid of the subsutural lira throughout the growth stages. Furthermore the anal sinus is somewhat shallower on the former than on the latter. The present specimens, in these respects, much closer to D. neglecta than $D$. losariensis.

$P$. (D.) neglecta including the type specimens and the present ones is featured by rather broad varix-like fold at the outside of the labrum, relatively weak subsutural lira, heavy columellar and parietal callus, moderately deep anal sinus on the shoulder, very shallow stromboid notch at the anterior part of the labrum, and high conical polygyrate smooth protoconch. Its axial sculpture, which is much stronger than the spiral ornamentation, is sharp, thin, and retrocurrently oblique, and abruptly disappear on the anal band. These features are quite identical to those of Ptychobela THIELE, 1925. Ptychobela is closely related to Inquisitor HEDLEY, 1918, in the general characteristics, but is separable from the latter in being devoid of the massive subsutural band.

Geological occurrence.-Lower Miocene (Indonesia).

Horizon.-Upper part of the Dingle Formation.

Locality.-SKGS-74.

\section{Subgenus Inquisitor (s.s.)}

Inquisitor (Inquisitor) molengraafi dinglensis subsp. nov.

Pl. 20, Figs. 3, 4, and 17; Text-fig. 36

Material.-Holotype: GK-L 6873 and paratype: 6874 from one and same locality. Both specimens are slightly broken at the labrum and slightly abraded at the apex.

\begin{tabular}{|c|c|c|c|c|c|c|c|c|c|}
\hline \multicolumn{2}{|c|}{ Measurements.- } & \multirow[b]{2}{*}{$\underset{(\mathrm{mm})}{\mathrm{Bd}}$} & \multirow[b]{2}{*}{$\underset{(\mathrm{mm})}{\mathrm{Ap}}$} & \multirow[b]{2}{*}{$\underset{(\mathrm{mm})}{\mathrm{D}}$} & \multirow[b]{2}{*}{$\underset{(\%)}{\mathrm{Bd} / \mathrm{H}}$} & \multirow[b]{2}{*}{$\underset{(\%)}{\mathrm{Ap} / \mathrm{H}}$} & \multirow[b]{2}{*}{$\underset{(\%)}{\mathrm{D} / \mathrm{H}}$} & \multirow{2}{*}{\multicolumn{2}{|c|}{$\underset{\text { (degrees) }}{\angle \mathrm{A}} \quad \angle \mathrm{P}$}} \\
\hline $\begin{array}{l}\text { specimen } \\
\text { GK-L }\end{array}$ & $\underset{(\mathrm{mm})}{\mathrm{H}}$ & & & & & & & & \\
\hline 6873 & 11.75 & 6.75 & 4.40 & 4.40 & 57.4 & 37.4 & 37.4 & 40.4 & 13. \\
\hline 6874 & 0.70 & 6.40 & 4.40 & .95 & 59.7 & 41.1 & 36.8 & 38 & 20 \\
\hline peci & \multicolumn{3}{|c|}{ rotoconch } & axials & & \multicolumn{2}{|c|}{$\begin{array}{l}\text { suture } \\
\text { angle }\end{array}$} & \multicolumn{2}{|c|}{$\begin{array}{l}\text { whorl profile } \\
\mathrm{D} / \mathrm{H} \text { on pen }\end{array}$} \\
\hline $68^{\prime}$ & .32 & .30 & 3. & 1 & 6. & \multicolumn{2}{|c|}{4.2} & \multicolumn{2}{|c|}{$3.55 / 1.65=2.15$} \\
\hline 6874 & .32 & .27 & 3.2 & 2 & 6.3 & \multicolumn{2}{|c|}{13.9} & \multicolumn{2}{|c|}{$3.0 / 1.4=2.14$} \\
\hline
\end{tabular}


Diagnosis.-The shell is small, thick, solid, and rhomboidally fusiform with moderately high spire and gradually contracted base. The protoconch is conical with about three volutions. The tip is lost on both specimens. The remainder volutions are smooth and slightly convex and separated each other by the impressed suture. The boundary between the protoconch and the teleoconch is marked by a distinct and retractly oblique and curved ridge. One or two very weak axial ribs are discernible at some distance from the end-ridge. The teleoconch consists of about six and a half whorls, which are distinctly concave below the suture and convex at the lateral part. The body whorl is large and occupies a little more than half of the height of the shell. It is convex at the periphery with rather the distinct angulation and scarcely contracted at the basal slope to the snout. The whorls are ornamented by the remarkably massive subsutural cord and very coarse and prominent axial plicae which are crossed by the moderate spiral lirae. The subsutural cord starts at the very beginning of the teleoconch, but its prominency is accelerated later to become the massive one of the body whorl. The profile of the cord is asymmetrically triangular with the sharp crest below the middle. The axial plicae are rounded at the crest, narrower than the interstices, and eight on the first whorl. They are distinctly oblique and abruptly faded out on the anal band. On the third and later whorls the axials are seven and their obliquity becomes indistinct. They reach the lower suture on the spire-whorls and disappear on the basal slope of the body whorl. Although the pattern of the spirals on the late whorls is fairly constant, those on the early whorls are somewhat variably spaced. The first main spiral lira is the peripheral one, which is situated at the peripheral angulation slightly below the middle of the whorl and coincides with the boundary between the concave anal band and the convex lateral surface. On the specimen GK-L 6873 there is another spiral lira on the lateral surface, while there are two on GK-L 6874. On the penultimate whorl of both specimens the primary spirals consists of equally spaced three lirae, between which are intercalated the weak secondary threads. The body whorl has six to seven pairs of the primary and secondary spirals on the lateral and basal surface and four on the snout. The primary lirae are much narrower than the interspaces. The suture is incised and somewhat wavy.

The aperture is elongately rhomboid with the moderately deep anal sinus posteriorly and rather short and and slightly oblique canal anteriorly. The labrum is broken but possibly thin at the very margin. A very massive varix is at some distance from the margin. The anal sinus is deep and U-shaped and narrowed at the entrance by the prominent callus pad. The distinct stromboid sinus is indicated by the growth lines. The inner lip is sharply reflected at the junction of the parietal and columellar lips and wholly covered with the thick callus. The basal fasciole of the snout is moderately strong and provided with the shallow umbilical slit. The anal band is ornamented with the distinct growth lines and faint spiral lines.

Comparison.- - It is evident that the present specimens are included in Inqusitor (s.s.) on the basis of the fusiform shell with scarcely contracted and moderately long base, the strong subsutural cord, deep U-shaped anal sinus with the 
heavy entering callus pad, shallow stromboid notch at the anterior part of the labrum, heavy callus of the inner lip with free edge, and the moderately buldged siphonal fasciole.

The present specimens closely resemble Drillia (Drillia) molengraafi MarTiN (1916-17, p. 230, pl. 1, f. 14) from the lower Miocene of West Progo Mountain, Java. The former is, however, readily distinguished from the latter in the ornamental design of the spirals. That is to say, $D$. (D.) molengraafi has an additional lira close to the peripheral lira on the anterior part of the anal band. This lira, which is somewhat weaker than the peripheral and lateral ones, is traced back on the early whorls. Moreover the protoconch of the present specimens has a weak axial ribs at some distance from the end edge. These facts are considered to fournish the reasonable basis for the subspecific separation of the present specimens from MARTIN's species.

Drillia (Austrodrillia ?) durgae BeETs (1941, p. 126, pl. 7, fs. 267 and 268) from the Upper Miocene of Borneo is another ally to the present subspecies in the general feature. The former is considered to be included in Inquisitor on the basis of the long and tapered base and the ornamental design including the strong subsutural cord. The present specimens are clearly distinguished from $I$. durgae in having less numerous primary spirals than the latter.

Horizon.-Upper part of the Dingle Formation.

Locality.-SKGS-74.

\section{Inquisitor (Inquisitor) batavianus (MARTIN)}

Pl. 20, Figs. 1, 2, 5, 11, and 15; Text-fig. 36

1883-87. Pleurotoma (Drillia) interrupta Lamarck var. Martin (partim), Samml. Geol. Reichs-Mus. Leiden, Ser. 1, Bd. 3, p. 65, Tab. 4, f. 66.

1895. Pleurotoma (Drillia) bataviana Martin, ibid. N. F. Bd. 1, Abt. 1, p. 43, Taf. 7, fs. 108, 108a and 108b.

Material.-GK-L 6871, 6872, 6903a, and 6903b from one and same locality. GK-L 6871 is adult and almost perfect in preservation and 6872 is immature and broken at the body whorl. Both 6903a and b are imperfect; the former is broken at the spire and the latter at the body whorl.

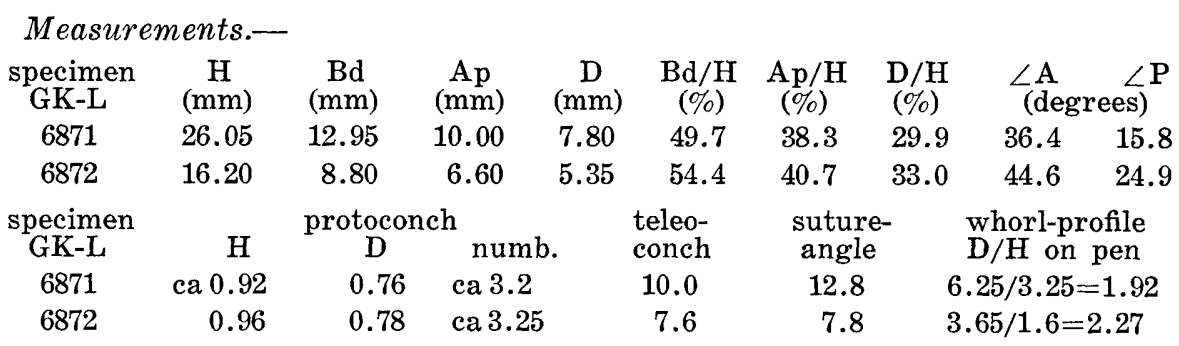

Remarks.-The present specimens are featured by the fusiform outline with the high conical spire and moderately long and weakly contracted base, bi-lirated prominent subsutural band, rather thin but strong spiral lirae separated by much narrower interspaces, prominent parietal and columellar callus, and very deep 
V-shaped anal sinus just below the subsutural cord. The protoconch is somewhat abraded but still illustrates the high conical outline and consists of about three smooth volutions. They are easily identified to Inquisitor (s.s.) on the basis of the features mentioned above.

The protoconch of the present specimens are bluntly conical with about three smooth volutions as noted above and quite intermediate between the conical and pointed protoconch of "Inquisitor awamoaensis (HUTTON)" and the globose and depressed one of "Pseudoinquisitor problematicus PowelL". Considering the serial variation of the feature in question among the allied species the author prefers to treat Pseudoinquisitor as a synonym of Inquisitor after POWELL (1967, p. 79).

There are a few closely allied species to the present specimens. They are Pleurotoma (Drillia) bataviana MARTiN (1895, p. 43, Taf. 7, fs. 108a and 108b), $P$. (D.) tjemorensis MARTIN (1906, p. 295, Taf. 43, fs. 705, 705a and 705b), and Drillia aesopus SchePMAN (1913, p. 410, pl. 26, fs. 6a and b).

The general feature of the protoconch and the early development of the ornamentation of the present specimens resemble those of D. aesopus, on which the spirals are, however, gradually reduced in the relative size and separated by wider interspaces on the later whorls.

$P$. (D.) bataviana and tjemorensis closely resemble each other and the former is distinguished from the latter only in having relatively short body whorl, sharp axial ribs, and the spirals of unequal strength according to the original author. Comparison of the type specimens, furthermore, clarifies that $P$. (D.) bataviana has sharper shoulder-angulation and more numerous axials than $P$. (D.) tjemorensis. On the former the axials are sharply crested and the subsutural band is prominent but simple, while on the latter the axials are fold-like and rather nodular at the periphery and the subsutural band is bifid.

The specimen GK-L 6903a and b are quite identical to $P$. (D.) bataviana except only for their bi-partile subsutural band. While GK-L 6871 and 6872 are provided with blunter and less numerous axial ribs, and bi-lirated subsutural band. Consequently the latter two show some similarity to $P$. (D.) tjemorensis. GK-L 6871 and 6872 are, however, clearly separated from tjemorensis in having definitely smaller ratio of the body whorl to the total height. The author believes that $P$. (D.) bataviana is more variable than the original author expected and the present specimens should be included in it.

Geological occurrence.-Upper Miocene to Pliocene (Indonesia).

Horizon.-Upper part of the Dingle Formation.

Locality.-SKGS-74.

Genus Microdrillia CASEY, 1903*

(type-species : Pleurotoma cossmanni MEYER=Pleurotoma meyeri CossmaN

by subsequent designation, CossmanN, 1906)

Subgenus Pulsarella LASERoN, 1954

(type-species: Pleurotoma cognata SMITH, by original designation)

* Synonym: Acrobela Thiele, 1925. 
Microdrillia (Pulsarella) madiunensis (MARTIN)

Pl. 21, Figs. 7 and 13; Text-figs. 37 and 39

1906. Drillia madiunensis MarTin, Samml. Geol. Reichs-Mus. Leiden, N. F. Bd.1, Abt. 1, p. 296, Taf. 43, fs. 707, 707a, and 707b.

Material.-GK-L 6876 and 6877 from one and same locality. GK-L 6877 is perfect in preservation.

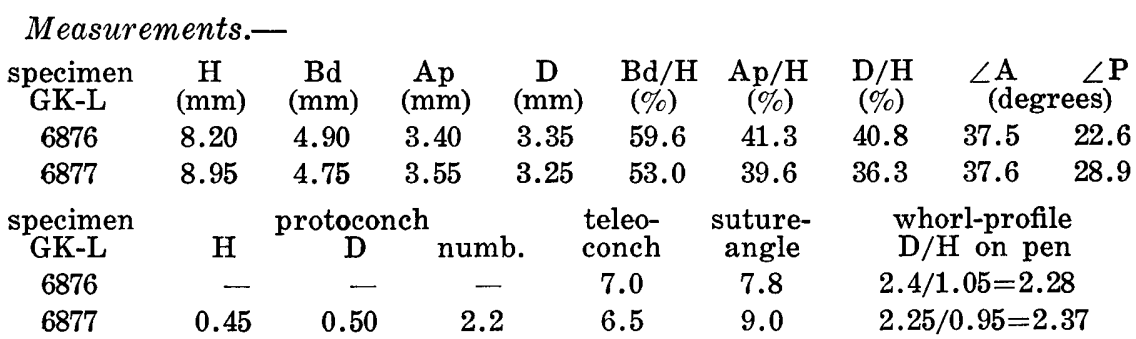
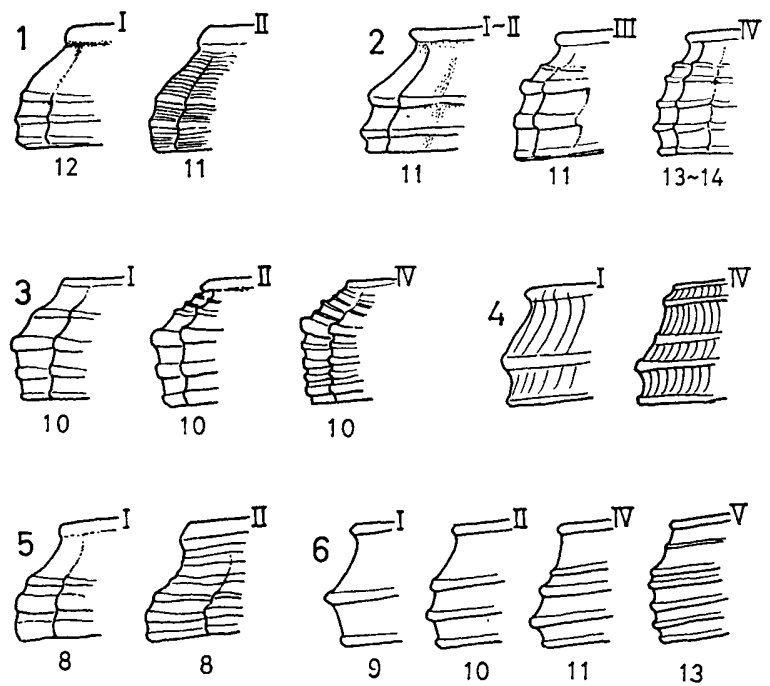

Fig. 37. Development of the ornamentation on the teleoconchs of some turrids.

1: Euclathurella (Thelecythara) franciscoana sp. nov.

2: $E$. (Miraclathurella) bagacayensis sp. nov.

3: Benthomangelia vandervlerki (BEETS).

4: Microdrillia (Pulsarella) madiunensis (MARTIN).

5: Pleurofusia (Pseudofusia) dinglensis subgen. et sp. nov.

6: Euclathurella (Euclathurella)? sp.

Roman numerical figures indicate the whorl-number and arabian numerical figures the number of the axials.

Remarks.-The present specimens are featured by the bi-keeled spire-whorls with the raised growth lines. The protoconch is paucispiral consisting of a little more than two volutions, of which the first one is large, blunt, and smooth and the second is broadly rounded at the side and smooth except for the axially lirated 
last one-fifth volution. The ornamental design of the teleoconch is the combination of the coarse, flat-topped, and simple spiral keels and the distinct, raised, close, and curved growth lines. On the spire-whorls the primary spiral lirae consist of the subsutural $\left(\mathrm{P}_{1}\right)$, somewhat weak suprasutural $\left(\mathrm{P}_{3}\right)$, and the prominent median (peripheral) one $\left(\mathrm{P}_{2}\right)$ which is situated at the lower two-fifths of the whorl-height. The suprasutural one is concealed under the succeeding whorl at early stage on some specimen. There are six and five to seven primary spirals respectively on the basal slope and snout of the body whorl besides the subsutural and peripheral ones. The interspace between $\left(P_{1}\right)$ and $\left(P_{2}\right)$ is wider than the others. The basal contraction is distinct. The columellar lip shows a weak fold-like flexure and the outer lip has a few raised threads inside at some distance from the very margin. The canal is oblique, widely open, and is not notched but truncated at the end.

The present specimens are quite identical to Drillia madiunensis MARTIN in both protoconch and teleoconch.

At first glance the present species is similar to Microdrillia CASEY, 1903, and Pulsarella LASERON, 1954. The paucigyrate and globose protoconch of the present species claims its alliness to Pulsarella, while the features of the teleoconch of the present species closely resemble those of Microdrillia. The author is inclined to include it in Pulsarella putting the importance on the protoconch, although it differs slightly from Pulsarella in being provided with longer body whorl.

Drillia difficilis SMITH (1879, p. 187, pl. 19, f. 8) living in Southwest Japan is so closely allied to Pulsarella madiunensis (MARTIN) that the distinction of them can not be practical basing only on the morphology of the teleoconch. The protoconch of $D$. difficilis, however, differs from that of $P$. madiunensis in being polygyrate with more than three volutions, of which the last is provided with the curved axials. This fact indicates that $D$. difficilis really belongs to Microdrillia.

Geological occurrence.-Pliocene (Indonesia).

Horizon.-Upper part of the Dingle Formation.

Locality.-SKGS-74.

Microdrillia (Pulsarella) sp. cf. P. madiunensis (MARTIN)

Pl. 21, Fig. 12

Material.-GK-L 6875 from the same locality as the preceding species.

\section{Measurements.-}

\begin{tabular}{|c|c|c|c|c|c|c|c|c|c|}
\hline$\underset{\text { GK-L }}{\text { specimen }}$ & $\underset{(\mathrm{mm})}{\mathrm{H}}$ & $\underset{(\mathrm{mm})}{\mathrm{Bd}}$ & $\underset{(\mathrm{mm})}{\mathrm{Ap}}$ & $\underset{(\mathrm{mm})}{\mathrm{D}}$ & $\underset{(\%)}{\mathrm{Bd} / \mathrm{H}}$ & $\underset{(\%)}{\mathrm{Ap} / \mathrm{H}}$ & $\underset{(\%)}{\mathrm{D} / \mathrm{H}}$ & \multicolumn{2}{|c|}{$\underset{\text { (degrees) }}{\angle \mathrm{A}} \stackrel{\angle \mathrm{P}}{ }$} \\
\hline 6875 & $11.9+$ & 6.95 & 4.7 & 4.9 & 58.3 & 39.4 & 41.1 & 39.5 & 24.0 \\
\hline $\begin{array}{l}\text { specimen } \\
\text { GK-L }\end{array}$ & \multicolumn{2}{|c|}{$\begin{array}{l}\text { teleo- } \\
\text { conch }\end{array}$} & \multicolumn{5}{|c|}{$\begin{array}{l}\text { whorl-profile } \\
D / H \text { on pen }\end{array}$} & & \\
\hline 6875 & \multicolumn{2}{|c|}{7.8} & 9. & & \multicolumn{3}{|c|}{$3.5 / 1.6=2.18$} & & \\
\hline
\end{tabular}

Remarks.-The present specimen is imperfectly preserved and the comparison of the protoconch with that of $M$. (P.) madiunensis is impossible. It, however, shows quite similar development of the ornament of the teleoconch until the 
juvenile stage, which corresponds to the body whorl of the type specimen of $M$. (P.) madiunensis and also to that of the specimens just described in the preceding paragraph. At the juvenile stage the whorl has a third distinct lira close to the lower suture. On the later whorl this lira becomes strong and change its relative position upward furnishing tri-lirated profile of the whorl. Consequently the later whorls of the present specimen are similar to those of $M .(P$. triporcata (SMITH) (1879, p. 188, pl. 19, f. 9) living in the Japanese waters, but the latter has tri-lirated whorls even at the earliest stage of the growth. Furthermore $M .(P$.$) triporcata is provided with coarser and less numerous growth lines$ than the latter. Considering that the present specimen came from the same locality as $M$. (P.) madiunensis and that the deviation between them is nothing but the reflection of the difference in the stage of growth. The author is inclined to include this gerontic specimen in $M$. (P.) madiunensis.

Horizon.-Upper part of the Dingle Formation.

Locality.-SKGS-74.

Subfamily Mangeliinae

Genus Euclathurella WoodRING, 1928

(type-species: Clathurella vendryesiana DALL by original designation)

Subgenus Miraclathurella WooDRING, 1928

(type-species: Miraclathurella vittata WoODRING by original designation)

Euclathurella (Miraclathurella) bagacayensis sp. nov.

Pl. 21, Figs. 3, 8, and 9; Text-figs. 37 and 38

Material.-Holotype: GK-L 6886 and paratype: GK-L 6887 from one and same locality.

Measurements.-

\begin{tabular}{|c|c|c|c|c|c|c|c|c|c|}
\hline pecimen & $\underset{(\mathrm{mm})}{\mathrm{H}}$ & $\underset{(\mathrm{mm})}{\mathrm{Bd}}$ & $\underset{(\mathrm{mm})}{\mathrm{Ap}}$ & $\underset{(\mathrm{mm})}{\mathrm{D}}$ & $\underset{(\%)}{\mathrm{Bd} / \mathrm{H}}$ & $\underset{(\%)}{\mathrm{Ap} / \mathrm{H}}$ & $\underset{(\%)}{\mathrm{D} / \mathrm{H}}$ & \multicolumn{2}{|c|}{ 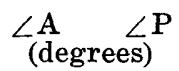 } \\
\hline 6886 & 10.20 & 5.95 & 4.25 & 3.80 & 58.2 & 41.7 & 37.2 & 34.2 & 27.3 \\
\hline 6887 & 9.40 & 5.80 & 4.10 & 3.60 & 61.6 & 43.5 & 38.2 & 38.2 & 21 \\
\hline GK & \multicolumn{3}{|c|}{ protoconch } & \multicolumn{2}{|c|}{$\begin{array}{l}\text { teleo- } \\
\text { conch }\end{array}$} & $\begin{array}{l}\text { suture- } \\
\text { angle }\end{array}$ & \multicolumn{3}{|c|}{$\begin{array}{l}\text { whorl-profile } \\
\text { D/H on pen }\end{array}$} \\
\hline & 0.90 & 0.90 & 2.6 & \multicolumn{2}{|c|}{4.8} & 14.0 & \multicolumn{3}{|c|}{$2.7 / 1.65=1.64$} \\
\hline 6887 & - & - & ca 3.0 & \multicolumn{2}{|c|}{4.2} & 10.2 & \multicolumn{3}{|c|}{$2.55 / 1.4=1.82$} \\
\hline
\end{tabular}

Diagnosis.-The shell is very small attaining about $10 \mathrm{~mm}$ in height and fusiform with slightly conoidal high spire and moderately long and scarcely contracted base. The protoconch is moderately low conical with about three volutions and the boundary between the protoconch and the teleoconch is marked by the sinusigera ridge. On both specimens the tip of the protoconch is not preserved. The remainder part of the first volution and the second one are broadly rounded at the side, smooth, and glossy. The third one is more narrowly rounded at the side, smooth and glossy at first, but has several very fine and close retrocurrently curved axial threads and one or two weak spiral lines at the last part. These axials are distributed on the upper surface, diminished below, and 

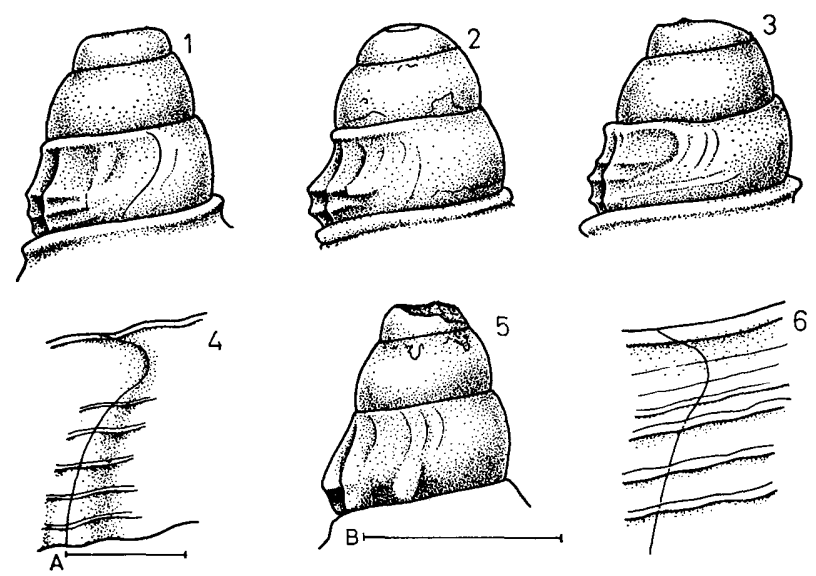

Fig. 38. Protoconchs and growthlines of som turrids.

1 and 4: Euclathurella (Thelecythara) franciscoana sp. nov., GK-L 6888.

1: $\quad$ E. (Thelecytharella) oyamai (SHUTo), subgen. nov., GK-L 7079. 3 and 6: E. (Miraclathurella) bagacayensis sp. nov., GK-L 6886.

5: Inquisitar (Ptychobela) neglectus (MARTIN), GK-L 6853.

Unit ber $A$ and $B$ indicate respectively $1 \mathrm{~mm}$ for growthlines and protoconchs.

finally replaced by the spirals on the lower surface.

The teleoconch consists of four to five whorls. The whorls are moderately convex at the side with the blunt peripheral angulation. The surface above the angulation is moderately sloped and somewhat concave to form the well defined anal band and the surface below the angulation is slightly convex and vertical. The whorls are ornamented by the prominent and slightly retrocurrently oblique axial plicae, prominent subsutural lira, and strong spiral lirae which are more prominent on the axials. The axials are eleven on the early three whorls and thirteen to fourteen on the last whorl. They are round at the crest and somewhat wider than the interspaces. They are prominent on the lateral surface and reach the lower suture without remarkable reduction in elevation but abruptly weakened on the anal band. On the body whorl, they become closer and weaker showing the adult feature. The spirals on the first whorl consist of the sharply ridged subsutural lira $\left(\mathrm{P}_{1}\right)$ close to the upper suture, peripheral $\left(\mathrm{P}_{3}=\mathrm{Per}\right)$ at lower onefifth, suprasutural $\left(\mathrm{P}_{4}\right)$ close to the lower suture, and a supraperipheral $\left(\mathrm{P}_{2}\right)$ at some distance from the Per. Of four lirae the supraperipheral one is distinctly weaker than the others and this tendency is maintained throughout the growth stages. The suprasutural lira may be concealed under the overlapping part of the succeeding whorl on some specimen. Another primary spiral lira $\left(\mathrm{P}_{5}\right)$ appears from the lower suture on the adolescent whorl. That is to say, the development of the spirals is adapical. On the body whorl they are regularly spaced, much narrower than the interspaces, and eight in number on the lateral and basal surface and six to seven on the snout. The secondary threads are zero to two on the anal band and about five to eight at the interspaces of the primaries 
of the lateral surface on the last part of the body whorl.

The aperture is elongately rhomboid with the defined, short, and wide canal anteriorly and the semitubular anal sinus posteriorly. The labrum is sharp and very slightly retrocurrently oblique and provided with the varix outside and weak stromboid sinus close to the entrance of the canal. The inner lip is bent with oblique parietal and almost vertical columellar lips. The callus on the inner lip is thick and solid especially at the entrance, semicircular at the main part, and fully occupies the anal band. The anal sinus indicated by the growth lines on the penultimate and earlier whorls is moderately deep V-shaped .

Comparison.-The teleoconch of the present species is featured by the fusiform outline with tall conoidal spire and the scarcely contracted base, the strong and sharply ridged subsutural lira, somewhat concave anal band, large axial ribs overriden by the prominent and regular primary spirals, elongately rhomboid aperture with semi-tubular anal sinus, heavy entrance callus pad, short and wide canal, weak stromboid sinus of the labrum, and the distinct varix. These features of the teleoconch are quite identical to those of Miraclathurella WOODRING, 1928, with the type-species, Miraclathurella vittata WoodRING. While its protoconch has one or two spiral lines forming obsolete angulation and several very weak and curved axial threads instead of the coarse axials and a blunt angulation of Miraclathurella. The mentioned sculpture on the last part of the protoconch of the present specimen is, however, rather variable: the paratype specimen clearly shows the angle-forming two spiral threads and several fine axial threads, while the holotype has only one obsolete spiral and a few very weak axials. WOODRING also mentioned the variability of the morphology of the genus: the angulation is distinct on the type-species and weak on the others. Considering these facts the author prefers to include the present specimens in Miraclathurella.

The present specimens resemble $M$. vittata WoodRING in the general features except for the body whorl and the protoconch just mentioned. The body whorl of $M$. vittata is provided with much weaker and closer axials and more numerous spirals than the present specimens.

Drillia audax Melvill and Standen (1901, p. 313, pl. 23, f. 1) from the Gulf of Oman is also allied to the present specimens. The latter, however, has coarser axials which are distinct even on the body whorl and more convex whorls than the former.

Horizon.-Upper part of the Dingle Formation.

Locality.-SKGS-74.

Subgenus Thelecythara WoODRING, 1928

(type-species: Cythara mucronata GUPPY by original designation)

Euclathurella (Thelecythara) franciscoana sp. nov.

Pl. 20, Fig. 6 and Pl. 21, Figs. 4-6; Text-figs. 37 and 38

Material.-Holotype: GK-L 6888 and paratype: GK-L 6889 from one and same locality. The holotype is almost perfect but the spire of the paratype is broken off. 


\begin{tabular}{|c|c|c|c|c|c|c|c|c|}
\hline \multicolumn{9}{|c|}{ Measurements.- } \\
\hline $\begin{array}{c}\text { specimen } \\
\text { GK-L }\end{array}$ & $\underset{(\mathrm{mm})}{\mathrm{H}}$ & $\underset{(\mathrm{mm})}{\mathrm{Bd}}$ & $\underset{(\mathrm{mm})}{\mathrm{Ap}}$ & $\underset{(\mathrm{mm})}{\mathrm{D}}$ & $\underset{(\%)}{\mathrm{Bd} / \mathrm{H}}$ & $\underset{(\%)}{\mathrm{Ap} / \mathrm{H}}$ & $\underset{(\%)}{\mathrm{D} / \mathrm{H}}$ & $\angle \underset{\text { (degrees) }}{\mathrm{A}} \angle \mathrm{P}$ \\
\hline 6888 & 9.70 & 5.90 & 3.95 & 3.45 & 60.7 & 40.7 & 35.6 & 41.6 \\
\hline $\begin{array}{c}\text { specimen } \\
\text { GK-L }\end{array}$ & $\mathrm{H}$ & $\begin{array}{r}\text { protoce } \\
\text { D }\end{array}$ & numb & & & $\begin{array}{l}\text { suture- } \\
\text { angle }\end{array}$ & & $\begin{array}{l}\text { ofile } \\
\text { pen }\end{array}$ \\
\hline 6888 & 0.90 & 0.9 & 3.0 & & .6 & 13.2 & 2.8 & $1.45=1.96$ \\
\hline
\end{tabular}

Diagnosis.-The shell is small and broadly fusiform with high conical spire and long and scarcely contracted base. The protoconch is smooth and conical with the blunt apex. It consists of three volutions, of which the first one is very small, slightly oblique and somewhat submerged in the second one and the second and the third volutions are roundly convex at the side. The end of the protoconch is clearly marked by a retrocurrently oblique, curved, and weak but distinct ridge. The teleoconch consists of about five convex whorls, which are ornamented with the remarkably oblique and strong axial ribs and moderately weak spiral threads together with fine and close spiral lines at the interstices. The first whorl has the distinct subsutural lira $\left(\mathrm{P}_{1}\right)$, below which is the slightly concave and narrow shoulder. The subsutural lira is still strong on the second whorl and gradually weakened thereafter. The first whorl is provided with twelve, moderately strong, and retrocurrently oblique axial ribs, which are strong at the periphery and hardly weakened below to the lower suture but distinctly weakened above on the shoulder. The axials are eleven on the second and third whorls and twelve to thirteen on the fourth and fifth (body) whorls respectively. They are rather abruptly faded away on the basal slope and do not reach the snout on the body whorl. The spiral ornamentation consists of four threads at first, of which the subsutural $\left(\mathrm{P}_{1}\right)$ is somewhat weaker than the others and the lower three $\left(\mathrm{P}_{2}, \mathrm{P}_{3}\right.$, and $\mathrm{P}_{4}$ ) are regularly spaced. The interspace between $\mathrm{P}_{1}$ and $\mathrm{P}_{2}$ is the concave shoulder. One weak line starts together with the primaries just above $\mathrm{P}_{2}$ and becomes weak later. Two very fine secondary lines are intercalated at each interspace between the primaries on the second whorl and several tertiaries follow them on the third whorl. Consequently the body whorl has about ten distinct threads of primary order and five to nine lines at each interspaces on the lateral surface and about seven to eight sets of spirals on the snout.

The aperture is elongately rhomboid. The labrum is thin and sharp with a deep anal sinus posteriorly slightly apart the suture, weak but distinct stromboid sinus anteriorly close to the entrance of the canal, and a distinct varix outside at some distance from the very margin. The inner lip is narrowly rounded at the junction between the parietal and columellar lips. The callus is very heavy at the entrance of the anal sinus forming a pad, moderately thin at the junction of the parietal and the columellar lip, and moderately thick and free-edged at the lower part of the columellar lip. The anterior canal is moderately long, somewhat narrowed at the upper entrance, and widened below to the obliquely truncated end. The anal sinus is deep, narrowed at the entrance by the callus pad, semicircular at the main part with the blunt apex. The anal sinus indicated by the growth lines on the penultimate and earlier whorls are moderately deep and V-shaped 
with almost symmetrical arms, of which the lower one extends obliquely oralward beyond the peripheral part of the whorl.

Comparison.-The characteristic features of the present species on the blunt protoconch of three smooth volutions, the aperture with the deep semicircular anal sinus, stromboid anterior sinus, very strong parietal callus pad, free-edged moderately thick columellar callus, and the convex whorl ornamented by the strong axials and weak and close spirals remind us some genera of the Clavinae and Mangeliinae.

The present specimens are readily distinguished from Crassispira SwAINson, 1810 , in being provided with the tapered base with moderately long canal instead of the wide aperture with short and imperfectly defined canal of Crassispira group. The former resembles Thelecythara WOODRING, 1928, in many characters except for somewhat weaker subsutural lira and other primary spirals. They also show some similarity to Miraclathurella, but the former is distinguished from the latter in being devoid of a few fine axial riblets at the last part of the protoconch and of strong spiral threads. From the viewpoint that the morphological features of the protoconch and aperture are the criteria of higher rank than the ornament in the taxonomy of Gastropoda, Thelecythara is considered to be the closest subgenus to the present specimens among the taxa mentioned above.

Drillia rubidofusus ScHePMAN (1913 p..408, pl. 26, f. 4) from Banda Sea is an ally to the present specimens, but the former is provided with closer primary spirals. Moreover the former is twice as large as the latter.

The present specimens also resemble Drillia dormitor VREDENBuRg (1921, p. 110, pl.14, f. 12) from the Lowest Miocene of Burma in general outline and aperture, but the former is provided with weaker subsutural band, more oblique axial folds, and stronger primary spirals than the latter. There is no other known species which has the comparable features of the protoconch and teleoconch to those of the present specimens.

Horizon.-Upper part of the Dingle Formation.

Locality.-SKGS-74.

$$
\begin{gathered}
\text { Subgenus Euclathurella (s.s.) } \\
\text { Euclathurella (Euclathurella) sp. } \\
\text { P1. 21, Figs. 10, 16, and } 17
\end{gathered}
$$

\begin{tabular}{|c|c|c|c|c|c|c|c|c|c|}
\hline \multicolumn{2}{|c|}{ Measurements.- } & & & & & & & \multirow{2}{*}{\multicolumn{2}{|c|}{$\underset{\text { (degrees) }}{\angle \mathrm{A}}$}} \\
\hline $\begin{array}{l}\text { specimen } \\
\text { GK-L }\end{array}$ & $\underset{(\mathrm{mm})}{\mathrm{H}}$ & $\underset{(\mathrm{mm})}{\mathrm{Bd}}$ & $\underset{(\mathrm{mm})}{\mathrm{Ap}}$ & $\underset{(\mathrm{mm})}{\mathrm{D}}$ & $\begin{array}{c}\mathrm{Bd} / \mathrm{H} \\
(\%)\end{array}$ & $\underset{(\%)}{\mathrm{Ap} / \mathrm{H}}$ & $\begin{array}{c}\mathrm{D} / \mathrm{H} \\
(\%)\end{array}$ & & \\
\hline 6885 & 12.45 & 7.05 & 5.20 & 5.10 & 56.5 & 41.7 & 30.9 & 34.2 & 19.7 \\
\hline $\begin{array}{l}\text { specimen } \\
\text { GK-L }\end{array}$ & \multicolumn{4}{|c|}{ whorls } & \multirow{2}{*}{\multicolumn{2}{|c|}{$\begin{array}{c}\text { angle } \\
14.0\end{array}$}} & \multicolumn{3}{|c|}{$\begin{array}{l}\text { whorl-profile } \\
\mathrm{D} / \mathrm{H} \text { on pen }\end{array}$} \\
\hline 6885 & \multicolumn{2}{|c|}{$2+$} & \multicolumn{2}{|c|}{ ca 5.1} & & & \multicolumn{3}{|c|}{$3.0 / 1.95=1.54$} \\
\hline
\end{tabular}

Material.-GK-L 6885. Slightly worn specimen.

Description.-The shell is small and slender fusiform. The protoconch is considered to be high conical and moderately polygyrate, although the details 
cannot be observed because of the corrosion, especially at the early volutions. The teleoconch consists of about five whorls. The first whorl is sharply angulated slightly below the middle of the shell-height and the angulation becomes indistinct and rounded on the later whorls. In consequence the whorl profile of the penultimate whorl is almost broadly rounded at the side. The body whorl is large occupying more than half of the shell-height, slightly concave at the anal band, broadly rounded at the side, and scarcely contracted at the base to the moderately long snout.

The ornamental design is composed of the distinct spiral lirae and the axial ribs. The spirals at the start consist of the subequal and prominent three lirae, the subsutural $\left(\mathrm{P}_{1}\right)$, peripheral $\left(\mathrm{P}_{2}=\mathrm{Per}\right)$, and suprasutural $\left(\mathrm{P}_{3}\right)$ ones. On the later whorls another primary spiral lirae come out one after another from the lower suture (adapical development), while the secondary threads are intercalated at the concave anal band and also at the interspace of the primaries on the lateral surface. The body whorl has a distinct subsutural lira, 17 sets of the primary lirae and secondary threads at the lateral and basal surfaces, 9 distinct lirae on the snout, and four fine lines and a distinct thread on the anal band. On the first whorl the axials are slightly protractly oblique, wider than the interspaces, strong, gradually weakened below the periphery and abruptly faded out on the anal band. They reduce the elevation as the shell grows and consequently they are very weak and hardly reach the lower suture on the penultimate whorl. On the body whorl they are somewhat crowded and hardly reach the lower one-third of the anal band posteriorly and disappear at the basal contraction anteriorly.

The aperture is elongately rhomboid with narrowly rounded posterior end and the broadly open and slightly notched anterior canal. The outer lip is moderately variced outside along the margin, protractly and roundly extended at the middle below the moderately shallow and rounded anal sinus. The stromboid sinus is very shallow. The callus on the inner lip is not thick except for the parietal entering callus.

Comparison.-The present specimen shows the close similarity to Euclathurella in the features of the teleoconch except for the shallow stromboid sinus of the labrum and weaker axials on the anal band than the latter. The former may be included in Euclathurella but the concrete identification is suspended because the details of its protoconch are not known.

It is somewhat similar to Vixinquisitor Powell, 1942 (type-species: Drillia vixumbilicata HARRIS), in the general facies, but is easily distinguished from the latter in having higher and less globose protoconch, moderately shallow and non-tubular anal sinus, and weak but clear stromboid labrum sinus.

It shows some resemblance to Mangilia elegantissima VREDENGURG (1921, p. 124, pl. 14, fs. 11a and b) from the Lowest Miocene of Burma. The former is, however, readily distinguished from the latter in having more attenuated base of the body whorl, more numerous and closer axials especially on the adolescent and early whorls, and more defined shoulder than the latter.

Horizon.-Upper part of the Dingle Formation.

Locality.-SKGS-74. 
Subgenus Thelecytharella subsp. nov.

(type-species: Agladrillia oyamai SHUTo, here designated)

Subgeneric diagnosis.-The shell is small attaining a little more than $10 \mathrm{~mm}$ and fusiform with the high conical spire and moderately long base. The apex is blunt and the base is tapered and truncated at the terminal. The protoconch is conical with two to three smooth volutions, of which the first is very small and somewhat submerged in the dome-shaped second one. The end of the protoconch is defined by a weak sinusigera ridge. The teleoconch consists of five to six whorls, which are moderately convex with defined peripheral angulation and somewhat concave anal band above. The ornamental design is the combination of the axial plicae and the spirals. The axials disappear abruptly on the anal band above and weakened below to the suture on the spire whorls and faded away on the upper part of the basal slope of the body whorl. They are prominent on the early whorls and become weaker and close on the penultimate and body whorls. The spirals consist of the prominent subsutural cord, strong primary lirae on the lateral surface, and the secondaries on the anal band and the interspaces of the primaries.

The aperture is elongately rhomboid with subparallel lips and moderately short and wide canal, which is truncated at the end. The labrum has the subcircular anal sinus posteriorly, the moderate stromboid sinus anteriorly, and the distinct varix outside. The inner surface is smooth. The inner lip is covered with the thick callus, which is especially thickened at the entrance of the anal sinus forming a pad.

Comparison.-In the original descripition the author included the species in Agladrillia Woodring, 1928, in spite of a few differences in the morphological features as pointed out in the original description. Somewhat submerged first volution of its protoconch is the formost important difference from Agladrillia. Furthermore the latter has remarkably contracted base instead of the tapered one of oyamai. The axials of Agladrillia keep the original strength even at the adult stage, while those of oyamai become weak and crowded on the body whorl. Hence it is better to separate "Agladrillia" oyamai from the nominated genus.

"Agladrillia" oyamai closely resembles Miraclathurella WoodRING, 1928, in the general characteristics of the teleoconch, but is readily distinguished from the latter in having different type of protoconch. The last one or half volution of the protoconch of Miraclatthurella has a few coarse axial riblets and a peripheral carina (or angulation) preceding to the riblets instead of the smooth protoconch of oyamai.

Thelecythara WooDRING, 1928, has the quite identical protoconch to the present species. Furthermore they closely resembles each other in the features of the aperture and the ornamentation except for the anal band and the shell form. " $A$ " oyamai has the distinct and concave anal band just below the subsutural cord, while Thelecythara is devoid of that cord. The shell form is really blunter and shorter in Thelecythara than in "A." oyamai as WoODRING described by the word "pupoid". 
In conclusion "A." oyamai has the intermediate features between the type species of Miraclathurella and Thelecythara and closer to the deviated species, Euclathurella (Miraclathurella) bagacayensis. Under such circumstance the author is inclined to place the above mentioned taxa together under Euclathurella as the subgenera respectively.

\section{Euclathurella (Telecytharella) oyamai (SHUTo)}

Pl. 19, Fig. 20 and Pl. 18, Figs. 23 and 24; Text-fig. 38.

1965. Agladrillia oyamai Shuto, Mem. Fac. Sci. Kyushu Univ. Ser. D, Vol.16, No. 2, p. 162, pl. 33, fs. 1-3 and 8.

Material.-GK-L 7079. A single perfect specimen.

Measurements.-

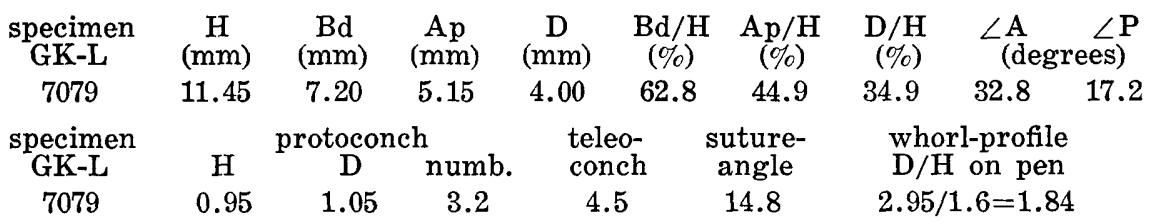

Remarks.-The present specimen is quite identical to Euclathurella (Thelecytharella) oyamai (SHUTo) from the Pleistocene bed of South Kyushu, Japan. It especially well conforms with the holotype specimen of the species.

Geological occurrence.-Upper Pleistocene (South Japan).

Horizon.-Upper part of the Ulian Formation.

Locality.-SKGS-72.

Genus Benthomangelia THIELE, 1925

(type-species: Surcula trophonoides ScHEPMAN by original designation)

Benthomangelia vandervlerki (BEETS)

Pl. 20, Figs. 8, 12, and 13; Text-figs. 37 and 39

1941. Turris vandervlerki BeEts, Verhandl. Geol-Mijnbouwk. Genootsch. Nederland en Koloniën, (Geol. Ser.), Deel, 13, p. 128, pl. 7, fs. 273 and 274.

Material.-GK-L 6884. Almost perfect but slightly broken at the labrum.

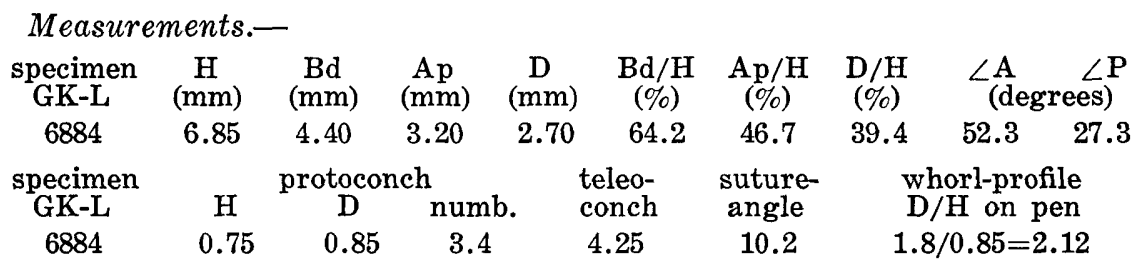

Remarks.-The present specimen quite conforms with Turris vandervlerki BEETS from the Upper Miocene of Borneo concerning with the protoconch and teleoconch of early stage of growth and shows some deviation from the latter in the adult feature. 

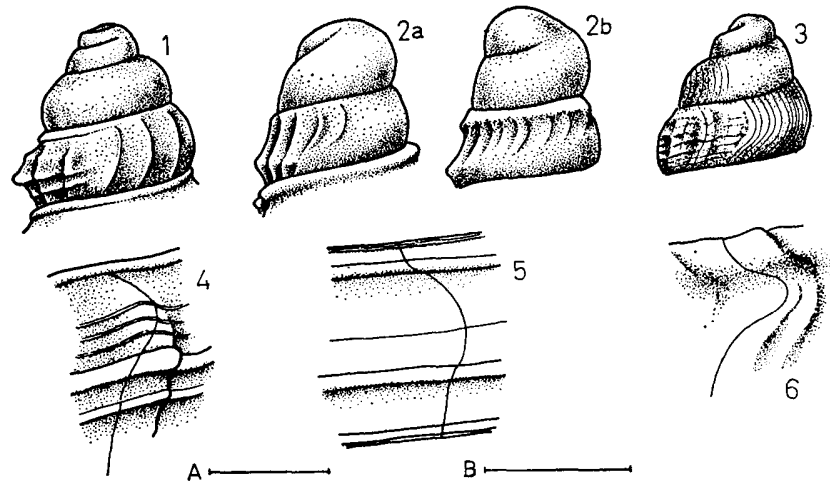

Fig. 39. Protoconchs and growthlines of some turrids.

1 and 4: Benthomangelia vandervlerki (BEETS), GK-L 6884.

2a, 2b, and 5: Microdrillia (Pulsarella) madiunensis (MARTIN), GK-L 6877.

3 and 6: Genota (Paragenota) gonzalesi subgen. et sp. nov., GK-L 7304 .

Unit bar A indicates $1 \mathrm{~mm}$ for growthlines and $B \quad 0.8 \mathrm{~mm}$ for fig. 1 and 3 and $0.5 \mathrm{~mm}$ for fig. $2 \mathrm{a}$ and $2 \mathrm{~b}$.

The low conical and rapidly growing protoconch of the present specimen consists of 3.4 volutions, of which the early two and a half volutions are roundly convex and smooth and the last 0.9 volution is provided with coarse, retractly oblique, and curved brephic axials. The beginning of the teleoconch is not marked by any sharp ridge or furrow but clearly indicated by the abrupt appearance of the distinct subsutural lira and other spiral threads. Furthermore the axials of the teleoconch differ from those on the protoconch in being less curved and less inclined than the latter.

At the beginning the spiral ornamentation consists of a strong subsutural lira $\left(P_{1}\right)$ and four lirae on the lateral surface $\left(P_{2}, P_{3}, P_{4}\right.$, and $\left.P_{5}\right)$, of which the second upper one $\left(\mathrm{P}_{3}\right)$ coincides with the median angulation and the lower one $\left(\mathrm{P}_{5}\right)$ is close to the lower suture and halfly concealed by the succeeding whorl. $\mathrm{P}_{2}$ is somewhat weaker than the others throughout the growth stages. At the half turn of the first whorl two fine threads are intercalated between $\mathrm{P}_{1}$ and $\mathrm{P}_{2}$. On the later part of the second whorl a secondary thread, which is as fine as those on the anal band, is intercalated below the peripheral lira and then another thread appears in the interspace above the suprasutural lira. The secondary threads on the lateral surface are rapidly increased in size and consequently they are almost as strong as the primaries on the later part of the body whorl. The subequal primaries and secondaries are 14 on the lateral and basal surface and 9 on the snout. The axial ribs are sharp and distinct even on the body whorl, although they abruptly become weak and disappear at the midway of the basal slope.

As recognized by the comparison of the description of the two, the present specimen differs from $T$. vandervlerki only in having stronger axial ribs and more distinct spirals on the body whorl than the latter. It is a problem whether 
the two should represent the varietal forms within the normal range of one and single species or they should be separated subspecifically. Considering the conformable ontogeny and the slight morphological divergence at the latest stage of growth, the author is inclined to recognize them as geographical varieties within a single species.

Although the original author distinguished this species from Benthomangelia THIELE, the present author can not find out any reasonable basis to agree with the original author. The present species is treated here as Benthomangelia.

B. trophonoides (ScHEPMAN) (1913 p..426, pl.28, f. 3) is an ally to the present specimen, but the former is more than twice as large as the latter and devoid of the distinct spirals on the concave shoulder.

Geological occurrence.-Upper Miocene (Northwest Indonesia).

Horizon.-Upper part of the Dingle Formation.

Locality.-SKGS-74.

\section{Subfamily Conorbiinae}

Genus Genota H. and A. AdAMs, 1853*

(type-species: Murex mitriformis Woon by subsequent designation, CossmanN, 1896)

Subgenus Paragenota subsp. nov.

(type-species: Genota (Paragenota) gonzalesi sp. nov., here desingated)

Subgeneric diagnosis.-The shell is moderately small and slenderly biconic with the moderately high conical spire and the scarcely contracted long base. The protoconch is low conical with about three volutions, of which the first one is smooth, very small, and globose tip, the second is moderately large and rounded at the side, and the third is provided with the fine, close, and opisthocyrtly curved axial riblets. The beginning of the teleoconch is sharply marked by the appearance of the spiral lirae. The spire-whorls of the teleoconch are about five and bluntly angled at the lower one-third to two-fifths. The surface above the angulation is slightly concave and steeply sloped and that below the angulation is moderately convex and slightly receded. The body whorl is large occupying more than two-thirds of the shell-height, moderately convexed at the periphery, gradually tapered to the indistinct snout. It is provided with a broad subsutural fold, which appears on the juvenile whorl as an obsolete spiral lira and becomes distinct on later whorls. The ornamentation consists of the opisthocyrtly curved, somewhat oblique, and moderately weak axial ribs, the fine spiral threads, and the distinct growth lines. On the spire-whorls two spiral threads are distinct and of primary order, each of which is intercalated by one secondary and several tertiary lines. The anal band and the axial valley on the lateral surface are microscopically finely reticulated by the spirals and the growth lines.

The aperture is long and narrow attaining more than half of the height of the shell. Its lower part is gradually narrowed to the poorly defined canal, which is somewhat oblique, widely open, and obliquely truncated terminally. The anal

* Synonym: Genotia P. FISCHER, 1863. 
sinus is V-shaped, regularly curved, moderately deep to moderately shallow, and symmetrical with the blunt apex slightly below the middle of the concave anal band. The callus of the inner lip is thin.

Comparison.-The present subgenus is closely allied to Genota H. and A. ADAMS, 1853, in the general character, but readily distinguished from the latter in having the fine and close brephic axials on the last volution of the conical protoconch instead of the papillate and smooth protoconch of Genota. The spirals of the present subgenus at the nepionic stage are quite similar to those of Genota, on which the spirals are broad and solid being separated by very narrow grooves throughout growth stages. While they become thinner with much wider interspaces at the adolescent and adult stages of the present subgenus. Furthermore the axials of the present subgenus are more or less distinct even above the peripheral angulation. On the basis of these differences the author prefers to separate the present form as a subgenus of Genota.

The present subgenus shows some affinity to the genus Spergo DaLl, 1894, with the type-species, Spergo glandiniformis DALL. The former, however, clearly differs from the latter in the features of the protoconch and also in the ornamental design of the teleoconch.

Paragenota also resembles Acamptogenotia RovERETo, 1899 (=Pseudotoma BELLARDI, 1875 non GRAY, 1825=Pseudotomina FINLAY, 1924) in the morphology of the teleoconch, but the former is readily distinguished from the latter in the character of the protoconch. The protoconch of Acamptogenotia intortus (BRoCCHI), the type-species of the genus, is polygyrate consisting of about four volutions, the last of which has spiral cords instead of the curved axials of the present subgenus.

\section{Genota (Paragenota) gonzalesi sp. nov.}

Pl. 21, Figs. 19-22; Text-fig. 39

Material.-Holotype: GK-L 7303 and paratype: GK-L 7304. Both specimens came from one and same locality. Preservation is fairly good but the labrum is broken slightly.

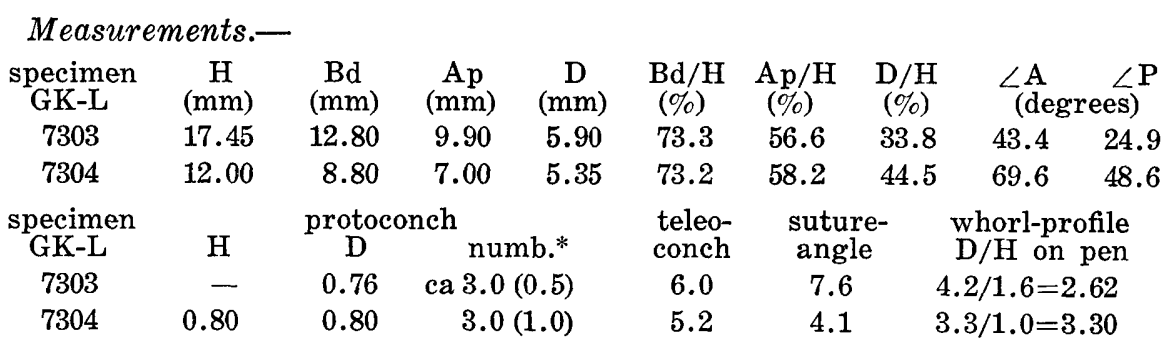

* The figures in the parentheses indicate the number of volution with close axials.

Diagnosis.-Same as the subgeneric diagnosis, but the supplementary comment should be added.

On the non angulated first whorl of the teleoconch the retractly oblique and opisthocyrtly curved axials are slightly narrower than the interspaces, strong at 
the peripheral surface, and somewhat weaker near the upper and lower sutures. On the second whorl, which is definitely angulated at the periphery, the axials are strong and subnodulous at the angulation and remarkably weakened above, but apparently reach the upper suture. On the later whorls especially on the body whorl the axials are subnodulous on the subsutural band, once somewhat weakened on the anal band, again subnodulous at the periphery, and then gradually weakened on the basal surface, where many other narrow axial riblets are intercalated irregularly. The axials are faded out just above the moderately strong basal fasciole.

The spiral ornamentation at the beginning of the first whorl consists of seven threads, of which three at the periphery are distinct and the upper and lower two threads are somewhat weaker than the peripheral ones. The lowest one of the peripheral threads coincides with the peripheral angulation of the later whorl. All the threads are separated one another by only narrow grooves at first, but the threads, especially those on the upper part, become abruptly weak and fine and are intercalated by the minute secondary and tertiary lines on the second and later whorls. The secondaries become as distinct as the primaries on the later whorls. These fine spirals and the growthlines form the fine reticulation on the subsutural band, the anal band, and the interspaces of the axials on the lateral surface. The primary and the secondary threads are counted about twenty to twenty-two on the lateral and basal surface of the body whorl and six on the snout. The curvature of the growthlines is somewhat sharper than that of the axial ribs.

The aperture is elongated pyriform with the pointed end posteriorly and the widely open canal anteriorly. The outer and inner lips are almost parallel at the middle part. The callus of the innerlip is very thin at the parietal part and moderately thick at the columellar lip.

Remarks and comparison.-Two specimens were examined. They differ from each other in the outlines of the shell in spite of the basic identity of the general features. That is to say, the holotype specimen is much slenderer than the paratype as indicated in the figures and measurements. The close comparison of both specimens denies the possibility that the morphological divergence is the reflexion of the different stage of growth by the specimens. The obvious difference between the specimens, although very slight, is maintained throughout growth stages. In spite of the fact mentioned the author does not prefer to separate these specimens as different species, because they, quite identical except for the size and outline, came from one and same locality. It is not clear whether they represent sexual dimorphism or asexual variation.

The present specimens, especially the paratype, show the resemblance to Pseudotoma bloetei Koperberg (1931 p,. 54, Taf. 2, f. 17) from the Pliocene of Timor. The profile of the shell and the sculpture on the teleoconch are similar between the two except for somewhat thinner and sharper axials of $P$. boetei. The protoconch of bloetei, according to the original description, is not fully preserved except for the last volution, which has the very obsolete spirals besides the distinct, close, and curved axial riblets. This indicates "Pseudotoma" bloete $i$ 
really belongs to Pleurotomella VERRILL, 1873.

Horizon.-Upper part of the Dingle Formation.

Locality.-SKGS-74.

\author{
Family Conidae \\ Genus Conolithus HerRmannsen, 1847* \\ (type-species: Conus antediluvianus BRUGUIÈRE by monotype)
}

Conolithus kanayai sp. nov.

Pl. 22, Figs. 15-18

Material.-Holotype: GK-L 6909 and paratype: GK-L 6908. Holotype specimen is full-grown and almost perfect except for the protoconch, while the paratype is broken at the apex and labrum. They came from one and same locality.

\begin{tabular}{|c|c|c|c|c|c|c|c|}
\hline \multicolumn{2}{|c|}{ Measurements.- } & \multirow[b]{2}{*}{$\underset{(\mathrm{mm})}{\mathrm{Bd}}$} & \multirow[b]{2}{*}{$\underset{(\mathrm{mm})}{\mathrm{D}}$} & \multirow[b]{2}{*}{$\underset{(\%)}{\mathrm{Bd} / \mathrm{H}}$} & \multirow[b]{2}{*}{$\begin{array}{l}\mathrm{D} / \mathrm{H} \\
(\%)\end{array}$} & \multirow[b]{2}{*}{$\underset{\text { (degrees) }}{\angle \mathrm{P}}$} & \multirow[b]{2}{*}{$\begin{array}{l}\text { whorls } \\
\text { proto tele }\end{array}$} \\
\hline $\begin{array}{l}\text { specimen } \\
\text { GK-L }\end{array}$ & $\underset{(\mathrm{mm})}{\mathrm{H}}$ & & & & & & \\
\hline & & 81.5 & 31.50 & $81.9-$ & $31.7-$ & 57.4 & - \\
\hline 6909 & $114.1+$ & 95.2 & 40.95 & 83.4- & $35.9-$ & 72.5 & $1+$ \\
\hline
\end{tabular}

Diagnosis.-The shell is large, solid, and asymmetrically biconical. The spire is slightly extraconical with the tangential angle of about 50 degrees at early and more than 70 degrees at the adult whorls. The basal cone is more than four times longer than the spire and regularly tapered anteriorward. The protoconch is not known. The teleoconch consists of about twelve whorls. The spire-whorls are rather sharply angulated at the middle of the whorl-height; the surface above the angulation is distinctly concave and moderately sloped, while the lateral surface is slightly convex and inclined outwardly. The early whorls are provided with the distinct nodules at the peripheral angulation. They are rather strong and not necessarily confined to the angulation but extend axially giving rise to the oblique ribs on the first to third whorls and thereafter they are weakened gradually. In consequence the peripheral angulation is almost smooth except for the obsolete undulation on the eighth whorl. A distinct spiral groove is discernible at some distance below the suture to define a subsutural lira on the first whorl. The subsutural lira is overriden by the coarse and somewhat protractly oblique growth lines. Between the infrasutural groove just mentioned and the peripheral angulation are intercalated a few fine grooves one by one on the third and later whorls. The subsutural lira becomes indistinct and subdivided by a shallow groove on later whorls. A few fine and shallow spiral grooves are discernible on the lateral surface of the early whorls, but they disappear on the penultimate one. The grooves above the peripheral angulation also become weak on the penultimate and quite disappear at the last part of the body whorl. The basal fasciole is strong with coarse sculpture, which is reduced upward and finally disappears at the middle of the basal slope.

* Synonym: Conolithes Swainson, 1840 non Conolites Schlotheim, 1820, nec Lamarck, 1822; Conospirus Gregorio, 1890; Conospira Cossmann, 1895; and Endemoconus LREDALE, 1931. 
The aperture is elongate and narrow with almost parallel lips, of which the inner one is almost straight, while the labrum is slightly depressed at the middle and then widened anteriorly. The anterior part is distinctly bent backward and obliquely truncated at the end. The anal sinus is very asymmetric with the upper arm directly converging to the suture with the angle of 80 degrees and its lower arm extending horizontally. The labrum profile is almost vertical but broadly rounded. The inner lip is covered by the moderately thin callus except for the moderately thick parietal one, which has a shallow and narrow spiral depression.

Comparison.-The specimens in hand include apparently different two forms. (The description is based on the holotype.)

The paratype specimen apparently differs from the holotype in less extraconical and somewhat higher spire, relatively narrower profile, and somewhat more distinct spiral grooves on the basal surface of the body whorl than the holotype. The mentioned difference is not evidenced to reflect the difference in growth stage of the two specimens. They may represent sexual dimorphism. That is to say the larger and broader specimen, GK-L 6909, may be female and the slenderer and smaller one, GK-L 6908, male.

The present specimens are safely included in Conolithus Herrmannsen, 1847 , on the basis of the diagnostic features mentioned above, especially of the large size, step-like concavo-convex spire-whorls with granulated angulation, and gradually tapered base with weak spiral grooves, although the former is slightly different from the type species of the genus in having remarkably shallower spiral furrow at the parietal lip and more produced basal fasciole than the latter. Among the known species of Conolithus, C. antediluvianus (BRUGUIÈRE) is the closest ally to the present species. The latter is, however, separated from the former in its more extraconical spire, more sharply defined shoulder, less numerous spiral grooves on the basal surface, and more smooth peripheral angulation on the later whorls besides the difference mentioned above.

Horizon.-Uppr part of the Dingle Formation.

Locality.-SKGS-74.

Genus Asprella Schaufuss, 1869*

(type-species: Conus asper LINNÉ=Conus sulcatus BRUGUIÈRE

by original designation)

Subgenus Asprella (s.s.)

Asprella (Asprella) busuegoi sp. nov.

P1. 24, Figs. 18, 19, and 22-24; Text-figs. 40 and 41

Material.-Holotype: GK-L 6431 and paratypes: GK-L 6429, 6430, and 6559. GK-L 6429 to 6431 came from loc. SKGS-73 and GK-L 6559 from SKGS-71.

* Synonym: Cylindrella Swainson, 1840, non L. Pheiffer, 1840. 

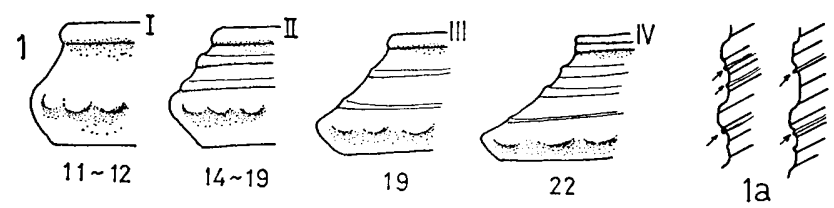

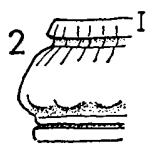

13

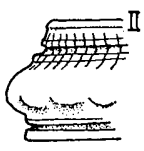

13
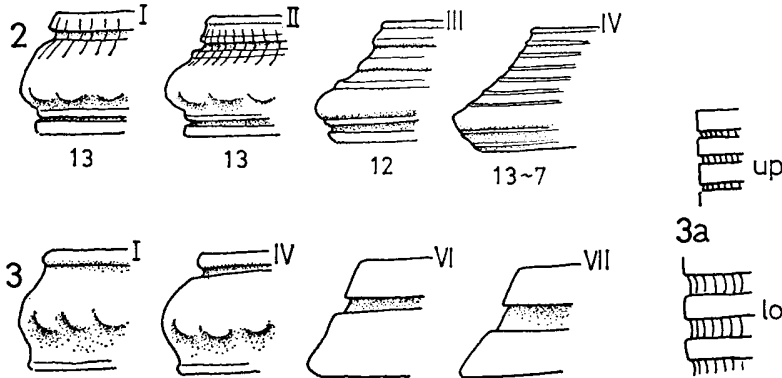

$3 a$

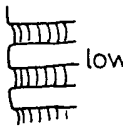

Fig. 40. Morphological development of the teleoconch-whorls of some conids.

1 and 1a: Asprella (Asprella) ornatissima (MARTIN).

2: A. (A.) insculpta (KIENER).

3 and 3a: A. (A.) busuegoi sp. nov.

Measurements.-

\begin{tabular}{|c|c|c|}
\hline $\begin{array}{c}\text { specimen } \\
\text { GK-L } \\
6429 \\
6431 \\
6559\end{array}$ & $\begin{array}{c}\mathrm{H} \\
(\mathrm{mm}) \\
18.00 \\
29.45 \\
21.45\end{array}$ & $\begin{array}{c}\mathrm{Bd} \\
(\mathrm{mm}) \\
13.95 \\
24.00 \\
16.80\end{array}$ \\
\hline $\begin{array}{l}\text { specimen } \\
\text { GK-L }\end{array}$ & \multicolumn{2}{|c|}{$\angle \mathrm{A}_{\text {(degrees) }} \angle \mathrm{P}$} \\
\hline $\begin{array}{l}6429 \\
6431 \\
6559\end{array}$ & $\begin{array}{l}44.3 \\
40.2 \\
36.9\end{array}$ & $\begin{array}{l}56.4 \\
67.7 \\
56.5\end{array}$ \\
\hline
\end{tabular}

\begin{tabular}{ccc}
$\begin{array}{c}\mathrm{Ap} \\
(\mathrm{mm})\end{array}$ & $\begin{array}{c}\mathrm{D} \\
(\mathrm{mm})\end{array}$ & $\begin{array}{c}\mathrm{Bd} / \mathrm{H} \\
(\%)\end{array}$ \\
13.10 & 6.30 & 77.4 \\
$-\overline{75}$ & 10.20 & 81.4 \\
15.75 & 7.20 & 78.4 \\
\multicolumn{3}{c}{ protoconch } \\
$\mathrm{H}$ & $\mathrm{D}$ & numb. \\
1.04 & .0 .94 & 2.5 \\
1.00 & 0.88 & 2.4 \\
1.08 & 0.90 & 2.4
\end{tabular}

$\mathrm{Ap} / \mathrm{H}$
$(\%)$
72.8
-
73.5
teleo-
conch
6.4
7.2
7.4

$\mathrm{D} / \mathrm{H}$

$(\%)$

35.0

34.7

33.7

Diagnosis.-The shell is moderately small, slender, and asymmetrically biconical with three to four times longer basal cone than the spire. The spire is moderately extraconical with acutely elevated early whorls. The protoconch is low conical and paucispiral consisting of less than two and a half volutions, which are separated one another by the deep suture. The first volution is very small, smooth, remarkably oblique, and bluntly rounded; the remainder volutions are regularly rounded, moderately convex, and also smooth except for the last oneeighth volution, which is provided with about two to three distinct and rather wide, almost vertical axial riblets. The termination of the protoconch is not sharply defined, but the appearance of the peripheral angulation with gemmules and distinct infrasutural spiral sulcus indicates the beginning of the teleoconch. The teleoconch of the largest specimen consists of 7.2 whorls. The blunt peripheral angulation is situated at the middle of the whorl, provided with axially and somewhat obliquely elongated blunt granules, and emarginated by the wide and sharp sulcus above and the shallow groove below on the first whorl. The subsutural part and the sulcus are ornamented by the coarse and raised growth lines. On the course of the growth stages the peripheral angulation gradually moves its position anteriorly and consequently it is at lower one-fourth on the 
penultimate whorl. Keeping pace with the change of the position, the granules are confined to the lower part of the angulation and finally they become very weak or obsolete on the latest whorls. On the second or third whorl another very weak spiral groove is intercalated between the infrasutural sulcus and the peripheral band and gradually becomes distinct and sharp. The basal surface of the body whorl is ornamented with about 32 to 33 narrow spiral sulcae, which is sharply defined with the steep wall and flat bottom, crossed by the raised growth lines, and separated one another by the flat-topped lirae. The spiral sulcae are regularly spaced and narrower at the upper part than at the lower. On the full grown specimen a few secondary spiral grooves are irregularly intercalated at the middle and lower parts. The aperture is very narrow and long with quite parallel lips.

Comparison.-The present specimens are characterized by the slender outline, uni-sulcate concave shoulder, gemmulated peripheral angulation of the early whorls, and regularly spaced distinct spiral sulcae on the lateral surface of the body whorl. With these diagnostic features they are closely allied to Conus longurionis KIENER, especially to MARTIN's fossil specimens from Indonesian Pliocene. They are, however, distinguished from each other in several points. The peripheral granules are still discernible on the fifth and sixth whorls on the present specimens, while they disappear on the third whorl on the Indonesian specimens. The spire of the latter is less extraconical than that of the former. In these respects the Indonesian specimens are close to the living $C$. longurionis from South China Sea. The decisive difference between the present specimens and $C$. longurionis is examplified in the feature of the protoconch; the protoconch of the present specimens is bluntly conical and paucispiral consisting of less than two and a half volutions, while that of longurionis is high conical, polygyrate, and weakly convex at the sides. On these basis the present specimens are reasonably separated from $C$. longurionis at the specific level.

The general profile and the uni-sulcate shoulder of the present specimens are similar to those of C. palabuanensis MARTIN (1895, p. 16, Taf.2, f. 26), but the latter has the flat-sided spire-whorls, which are devoid of the peripheral angulation and gemmules.

Conus sondeianus Martin (1895, p. 14, Taf. 1 , fs. 16 and 17) is also similar to the present specimens in the general profile of the shell and the gemmulated whorls, but the sulcae of the shoulder on the former species are several instead of only one of the latter.

Horizons.-Santa Barbara Silt and the upper part of the Ulian Formation.

Localities.-SKGS-71 and 73.

\section{Asprella (Asprella) insculpta (KIENER)}

PI. 23, Figs. 1-3 and 10 and Pl. 24, Figs. 20 and 21; Text-figs. 40 and 41

1839. Conus insculptus KIENER, Coq. Viv. Monogr. Conus, p. 309, pl. 99, f. 2.

1843. Conus insculptus, REEve, Conch. Icon. Vol. 1, Conus, Suppl. pl. 7, f. 267.

1866. Conus insculptus, Sowerby, Thesaurus Conch. Vol. 3, p. 12, pl. 202, f. 363.

1883-87. Conus insculptus, Martin, Samml. Geol. Reichs-Mus. Leiden, Ser. 1, 
Bd. 3, p. 47 , Tab. 4 , f. 48 .

1884. Conus insculptus, Tryon, Man. Conch. Ist Ser. Vol. 6, p. 75, pl. 23, f. 93.

1915. Conus insculptus, Tesch, Paläont v. Timor, Lief. 5, p. 19, Taf. 73, fs. 13a, $\mathrm{b}, 14 \mathrm{a}$, and $\mathrm{b}$.

Material.-GK-L 6919 to 6933 from one and same locality.

Measurements.-

\begin{tabular}{|c|c|c|c|c|c|c|c|}
\hline $\begin{array}{l}\text { specimen } \\
\text { GK-L }\end{array}$ & $\underset{(\mathrm{mm})}{\mathrm{H}}$ & $\underset{(\mathrm{mm})}{\mathrm{Bd}}$ & $\underset{(\mathrm{mm})}{\mathrm{Ap}}$ & $\underset{(\mathrm{mm})}{\mathrm{D}}$ & $\underset{(\%)}{\mathrm{Bd} / \mathrm{H}}$ & $\underset{(\%)}{\mathrm{Ap} / \mathrm{H}}$ & $\underset{(\%)}{\mathrm{D} / \mathrm{H}}$ \\
\hline 6919 & $32.90+$ & 25.60 & 23.85 & 12.25 & 77.8 & $72.5-$ & $37.2-$ \\
\hline 6920 & 29.30 & 23.80 & 22.00 & 10.90 & 81.2 & 75.1 & 37.2 \\
\hline 6921 & 30.15 & 23.90 & 21.70 & 9.85 & 79.2 & 71.9 & 32.6 \\
\hline 6922 & 29.10 & 22.30 & 20.75 & 10.30 & 76.6 & 71.2 & 35.4 \\
\hline 6924 & 20.75 & 16.00 & 14.25 & 6.95 & 77.1 & 68.6 & 33.5 \\
\hline 6926 & 17.10 & 13.40 & 12.45 & 5.90 & 78.4 & 72.8 & 34.5 \\
\hline $\begin{array}{l}\text { specimen } \\
\text { GK-L }\end{array}$ & \multicolumn{2}{|c|}{$\angle \mathrm{A}_{\text {(degrees) }} \angle \mathrm{P}$} & \multicolumn{3}{|c|}{$\begin{array}{l}\text { protoconch } \\
\text { D numb. }\end{array}$} & $\begin{array}{l}\text { teleo- } \\
\text { conch }\end{array}$ & \\
\hline 6919 & - & 56.1 & - & - & - & 9 & \\
\hline 6920 & 一 & 62.4 & - & - & $0.3+$ & 8.7 & \\
\hline 6921 & 40.6 & 53.2 & $0.99+$ & 0.90 & ca 3.0 & 8.3 & \\
\hline 6922 & 37.2 & 53.4 & $1.00+$ & 0.89 & 3.25 & 8.4 & \\
\hline 6924 & 34.1 & 50.1 & $1.10+$ & 0.81 & 3.3 & 7.1 & \\
\hline 6926 & 38.1 & 57.7 & $0.93+$ & 0.81 & 3.25 & 6.1 & \\
\hline
\end{tabular}
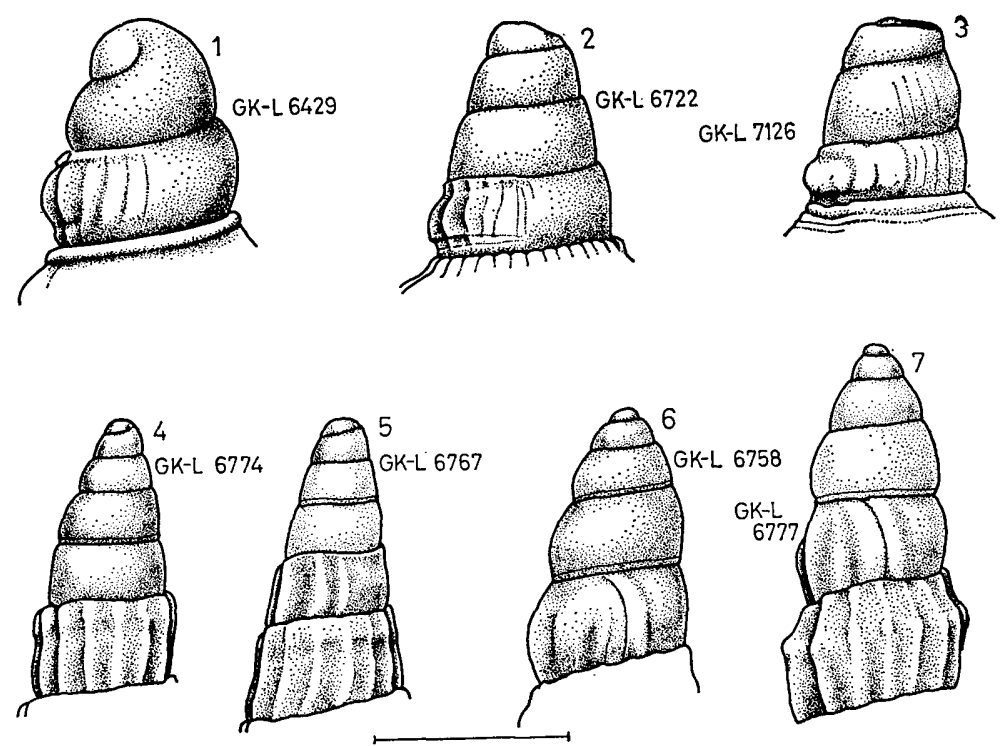

Fig. 41. Protoconchs of some conids and terebrids.

1: Asprella (Asprella) busuegoi sp. nov.

2: A. (A.) insculpta (KIENER).

3: A. (A.) ornatissima (MARTIN).

4 and 5: Myurella (Clathroterebra) woodwardiana (MARTIN).

6 and 7: Triplostephanus santosi sp. nov.

Unit bar indicates $1 \mathrm{~mm}$ for all the figures. 
Remarks.-The present specimens are quite identical to Conus insculptus KIENER in the characteristic features of the protoconch and teleoconch. The protoconch is high conical with three and one third smooth volutions, of which the first one is somewhat depressed and the others are slightly rounded. The teleoconch-whorls are sharply angulated and markedly granulated at the periphery throughout the growth stages. The shoulder is provided with five to six shallow spiral sulcae and fine, close, and raised growth lines. The spiral sulcae on the shoulder are as wide as the interspaces and reduced outwardly in their size one by one. The sulcae on the basal surface are about 27 to 28 on the adult specimens. They are much narrower than the spiral lirae at the posterior part and somewhat wider on the anterior part, although the width of each set of sulcus and lira is almost equal throughout on the basal surface except for the narrow area just below the angulation, where both the sulcae and lirae are finer and closer.

Comparing with the Indonesian fossil material the present specimens are provided with coarser and less numerous peripheral granulations. In this respect the present specimens are closer to the living one in the Philippines waters.

Geological occurrence.-Upper Miocene and Pliocene (Indonesia).

Recent distribution.-Tropical Indo-Pacific region.

Horizon.-Upper part of the Dingle Formation.

Locality.-SKGS-74.

\section{Asprella (Asprella) sinensis (SOWERBY) \\ Pl. 22, Figs. 6, 8, and 9; Text-fig. 42}

1833. Conus sinensis Sowerby, Conch. Illust. p. 56 .

1843. Conus sinensis, ReEve, Conch. Icon. Vol. 1 , Conus, pl. 15, fs. 76 and 77a.

1866. Conus sinensis, Sowerby, Thesaurus Conch. Vol. 3, p.12, pl.202, f. 379 (as C. sowerbyi REEVE).

1884. Conus sinensis, TrYon, Man. Conch. Ist Ser. Vol. 6, p. 76, pl. 24, f. 4.

1895. Conus sinensis, Martin, Samml. Geol. Reichs-Mus. Leiden, N. F. Bd. 1, Abt. 1, p. 13, Taf. 1, fs. 13, 14, and 15.

1915. Conus sinensis, TESch, Paläont. v. Timor, Lief. 5, p. 18, Taf. 73, fs. 9-11.

Material.-GK-L 6906 and 6907 from loc. SKGS-74 and GK-L 7500 from SKGS-71. GK-L 7500 is somewhat abraded.

\begin{tabular}{|c|c|c|c|c|c|c|c|c|}
\hline \multicolumn{2}{|c|}{ Measurements.- } & \multirow[b]{2}{*}{$\underset{(\mathrm{mm})}{\mathrm{Bd}}$} & \multirow[b]{2}{*}{$\underset{(\mathrm{mm})}{\mathbf{D}}$} & \multirow[b]{2}{*}{$\begin{array}{c}\mathrm{Bd} / \mathrm{H} \\
(\%)\end{array}$} & \multirow[b]{2}{*}{$\underset{(\%)}{\mathrm{D} / \mathrm{H}}$} & \multirow[b]{2}{*}{$\underset{\text { (degrees) }}{\angle \mathrm{P}}$} & \multirow[b]{2}{*}{$\begin{array}{l}\text { basal } \\
\text { angle }\end{array}$} & \multirow[b]{2}{*}{$\begin{array}{l}\text { whorls } \\
\text { numb. }\end{array}$} \\
\hline $\begin{array}{l}\text { pecimen } \\
\text { GK-L }\end{array}$ & $\underset{(\mathrm{mm})}{\mathrm{H}}$ & & & & & & & \\
\hline 69 & $27.7+$ & 22.1 & 14.6 & $79.7-$ & $52.7-$ & ca 67 & 42 & \\
\hline 6907 & $17.5+$ & 13.6 & 9.6 & 77.7- & $54.8-$ & ca 63 & ca 47 & 6. \\
\hline
\end{tabular}

Remarks.-The specimens in hand are imperfectly preserved but characteristic enough to serve for taxonomical comparison. GK-L 6906 and 6907 conform with the figure $77 \mathrm{a}$ of REEVE $(1843, \mathrm{pl} .15)$. They show quite similar pattern of the development of the spiral grooves on the shoulder to that of Javan fossil specimens. MARTIN's specimens illustrate the undulate periphery after granulate stage until the adolescent stage, although the stage when the peripheral undulation disappears is rather variable among the specimens. While on the present 
specimens the whorls are apparently devoid of the peripheral undulation of the preserved second or third (=original fifth or sixth) whorl. But this is simply caused by the heavy abrasion of the shell material at the periphery on the present specimens. The preserved first whorl of GK-L 6907 clearly shows the remnant of the fine and close granules. The specimens are safely identified to $A$. sinensis.

They are also similar to $A$. acutangula (CHEMNITz), but are readily distinguished from the latter in having higher spire, longer base, and less sharp spiral grooves on the shoulder. Furthermore the present specimens have the weak but distinct contraction at the base, while the basal slope of $A$. acutangula is broadly rounded and convex throughout.

Geological occurrence.-Pliocene (Indonesia).

Recent distribution.-South China Sea.

Horizons.-Santa Barbara Silt and the upper part of the Dingle Formation. Localities.-SKGS-71 and 74 .

\section{Asprella (Asprella) mucronata (REEVE)}

P1. 22, Figs. 3 and 5; Text-fig. 42

1843. Conus mucronatus Revve, Proc. Zool. Soc. p. 172.

1843. Conus mucronatus, ReEve, Conch. Icon. Vol. 1, Conus, pl. 37, f. 204.

1866. Conus mucronatus, Sowerby, Thesaurus Conch. Vol. 3, p. 35, pl. 206, f. 481.

1884. Conus mucronatus, Tryon, Man. Conch. Ist Ser. Vol. 6, p. 72, pl. 22, f. 73.

1960. Conus mucronatus, MaCNeIL, U. S. Geol. Surv. Prof. Pap. No. 339, p. 122, pl. 6 , fs. 7 and 14.

Material.-GK-L 6910 to 6916 from loc. SKGS-74 and GK-L 7513 from SKGS-75.

\begin{tabular}{|c|c|c|c|c|c|c|c|}
\hline \multicolumn{2}{|c|}{ Measurements.- } & \multirow[b]{2}{*}{$\underset{(\mathrm{mm})}{\mathrm{Bd}}$} & \multirow[b]{2}{*}{$\underset{(\mathrm{mm})}{\mathrm{D}}$} & \multirow[b]{2}{*}{$\underset{(\%)}{\mathrm{Bd} / \mathrm{H}}$} & \multirow[b]{2}{*}{$\begin{array}{l}\mathrm{D} / \mathrm{H} \\
(\%)\end{array}$} & \multirow[b]{2}{*}{$\underset{\text { (degrees) }}{\angle \mathrm{P}}$} & \multirow[b]{2}{*}{$\begin{array}{l}\text { whorls } \\
\text { numb. }\end{array}$} \\
\hline $\begin{array}{l}\text { specimen } \\
\text { GK-L }\end{array}$ & $\underset{(\mathrm{mm})}{\mathrm{H}}$ & & & & & & \\
\hline 6910 & $42.2+$ & 37.8 & 21.0 & $89.5-$ & $49.8-$ & 99 & $9.5+$ \\
\hline 6911 & $27.1+$ & 23.6 & 12.9 & $87.1-$ & 47.5 & 86 & $7.1+$ \\
\hline
\end{tabular}

Remarks.-The specimens in hand are imperfect in preservation. The majority of them is more or less abraded or broken at some degree. They, however, show the characteristic features of Asprella. That is to say, they have slightly extraconical and moderately high spire and the tapered base of the body whorl. The whorls are granulated at the peripheral angulation at the early stage and wavy at the later. The spiral sulcae on the basal surface are distinct.

They are identical to Conus mucronatus REEvE, living in the Philippines, in the profile of the body whorl, the pattern of the spiral sulcae on the slightly concave shoulder, and the detailed character of the spiral sulcae on the lateral surface besides the diagnostic features mentioned above.

A. socialis (MARTIN) (1895, p. 17, Taf. 7, fs. 27-30) is a close ally to the present specimens. The ontogenetic development of the spiral sulcae on the shoulder of $A$. socialis almost conforms that of $A$. mucronata, but the latter shows the adult features of $A$. socialis at much earlier stage of growth and attains 

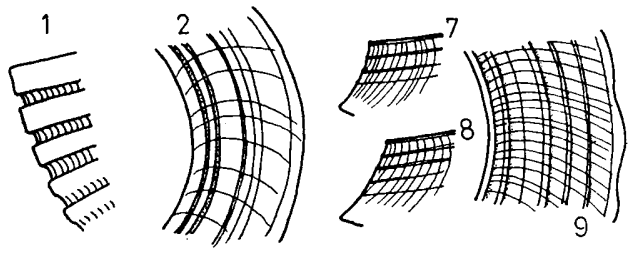

Fig. 42. Ornamentation of some conids.

1 and 2: Phasmaconus martini nom. nov., basal surface and shoulder of the body whorl.

3-6: Asprella (Asprella) sinensis (SowERBY).

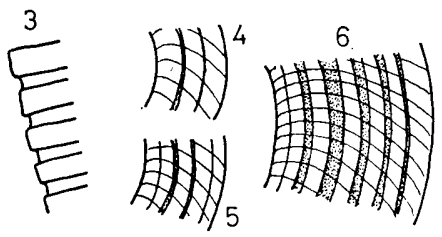

3: basal surface, 4-6: shoulder of the first to second whorl, third whorl, and body whorl.

7-9: A. (A.) mucronata (REEve).

7: third whorl, 8: fifth whorl, and 9: body whorl.

further development. The other minor differences are detected between the two; A. mucronata has more curved side of the basal slope and coarser spirals than A. socialis. Evaluating the ontogenetic alliness of the two, the author is inclined to treat them respectively as a subspecies of a single species, A. mucronata.

Geological occurrence.-Upper Miocene (Okinawa).

Recent distribution.-Philippines waters.

Horizons.-Upper and uppermost parts of the Dingle Formation.

Localities.-SKGS-74 and 75.

Asprella (Asprella) ornatissima (MARTIN)

Pl. 22, Figs. 1, 2, 4, and 11-14; Text-figs. 40 and 41

1883. Conus ornatissimus Martin, Palaeont. Nederland.-Indië Verhand. No.18, p. 313, Tab. 10, f. 20.

1895. Conus ornatissimus, Martin, Samml. Geol. Reichs-Mus. Leiden, N. F. Bd. 1, Abt. 1, p. 12, Taf. 1, f. 10.

1915. Conus ornatissinus, Tesch, Paläont. v. Timor, Lief. 5, p. 16, Taf. 73, fs. 3a, $\mathrm{b}, 4 \mathrm{a}, \mathrm{b}, 5 \mathrm{a}, \mathrm{b}, 6 \mathrm{a}$, and $\mathrm{b}$.

1927. Conus ornatissinus, Fischer, ibid. Lief. 15, p. 104, Taf. 214, fs. 87 a and b.

1935. Conus ornatissimus, NomUra, Sci. Rep. Tohoku Imp. Univ. 2nd Ser. Vol. 18, No. 2, p. 109, pl. 7, fs. 4a and b.

1948. Conus vlerki Cox, Schweiz. Paläont. Abh. Vol. 66, p. 59, pl. 6, fs. $3 a$ and b.

Material.-GK-L 6917 and 6918 from loc. SKGS-74 and GK-L 7124 to 7143 from SKGS-75. The preservation is generally good.

\begin{tabular}{|c|c|c|c|c|c|c|c|c|c|c|}
\hline \multicolumn{3}{|c|}{ Measurements.- } & \multirow[b]{2}{*}{$\underset{(\mathrm{mm})}{\mathrm{D}}$} & \multirow[b]{2}{*}{$\underset{(\%)}{\mathrm{Bd} / \mathrm{H}}$} & \multirow[b]{2}{*}{$\begin{array}{l}\mathrm{D} / \mathrm{H} \\
(\%)\end{array}$} & \multirow[b]{2}{*}{$\underset{\text { (degrees) }}{\angle \mathrm{P}}$} & \multirow{2}{*}{\multicolumn{2}{|c|}{ protoconc }} & \multirow[b]{2}{*}{$\begin{array}{l}\text { h } \\
\text { numb. }\end{array}$} & \multirow[b]{2}{*}{$\begin{array}{l}\text { teleo- } \\
\text { conch }\end{array}$} \\
\hline $\begin{array}{l}\text { pecimen } \\
\text { GK-L }\end{array}$ & $\underset{(\mathrm{mm})}{\mathrm{H}}$ & $\underset{(\mathrm{mm})}{\mathrm{Bd}}$ & & & & & & & & \\
\hline 6917 & $39.45+$ & 34.95 & 30.30 & $88.6-$ & 51.5 & 94.4 & - & - & - & $9+$ \\
\hline 6918 & 37. & 32.00 & 7.30 & $84.4-$ & $45.6-$ & 86.7 & - & - & - & 10.5 \\
\hline 712 & & 38.95 & & 87. & 49 & 91.1 & - & 0.82 & - & 10.0 \\
\hline 712 & & 38.30 & .75 & 87. & 47 & 97.1 & .99 & 0.8 & 3.3 & 10.4 \\
\hline 712 & & 7.20 & .20 & 87.1 & 47. & 96.6 & 0.90 & 0.80 & 3.3 & 10.6 \\
\hline 7128 & 36.60 & 30.60 & 16.60 & 83.6 & 45.3 & 78.3 & $0.81+$ & 0.82 & 3.3 & 10.1 \\
\hline
\end{tabular}

Remarks.-This is one of the most common gastropod species among the younger Tertiary faunas from the island of Panay. The specimens, though 
rather variable in morphology, show some common features. The spire is elevately pointed at the apex and sloped down gently at the neanic and later part to form a large pleural angle. The base is broadly rounded at the side, attenuated to the snout, and provided with the distinct fasciole. The whorls are sharply angulated at the periphery, but the angulation can not be observed except on the body whorl because of the extreme overlapping by the succeeding whorls. The peripheral angulation is coronated with the laterally elongated coarse granules. The ramp is sculptured by the distinct spiral grooves and protractly curved and raised growth lines. The lateral surface of the body whorl is also covered with the fine lattice sculpture of the spiral sulcae and close growth lines, the latter of which are distinct at the sulcae but very weak or obsolete on the spiral lirae. The spiral lirae consisting of the alternation of the primary and secondary ones are flat or rounded at the crest and generally narrower than the sulcae.

The diagnostic features mentioned above indicate that the specimens are included in Asprella (s.s.). On many specimens the spiral lirae on the basal surface of the body whorl are hardly crossed over by the growth lines and consequently they are almost smooth. While the primary lirae of some specimens (one-sixth of the total number of the specimens) are provided with the fairly distinct microgranules and another one-fourth of the specimens illustrates the apparent tendency for granulation of the primary lirae. In this respect the present specimens resemble Conus sulcatus costatus CHEMnitz, especially to the fossil specimens from the Pliocene of Sondé, Java. The former is, however, readily distinguished from the latter on the basis of the remarkable difference that the present specimens are provided with much weaker growth lines on the ramp and basal slope and with simple lirae on the lateral surface instead of the coarse and subgranular growth lines and markedly granulated and twinned lirae of $C$. sulcatus costatus.

The specimens in hand are also distinguished from Conus cancellatus BRUGUIÈRE in having narrower spiral lirae. They are safely included in C. ornatissimus MARTIN, which is originally described on the material from the Younger Miocene of Tjilongan, Java.

Geological occurrence.--Upper Miocene (Indonesia) and Pliocene (Indonesia and Taiwan).

Horizons.-Upper and uppermost parts of the Dingle Formation.

Localities.-SKGS-74 and 75 .

Genus Phasmaconus Mörch, 1852

(type-species: Conus radiatus GMELIN by subsequent designation, IREDALE, 1930)

Phasmaconus martini nom. nov.

Pl. 22, Figs. 7 and 10; Text-fig. 42

1921. Conus jenkinsi, Martin, Samml. Geol. Reichs-Mus. Leiden, N. F. Bd. 1, Abt. 2, p. 448, Taf. 58, fs. 7 and 8. (non 1879-80, p. 10).

Material.-GK-L 6428 from loc. SKGS-74 and GK-L 6558 from SKGS-71. 


\begin{tabular}{|c|c|c|c|c|c|c|c|c|c|c|}
\hline \multicolumn{3}{|c|}{ Measurements.- } & \multirow[b]{2}{*}{$\underset{(\mathrm{mm})}{\mathrm{D}}$} & \multirow[b]{2}{*}{$\underset{(\%)}{\mathrm{Bd} / \mathrm{H}}$} & \multirow[b]{2}{*}{$\underset{(\%)}{\mathrm{D} / \mathrm{H}}$} & \multirow[b]{2}{*}{$\underset{\text { (degrees) }}{\angle \mathbf{P}}$} & \multirow{2}{*}{\multicolumn{3}{|c|}{ protoconch }} & \multirow[b]{2}{*}{$\begin{array}{l}\text { teleo- } \\
\text { conch }\end{array}$} \\
\hline $\begin{array}{l}\text { pecimen } \\
\text { GK-L }\end{array}$ & $\underset{(\mathrm{mm})}{\mathrm{H}}$ & $\underset{(\mathrm{mm})}{\mathrm{Bd}}$ & & & & & $\mathrm{H}$ & & h & \\
\hline 6428 & 28.4 & 25.2 & 12.7 & 88.8 & 44.9 & 88.7 & 0.75 & 0.68 & 2.6 & 8.0 \\
\hline 6558 & 23.4 & 20.8 & 10.5 & 88.9 & 44.9 & 97.5 & - & - & $\longleftarrow 9$. & 6 \\
\hline
\end{tabular}

Remarks.-MARTIN described Conus jenkinsi on the basis of a single imperfect specimen from Vindplaat $O$ of Java (1879-80, p. 10, Tab. 1, f. 4) and later redescribed on the material from the Njalindoen bed (1921, p. 448, Taf. 58, fs. 7 and 8). Detailed examination of the specimens mentioned above unfortunately leads to the conclusion that the specimens from the Njalindoeng bed are quite different from the original type in the ornamental pattern of the shoulder as is indicated in Text-fig. 42 and should be separated specifically from the latter. Strictly speaking they, furthermore, differ in the profile of the spire, shoulderangulation of the body whorl, and pattern of the basal sulcae, but the features just mentioned are in general rather variable within a single species of the conids and can not be put the extreme importance on them.

Hence the author prefers to give a new name to the Njalindoeng material in honor of late Professor Martin. Holotype: Rjikksmus. Geol. Min. Leiden, St. 7557-a (larger specimen, $\mathrm{H}=38.6 \mathrm{~mm}$, MARTIN, 1921, pl. 58, f. 7) ; paratypes : St. 7557-b (smaller specimen, $\mathrm{H}=23.1 \mathrm{~mm}$, MARTiN, 1921, pl. 58, f. 8) and St. 47097. Type-locality: Tji Talahab.

The protoconch of "Conus martini" is high conical and polygyrate, but the details are not examined because of abrasion. The early teleoconch-whorls are provided with very prominent, wide, and smooth peripheral carina. The surface above the carina is concave and moderately sloped. The lateral surface below the carina is almost vertical at first and is perfectly overlapped by the succeeding whorl later. The peripheral carina becomes weak and further rounded on the later whorls to illustrate roundly curved periphery. The spiral sulcae are developed on the lower part of the basal surface and on the shoulder. The basal sulcae are shallowly U-shaped and crossed by the growth lines. The sulcae on the shoulder are generally shallow and narrow. They are five on the later whorls; upper two of five are distinctly stronger and separated each other by wider interspaces than the other three. On the basis of these features the present species is reasonably included in Phasmaconus MöRCH, 1952.

The specimens from Panay are almost identical to Phasmaconus martini except for less rounded shoulder-angulation and simpler basal sulcae than the latter. The differences noted above are so slight and the morphological development of the spire is so similar that it seems reasonable to include the specimens from Panay in P. martini.

The present material is also similar to Conus cinereus Hwass, but they show the different morphological development. That is to say, C. cinereus is devoid of the sharp carina on the neanic whorl and more convex on the adolescent whorls than the present specimens.

Geological occurrence.-Upper Miocene (Indonesia).

Horizons.-Santa Barbara Silt and the upper part of the Dingle Formation. 
Localities.-SKGS-71 and 74.

\author{
Family Terebridae \\ Genus Triplostephanus DALL, 1908 \\ (type-species: Terebra triseriata GRAY by original designation)
}

There are several terebrid specimens characterized by the subcylindrical spire consisting of slowly growing numerous whorls, heavily granulated subsutural twinned bands, a few distinct spiral lirae on the lateral surface, slightly curved and thin axial riblets, and two columellar plaits. They are reasonably included in Triplostephanus DALL, 1908. Specific distinction of Triplostephanus is not easy through the comparison of the morphological characters only on the adult whorls, because such attractive characters as the ratios of the width of the sub- and infrasutural bands and number of the spirals on the lateral surface are not stable in a single population of the species. The superimposing threads on the sub- and infrasutural bands are, however, rather stable in their number and position as far as the present material is concerned. In respect of this feature three forms may be distinguished among the closely allied specimens from one and same locality. The first form is non lirated; the second has the subsutural band with only one but distinct lira accompanied by side-grooves and non lirated infrasutural one; and the third is provided with numerous threads on the twinned bands. The difference among three forms seems sharp without intermediate specimens, although this is not confirmed through the comparison of the morphological development among these forms because of paucity of excellently preserved specimens. Hence the author prefers to treat these forms as independent species, although they come from one and same locality.

subsutural band non lirated ..........Triplostephanus jenkinsi (MARTIN)

subsutural band with one distinct lira ............. santosi sp. nov. subsutural band with numerous threads .........

T. pamotanensis timorensis (KOPERBERG)

Another one species of Triplostephanus is also distinguished in the sample from the same locality, but it is quite different from the groups mentioned above.

Triplostephanus santosi sp. nov.

Pl. 23, Figs. 13, 19, and 22; Text-figs. 41 and 43

Material.-Holotype: GK-L 6777 and paratypes: GK-L 6752, 6753, and 6758 from one and same locality.

Measurements.-

\begin{tabular}{|c|c|c|c|c|c|c|c|c|}
\hline $\begin{array}{l}\text { specimen } \\
\text { GK-L }\end{array}$ & $\underset{(\mathrm{mm})}{\mathrm{H}}$ & $\underset{(\mathrm{mm})}{\mathrm{Bd}}$ & $\underset{(\mathrm{mm})}{\mathrm{Ap}}$ & $\underset{(\mathrm{mm})}{\mathrm{D}}$ & $\underset{(\%)}{\mathrm{Bd} / \mathrm{H}}$ & $\underset{(\%)}{\mathrm{Ap} / \mathrm{H}}$ & $\underset{(\%)}{\mathrm{D} / \mathrm{H}}$ & $\underset{\text { (degrees) }}{\angle \mathrm{P}}$ \\
\hline 6758 & 26.3 & 8.0 & 4.95 & 5.20 & 30.5 & 18.8 & 19.8 & 9.5 \\
\hline 6777 & 33.0 & 9.2 & 5.45 & 6.95 & 27.9 & 16.5 & 21.1 & 8.6 \\
\hline $\begin{array}{l}\text { specime } \\
\text { GK-L }\end{array}$ & \multicolumn{3}{|c|}{$\begin{array}{l}\text { protoconch } \\
\text { D }\end{array}$} & umb. & $\begin{array}{l}\text { teleo- } \\
\text { conch }\end{array}$ & $\begin{array}{c}\text { suture } \\
\text { angle }\end{array}$ & \multicolumn{2}{|c|}{$\begin{array}{l}\text { whorl-profile } \\
\mathrm{D} / \mathrm{H} \text { on pen }\end{array}$} \\
\hline 6758 & 1.20 & \multicolumn{2}{|c|}{0.68} & 4.5 & 13.4 & 16.4 & \multicolumn{2}{|c|}{$4.6 / 2.9=1.62$} \\
\hline 6777 & 1.15 & \multicolumn{2}{|c|}{0.75} & 4.4 & 15 & 12.4 & \multicolumn{2}{|c|}{$6.1 / 3.5=1.84$} \\
\hline
\end{tabular}



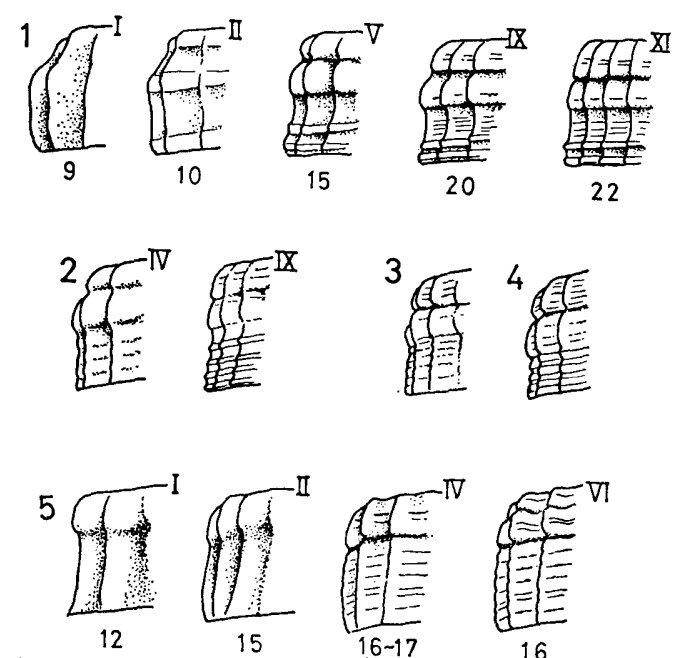

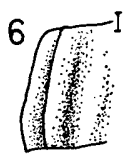

ca 14

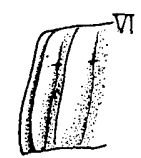

13
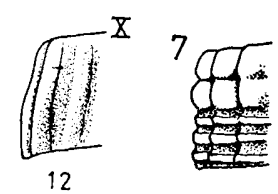

Fig. 43. Morphological development on the teleoconchs of some terebrids.

1 and 2: Triplostephanus santosi $\mathrm{sp.}$ nov.

3 and 4: T. sp. cf. T. pamotanensis timorensis (KOPERBERG).

3: preserved first whorl $(\mathrm{D}=1.3$ $\mathrm{mm})$. 4: preserved fifth whorl.

5: Myurella (Clathroterebra) woodwardiana (MARTIN).

6: Punctoterebra cabatuanensis sp. nov.

7: Triplostephanus sp. cf. T. jenkinsi (MARTIN), $\mathrm{D}=2.5 \mathrm{~mm}$.

Diagnosis. - The shell is moderately small, moderately solid, and turreted with slowly growing numerous whorls. The pleural angle is very small. The protoconch is multigyrate with about four and a half smooth and roundly convex volutions. The tip is small and horizontal. The penultimate volution is as large as the last one furnishing the conoidal outline of the protoconch. A weak spiral thread is discernible close to the lower suture of the penultimate and antipenultimate volutions. The end of the protoconch is sharply marked by a curved, smooth, wide, and elevated axial ridge.

The first teleoconch-whorl is hexagonal in profile with a marked peripheral angulation at about upper one-third. The subsutural lira is rather weak and subgranulated at the intersections by the axial ribs, which are slightly antecurrently oblique on the shoulder and reflexed at the peripheral angulation and almost vertical and straight below the angulation. The angulation-lira is much stronger and more granular than the subsutural one. The lateral surface is almost smooth except for the axials on the first whorl and a few faint spiral lines appear on the second whorl. The lower two lines are somewhat distinct and become stronger on the later whorls, while the other lines become finer together with the secondary ones. Finally the spirals on the lateral surface become obsolete on the adult whorls except for the distinct lower two threads. The peripheral angulation becomes indistinct on the fifth to sixth whorl, although the peripheral lira (infrasutural lira) persists its strength through these stages. The subsutural lira is increased in size and surpasses the infrasutural one on the seventh to eighth whorl and one and a half times wider than the latter on the 
adult whorls. These lirae are superimposed by a fine spiral thread with accompanying grooves at both sides.

The body whorl is once concave below the infrasutural lira, which is separated from the wider subsutural lira by a narrow but deep groove, and then again roundly convex at the basal corner. The basal corner is provided with the close alternation of the fine and wide spirals. The basal contraction is abrupt. The basal surface is ornamented with a few fine spiral lines. The aperture is rhomboid with bent and short canal, although the details are not observed because of the imperfect preservation. The columellar plaits are two, of which the lower one defines the lower end of the columellar lip and the upper one separates the callus from the basal fasciole.

Comparison.-The present specimens apparently represent a member of $T$. cumingii group with typical features. They especially resemble T. jenkinsi (MARTIN) in the features of the aperture and the ornamentation, but the former is clearly distinguished from the latter in the characteristics of the subsutural band. The upper cord of the twinned band of the present specimens is superimposed by a fine but distinct thread with a fine groove respectively at both sides, while that of $T$. jenkinsi is simple.

Comparing with $T$. cumingii (DESHYES), the present specimens have much coarser and less oblique axials.

Myurella insulindae Fischer (1927, p. 88, Taf. 214, fs. 65a, b, 66a, and b) show quite similar ornamentation to the present specimens. The former, however, has only one weak columellar plaits instead of two on the latter and the subsutural and infrasutural cords are superimposed by several lines on insulindae instead of one on the present specimens.

OYAMA described several kinds of the protoconch and the early development of the ornamentation of the teleoconch in his revision of the taxonomy of Terebridae (1961, 176-189). The protoconch of the present specimens does not show similar feature to Triplostephanus, Myurella, and Cinguloterebra at all in spite of the close resemblance of the adult feature to them. Triplostephanus and Myurella, according to OYAMA, have the polygyrate and high conical protoconch with peripheral carina on the later volutions close to the lower suture and Cinguloterebra has the blunt, paucispiral, and mammilate protoconch. The protoconch of the present specimens show similar profile to that of Triplostephanus and Myurella, but are provided with a weak spiral thread close to the lower suture on the second last volution instead of the carina illustrated by Triplostephanus and Myurella. The spiral thread just mentioned is emarginated posteriorly by a very fine groove. This is not carina at all, but may be taken erroneously as the remnant of the carina when the protoconch suffered the weak abrasion. The other possibility is that the spiral thread of this kind may be modified to a weak carina on the different species. The early development of the ornamentation on the teleoconch of the present specimens is, however, quite identical to that of Myurella and Triplostephanus. Under the circumstance that detailed examination of the protoconch and the early development of the ornament have been done only on the limited number of species, the author prefers to include the present speci- 
mens in the genus Triplostephanus.

Horizon.-Upper part of the Dingle Formation.

Locality.-SKGS-74.

Triplostephanus sp. cf. T. pamotanensis timorensis (KOPERBERG)

PI. 23, Figs. 18, 20, and 21; Text-fig. 43

1915. Terebra pamotanensis, TeSch, (non MartiN), Paläont. v. Timor, Lief. 5, p. 37, Taf. 79 , f. 77.

1931. Terebra (Myurella) torquata timorensis KoPERBERG, $2^{\mathrm{e}}$ Nederland. TimorExpeditie, 1916, Lief. 7, p. 39.

Material.-GKL 6754-6757, 6762, and 6763. All the specimens are broken at the apex and the aperture.

Measurements. - The largest specimen is measured in the height $(39.8+\mathrm{mm})$, diameter $(7.7 \mathrm{~mm})$, and the number of the whorls $(13+)$.

Remarks.-Comparing with the preceding species the present specimens have more regular spiral threads on the concave lateral surface below the subsutural twinned band. The upper cord of the twinned band is slightly stronger than the lower one and superimposed by the several spiral grooves, while the lower one is subdivided into three. The spirals are crossed over by the strong axial riblets, which are slightly curved and almost vertical except for slightly oblique upper part. In these respects the present specimens are similar to T. pamotanensis MARTIN from the Lower Miocene of Rembang, Java, but the former is distinguished from the latter in having definitely smaller number of the axials.

They are almost identical to Terebra (Myurella) torquata timorensis KoPERBERG from the Lower Pliocene of Timor, but the concrete identification is suspended because of the imperfect preservation of the present matrial. KoPERBERG's subspecies is considered to have closer affinity to $T$. pamotanensis than $T$. torquata in the characteristics of the subsutural band.

Geological occurrence.-Lower Pliocene.

Horizon.-Upper part of the Dingle Formation.

Locality.-SKGS-74.

\section{Triplostephanus sp. cf. T. jenkinsi (MARTIN)}

Pl. 23, Figs. 24; Text-fig. 43

1883-87. Terebra jenkinsi Martin, Samml. Geol. Reichs-Mus. Leiden, Ser.1, Bd. 3, p. 75 , Tab. 5 , f. 79.

Material.-GK-L 6759 to 6761 and 6764 to 6765 from one and same locality. All the specimens are more or less broken at the apex and body whorl.

Measurements.-The largest specimen is measured $22.7 \mathrm{~mm}$ in height and $4.6 \mathrm{~mm}$ in maximum diameter. Its pleural angle is 7.8 degrees. 
Remarks.-Terebra jenkinsi MARTIN from the Upper Miocene beds of Java is featured by the prominent and nodulous subsutural band which is followed by a slightly narrower second cord just below. The groove which separates sharply the two cords is deep and narrow. The lateral surface between the infrasutural cord and the lower suture is provided with three (or four) narrow but raised spiral threads. The growth lines are coarse, elevated, slightly antecurrently oblique, curved with the concave face oralward, and granular on the spiral threads. This species shows the close affinity to T. cumingii DESHAYES, but is distinguished from the latter in the subsutural band, on which the upper cord is only slightly wider than the lower one and is not superimposed by the secondary spiral grooves even at the adult stage. Furthermore their spiral threads on the lateral surface are more regularly spaced and less numerous, the labrum profile indicated by the growthlines is less oblique, and the growth lines are much coarser than on T. cumingii.

The present specimens almost perfectly conform with the type specimens of T. jenkinsi, but the upper cord of the subsutural band is only slightly wider than the lower one, although their size is remarkably different on the type specimens.

Geological occurrence.-Upper Miocene (Indonesia).

Horizon.-Upper part of the Dingle Formation.

Locality.-SKGS-74.

Triplostephanus sp. cf. T. cumingii (DESHAYES)

Pl. 23, Fig. 15

1857. Terebra cumingii Deshayes, Jour. d. Conch. Tom. 5, p. 66, pl. 3, f. 1.

1859. Terebra cumingii, DeshaYes, Proc. Zool. Soc. London, p. 311.

1860. Terebra cumingii, ReEve, Conch. Icon. Vol. 12, Terebra, pl. 8, f. 29.

1895. Terebra cumingii, MARTIN, Samml. Geol. Reichs-Mus. Leiden, N. F. Bd. 1, Abt. 1, p. 9, Taf. 1, fs. 4 and 4 a.

1900. Terebra cumingii, Cossmann, Journ. d. Conch. p. 27, pl. 2, fs. 14 and 18.

1927. Terebra (Myurella) cumingii, Fischer, Paläont. v. Timor, Lief. 15, p. 87, Taf. 214, fs. 63 and 64.

Material.-GK-L 6751. A single imperfect specimen which is broken both at the apex and the aperture.

Measurements. $-\mathrm{H}=15.6 \mathrm{~mm}, \mathrm{D}=2.9 \mathrm{~mm}$, and number of whorls $=12+$.

Remarks.-The present specimen is characteristic by the cylindrical spire and the prominent subsutural band with the infrasutural narrower and lower costa immediately below it and most probably included in Triplostephanus, although its apical part cannot be examined. The spiral groove which separates the subsutural fold and the infrasutural costa is deep and sharp. The lateral surface is remarkably concave and provided with unequal four spiral threads, of which the lowest one is much stronger and more heavily granular than the others. The axials are close (24 on the second last whorl), slightly antecurrently oblique, slightly curved with the concave face oralward, and cross over the spirals rendering granular aspect especially on the infrasutural and suprasutural spirals. The 
columella has a distinct plait.

On the basis of these features the present specimen is almost perfectly identical to Triplostephanus cumingii (DESHAYES).

It also resembles $T$. pamotanensis (MARTIN) (1906, p. 284, Taf. 42, fs. 81 and 81a) from the lower Miocene of Java, but the former has more massive subsutural fold and more distinctly granulated suprasutural lira than the former.

Geological occurrence.-Pliocene (South India and Indonesia).

Recent distribution.-South China Sea.

Horizon.-Upper part of the Dingle Formation.

Locality.-SKGS-74.

Genus Cinguloterebra OYAMA, 1961

(type-species: Terebra hedleyana PILSBRY by original designation)

Cinguloterebra? sp.

Pl. 23, Fig. 5

Material.-GK-L 6454. A single imperfect specimen.

Measurements.-

$\begin{array}{cccccccc}\text { specimen } & \underset{\mathrm{H}}{\mathrm{H}-\mathrm{L}} & \begin{array}{c}\mathrm{Bd} \\ (\mathrm{mm})\end{array} & \begin{array}{c}\mathrm{D} \\ (\mathrm{mm})\end{array} & \begin{array}{c}\angle \mathrm{m} \\ (\mathrm{mm})\end{array} & \begin{array}{c}\text { whorls } \\ \text { (degrees) }\end{array} & \begin{array}{c}\text { suture- } \\ \text { numb. }\end{array} & \begin{array}{c}\text { angle } \\ \mathrm{D} / \mathrm{H} \text { on } \text { on pen }\end{array} \\ 6454 & 17.1+ & 4.2 & 3.5 & 7.5 & 9+ & 12.2 & 3.3 / 2.1=1.57\end{array}$

Description.-The shell is small and cylindrical with very slowly growing whorls. The whorls are moderately convex at the upper half and slightly concave at the lower half. The subsutural band is wide occupying about one-third of the whorl-height. It is obliquely crenulated by the axial ribs, which are broadly curved with the antecurrently oblique upper arm and almost vertical lower arm. They are prominent on the subsutural band and gradually weakened below. There is a distinctly raised and remarkably crenulated lira close to the subsutural band, from which the lira is separated by a narrow and deeply incised infrasutural groove. This crenulated lira is about one half as wide as the subsutural band. The concave lateral surface is covered by five spiral threads, which are regularly spaced, separated from one another by very narrow and shallow grooves, and cross over the axial ribs. The lowest thread close to the lower suture is somewhat stronger and wider than the others.

The body whorl is short and narrowly rounded at the basal corner to form the marked contraction below. The basal surface is abraded. The aperture is broken. The columellar plait is a single but very sharp.

Comparison.-The cylindrical spire and the bi-costate nodular subsutural part indicate that the present specimen possibly belongs to Triplostephanus or Cinguloterebra. Its sculpture on the later whorls is closely similar to that of Terebra hedleyana PILSBRY (1904, p. 3, pl. 1, fs. 1 and 1a) and T. succinea HINDS (1843, p. 149, and REEVE, 1860, pl.5, f. 17), which together are included in Cinguloterebra by OYAMA. The present specimen has higher whorls and smaller pleural angle than $T$. hedleyana. It is also distinguished from $T$. succinea in 
being much smaller in size and larger in the pleural angle.

Horizon.-Santa Barbara Silt.

Locality_SKGS-71.

Genus Myurella HiNDs, 1844

(type-species: Terebra myuros LAMARCK by subsequent designation, DALL, 1908)

Subgenus Clathroterebra OYama, 1961

(type-species: Terebra fortunei DESHAYES by original designation)

Myurella (Clathroterebra) woodwardiana (MARTIN)

P1. 23, Figs. 8, 9, 11, 12, 14, 16, 17, and 23; Text-figs. 41 and 43

1883-87. Terebra woodwardiana Martin, Samml. Geol. Reichs-Mus. Leiden, Ser. 1, Bd. 3, p. 73, Tab. 5, f. 76 .

1915. Terebra woodwardiana, Tesch, Paläont. v. Timor, Lief. 5, p. 38, Taf. 79, fs. $79 \mathrm{a}$ and $\mathrm{b}$.

1927. Terebra (Myurella) woodwardiana, Fischer, ibid. Lief. 15, p. 90, Taf. 214, f. 68.

1938. Terebra (Myurella) bomasensis, OOSTINGH (partim), De Ingenieur in Ned.-Indië, 1938, No. 4, p. 54, Taf. 4, f. 83.

Material.-GK-L 6750,6766 to 6776 , and 6779 to 6780 from loc. SKGS-74 and GK-L 6455 from SKGS-71.

\begin{tabular}{|c|c|c|c|c|c|c|c|c|}
\hline \multicolumn{2}{|c|}{ Measurements.- } & \multirow{2}{*}{\multicolumn{2}{|c|}{$\underset{(\mathrm{mm})}{\mathrm{Bd}}$}} & \multirow[b]{2}{*}{$\underset{(\mathrm{mm})}{\mathrm{Ap}}$} & \multirow[b]{2}{*}{$\underset{(\mathrm{mm})}{\mathbf{D}}$} & \multirow[b]{2}{*}{$\underset{(\%)}{\mathrm{Bd} / \mathrm{H}}$} & \multirow[b]{2}{*}{$\underset{(\%)}{\mathrm{Ap} / \mathrm{H}}$} & \multirow[b]{2}{*}{$\begin{array}{c}\mathrm{D} / \mathrm{H} \\
(\%)\end{array}$} \\
\hline $\begin{array}{l}\text { specimen } \\
\text { GK-L }\end{array}$ & $\underset{(\mathrm{mm})}{\mathrm{H}}$ & & & & & & & \\
\hline 6767 & 19.20 & 6.20 & & 4.30 & $4.5+$ & 32.3 & 22.4 & $23.4 t$ \\
\hline 6774 & 11.75 & 4.10 & & 2.70 & 2.65 & 34.9 & 22.9 & 22.5 \\
\hline 6779 & $21.9+$ & 6.70 & & - & 4.35 & 30.6 & - & 19.8 \\
\hline 6780 & $17.35+$ & 4.70 & & 3.00 & 3.30 & 27.2 & 17.3 & 19.0 \\
\hline$? 6455$ & ca 16.8 & 5.60 & & 3.75 & 3.45 & 33.3 & 22.3 & 20.5 \\
\hline $\begin{array}{l}\text { specimem } \\
\text { GK-L }\end{array}$ & $\underset{\text { (degrees) }}{\angle \mathbf{P}}$ & $\mathrm{H}^{\text {pro }}$ & $\begin{array}{l}\text { tocor } \\
\text { D }\end{array}$ & $\begin{array}{l}\text { nch } \\
\text { numb. }\end{array}$ & $\begin{array}{l}\text { teleo- } \\
\text { conch }\end{array}$ & $\begin{array}{l}\text { suture- } \\
\text { angle }\end{array}$ & $\begin{array}{l}\text { whorl-1 } \\
\mathrm{D} / \mathrm{H} \text { ol }\end{array}$ & \\
\hline 6767 & 10.3 & 1.05 & 0.62 & 4.3 & 12.4 & 12.8 & $2.05 / 2.1$ & \\
\hline 6774 & 10.5 & 1.08 & 0.64 & 4.4 & 10.0 & 13.9 & $2.35 / 1.3$ & .73 \\
\hline 6779 & 7.1 & - & - & - & $13+$ & 13.7 & $3.85 / 2.4$ & .57 \\
\hline 6780 & 6.9 & - & - & - & $15+$ & 13.4 & $3.0 / 2.0=$ & \\
\hline$? 6455$ & 5.5 & - & - & - & $10.5+$ & 14.3 & $2.85 / 2.0$ & .39 \\
\hline
\end{tabular}

Remarks.-The present specimens are featured by their protoconchs and subsutural bands. The protoconch is high, slightly conoidal, and polygyrate with more than four volutions, the second last of which has a weak suprasutural spiral thread like as Triplostephanus santosi. The subsutural band on the present material is not so prominent as on Triplostephanus and is not followed by the second fold. On the basis of these characteristics the present material is reasonably included in Myurella HiNDs, 1844. Further the profile of the adult whorls of the present specimens indicates their closer relation to Clathroterebra OYAMA, 1961, than to Myurella (s.s.).

The present specimens are identical to "Terebra woodwardiana" MARTIN 
with similar profile of the shell, ornamentation, and aperture. On the type specimen of $T$. woodwardiana the infrasutural spiral sulcus cuts the axials to furnish a very distinct subsutural fold above. Ontogenetically speaking this infrasutural sulcus starts as a obsolete depression at the interspaces between the axial ribs and the weak constriction of the rib themselves. Then this depression is gradually developed to the sulcus, which does not cross over the axials at early and do on the juvenile whorl. Almost perfectly similar development of the infrasutural sulcus is observed on the majority of the present material from Panay, while on some of the specimens the sulcus cuts across the axials only on the body whorl.

GK-L 6455 is somewhat abraded but the basic pattern of the sculpture is still observable. This specimen conforms to the specimens from SKGS-74 very well except for slightly broader spirals and less elevated subsutural band. Last mentioned feature, however, should depend on abrasion. GK-L 6455 is considered to be included in $M$. woodwardiana.

The present specimens are also similar to Terebra bomasensis MARTIN (1916, p. 226, Taf. 1, fs. 6, and 6a) from the Upper Miocene of Java. The former is, however, clearly distinguished from the latter in many points. Firstly the whorls of the former are more convex at sides and more contracted toward the lower suture, secondly the subsutural band of the present material is somewhat stronger than that of bomasensis, and thirdly the callus, especially the columellar callus, is by far thicker with free edge on the present specimens than on bomasensis.

MARTIN compared the type-specimen of $T$. woodwardiana with $T$. bawangana BöTTGER (1883, p. 233, Taf. 11, f. 5) from the Oligocene of Java, but T. woodwardiana is readily distinguished from $T$. bawangana in having longer and less convex body whorl.

Geological occurrence.-Miocene to Pliocene (Indonesia).

Horizons.-Upper part of the Dingle Formation and the Santa Barbara Silt. Localities.-SKGS-71 and 74 .

Genus Diplomeriza DALL, 1919*

(type-species: Buccinum duplicatum LINNÉ by monotype)

Diplomeriza duplicata (LINNÉ)

Pl. 23, Fig. 4

1758. Buccinum duplicatum LINNÉ, Systema Naturae ed. 10, p. 742.

1844. Terebra duplicata, Lamarck, Hist. d. Anim. s. Vert. (Deshayes's ed.) Tom. 10, p. 243.

1838. Terebra lamarcki Kiener, Coq. Viv. Pt. 2, p. 30, pl. 9, f. 19.

1860. Terebra duplicata, ReEve, Conch. Icon. Vol. 12, Terebra, pl. 1, fs. $3 a$ and b. 1888. Terebra duplicata, Tryon, Man. Conch. Ist. Ser. Vol. 7, p. 17, pl. 4, fs. 49-51. 1900. Terebra duplicata, Newton, Geol. Mag. Decade 4, Vol. 7, p. 517, pl. 20, f.6. 1928. Terebra sp. 10, MARTIN, Wet. Meded. No.10, p. 12, f. 22.

1938. Diplomeriza duplicata, Oostingh, Ingenieur in Ned.-Indië, 1938, No.4, p. 49 , pl. 4, f. 72.

* Synonym: Duplicaria Dall, 1908, non RAfinesque, 1833, and Myurellisca BaRtsch, 1923 . 
1944. Diplomeriza duplicata, Wenz, Handb. Paläozool. Bd. 6, Gastropoda, p. 1479, f. 4170 .

1961. Noditerebra (Diplomeriza) duplicata, OYAMA, Molluscan Shells, Noditerebra, pl. 2, fs. 1 and 9.

1966. Diplomeriza duplicata, HABE and KoSUge, Shells of the world in colour, Vol. 2, p. 100, pl. 39, f. 16.

1967. Duplicaria duplicata, CERnohorsky, Marine shells of the Pacific, p. 208, pl. 53, f. 395.

Material.-GK-L 6778. A single imperfect but characteristic specimen.

\section{Measurements.-}

$\begin{array}{ccccccccc}\underset{\text { Specimen }}{\text { GK-L }} & \underset{(\mathrm{mm})}{\mathrm{H}} & \underset{(\mathrm{mm})}{\mathrm{Bd}} & \underset{(\mathrm{mm})}{\mathrm{Ap}} & \underset{(\mathrm{mm})}{\mathrm{D}} & \begin{array}{c}\angle \mathrm{P} \\ (\text { degrees })\end{array} & \begin{array}{c}\text { whorls } \\ \text { numb. }\end{array} & \begin{array}{c}\text { suture- } \\ \text { angle }\end{array} & \begin{array}{c}\text { whorl-profile } \\ \mathrm{D} / \mathrm{H} \text { on pen }\end{array} \\ 6778 & 33.3+ & 11.2 & 6.45 & 5.90 & \text { ca } 6.1 & 9+ & 16.4 & 5.45 / 4.5=1.21\end{array}$

Remarks.-The specimen in hand is quite identical to Diplomeriza duplicata (LINNÉ) with diagnostic features. The whorls are deeply grooved at the upper two-fifths of the whorl-height. The surface above and below the groove is very slightly convex. The close axial ribs are roof-shaped, slightly antecurrently oblique on the subsutural band, and almost vertical on the main surface. They are counted 17 on the preserved first whorl, and increased in number gradually to 20 and 25 respectively on the penultimate (preserved eighth) and the body whorl. The axials abruptly disappear close to the basal fasciole which is emarginated by a sharply elevated thin spiral ridge. The columellar lip is provided with two folds.

The present specimen is readily distinguished from $D$. dussumieri (KIENER) in having more sharply defined axials on the subsutural part.

D. herklotsi (MARTIN) (1879-80, p. 34, Tab.6, f. 15) has strong axials on the subsutural part, which is, however, narrower (less than one-third of the whorl-height) than that of the present species and separated from the main part by zigzag groove. Furthermore the axials on the subsutural part are straight and vertical.

Geological occurrence.-Pliocene (Indonesia) and Pleistocene (Saudi Arabia). Recent distribution.-Indo-Pacific from Sanzibar to South China Sea.

Horizon.-Upper part of the Dingle Formation.

Locality.-SKGS-74.

Genus Punctoterebra BARTsCH, 1923

(type-species: Terebra nitida HINDs by original designation)

Punctoterebra cabatuanensis sp. nov. Pl. 23, Figs. 6 and 7; Text-fig. 43

Material.-Holotype: GK-L 6456. A single almost perfect specimen which is slightly broken at the protoconch.

Measurements.-

$\begin{array}{ccccccccc}\underset{\text { specimen }}{\text { GK-L }} & \underset{(\mathrm{mm})}{\mathrm{H}} & \underset{(\mathrm{mm})}{\mathrm{Bd}} & \underset{(\mathrm{mm})}{\mathrm{Ap}} & \underset{(\mathrm{mm})}{\mathrm{D}} & \begin{array}{c}\mathrm{Bd} / \mathrm{H} \\ (\%)\end{array} & \underset{(\%)}{\mathrm{Ap} / \mathrm{H}} & \underset{(\%)}{\mathrm{D} / \mathrm{H}} & \begin{array}{c}\angle \mathrm{P} \\ 6456\end{array} \\ 17.5+ & 6.30 & 4.30 & 4.30 & 36.0- & 24.6- & 24.6- & 6.4\end{array}$




\begin{tabular}{cccccccccc} 
specimen & \multicolumn{2}{c}{ whorls } & whorl-profile & \multicolumn{4}{c}{ axials } & III \\
GK-L & proto & teleo & D/H on pen & I & II & III $\sim$ VI & VII & VIII IX XI \\
6456 & $1+$ & 11.5 & $3.5 / 2.4=1.46$ & $?$ & 14 & 13 & 12 & 13 & 12
\end{tabular}

Diagnosis.-The shell is small, turreted, and glossy. The protoconch is unknown except for the smooth last volution, which is very low comparing with the width. The teleoconch consists of eleven and a half whorls, which are provided with roof-shaped axial ribs. The spire-whorls are quadrate in profile, about one and a half times wider than high, slightly convex at the sides with the maximum convexity at lower one-third of the whorl-height. The ribs are fourteen at first, gradually decreased in number to twelve on the penultimate whorl. They are almost vertical and slightly curved with the concave side forwardly. The interspaces between the ribs are smooth at first and V-shaped with a axial grooves at the bottom later. A weak spiral groove is intercalated at the interspaces of the ribs on the fifth whorl and thereafter it becomes distinct to form a punctation. On the middle and the later whorls a few obsolete spiral striae are discernible at the upper half of each whorl. The suture is distinctly impressed. The body whorl is large occupying more than one-third of the shell-height, one and a half times heigher than the width, and remarkably contracted at the base to the short and markedly bent snout. The growthlines are coarse at the basal surface, while they are very fine on the spire-whorls.

The aperture is moderately narrow, somewhat elongated, pointed posteriorly, and broadly notched at the anterior end. The basal fasciole is distinct and emarginated by two spiral lirae, of which the lower one is the extension of the marginal plait of the columellar lip. Another broad spiral ridge is developed at the lower two-fifths of the fasciole, on which the sigmoidal fasciole lines bend. The outer lip is simple and rather thin.

Comparison.-The present specimen is reasonably included in Punctoterebra BARTSCH, 1923, on the basis of the roof-shaped axial ribs, an infrasutural row of the punctation at and near the bottom of the axial valleys, and lack of the spiral grooves and threads on entire surface. The present specimen is closely allied to Punctoterebra nitida (HINDs) (1843, p. 152) from the tropical seas of East Asia. The former is, however, readily distinguished from the latter in having a half time smaller shell, slightly curved axials, and much more bent snout.

Terebra (Strioterebrum) coxi OostingH (1938, p. 55, Taf. 4, f. 88, Taf. 5, fs. 89a and b) is considered to be included in Punctoterebra because of its general morphological features. The present specimen is easily distinguished from $P$. coxi in having slenderer shell, curved and more numerous axials, and remarkably bent snout.

$P$. lauta (PEASE) is another ally to the present species, but the latter is readily distinguished from the former in having slightly but distinctly curved axial ribs instead of straight ones of the former.

Horizon.-Santa Barbara Silt.

Locality.-SKGS-71. 


\section{Subclass Opisthobranchia \\ Order Cephalaspidea \\ Superfamily Bulloidea \\ Family Ringiculidae}

Genus Ringicula DeshaYes, 1838

(type-species: Auricula ringens LAMARCK by subsequent designation, GRAY, 1847)

Subgenus Ringiculina Monterosato, 1884

(type-species: Ringicula leptocheila BRUGNONE by original designation)

\section{Ringicula (Ringiculina) arctata glabra MARTIN}

Pl. 24, Figs. 7-9, 12, and 13

1883-87. Ringicula glabra Martin, Samml. Geol. Reichs-Mus. Leiden, Ser. 1, Bd. 3, p. 44, Tab. 4, f. 44 .

Material.-GK-L 6365 to 6367 and 7412 from loc. SKGS-73 and GK-L 6457 to 6464 from loc. SKGS-71.

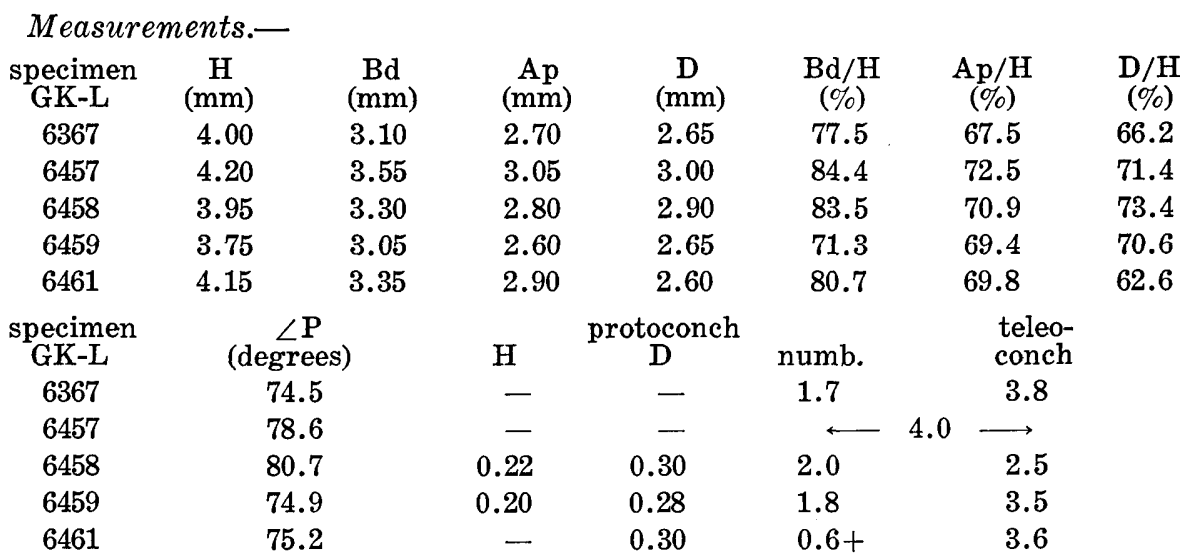

Remarks.-The specimens in hand are quite identical to the type-specimen of Ringicula glabra MARTIN from the Pliocene of Java. The first teleoconch-whorl has eleven to twelve spiral threads, which are equally spaced, equidimensional, and separated by narrower interstices. The spirals, however, rapidly become weak and further obsolete especially at the upper part of the whorls. In consequence they are only represented by a few striae covering the lower half on the penultimate whorl and about seven to nine ones on the body whorl. The aperture shows very unique feature; the outer lip is thickened inside, especially at the middle, to form a blunt and prominent swelling and the parietal callus is extremely thick with a sharp tooth at the middle of the parietal lip. Consequently the aperture is narrowed at the middle and separated into two ovoid parts. The posterior canal is very distinct being defined by the elongate and sharp ridge which is the upward extension of the parietal tooth.

On the basis of the diagnostic features mentioned above the present specimens are apparently closely allied to Ringiculina MONTEROSATO, 1884, but the former is 
slightly different from the latter in having a sharp swell like a blunt denticle at the middle of the labrum. It comprises a particular group of the species together with Ringicula arctata GouLD (1860, p. 325; JoHNSON, 1964, p. 42, pl. 15, f. 9), R. assulara WATSON (1886, p. 635, p. 47, f. 10) and R. propinquans HINDS (1844, p. 96 and SchePMAN, 1913, p. 475, p. 32, f. 10). They may represent a subgenus, but the author places tentatively this group of species under Ringiculina in the present report.

The specimens in hand show remarkable variability of some characters such as profile and strength of the spirals. GK-L 6461 represents the slender form, while 6458 the bulbous form with outwardly expanded labrum. The majority of the specimens is intermediate as to the mentioned character between the two end forms and conforms to the profile of $R$. glabra. The bulbous sepcimen is close to $R$. propinquans. Almost all the specimens lose the spiral grooves at the middle and upper part of the body whorl, while GK-L 6458 clearly shows the spirals on the entire surface even of the last part of the body whorl. In conclusion they are reasonably identified to $R$. glabra as a whole in spite of the variability.

$R$. glabra should be treated as a subspecies of $R$. arctata Gould, because the difference between the two is concerned only with the strength of the spiral grooves on the body whorl.

Geological occurrence.-Miocene (Indonesia).

Horizons.-Santa Barbara Silt and the upper part of the Ulian Formation.

Localities.-SKGS-71 and 73.

\author{
Family Acteonidae \\ Genus Pupa RöDING, 1798* \\ (type-species: Pupa grisebia RöDING=Bula solidula LINNÉ by \\ subsequent designation, SUTER, 1913) \\ Pupa sp. cf. P. reussi (MARTIN) \\ P1 24, Figs. 5, 6, and 16
}

1879-80. Actaeon reussi Martin, Tertiärschicht. a. Java, p. 79, Tab. 12, f. 13.

Material.-GK-L 7065 and 7066. Preservation is not necessarily perfect especially at the apical part.

\begin{tabular}{|c|c|c|c|c|c|c|c|c|c|}
\hline \multicolumn{10}{|c|}{ Measurements.- } \\
\hline $\begin{array}{l}\text { specimen } \\
\text { GK-L }\end{array}$ & $\underset{(\mathrm{mm})}{\mathrm{H}}$ & $\underset{(\mathrm{mm})}{\mathrm{Bd}}$ & $\underset{(\mathrm{mm})}{\mathrm{Ap}}$ & $\underset{(\mathrm{mm})}{\mathrm{D}}$ & $\underset{(\%)}{\mathrm{Bd} / \mathrm{H}}$ & $\underset{(\%)}{\mathrm{Ap} / \mathrm{H}}$ & $\underset{(\%)}{\mathrm{D} / \mathrm{H}}$ & $\underset{\text { (degrees) }}{\angle \mathrm{P}}$ & $\begin{array}{l}\text { teleo- } \\
\text { conch }\end{array}$ \\
\hline 7065 & 4.91 & 3.85 & 2.75 & 2.40 & 77.7 & 55.5 & 48.5 & 40.9 & $4.1+$ \\
\hline 7066 & 4.10 & 3.10 & 2.40 & 2.10 & 75.4 & 58.4 & 51.1 & 39.2 & 5.5 \\
\hline
\end{tabular}

Remarks.-The ornamentation of the present specimens consists of rather irregularly spaced spiral threads and much narrower spiral grooves. The threads are flat-topped and the grooves are crossed by the close and raised growth lines. Majority of the primary spiral threads is splitted into two parts by the super-

* Synonym: Solidula Fischer von Waldheim, 1807; Dactylus Schumacher, 1817; Buccinulus H. and A. AdAms, 1854; and Solidulus FÉrusSAC, 1829. 
imposed median groove which starts on the early whorls, but a few primaries are not splitted and persist their original breadth even on the body whorl. A few grooves near the upper suture are remarkably wider than the others. The suture is deeply incised. The aperture is roundly wedge-shaped, narrowed, finally pointed posteriorly, and expanded sideward at the anterior end. The inner lip is covered with the distinct callus and provided with a prominent and oblique terminal twinned-plait. Another weak and horizontal plait is situated at the lower part of the parietal lip at some distance from the entrance of the aperture. The area between two plaits is remarkably excavated.

Pupa RöDING, 1798, and Acteon MonTfORT, 1810, closely resemble each other in the general profile of the shell, details of the protoconch, canaliculate suture, spiral sculpture, and the outline of the aperture. The difference in the inner lip is taken for the criterion for generic separation of the two. Voluta tornatila LINNÉ, the type species of Acteon, has only one columellar fold at the anterior end of the columella and is devoid of the parietal plait, while Pupa grisebia RöDING=Bula solidula LINNÉ, the type species of $P$ upa, has twin-plaited columella and occasionally an additional parietal plait at some distance from the entrance of the aperture.

On the present specimens from Panay the columellar plait is weakly bi-partile and a moderate plait is situated at the lower part of the parietal lip as noted above. On the basis of the mentioned feature the present specimens are reasonably included in Pupa. The position of the parietal plait is rather variable; it is far apart from the entrance of the aperture and hardly visible from outside on the specimen GK-L 7065, while it is near the entrance to allow easy observation.

Size and ornamentation of the present specimens quite conform with those of Actaeon reussi MARTIN from the Miocene of Java. The columella of the type specimen of reussi is slightly worn and does not clearly illustrate the bifurcation of the plait. Furthermore its aperture is filled with the consolidated sediment, which makes unable the examination of the parietal plait. This is the reason why the author suspends the concrete identification.

The present specimens are also similar to the Miocene species, Actaeon javanus MARTIN (1883-87, p. 44, Tab. 4, f. 43) in the general facies of the shell. The former is, however, readily distinguished from the latter in much larger size, more swollen outline of the shell, more numerous spirals, and a few wider spiral grooves near the upper suture.

Geological occurrence.-Miocene (Indonesia).

Horizon.-Upper part of the Ulian Formation.

Locality.-SKGS-72.

Family Scaphandridae

Genus Cylichna LovÉN, 1846

(type-species: Bulla cylindracea PENNANT by subsequent designation, HERRMANNSEN, 1852)

Subgenus Eocylichna KURODA and HABE, 1952

(type-species: Cylichna braunsi YoKoYAMA by original designation) 
Cylichna LovÉN, 1846, Eocylichna KURODA and HABE, 1952, and Adamnestia IREDALE, 1936, closely resemble one another in the general feature. ZILCH (1959, p. 23) treated the latter two taxa as the synonyms of Cylichna, while HABE (1961, p. 91) described them as independent genera. The morphological difference of three taxa is seen at the apical feature. The adapical umbilicus of Adamnestia is deep bordered by the rounded rim, while similarly deep umbilicus of Eocylichna is provided with the sharply angulated rim. Cylichna is characterized by the adapical umbilicus covered with the callus. They are practically separable one another as noted above, but the author is inclined to treat them respectively a subgenus of a single genus, Cylichna, considering the degree of difference among them.

\section{Cylichna (Eocylichna) sibogae SCHEPMAN}

Pl. 24, Fig. 15

1913. Cylichna sibogae SchePMAN, Siboga Expeditie, Lief. 49, pt. 6, p. 472, pl. 32, f. 7 .

1920. Cylichna braunsi Yokoyama, Jour. Coll. Sci. Imp. Univ. Tokyo, Vol. 39, Art. 6, p. 28, pl.1, f. 5.

1927. Cylichna serana Fischer, Paläont. v. Timor, Lief. 15, p. 108, Taf. 215, fs. $94 \mathrm{a}$ and $\mathrm{b}$.

1954. Eocylichna braunsi, Taki and OYama, Palaeont. Soc. Japan, Spec. Pap. No. 2, p. 29, pl. 2, f. 5 .

1961. Eocylichna braunsi, HABE, Colored Illustr. Shells Japan, Vol. 2, p. 91, pl. 43, f. 17 .

Material.-GK-L 6469.

Measurements. $-\mathrm{H}=6.8 \mathrm{~mm}, \max . \mathrm{D}=2.4 \mathrm{~mm}, \mathrm{D} / \mathrm{H}=35.3$ percent .

Remarks.-The present specimen is featured by the cylindrical involute shell with umbilicate posterior end and weakly defined and slightly twisted columellar fold. The adapical umbilicus is emarginated with a sharp ridge and partly covered with distinct callus. The entire surface is covered with about $60 \mathrm{~min}$ utely wavy striations, of which those on the posterior and anterior parts are distinct and the others are obsolete. The figure 15 in plate 24 does not accurately illustrate the original profile of the shell but assumes the narrower outline, because the specimen was imperfectly restored after fracturing.

The present specimen is quite identical to Cylichna sibogae SchepmaN, which is included in the subgenus Eocylichna with the characteristic features. It also resembles both the living Eocylichna braunsi (YoKoYAMA), which was originally described on the basis of the material from the younger Pliocene of Central Japan, and E. serana (FISCHER) from the Pliocene of Timor. The comparison of the original descriptions does not lead to the conclusion to separate them as different species. Hence they are treated conspecific.

Geological occurrence.-Pliocene (Indonesia) and Pleistocene (Japan).

Recent distribution.- - Southeast Asia from South Japan to Indonesia.

Horizon.-Santa Barbara Silt.

Locality.-SKGS-71. 
Genus Atys MONTFORT, 1810

(type-species: Atys cymbulus MONTFORT=Bulla nauca LINNÉ by original designation)

Subgenus Aliculastrum PILSBRY, 1896*

(type-species: Bulla cylindrica HeLBLING by original designation)

Atys (Aliculastrum) porcellanus Gould

Pl. 24, Figs. 1 and 2

1859. Atys porcellana Gould, Proc. Boston Soc. Nat. Hist. Vol. 7, p. 138.

1964. Atys porcellana, Johnson, U. S. Nat. Mus. Smithson. Inst. Bull. 239, p. 130, pl. 12, f. 13.

Material.-GK-L 6743. A single almost perfect specimen.

Measurements. $-\mathrm{H}=8.05 \mathrm{~mm}, \mathrm{D}=3.7 \mathrm{~mm}, \mathrm{D} / \mathrm{H}=45.9$ percent.

Remarks.-The shell is solid and involute with the small but distinct adapical umbilicus, which is separated from the lateral surface by a narrowly rounded ridge. The aperture is simple at the outer part, vertically expanded posteriorly like a small wing, and expanded with broadly rounded margin at the anterior end. The columellar fold is distinct and situated at the lower termination of the columellar callus with a distinct concavity behind it. The ornamentation consists of the minute, close, and somewhat wavy striae, which are moderately distinct at the upper part and coarse and distinct at the lower part. The growth lines are also generally minute, but they are distinct at the last part of the body whorl.

On the basis of the diagnostic features mentioned above it is identical to Atys porcellanus GouLD, living in the southern Japanese waters.

It is also similar to Cylichna crispula WATSON (1886, p. 666, pl. 49, f. 12) from North Australia, but the former is distinguished from the latter in having much more distinct adapical umbilicus and posterior auricle of the labrum than the latter.

It is similar to Diniatys jecoralis SMITH (1903, p. 320, pl. 23, f. 18) from the Gulf of Oman, but the former is readily distinguished from the latter in being devoid of the tooth-like projection at the columellar lip.

Recent distribution.-South Japan.

Horizon.-Upper part of the Dingle Formation.

Locality._SKGS-74.

\author{
Family Bullidae \\ Genus Bulla LINNÉ, $1758^{* *}$
}

(type-species: Bulla ampulla LINNÉ by Opinion 196)

Subgenus Bulla (s.s.)

\footnotetext{
* Synonym: Alicula Ehrenberg, 1831, non Eichwald, 1830.

** Synonym: Bullus Montfort, 1810; Bullites Schlotheim, 1813, non Gmelin, 1793;

Bullaria auct. non Rafinesque, 1815; and Quibula IREDALe, 1929.
} 


\title{
Bulla (Bulla) ampulla LINNÉ
}

Pl. 24, Figs. 3 and 4

1758. Bulla ampulla Linné, Systema Naturae, ed. 10, p. 727, No. 334 (pars).

1855. Bulla (Bulla) ampulla, A. Adams, Thesaurus Conch. Vol. 2, p. 575, pl.122, fs. 59-62.

1868. Bulla ampulla, ReEve, Conch. Icon. Vol. 16, Bulla, pl.1, f. 3.

1893. Bulla ampulla, Pilsbry, Man. Conch. Vol. 15, p. 343, pl. 34, fs. 1-3.

1895. Bulla ampulla, Kobelt, Conch. Cab. ed.2, Vol.1, Bullacea, p. 72, pl. 1, fs. 5-7.

1895. Bulla ampulla, Martin, Samml. Geol. Reichs-Mus. Leiden, N. F. Bd. 1, Abt. 1, p. 8, Taf. 1, fs. 2 and 3.

1931. Bullaria ampulla, ThIele, Handb. system. Weichtierkunde, Bd. 1, p. 384, f. 483 .

1959. Bulla (Bulla) ampulla, ZıLch, Handb. Paläozool. Bd. 6, Gastropoda Teil. 2, p. 38 , f. 120.

1961. Bulla ampulla, HABE, Colored Illustr. Shells Japan, Vol. 2, p. 88, pl. 42, f. 17.

1966. Bulla ampulla, HABE and Kosuge, Shells of the world in colour, Vol.2, p. 116, pl. 43 , f. 19 .

Material.-GK-L 6369. Broken at the anterior part but characteristic enough to serve for identification.

Measurements. $-\mathrm{H}=\mathrm{ca} 33 \mathrm{~mm}, \max \mathrm{D}=24 \mathrm{~mm}, \mathrm{D} / \mathrm{H}=\mathrm{ca} 73$ percent.

Remarks.-Bulla ampulla LINNÉ is very simple in the morphology. It is separated from the related species by the criteria that the size, general outline, and the degree of the upward reflection of the posterior part of the labrum are distinctive among the allied species. The present specimen is quite identical to the living ones in the characteristic features mentioned above.

Geological occurrence.-Pliocene (Indonesia).

Horizon.-Upper part of the Ulian Formation.

Locality.-SKGS-73.

\author{
Order Entomotaeniata \\ Superfamily Pyramidelloidea \\ Family Pyramidellidae \\ Genus Syrnola A. ADAMs, 1860
}

(type-species: Syrnola gracillima A. AdAMs by monotype)

Subgenus Puposyrnola Cossmann, 1921

(type-species: Auricula acicula LAMARCK by original designation)

Syrnola (Puposyrnola) brunnea (A. ADAMs)

Pl. 21, Fig. 14

1855. Obeliscus brunneus A. AdAMs, in Sowerby's Thes. Conch. Vol. 2, p. 810, pl. 171, f. 35.

1865. Pyramidella brunnea, ReEve, Conch. Icon. Vol. 15, Pyramidella, pl. 1, f. 2.

1865. Pyramidella fulva, ReEve, ibid. pl. 6, f. 42.

1886. Pyramidella (Syrnola) brunnea, TrYoN, Man. Conch. Ist Ser. Vol. 8, p. 306, pl. 93, fs. 8 and 9. 
1906. Pyramidella (Syrnola) brunnea, DALL and BARTsch, Proc. U. S. Nat. Mus. Vol. 30 , No. 452 , p. 332 , pl. 24 , fs. 4 and 7.

1920. Pyramidella aff. bataviana, Tesch (non Martin), Paläont. v. Timor, Lief. 8, p. 64, Taf. 132, fs. 197a and b.

1937. Syrnola (Syrnola) brunnea, Nomura, Saito Ho-on Kai Mus. Res. Bull. No. 13 , p. 48 , pl. 11 , fs. 59 and b.

Material.-GK-L 6368. Broken at the apical part.

\section{Measurements.-}

$\begin{array}{cccccccc}\underset{\text { specimen }}{\text { GK-L }} & \begin{array}{c}\mathrm{H} \\ (\mathrm{mm})\end{array} & \begin{array}{c}\mathrm{Bd} \\ (\mathrm{mm})\end{array} & \begin{array}{c}\mathrm{Ap} \\ (\mathrm{mm})\end{array} & \begin{array}{c}\mathrm{D} \\ (\mathrm{mm})\end{array} & \begin{array}{c}\angle \mathrm{P} \\ (\text { degrees) }\end{array} & \begin{array}{c}\text { suture- } \\ \text { angle }\end{array} & \begin{array}{c}\text { whorl-profile } \\ \mathrm{D} / \mathrm{H} \text { on pen }\end{array} \\ 6368 & 9.2+ & 3.55 & 2.15 & 3.10 & 12.0 & 8.6 & 2.7 / 1.35=2.00\end{array}$

Remarks.-The present specimen, although broken at the apical part, is characteristic enough for the concrete identification. It is featured by the flat side of the whorl, very impressed suture, a single strong columellar tooth near the upper end of the columellar lip, three distinct thread-like teeth inside the body whorl at remarkable distance from the margin of the labrum, and microscopic spiral lines on the whorls. It is identical to Syrnola (Puposyrnola) brunnea (A. ADAMS) living in the east Asian waters from south Japan to South China Sea.

The fossil specimen, reported by TESCH from the Pliocene of Timor as Pyramidella aff. bataviana, is readily distinguished from $P$. bataviana MARTIN which has the definite basal angulation. The former is better to be identified to the present species.

Geological occurrence.-Pliocene (North Indonesia).

Recent distribution.-Tropical southeast Asian waters.

Horzon.-Upper part of the Ulian formation.

Locality.-SKGS-73.

\section{References Cited}

Аввотт, Tucker (1960): The genus Strombus in the Indo-Pacific. Indo-Pacific Mollusca, 1, (2), 33-146, pls. 11-117.

Abrard, René (1942): Mollusques pléistocènes de la Côte française des Somalis recueillis par E. Aubert de la Rüe. Arch. Mus. Nat. d'Hist. Nat. Paris, 6, (18), 5-105.

ADAMs, Arthur (1852): Catalogue of the species of Nassa, a genus of gastropodous mollusca, belonging to the family Buccinidae in the collection of Hugh CuMING Esq. Proc. Zool. Soc. London, f. 1851, 94-112 and 113-114.

(1855) : Descriptions of new genera and species of gastropodous mollusca. ibid., f. $1853,182-187$.

(1855): A monograph of Umbonium (Rotella), a genus of Trochidae. ibid., f. $1853,187-189$.

- and ReEve, L. A. (1850): Mollusca in zoology of the voyage of H. M. S. Samarang 1843-1846 and 1848-1850. 1-87, pls. 1-24, London.

ADAMS, Henry and ADAMS, Arthur (1853-58): The genera of recent mollusca arranged according to their organization. 1, 1-484, and 2, 1-661, London.

Azuma, Masao (1961): Descriptions of five new species of Japanese marine gastropoda. Venus 21, (2), 190-196. 
BANDY, Orville (1963) : Cenozoic planktonic foraminiferal zonation and basinal development in the Philippines. Bull. Amer. Assoc. Petrol. Geol. 47, (9), 1733-1745.

(1964): Cenozoic planktonic foraminiferal zonation. Micorpaleont. 10, (1), 117.

and WADE, Mary E. (1967): Miocene-Pliocene-Pleistocene boundaries in deepwater environments. Progress in Oceanography, 4, 51-86.

BANNer, F. T. and Blow, W. H. (1965) : Progress in the planktonic foraminiferal biostratigraphy of the Neogene. Nature, 208, (5016), 1164-1166.

and - (1967): The origin, evolution and taxonomy of the foraminiferal genus Pulleniatina Cushman, 1927. Micropaleont. 13, (2), 133-162.

BARNARD, K. H. (1958) : Contribution to the knowledge of South African marine mollusca. Pt. 1, Gastropoda: Prosobranchiata; Toxoglossa. Ann. South African Mus. 44, 73-163, fs. 1-30.

Bartsch, Paule (1923): A key to the family Terebridae. Nautilus, 37, 60-64.

BAYER, C. (1937) : Catalogue of the Doliidae in the Rijksmuseum van Natuurlijke Historie. Zool. Meded. Leiden, 20, (1-2), 29-50.

BEETs, C. (1941): Eine jungmiocäne Molluskenfauna von der Halbinsel Mangkalihat, Ost-Borneo. Verh. Geol.-nijnb. Genoot. Ned. Kol. Geol. Ser, 13, (1), 1-218, Taf, 1-8.

(1942): Mollusken aus dem Tertiär des Ostindischen Archipels. Leid. Geol. Meded. 13, 218-254, Taf. 24-26.

(1944a) : Die Gattung Buccinulum im Altmiocän den Insel Madura (Ost-Indië). Geol. Mijnb. N. S. Jaarg. 6, (1-2), 14-16.

(1944b) : Über Ootomella und Buccinaria. Basteria, 9, (1), 32-38.

(1950a): On Lower Tertiary mollusca from S. W. and Central Celebes. Leid. Geol. Meded. 15, 282-292, $1 \mathrm{pl}$.

(1950b): Revised determinations of East Indian and related fossil mollusca. Verh. Ned. Geol. Mijnb. Genoot., Geol. Ser. 15, 329-341.

(1953): Reconsideration of the so-called Oligocene fauna in the asphaltic deposits of Buton (Malay Archipelago), 1. Mio-Pliocene Mollusca. Leid. Geol. Meded. 17, 237-258.

BELLARDI, Luigi (continued by F. SACCo) (1872-1904): I molluschi dei terreni terziari del piemonte e della Liguria. Pt. 1-30, Milano.

BiRd, Samuel O. (1967): The binominal distribution applied to the percentage method of stratigraphic correlation. Bull. Geol. Soc. Amer. 78, (12), 1507-1514.

BöTTGER, O. (1880) : Die Tertiärformation von Sumatra und ihre Thierreste. Die Conchilien der unteren Tertiärschichten. Paläontogr. Supple. 3, (8-9), 3-120, Taf. $1-12+1$.

(1895): Die marinen Mollusken der Philippinen, 4, Pleurotomiden. Nachr.-Bl. Deutsch. Malak. Gesel. f. 1895, 1-41.

Böнм, A. (1882) : Uber einige Tertiäre Fossilien von den Insel Madura nörtlich von Java. Denkschr. Kaiser. Akad. Wissensch. Classe, 45, (2), 359-372, Taf.1-3.

BoLLI, Hans M. (1964) : Observations on the stratigraphic distribution of some warm water planktonic foraminifera in the Young Miocene to Recent. Ecl. Geol. Helvet. $57,(2), 541-552$.

(1966): The planktonic foraminifera in well Bodjonegoro-1 of Java. ibid., 59, (1), 449-465, 1 tab., 1 pl.

BoRN, Ignaz von (1780): Testacea musei caesarei vindobonensis. 1-442, tab. 1-18.

(1780): Index rerum naturalium musei caesarei vindobonensis. 1, Testacea. (not accessible).

BRUGuiere, J. G. (1789-1816) : Histoire naturelle des vers, de mollusques (in Dictionaire Encyclopedique methodique, 1782-1832), 1, 1-758, 488 pls.

CERnohorsky, Walter Oliver (1968): The Ovulidae, Pediculariidae and Triviidae of Fiji. Veliger, 10, (4), 353-374, pls. 50-52. 
Cita, M. B., Silva, I. P. e Rossi, R. (1965) : Foraminiferi planctonici del Tortonianotipo. Riv. Ital. Paleont. 71, (1), 217-308, pls. 18-31.

Corby, G. W. et al (1951): Geology and oil possibilities of the Philippines. Rept. Philippines Dept. Agric. and Nat. Res., Tech. Bull. (21), 1-363.

Cossmann, Maurice (1895-1925): Essais de Paléoconchologie comparée. Tom. 1-13, Paris.

(1900-1924) : Faune pliocénique de Karikal (Inde française). Journ. de Conch. $48,14-66,51,105-173,58,34-86$, et $68,85-150$.

Cox, L. R. (1948): Neogene mollusca from the Dent peninsula, British North Borneo. Schweiz. Paläont. Abhandl. 66, 1-77, pls. 1-6.

(1955) : Observations on gastropod descriptive terminology. Proc. Malac. Soc. London, 31, 190-202.

Dall, William H. (1881) : Preliminary report on the mollusca (Blake deep sea expedition in the Gulf of Mexico). Bull. Mus. Comp. Zool. 9, 33-144.

(1904): A historical and systematic review of the frog-shells and Tritons. Smiths. Misc. Coll. 47, (1475), 114-144.

(1905): Notes on some preoccupied names of mollusks. Nautilus, 18, 113.

(1908) : Subdivisions of the Terebridae. ibid., 21, 124-125.

(1918): Notes on the nomenclature of the mollusks of the family Turritidae. Proc. U. S. National Mus. 54, 313-333.

(1919): Notes on the name Duplicaria. Nautilus, 33, 32.

Dalton, L. V. (1908): Notes on the geology of Burma. Quart. Jour. Geol. Soc. London, 64, 604-643.

DELL, R. K. (1956) : The archibenthal mollusca of New Zealand. Dominion Museum Bull. (18), 1-235, 27 pls.

Deshayes, G. P. (1835-45) : Histoire naturelle des animaux san vertèbres. 11, Paris.

DrCkerson, R. E. (1921) : Notes on the fauna of the Vigo group and its bearing on the evolution of marine molluscan faunas. Proc. Calif. Acad. Sci. 11, 1-26.

(1922): Review of the Philippine palaeontology. Philip. Journ. Sci. 20, 195229.

Dinlwyn, Lewis W. (1817) : A descriptive catalogue of recent shells. 2 vols. 1-1092.

Dollfus, M. G. (1917) : Paleontologie du voyage a lile Celebes de M. E. C. Abendanon. E. C. Abendanon, Midden-Celebes-Expeditie. Geologische en geographische doorkruisingen van Midden Celebes (1909-1910), 3, 959-1016, pls. 1-4.

DUNKER, Wilhelm (1846-47) : Diagnoses buccinorum quorundam novorum. Zeitschr. f. Malak. 3, 170-172 und 4, 59-64.

(1882): Index molluscorum maris japonici. 1-301, 16 pls. Kassel.

Eames, F. E., BANNer, F. T., Blow, W. H., and Clarke, W. J. (1962) : Fundamentals of Mid-Tertiary stratigraphical correlation. Cambridge, The University Press. $1-163,17$ pls, 3 tabs.

Finlay, H. J. (1927): New specific names for Austral mollusca. Trans. Proc. New Zealand Inst. 57, 488-533. (1930) : Invalid molluscan names. ibid. 61, (1), 37-48.

Fischer, P. J. (1927) : Beitrag zur Kenntnis der Pliozänfauna der Molukken Inseln Seran und Obi. Paläont. v. Timor. (15), 1-179, Taf. 212-217.

GMelin, J. F. (1791-92) : Systema naturae, ed. 13, 1, 2225-4120, 2, 1-1661.

Gonzales, Benjamin A. (1961) : Revisions on the correlations of some of the units in the Indonesian letter classification as used in the Philippines. Philip. Geol. 15, (4), 170-179.

(1963): Foraminiferal analyses on measured sections along the Tarao (Jarao) and Tanian rivers, southwestern Iloilo. Bureau of Mines, Rep. Investig. (46), 135,5 tabs.

Arong, N. T., and Santos, P. J. (1963) : Rock-stratigraphic units in southwest Iloilo basin. Bureau of Mines, Mimeogr. with 1 map. 
Gould, Augustus A. (1861): Description of new shells collected by the North Pacific Exploring Expedition. Proc. Boston Soc. Nat. Hist. 7, 382-389.

Graham, A. (1965): The buccal mass of ianthinid prosobranchs. Proc. Malac. Soc. London, 36, 323-338.

GRAY, J. E. (1834) : Enumeration of the species of the genus Terebra, with characters of the many hitherto undescribed. Proc. Zool. Soc. London, 59-63.

(1847) : List of the genera of recent mollusca, their synonyma and types. ibid., 129-206.

(1858): An attempt to distribute the species of Oliva (Oliva, LAMARck) into natural groups and to define some of the species. ibid., 26, 38-57.

HaANStra, U. und SPIKER, E. (1932a) : Utber Fossilien aus dem Altmoizän von Rembang (Nord Java). Proc. Konink. Akad. Wetensch. Amsterdam, 35, (8), 1095$1103,1 \mathrm{pl}$.

und - (1932b): Uber jungneogene Molluskenfaunen aus den Residenzen Benkoelen und Palembang, S. W. Sumatra. ibid., 35, (9), 1313-1324.

HABE, Tadashige (1950): On the radulae of Japanese marine gastropods. Venus, 14, (1) $1-9,27 \mathrm{fs}$.

(1951): On the radulae of Japanese marine gastropods, pt. 3. ibid., 14, (5-8), 190-199, 23 fs.

(1958): On the radulae of Japanese marine gastropods, pt. 4. ibid., 20, (1), 43-60.

(1961a): Description of four new cancellariid species with a list of the Japanese species of the family Cancellariidae. ibid., 21, (4), 431-441, pls. 23-24.

(1961b): Colored illustrations of the shells of Japan, Vol. 2, $183 \mathrm{pp}+$ append. 43 pp., 66 pls., Tokyo.

and Kosuge, Sadao (1966): Shells of the world in colour. Vol. 2, 193 pp., 68 pls., Tokyo.

HANLey, Sylvanus (1859): Systematic list of the species of Dolium restricted. Proc. Zool. Soc. London, 487-493.

HATAI, Kotora (1941): Recent marine shell-bearing mollusea of the South Sea Islands (pt. 1). 1-160, pls. 1-79, Sendai.

- and Nisiyama, Syozo (1940): On some fossil species of Cancellaria from Japan. Saito Ho-on Kai Mus. Res. Bull. (19), 117-132, 1 pl.

Hayasaka, Ichiro and Hayasaka, Shozo (1960): Molluscan fossils from Tungyüping in the Penghu Islands, Taiwan. Trans. Proc. Palaeont. Soc. Japan. N. S. (38), 263-274, pl. 31.

Hayasaka, Shozo (1961) : The geology and paleontology of the Atsumi Peninsula, Aichi Prefecture, Japan. Sci. Rep. Tohoku Univ. 2nd Ser. 33, (1), 1-103, 12 pls., 1 map.

HEDLEY, Charles (1918): A check-list of the marine fauna of New South Wales Mollusca. Journ. Roy. Soc. N. S. Wales, f. 1917, 51, Suppl. M, 1-120.

(1922): A revision of the Australian Turridae. Rec. Austral. Mus. 13, (6), 213-259, pls. 52-56.

HERRMANNSEN, A. N. (1846-1852): Indicis generum malacozoorum primordia. 1, 1$637,2,1-717+$ suppl. \& corrig. 1-140, Casellis.

Hidalgo, J. G. (1904-1905): Catalogo de los molluscus testaceos de las islas Filipinas, Joló y Marianas. I, Molluscus marinos. 1-408, Madrid.

HINDS, R. B. (1844): The zoology of the voyage of H.M. S. Sulphur, under the command of Capt. Sir E. BELCHER during 1836-42. 2 Vols. London.

HIRASE, Yoichiro (1914-22): The illustrations of a thousand shells. pt. 1-4, Tokyo.

(1917): Terebridae of the Japanese Empire. 1-50, 8 pls, Tokyo.

IDA, Kazuyoshi (1952): A study of fossil Turritella in Japan. Geol. Surv. Japan Rep. (150), 1-64, 25 text-fs., pls. 1-7.

IREDALE, Tom (1918) : Molluscan nomenclatural problems and their solution, I. Proc. Malacol. Soc. London, 13, 28-40. 
(1821): Molluscan nomenclatural problems and their solutions, II. ibid., 14, 198-208.

(1924) : Results from Roy BeLL's molluscan collections. Proc. Linn. Soc. New South Wales, 49, 179-278, pls. 31-36.

(1929) : Mollusca from the continental shelf of eastern Australia. Rec. Austral. Mus. 17, 157-189, pls. 38-41.

(1930): Queensland molluscan notes, No.2. Mem. Queensland Mus. 10, 73-88, pl. 9.

(1931): Australian molluscan notes I. Rec. Austral. Mus. 18, 201-235, pls. 22 25.

(1936) : Australian molluscan notes II. ibid., 19, 267-340, pls. 20-24.

Jenkins, H. M. (1864) : On some Tertiary mollusca from mount Séla in the island of Java. Quart. Jour. Geol. Soc. London, 20, 45-73.

Johnson, Richard I. (1964): The recent mollusca of Augustus Addison Gould. Bull. Smithsonian Inst. U. S. Nat. Mus. (239), 1-182, pls. 1-45.

Jousseaume, F. (1883) : Description d'espèces et genres nouveaux de mollusques. Bull. Soc. Zool. France, 8, 186-204, pl. 10.

(1884) : Etude sur la famille des Cypraeidae. ibid., 9, 81-100.

(1931): Cerithiidae de la mer rouge. Jour. de Conch. 74, 270-296.

JuttiNG, T. van Benthem (1937) : Non marine mollusca from fossil horizons in Java. Zool. Meded. Leiden, 20, 83-180, pls. 4-12, 1 tab.

KEEN, A. Myra (1961) : A proposed reclassification of the gastropod family Vermetidae. Bull. Brit. Mus. (N. H.), 7, (3), 183-213, 2 pls.

KIENER, L. C. (et P. FISCHER): (1834-1880): Species général et iconographie des coquilles vivantes, Comprenant la collection du Muséum d'Histoire Naturelle de Paris, la collection LAMARCK, cella du Prince MASSÉNA ... et les découvertes récentes des voyageurs. Tom. 1-11, Paris.

KILIAS, Rudolf (1962): Tonnidae. Das Tierreich, (77), 1-63, $47 \mathrm{fs}$.

KIRA, Tetsuaki (1954) : Colored illustrations of the shells of Japan. $172+24$ pp., 67 pls., Tokyo.

KLEINPEL, R. M. (1957): Notes on Cenozoic correlations and geologic history in the Philippines. Philip. Geol. 12, (1), 1-15.

KOPERBERG, E. J. (1931) : Jungtertiäre und quartäre Mollusken von Timor. $2^{e}$ Nederlandsche Timor-Expeditie, 1916. (7), 1-165, Taf.1-3.

Kotaka, Tamio (1959): The Cenozoic Turritellidae of Japan. Sci. Rep. Tohoku Univ. 2nd. Ser. 31, (2), 1-135, pls. 1-15, 3 tabs. 7 charts.

KurodA, Tokubei (1941): A catalogue of molluscan shells from Taiwan (Formosa), with descriptions of new species. Mem. Fac. Sci. Agr. Taihoku Imp. Univ. 22, (4), 1-216, pls. 1-7.

(1961): On a few small groups of Japanese Gastropoda. Prof. MakiYama Memorial Volume, 175-190, pls. 1-2.

and HABE, Tadashige (1952): Check list and bibliography of the recent marine mollusca of Japan. 1-210, Tokyo.

LAdD, Harry S. (1934): Geology of Vitilevu, Fiji. Bull. Bernice P. Bishop Mus. (119), $1-263,44 \mathrm{pls}$.

Lamarck, J. B. P. A. (1799): Prodrome d'une nouvelle classification des coquilles. Mém. Soc. Hist. Nat. Paris, 1, 63-91.

(1818-22): Histoire naturelle des animaux sans vertèbres. prem. ed. Tom. 5-7, Paris.

LASERoN, C. F. (1954): The New South Wales Turridae. Roy. Zool. Soc. N. S. Wales, Handb. 1-56, 12 pls.

(1958): Liotiidae and allied mollusea from the Dampierian zoogeographical province. Rec. Austral. Mus. 24, (11), 165-182, 87 text-fs.

Laursen, Dan (1953): The genus Janthina, a monograph. Dana-Report, (38), 1-40, 
1 pl.

LINK, Heinrich F. (1807) : Beschreibung der Naturalien-Sammlung der Universitat zu Rostock. Abt. 1-6, Rostock.

Linnaeus, Caroli (1758) : Systema naturae, ed. 10, (regnum animale), 823 pp, Holmiae. LISCHKE, C. E. (1869): Japanische Meeres-Conchylien, Bd. 1, 1-191, Taf. 1-14, Cassel. MACNEIL, F. Stearns (1960): Tertiary and Quarternary Gastropoda of Okinawa. U.S. Geol. Surv. Prof. Pap. (339), 1-148, pls. 1-19.

MacPherson, J. Hope and Gabried, C. J. (1962): Marine molluses of Victoria. Nat. Mus. Victoria, Handb. (2), 1-475, 486 text-fs.

MakiYama, Jiro (1935): Morphogenetic history of Umboniidae (in Japanese). Venus, 5, (5), 241-255, 2 text-fs.

(1936): The Meisen Miocene of North Korea. Mem. Coll. Sci. Kyoto Imp. Univ. Ser. B, 11, 193-228, 2 pls.

(1940): Nomenclatural notes on some genera of Turridae. Trans. Palaeont. Soc. Japan, (102), 25-26.

Martin, K. (1879-80): Tertiärschichten auf Java nach den Entdeckungen von Fr. JUNGHUhN. 126 pp., 24 tabs., Leiden.

(1883) : Nachträge zu den "Tertiärschichten auf Java", Iter Nachtrag, Mollusken. Paläontologie van Nederlansch-Indië, Verh. (18), 285-358, Tab. 9-13.

(1883-87): Paläontologische Ergebnisse von Tiefbohrungen auf Jave, nebst allgemeinen Studien über das Tertiär von Java, Timor, und einigen anderer Inseln. Samml. Geol. Riechs-Mus. Leiden, Ite Ser. 3, (1), 1-42, Tab. 1-3; (2-3), 43-184, Tab. 4-9; (4-5), 185-304, Tab. 10-14, \& (6), 305-381, Tab. 15.

(1895-1922) : Die Fossilien von Java. ibid., N. F. 1, Abt. 1, (1-10), 1-325, Taf. 1-45, und Abt. 2, (1-4), 333-538, Taf. 46-68.

(1907): Eine altmiocäne Gastropodenfauna von Rembang, nebst Bemerkungen über den stratigraphischen West der Nummulitiden. ibid., Ite Ser., 8, 145-152.

(1914) : Miocäne Gastropoden von Ost-Borneo. ibid., Ite Ser., 9, 326-336.

(1919): Unsere paläozoologische Kenntnis von Java mit einleitenden Bemerkungen über die Geologie der Insel. 1-156, Taf. 1-4, Leiden.

(1926): Plioceene versteeningen van Cheribon in Java. Wetensch. Meded. Dienst Mijnb. Ned.-Indië, (4), 1-23, Taf. 1.

(1928a): Mollusken aus dem Neogen von Atjeh in Sumatra. ibid., (10), 1-36, Taf. 1.

(1928b) : Eine Nachlese zu den Neogen Mollusken von Java. Leid. Geol. Meded. 3, (2), 105-129.

(1933) : Eine neue tertiäre Molluskenfauna aus dem Indischen Arschipel. ibid., 6, (1), 7-32, Taf. 1-5.

(1935) : Oligocäne Gastropoden von Buton. ibid., 7, (2), 111-118, 1 Taf.

Martini, F. H. W. (und Chemnitz, J. H.) (1769-95): Neues Systematisches Conchylien-Cabinet. Bd. 1-11.

MaY, W. L. (rev. by MacPherson, J. Hope) (1958) : An illustrated index of Tasmanian shells. $72 \mathrm{pp} ., 50 \mathrm{pls}$.

Meer MoнR, J. C. van der (1923-27) : Beiträge zur Kenntniss der Pliozän-Fauna Javas. Natuur. Tjids. Ned.-Indï̈, 83, (2), 124-136, Taf.1-6; 84, (3), 199-201, Taf. 1; en 86, (3), 205-208, Taf. 1-2.

Melvill, J. C. (1917): A revision of the Turridae (Pleurotomidae) occurring in the Persian Gulf, Gulf of Oman and the North Arabian Sea as evidenced mostly through the results of dredgings carried out by Mr. F. W. Townsend, 1893-1914. Proc. Malac. Soc. London, 12, 140-201, pls. 8-10.

and Standen, R. (1901 and 1906): The mollusca of the Persian Gulf, Gulf of Oman and Arabian Sea as evidenced mainly through the collection of Mr. F. W. TownSEND, 1883-1900, with descriptions of new species. Proc. Zool. Soc. London, $327-460$, pls. 21-24 and 783-848, pls. 53-56. 
Menke, C. T. (1828 et 1830): Synopsis methodica molluscorum generum omnium et specierum earm, quae in museo menkeano adservatur; cum synonymia critica et navarum specierum diagnosibus. 1-91 et editio altere 1-168, Pyrmonti.

MONTFORT, P. Denys de (1808 et 1810): Conchyliologie systématique et classification méthodique de coquilles. Tom. 1-2, Paris.

Mörch, O. A. L. (1852): Catalogus conchyliorum quae reliquit D. Alphonso D'AGUORRA et GADEA comes de Yoldi, I, 1-47, Kopenhagen.

MoRisita, Masaaki (1959): Measuring of interspecific association and similarity between communities. Mem. Fac. Sci. Kyushu Univ. Ser. E, Biology, 3, (1), 65-80.

Newton, R. B. (1900) : Pleistocene shells from the raised beach deposits of the Red Sea. Geol. Mag. N. S. Dec. 4, 7, 500-514 and 544-560, pls. 20-22.

NoEtLing, F. (1895): On some marine fossils from the Miocene of Upper Burma. Mem. Geol. Surv. India, 27, 1-45.

(1901): Fauna of the Miocene beds of Burma. Palaeont. Indica N. S. 1, (3), $1-378,25$ pls.

Nomura, Sitihei (1935): Catalogue of the Tertiary and Quatery Mollusca from the island of Taiwan (Formosa) in the Institute of Geology and Palaeontology, Tohoku Imperial University, Sendai, Japan. Sci. Rep. Tohoku Imp. Univ. 2nd Ser. 18, (2), 53-228, pls. 6-10.

(1937): Additional Pyramidellidae from Siogama Bay, with remarks on the molluscan fauna, especially Pyramidellidae from Sagami Bay, being a comparative study. Saito Ho-on Kai Mus. Res. Bull. 13, 11-107, pls. 4-14.

(1940): Mollusca dredged by the Husa-maru from the Pacific coast of Tiba Prefecture, Japan. Rec. Oceanogr. Works Japan, 12, (1), 81-116, pl. 2.

and Zinbō, Noburu (1934): Molluscan fossils from the Shimajiri beds of Okinawa-zima, Ryukyu Islands. Sci. Rep. Tohoku Imp. Univ. 2nd Ser. 18, (3), 226$266,1 \mathrm{pl}$.

Olsson, Axel A. and Harbison, Anne (1953): Pliocene Mollusca of southern Florida with special chapters on Turridae by Willian G. FARGO and Vitrinellidae and Freshwater Mollusks by Henry A. PILSBRY. Acad. Nat. Sci. Philad. Monogr. (8), $1-457,65$ pls.

Oostingh, C. H. (1931) : Beitrag zur Kenntnis der Molluskenfauna von Süd-Sumatra. Arch. Mollusk. 63, 166-254, Taf. 19.

(1933): Neue Mollusken aus dem Pliozän von Süd-Bantam (Java). Mijningenieur, jaarg. 14, (11), 192-197, 13 fs.

(1934): Die Purpurinen aus dem Pliocän Tijdjoerej in Cheribon, Java. Ingen. Ned.-Indië, IV (Mijnb. en Geol.) jaarg 1934, (2), 28-30, 4 fs.

(1935a) : Die Mollusken des Pliozäns von Boemiajoe (Java). Wetensch. Meded. 26, 1-247, Taf. 1-17, 1 Karte.

(1935b) : Einige neue Gastropoden aus dem Miocän von Mittel-Bantam, (Java). Ingen. Ned.-Indië, IV (Mijnb. en Geol.), jaarg. 1935, (9), 79-83, 4 fs.

(1938-40): Die Mollusken des Pliocäns von Süd-Bantam in Java. ibid., jaarg. 5, (2), 17-33, Taf. 1-2; (3), 35-47, Taf. 3; (4), 49-61, Taf. 4-5; (7), 105-116, Taf. 6-7; en (8), 119-129, Taf. 8-9; jaarg. 6, (1), 7-16, Taf. 10-11; (4), 43-51, Taf. 12; (8), 103-119, Taf. 13-14; en (12) , 163-189, Taf. 15-16; en jaarg. 7, 4562 , Taf. $17-19$.

(1939): Note on the stratigraphical relations between some Pliocene deposits in Java. ibid., jaarg. 6, (9), 140-141.

(1941): Over de tertiaire molluskenfauna van Palembang. ibid., jaarg. 8, 2129.

OTUKA, Yanosuke (1938): Catalogue of the Japanese species of genus Turritella. Venus, 8, (1), 37-44, 31 fs.

(1959): Japanese species of Orthosurcula. ibid., 20, (3), 245-248, 1 pl.

OYAMA, Katura (1953): Review of the known species of the Japanese Turridae (1). Venus, 17, (3), 151-160. 
(1954): Review of the known species of the Japanese Turridae (2). ibid., 18, (1) , 17-20.

(1961a) : On some new facts of the taxonomy of Terebridae. ibid., 21, (2), 176189.

(1961b) : On Japanese terebrid fossils and a few new facts of the family. ibid., 21, (3), 281-288.

(1961c): Biogeographical notes on Japanese Terebridae. ibid., 21, (4), 442462.

(1966) : On living Japanese Turridae. ibid., 25, (1), 1-20.

PANNEKoEK, Anna (1936): Beiträge zur Kenntnis der altmiocänen Molluskenfauna von Rembang (Java). 88 pp., 4 pls., Amsterdam.

PARKer, F. L. (1967) : Late Tertiary biostratigraphy (planktonic foraminifera) of tropical Indo-Pacific deep-sea cores. Bull. Amer. Paleont. 52, (235), 115-208, pls. 17-32.

Perry, G. (1811): Conchology (the natural history of snails, containing a new arrangement of the genera and species). 4 pp., 61 pls., London.

PHILIPPI, R. A. (1842-47): Abbildungen und Beschreibungen neuer oder wenig bekanter Conchylien, unter Mithilfe mehrerer Deutscher Conchyliologen. (1), 1-204; (2), 1-232; (3), 1-82; und (4), 1-138, Kassel.

Pilsbry, H. A. (1929) : Neverita reclusiana (Desh.) and its allies. Nautilus, 42, 109$113, \mathrm{pl} .6$.

Powels, A. W. B. (1942) : The New Zealand recent and fossil Mollusca of the Family Turridae with general notes on turrid nomenclature and systematics. Bull. Auckland Inst. \& Mus. (2), 1-192, pls. 1-14.

(1944): The Australian Tertiary Mollusca of the Family Turridae. Rec. Auckland Inst. \& Mus. 3, (1), 1-68, pls. 1-8.

(1964): The family Turridae in the Indo-Pacific. Pt. 1, The subfamily Turrinae. Indo-Pacific Mollusca, 1, (5), 227-345, pls. 172-262.

(1966): The molluscan families Speightiidae and Turridae. An evaluation of the valid taxa, both recent and fossil, with lists of characteristic species. Bull. Auckland Inst. \& Mus. (5), 1-184, pls. 1-23.

(1967): The family Turridae in the Indo-Pacific. Pt. Ia, The subfamily Turrinae concluded. Indo-Pacific Mollusca, 1, (7), 409-432, pls. 298-310.

Preston, H. B. (1910) : Descriptions of five new species of marine shells from the bay of Bengal. Rec. Indian Mus. 5, 117-121.

QUAY, J. R. C. et GAIMARD, J. P. (1832-35): Voyage de découvertes de l'Astrolabe éxécuté par ordre du Roi, pendant les années 1826-1829, sours le commenernent de M. J. Dumont d'Unville, zoologie. 2, 686 pp.; 3, 954 pp.; et 4, pls. 45-66.

Recluz, M. C. (1844) : On new species of Natica. Proc. Zool. Soc. London, f. 1843, 136141.

ReEve, Lovel A. (continued by Sowerby, G. B.) (1843-78) : Conchologia Iconica. Vols. 1-20, London.

Regteren Altene, C. O. van (1938a) : The marine Mollusca of the Kendeng beds (east Java), Gastropoda, pt. I. Leid. Geol. Meded. 10, 217-320.

(1938b) : Renamed mollusca from the Dutch East Indian Tertiaries. Natuurk. Tijd. Ned.-Indië, 98, (4), 208-212.

(1939): Notes on Caenozoic and recent Mollusca from the Dutch East Indies. Basteria, 4, (3-4), 45-46, pl. 3 (part).

(1941): The marine Mollusca of the Kendeng beds, East Java, Gastropoda, pt. II. Leid. Geol. Meded. 12, 1-86.

(1942) : The marine Mollusca of the Kendeng beds, East Java. Gastropoda, pt. IV. ibid., 13, 89-120.

(1948): Notes on Caenozoic and recent Mollusca from the Dutch East Indies. (6-7), Stenoglossa. Basteria, 12, (1), 10-12. 
(1950): The marine Mollusca of the Kendeng beds, East Java. Gastropoda, pt. V. Leid. Geol. Meded. 15, 205-240.

und BEETs, C. (1945): Eine neogene Molluskenfauna von Tji Gugur (Priangan), W. Java. Verh. Geol. Mijnb. Genootsch. Geol. Ser. 14, 37-70, 1 Taf.

RoBERTSON, Robert (1964): Dispersal and wastage of larval Philippia krebsii (Gastropoda: Architectonicidae) in the north Atlantic. Proc. Acad. Nat. Sci. Philad. 116, (1) , 1-27.

RöDING, P. F. (1798): Museum Boltenianum sive catalogus cimeliorum e tribus regnis naturae. ... 2 Bd. 1-199, Hamburg.

SaKURAI, Kinichi and HABE, T. (1964): Descriptions of two new vexillid species dedicated to Dr. T. KURODA's 77th birthday. Venus, 23, (1), 29-33, pls. 2-3.

Scheltema, R. S. (1961) : Metamorphosis of the veliger larvae of Nassarius obsoletus (Gastropoda) in response to bottom sediment. Biol. Bull. 120, (1), 92-109.

Schepman, M. M. (1908-13) : Prosobranchia of the Siboga Expedition. Siboga Expedition Monogr. (49), 1-477, pls. 1-32.

ScHILDER, F. A. (1937): Neogene Cypraeacea aus Ost-Java (Mollusca, Gastropoda). Ingen. Ned.-Indïe, IV (Geol. en Mijnb.), Jaarg. 4, (11), 195-210, $40 \mathrm{fs}$. (1939) : Uber einige fossile Cypraeacea aus dem Sunda-Archipel. Neues Jahrb. Min. Geol. Paläont. Beilage Bd., 81, (3), 494-500, Taf. 19.

SchUMACHer, C. F. (1817): Essai d'un nouveau système des habitations des vers testaces. 1-287, 22 pls., Copenhague.

SHUto, Tsugio (1961a): Palaeontological study of the Miyazaki Group: a general account of the faunas. Mem. Fac. Sci. Kyushu Univ., Ser. D (Geol.), 10, (2), 73206, tabs. $1-5$, pls. 11-13.

(1961b): Conacean gastropods from the Miyazaki Group. ibid., 11, (2), 71150, pls. 3-10.

(1962): Buccinacean and Volutacean gastropods from the Miyazaki Group. ibid., 12, (1), 27-85, pls. 6-13.

(1964): Naticid gastropods from the Miyazaki Group. Trans. Proc. Palaeont. Soc. Japan, N. S. (55), 281-293, pls. 42-43.

(1965): Turrid gastropods from the Upper Pleistocene Moeshima shell bed. Mem. Fac. Sci. Kyushu Univ. Ser. D (Geol.), 16, (2), 143-207, pls. 29-35.

Siemon, F. (1929): Jungtertiäre Molluskenfauna aus Niederländisch Ost-Indien. Berichte d. Naturforsch. Gesel. Freiburg, I Br., 29, (1-2), 1-61.

SмIтн, Edgar A. (1875) : A list of the Gastropoda collected in Japanese seas by Commander H. C. St. JoHN, R. N. A. Ann. Mag. Nat. Hist. Ser. 4, 15, 414-427 and 16, 103-115.

(1879) : On a collection of Mollusca from Japan. Proc. Zool. Soc. London, f. 1879, 181-218, pls. 19-20.

(1894-95) : Natural history notes from H. M. Indian marine survey steamer 'Investigator' Commander C. F. OLDHAM R. N. Ser. II, No. 10, Report upon some Mollusca dredged in the Bay of Bengal and Arabian Sea. Ann. Mag. Nat. Hist. Ser. 6, 14, (81), 157-174, pls. 3-5; and 16, 1-19, pls. 1-2.

(1897-1909): Illustrations of the zoology of the Royal Indian Marine Survey Ship 'Investigator': Mollusca. pt. 1-6, 23 pls., Calcutta.

SMITH, Warren D. (1913): Contributions to the stratigraphy and fossil invertebrate fauna of the Philippine Islands. Philip. Jour. Sci. Ser. a, 8, (4), 235-281, 7 pls.

SowERBY, G. B. (1832-41) : Conchological illustrations. pt. 1-200, London. (1841) : Descriptions of some new species of Murex, principally from the collection of H. Cuming Esq. Proc. Zool. Soc. London, f. 1840, 137-147.

(1842-87): Thesaurus conchyliorum. Vols. 1-5, London.

(1889): Descriptions of fourteen new species of shells from China, Japan and the Andamam Islands, chiefly collected by Deputy Surgeon General R. HUNGERFORD. Proc. Zool. Soc. London. f. 1888, (38), 565-570, pl. 28. 
(1909) : Descriptions of new species of Terebra, Pleurotoma, Trochus, Tellina, Dosinia and Modiola. Proc. Malac. Soc. London, 8, (4) ; 198-201.

SwaInson, W. (1820-33) : Zoological illustrations. Ist Ser. pls. 1-182, and 2nd Ser., pls. 1-136, London.

(1840): A treatise on malacology $419 \mathrm{pp}$.

Sykes, E. R. (1930): On a new species of Turris from Japan. Proc. Malac. Soc. London, 19, (2), 82.

TAKaYANAGI, Yokichi and SaIto, Tsunemasa (1962) : Planktonic foraminifera from the Nobori Formation, Shikoku, Japan. Sci. Rep. Tohoku Univ. 2nd Ser. Spec. Vol. (5) , 67-106, pls. 24-28.

TAKI, Isao (1930): Notes on the ecology of mollusca, pt. 1, Venus 2, (3), 136-146. and OYama, K. (1954) : Matajiro Yokoyama's "The Pliocene and later faunas from the Kwanto region in Japan". Palaeont. Soc. Japan Spec. Pap. (2), 1-68, 49 pls.

—, Otuka, Yanosuke, and Suzuki, Koichi (ed.) (1943) : Conchologia Asiatica, 1, (1-4), 1-136, 22 pls.

TAKI, Iwao (1943): The mollusca of the Inland Sea of Japan, pt. 2. Venus, 13, (1-4), 111-118, 14 fs.

Tesch, P. (1915 und 1920) : Jungtertiäre und Quartäre Mollusken von Timor. Teil I und Teil II. Paläont. v. Timor, (5), 1-70, Taf. 83-95 und (8), 41-121, Taf. 129140.

THIELE, Johannes (1925): Gastropoda. Wissenschaft. Ergebn. Deutsch. TiefseeExped. 17, (2), 36-282, Taf. 13-46. (1929-31): Handbuch der systematischen Weichtierkunde. 1, 1-778, 783 fs. Jena.

Thorson, Gunnar (1946) : Reproduction and larval development of Danish marine bottom invertebrates, with special reference to the planktonic larve in the Sound (Oresund). Komm. f. Danmarks Fisk. Havunders $\phi r g . ~ M e d d e l . ~ 4, ~ 1-523$.

(1957) : Bottom communities. Mem. Geol. Soc. Amer. (67), Vol. 1, 461-534.

(1961) : Length of pelagic larval life in marine bottom invertebrates as related to larval transport by oceanic currents. Oceanography. Amer. Assoc. Advancement of Sci. 455-474.

Tokunaga, Shigeyasu (1906) : Fossils from the environs of Tokyo. Jour. Col. Sci. Imp. Univ. Tokyo, 21, (2), 1-96, pls. 1-6.

Tryon, G. W. (continued by Pilsbry, H. A.) (1880-90) : Manual of Conchology. Ser. 1, Vols. 2-12, Philadelphia.

VLERK, I. M. van der (1931) : Caenozoic Amphineura, Gastropoda, Lamellibranchiata, Scaphopoda. Leid. Geol. Meded. 5, 297-389.

VREDENBURG, Ernest (1921a): Illustrated comparative diagnoses of fossil Terebridae from Burma. Rec. Geol. Surv. India, 51, (4), 339-361, pl. 10. (1921b) : Comparative diagnoses of Pleurotomidae from the Tertiary formations of Burma. ibid., 53, (2), 83-129, pls. 13-14.

(1921c): Comparative diagnoses of Conidae and Cancellariidae. ibid., 53, (2), 130-141, pl. 15.

(1923a): Indian Tertiary Gastropods, IV. Olividae, Harpidae, Marginellidae, Voltidae and Mitridae, with comparative diagnoses of new specimens. ibid., 54, 243-276, pls. 14-16.

(1923b): Indian Tertiary Gastropoda. V. Fusidae, Turbinellidae, Chrysodomidae, Strepturidae, Buccinidae, Nassidae, Columbellidae, with short diagnoses of new species. ibid., 55, 52-77, pls. 1-5.

(1925-28) : Description of Mollusca from the Post-Eocene Tertiary formation of North-western India. Mem. Geol. Surv. India, 50, 1-506, pls. 1-13.

WANNER, J. und HAHN, E. (1935) : Miocäne Mollusken aus der Landschaft Rembang (Java). Zeitschr. deutsch. Geol. Gesel. 87, (4), 222-273, 5 Taf. 
WATSON, R. B. (1886) : Report on the Scaphopoda and Gastropoda collected by H. M. S. Challenger during the years 1873-76. Challenger Zool., 15, 1-756, pls. 1-49.

WENZ, Wilhelm (1938-44) : Handbuch der Paläozoologie (von Otto H. ScHINDEWOLF), Bd. 6, Gastropoda, Teil I und II, 1-1639, 4211 fs. Berlin.

WISSEMA, Gustaaf G. (1947): Young Tertiary and Quarternary Gastropoda from the island of Nias (Malay Archipelago). 1-212, pls. 1-5, 7 tabs. Leiden.

Woodring, Wendel P. (1928): Miocene mollusks from Bowden, Jamaica, pt. 2. Publ. Carnegie Inst. Washington, (385), 1-459, $40 \mathrm{pls}$.

Woodwards, H. (1879) : Notes on a collection of fossil shells etc from Sumatra (obtained by M. VerbeEK), pt. 1. Geol. Mag. Decade 2, 6, (9), 385-393; pt. 2, (10), $441-444$, pl. 11 ; pt. 3 , (11), 492-500, pls. 12-13: and pt. 4 , (12), 535-549, pls. 14-15.

YEN, Teng-Chien (1942): A review of Chinese gastropods in the British Museum. Proc. Malac. Soc. London, 24, 170-289, pls. 11-28.

Yokoyama, Matajiro (1920): Fossils from the Miura peninsula and its immediate north. Jour. Coll. Sci. Imp. Univ. Tokyo, 39, (6), 1-198, pls. 1-20.

(1928) : Mollusca from the oil-field of the island of Taiwan. Imp. Geol. Surv. Japan, Rep. (101), 1-112, pls. 1-18.

(1929) : Pliocene shells from Tonohama, Tosa. ibid., (104), 9-17, pls. 7-8.

ZILCH, Adolf (1959-60): Handbuch der Paläozoologie (von Otto H. SCHINDEWoLF), Bd. 6, Gastropoda, Teil 2, Euthyneura, 1-830, 2515 fs., Berlin. 